BRUNO XIMENES TAKAHASHI

\title{
Metodologia Moderna para Análise de Fadiga Baseada em Elementos Finitos de Componentes Sujeitos a Fadiga Uni e Multiaxial
}

Dissertação apresentada à Escola Politécnica da Universidade de São Paulo para obtenção do título de Mestre em Engenharia Mecânica

Orientadora: $\operatorname{Prof}^{\mathrm{a}}$. Dr ${ }^{\mathrm{a}}$. Larissa Driemeier

São Paulo

2014 

BRUNo Ximenes TAKaHASHI

\section{Metodologia Moderna para Análise de Fadiga Baseada em Elementos Finitos de Componentes Sujeitos a Fadiga Uni e Multiaxial}

Dissertação apresentada à Escola Politécnica da Universidade de São Paulo para obtenção do título de Mestre em Engenharia Mecânica

Curso e área de concentração:

Engenharia Mecânica, Projeto e Fabricação

Orientadora: Prof ${ }^{\mathrm{a}}$. Dr ${ }^{\mathrm{a}}$. Larissa Driemeier

São Paulo

2014 
Autorizo a reprodução e divulgação total ou parcial deste trabalho, por qualquer meio convencional ou eletrônico, para fins de estudo e pesquisa, desde que citada a fonte.

Autorizo o uso do código-fonte da subrotina apresentada neste trabalho, para fins de estudo e pesquisa, desde que citada a fonte.

Este exemplar foi revisado e corrigido em relação à versão original, sob responsabilidade única do autor e com a anuência de seu orientador.

São Paulo, 05 de Agosto de 2014.

Assinatura do autor:

Assinatura do orientador:

\section{FICHA CATALOGRÁFICA}

Takahashi, Bruno Ximenes

Metodologia moderna para análise de fadiga baseada em elementos finitos de componentes sujeitos a fadiga uni e multiaxial / B.X. Takahashi. - São Paulo, 2014.

$338 \mathrm{p}$.

Dissertação (Mestrado) - Escola Politécnica da Universidade de São Paulo. Departamento de Engenharia Mecatrônica e de Sistemas Mecânicos.

1.Fadiga dos materiais 2.Resistência dos materiais 3.Método dos elementos finitos I.Universidade de São Paulo. Escola Politécnica. Departamento de Engenharia Mecatrônica e de Sistemas Mecânicos II.t 
Aos meus pais, que não mediram esforços para que eu tivesse as melhores condições possiveis, tanto nos estudos quanto em todas as áreas da vida. E principalmente por terem me ensinado que o objetivo na vida é ser feliz.

Ao теи irmão, que sempre me alegrava nos momentos mais estressantes, através do seu dom natural de fazer as pessoas rirem. 
Title:

Author:

Keywords:

Area of concentration:

Academic title:

Group:

Department:

Faculty:

University:

Address:

Supervisor:

Examining board:
Modern Methodology for FE-Based Fatigue Analysis of Components Under Uni- and Multiaxial Fatigue

Ing. Bruno Ximenes Takahashi

Fatigue, Durability, Multiaxial Fatigue, FE-Based Fatigue Analysis, FKM-Guideline, Relative Stress Gradient Method, Finite Element Analysis.

Mechanics of Solids, Deformable Bodies and Continua, Fatigue.

Master of Science in Mechanical Engineering

Group of Solid Mechanics and Structural Impact (GMSIE) [www.gmsie.usp.br]

Department of Mechatronics and Mechanical Systems

Polytechnical School

University of São Paulo (USP)

Av. Professor Mello Moraes 2231

Zip Code: 05508-900

Sao Paulo, SP, Brazil

Prof. Dr. Larissa Driemeier

Prof. Dr. Avelino Alves Filho (NCE)

Prof. Dr. Gilberto Francisco Martha de Souza (Poli-USP) 


\section{Agradecimentos}

Agradeço aos meus pais e irmão que me apoiaram em todos os instantes e que foram compreensivos nos momentos em que eu não estava presente, principalmente torcendo para o meu sucesso.

Agradeço à Prof ${ }^{a}$. Dr ${ }^{\mathrm{a}}$. Larissa Driemeier que sempre se mostrou solícita em ajudar, sempre teve tempo para atender e tirar minhas dúvidas e tempo para discutir sobre assuntos complexos da dissertação. Agradeço por ter me dado liberdade suficiente para que eu pudesse seguir pelo caminho que eu entendesse ser o melhor, aprendendo com meus próprios erros, mas também desenvolvendo um trabalho robusto e de qualidade. Agradeço também pelo grande esforço que fez para ler e avaliar a dissertação neste período final do mestrado. Muito obrigado pelo apoio constante, incentivo e pela amizade.

Agradeço ao Grupo de Mecânica dos Sólidos e Impacto em Estruturas (GMSIE), por ter me proporcionado um espaço onde eu pudesse desenvolver este trabalho. Agradeço em especial aos integrantes e ex-integrantes do laboratório, caracterizados por Roberto Oshiro, Renato Yamassaki, Rafael Celeghini, Leonardo Mazzariol, Davi Martins, Miguel Gonzales, Rafael Traldi, Wallaci Reis, Henrique Ramos, Vinícius Cruz, Eduardo Morales, Ramôn Auersvaldt, Caio Fukumori e Esdras Coraldi, pela amizade e pelos muitos momentos de descontração e alegria, fundamentais para recarregar as energias.

Agradeço aos engenheiros Jeff Mentley (HBM nCode), Peter Heyes (HBM nCode), Giovanni Moraes Teixeira (Safe Technology / Dassault Systèmes), Sussumu Nohara (PSA Pegeout Citroën), Leonardo Barban (Promon Engenharia) e Vanessa Seriacopi (Laboratório de Fenômenos de Superfície - USP), que agregaram valor à este trabalho, seja por inúmeras conversas ou por dicas rápidas, mas muito valiosas. 

A maioria das falhas por fadiga não são resultados de um especialista em fadiga realizando uma análise errada. A maioria das falhas é o resultado de um nãoespecialista não considerando fadiga de uma maneira adequada porque o assunto é muito complicado, por falta de conhecimento no assunto, por falta de propriedades de fadiga e por outros motivos semelhantes.

Prof. Dr. Darrell F. Socie Professor at the University of Illinois at Urbana-Champaign Fatigue Expert 



\section{Resumo}

Grande parte dos componentes mecânicos e estruturas são solicitados por carregamentos que variam com o tempo e frequentemente falham por fadiga. Neste sentido, é indubitável que o modo de falha por fadiga seja considerado no projeto mecânico de componentes, equipamentos e estruturas sujeitas a carregamentos cíclicos. Os livros de projetos de máquinas ainda são os mais utilizados na indústria como referência teórica e prática ao dimensionamento contra a fadiga de produtos. Entretanto, muitos deles ainda não incluem as últimas descobertas e metodologias mais modernas para o cálculo de durabilidade de estruturas. Adicionalmente, de uma maneira geral, grande parte dos livros especializados em fadiga também não trazem informações detalhadas sobre a previsão de vida em fadiga sob a ótica do projeto mecânico, como a análise utilizando critérios de Fadiga Multiaxial e a análise de fadiga baseada em Elementos Finitos (FE-Based Fatigue Analysis). Baseado neste cenário, este trabalho tem o objetivo de propor um procedimento para avaliar a vida em fadiga de componentes e estruturas reunindo os métodos mais recentes utilizados nesta área. Dentre os vários assuntos incluídos no procedimento proposto, destacam-se: as importantes contribuições propostas pelo Conselho Alemão de Pesquisa em Engenharia (FKM-Guideline); a utilização de Análise por Elementos Finitos (FEA) na previsão de vida em fadiga; o cálculo do fator de tensão média utilizando pseudo tensões provenientes de FEA; a contabilização do efeito de entalhe em componentes com geometria complexa utilizando o Método do Gradiente de Tensão Relativo em conjunto com FEA, que pode ser aplicado tanto em carregamento uniaxial quanto em carregamento multiaxial; a contabilização do dano por fadiga em carregamento multiaxial de amplitude variável; a densidade da malha de elementos finitos adequada para utilizar em fadiga computacional; e a aplicação da teoria e dos critérios de Fadiga Multiaxial, principalmente em FE-Based Fatigue Analyses, cuja utilização é imprescindível em estruturas sujeitas a tensões cíclicas em mais de uma direção $(\mathrm{x}, \mathrm{y}, \mathrm{z})$.

Palavras-chave: Fadiga, Durabilidade, Fadiga Multiaxial, Fadiga Baseada em Elementos Finitos, FE-Based Fatigue Analysis, FKM-Guideline, Método do Gradiente de Tensão Relativo, Análise por Elementos Finitos. 



\section{Abstract}

Most of mechanical components and structures are subjected to time varying loading and therefore often present fatigue failure. Therefore, it is essential to consider the fatigue failure mode in the project of components, machines and structures under cyclic loading. Design of Machine Elements books are still the most used in industry as theoretical and practical reference for designing products against fatigue. However, many of them still do not include the latest findings and methodologies used in fatigue life assessment of structures. Additionally, overall, most of the specialized fatigue books also do not include detailed information about fatigue life assessment in a mechanical project view, as the fatigue analysis using Multiaxial Fatigue criteria and the fatigue life prediction using the Finite Element Method (FE-Based Fatigue Analysis). Based on this fact, this thesis proposes a procedure for predicting component and structures fatigue life, gathering together the most recent methods used in the fatigue area. Among the several subjects included in this procedure, we can highlight: the important contributions of the German Engineering Research Council (FKM-Guideline); the use of Finite Element Analysis (FEA) in the fatigue life assessment; the calculation of the mean stress factor using the pseudo stresses from FEA; the computation of the notch effect in geometrically complex components using the Relative Stress Gradient Method in conjunction with FEA, method which can be applied both in uniaxial loading and multiaxial loading; the estimation of the fatigue damage in structures under variable amplitude multiaxial fatigue loading; the selection of an adequate Finite Element mesh density to use in computational fatigue; and the aplication of the Multiaxial Fatigue theory and criteria, specially in FE-Based Fatigue Analyses, of which use is essential in structures under ciclic stresses in 2 or 3 directions $(\mathrm{x}, \mathrm{y}, \mathrm{z})$.

Keywords: Fatigue, Durability, Multiaxial Fatigue, FE-Based Fatigue Analysis, FKM-Guideline, Relative Stress Gradient Method, Finite Element Analysis. 



\section{Sumário}

\begin{tabular}{lll}
\hline & Introdução & 1
\end{tabular}

1.1 Contextualização . . . . . . . . . . . . . . . . . . . . 1

1.2 Aspectos Históricos . . . . . . . . . . . . . . . . . . . . . . 4

1.3 Acidentes e Motivação do Trabalho . . . . . . . . . . . . . . . . . . . . . . . 8

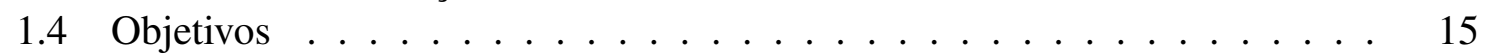

1.5 Metodologia . . . . . . . . . . . . . . . . . . 15

1.6 Organização do Trabalho . . . . . . . . . . . . . . . . . . 17

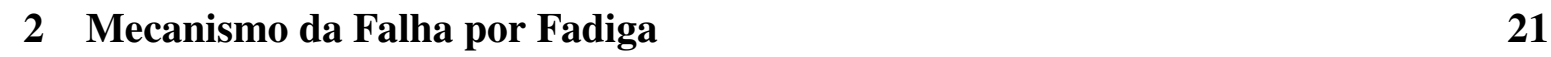

$2.1 \quad$ Estágio I: Nucleação de Trinca . . . . . . . . . . . . . . . . . . . . . 23

2.2 Estágio II: Propagação de Trinca . . . . . . . . . . . . . . . . . . . . . . . . . . . 27

2.3 Estágio III: Fratura repentina $\ldots \ldots \ldots \ldots$. . . . . . . . . . . . 31

2.4 Conclusões do Capítulo $2 \ldots \ldots \ldots$. . . . . . . . . . . . . . . 32

3 Métodos para Previsão de Vida em Fadiga 35

3.1 Método Tensão-Vida . . . . . . . . . . . . . . . . . . . 37

3.2 Método Deformação-Vida . . . . . . . . . . . . . . . . . . . . . . . . . . . . 38

3.3 Método da Propagação de Trincas . . . . . . . . . . . . . . . . . . 43

3.4 Idealização do Processo de Fadiga em Fases . . . . . . . . . . . . . . . . 46

$3.5 \quad$ Filosofias de Projeto em Análise de Fadiga . . . . . . . . . . . . . . . . . . . . . 51

3.6 Conclusões do Capítulo $3 \ldots \ldots \ldots \ldots$. . . . . . . . . . . . . 53

4 Análise de Fadiga Uniaxial Baseada em Tensão 55

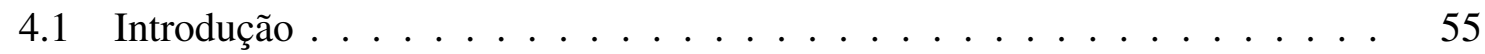

4.2 Curva S-N Espécime . . . . . . . . . . . . . . . . . . . 56

$4.2 .1 \quad$ Estimativa do limite de fadiga $S_{E, s p}$ de aços . . . . . . . . . . 64

4.2.2 Estimativa da resistência à fadiga $S_{B, s p}$ para aços . . . . . . . . 70

4.2.3 Estimativa do limite de fadiga de outras ligas metálicas . . . . . . . 71

4.2.4 Estimativa da resistência à fadiga $S_{B, s p}$ de outras ligas metálicas . . 82

4.3 Curva S-N Unnotched $\ldots \ldots \ldots \ldots \ldots$

4.3 .1 Conceito de Similaridade . . . . . . . . . . . . . . . . . . . 85

4.3 .2 Método da Curva S-N Sintética . . . . . . . . . . . . . . . . 90 90

4.3 .3 Fator de Tipo de Carregamento . . . . . . . . . . . . . . . . . . . . 96

4.3 .4 Fator de Tamanho . . . . . . . . . . . . . . . . . . . . . . . . . . . 98

4.3 .5 Fator de Rugosidade . . . . . . . . . . . . . . . . . . . . . 103

4.3 .6 Fator de Tratamento Superficial . . . . . . . . . . . . . . . . . . . . . . . 104

$4.3 .7 \quad$ Fator de Corrosão . . . . . . . . . . . . . . . . . . . . . . 106 
4.3 .8 Fator de Confiabilidade . . . . . . . . . . . . . . . . . . . . . . . . . . . . . . . . 108

$4.3 .9 \quad$ Fator de Temperatura $\ldots \ldots \ldots \ldots$

4.3 .10 Fator de Tensão Média . . . . . . . . . . . . . . . . . . . . . . . . 114

4.3 .11 Efeito da Frequência do Carregamento . . . . . . . . . . . . . . . . 124

4.4 Curva Tensão-Vida Local . . . . . . . . . . . . . . . . . . . . . . . . . 127

$4.4 .1 \quad$ Fator de Entalhe via Método $K_{f} \ldots \ldots$. . . . . . . . . 133

4.4.2 Fator de Entalhe via o Método do Gradiente de Tensão Relativo . . 135

4.5 Carregamento de Amplitude Variável e Dano por Fadiga . . . . . . . . . . 144

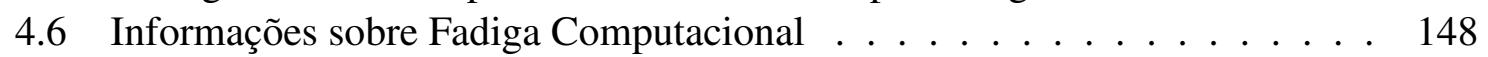

4.6.1 Sobre o Cálculo do Fator de Tensão Média em Fadiga Computacional 148

4.6.2 Sobre Carregamento de Amplitude Variável em Fadiga Computacional 158

4.6.3 Densidade da Malha de Elementos Finitos em Fadiga Computacional 165

4.7 Conclusões do Capítulo $4 \ldots \ldots \ldots \ldots \ldots$. . . . . . . . . . . . . . . . . .

5 Análise de Fadiga Multiaxial Baseada em Tensão 171

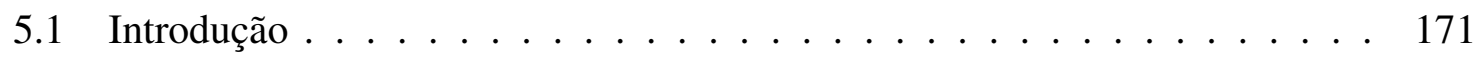

5.2 Avaliação do Tipo de Carregamento . . . . . . . . . . . . . . . . . . . . . . . 182

$5.3 \quad$ Fator de Entalhe $\left(n_{K}\right)$ Aplicado em Fadiga Multiaxial . . . . . . . . . . . . 191

5.4 Carregamento de Amplitude Variável e Dano por Fadiga em Fadiga Multiaxial 198

5.5 Modelos de Dano por Fadiga . . . . . . . . . . . . . . . . 200

5.5 .1 Modelos Baseados em Tensão Equivalente . . . . . . . . . . . . . 202

5.5.1.1 Modelo da Tensão Principal Sinalizada . . . . . . . . . . 205

5.5.1.2 Modelo da Tensão de Cisalhamento Sinalizada (Modelo de Tresca $\ldots \ldots \ldots \ldots \ldots . \ldots . \ldots 214$

5.5 .1 .3 Modelo de von Mises Sinalizado . . . . . . . . . . . 221

5.5 .1 .4 Modelo de Sines . . . . . . . . . . . . . . . 228

5.5 .2 Modelos Baseados no Plano Crítico . . . . . . . . . . . . . 237

\begin{tabular}{lll}
5.5 .2 .1 & Amplitude da Tensão Cisalhante e Tensão Normal no Plano \\
\hline & Crítico . . . . . . . . . . . . . 238
\end{tabular}

$5.5 .2 .2 \quad$ Modelo de Findley . . . . . . . . . . . . . . . 243

5.5 .2 .3 Modelo de Gaier e Dannbauer. . . . . . . . . . . . . . . 251

5.5 .3 Modelos Baseados em Tensão Mesoscópica . . . . . . . . . . . . . 259

$5.5 .3 .1 \quad$ Modelo de Dang Van . . . . . . . . . . . . . . . . . . 259

5.6 Conclusões do Capítulo $5 \ldots \ldots \ldots \ldots \ldots$. . . . . . . . . . . 271

$6 \quad$ Aplicação da Metodologia $\quad 275$

6.1 Introdução . . . . . . . . . . . . . . . . . . . . . . . . . . . . . . . 275

6.2 Softwares Comerciais para Análise de Fadiga . . . . . . . . . . . . . . . . 276

6.2 .1 nCode DesignLife . . . . . . . . . . . . . . . . . . . . 276

$6.2 .2 \quad$ MSC.Fatigue . . . . . . . . . . . . . . . . . . . 278

6.2 .3 fe-safe . . . . . . . . . . . . . . . . . . . . . . . . . . . . . . . . . . . . . . . . . . . .

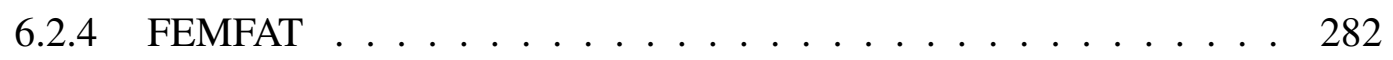

6.2 .5 LMS Virtual.Lab Durability . . . . . . . . . . . . . . . . . . . . . 285

$6.2 .6 \quad$ NX Advanced Durability . . . . . . . . . . . . . . . . . . . . . . . . . . . . . . . . . . . . . . . . . . . . .

6.2 .7 winLIFE . . . . . . . . . . . . . . . . . 286

6.3 Detalhamento da Análise de Fadiga Computacional . . . . . . . . . . . . . 288

6.3 .1 Etapa 1: Entrada de Dados . . . . . . . . . . . . . . 288 
$6.3 .2 \quad$ Etapa 2: Propriedades de fadiga . . . . . . . . . . . . . . . 293

6.3.3 Etapa 3: Critério de Fadiga Multiaxial . . . . . . . . . . . . . . . . 293

6.4 Estudos de Caso para Validação do Procedimento . . . . . . . . . . . . . . 294

$6.4 .1 \quad$ Estudo de Caso 1 . . . . . . . . . . . . . . . . . . 296

6.4 .2 Estudo de Caso $2 \ldots \ldots \ldots$. . . . . . . . . . . . . 297

6.4 .3 Estudo de Caso 3 . . . . . . . . . . . . . . . . . . . 299

6.4 .4 Estudo de Caso $4 \ldots \ldots \ldots$. . . . . . . . . . . . . . 306

6.4 .5 Estudo de Caso 5 . . . . . . . . . . . . . . . . . . . . . . . . . . . . . . . . . . 309

6.5 Conclusões do Capítulo $6 \ldots \ldots \ldots \ldots$. . . . . . . . . . . . . 317

\begin{tabular}{llr}
\hline 7 & Conclusões & 321 \\
\hline
\end{tabular}

7.1 Trabalhos Futuros $\ldots \ldots \ldots$. . . . . . . . . . . . . . . . 324 



\section{Lista de Figuras}

1.1 Análise estrutural de um braço de suspensão inferior de um carro através do Método dos Elementos Finitos|(Compass Automotive Group, 2013). . . . . 5

1.2 Processo inteiro de análise de durabilidade utilizando Análise de Dinâmica de Sistemas Multicorpos, Análise por Elementos Finitos e Análise de Fadiga baseada em Elementos Finitos (Barbosal|2013). . . . . . . . . . . . . . . 9

1.3 Ensaio de durabilidade de veículo completo utilizando um simulador de pista (Exova Defiance, 2013). . . . . . . . . . . . . . 9

2.1 Tensões variantes no tempo. . . . . . . . . . . . . . . . 22

2.2 Principais células unitárias em metais: (a) Estrutura cúbica de corpo centrado (CCC), (b) Estrutura cúbica de face centrada (CFC), (c) Estrutura hexagonal compacta (HC) (adaptado de Milan et al., 2008). . . . . . . . . . . . . 24

2.3 Principais sistemas de deslizamento nos reticulados CCC , CFC e HC (adaptado de Van Vlack, 2000). . . . . . . . . . . . . . 25

2.4 Formação de intrusões e consequentes trincas curtas, conforme a aplicação do carregamento cíclico (adaptado de Schijve (2008) e Mentley[(2013)). . . 26

2.5 Formação de intrusões e extrusões captado por Microscópio Eletrônico de Varredura (MEV) (Ma \& Laird,[1989). . . . . . . . . . . . . . . . . . . . . 27

2.6 Formação de PSBs em apenas alguns grãos. Crescimento de trincas de está-

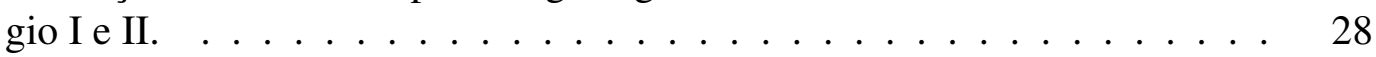

2.7 Nucleação de trincas de estágio I do Tipo A (crescimento ao longo da superfície) e do Tipo B (crescimento para dentro da superfície) (Socie, 2004a). . 29

2.8 Propagação de uma trinca de estágio II (Mentley[2013). . . . . . . . . . . 30

2.9 Estrias de fadiga em liga de alumínio 2014-T6 visto em MEV Meyers \& 30

2.10 Diferentes cenários de crescimento de uma trinca por fadiga (Schijve, 2008). 31

2.11 Representação das superfícies características de uma fratura em fadiga, com distinção da nucleação, propagação e instabilidade da trinca. . . . . . . . . . 32

3.1 Processo de previsão de vida de componente utilizando|Análise por Elementos Finitos (FEA) $\ldots \ldots \ldots \ldots \ldots$

3.2 Exemplo de curva $\mathrm{S}-\mathrm{N}$

$3.3 \quad$ Montagem do espécime na máquina de ensaio de fadiga. . . . . . . . . . 39

3.4 Tensão ao longo do tempo aplicada no espécime. . . . . . . . . . . . . . 39

$3.5 \quad$ Conceito do método $\varepsilon$-N baseado na deformação local (Socie, 2008). . . . . 41

$3.6 \quad$ Exemplo de curva $\varepsilon-\mathrm{N}$. . . . . . . . . . . . . . . . 41

$3.7 \quad$ Dimensões de um tipo de espécime utilizado para obtenção de curva $\mathcal{\varepsilon}-\mathrm{N}$. . $\quad 42$ 
3.8 Deformação cíclica aplicada no espécime de fadiga para obtenção da curva

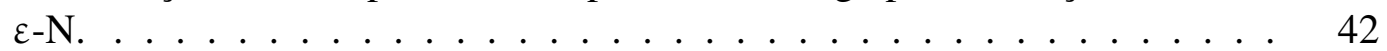

3.9 Crescimento de trinca em função do número de ciclos. . . . . . . . . . . . . . . . . 44

3.10 Lei de Paris. . . . . . . . . . . . . . . . . . . . . . . . . 46

3.11 Idealização do processo de projeto de fadiga. . . . . . . . . . . . . 47

3.12 Fase de Iniciação de Trinca e de Propagação de Trinca na curva S-N. . . . . . 47

3.13 Diagrama esquemático ilustrando as duas fases de fadiga (iniciação e propagação de trinca) em um componente de engenharia e os métodos usados para estimar a vida em fadiga $($ Suresh [1998). . . . . . . . . . . . . . . 49

3.14 Intervalos de inspeção na filosofia de Projeto Tolerante ao Dano. . . . . . . 52

$4.1 \quad$ Exemplo de espécime para ensaio de fadiga de flexão rotativa. . . . . . . . 57

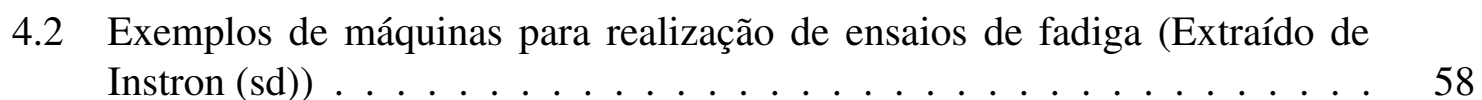

4.3 Símbolos usados no método S-N. . . . . . . . . . . . . . . . . . . 58

4.4 Ciclos de tensão com diferentes valores de tensão médias $\left(S_{m}\right)$ e razão de tensão $(R) . \ldots \ldots \ldots \ldots \ldots \ldots$

4.5 Exemplos de curvas $\mathrm{S}-\mathrm{N}$ para metais. . . . . . . . . . . . . . . 60

4.6 Desenho esquemático de Curva $S$-N Espécime para metais que exibem limite de fadiga (ex: aços ferríticos e martensíticos, ferros fundidos, ferros forjados, ligas de titânio e ligas de molibidênio) $\ldots \ldots$. . . . . . . . . 63

4.7 Interpretação gráfica dos parâmetros $C_{B, s p}$ e $C_{E, s p}$ em uma Curva S-N Espécime 65

4.8 Dados de 89 testes de fadiga em aços trabalhados (Do inglês, Wrought Steels) com $S_{u}<1400$ MPa usados por Juvinall (1967, pg. 210, fig. 11.7) para justificar a estimativa espressa pela equação (44.10) Juvinall[1967] . . . . . . . 66

4.9 Influência da microestrutura no limite de fadiga dos aços (Extraído de Juvi-

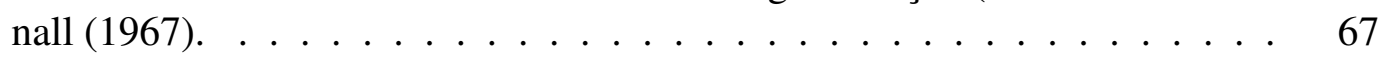

4.10 Relação entre limite de fadiga para flexão rotativa de espécimes não entalhados versus limite de resistência à tração (Coletado de dados compilados de Grover et al.(1960) e SAE International (1968, pg. 42)). . . . . . . . . . . 68

4.11 Relação entre limite de fadiga para flexão rotativa de espécimes de aço não entalhados versus limite de resistência à tração (Extraído de Forrest (1962)). 68

4.12 Resistência à fadiga $S_{B, s p}$ dos aços em $N=10^{3}$ ciclos (de Castro \& Meggiolaro, 2009a, fig. 4.28). . . . . . . . . . . . . . . 72

4.13 Relação entre resistência à fadiga de espécimes não-entalhados sob flexão rotativa e o limite de resistência à tração de ferros fundidos e ferros forjados

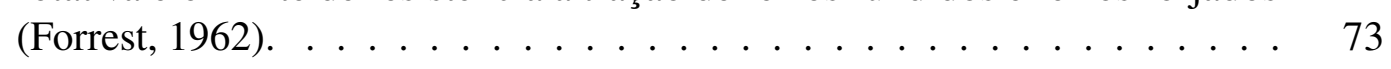

4.14 Curvas S-N Espécime para metais sem patamar de fadiga. . . . . . . . . . 75

4.15 Relação entre $S_{K, s p}$ e $S_{u}$ em ligas de alumínio. . . . . . . . . . . . . . . 76

4.16 Limites de fadiga de 218 ligas de alumínio. Os dados foram coletados da literatura e analisados por de Castro \& Meggiolaro(2009a). . . . . . . . . 77

4.17 Diferentes comportamentos em fadiga de curvas S-N e definição de limite de fadiga e limite de endurance (Susmel[,2009). . . . . . . . . . . . . . . . 78

4.18 Relação entre resistência à fadiga de espécimes sem entalhe sob flexão rotativa $\left(S_{K, s p}\right)$ e limite de resistência à tração $\left(S_{u}\right)$ em ligas de cobre (Forrest, 1962). 
4.19 Limite de endurance $\left(S_{K, s p}\right)$ de 71 ligas de bronze (de Castro \& Meggiolaro,

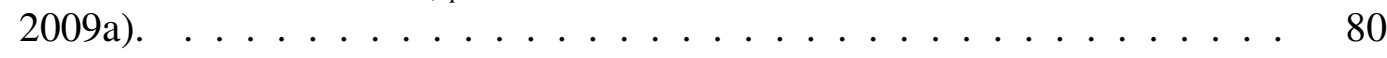

4.20 Limite de fadiga $\left(S_{E, s p}\right)$ de 49 ligas de titânio (de Castro \& Meggiolaro, 2009a). 80

4.21 Limite de fadiga de 60 polímeros (de Castro \& Meggiolaro, 2009a). . . . . 81

4.22 Curvas S-N de alguns polímeros (Meyers \& Chawla, 2009, fig. 14.4). . . . 82

4.23 Conceito da filosofia do método S-N (adaptado de de Castro \& Meggiolaro, 2009a) ................................. 87

4.24 Curva S-N obtida através da aplicação dos fatores modificadores. . . . . . . 93

4.25 Curva $\sigma-\mathrm{N}$ Local de um nó FE do componente, obtida com o uso dos fatores modificadores. . . . . . . . . . . . . . . . . 94

4.26 Componente mecânico genérico . . . . . . . . . . . . . . . . . . 94

4.27 Conceito do Método da Curva $\sigma-N$ Local aplicado em um componente analisado via o MEF (Extraído de Magna Powertrain (2011)). . . . . . . . . . 95

4.28 Descrição quantitativa do fator de tamanho $C_{L}$ (baseado nos dados de Heywood (1962) e Kuguel $(1961)) . \ldots \ldots \ldots$. . . . . . . . . . . 99

4.29 Descrição quantitativa do fator de rugosidade $C_{R O}$ para aços sob tensão normal (FKM-Guideline, 2003). . . . . . . . . . . . . . . . . 105

4.30 Diferença entre curvas S-N de alumínio trabalhando ao ar livre e sob água do mar. . . . . . . . . . . . . . . . 107

4.31 Resultado de 378 testes de fadiga do aço 980X para diversos níveis de tensão

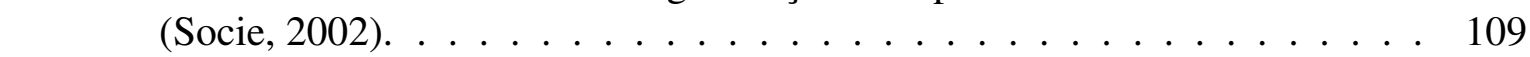

4.32 Interpolação da curva S-N (Socie, 2002). . . . . . . . . . . . . . . . . . 109

4.33 Curvas P-S-N e as duas maneiras de se interpretar uma curva S-N para dife-

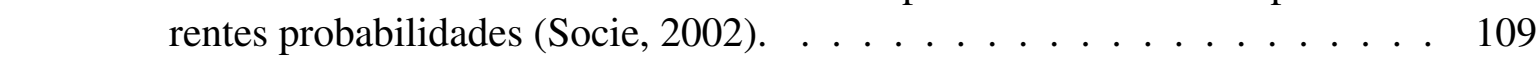

4.34 Construção dos gráficos de vida constante para tensão normal nas coordenadas $S_{a}$ e $S_{m}$ (Lee et al. 2011). . . . . . . . . . . . . . . . 116

4.35 Relações entre tensão alternada $\left(S_{a}\right)$, tensão média $\left(S_{m}\right)$ e razão de tensão (R) (Steinbeis GmbH \& Co, 2013). . . . . . . . . . . . . . . . . . . . 116

4.36 Diagrama de Haigh para contabilização do efeito da tensão média sob Tensão Cíclica Normal . . . . . . . . . . . . . . . . . . . . . 125

4.37 Construção do diagrama de Haigh para ferro fundido nodular (Magna Power-

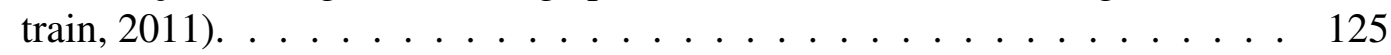

4.38 Construção do diagrama de Haigh para ferro fundido cinzento (Magna Power-

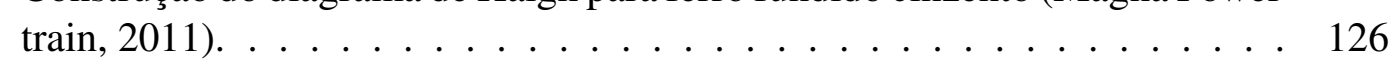

4.39 Diagrama de Haigh para contabilização do efeito da tensão média sob Tensão Cíclica Cisalhante . . . . . . . . . . . . . . 126

4.40 Componentes entalhado e não entalhado com a mesma vida em fadiga. . . . 130

4.41 Espécimes de fadiga com diferentes tipos de entalhes. . . . . . . . . . . . . 131

4.42 Efeito de um entalhe no comportamento Tensão-Vida de metais em regime

4.43 Curva S-N Local de amplitude constante para um componente entalhado de

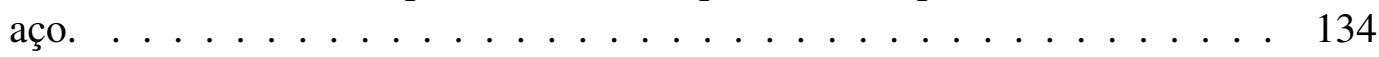

4.44 Distribuição de pseudo tensão e gradiente de tensão na raiz de um entalhe (adaptado de Eichlseder[(2000a)). . . . . . . . . . . . . . . 136

4.45 Efeito do gradiente de tensão relativo na razão $n_{K}=K_{t} / K_{f}$ para vários materiais em termos da resistência mecânica. . . . . . . . . . . . . . 
4.46 Efeito do gradiente de tensão relativo na razão $n_{K}=K t / K f$ para ligas de alumínio e latão (adaptado de Santus (2007) e de Moraes Filho(2007)). . . 138

4.47 Razão $\frac{K_{t}}{K_{f}}$ para tensão normal como função do gradiente de tensão relativo (FKM-Guideline, 2003). . . . . . . . . . . . . . . . . 140

4.48 Obtenção da Curva $\sigma$-N Local de um componente entalhado metálico (que possui limite de fadiga). . . . . . . . . . . . . . . . . . . 143

4.49 Obtenção da Curva $\sigma-\mathrm{N}$ Local de um componente entalhado metálico utilizando a inclinação $k_{u n} . \ldots \ldots \ldots \ldots \ldots$. . . . . . . . . . . . . . . . . .

4.50 Aplicação do Método de Rainflow em um histórico de tensões variável . . . 146

4.51 Matriz de Rainflow no nó $n_{i}$ localizado na superfície do modelo de Elementos Finitos (extraído de MathWorks (2010)). . . . . . . . . . . . . . . . . 147

4.52 Curva S-N Local de um componente entalhado modificada para contabilizar carregamento de amplitude variável. . . . . . . . . . . . . . . . . . 149

4.53 Curva $\sigma^{e}$-N Local de um componente entalhado modificada para contabilizar carregamento de amplitude variável. . . . . . . . . . . . . . . . . . 149

4.54 Curvas S-N já corrigidas pelo efeito da tensão média utilizando o modelo de

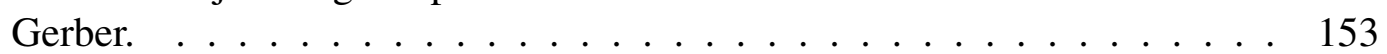

4.55 Curvas S-N já corrigidas pelo efeito da tensão média utilizando o modelo de

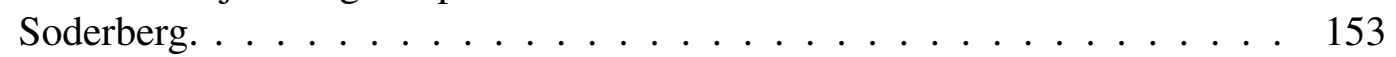

4.56 Curvas S-N já corrigidas pelo efeito da tensão média utilizando o modelo de Goodman. . . . . . . . . . . . . . . . . 154

4.57 Curvas S-N já corrigidas pelo efeito da tensão média utilizando o modelo de Morrow I. . . . . . . . . . . . . . . . . . 154

4.58 Curvas $\mathrm{S}-\mathrm{N}$ já corrigidas pelo efeito da tensão média utilizando o modelo ASME-Elíptico. . . . . . . . . . . . . . . 155

4.59 Curvas S-N já corrigidas pelo efeito da tensão média utilizando o modelo SWT. 155

4.60 Curvas S-N já corrigidas pelo efeito da tensão média utilizando o modelo de

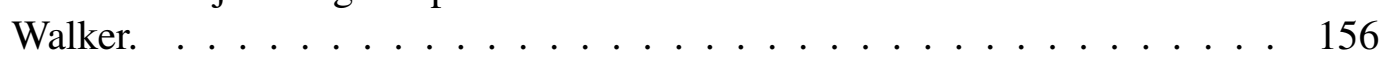

4.61 Parâmetro $\epsilon_{C_{m}}$ para o modelo de Gerber. . . . . . . . . . . . . . . . . . 159

4.62 Parâmetro $\epsilon_{C_{m}}$ para o modelo de Soderberg. . . . . . . . . . . . . . . . . . 159

4.63 Parâmetro $\epsilon_{C_{m}}$ para o modelo de Goodman. . . . . . . . . . . . . . . . . . 160

4.64 Parâmetro $\epsilon_{C_{m}}$ para o modelo de Morrow I. . . . . . . . . . . . . . . . . 160

4.65 Parâmetro $\epsilon_{C_{m}}$ para o modelo ASME-Elíptico. . . . . . . . . . . . . . . . 161

4.66 Parâmetro $\epsilon_{C_{m}}$ para o modelo SWT. . . . . . . . . . . . . . . . . . . 161

4.67 Parâmetro $\epsilon_{C_{m}}$ para o modelo de Walker. . . . . . . . . . . . . . . . . . . . 162

4.68 Parâmetro $\epsilon_{C_{m}}$ de todos os modelos de correção de tensão média, medido em um componente com $K_{t}=1,5 . \ldots \ldots \ldots$. . . . . . . . . . . 162

4.69 Parâmetro $\epsilon_{C_{m}}$ de todos os modelos de correção de tensão média, medido em um componente com $K_{t}=2,0 . \ldots \ldots \ldots \ldots$. . . . . . . . . . 163

4.70 Parâmetro $\epsilon_{C_{m}}$ de todos os modelos de correção de tensão média, medido em um componente com $K_{t}=3,0 . \ldots \ldots \ldots \ldots$. . . . . . . . . . 163

4.71 Parâmetro $\epsilon_{C_{m}}$ de todos os modelos de correção de tensão média, medido em um componente com $K_{t}=4,0 . \ldots \ldots \ldots \ldots$. . . . . . . . . . . . . .

4.72 Contabilização da matriz de Rainflow na curva $\sigma^{e}$-N Local de um componente entalhado. . . . . . . . . . . . . . . . . . 164

4.73 Perfil de dano por fadiga em todo o modelo FE. . . . . . . . . . . . 166 
5.1 Elemento infinitesimal na superfície de um eixo cilíndrico. . . . . . . . . . 174

$5.2 \quad$ Histórico de tensão normal e cisalhante na superfície do eixo. . . . . . . . . . 174

5.3 Tensões principais máxima e mínima com relação ao eixo local x, nos intervalos de tensão A até M, para carregamento proporcional. . . . . . . . . . . 175

5.4 Tensões principais máxima e mínima com relação ao eixo local $\mathrm{x}$, nos intervalos de tensão A até M, para carregamento não proporcional. . . . . . . . 176

5.5 Diagrama de fases dos dois tipos de carregamentos sobre o eixo. . . . . . . 177

$5.6 \quad$ Efeito do tipo de carregamento na vida em fadiga. . . . . . . . . . . . . 178

5.7 Históricos de carregamentos proporcionais e não proporcionais (Itoh et al.,

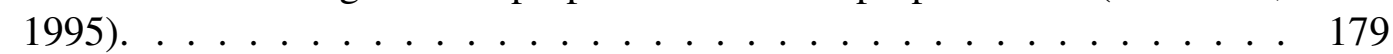

5.8 Definição do fator de proporcionalidade $\left(F_{N P}\right)$ a partir da história de deformações (Meggiolaro \& de Castro, 2005). . . . . . . . . . . . . . . . . 179

5.9 Comparação de curva $\sigma-\varepsilon$ cíclicas para o mesmo material sob carregamentos em fase e $90^{\circ}$ fora de fase. . . . . . . . . . . . . . . . 181

5.10 Razão de biaxialidade para vários casos de carregamento (adaptado de Heyes

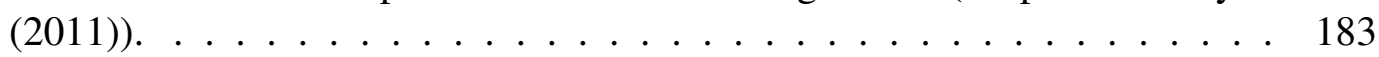

5.11 Transformação do tensor de tensão 3D dos nós superficiais em estado plano de tensões. . . . . . . . . . . . . . . . 186

5.12 Estado plano de tensões na superfície de um componente em uma malha de Elementos Finitos.

5.13 Exemplo de carregamento proporcional (MSC.Software, 2008). . . . . . . 187

5.14 Exemplo de carregamento não proporcional (MSC.Software, 2008). . . . . 188

5.15 Perfil da razão de biaxialidade em todo o modelo. . . . . . . . . . . . . . 189

5.16 Perfil de dano por fadiga em todo o modelo FE. . . . . . . . . . . . . . . . 190

5.17 Resumo para verificação do tipo de carregamento. . . . . . . . . . . . . . . 191

5.18 Exemplo de cálculo do gradiente de tensão relativo em uma malha de Elementos Finitos (Steinbeis GmbH \& Co, 2013). . . . . . . . . . . . . . . . . 193

5.19 Exemplo da aplicação do fator de entalhe $n_{K}$ em fadiga multiaxial em análise de fadiga baseada em Elementos Finitos (adaptado de Mentley \& Pompetzki

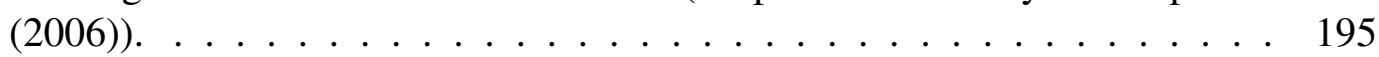

5.20 Histórico de tensão corrigido pelo fator de entalhe $\left(n_{K}\right)$ em análise de fadiga baseada em Elementos Finitos (adaptado de Mentley \& Pompetzki|(2006)). 196

5.21 Cálculo da vida de um componente sob fadiga multiaxial. . . . . . . . . . . 197

5.22 Ilustração do Método de Rainflow Multiaxial: histórico de tensão normal e de cisalhamento (extraído de Lee et al.(2011)). . . . . . . . . . . . . . . 199

5.23 Exemplo de componente entalhado. . . . . . . . . . . . . . . . 207

5.24 Forças e tensões aplicadas no componente entalhado ilustrado na figura 5.23] 208

5.25 Exemplo da aplicação do Critério da Tensão Principal Sinalizada em uma análise de fadiga baseada em Elementos Finitos. . . . . . . . . . . . . . 212

5.26 Cálculo da vida em fadiga de cada bloco $j$ da Matriz de Rainflow do nó $i$,

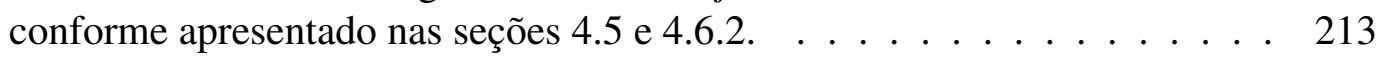

5.27 Tensões aplicadas no componente entalhado ilustrado na figura 5.24a. . . . 216

5.28 Exemplo da aplicação do Critério da Tensão de Cisalhamento Sinalizada em uma análise de fadiga baseada em Elementos Finitos. . . . . . . . . . . . . 219

5.29 Cálculo da vida em fadiga de cada bloco $j$ da Matriz de Rainflow do nó $i$, conforme apresentado nas seções $4.5|\mathrm{e}| 4.6 .2 \mid \ldots \ldots . . \ldots 220$

5.30 Tensões aplicadas no componente entalhado ilustrado na figura|5.23] . . . . 223 
5.31 Exemplo da aplicação do Critério de von Mises Sinalizado em uma análise de fadiga baseada em Elementos Finitos. . . . . . . . . . . . . . . 226

5.32 Cálculo da vida em fadiga de cada bloco $j$ da Matriz de Rainflow do nó $i$, conforme apresentado nas seções $4.5|\mathrm{e}| 4.6 .2 \mid \ldots \ldots 227$

5.33 Modelo de von Mises como o critério de fadiga multiaxial mais utilizado (Shamsaei \& Fatemi, 2010b). . . . . . . . . . . . . . . . . . . . . . 229

5.34 Exemplo da aplicação do Critério de Sines em uma análise de fadiga baseada em Elementos Finitos. . . . . . . . . . . . . . . 235

5.35 Cálculo da vida em fadiga de cada linha $j$ da Tabela Rainflow do nó $i$, conforme apresentado na seção 5.4$] \ldots \ldots \ldots 236$

5.36 Sistema de coordenadas auxiliar X'-Y'-Z' e transformação do tensor de tensão. 239

5.37 (a) Espécime sob carregamento multiaxial; (b) Plano de corte no material intitulado $\Delta$; (c) Vetor tensão $\mathbf{t}(\mathrm{t})$ atuando em um ponto do material $\mathbf{O} \mathrm{e}$ descrevendo um caminho de tensão $\Phi$; (d) Projeção do vetor tensão t(t) em um plano material $\Delta$ para um período de um ciclo de carregamento complexo gerando uma curva fechada $\Phi$ (adaptado de Araújo et al., 2011). . . . . . . 240

5.38 Cálculo do Máximo Envelope Retangular Circunscrito (MERC) no Plano $\Delta$ (adaptado de Araújo et al.(2011)). . . . . . . . . . . . . . . . . 242

5.39 Exemplo da aplicação do Critério de Findley em uma análise de fadiga baseada em Elementos Finitos. . . . . . . . . . . . . . . . . . . . . 249

5.40 Cálculo da vida em fadiga de cada linha $j$ da Tabela Rainflow do nó $i$, con-

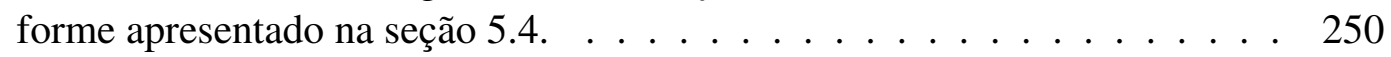

5.41 Exemplo de varredura de planos no modelo de Gaier e Dannbauer. . . . . . 252

5.42 Exemplo da aplicação do Critério de Gaier e Dannbauer em uma análise de fadiga baseada em Elementos Finitos. . . . . . . . . . . . . . . 257

5.43 Cálculo da vida em fadiga de cada bloco $j$ da Matriz de Rainflow do nó $i$,

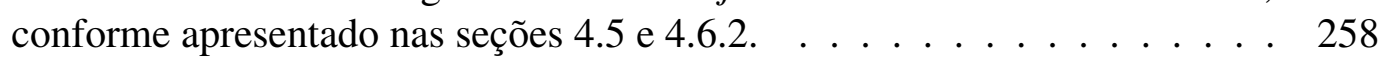

5.44 Tensões e deformações na escala macroscópica e mesoscópica. . . . . . . . 260

5.45 Acomodação elástica sob carregamento multiaxial vista no plano octaédrico (adaptado de Socie(2004a)). . . . . . . . . . . . . . . 261

5.46 Tensão cisalhante e hidrostática utilizadas no critério de Dang Van (adaptado de Heyes(2011)). . . . . . . . . . . . . . . . . . . . . . . . . . . . 265

5.47 Critério de Dang Van para sucesso ou falha. . . . . . . . . . . . . . . . 266

5.48 Análise de fadiga de um eixo sujeito à carregamento multiaxial não proporcional de amplitude variável, utilizando o modelo de Dang Van e o software nCode Design Life (HBM)] . . . . . . . . . . . . . . . . . . . 270

$6.1 \quad$ Fluxograma do processo global de análise de fadiga de um componente. . . 289

$6.2 \quad$ Etapa 1: Entrada de dados. . . . . . . . . . . . . . . . . . 290

6.3 Etapa 2: Propriedades de fadiga. . . . . . . . . . . . . . . . . . . . . . . . . . . . . . . . . . . . . . . . .

6.4 Etapa 3: Critério de Fadiga Multiaxial. . . . . . . . . . . . . . . . . . . . . 292

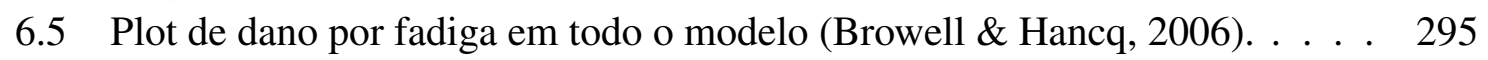

$6.6 \quad$ Plot da vida em fadiga em todo o modelo (Browell \& Hancq, 2006). . . . . 295

6.7 Algorítmo para o cálculo da razão de biaxialidade e da orientação $\phi_{p}$. . . . 296

6.8 Resultados de fadiga gerados em teste de espécimes cilíndricos sem entalhe de aço S690 sob flexão rotativa (Susmel[2009). . . . . . . . . . . . . . . 297 
6.9 Tensão e vida em fadiga nos nós de canto da superfície da malha FE, calculada utilizando o software $x$ Durability. . . . . . . . . . . . . . . . 298

6.10 Espécimes. . . . . . . . . . . . . . . . . . . 299

6.11 Curvas $\mathrm{S}-\mathrm{N}$. . . . . . . . . . . . . . . . . . . . . . . . . 300

6.12 Curvas $\sigma-\mathrm{N} \ldots \ldots \ldots \ldots \ldots \ldots$

6.13 Local de iniciação de trinca com um sistema de coordenadas em um componente estrutural sujeito a cargas externas (Lee et al., 2011). . . . . . . . . . 307

6.14 Planos críticos em potencial em um local de iniciação de trinca (Lee et al.,

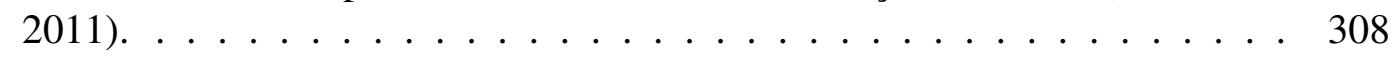

6.15 Dimensões da viga. . . . . . . . . . . . . . . . . . . . . . . 312

6.16 Viga engastada e nó número 110.877 . . . . . . . . . . . . . . . . . . . . 312

6.17 Instante de aplicação da força $F_{y} . \ldots \ldots \ldots$. . . . . . . . . 312

6.18 Instante de aplicação do momento torçor $M_{x}$. . . . . . . . . . . . . . . 312

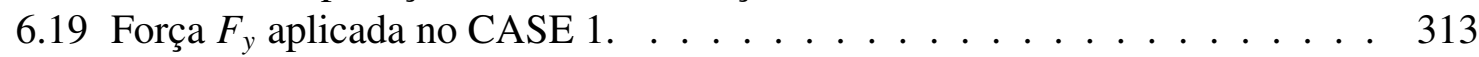

6.20 Momento $M_{x}$ aplicado no CASE 1. . . . . . . . . . . . . . . . 313

6.21 Tensões cíclicas aplicadas no nó 110.877 durante os 6 CASES. $\ldots . \ldots .314$ 



\section{Lista de Tabelas}

$3.1 \quad$ Distribuição entre fase de iniciação e propagação em metais. . . . . . . . . . 50

3.2 Comparação entre filosofias de projeto. . . . . . . . . . . . . . . 52

3.3 Comparação entre os Métodos de Previsão de Vida em Fadiga. . . . . . . . . 54

4.1 Estimativa do limite de fadiga de espécimes sob flexão rotativa $\left(S_{E, s p}\right)$ para aços (Extraído de Lee et al.(2005). . . . . . . . . . . . . . . . . 67

$4.2 \quad$ Fatores do limite de fadiga para aços (FKM-Guideline, 2003). . . . . . . . 69

4.3 Fatores do limite de fadiga para ferros fundidos (FKM-Guideline, 2003). . . 72

4.4 Fatores do limite de fadiga $\left(C_{E, s p}\right)$ para ligas de alumínio (adaptado de FKMGuideline, 2003] e Sonsino, 2007). . . . . . . . . . . . . . . . 77

4.5 Fator de correção em tensão normal $\left(C_{\sigma}\right)$ (Lee et al., 2005) . . . . . . . . . 98

4.6 Fator de correção de tensão de cisalhamento $\left(C_{\tau}\right)$ (FKM-Guideline, 2003). . 98

4.7 Constantes usadas para estimar o fator modificador de tamanho (FKM-Guideline,

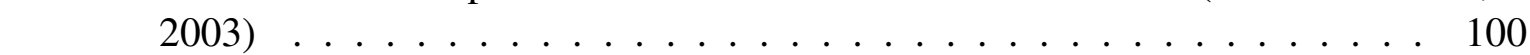

4.8 Cálculo do diâmetro efetivo $d_{\text {eff }}($ FKM-Guideline],2003) $\ldots$. . . . . . . . . 102

$4.9 a_{R}$ e $S_{u, \min }$ para vários metais FKM-Guideline (2003) $\ldots$. . . . . . . . . . . . 104

4.10 Fator de tratamento superficial para vários metais (adaptado de FKM-Guideline,

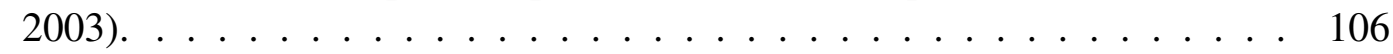

4.11 Fator de confiabilidade FKM-Guideline (2003). . . . . . . . . . . . . . . 112

4.12 Fator de confiabilidade usuais em projeto de fadiga. . . . . . . . . . . . . . 112

4.13 Métodos para a determinação de $C_{m}$ (adaptado de Lee et al.(2011), Dowling (2004), Susmel (2009) e Papuga (2005)) . . . . . . . . . . . . . . . . 119

4.14 Fatores $a_{C_{m}}$ e $b_{C_{m}}$ para vários materiais (em temperatura ambiente) FKM-

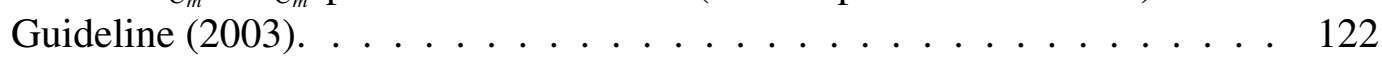

4.15 Fatores $a_{G}$ e $b_{G}$ para vários materiais (FKM-Guideline, 2003). . . . . . . . 139

4.16 Modelos de correção da tensão média utilizando pseudo tensões . . . . . . 152

$5.1 \quad$ Influência do caminho de carregamento na vida em fadiga. . . . . . . . . . 180

5.2 Coeficiente de encruamento não proporcional para vários metais (Socie \&

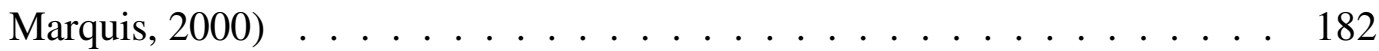

5.3 Resultado da Contagem de Reversão Multiaxial . . . . . . . . . . . . . . . 199

6.1 Resultados de fadiga gerados em teste de espécimes cilíndricos sem entalhe de aço S690 sob flexão rotativa. . . . . . . . . . . . . . . . . . . 296

6.2 Resultados do software $x$ Durability. . . . . . . . . . . . . . . . . . . . 297

6.3 Estimativa de vida utilizando a teoria. . . . . . . . . . . . . . . . . . . 298

6.4 Estimativa de vida utilizando análise numérica. . . . . . . . . . . . . . . . 299

6.5 Dados da Curva S-N azul e Curva $\sigma-\mathbf{N}$ azul. . . . . . . . . . . . . . . . 302 


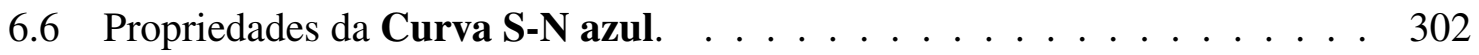

6.7 Propriedades da Curva $\sigma-\mathbf{N}$ azul. $\ldots \ldots \ldots \ldots$. . . . . . . . . . . . 302

6.8 Dados da Curva S-N vermelha e Curva $\sigma-N$ vermelha. . . . . . . . . . . 303

6.9 Propriedades da Curva S-N vermelha. . . . . . . . . . . . . . . . . . . . 303

6.10 Propriedades da Curva $\sigma-\mathbf{N}$ vermelha. . . . . . . . . . . . . . . . . . 303

6.11 Dados da Curva $S-N$ verde e Curva $\sigma-N$ verde. . . . . . . . . . . . . . 305

6.12 Propriedades da Curva S-N verde. . . . . . . . . . . . . . . . . . . . 305

6.13 Propriedades da Curva $\sigma-\mathbf{N}$ verde. . . . . . . . . . . . . . . . . . . . . . 305

6.14 Dados da Curva $\sigma-\mathbf{N}$ preta. $\ldots \ldots \ldots$. . . . . . . . . . . . . . 306

6.15 Propriedades da Curva $\sigma-\mathbf{N}$ preta. . . . . . . . . . . . . . . . . . . . 306

6.16 Tensões $\sigma_{n, \max }$ e $\tau_{a}$ em alguns planos de análise. . . . . . . . . . . . . . . . . 309

6.17 Tensões $\sigma_{n, \max }$ e $\tau_{a}$ em alguns planos de análise. . . . . . . . . . . . . . . 310

6.18 Cargas aplicadas na viga e tensões no nó crítico 110.877 para cada LoadStep. 316 6.19 Máxima Tensão de Findley $\left(\max _{\theta, \phi}\left\{\tau_{\text {findley,a }}\right\}\right)$ para o nó crítico e estimativa da vida em fadiga utilizando o Critério de Findley para cada CASE. . 31T 


\section{Lista de Abreviaturas e Siglas}

CAE Engenharia Assistida por Computador.

CCC Cúbica de Corpo Centrado.

CFC Cúbica de Face Centrada.

CFD Dinâmica dos Fluidos Computacional.

COV Coeficiente de variação (estatística).

FEA Análise por Elementos Finitos.

FKM Conselho Alemão de Pesquisa em Engenharia.

FKM-Guideline Diretriz Técnica do FKM.

HC Hexagonal Compacta.

HCF Fadiga de Alto Ciclo.

LCF Fadiga de Baixo Ciclo.

MBD Dinâmica de Sistemas Multicorpos.

MEF Método dos Elementos Finitos.

PSBs Bandas de deslizamento persistentes.

rpm Rotações por minuto.

RSG Gradiente de Tensão Relativo.

STD Desvio padrão (estatística).

UHCF Fadiga de Ultra-Alto Ciclo.

UTC Limite de Resistência à Compressão.

UTS Limite de Resistência à Tração. 



\section{Lista de Símbolos}

$A_{-1}$ Limite de fadiga de um componente sob tração-compressão alternada ( $\left.\mathrm{R}=-1\right)$.

$A_{0,5}$ Limite de fadiga de um componente sob carregamento axial com $\mathrm{R}=0,5$.

$A_{0}$ Limite de fadiga de um componente sob tração-compressão repetida (pulsante) $(\mathrm{R}=0)$.

$A_{E, \text { un }}$ Limite de fadiga de um componente, obtido com carregamento axial (tração-compressão), obtido com um determinado valor de Razão de Tensões (R).

$C_{C}$ Fator modificador de corrosão.

$C_{D}$ Fator modificador de tamanho.

$C_{L}$ Fator modificador de carregamento.

$C_{R}$ Fator modificador de confiabilidade.

$C_{T}$ Fator modificador de temperatura.

$C_{\sigma}$ Fator de correção em tensão normal.

$C_{\tau}$ Fator de correção em tensão cisalhante.

$C_{m}$ Fator modificador de tensão média, calculado utilizando tensões nominais.

$C_{B, \sigma}$ Fator de durabilidade para $N_{B}$ ciclos.

$C_{E, \sigma}$ Fator de durabilidade para $N_{E}\left(\right.$ ou $\left.N_{K}\right)$ ciclos).

$C_{R O}$ Fator modificador de rugosidade.

$C_{S T}$ Fator modificador de tratamento superficial.

$C_{m, \sigma^{e}}$ Fator modificador de tensão média, calculado utilizando pseudo tensões.

$C$ Coeficiente da curva $d a / d N$.

$D_{P M}$ Valor crítico do dano de Palmgreen-Miner.

E Módulo de elasticidade.

$F_{N P}$ Fator de não-proporcionalidade.

$H_{C, N P}$ Coeficiente da curva Ramberg-Osgood multiaxial. 
$K_{f}$ Fator de entalhe em fadiga.

$K_{t}$ Fator de concentração de tensão elástico.

$K_{c}$ Fator de intensidade de tensão crítico ou Tenacidade à fratura.

$K_{\max }$ Fator de intensidade de tensão máximo.

$K_{\min }$ Fator de intensidade de tensão mínimo.

$K$ Fator de intensidade de tensão.

$M_{\sigma}$ Fator de sensibilidade à tensão média.

$N_{B}$ Ciclo da fronteira LCF [em número de ciclos].

$N_{E}$ Ciclo do limite de fadiga [em número de ciclos].

$N_{K}$ Ciclo do limite de endurance [em número de ciclos].

$N_{T}$ Vida de transição [em número de ciclos].

$N_{i}$ Vida relacionada à fase de iniciação de trinca [em número de ciclos].

$N_{p}$ Vida relacionada à fase de propagação de trinca [em número de ciclos].

$N$ Vida [em número de ciclos].

$Q$ Razão de amplitudes.

$R_{Z}$ Valor médio da rugosidade da superfície (em $\left.\mu \mathrm{m}\right)$.

$R$ Razão de tensões.

$S_{f}^{\prime}$ Coeficiente de resistência à fadiga da Curva S-N Local.

$S_{f, s p}^{\prime}$ Coeficiente de resistência à fadiga da Curva S-N Espécime.

$S_{f, u n}^{\prime}$ Coeficiente de resistência à fadiga da Curva S-N Unnotched.

$S_{B}$ Resistência à fadiga para $N_{B}$ ciclos da Curva S-N Local.

$S_{E}$ Limite de fadiga da Curva $S$-N Local.

$S_{u}$ Limite de resistência à tração para 50\% de confiabilidade (R50\%), obtido em um ensaio de tração quase-estático para obtenção da curva $\sigma-\varepsilon$.

$S_{y}$ Limite de escoamento para 50\% de confiabilidade (obtido em um ensaio de tração quaseestático para obtenção da curva $\sigma-\varepsilon$ ).

$S_{B, s p}$ Resistência à fadiga para $N_{B}$ ciclos da Curva $S$-N Espécime.

$S_{B, \text { un }}$ Resistência à fadiga para $N_{B}$ ciclos da Curva $S-N$ Unnotched.

$S_{E, s p}$ Limite de fadiga da Curva $S$-N Espécime. 
$S_{E, u n}$ Limite de fadiga da Curva $S$-N Unnotched.

$S_{K, s p}$ Limite de endurance da Curva $S$-N Espécime.

$S_{K, \text { un }}$ Limite de endurance da Curva S-N Unnotched.

$S_{a}$ Tensão nominal alternada.

$S_{\max }$ Tensão nominal máxima.

$S_{m e s o, 1}$ Maior valor do elemento de dentro do Tensor de Tensão Deviatórica Mesoscópica no instante " $t$ ".

$S_{\text {meso } 3}$ Menor valor do elemento de dentro do Tensor de Tensão Deviatórica Mesoscópica no instante " $t$ ".

$S_{\text {min }}$ Tensão nominal máxima.

$S_{m}$ Tensão nominal média.

$S_{u, 97.5}$ Limite de resistência à tração para 97,5\% de confiabilidade (R97,5\%) obtido em um ensaio de tração quase-estático para obtenção da curva $\sigma-\varepsilon$.

$S_{u, c}$ Limite de resistência à compressão para 50\% de confiabilidade (R50\%), obtido em um ensaio de compressão quase-estático para obtenção da curva $\sigma-\varepsilon$.

$S$ Tensão nominal.

$T_{-1}$ Limite de fadiga de um componente sob torção alternada $(\mathrm{R}=-1)$.

$T_{0}$ Limite de fadiga de um componente sob torção repetida (pulsante) $(\mathrm{R}=0)$.

$T_{E, \text { un }}$ Limite de fadiga de um componente, obtido sob torção, obtido com um determinado valor de Razão de Tensões (R).

$V$ Razão entre a tensão principal máxima absoluta e a tensão principal mínima absoluta.

$Y$ Fator adimensional função da geometria da trinca.

$\Delta K$ Variação do fator de intensidade de tensão.

$\Delta^{*}$ Plano crítico.

$\alpha_{F}$ Fator de sensibilidade à tensão normal de Findley.

$\alpha_{S}$ Fator de sensibilidade à tensão normal de Sines.

$\alpha_{G D}$ Fator de tensão normal ajustada.

$\alpha_{N P}$ Coeficiente de sensibilidade à carregamento não-proporcional.

$\beta_{F}$ Limite de fadiga de Findley.

$\beta_{S}$ Limite de fadiga de Sines. 
$\chi_{\sigma}^{\prime}$ Gradiente de Tensão Relativo para tensão normal.

$\chi_{\tau}^{\prime}$ Gradiente de Tensão Relativo para tensão cisalhante.

$\chi^{\prime}$ Gradiente de Tensão Relativo.

$\epsilon_{C_{m}}$ Erro relativo de $C_{m}$.

$\gamma$ Parâmetro de material utilizado no modelo de Walker para correção de tensão média.

$\phi_{P}$ Orientação da tensão principal máxima.

$\underline{S}(t)$ Tensor de Tensão Deviatórica Macroscópica.

$\underline{S}_{\text {meso }}$ Tensor de Tensão Deviatórica Mesoscópica.

$\underline{\rho}^{*}$ Tensor de Tensão Residual Local na Escala Mesoscópica.

$\underline{\sigma}(t)$ Tensor de Tensão Macroscópica.

$\underline{\sigma}_{h}(t)$ Tensor de Tensão Hidrostática.

$\underline{\sigma}_{m e s o}(t)$ Tensor de Tensão Mesoscópica.

$\sigma_{f}^{\prime}$ Pseudo coeficiente de resistência à fadiga. Também chamado de coeficiente de resistência à fadiga da Curva $\sigma-N$ Local.

$\sigma^{e}$ Pseudo tensão ou tensão fictícia.

$\sigma_{1}$ Tensão principal máxima.

$\sigma_{2}$ Tensão principal intermediária.

$\sigma_{3}$ Tensão principal mínima.

$\sigma_{E}^{e}$ Pseudo limite de fadiga. Também chamado de limite de fadiga da Curva $\sigma-N$ Local.

$\sigma_{a}^{e}$ Pseudo tensão alternada.

$\sigma_{f}$ Tensão verdadeira de fratura.

$\sigma_{m}^{e}$ Pseudo tensão média.

$\sigma_{1, \text { signed,a }}$ Amplitude da tensão principal máxima sinalizada.

$\sigma_{1, \text { signed,m }}$ Média da tensão principal máxima sinalizada.

$\sigma_{1, \text { signed }}$ Tensão principal máxima sinalizada.

$\sigma_{E, s p, R=0}$ Limite de fadiga da Curva $S$-N Espécime obtida com carregamento de tração pulsante $(R=0)$.

$\sigma_{E, s p}$ Limite de fadiga da Curva $S$-N Espécime obtida com carregamento de tração-compressão alternada $(\mathrm{R}=-1)$.

$\sigma_{G D}$ Tensão de Gaier e Dannbauer. 
$\sigma_{V M, a}$ Amplitude da tensão de von Mises.

$\sigma_{V M, m}$ Média da tensão de von Mises.

$\sigma_{V M, s i g n e d}$ Tensão de von Mises sinalizada.

$\sigma_{e q, a}$ Tensão equivalente alternada.

$\sigma_{e q}$ Tensão equivalente.

$\sigma_{h, m}$ Componente hidrostática das tensões médias.

$\sigma_{\max }^{e}$ Pseudo tensão máxima.

$\sigma_{\text {min }}^{e}$ Pseudo tensão mínima.

$\sigma_{n, \max }$ Máxima tensão normal ao plano Delta.

$\sigma$ Tensão.

$\tau_{a}$ Máxima amplitude de tensão cisalhante.

$\tau_{E, s p}$ Limite de fadiga da Curva $S$-N Espécime obtida com carregamento de torção alternada $(\mathrm{R}=-1)$.

$\tau_{F, a}$ Tensãp de Findley.

$\tau_{\text {meso }}$ Tensão Cisalhante Mesoscópica.

$\tau_{\text {oct,a }}$ Tensão de cisalhamento octaédrica alternada.

$\tau_{\text {signed,a }}$ Amplitude da tensão de Tresca sinalizada.

$\tau_{\text {signed,m }}$ Média da tensão de Tresca sinalizada.

$\tau_{\text {signed }}$ Tensão de Tresca sinalizada.

$\varepsilon^{e}$ Pseudo deformação ou deformação fictícia.

$\varepsilon_{e q}$ Deformação equivalente.

$\varepsilon_{a, e}$ Deformação alternada elástica.

$\varepsilon_{a, p}$ Deformação alternada plástica.

$\varepsilon_{a}$ Deformação alternada total.

$\varepsilon_{f}^{\prime}$ Coeficiente de ductilidade à fadiga.

$\varepsilon$ Deformação.

$a_{c}$ Tamanho crítico de trinca.

$a_{i}$ Tamanho inicial de trinca.

$a_{s s}$ Parâmetro de material de Siebel e Stieler. 
a Tamanho da trinca.

$a$ Razão de biaxialidade.

$b_{\sigma}$ Pseudo Expoente de resistência à fadiga. Também chamado de expoente de resistência à fadiga (ou inclinação) da Curva $\sigma-N$ Local.

$b_{s p}$ Expoente de resistência à fadiga (ou inclinação) da Curva S-N Espécime.

$b_{u n}$ Expoente de resistência à fadiga (ou inclinação) da Curva S-N Unnotched.

$b$ Expoente de resistência à fadiga (ou inclinação) da Curva S-N Local.

$c$ Expoente de ductilidade à fadiga.

$d_{\text {eff }}$ Diâmetro efetivo.

$d a / d N$ Taxa de propagação de trinca por fadiga [mm/ciclo ou $\mathrm{m} /$ ciclo].

$k_{s p}^{*}$ Fator de inclinação da Curva S-N Espécime para a região de ultra-alto ciclo.

$k_{\sigma}$ Fator de inclinação da Curva $\sigma-N$ Local.

$k_{s p}$ Fator de inclinação da Curva $S$-N Espécime.

$k_{u n}$ Fator de inclinação da Curva S-N Unnotched.

$k$ Fator de inclinação da Curva S-N Local.

$m$ Expoente da curva $d a / d N$.

$n_{2}$ Expoente de encruamento da Equação de Ramberg-Osgood.

$n_{K}$ Fator de entalhe.

$n_{K, \sigma}$ Fator de entalhe para tensão normal.

$n_{K, \tau}$ Fator de entalhe para tensão cisalhante.

$n$ Expoente de encruamento da Equação de Ludwik.

$q$ Fator de sensibilidade ao entalhe. 


\section{Capítulo 1}

\section{Introdução}

\subsection{Contextualização}

Fadiga é um tipo de falha mecânica, causada pela aplicação repetida de carregamentos variáveis. Este modo de falha é caracterizado pela nucleação e propagação lenta e gradual de trincas que levam à ruptura e ao colapso súbito de um componente mecânico devido às variações de tensão e deformação.

É um fenômeno complexo, de intenso caráter estatístico e dependente de diversos fatores como: carregamento, geometria, microestrutura do material, processos de fabricação (tensões residuais, acabamento superficial, tratamentos superficiais, defeitos, etc.) e fatores ambientais (temperatura, corrosão, etc.).

Grande parte das falhas que ocorrem em componentes mecânicos sujeitos a carregamentos dinâmicos é decorrente da fadiga. É importante salientar que os níveis de tensão em que ocorre a ruptura em carregamento cíclico são muito inferiores aos necessários para ruptura por carregamento estático. Aliás, o fenômeno de fadiga ocorre em componentes sujeitos à tensões abaixo do limite de escoamento do material do componente.

Esforços têm sido realizados desde 1837 a fim de se entender quais fatores influenciam na falha por fadiga e, também, para criar uma metodologia sistêmica e confiável para prever a durabilidade estrutural de produtos. A criação de uma metodologia para previsão de vida em fadiga 11 permite que a análise de durabilidade seja feita antes da manufatura do produto, possibilitando assim a modificação deste ainda na fase de projeto, em caso do não atendimento aos requisitos.

Antes de 1960, o desenvolvimento de componentes mecânicos quanto à fadiga era fortemente dependente de ensaios com produtos em escala real, pois uma metodologia não estava

\footnotetext{
${ }^{1}$ Entende-se por vida em fadiga quantos ciclos um componente ou estrutura irá suportar até que ocorra sua ruptura do mesmo devido ao fenômeno de fadiga.
} 
desenvolvida o suficiente de maneira a prever com boa precisão a vida em fadiga destes componentes, cuja geometria, carregamento e outros fatores eram frequentemente complexos. Costumava-se construir os componentes, colocá-los em bancadas de teste, aplicar ciclos de carregamento sobre estes e verificar quando ocorreria a falha por fadiga. Este procedimento de teste chama-se ensaio de fadiga de componente e era realizado com muitas amostras, devido à considerável dispersão intrínseca ao fenômeno de fadiga. Quando os resultados dos ensaios demonstravam que o componente falhava antes da vida desejada, costumava-se alterar o produto, fabricar a nova versão e realizar todos os ensaios novamente, a fim de verificar se o produto alterado atenderia aos requisitos. Este processo era repetido exaustivamente até que os requisitos de projeto fossem atendidos. Consequentemente, o processo de avaliação de vida em fadiga de componentes era longo e custoso. Por causa da metodologia pouco desenvolvida e dos altos custos dos ensaios, os engenheiros preferiam projetar componentes contendo altos fatores de segurança, de maneira que os mesmos atendessem os critérios de projeto no primeiro ensaio.

A partir de 1960, com o surgimento de computadores, programas computacionais começaram a ser desenvolvidos e utilizados afim de auxiliar engenheiros nos mais diversos projetos, principalmente em cálculos matemáticos complexos. Com o passar do tempo, estas técnicas foram implementadas computacionalmente sendo que em 1965 foi lançado pela NASA o primeiro software de FEA, o Nastran (Nasa Stress Analysis), cuja função era realizar análises estruturais de estruturas complexas. A partir deste momento, houve uma grande melhoria na previsão do comportamento mecânico de componentes, estruturas e sistemas com geometria e características complexas, inclusive aqueles sujeitos à fadiga.

Há outro motivo para a análise de fadiga ser realizada computacionalmente, a ser descrito a seguir. Estruturas reais sob carregamentos cíclicos estão frequentemente sujeitas a estados de tensões multiaxiais cíclicas. Alguns exemplos são: virabrequins, blocos de motores, eixos, ponta de eixo, manga de eixo, bandeja de suspensão, monoblocos de veículos, carcaças de máquinas no geral, etc. A utilização da teoria de fadiga uniaxial na avaliação da vida em fadiga de componentes sujeitos à fadiga multiaxial leva a resultados grandemente errados. A razão disso é que os critérios de falha de fadiga uniaxial não consideram a multiaxialidade de tensões. Geralmente, tensões multiaxiais cíclicas resultam em vidas em fadiga muito menores do que tensões uniaxiais cíclicas. Portanto, componentes sujeitos à fadiga multiaxial devem indiscutivelmente ser analisados utilizando a teoria de fadiga multiaxial. A previsão da vida útil em um problema de fadiga multiaxial é mais complexa, difícil e demorada, comparada à fadiga uniaxial., sendo necessários profundos conhecimentos da parte do engenheiro para se resolver o problema de maneira adequada. O motivo disso é que os critérios de fadiga multiaxial que geram bons resultados estão baseados na idéia de que a variável dano de cada ponto deve ser maximizada ${ }^{2}$ Logo, em cada ponto do componente tem-se uma

\footnotetext{
${ }^{2} \mathrm{O}$ capítulo 5 apresentará em detalhes os critérios de fadiga multiaxial.
} 
etapa com dezenas de passos. A situação se agrava ainda mais porque é necessário fazer esta varredura para cada ponto da estrutura. Não há dúvida, portanto, que análises de fadiga multiaxial necessitem evidentemente serem realizadas em um computador.

Nos últimos 10 anos, a Análise de Fadiga Baseada em Elementos Finitos, do inglês FEBased Fatigue Analysis, tem se tornado cada vez mais utilizada e confiável no projeto de durabilidade de produtos e estruturas. Este tipo de análise utiliza os resultados de Análises por Elementos Finitos (os valores de tensões ou deformações ao longo do tempo) para realizar a previsão de vida em fadiga. Aliás, a facilidade e rapidez na resolução de problemas complexos utilizando Análises por Elementos Finitos, a disseminação do uso de FEA na indústria e a facilidade em se realizar análises de fadiga complexas são os principais fatores que têm aumentado o uso da Análise de Fadiga baseada em Elementos Finitos. Socie (2004b) relata sua opinião de que "há a necessidade de ferramentas para análise de fadiga fáceis de serem utilizadas, assim previsões de vida em fadiga poderão ser confiavelmente conduzidas por especialistas e não-especialistas.”. Recentes avanços em análise de fadiga significam que ela pode ser tão precisa quanto outros aspectos na engenharia. Além do mais, avanços em projeto de software estão também reduzindo drasticamente o tempo de análise. Atualmente, o estado da arte de uma Análise de Fadiga baseada em Elementos Finitos não mais está limitada apenas a cálculos da vida em fadiga. Os atuais softwares de fadiga, baseados em resultados de Análise por Elementos Finitos, podem agora incluir o nível de tensões de trabalho seguro, curvas de garantia do produto, efeitos de altas temperaturas, influência dos processos de manufatura do componente e a influência das tensões de montagem. Embora estes softwares contenham recursos poderosos que facilitam o trabalho do engenheiro de CAE Engenharia Assistida por Computador), muita experiência e know-how são ainda necessários para obter bons resultados de simulações de fadiga e durabilidade de um componente, estrutura ou produto. A razão disso é que todos os recursos de dentro desses softwares são derivados da teoria de fadiga. Logo, para saber utilizá-los adequadamente, é necessário que o usuário conheça a teoria em que se baseiam os recursos disponíveis. Adicionalmente, muita experiência é necessária porque um problema de fadiga é governado por uma grande quantidade de variáveis, como exemplo:

- Determinação correta, precisa e confiável do valor das tensões e/ou deformações ao longo do tempo, em cada ponto do componente/estrutura;

- Existência de ampla variedade de parâmetros de material, que são difíceis de serem obtidos através de ensaios;

- Entendimento do conceito e parâmetros das curvas S-N e $\mathcal{\varepsilon}-\mathrm{N}$ e habilidade para estimar os parâmetros das mesmas (a serem vistas nos capítulos 4 e 5 ;

- Existência de muitos critérios de fadiga baseados em tensão e em deformação para fadiga uniaxial. O número aumenta ainda mais quando consideramos os critérios de fadiga multiaxial baseados em tensão e em deformação;

- Necessidade de se utilizar critérios de fadiga diferentes para carregamento proporcional e não proporcional; 
- Métodos específicos para metais dúcteis e frágeis;

- Entendimento do conceito de plano crítico e dos critérios baseados em plano crítico;

- Existência de um método diferente para contagem de ciclos na presença de carregamento multiaxial.

Não há dúvida, portanto, que não é trivial nem fácil realizar uma análise de durabilidade de um componente. A figura 1.1 ilustra o cálculo estrutural de um braço de suspensão inferior de um carro, utilizando o Método dos Elementos Finitos (MEF). Esta análise tem o objetivo de se determinar os valores das tensões flutuantes neste componente. Com esta informação, os engenheiros são capazes de avaliar qual será a vida em fadiga deste componente. A figura 1.2 apresenta o atual processo de análise de durabilidade utilizado na indústria. Este processo consiste na integração das ferramentas computacionais para a resolução de problemas de engenharia. Neste exemplo, uma análise de Dinâmica de Sistemas Multicorpos (MBD) de um veículo completo é realizada utilizando carregamentos de pista obtidos por medição in-loco. O resultado desta análise vai determinar quais os locais e direções dos carregamentos em cada componente do automóvel. Em cada componente, realiza-se uma Análise por Elementos Finitos com os carregamentos obtidos na etapa anterior. Por fim, utiliza-se os resultados de tensão da etapa anterior para realizar a análise de fadiga em cada componente. Esta análise geralmente é feita em softwares específicos para esta função, como o $n$ Code Design Life (HBM), o FEMFAT (Magna Powertrain), o MSC Nastran Embedded Fatigue (MSC.Software), o fe-safe (Dassault Systèmes), o winLIFE (Steinbeis Foundation) e o $F a$ tiga (Fatec Engineering), A figura 1.3 ilustra o teste de durabilidade em um veículo completo da marca Lexus $^{\circledR}$, utilizando um simulador de pista. Este ensaio tem o objetivo de determinar experimentalmente a vida em fadiga de vários componentes do veículo. O simulador é composto de atuadores hidráulicos que conseguem aplicar em cada uma das rodas carregamentos em todas as direções ${ }^{3}$.

\subsection{Aspectos Históricos}

De acordo com Schütz (1996), falhas por fadiga em componentes estruturais foram publicadas pela primeira vez em 1837 pelo engenheiro Wilhelm Albert, que elaborou uma máquina de ensaio para avaliar a durabilidade de correntes transportadoras utilizadas nas minas de Clausthal-Zellerfeld/Alemanha, onde trabalhava. Entretanto, a primeira pesquisa científica e sistemática em fadiga foi publicada em 1870, pelo engenheiro August Wöhler. Este trabalho foi o resultado de 10 anos de ensaios de fadiga, que objetivavam entender as constantes falhas nos eixos ferroviários que ocorriam na época. Desde então, o número de trabalhos publicados e novas ferramentas da área cresce vertiginosamente. Schijve (2008)

\footnotetext{
${ }^{3}$ Forças e Momentos nas 3 direções ortogonais, totalizando 6 tipos de carregamento em cada roda.
} 


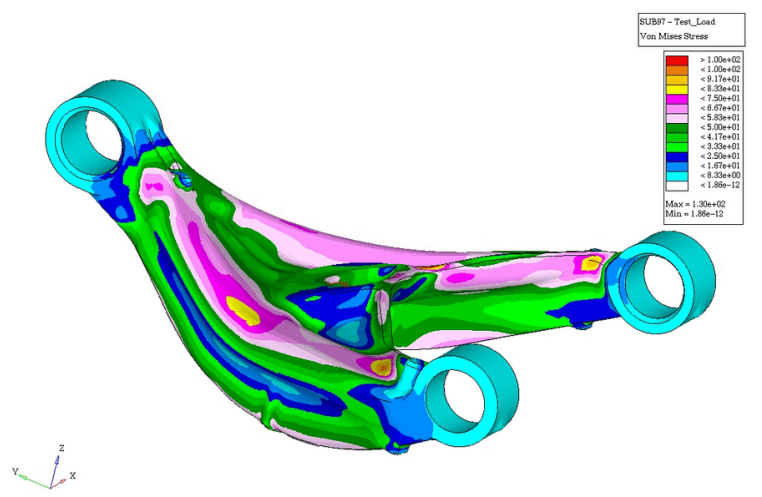

Figura 1.1 Análise estrutural de um braço de suspensão inferior de um carro através do Método dos Elementos Finitos (Compass Automotive Group, 2013).

corroba esse fato ao afirmar que menos de 100 trabalhos foram publicados no século XIX, enquanto que aproximadamente 100.000 referências foram publicadas no século XX.

Segue abaixo um histórico sobre os trabalhos e os acontecimentos mais importantes na área da fadiga dos materiais:

1837 Wilhelm Albert, engenheiro de minas, publica o primeiro artigo sobre fadiga (Schütz, 1996). Ele elaborou uma máquina para ensaio de correntes transportadoras utilizadas em minas. Seu artigo mostrava a correlação entre carga aplicada nas correntes e durabilidade das mesmas.

1839 Jean-Victor Poncelet projeta um eixo de ferro fundido para moinhos e utiliza o termo fadiga pela primeira vez em um livro sobre Mecânica (Schütz, 1996). Ele descreve os metais como estando cansados nas suas palestras em Metz-França. O termo fadiga foi utilizado devido à analogia com o corpo humano, que chega à exaustão (também chamado de fadiga) após executar tarefas durante horas sem descansar.

1870 August Wöhler publica pela primeira vez resultados de uma pesquisa científica sistemática que durou 10 anos para ser concluída (Schütz, 1996). Wöhler tinha o objetivo de descobrir porque inúmeras falhas em eixos ferroviários estavam ocorrendo na época. Para isto, ele realizou ensaios nos mesmos para entender como eles falhavam quando submetidos a carregamento cíclico. Ele concluiu que o intervalo de tensão cíclica é mais importante que o pico de tensão e introduziu os conceitos de Curva $S-N$ e Limite de Fadiga.

1887 Lanza constrói a primeira máquina de teste de fadiga rotativa de flexãotorção e apresenta o primeiro trabalho sobre Fadiga Multiaxial (Socie \& Marquis, 2000). 
1903 James Alfred Ewing realiza estudos da microestrutura dos metais utilizando microscópios e propõe a Teoria de Cristalização (Schütz, 1996). Ele foi o primeiro a propor que as falhas por fadiga eram originadas em defeitos microscópicos ou em Bandas de Deslizamento Persistentes. Ewing também observou que o colapso de um componente devido à fadiga é causado por uma única trinca dominante.

1910 Olin Hanson Basquin, na época professor da Universidade de Northwestern em Illinois (EUA), analisou os dados dos testes de Wöhler de 40-50 anos antes e percebeu que o número de ciclos diminuía em uma relação potencial com a tensão (Schütz, 1996). Desta maneira, foi proposto que a curva $\mathrm{S}-\mathrm{N}$ poderia ser representada através de uma relação log-log entre tensão (S) e vida (N) (Schütz, 1996). A utilização dos dados de Wöhler por Basquin indica que Wöhler era muito conhecido pelos pesquisadores das gerações seguintes e que poucos dados experimentais novos foram obtidos do período de Wöhler até Basquin.

1911 Leonard Bairstow realiza ensaios com carregamentos cíclicos acima do limite de escoamento e, combinando as pesquisas de Bauschinger e Ewing, descobre o fenômeno intitulado de Laços de Histerese (Hysteresis Loops) (Schütz, 1996).

1945 M. A. Miner populariza o conceito de acúmulo linear de dano em fadiga (Miner, 1945), criado por A. Palmgren em 1924 (Palmgren, 1924), como sendo uma ferramenta prática do projeto de componentes. Esta hipótese de acúmulo linear de dano ficou conhecida como Regra de Palmgren-Miner.

1950 H. J. Gough e H. V. Pollard realizam o primeiro trabalho sistemático na área de Fadiga Multiaxial (Gough, 1950, Gough \& Pollard, 1935). Eles executaram diversos testes de fadiga com corpos de prova submetidos a cargas axiais e torcionais cíclicas, aplicadas simultaneamente. A partir da análise desses dados, eles propuseram equações que estimam quando ocorre falha por fadiga na presença de carregamentos multiaxiais cíclicos, tanto para metais dúcteis quanto frágeis.

1954 Louis F. Coffin e Samuel Stanford Manson, trabalhando independentemente em problemas de fadiga térmica, propõe um novo conceito em análise de fadiga (Coffin, 1954a b; Manson, 1953), que utiliza valores de deformação cíclica, $\varepsilon$, para o cálculo de vida em fadiga ao invés de valores de tensão, introduzido por A. Wöhler. A nova metodologia necessita do levantamento de curvas $\varepsilon-\mathrm{N}$ do material analisado. A equação que descreve as curvas $\varepsilon-\mathrm{N}$ é chamada Equação de Coffin-Manson. 
1959 William Nichols Findley enuncia o Critério de Findley (Findley, 1959), primeiro critério de Fadiga Multiaxial baseado na ideia de Plano Crítico. Este critério nasceu a fim de determinar a vida de estruturas sujeitas a carregamentos que geram estados de tensão multiaxiais cíclicos.

1961 Paul C. Paris propõe um método para prever a taxa de crescimento de uma trinca individual sujeita a carregamento cíclico (Schütz, 1996). Surge então a Teoria de Propagação de Trincas (Metodologia $d a / d N$ ) que utiliza os conceitos do Fator de Intensidade de Tensões $(\Delta K)$ em carregamentos cíclicos.

1968 M. Matsuishi e Tatsuo Endo elaboram um algoritmo de contagem que possibilita, juntamente com a regra de Palmgren-Miner, estimar a vida em fadiga de estruturas sujeitas a carregamentos cíclicos com amplitude variável, como os carregamentos aleatórios encontrados em automóveis, aeronaves e navios (Schütz, 1996). O nome deste algoritmo é Método de Contagem de Ciclos Rainflow ou apenas Método de Rainflow.

1970 Wolf Elber explica o fenômeno de Fechamento da Trinca de Fadiga e propõe que este conceito seja introduzido na previsão de vida em fadiga através da Mecânica da Fratura (Schütz, 1996). Esta descoberta melhora significativamente a previsão de vida em fadiga baseada na Mecânica da Fratura.

1996 H. C. Wang e M. W. Brown (Wang \& Brown, 1996) propõe um método que permite a identificação do número de ciclos a serem utilizados no cálculo de vida em fadiga de estruturas sujeitas a carregamentos multiaxiais cíclicos de amplitude variável. A regra de Palmgren-Miner pode ser utilizada apenas em carregamentos que geram estado de tensão uniaxial na estrutura, portanto o método de contagem de Wang e Brown pode ser considerado como uma versão multiaxial da regra de Palmgren-Miner. Este método ficou conhecido como Método de WangBrown.

1990's A década de 1990 se caracteriza pela disseminação e utilização intensa de ferramentas computacionais na resolução de problemas de engenharia, principalmente no âmbito industrial (Socie, 2002). As principais ferramentas computacionais utilizadas pela indústria são FEA, Análise de MBD e Análise de Dinâmica dos Fluidos Computacional (CFD). 
2000 Diversos pesquisadores têm proposto modelos de acúmulo de dano em fadiga, baseados na Mecânica do Dano Contínuo (Desmorat, 2006). Como exemplo, pode-se citar Lemaitre, Chaboche e Paas. Embora estes modelos sejam mais complexos e pareçam ser mais precisos, ainda não são utilizados na indústria devido à complexidade, devido à falta de softwares comerciais que contenham estes modelos e principalmente ao alto custo computacional.

2000's A década de 2000 se caracteriza pela integração das ferramentas computacionais disseminadas na década de 1990. Estas ferramentas, que na década anterior eram utilizadas individualmente, são melhoradas e passam a se comunicar facilmente umas com as outras. Como exemplo, uma análise de durabilidade de componentes veiculares sujeitos à carregamentos de pista é realizada mais facilmente; para isso, necessita-se realizar uma análise de Dinâmica de Sistemas Multicorpos, logo após utilizar os resultados em uma Análise por Elementos Finitos e, por último, utilizar os resultados de FEA em uma análise de fadiga (intitulada FE-Fatigue Based Analysis).

2007 Cetin Morris Sonsino publica um artigo (Sonsino, 2007) com conclusões importantes na área da fadiga de ultra-alto ciclo. Neste artigo, diversos metais são testados em fadiga até a região de ultra-alto ciclo (i.e. após $10^{6}$ ciclos). A conclusão é que nenhum dos metais testados apresentou Limite de Fadiga. Sonsino conclui o artigo afirmando que o Limite de Fadiga não existe para os metais, em oposição ao que Wöhler informou 137 anos atrás.

\subsection{Acidentes e Motivação do Trabalho}

A comunidade científica e a indústria possuem grande interesse nesta área devido a falhas por fadiga resultarem em amplos prejuízos financeiros e à segurança das pessoas.

No âmbito econômico, Dowling (1998) afirma, baseado em dados do relatório do governo norte-americano (Reed et al., 1983):

"O custo anual da fadiga em materiais para a economia dos Estados Unidos em 1982 foi de aproximadamente US\$ 100 bilhões, correspondendo a $3 \%$ do Produto Interno Bruto daquele ano. Estes custos resultam da ocorrência e prevenção de falhas por fadiga em veículos rodoviários, veículos ferroviários, aeronaves de todos os tipos, pontes, guindastes, equipamentos de usinas elétricas, estruturas offshore e uma grande variedade de máquinas e equipamentos, incluindo itens domésticos de uso cotidiano como brinquedos e equipamentos de esporte." 


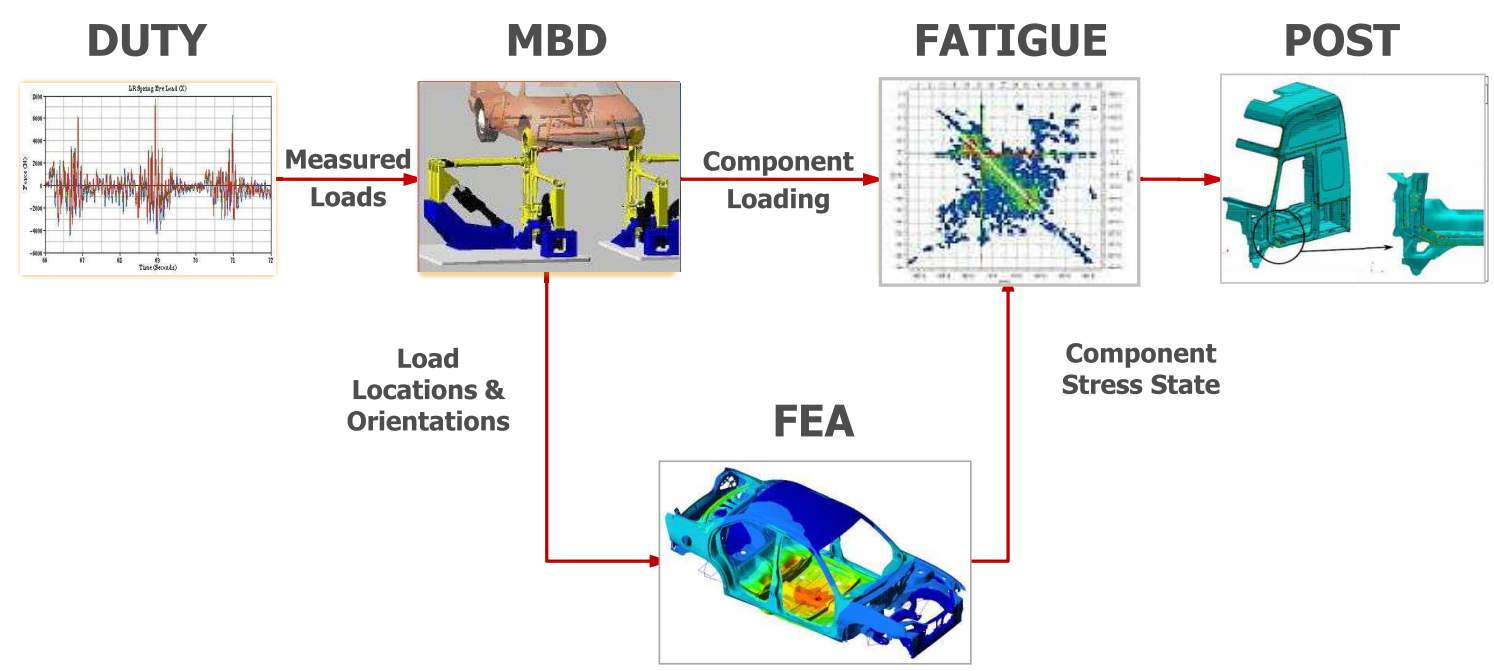

Figura 1.2 Processo inteiro de análise de durabilidade utilizando Análise de Dinâmica de Sistemas Multicorpos, Análise por Elementos Finitos e Análise de Fadiga baseada em Elementos Finitos (Barbosa, 2013).
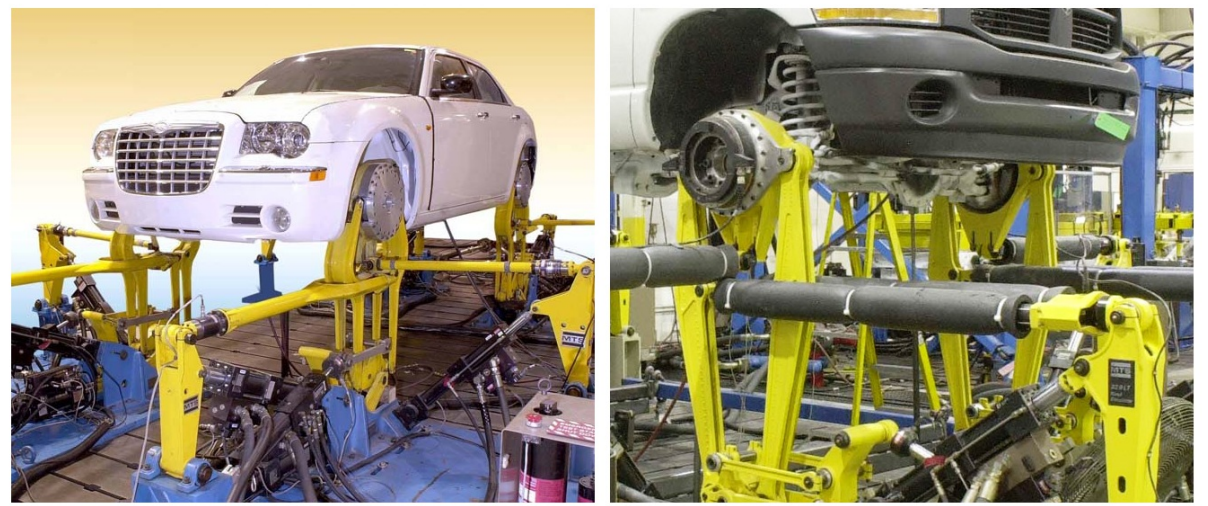

Figura 1.3 Ensaio de durabilidade de veículo completo utilizando um simulador de pista (Exova Defiance, 2013).

Sob a ótica econômica, percebe-se que os gastos devido a falhas por fadiga juntamente com os gastos com a prevenção deste modo de falha são gigantescos. O dimensionamento correto de produtos e estruturas no quesito fadiga poderia reduzir consideravelmente estes valores. No âmbito da segurança das pessoas, as falhas por fadiga das últimas décadas são responsáveis por centenas de mortes desde o início da Revolução Industrial.

Segue abaixo um histórico sobre alguns os acidentes mais graves que ocorreram devido a falha por fadiga: 
1842 Acidente ferroviário de Versailles: Um trem de passageiros sai de Versailles com destino a Paris. Este possuía 120m de comprimento, 16 vagões e era puxado por 2 locomotivas. Enquanto viajava a $40 \mathrm{~km} / \mathrm{h}$, um dos eixos da locomotiva falhou por fadiga e toda a composição se descarrilhou e pegou fogo.

As chamas eram tão intensas que um número de fatalidades não pôde ser determinado com precisão, mas estima-se que houve entre 52 e 200 mortes e centenas de pessoas ficaram seriamente feridas.

1860 Registros mostraram que mais de 200 pessoas morreram na GrãBretanha entre 1860 e 1889 devido a falhas em eixos de locomotivas e vagões ferroviários.

1919 Inundação de Melaço de Boston: Um grande tanque de melaço rompeu em um atípico dia quente de inverno, lançando cerca de 8,7 milhões de litros do líquido nas ruas de Boston a uma velocidade de $56 \mathrm{~km} / \mathrm{h}$. Houve 21 mortes, 150 feridos e a cidade ficou devastada. A falha ocorreu devido a uma trinca por fadiga que nucleou e cresceu na base do tanque.

1940 Navios da série Liberty: O governo norte-americano mandou construir 4694 navios cargueiros durante a $2^{\text {a }}$ guerra mundial. Esta é a maior classe de navios construídos em todos os tempos. Entretanto, 1289 navios apresentaram algum tipo de fratura, de modo que 233 delas foram catastróficas, e ainda, 19 navios partiram-se ao meio.

As causas destas falhas foram várias, dentre elas a falha por fadiga em estruturas soldadas e as falhas causadas por temperaturas baixas. Estas falhas resultaram na perda de dezenas de vidas, além do prejuízo de milhares de dólares para o governo norte-americano. Por este motivo, houve críticas às metodologias de engenharia utilizadas na época, como por exemplo à revisão dos processos de soldagem, do ensaio Charpy e do projeto mecânico de estruturas soldadas.

Os esforços da comunidade científica culminaram em melhorias de algumas práticas de projeto mecânico, contribuindo inclusive para o desenvolvimento da análise de fadiga utilizando a Mecânica da Fratura, proposta por Paul Paris em 1961 [(Schütz, 1996)]. 
1954 Aeronave Comet: Comet foi a primeira aeronave a jato a entrar em serviço regular de transporte de passageiros. Neste ano, duas aeronaves Comet se desintegraram no ar, matando todos os passageiros e tripulantes. Depois de muitas horas de investigações, foi concluído que as aeronaves estavam falhando por fadiga, com a trinca se iniciando nos rebites localizados nos cantos quadrados das janelas, região de alta concentração de tensões. Esta investigação concluiu que é fundamental a realização de testes de fadiga em escala real. Os acidentes com a aeronave Comet também introduziram o assunto de fadiga em estruturas metálicas no dia-a-dia dos engenheiros aeronáuticos, além de contribuir para o desenvolvimento da análise de fadiga utilizando a Mecânica da Fratura 4 .

1969 Caça F-111: O caça norte-americano perdeu a asa esquerda em voo após apenas 100 horas de operação. A falha ocorreu devido a uma trinca por fadiga a partir de um defeito no pivô de ajuste da asa, introduzido a partir do forjamento de um canto com raio muito pequeno. O problema foi agravado devido ao material possuir uma baixa tenacidade. A partir deste acidente, a Força Aérea norte americana criou um grupo de estudo a fim de desenvolver uma nova metodologia para garantir a integridade estrutural de suas aeronaves.

Este trabalho culminou na criação da filosofia e metodologia DTA ( $D a$ mage Tolerance Analysis - Análise de Tolerância ao Dano), um procedimento usado na área de projeto mecânico que possui o objetivo de desenvolver estruturas sujeitas à cargas cíclicas (e portanto ao fenômeno de fadiga) utilizando Mecânica da Fratura. A metodologia DTA nasceu em 1961 com o artigo de Paul Paris, amadureceu ao longo dos anos posteriores e foi introduzida pela primeira vez na norma militar americana MIL-ST-83444 em 1974.

A aplicação da filosofia DTA teve enorme sucesso, pois houve apenas 1 único acidente fatal em aeronave militar norte americana devido à fadiga entre 1974 e 1996 (22 anos), em contraste com números muito maiores que ocorriam anteriormente aos requisitos DTA. Devido ao grande sucesso da aplicação da filosofia na área aeronáutica, a mesma passou a ser utilizada nas mais diversas áreas da indústria, como aeroespacial, naval, automotiva e de máquinas e ferramentas. É importante informar que a implantação de um sistema deste tipo envolve um aumento dos custos, tanto na fase de projeto quanto na fase de uso da estrutura.

\footnotetext{
${ }^{4}$ Segundo Norton (2006), acredita-se que essas falhas nos aviões Comet também custaram ao Reino Unido a perda da liderança no segmento da indústria comercial de aeronaves. O tempo perdido, reprojetando seus aviões e estratégias, deu à indústria de aviões dos Estados Unidos a chance para tomar a liderança na área, que é mantida até hoje. A Inglaterra, apenas recentemente, tem começado a conseguir alguma parte desse mercado, através do Airbus desenvolvido em parceria com outros países da Europa.
} 
1980 Plataforma semissubmersível Alexander L. Kielland: a plataforma norueguesa de captação de óleo afundou, matando 123 pessoas. A plataforma demorou apenas 14 minutos para submergir totalmente. O relatório de investigação concluiu que uma falha por fadiga ocorreu em uma parte da sua armação.

1988 Voo 243 da Aloha Airlines: o Boeing 737 sofreu uma descompressão repentina devido a uma falha por fadiga em uma janela de acesso no teto da aeronave. $\mathrm{O}$ avião perdeu grande parte de sua fuselagem no acidente, mas mesmo assim conseguiu aterrissar. Dentre os 90 passageiros e 5 tripulantes, apenas 1 pessoa morreu. Entretanto, 65 pessoas se feriram, 8 delas gravemente.

1989 Voo 232 da United Airlines: O avião DC-10-10 produzido pela empresa McDonnell Douglas saiu do aeroporto internacional de Stapleton, em Denver, com destino ao aeroporto internacional de O'Hare, em Chicago. Em 19 de Julho de 1989, O DC-10-10 sofreu uma falha catastrófica da turbina da cauda, que levou a perda de todos os sistemas de controles. Milagrosamente, a tripulação conseguiu pousar o avião. Das 296 pessoas a bordo, 111 morreram no acidente enquanto 185 sobreviveram. A perícia concluiu, após o acidente, que havia nucleado e se propagado uma trinca no rotor da turbina da cauda da aeronave. A investigação atribuiu as causas do acidente à falha do processo de manutenção da United Airlines e culpou a equipe de manutenção por não ter detectado a trinca por fadiga durante as inspeções periódicas da aeronave (NTSB (National Transportation Safety Board), 1990).

1994 Morte do piloto de F-1 Ayrton Senna: Na sétima volta do Grande Prêmio de San Marino, no autódromo de Ímola, Itália, Ayrton Senna perde o controle de seu carro Willians, passa direto pela curva Tamburello e bate contra o muro a $216 \mathrm{~km} / \mathrm{h}$. O relatório de 70 páginas do comitê de investigação concluiu que Senna saiu da pista porque a coluna da direção fraturou por fadiga. Senna tinha dito durante várias corridas que o volante estava muito distante de seu corpo. Por causa disto, os mecânicos cortaram a barra de direção e soldaram uma bucha a fim de aumentar o comprimento deste componente.

A investigação concluiu que, durante a passagem pela curva Tamburello, houve a ruptura da coluna de direção, exatamente na solda realizada. Sete pessoas foram indiciadas por homicídio culposo, negligência e imprudência, inclusive o fundador da escuderia Williams, Frank Williams. Em dezembro de 1997, o juiz Antonio Constanzo absolveu todos os acusados. 
1998 Desastre do trem de Eschede: O trem mais moderno e veloz da alemanha descarrilhou e chocou-se a $200 \mathrm{~km} / \mathrm{h}$ contra os pilares de um viaduto. Após um dos vagões se chocar contra os pilares, os vagões seguintes foram arrastados e batendo uns sobre os outros, num destruidor efeito sanfona. O impacto foi tão violento que toda a ponte desmoronou, esmagando o que tinha restado dos vagões; além disso, os corpos das vítimas estavam tão mutilados que apenas um deles tinha sido identificado após 24 horas do acidente.

Acredita-se que a geometria da roda resultou em nucleação de uma trinca na parte interna deste componente. Algumas saliências na roda, devido ao defeito no processo de fundição e de fabricação, aumentaram dramaticamente as forças dinâmicas na montagem e aumentaram muito o desgaste irregular da roda. Com o passar dos ciclos, as rodas foram ficando no formato de elipse, o que aumentava ainda mais a vibração e ressonância do sistema (quando em velocidade de cruzeiro) e, consequentemente, o crescimento das trincas já nucleadas.

A investigação também concluiu que forças dinâmicas repetitivas aplicadas nas rodas não foram consideradas na modelagem estatística de falha na fase de projeto do trem, resultando em um fator de segurança insulficiente. O sistema ferroviário alemão teve que recolher 60 trens da mesma geração para realizar recall.

Foram necessárias 600 pessoas do resgate para atender os feridos no acidente e muitos helicópteros da polícia e de hospitais tiveram que ser utilizados. Houve ao todo 101 mortes e 88 feridos, muitos em estado gravíssimo. Este foi o pior acidente ocorrido no país desde a $2^{\text {a }}$ Guerra Mundial (Revista Veja, 1998; Wikipedia, 2013).

2002 O vazamento de óleo do Petroleiro "Prestige": Um vazamento de óleo do navio Prestige ocorreu na costa Galega, causado por um furo no tanque de armazenamento de óleo. O vazamento poluiu milhares de quilômetros da região costeira e mais de mil praias da Espanha, França e Portugal. Pior ainda, o fenômeno prejudicou fortemente a indústria pesqueira local. Este vazamento foi o maior desastre ambiental da história da Espanha e de Portugal.

Investigadores do governo espanhol concluiram vazamento foi causado por uma trinca causada por fadiga no casco do Prestige. Além do mais, a falha era perfeitamente previsível e na verdade já tinha sido prevista no projeto deste navio. Existiam 3 navios idênticos ao Prestige e 2 deles foram submetidos à extensas inspeções sob o programa Casco Seguro em 1996.

A organização responsável por estas inspeções concluiu que todos os 4 navios deveriam ser sucateados em 2001 devido a presença de dezenas de trincas por fadiga. O próprio projeto desses 4 petroleiros mostrava claramente que todos os navios iriam falhar por fadiga entre os frames 61 e 71 no prazo de 5 anos, e portanto deveriam ser descartados após este período. 
Os 3 navios irmãos do Prestige foram sucateados. Entretanto, por alguma razão desconhecida, apenas o Prestige não foi descartado, e, pouco mais do que cinco anos depois da inspeção, como previsto, seu casco falhou entre as armações 61 e 71 (Jornal El País, 2008).

2013 Recall da Toyota e Lexus: A montadora japonesa Toyota anunciou um recall de 242.000 veículos híbridos Toyota Prius e Lexus HS $250 \mathrm{~h}$ em todo o mundo, por causa de uma falha no sistema de freios. Estes carros estão equipados com um acumulador de pressão de freio que pode desenvolver uma trinca por fadiga devido à vibração. Nenhum acidente devido à este problema foi reportado até agora.

A revisão anterior sobre acidentes causados por fadiga evidencia que a fadiga em metais é ainda um grande problema para a indústria, para o governo e para a sociedade. Campbell (1981) afirma que um total de 306 acidentes fatais ocorreram entre 1934 e 1981 por causa do fenômeno de fadiga, tendo esses acidentes resultado em 1803 mortes. A maior parte desses desastres ocorreram com aeronaves civis e apenas a minoria com aeronaves militares. Falhas em asa e motores são a causa mais frequente de acidentes em aeronaves de asa fixa, enquanto que a falha mais comum em helicópteros ocorre nos rotores da cauda. Em meados de 1981, estimava-se que o fenômeno de fadiga causava 18 acidentes fatais com aeronaves a cada ano.

Socie (2004b) afirma que a maioria das falhas por fadiga não são resultados de um especialista em fadiga realizando uma análise errada. A maioria das falhas é o resultado de um não-especialista não considerando fadiga de uma maneira adequada porque o assunto é muito complicado, por falta de conhecimento no assunto, por falta de propriedades de fadiga e por outros motivos semelhantes. Socie acredita que fadiga não mais será ensinada na maioria das universidades de pesquisa devido ao fato destas universidades focarem em novas ciências.

De uma maneira geral, os livros de projetos de máquinas ainda são os mais utilizados como referência teórica por profissionais da indústria para o dimensionamento contra a fadiga de produtos e componentes. A maioria destes livros, entretanto, ainda não contém as descobertas e metodologias mais recentes para cálculo de durabilidade de estruturas, em especial ao que diz respeito à Fadiga Multiaxial e à análise de fadiga utilizando-se o Método dos Elementos Finitos. Isto representa um grande problema porque induz engenheiros a projetarem produtos de maneira inadequada, com grande propensão a falhas por fadiga ou superdimensionados. Além disso, A maioria destes livros, entretanto, ainda não contém alguns os métodos recentes para cálculo de durabilidade de estruturas, em especial assuntos relacionados à fadiga multiaxial e, principalmente, análise de fadiga utilizando-se o Método dos Elementos Finitos. Uma extensa revisão bibliográfica foi realizada e verificou-se que a maioria dos livros específicos da área de fadiga não descrevem em detalhes sobre análise de fadiga uni e multiaxial baseadas em Elementos Finitos. Nos últimos anos, poucos foram 
os trabalhos que propuseram metodologias para previsão de vida em fadiga que incluíssem conceitos de Fadiga Multiaxial e Análise por Elementos Finitos. Apenas foram encontradas publicações que abordam parcialmente estes tópicos. Os trabalhos encontrados que mais se aproximam do tema análise de fadiga uni e multiaxial baseada em Elementos Finitos são livros Lee et al. (2011) e Bishop \& Sherratt (2000), a diretriz técnica alemã (FKM-Guideline, 2003), o relatório técnico de Fatemi \& Montazersadgh (2007) e os artigos de Spiteli et al. (2007), Langlais et al. (1995) e Santos et al. (2003).

É importante a utilização de uma metodologia de fadiga que permita uma previsão segura e mais precisa da vida de produtos sujeitos a falhas por fadiga. Não há dúvida que esta metodologia deve estar pautada nas últimas descobertas científicas da área de fadiga, para que uma estimativa de vida traga bons resultados. Adicionalmente, é interessante que esta metodologia também incluía conceitos de Fadiga Multiaxial e utilize resultados de análises por Elementos Finitos para estimar a vida em fadiga, uma vez que a ferramenta CAE se tornou peça fundamental no projeto de desenvolvimento de produtos na indústria.

\subsection{Objetivos}

Baseado neste cenário, esta dissertação tem o objetivo de propor uma metodologia moderna para prever a vida em fadiga de componentes mecânicos, peças e estruturas, feitos em metal, utilizando os métodos e resultados mais recentes desta área. Esta metodologia deve ser capaz de lidar com fadiga uniaxial, fadiga multiaxial e em conjunto com Análises por Elementos Finitos. Esta metodologia será constituída de diversos métodos comprovados e encontrados em livros, artigos científicos e outras publicações cientificas.

\subsection{Metodologia}

Na pesquisa bibliográfica realizada foi identificado muitos métodos modernos e apropriados a serem adotados. Na metodologia proposta estão incluídas importantes contribuições propostas pelo Conselho Alemão de Pesquisa em Engenharia FKM (2003), a utilização do Método da Curva S-N Sintética (baseando-se principalmente em Lee et al. (2011), Lee et al. (2005), Eichlseder (2000b)), o projeto considerando efeitos de Fadiga Multiaxial (baseandose principalmente em Socie \& Marquis (2000), Lee et al. (2011), Lee et al. (2005), Heyes (2011), Papuga (2005), Karolczuk \& Macha (2005), Fojtík (2011), Papadopoulos et al. (1997), Steiner et al. (2000), Ingrassia et al. (2011), Fatemi (sdc), Socie (2004a), Shamsaei \& Fatemi (2010b), Bishop \& Sherratt (2000)) e a utilização de resultados de análises

\footnotetext{
${ }^{5}$ Do alemão, Forschungskuratorium Maschinenbau.
} 
por Elementos Finitos para realização da previsão de vida em fadiga (baseando-se principalmente em Lee et al. (2011), Heyes (2011), MSC.Software (2008), Bishop \& Sherratt (2000), Steiner et al. (2000), Fatemi \& Montazersadgh (2007), Ingrassia et al. (2011), Mendes \& Cardoso (2007) e Novotny \& Pistek (2007)).

Destacam-se neste trabalho:

1. A realização de análise de previsão de vida em fadiga utilizando resultados de Análise por Elementos Finitos;

2. A contabilização recente do efeito de tamanho através da FKM-Guideline (2003);

3. A contabilização recente e muito útil do efeito do tratamento superficial proposta por FKM-Guideline (2003);

4. A contabilização do efeito de corrosão pela Bureau Veritas (1998);

5. A contabilização do efeito de tensão média utilizando o padronizado diagrama de Haigh, conforme FKM-Guideline (2003);

6. A contabilização do efeito de tensão média utilizando pseudo tensões provenientes de FEA:

7. A contabilização do efeito de entalhe utilizando pseudo tensões provenientes de FEA:

8. A contabilização do efeito de entalhe utilizando o Método do Gradiente de Tensão Relativo juntamente com o MEF, tanto para carregamento uniaxiail quanto para carregamento multiaxial;

9. A densidade da malha de elementos finitos adequada para utilizar em fadiga computacional;

10. A utilização de Critérios de Fadiga Multiaxial para previsão de vida em fadiga, inclusive em FE-Based Fatigue Analyses;

11. A contabilização do dano por fadiga em carregamento multiaxial de amplitude variável;

12. A densidade da malha de elementos finitos adequada para utilizar em fadiga computacional;

13. A verificação do tipo de carregamento através da análise da razão de biaxialidade " $a$ " e da orientação da tensão principal máxima " $\phi_{p}$ ";

14. O detalhamento da utilização de Critérios de Fadiga Multiaxial, principalmente em FE-Based Fatigue Analyses.

Também foi desenvolvido neste trabalho um software para cálculo de vida em fadiga, utilizando a metodologia proposta neste trabalho. O software foi necessário porque a análise de fadiga deveria utilizar resultados de Análises por Elementos Finitos Adicionalmente, o método de fadiga multiaxial exige que os cálculos sejam feitos computacionalmente, conforme explicado na seção 1.1. Este software, ora denomidado xDurability, foi escrito utilizando o software $M A T L A B^{\circledR}$. O xDurability lê automaticamente o arquivo contendo a malha de Elementos Finitos, feita no software HyperMesh, e identifica a posição de todos os nós e 
elementos da malha, assim como a relação entre elementos e nós. Ele também lê os resultados de tensão das Análises por Elementos Finitos, gerados pelo software $A N S Y S^{\circledR}$, e utiliza estes valores para efetuar todos os cálculos que resultam na previsão da vida do componente analisado.

Uma cópia do software Durability foi gravada dentro de um CD e está sendo entregue anexa a esta dissertação. O software compreende 25 arquivos com extensão *.m (MATLAB $\left.{ }^{\circledR}\right)$ sendo o arquivo $x$ Durability_1_main.m o corpo do software. Para se executar o software deve-se realizar o input dos parâmetros na seção INPUT DATA e executar o arquivo $x D u$ rability_1_main.m dentro do MATLAB ${ }^{\circledR}$. Existe um exemplo já com todos os parâmetros especificados dentro da pasta EXEMPLO1. Para executar este exemplo é preciso apenas executar o arquivo $x$ Durability_1_main.m dentro do MATLAB ${ }^{\circledR}$.

Autorizo a reprodução e divulgação total ou parcial deste trabalho, por qualquer meio convencional ou eletrônico, para fins de estudo e pesquisa, desde que citada a fonte. Autorizo o uso do código-fonte da subrotina contida dentro do CD anexo à esta dissertação, para fins de estudo e pesquisa, desde que citada a fonte.

\subsection{Organização do Trabalho}

O capítulo 2 tem como objetivo apresentar o fenômeno de fadiga sob a ótica do material. Serão abordados assuntos sobre discordâncias, bandas de deslizamento persistentes, nucleação de trincas, propagação de trincas e fratura repentina.

O capítulo 3 mostrará os 3 métodos existentes para se analisar uma estrutura sujeita à fadiga. Este capítulo também mostrará que o processo de fadiga pode ser idealizado em fases, mostrando os métodos supracitados se relacionam entre si e como deve ser a escolha do(s) melhor(es) método(s) para a resolução de um problema de fadiga. O capítulo 3 também apresenta as duas filosofias de projeto relacionadas à fadiga e quando cada uma deve ser aplicada.

O capítulo 4 discursará sobre como realizar análises de fadiga uniaxial de uma estrutura utilizando o método baseada em tensão. Este capítulo ensinará como estimar adequadamente as Curvas Tensão-Vida de espécimes padronizados, de espécimes não padronizados e não entalhados e de componentes genéricos, assim como apresentará o conceito da Curva S-N Sintética, fundamental quando se realiza análise de fadiga baseada em Elementos Finitos. Também serão apresentadas as mais recentes e melhores maneiras de se contabilizar os efeitos tecnológicos na vida em fadiga de um componente, como por exemplo o efeito do tratamento superficial, efeito da corrosão, efeito da frequência do carregamento, efeito da tensão média, efeito de entalhe, efeito de tamanho, dentre outros. Ênfase será dada ao 
cálculo do fator de entalhe e ao fator da tensão média devido à importância destes fatores quando se utiliza FEA e devido a falta de publicações sobre estes assuntos. Também será visto em detalhes outros detalhes de fadiga computacional como carregamento de amplitude variável e acúmulo de dano por fadiga. Ênfase é dada nos procedimentos propostos recentemente pelo Conselho Alemão de Pesquisa em Engenharia (FKM por resultarem em maior precisão na previsão de vida em fadiga de componentes. Também será dada ênfase na contabilização do efeito de entalhe sobre a Curva Tensão-Vida do componente, em especial utilizando Elementos Finitos.

O capítulo 5 apresentará o conceito de Fadiga Multiaxial e quando este fenômeno deve ser considerado. Também será discursado sobre a diferença entre carregamentos proporcionais e não proporcionais, como avalizar cada tipo de carregamento e quando cada critério de fadiga multiaxial deve ser utilizado. Este capítulo também explicará detalhadamente como considerar o efeito de entalhe em uma análise de fadiga baseada em FE quando carregamentos multiaxiais estão presentes. Este tópico é explicado de maneira bastante detalhada devido à falta de publicações sobre o assunto. Em seguida, os critérios de fadiga multiaxial mais conhecidos, mais utilizados e que geram a melhor correlação com dados experimentais serão apresentados, principalmente aqueles utilizados em softwares de fadiga comerciais (a serem apresentados no capítulo 6). Todos os critérios serão apresentados de maneira bastante detalhada, pois percebe-se uma excassez de informações sobre os mesmos em livros, artigos e publicações científicas. Adicionalmente, todos os critérios são apresentados de maneira a ser visível sua utilização na prática, principalmente em análises de fadiga baseadas em Elementos Finitos (FE-Based Fatigue Analysis). A última parte do capítulo informa como carregamentos de amplitude variável são contabilizados em fadiga multiaxial.

O capítulo 6é dividido em 3 partes. A primeira parte apresenta o software de análise de fadiga baseado em Elementos Finitos desenvolvido nesta dissertação, intitulado xDurability, assim como apresenta detalhadamente os softwares comerciais de análise de fadiga existentes no mercado. A segunda parte deste capítulo apresenta o processo global de análise de fadiga baseada em Elementos Finitos (FE-Based Fatigue Analysis). Este processo global é então dividido em 3 etapas e cada uma das etapas é detalhada. Na terceira e última parte deste capítulo, são analisados 5 estudos de casos de fadiga a fim de demonstrar a aplicabilidade da metodologia de análise de fadiga proposta nesta dissertação, assim como para validar o software $x$ Durability desenvolvido em linguagem $M A T L A B^{\circledR}$ nesta dissertação, que contém em sua programação toda a metodologia apresentada nos capítulos $4 \mathrm{e} 5$. O software $x$ Durability utiliza os resultados de análises estruturais por Elementos Finitos e realiza a estimativa de vida da estrutura partir destes resultados. Os 5 estudos de casos foram resolvidos utilizando este software devido a grande quantidade de dados que devem ser tratados nos problemas de fadiga baseados em Elementos Finitos.

O capítulo 7 finaliza esta dissertação, enfatizando os pontos mais importantes na mesma 
e relatando as conclusões deste trabalho. 


\section{Capítulo 2}

\section{Mecanismo da Falha por Fadiga}

Nos ensaios mecânicos que visam obter as propriedades de materiais relacionadas ao diagrama tensão-deformação o carregamento é aplicado progressivamente a baixa velocidade, até a ruptura do espécime. Esses ensaios são realizados em velocidades muito baixas e são conhecidos como ensaios estáticos. Além do mais, o espécime ${ }^{1}$ é testado até a ruptura e portanto as tensões são aplicadas apenas uma vez. Tais condições de ensaio se aproximam bastante das condições para as quais muitos componentes de máquina e estruturais estão sujeitos.

Há muitas situações, entretanto, em que as tensões em um componente mecânico variam com o tempo e flutuam entre diferentes magnitudes inúmeras vezes. Por exemplo, um ponto particular na superfície de um eixo rotativo (ou giratório) sujeito a ação de uma carga de flexão sofre tanto tração quanto compressão para revolução do eixo. Se o eixo é parte de um motor elétrico que rotaciona a $1000 \mathrm{rpm}$ (Rotações por minuto), este ponto está sujeito à tração e compressão 1000 vezes a cada minuto. Se, adicionamente, o eixo estiver também sujeito à um carregamento axial (como em um eixo que comporta uma engrenagem helicoidal), este ponto terá uma componente axial de tensão superimposta à componente de flexão. Esse e outros tipos de carregamentos que ocorrem em componentes de máquinas produzem tensões que são chamadas tensões alternadas, repetidas ou variáveis. A figura 2.1 ilustra três exemplos de tensões cíclicas.

Frequentemente, componentes de máquinas falham sob a ação de cargas variáveis; porém as tensões máximas aplicadas nestes componentes estavam bem abaixo do limite de resistência e muito frequentemente abaixo do limite de escoamento. A característica mais notável destas falhas é que as tensões se repetem um grande números de vezes; assim a falha é chamada de falha por fadiga.

Quando uma peça de uma máquina falha estáticamente, ela geralmente desenvolve uma deflexão grande, pois a tensão excede o limite de escoamento. Assim, a peça é geralmente

\footnotetext{
${ }^{1}$ Também chamado de corpo de prova.
} 


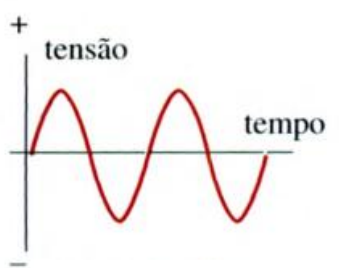

(a) Alternada

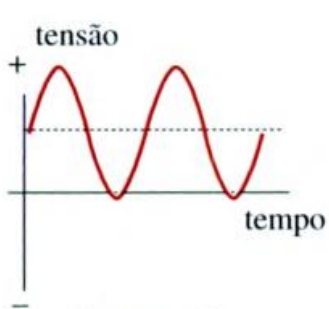

(b) Repetida

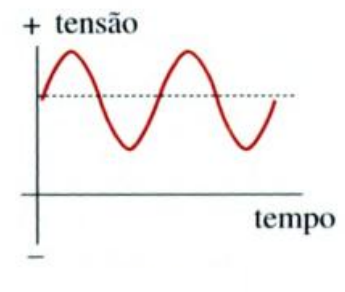

(c) Pulsante

Figura 2.1 Tensões variantes no tempo.

substituída antes da fratura ${ }^{2}$ ocorrer. Assim, muitas falhas estáticas dão avisos visíveis com antecedência; contudo, uma falha por fadiga é repentina. É uma falha repentina e total e, portanto, perigosa. É relativamente simples se projetar componentes mecânicos contra falhas estáticas porque nosso conhecimento sobre este tipo de falha é amplo. Fadiga é um fenômeno muito mais complicado, ainda não completamente compreendido, e o profissional que busca know-how e habilidade nesta área necessita adquirir o máximo possível de conhecimento no assunto.

Falhas por fadiga sempre são causadas por uma pequena trinca que se propagou até causar a fratura do componente/estrutura. As trincas de fadiga geralmente estão localizadas na superfície da peça e podem ser originadas no processo de fabricação do componente. Fischer \& Yen (1972) mostraram que praticamente todas as partes de uma estrutura contém descontinuidades, variando de microscópicas até macroscópicas, introduzidas nos processos de manufatura. Trincas por fadiga também podem se desenvolver ao longo do tempo devido às deformações cíclicas ao redor de uma descontinuidade que cause concentração de tensão, como um entalhe. Como exemplo, as falhas de aspecto frágil ocorridas nos navios norteamericanos da série Liberty (mencionadas na seção 1.3) tiveram origem em trincas iniciadas em um golpe de arco voltaico deixado por um soldador descuidado. A falha no avião Comet se iniciou em trincas menores que $1,8 \mathrm{~mm}$ de comprimento, nos rebites de uma janela com formato aproximadamente quadrado, que gerou concentração de tensão elevada. Desta maneira, é fundamental que peças dinamicamente carregadas sejam projetadas para minimizar a concentração de tensões.

A falha por fadiga é caracterizada pela nucleação e propagação lenta e gradual de uma trinca, levando à ruptura e ao colapso súbito do componente quando o mesmo é submetido à tensões/deformações variáveis. Não há dúvida que este fenômeno está fortemente relacionado ao comportamento micromecânico dos materiais, uma vez que há propagação de trinca no material. Desta maneira, é importante entender como ocorre o processo de fadiga como um fenômeno no material.

A falha por fadiga tem uma aparência similar à fratura frágil em um ensaio de tração

\footnotetext{
${ }^{2}$ Fratura e ruptura são sinônimos nesta dissertação.
} 
estático. A superfície de fratura é plana, perpendicular à direção da tensão variável, e com a ausência do fenômeno de estricção. As características da fratura de uma falha por fadiga são bastantes diferentes de uma fratura frágil estática. A falha por fadiga pode ser dividida em três estágios: (I) nucleação da trinca, (II) propagação da trinca e (III) ruptura repentina devido ao crescimento instável da trinca. Estes três estágios são explicados a seguir.

\subsection{Estágio I: Nucleação de Trinca por Fadiga}

O estágio I é o período em que ocorre a nucleação de uma ou mais trincas curtas $\mathrm{3}^{3}$ na superfície do material devido à deformação plástica cíclica, seguida pela propagação cristalográfica (i.e., dentro do grão) das mesmas e se estendendo geralmente de 1 a 5 grãos. No estágio I, as trincas não são visíveis a olho nu. É importante ressaltar que existe uma tendência da comunidade científica de empregar a nomenclatura short crack (trinca curta) para descrever trinca de estágio I e a nomenclatura long crack (trinca longa) para designar trinca de estágio II. A palavra microtrinca (em inglês microcrack) está caindo em desuso, pois sua interpretação é ambígua porque pode ser interpretada tanto como uma trinca de estágio I quanto como uma trinca com comprimento da ordem de escala micrometro (i.e., trinca com comprimento de $1 \mu \mathrm{m}$ a $999 \mu \mathrm{m})$.

Em uma estala microscópica, os metais não são homogêneos nem isotrópicos. Quando vistos em um tamanho de escala suficientemente pequeno, verifica-se que os metais de engenharia são materiais policristalinos e, portanto, formados por pequenos grãos com orientação cristalina diferente. Cada grão possui uma rede cristalina ordenada, onde os átomos estão dispostos em arranjos que se repetem pela estrutura, chamados de células unitárias. De acordo com Meyers \& Chawla (2009), ao todo existem quatorze tipos de células unitárias que podem compor uma estrutura cristalina. Para os metais, as três principais células unitárias são a Cúbica de Corpo Centrado (CCC), a Cúbica de Face Centrada (CFC) e a Hexagonal Compacta (HC), A figura 2.2 ilustra o arranjo destas células univárias. As redes cristalinas de cada grão possuem defeitos, que referem-se a qualquer imperfeição que altere a periodicidade da rede cristalina. Essas heterogeneidades existem não somente devido à estrutura do grão, mas também porque há presença de vazios minúsculos ou partículas com composição química diferente do restante do material. As discordâncias, principal defeito responsável pela plasticidade e, consequentemente fadiga em metais, também são defeitos existentes na rede cristalina. Uma análise mais profunda sobre células unitárias e defeitos cristalinos pode ser encontrada em Meyers \& Chawla (2009).

Suponhamos um componente feito de metal dúctil não apresenta trincas após seu processo de fabricação, nem em sua superfície, nem trincas internas. Entretanto, este metal

\footnotetext{
${ }^{3}$ Do inglês, short cracks, sinônimo de trincas de estátio I.
} 


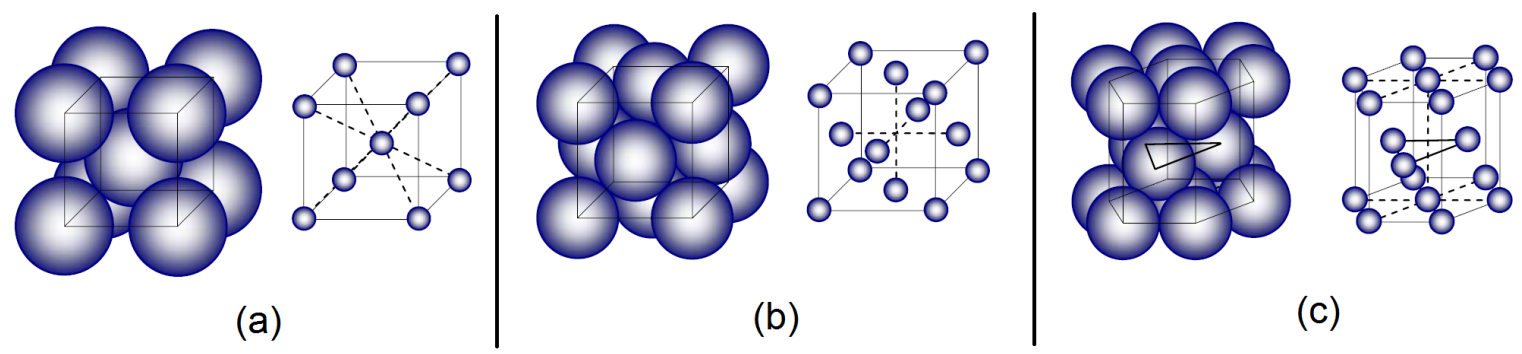

Figura 2.2 Principais células unitárias em metais: (a) Estrutura cúbica de corpo centrado (CCC), (b) Estrutura cúbica de face centrada (CFC), (c) Estrutura hexagonal compacta (HC) (adaptado de Milan et al., 2008).

possui partículas e inclusões que são comuns em materiais de engenharia. Suponhamos também que existam algumas regiões de concentração geométrica de tensão na superfície deste componente (entalhes), justamente em locais com significativas tensões variantes no tempo e que contenham uma componente positiva (tração), como ilustra a figura 2.1. Conforme a tensão no entalhe oscila, as discordâncias presentes na rede cristalina (dentro de grãos da superfície do componente) fazem com que os átomos se movam. Na verdade, o movimento ocorre um plano atômico inteiro dentro do grão, movimentando diversos átomos. Estes planos de escorregamento são geralmente chamados de Bandas de deslizamento persistentes $(P S B s)$ ||

A movimentação dos planos de escorregamento não acontece em todas as direções dentro de uma rede cristalina. Cada rede cristalina (inclusive a $\mathrm{CCC}, \mathrm{CFC}$ ou $\mathrm{HC}$ ) possui determinados planos nos quais os átomos tendem a se movimentarem com mais facilidade. A figura 2.3 apresenta os planos de deslizamento de cada um dos 3 reticulados cristalinos presentes em metais, planos estes que irão se formar as $\mathrm{PSBS}$. As setas nessas figuras representam as direções em que há ocorre a movimentação destes planos quando sob a ação da tensão externa.

O deslizamentos relativo entre planos atômicos (caracterizado pela movimentação de discordâncias localizadas dentro dos grãos da superfície da peça) acontecem já nos primeiros ciclos do carregamento. E enquanto houver carregamento cíclico atuante na região, mais PSBs são formadas. Cada plano tende a se movimentar apenas uma vez, durante meio ciclo de carregamento, pois durante este período ocorre encruamento localizado entre estes dois planos, dificultando assim sua nova movimentação. Por esta razão, a medida que os ciclos de tensão ocorrem, bandas de deslizamento adicionais aparecem e agrupam-se formando intrusões e extrusões, conforme ilustram as figuras 2.4 e 2.5. Uma trinca curta é formada conforme uma intrusão se torna mais profunda, conforme apresentado na figura 2.5 .

Há milhares de grãos na superfície de um componente metálico e cada grão possui uma

\footnotetext{
${ }^{4}$ Também chamadas de Bandas de Deslizamento, Persistent Slip Bands ou apenas Slip Bands.
} 


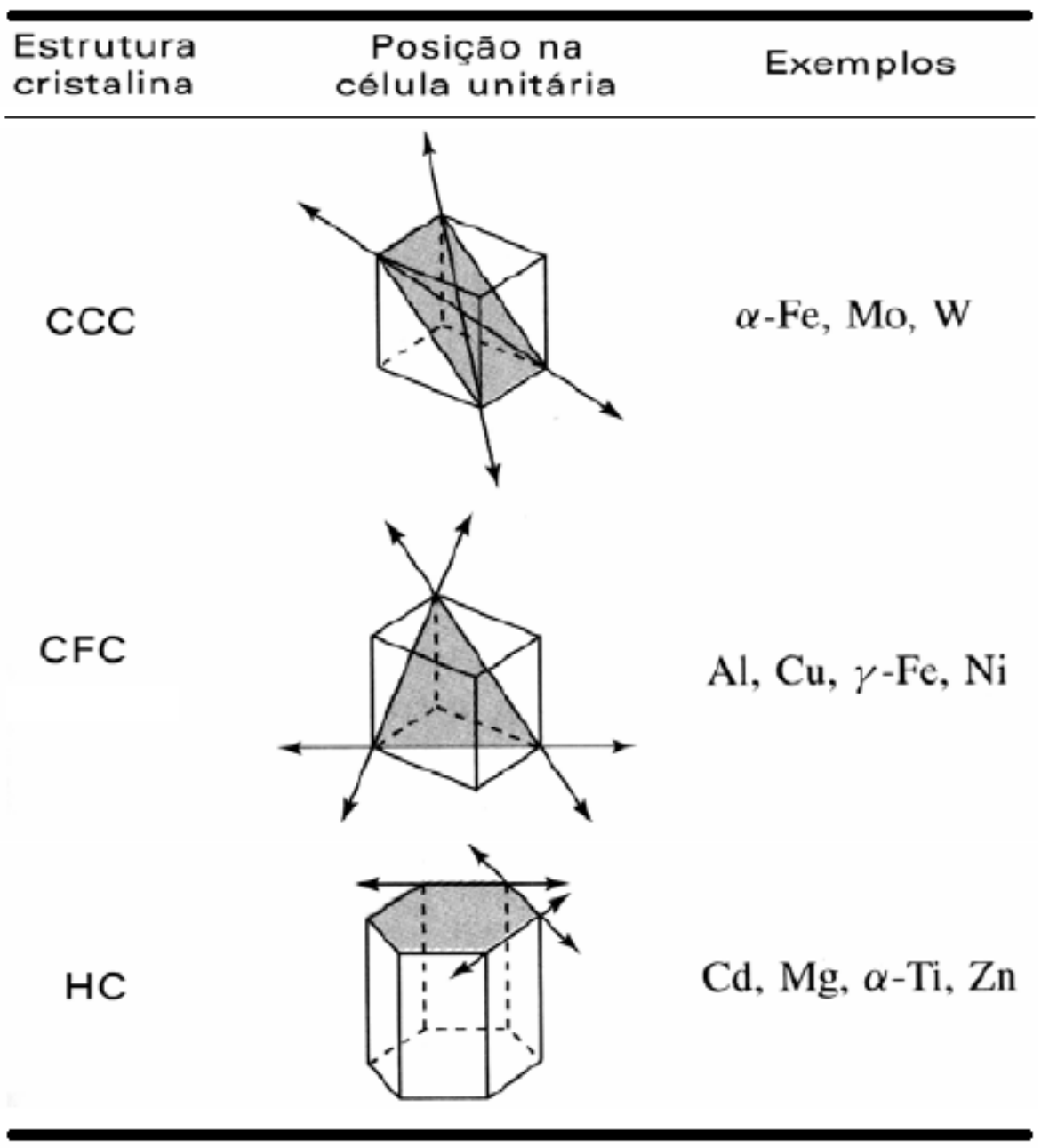

Figura 2.3 Principais sistemas de deslizamento nos reticulados CCC , CFC e HC (adaptado de Van Vlack, 2000).

orientação de sua rede cristalina. Cada direção de deslizamento necessita de uma tensão de cisalhamento mínima para que haja movimentação entre planos de escorregamento. Portanto, as PSBS irão se movimentar na direção na qual a tensão de cisalhamento local necessária para mover a discordância é a menor possível. Desta forma, como é observado por Meyers \& Chawla (2009) e Mentley (2013), intrusões e extrusões serão formadas naqueles grãos cuja orientação dos planos de escorregamento são aproximadamente coplanares com o plano da máxima tensão de cisalhamento. Em outras palavras, uma trinca surgirá naquele grão em que há coincidência entre a direção da tensão de cisalhamento aplicada e a direção do plano de escorregamento indicado na figura 2.3. Segundo Mentley (2013), por este motivo, poucas trincas de estágio I na superfície de um componente metálico crescem a ponto de se tornarem trincas de estágio II, conforme apresenta a figura 2.6, a grande maioria delas tem energia insuficiente para para ultrapassar os contornos de grãos, que atuam como uma barreira. Entretanto, quando um ciclo com alto valor de tensão é aplicado, uma trinca consegue ultrapassar a barreira e continua crescendo (Mentley, 2013). A figura 2.6 ilustra esse 

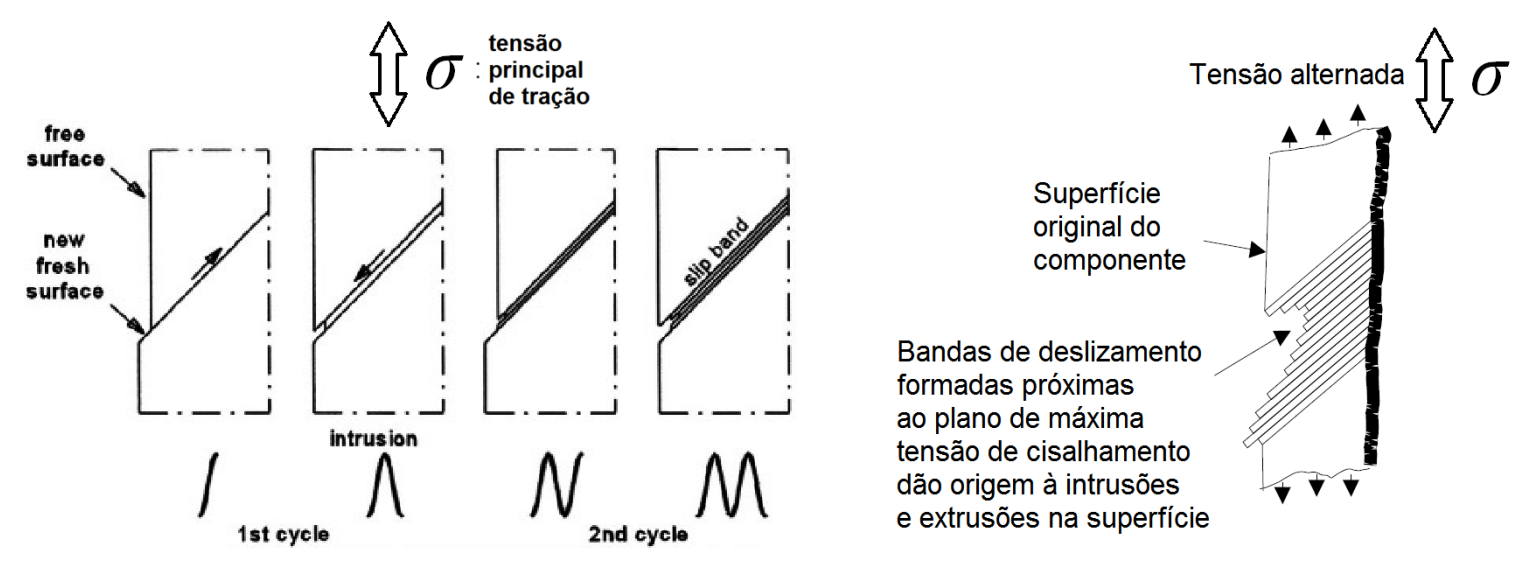

Figura 2.4 Formação de intrusões e consequentes trincas curtas, conforme a aplicação do carregamento cíclico (adaptado de Schijve (2008) e Mentley (2013)).

fenômeno. A aplicação cíclica da tensão na superfície do componente gera a formação de PSBs nos grãos localizados próximos à superfície (figura 2.6(c)). Com o passar do carregamento cíclico, uma trinca de estágio I se forma nas PSBS até encontrar o contorno de grão mais próximo e, devido à um ciclo de alta tensão, esta trinca consegue ultrapassar o contorno de grão e continuar se propagando no grão seguinte (figura 2.6(d)).

Segundo Norton (2006), mesmo na ausência de um entalhe (como em corpos de prova planos ou em componentes sem entalhes) este mecanismo ainda pode ocorrer, desde que a tensão de cisalhamento local (i.e., no grão superficial) exceda a tensão de escoamento em cisalhamento para movimentar os planos de escorregamento daquele grão. Adicionalmente, vazios e inclusões preexistentes servirão como intensificadores de tensão para iniciar uma trinca de estágio I.

As explicações dadas nesta seção 2.1 e ilustradas pelas figuras 2.4, 2.5 e 2.6 partem do princípio que o componente mecânico está sujeito apenas a 1 tipo de carregamento: carregamento cíclico puramente axial, perpendicular à superfície do componente. Entretanto, há casos em que o ponto localizado na superfície está sujeito a tensões em mais de uma direção. Este estado de tensões multiaxiais também irá gerar uma trinca de estágio I, que, neste caso, pode ser de 2 tipos distintos, conforme é explicado por Socie \& Marquis (2000). A figura 2.7 ilustra este fenômeno. Em uma trinca de estágio I do Tipo A, a tensão de cisalhamento atua na superfície livre, na direção paralela ao comprimento da trinca. Neste caso, não há tensão de cisalhamento atuando perpendicular à superfície do componente. Como resultado, estes tipos de trinca tendem a ser trincas rasas e superficiais e tem uma razão de aspecto 5 pequena. Trincas do Tipo $B$ são provocadas pelo cisalhamento a $45^{\circ} \mathrm{C}$ com a superfície livre e são aquelas trincas descritas pelo modelo de intrusão-extrusão.

\footnotetext{
${ }^{5}$ Entende-se por razão de aspécto a relação entre a largura e o comprimento de uma trinca.
} 


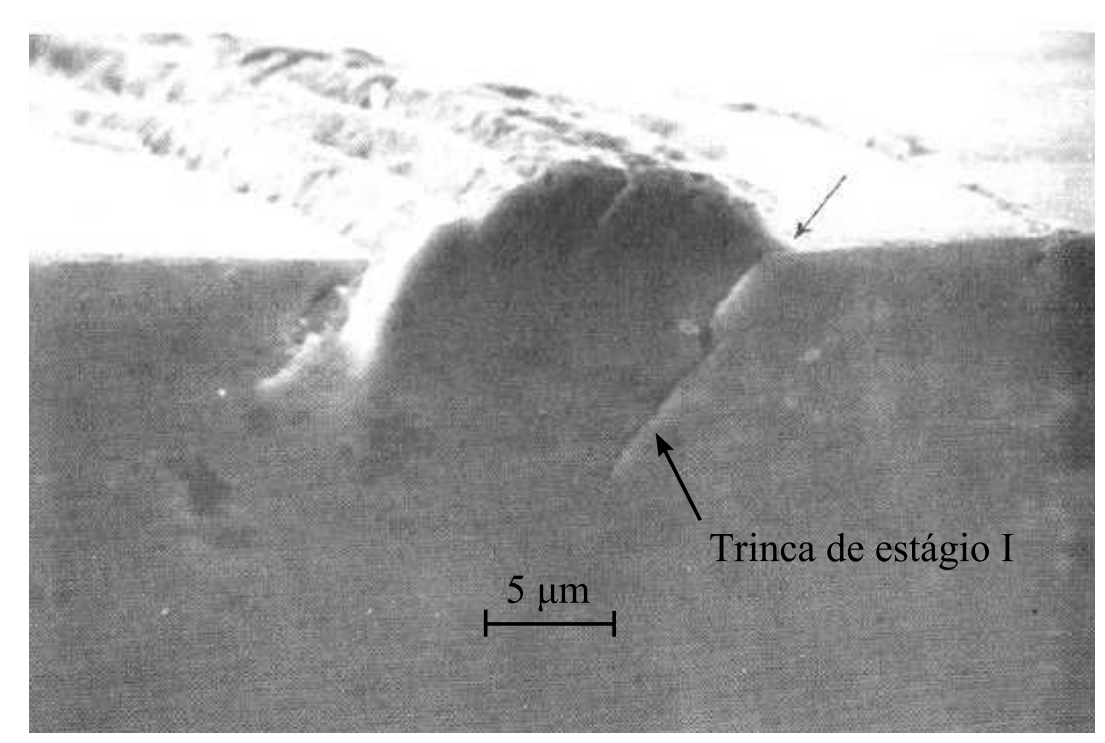

Figura 2.5 Formação de intrusões e extrusões captado por Microscópio Eletrônico de Varredura (MEV) (Ma \& Laird, 1989).

\subsection{Estágio II: Propagação de Trinca por Fadiga}

Geralmente, mais de uma trinca de estágio I nucleiam na superfície do material cristalino, mas a maioria destas trincas param de crescer quando encontram contornos de grão ou precipitados. Entretanto, se o carregamento cíclico é alto o suficiente, então esta trinca dominante supera o primeiro contorno de grão e continua a crescer no próximo grão. Este processo se repete então até a trinca de estágio I encontrar o $2^{\circ}, 3^{\circ}$ ou o $4^{\circ}$ contorno de grão. Nesta etapa, a trinca de estágio I se transforma em uma trinca de estágio II $]^{6}$ No estágio II, ocorre uma mudança na direção de propagação da trinca, que passa a se propagar na direção perpendicular à tensão principal máxima alternada $\sigma_{1, a}$ (isto nos casos onde há apenas estado uniaxial de tensões). As figuras 2.6(a) e (b) trazem uma representação dos estágios de propagação de uma trinca por fadiga, inclusive a transição entre os estágios I e II.

Ao contrário de uma trinca curta, a trinca de estágio II é fisicamente grande comparada com a microestrutura do material. Ela não é mais sensível a variáveis microestruturais (contornos de grão, precipitados e inclusões) porque a zona do processo de dano (i.e., a deformação plástica) se estende sobre vários grãos. Isto resulta em uma grande concentração de tensão de tração na ponta da trinca. Trincas de estágio II irão crescer apenas se o carregamento cíclico gerar tensão de tração na ponta da trinca. Isto só irá acontecer se a tensão máxima do carregamento cíclico (na ponta da trinca) for maior do que zero, pois a tensão de tração tende à abri-la, aumentando o seu comprimento/tamanho a cada ciclo de carregamento, conforme ilustra a figura 2.8 .

\footnotetext{
${ }^{6}$ Também chamada de trinca longa (do inglês, long crack).
} 


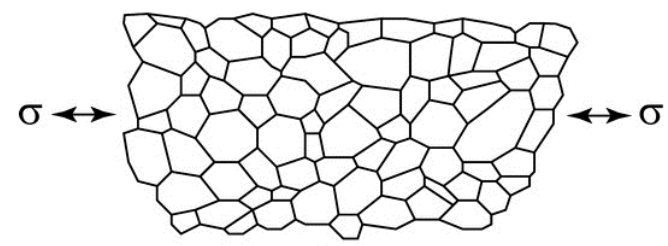

(a)

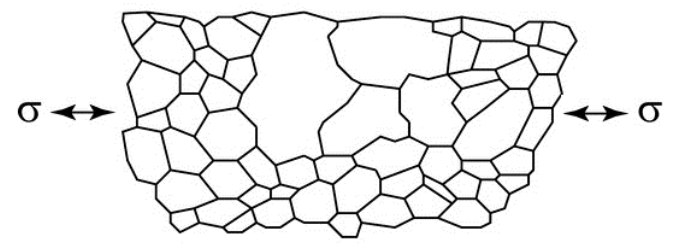

(b)

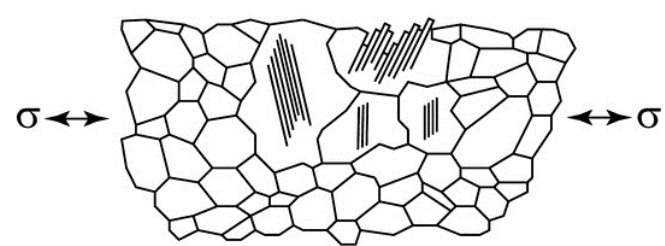

(c)

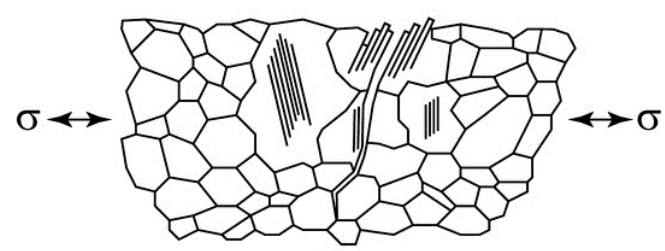

(d)

(a) Meyers \& Chawla (2009)
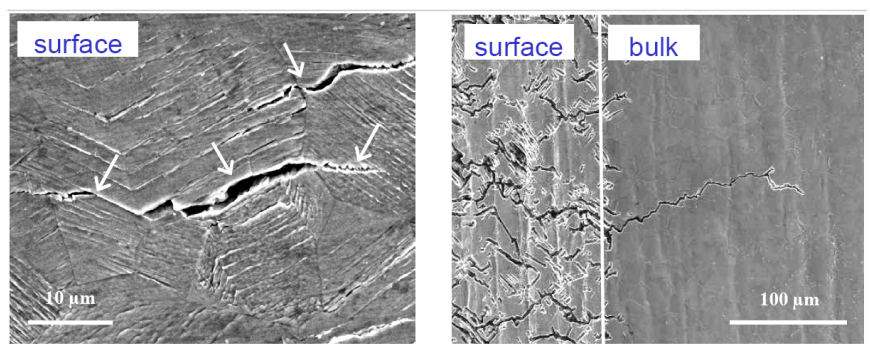

(b) Aço austenítico 20-25 em fadiga de tração-compressão $\left(20^{\circ}, \Delta \varepsilon_{p} / 2=0,4 \%\right)$ : Trincas curtas na superfície e trinca longa predominante na parte interna (Socie, 2004b).

Figura 2.6 Formação de PSBs em apenas alguns grãos. Crescimento de trincas de estágio I e II. 


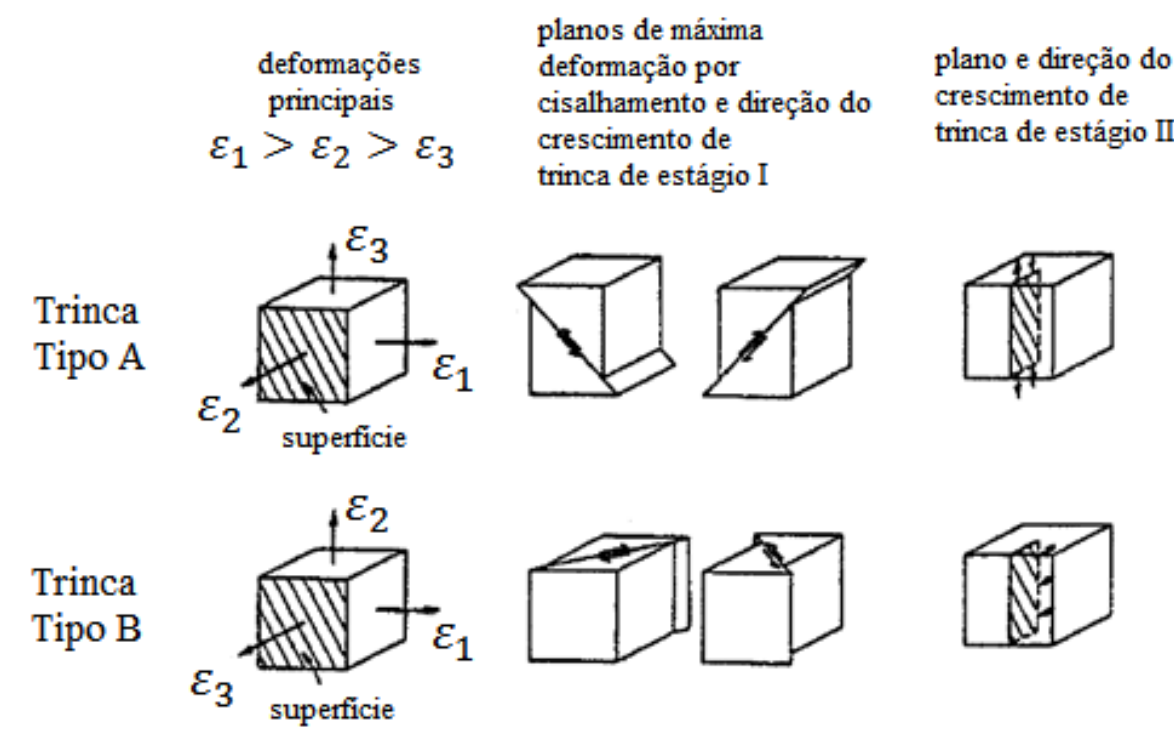

(a) Exemplo 1

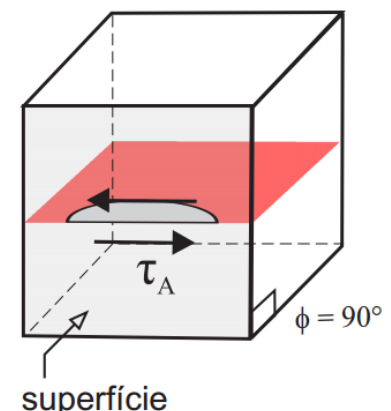

Tipo A

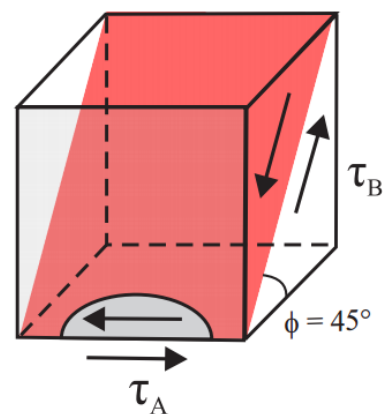

Tipo B

(b) Exemplo 2

Figura 2.7 Nucleação de trincas de estágio I do Tipo A (crescimento ao longo da superfície) e do Tipo B (crescimento para dentro da superfície) (Socie, 2004a). 


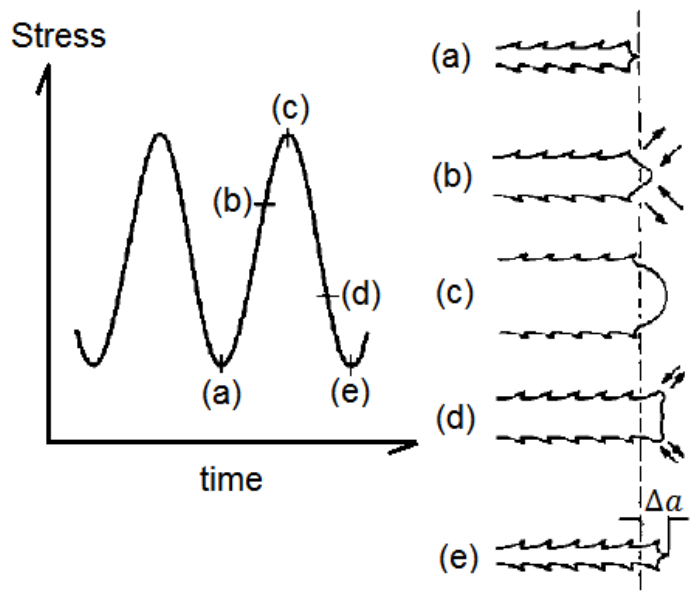

(a) Avanço em cada ciclo

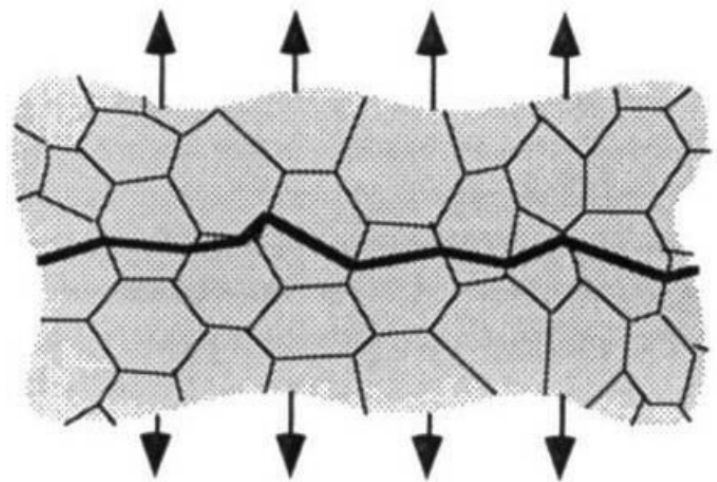

(b) Processo de propagação dentro dos grãos

Figura 2.8 Propagação de uma trinca de estágio II (Mentley, 2013).

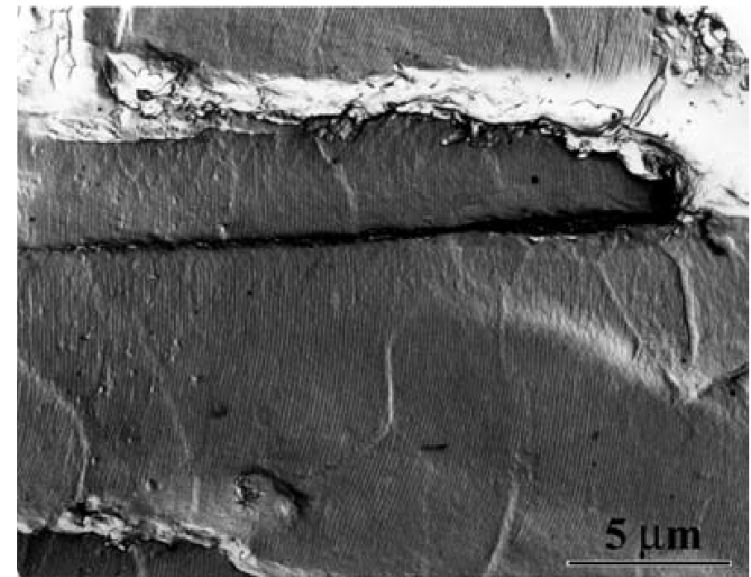

(a) Início do estágio II

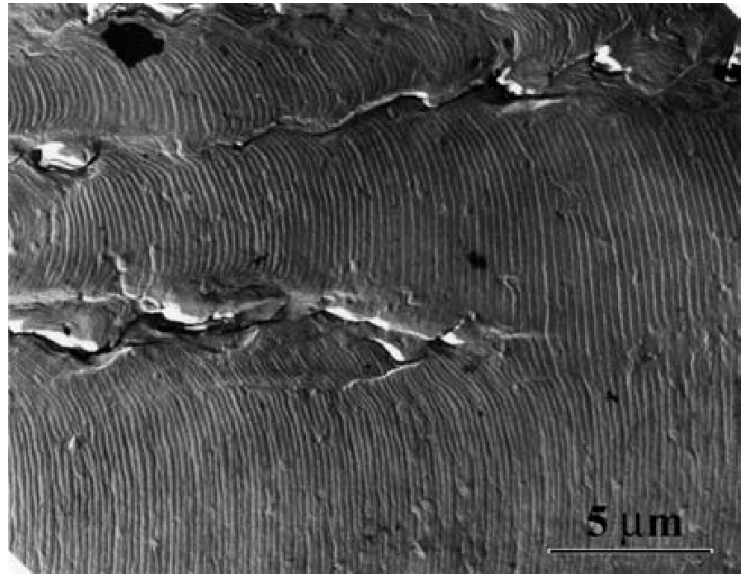

(b) Final do estágio II

Figura 2.9 Estrias de fadiga em liga de alumínio 2014-T6 visto em MEV Meyers \& Chawla (2009).

A propagação da trinca no estágio II deixa marcas na superfície fraturada. Esta marcas são chamadas de marcas de praia ou marcas de estrias. As marcas de praia estão sempre presentes no estágio II, desde o início até o fim deste estágio, entretanto são mais visíveis no final. A figura 2.9 apresenta as marcas de praia de uma liga de alumínio 2014-T6 vistas em um Microscópio Eletrônico de Varredura (MEV).

Cada estria representa um ciclo de carga (carregamento + descarregamento), conforme indica a figura 2.8. Desta maneira, um espaçamento pequeno entre as estrias indica um menor avanço da trinca em cada ciclo. Conforme pode ser visto na figura 2.9, o espaçamento pequeno entre as estrias no início do estágio II indica uma taxa de propagação da trinca menor do que no final deste estágio. Em outras palavras, a velocidade com que a trinca se propaga é menor no começo do estágio II e vai aumentando gradativamente quanto maior 
for o tamanho da trinca (Anderson, 2005). As marcas de praia também serão mais espaçadas quanto maior for a tensão normal alternada perpendicular à trinca de estágio II.

Os trabalhos de Anderson (2005), Lee et al. (2005), Bishop \& Sherratt (2000) e Mentley (2013) afirmam que, geralmente, se o componente mecânico não possuir trincas logo após seu processo de manufatura ou após sua montagem no produto final, então a maior parte da vida do componente é gasta na nucleação da trinca (i.e., no estágio I) e a menor parte na fase de propagação da trinca (i.e, no estágio II). Caso contrário, então o estágio II terá duração muito maior do que o estágio I. Schijve (2008) representa esta idéia na figura 2.10.

Escala de falha comprimento da trinca

(Tamanhos típicos)
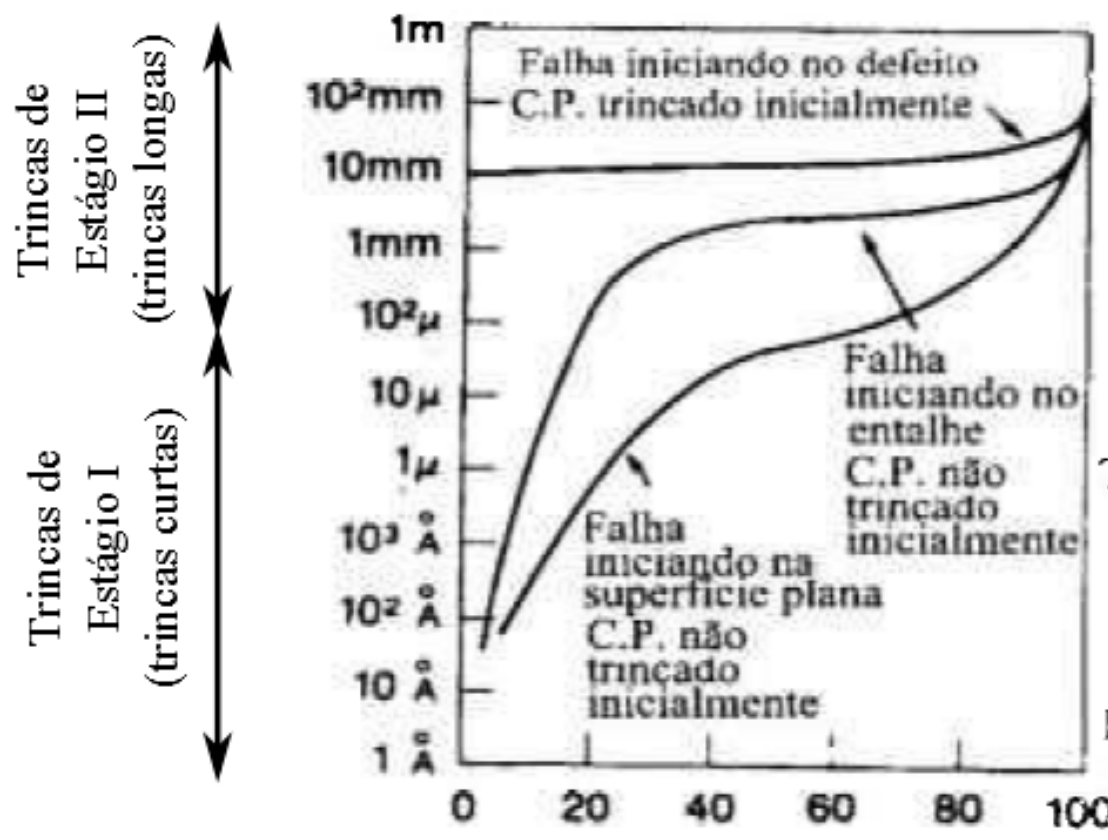

Componente automotivo ou C.P.

Porcentagem da Vida em Fadiga

Figura 2.10 Diferentes cenários de crescimento de uma trinca por fadiga (Schijve, 2008).

\subsection{Estágio III: Fratura repentina devido ao cres- cimento instável da trinca}

A trinca de estágio II irá continuar a crescer enquanto houver aplicação de tensão de tração cíclica. Em algum momento, o tamanho da trinca se torna grande o suficiente de maneira que o material remanescente não consegue suportar o carregamento, resultando em 


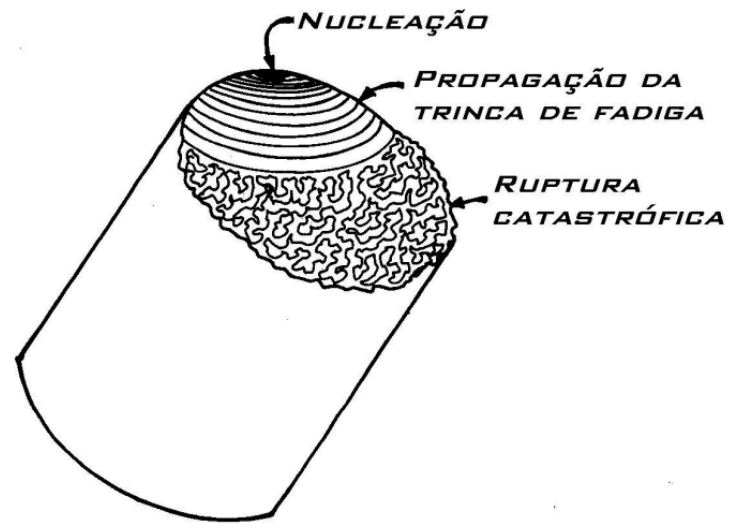

(a) Esboço da superfície de fratura (Schijve 2008).

Figura 2.11 Representação das superfícies características de uma fratura em fadiga, com distinção da nucleação, propagação e instabilidade da trinca.

uma fratura repentina, rápida e catastrófica, sem sinal de aviso prévio. Exames a olho nu de peças que falharam por fadiga mostram um padrão típico como ilustram as figuras 2.11a e 2.11b. Há uma região repleta de marcas concêntricas chamadas marcas de praia, que apontam para o local da nucleação da trinca, e uma região que parece opaca e áspera/rugosa, com aparência de fratura frágil. Esta região áspera é exatamente onde ocorreu a fratura referente ao estágio III.

\subsection{Conclusões do Capítulo 2}

Este capítulo descreveu os aspéctos microscópicos de uma fratura por fadiga. A fratura por fadiga pode ser dividida em três estágios: nucleação da trinca, propagação da trinca e fratura repentina.

No estágio de nucleação da trinca as tensões cíclicas causam deformações plásticas cíclicas dos grãos da matriz metálica. Estas deformações cíclicas são deformações cisalhantes que acontecem na direção paralela aos planos de menor resistência mecânica da célula unitária, e cuja direção também é paralela aos planos de máxima tensão de cisalhamento local. O acúmulo dos deslizamentos dá origem à extrusões e intrusões; estas últimas vão aumentando de profundidade e podendo ser caracterizada como uma trinca, até atingir um contorno de grão.

Quando uma intrusão ultrapassa o contorno de grão e passa a se propagar perpendicularmente à tensão normal à trinca então diz-se que o estágio é de propagação de trinca. Neste 
estágio, o tamanho da trinca (i.e., zona de deformação plástica na ponta da trinca ${ }^{7}$ ) é grande o suficiente para que os contornos de grão e a direção do reticulado cristalino não influencie na direção de propagação da trinca; apenas as tensões ligeiramente afastadas da ponta da trinca. As marcas de praia são formadas neste estágio. Quanto maior a velocidade de propagação da trinca mais visíveis serão estas marcas e a estrutura estará mais próxima da fratura repentina.

A fratura repentina é o terceiro e último estágio de uma fratura por fadiga. Este estágio acontece porque o tamanho da trinca se torna tão grande que o material remanescente não consegue suportar o carregamento, resultando em uma fratura repentina, rápida e catastrófica, sem sinal de aviso prévio.

${ }^{7}$ também chamada de Zona de Processo de Fratura (ZPF). 


\section{Capítulo 3}

\section{Métodos para Previsão de Vida em Fadiga}

$\mathrm{O}$ atual processo de análise de fadiga pode ser estruturado conforme apresenta a figura 3.1. Neste fluxograma, a geometria, o carregamento e as propriedades do material são os três parâmetros de entrada na análise de análise de tensões, produzindo assim um histórico de tensão $(\sigma-t)$ ou deformação $(\varepsilon-t)$ em todos os pontos do componente, inclusive no ponto mais crítico. Entende-se por ponto crítico o primeiro ponto em que uma trinca por fadiga irá nuclear se propagará até que o componente frature em duas ou mais partes. Antigamente, a análise de tensões era realizada utilizando cálculos manuais. Atualmente, porém, a maioria das análises de tensões são realizadas utilizando FEA, pois resulta em boa precisão dos valores de tensões/deformações e dos locais críticos do componente. Após esta etapa, a análise de fadiga é realizada para se determinar a durabilidade da estrutura. Faz-se necessário então escolher o Método de Fadiga a ser utilizado, que pode ser o Método $S-N$, o Método $\varepsilon-N$, o Método da Mecânica da Fratura Linear Elástica (MFLE) ou uma combinação entre esses métodos, a serem detalhados nas seções 3.1, 3.2, 3.3 e 3.4. Em seguida, deve-se escolher o Critério de Fadiga a ser adotado a partir do Método de Fadiga previamente escolhido. Para execução dessa etapa, novas propriedades do material, relativas a seu comportamento sob tensão cíclica, são então utilizadas.

As propriedades de fadiga do componente podem ser obtidas tanto através do ensaio de fadiga do componente real quanto através de estimativa, utilizando para isso as propriedades de fadiga do espécime e os fatores modificadores. O Critério de Fadiga, as propriedades de fadiga do componente e os histórico de tensão (ou deformação) irão ser utilizados em conjunto na etapa intitulada Contabilização do Dano Cumulativo, cujo objetivo é de calcular o dano por fadiga causado pelo carregamento externo aplicado. Após esta etapa, finalmente a previsão de vida do componente é realizada. Se o esta previsão de vida indicar que o componente deve ser modificado por não atender os requisitos de projeto, então o processo deve ser refeito desde o início.

Os três métodos de fadiga usados em projeto de durabilidade são o Método $S$ - $N$, o Mé- 


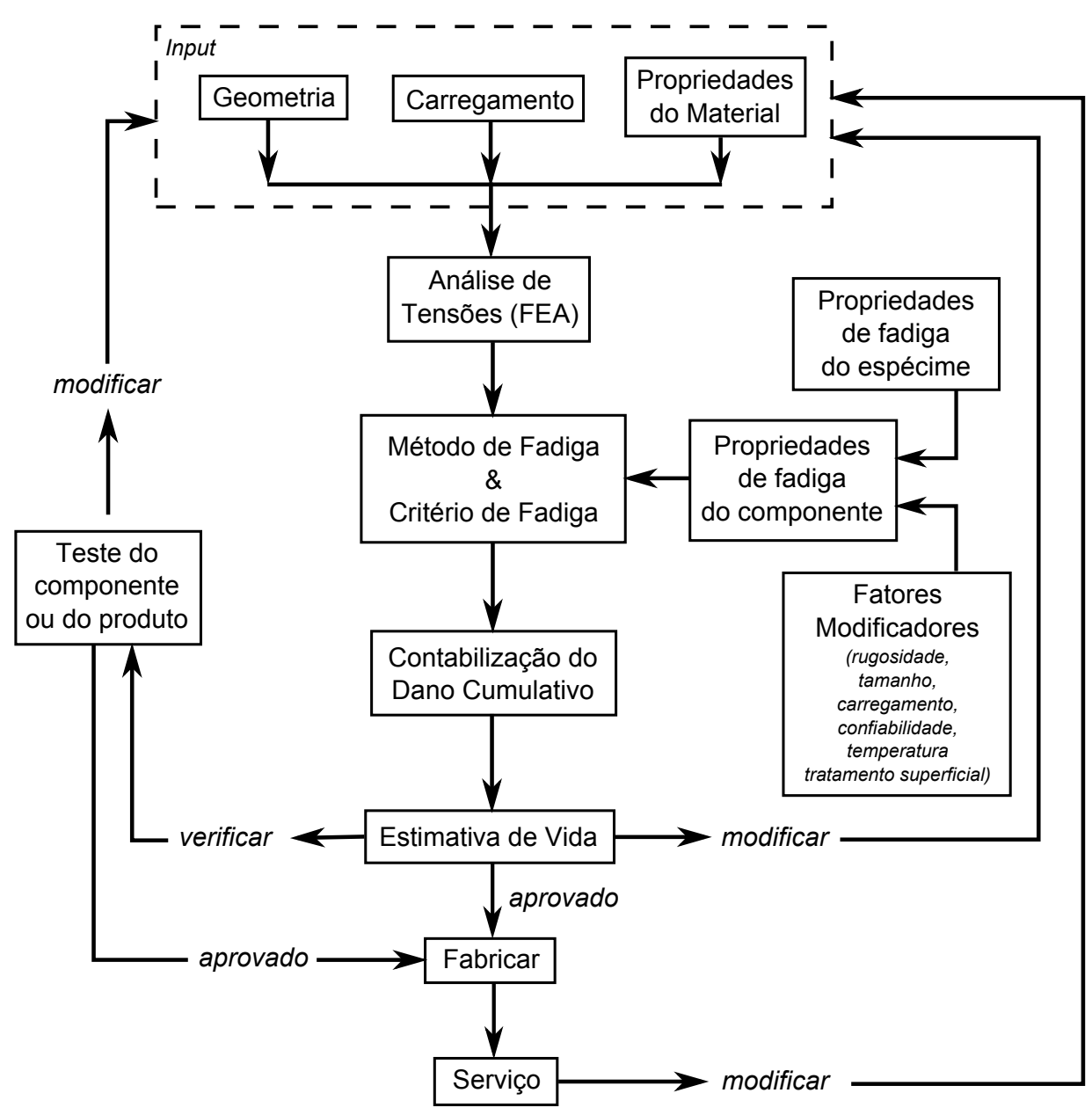

Figura 3.1 Processo de previsão de vida de componente utilizando FEA.

todo E-N e o Método da Mecânica da Fratura Linear Elástica (MFLE). Os métodos tentam prever/estimar a vida em fadiga do componente através do número de cíclos de carregamento $(N)$ em que ocorrerá a falha. Entende-se por falha como sendo a fratura repentina mencionada na seção 2.3. Fadiga de Baixo Ciclo (LCF) se caracteriza quando há deformações plásticas cíclicas em alguma região do componente, cuja falha geralmente ocorrerá em $1 \leq N \leq 10^{3}$ ciclos nesta condição de deformação (Shigley et al. (2003), Lee et al. (2005), de Castro \& Meggiolaro (2009a)). Por esta razão, um componente que tenha uma vida de $1 \leq N \leq 10^{3}$ ciclos é classificado como tendo um problema de Fadiga de Baixo Ciclo. Por outro lado, um problema de Fadiga de Alto Ciclo (HCF) se caracteriza apenas por deformações elásticas cíclicas no componente que, por serem de menor intensidade que as deformações plásticas; geralmente faz com que um componente metálico falhe com $N \geq 10^{3}$ ciclos. Esté é o motivo que Fadiga de Alto Ciclo é caracterizada por uma vida $N \geq 10^{3}$ ciclos.

Antes de começar os cálculos de fadiga, o engenheiro deve decidir qual método de análise é mais adequado para resolver o problema objeto de análise. Embora existam os três 
métodos descritos anteriormente, nem todos podem ser utilizados em um mesmo problema. Existem problemas em que apenas um método é possível de ser utilizado, outros já admitem a utilização de dois deles. As respostas às perguntas abaixo irão determinar qual método de previsão de vida em fadiga é o mais adequado para se utilizar, uma vez que esta escolha depende das características do problema.

- Qual deverá ser a vida útil do componente/estrutura analisado?

- O carregamento aplicado no componente causa deformações plásticas cíclicas?

- O componente será substituído quando atingir a vida útil especificada na fase de projeto, independente de ter ou não surgido trincas no mesmo?

- O componente analisado é soldado?

- Há trincas no componente logo após sua fabricação ou sua montagem no produto?

- É possível realizar inspeções periódicas a fim de se acompanhar o tamanho de trincas no componente ao longo de sua vida?

- O componente estrutural será regularmente inspecionado quanto a trincas e será substituído quando existirem trincas e estas atingirem um tamanho máximo pré-estabelecido na fase de projeto?

As seções 3.1, 3.2 e 3.3 descreverão em mais detalhes cada um dos 3 métodos de fadiga.

\subsection{Método Tensão-Vida}

Este método, também conhecido como Método $S-N$ ou Método Baseado em Tensãd um histórico de tensão $(S)$ é estimado para a parte do componente que se julga mais crítica (ponto crítico). Após isto, compara-se esse histórico com a resitência à fadiga do material do componente e determina-se assim o número máximo de ciclos de carregamento $(N)$ que o componente conseguirá suportar antes de haver fratura por fadiga. Este método é baseado apenas em níveis de tensão e é o mais utilizado, por sua fácil aplicação, por existir uma grande quantidade de dados de material na literatura (propriedades de fadiga) e por representar adequadamente problemas de alto ciclo $\left(N>10^{5}\right.$ ciclos $)$.

Neste método, a resistência à fadiga de um material é representada pela Curva $S-N)^{2}$, mostrada na figura 3.2. A curva S-N é obtida através de vários ensaios mecânicos, sendo que em cada ensaio um espécime é sujeito a uma força axial cíclicla de magnitude específica. A figura 3.3 apresenta um espécime montado em uma máquina de fadiga de carregamento axial. Esta força varia no tempo e gera uma tensão axial no espécime, que geralmente é uma função senoidal com amplitude igual à $S_{a}$, conforme ilustra a figura 3.4. Esta força/tensão

\footnotetext{
${ }^{1}$ Do inglês, Stress-Life Approach ou Stress-Based Approach.

${ }^{2}$ Também chamada de Curva Tensão-Vida ou Curva de Wölher.
} 
é aplicada no espécime até que ocorra a falha, caracterizada pela separação do mesmo em duas partes. Uma vez ocorrida a falha, um ponto é marcado em um gráfico, sendo o valor da ordenada igual à tensão alternada $S_{a}$ e o valor da abscissa igual ao número de cíclos em que ocorreu a falha $N$. Este procedimento é repetido com vários espécimes, cada ensaio sendo realizado com um valor diferente de $S_{a}$. O primeiro ensaio é realizado de maneira que o espécime seja submetido a uma tensão um pouco inferior ao limite de escoamento do material. O segundo teste é feito a uma tensão $S_{a}$ menor que aquela utilizada no primeiro. O terceiro teste é feito a uma tensão $S_{a}$ menor do que a do segundo, e assim por diante. Cada espécime testado irá falhar em um número de ciclos diferente. Quanto mais baixa é a tensão alternada $S_{a}$, maior será o número de ciclos para a falha $N$. A curva S-N é a curva que melhor interpola a nuvem de pontos, sendo portanto uma média do fenômeno.

É importante salientar que o método S-N pode ser utilizado apenas quando o componente não possuir trincas no instante inicial de sua utilização. Além desse fator, esse método somente pode ser utilizado quando não há deformação plástica cíclica presente no componente analisado (ou quando há pouquíssima deformação plástica cíclica). Isto ocorre porque apenas deformações elásticas cíclicas foram consideradas quando a curva S-N foi obtida. Consequentemente, segundo Shigley et al. (2003), este método é menos preciso em aplicações onde $N$ tende a se aproximar de $10^{3}$ ciclos, devido ao início do processo de plastificação.

O método Baseado em Tensão será a base para este trabalho e será explicado em mais detalhes nos capítulos 4 e 5 .

\subsection{Método Deformação-Vida}

Na seção 3.1 foi apresentado a análise e dimensionamento de componentes utilizando o método baseado em tensão. Este método previsão de vida em fadiga funciona bem para situações em que apenas estão presentes tensões e deformações elásticas. Contudo, é comum haver casos em que tensões elásticas cíclicas ocorram na maior parte de um componente, mas ocorram deformações plásticas cíclicas em concentradores de tensão, como entalhes. Por esta razão, outra abordagem foi desenvolvida na metade década de 1950. Este novo método utiliza a deformação local como parâmetro de fadiga governante e tem mostrado ser eficiente em prever a vida em fadiga de um componente sujeito a deformação plastica cíclica.

Este método é conhecido como Método $\varepsilon-N$ ou Método Baseado em Deformação $]^{3} \mathrm{O}$ método está baseado na hipótese que a vida gasta na nucleação e crescimento de uma trinca em um componente entalhado pode ser aproximada por um espécime não entalhado polido submetido à mesma deformação cíclica que àquela presente no local de iniciação da trinca

${ }^{3}$ Do inglês, Strain-Life Approach ou Strain-Based Approach. 


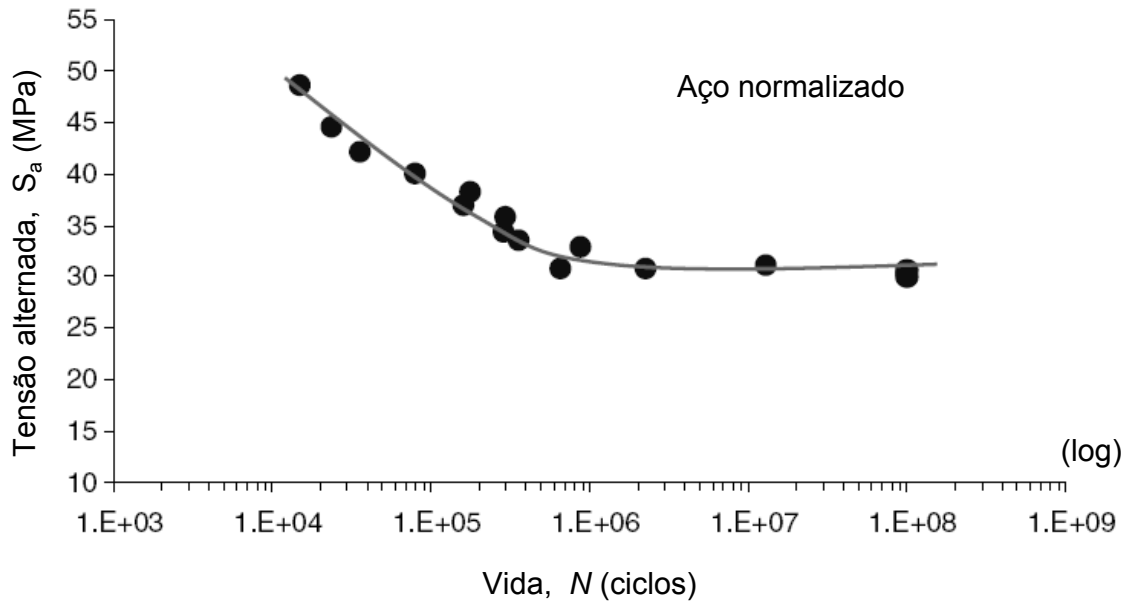

Figura 3.2 Exemplo de curva $\mathrm{S}-\mathrm{N}$

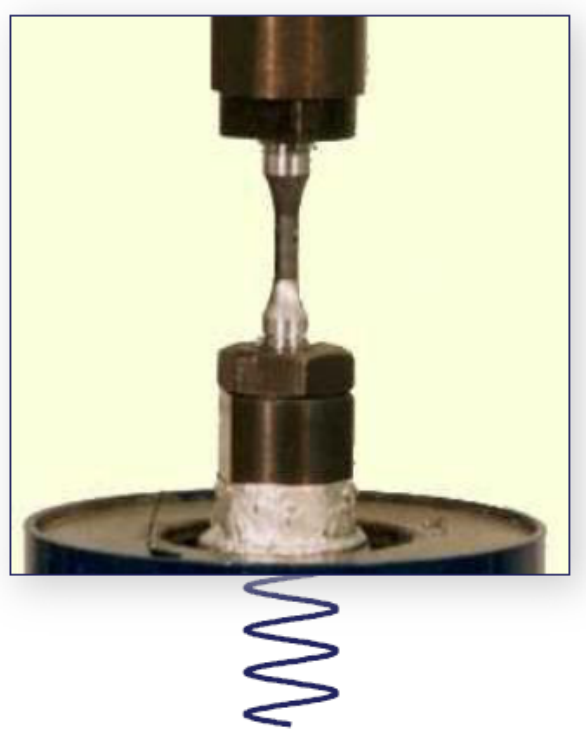

Tensão axial

Figura 3.3 Montagem do espécime na máquina de ensaio de fadiga.

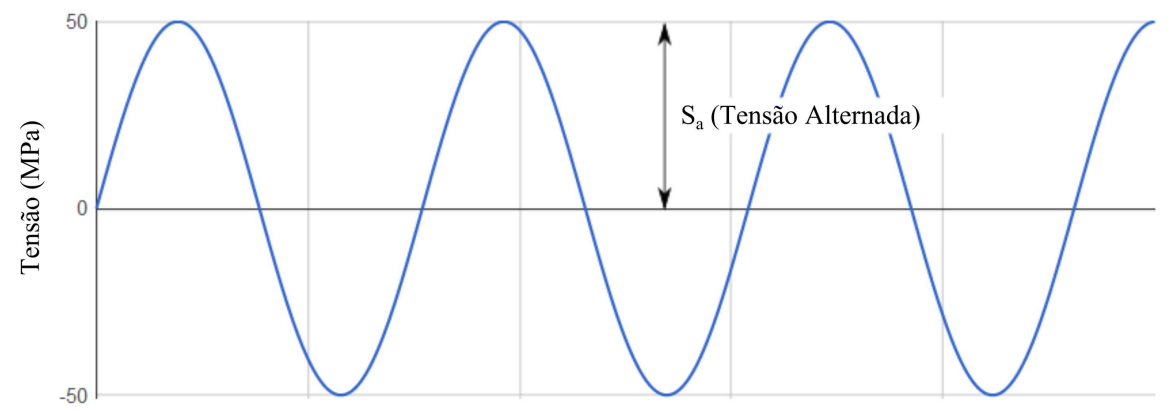

Figura 3.4 Tensão ao longo do tempo aplicada no espécime. 
no componente. A figura 3.5 ilustra este conceito. Utilizando este conceito é possível determinar a vida em fadiga em uma região de um componente carregado ciclicamente se for conhecida a relação entre a deformação e a vida em fadiga de um espécime. Esta relação deformação-vida $(\varepsilon-\mathrm{N})$ é tipicamente representada conforme a figura 3.6. Esta curva é gerada conduzindo-se ensaios em espécimes polidos e sem entalhes, sujeitos à força axial cíclica, afim de gerar deformação cíclica controlada. A figura 3.7 apresenta a geometria e dimensões de um dos espécimes utilizados em ensaio de fadiga baseado em deformação.

A obtenção da curva $\varepsilon$-N é mais complexa que a da curva S-N e feita conforme descrito a seguir. Uma máquina de fadiga aplica em um espécime um deslocamento axial cíclico ao longo do tempo, de maneira a produzir no espécime (na região da seção uniforme) um nível alto de deformação cíclica. Esta deformação cíclica também varia no tempo e sua amplitude $\varepsilon_{a}$ é constante ao longo de todo aquele ensaio, conforme ilustra a figura 3.8 . $\mathrm{Na}$ verdade, a deformação aplicada no espécime é a deformação alternada total $\varepsilon_{a}$, que é igual à soma da deformação alternada elástica $\varepsilon_{a, e}$ com a deformação alternada plástica Através de manipulações matemáticas é possível obter separadamente $\varepsilon_{a, e}$ e $\varepsilon_{a, p}$ e plotá-las no mesmo gráfico $\varepsilon-\mathrm{N}$, conforme apresentado na figura 3.6. Portanto, Portanto, a curva total é igual à soma da curva elástica com a curva plástica. Entretanto, é a curva total, caracterizada pela deformação alternada $\varepsilon_{a}$, que deve ser utilizada no cálculo de vida em fadiga.

Durante cada ensaio, uma trinca irá nuclear na superfície do espécime (na região da seção uniforme) polido e crescer até que ocorra a fratura do mesmo. Ao final de cada ensaio, anotase 2 pontos no gráfico $\varepsilon-\mathrm{N}$ : o primeiro ponto possui coordenadas $\left(\varepsilon_{a, e}, 2 N\right)$ e o segundo ponto possui coordenadas $\left(\varepsilon_{a, p}, 2 N\right)$. O valor da abscissa é igual ao número de reversões $2 N$ em que ocorreu a falha. Deve-se observar que um ciclo é igual à 2 reversões. Este procedimento é repetido várias vezes, sendo que em cada ensaio submetido a um valor de $\varepsilon_{a}$ diferente. $\mathrm{O}$ primeiro ensaio geralmente é realizado de maneira que o espécime seja submetido a uma deformação um pouco inferior ao limite de resistência à tração do material. O ensaio seguinte é feito a uma deformação menor que aquela utilizada no anterior; consequentemente, cada espécime testado irá falhar em um número de ciclos diferente. Quanto mais baixa é a diferente. Quanto mais baixa é a deformação alternada aplicada $\varepsilon_{a}$, para a falha $2 N$. Ao final, realiza-se uma interpolação à curva elástica e obtém-se a equação que a descreve. $\mathrm{O}$ mesmo procedimento é feito para a curva plástica. Finalmente, a curva $\varepsilon-\mathrm{N}$ é obtida através da soma das duas $\varepsilon-\mathrm{N}$ é obtida através da soma das duas curvas supracitadas.

A transição de vida em fadiga $\left(2 N_{T}\right)$ representa o número de reversões na qual a deformação alternada elástica é igual a deformação alternada plástica. Em outras palavras, a transição de vida em fadiga representa o instante em que a influência da deformação plástica passa a ser menor do que a da deformação elástica. É importante ressaltar que o método S-N deve ser utilizado somente quando não há (ou quando há pouquíssima) deformação plástica no componente analisado, e isto somente acontece quando a curva plástica cruza o eixo das 


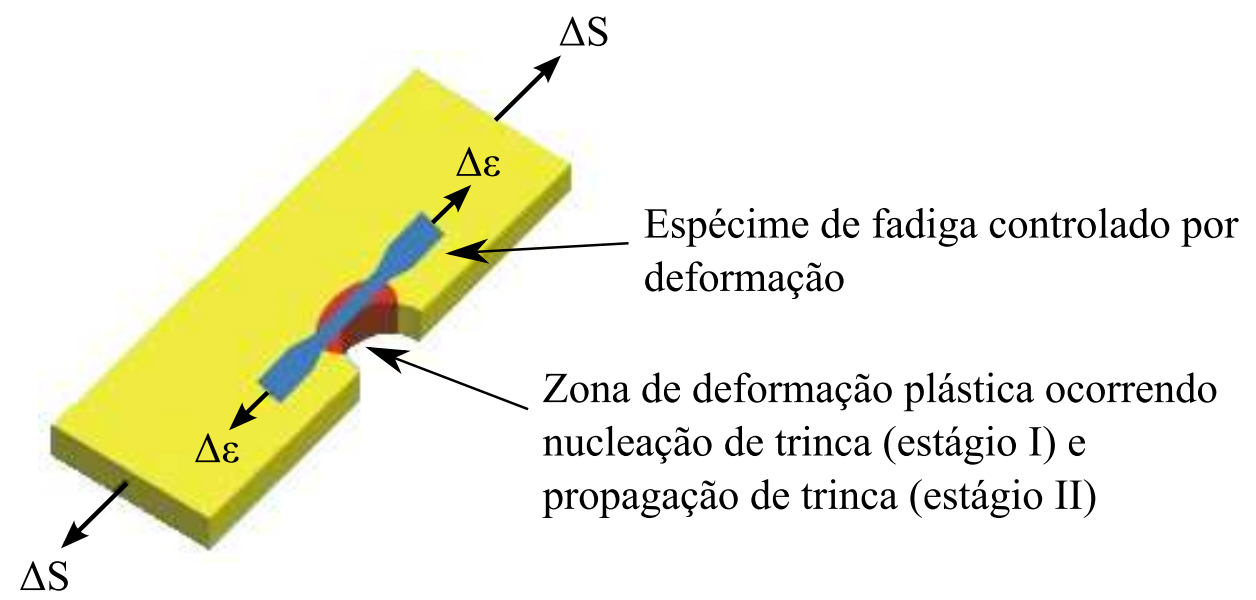

Figura 3.5 Conceito do método $\varepsilon$-N baseado na deformação local (Socie, 2008).

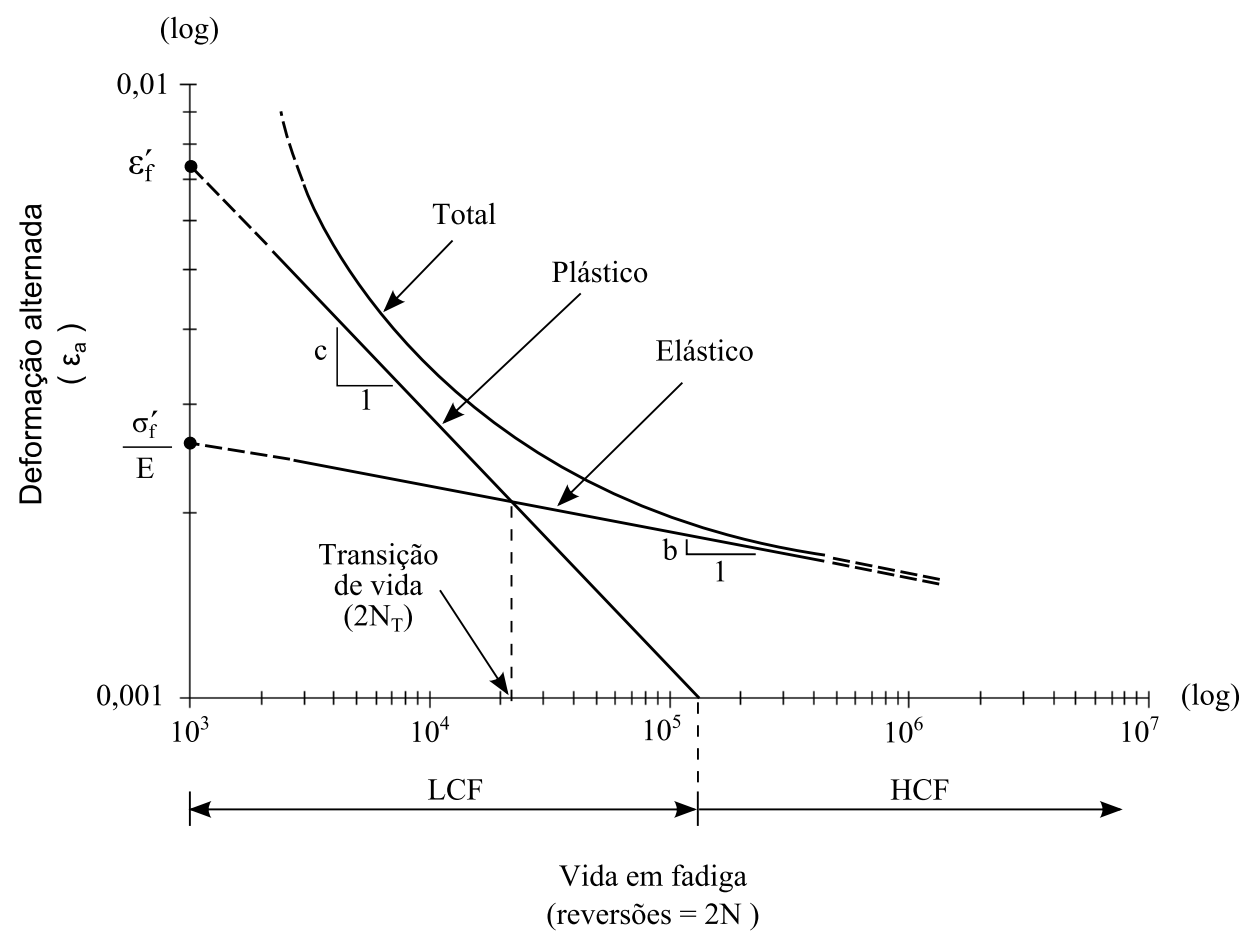

Figura 3.6 Exemplo de curva $\varepsilon-\mathrm{N}$. 


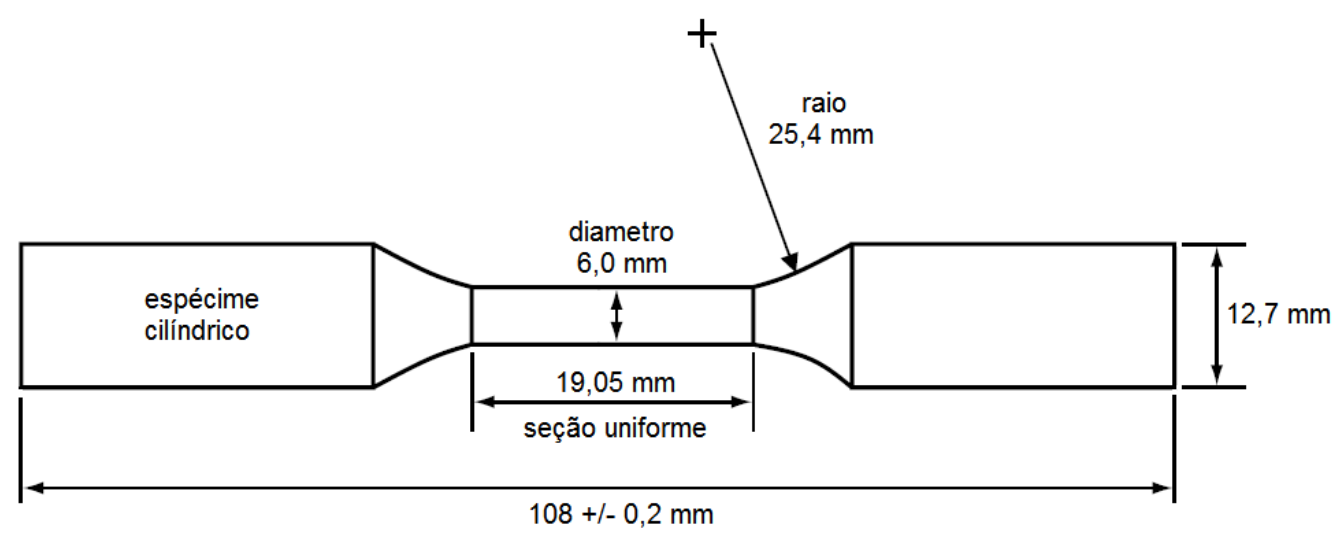

Figura 3.7 Dimensões de um tipo de espécime utilizado para obtenção de curva $\varepsilon-\mathrm{N}$.

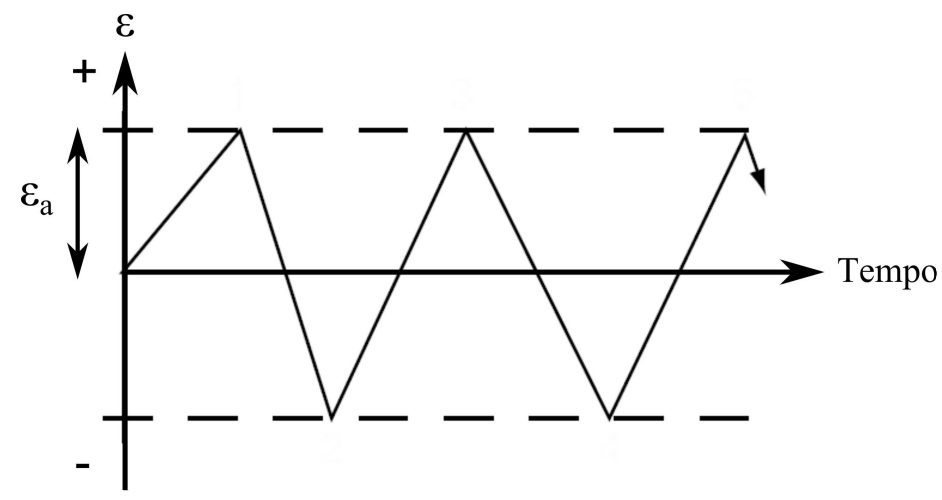

Figura 3.8 Deformação cíclica aplicada no espécime de fadiga para obtenção da curva $\varepsilon-\mathrm{N}$. 
abscissas. Costuma-se dizer que a região à esquerda deste ponto é chamada de $[\mathrm{LCF}$ e a região à direita é chamada de Fadiga de Alto Ciclo $(\mathrm{HCF}$, conforme apresenta a figura 3.6.

É importante destacar que, igualmente à abordagem S-N, o método $\varepsilon-\mathrm{N}$ deve ser utilizado apenas quando o componente não possuir trincas no instante inicial de sua utilização.

O método $\varepsilon$-N é o único que pode ser utilizado quando as tensões no componente estão acima do limite de escoamento do material do componente, portanto sempre deve-se utilizar esta abordagem em regime de LCF. Entretanto, este método também pode ser utilizado perfeitamente quando há apenas deformações elásticas presentes. Isto ocorre porque, no regime $\mathrm{HCF}$, a equação que estima a vida no método $\varepsilon-\mathrm{N}$ torna-se idêntica à equação que estima a vida no método $\mathrm{S}-\mathrm{N}$, conforme pode ser visto na figura 3.6. O método $\mathrm{S}-\mathrm{N}$ é, na verdade, um sub-grupo do método $\varepsilon-\mathrm{N}$.

Além do mais, o método $\varepsilon-\mathrm{N}$ possui também outra vantagem sobre o método $\mathrm{S}-\mathrm{N}$ : um componente em serviço pode ter um requisito de vida bastante longa e ser submetido a cargas de magnitude baixa (que não geram escoamento localizado em nenhuma parte do componente, nem nos entalhes) na maior parte do tempo, mas ser submetido raramente a cargas elevadas que causam escoamento em um ponto crítico. Neste caso, o grande número de cargas baixas pode causar dano insignificante ao componente, mas o método $\varepsilon-\mathrm{N}$ continua sendo apropriado, pois consegue contabilizar o dano causado tanto pelas cargas de baixa magnitude quanto pelos picos de carga.

Por outro lado, embora o método $\varepsilon-\mathrm{N}$ seja mais abrangente que a abordagem $\mathrm{S}-\mathrm{N}$, ele é também mais difícil de ser utilizado e exige maior entendimento por parte do engenheiro. Adicionalmente, a quantidade de curvas $\mathcal{\varepsilon}-\mathrm{N}$ disponíveis na literatura é muito menor do que as curvas S-N, o que dificulta consideravelmente a realização de análises utilizando este método.

\subsection{Método da Propagação de Trincas}

Este método, também conhecido como Método da/dN ou Método de Crescimento de Trincas ${ }^{4}$, parte do princípio que uma trinca já está presente em componente e que foi detectada (geralmente utilizando equipamentos especiais). Desta forma, esse método, proposto inicialmente por Paul C. Paris em 1961, é utilizado para prever quanto tempo a trinca inicial demorará para crescer até que haja a ruptura do componente.

Seja um componente estrutural que possua em sua superfície uma trinca de tamanho $a_{i}$. O motivo desta trinca ter surgido é irrelevante; esta trinca pode ter surgido logo após a

\footnotetext{
${ }^{4}$ Do inglês, Crack Growth Approach ou Fracture Mechanics Approach.
} 
manufatura do componente, logo após a montagem do componente em um produto ou ter nucleado e crescido a partir da superfície lisa por causa das tensões/deformações cíclicas aplicadas pelos carregamentos externos. Entende-se por superfície lisa qualquer uma que não possua microtrincas ou trincas. Considerando que este componente está sujeito a uma força cíclica de amplitude constante, então a trinca irá crescer conforme ilustra a figura 3.9. A velocidade de propagação da trinca é igual à derivada desta curva $(d a / d N)$ e varia conforme o tamanho da trinca aumenta. Portanto, quanto maior o tamanho da trinca, maior é a taxa de crescimento da mesma. Também observa-se que a fratura (estágio III) ocorre quando a trinca alcança o tamanho crítico de trinca $a_{c}$.

A ponta de uma trinca possui uma geometria diferenciada; no passado alguns pesquisadores tentaram aproximar sua geometria como sendo um entalhe de raio de arredondamento muito pequeno na ponta. Entretanto, esta abordagem não foi promissora porque as tensões na ponta da trinca tendiam a infinito. A solução para este problema foi proposta por Irwin e seu grupo de trabalho (Irwin, 1957), que criou o conceito de fator de intensidade de tensão $K$. Esta variável, representada pela equação (3.1), é uma quantidade que está relacionada à trinca analisada e é função da geometria/tipo de trinca $(Y)$, do tamanho da trinca $(a)$ e da tensão $(\sigma)$ em uma região afastada da ponta da trinca (onde já não ocorre mais singularidade). Desta forma, Irwin pôde perceber que cada metal possui um valor constante $K_{c}$, chamado $f a$ tor de intensidade de tensão crítico ou tenacidade à fratura do material. Quando $K$ atinge o valor de $K_{c}$ então ocorre a fratura do material. A partir de Irwin (1957) o fator de intensidade de tensão passou a ser o fator principal de uma análise estrutural de materiais com trincas.

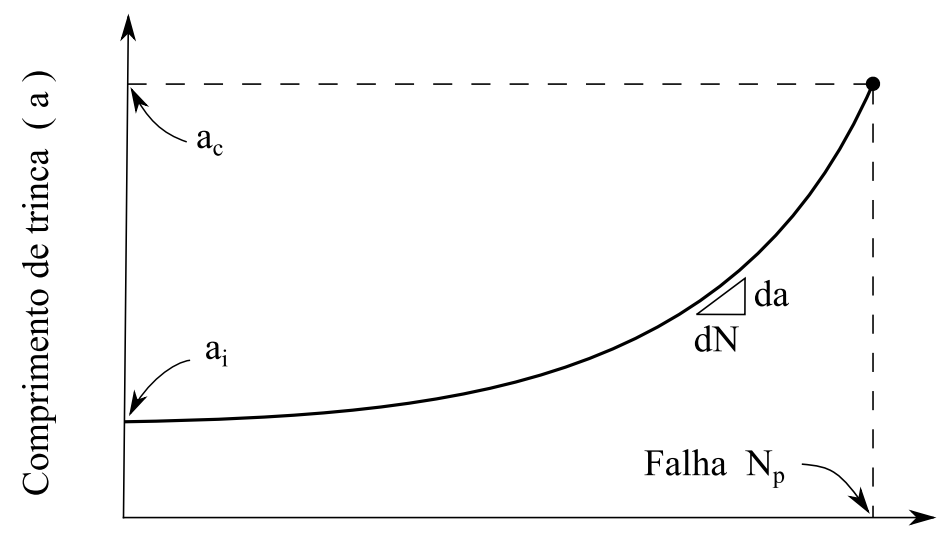

Ciclos ( N )

Figura 3.9 Crescimento de trinca em função do número de ciclos.

$$
K=\sigma Y \sqrt{\pi a}
$$

Mais tarde, Paris et al. (1961) publicaram uma lei que relaciona a taxa de crescimento da trinca durante um carregamento cíclico com variação do fator de intensidade de tensão. A 
lei de Paris pode ser visualizada como um gráfico linear log-log, onde o eixo x é denotado pela variação do fator de intensidade de tensões $(\Delta K)$ e o eixo y denotado pela taxa de crescimento da trinca $(d a / d N)$. A figura 3.10 apresenta esta relação.

A lei Paris pode ser utilizada para quantificar a vida residual (em termos de ciclos de carga) de um espécime com um tamanho de trinca particular. Sendo o fator de intensidade de tensão definido pela equação (3.1) e a variação do fator de intensidade de tensões é definida por

$$
\begin{aligned}
\Delta K & =K_{\max }-K_{\min } \\
& =\sigma_{\max } \cdot Y \cdot \sqrt{\pi a}-\sigma_{\min } \cdot Y \cdot \sqrt{\pi a} \\
& =\Delta \sigma \cdot Y \cdot \sqrt{\pi a}
\end{aligned}
$$

e taxa de crescimento da trinca é calculada por

$$
\frac{d a}{d N}=C(\Delta K)^{m}
$$

Onde

$\Delta \sigma$ : Variação da tensão cíclica daquele ciclo de carregamento

$Y \quad$ : Fator adimensional função da geometria da trinca

$a \quad$ : Comprimento da trinca

$C \quad$ : Coeficiente da curva $d a / d N$

$m$ : Expoente da curva $d a / d N$

A equação (3.3) deve ser utilizada de maneira iterativa. Na primeira iteração, o comprimento de trinca é $a_{i}$. A aplicação de um ciclo de carregamento com tensão máxima $\sigma_{\max } \mathrm{e}$ tensão mínima $\sigma_{\text {min }}$ resultará em um crescimento de $d a$. Na segunda iteração o comprimento de trinca a ser utilizado na equação é $a=a_{i}+d a$. Os cálculos são realizados sucessivamente até que o comprimento da trinca atinja o tamanho crítico $a_{c}$. Neste momento ocorrerá a fratura instantânea. Então, o número de ciclos restantes até a falha $N_{p}$ será igual ao número de iterações executadas.

Recomenda-se o uso de métodos numéricos para encontrar soluções razoáveis, pois pois o processo é iterativo e frequentemente não linear devido aos fatores $\Delta K$ e $Y$ dependerem fortemente do comprimento de trinca $a$.

As áreas de aplicação do Método de Propagação de Trinca são múltiplas: da petroquímica à nuclear, da construção naval à indústria aeroespacial, no transporte rodoviário e ferroviário e, de modo geral, em todo segmento industrial. 


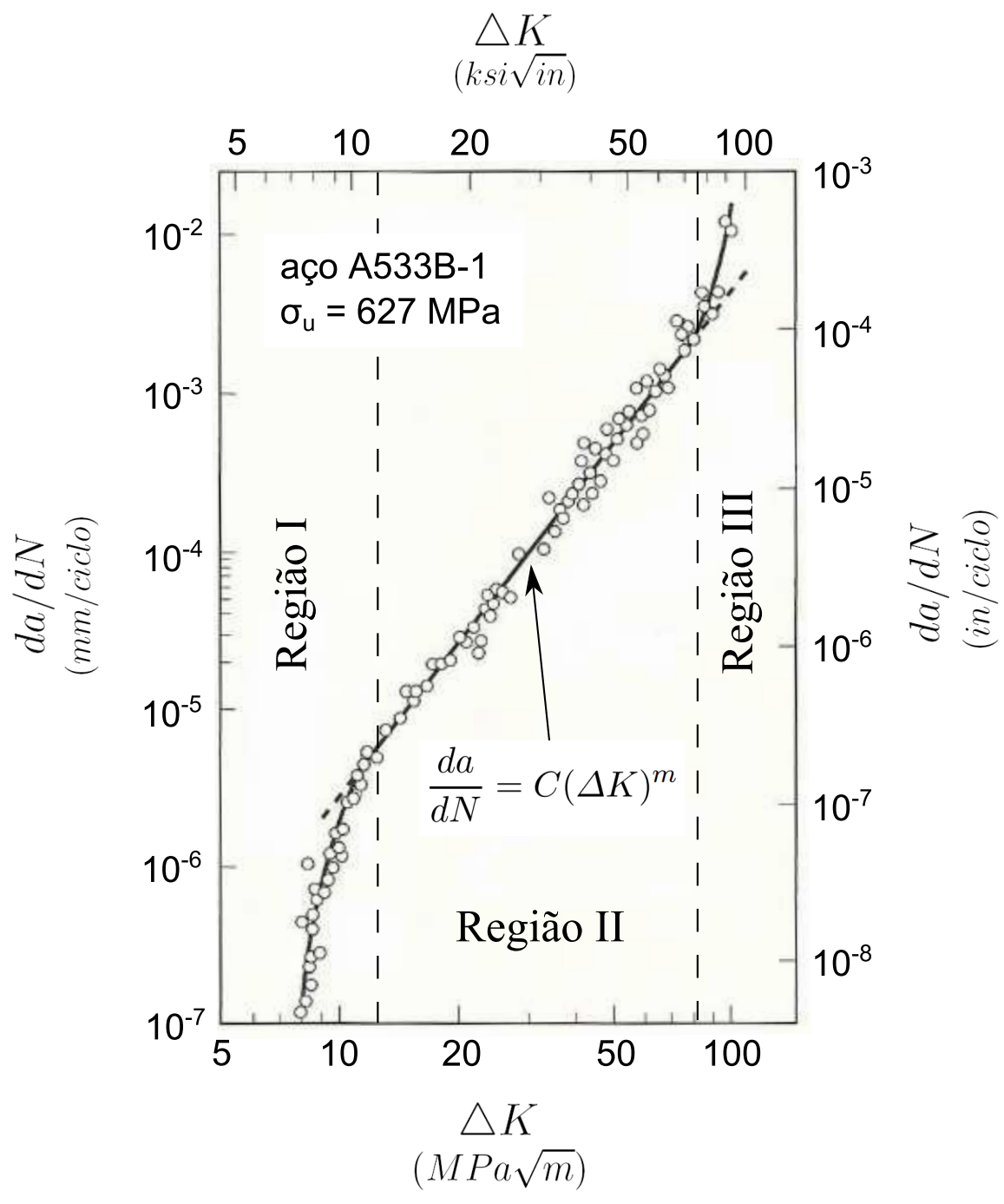

Figura 3.10 Lei de Paris.

\subsection{Idealização do Processo de Fadiga em Fases}

É possivel relacionar os métodos vistos anteriormente idealizando o processo de fadiga, conforme mostra as figuras 3.11 e 3.12 . É possível dividir a vida em fadiga em duas fases. A primeira chama-se fase de iniciação de trinca e é o tempo necessário para uma trinca nuclear de uma superfície lisa e não-trincada e crescer até o tamanho $a_{i}$. A segunda é intitulada por fase de propagação de trinca e corresponde ao tempo gasto para uma trinca crescer do tamanho inicial $a_{i}$ até a ruptura do componente. Consequentemente, a vida total de um componente $\left(N_{f}\right)$ é igual à vida gasta na fase de iniciação de trinca $\left(N_{i}\right)$ somada à vida gasta na fase de propagação de trinca $\left(N_{p}\right)$ :

$$
N=N_{i}+N_{p}
$$

$\mathrm{O}$ método $\varepsilon-\mathrm{N}$ parte do princípio que o componente não possui trincas e visa calcular o número de cíclos necessário para uma trinca nuclear e crescer até que haja a ruptura do 
espécime mostrado na figura 3.7, conforme apresenta a figura 3.5. Por outro lado, o método $\mathrm{da} / \mathrm{dN}$ parte do princípio que o componente possui uma trinca pré-existente e visa calcular o número de ciclos necessários para a trinca crescer do tamanho inicial $a_{i}$ até a ruptura do componente.

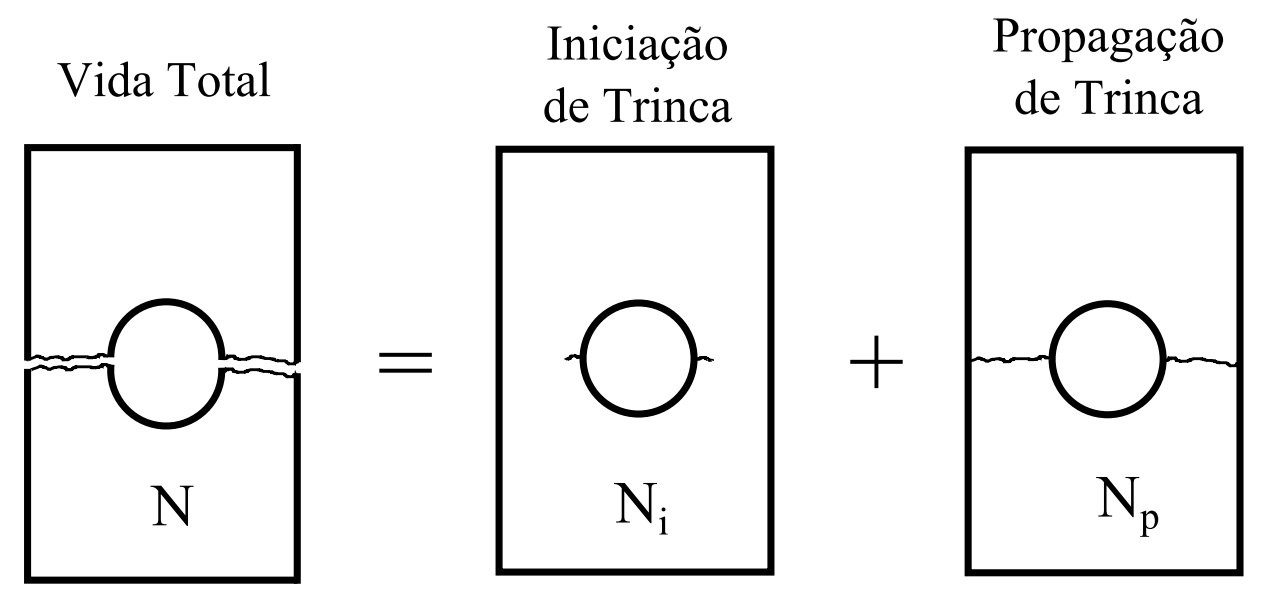

Figura 3.11 Idealização do processo de projeto de fadiga.

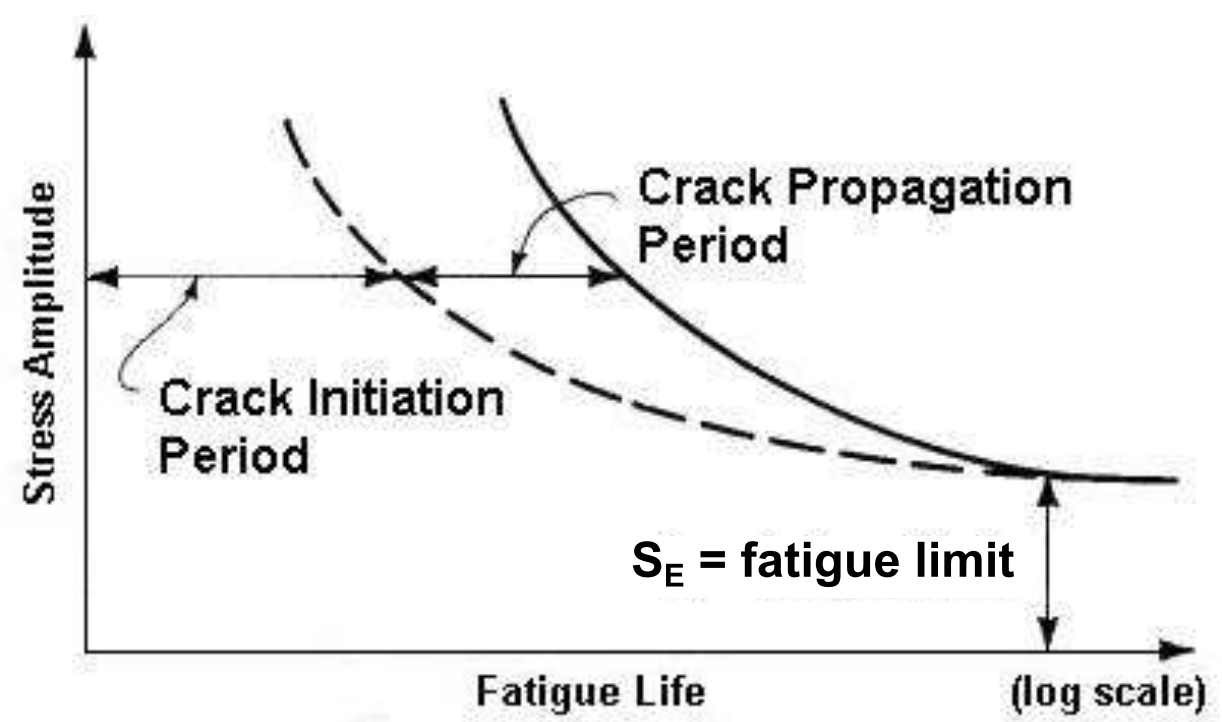

Figura 3.12 Fase de Iniciação de Trinca e de Propagação de Trinca na curva $\mathrm{S}-\mathrm{N}$.

Esta forma de pensar apresentada nas figuras 3.11 e 3.12 contribuiu para o surgimento de uma nova estratégia em análise de fadiga de componentes sem defeitos iniciais (i.e., componentes inicialmente não trincados). A estratégia consiste no seguinte: primeiramente, aplica-se o método $\varepsilon-\mathrm{N}$ para se determinar a vida de iniciação de trinca, entendendo-se que o tamanho de trinca do início fase de propagação $\left(a_{i}\right)$ será aproximadamente igual ao diâmetro do espécime utilizado no Método $\varepsilon-\mathrm{N}$. Após isto, aplica-se o Método da/dN para prever a vida remanescente do componente. Este tipo de procedimento é ilustrado pela figura 3.13 . Essa estratégia tem sido utilizada cada vez mais nos últimos anos, embora sejam poucos 
autores que citam o uso desse elegante procedimento (Suresh, 1998; Fatemi, sda Bishop \& Sherratt, 2000; Lee et al., 2011; Mentley, 2013). Já Fatemi (sda) caracteriza esta estratégia como sendo um $4^{\circ}$ método de previsão de vida em fadiga, nomeando-a de Método dos Dois Estágios.

É importante ressaltar que, embora o conceito mostrado na figura 3.11 defina uma ferramenta de visualização útil, isto tem pouca justificativa física. Cientistas de Materiais irão chamar a atenção de que o Método $\varepsilon-\mathrm{N}$ não identifica, de fato, o período de nucleação de trinca (Bishop \& Sherratt, 2000). Ao invés disso, este método identifica o tempo gasto para uma trinca crescer de um tamanho indetectável (superfície aparentemente não-trincada) até um tamanho que possa ser identificado usando ferramentas de inspeção disponíveis. Desta forma, não se deve confundir a fase de iniciação de trinca (mostrada nas figuras 3.11 e 3.12) com o período de nucleação de trinca. O período de nucleação de trinca é o tempo (número de ciclos) necessário para uma trinca de estágio I (short crack) se desenvolver por completo, ou seja, nuclear e crescer conforme descrito na seção Estágio I: Nucleação de Trinca (2.1). O tempo (número de ciclos) gasto em todo o estágio I não é necessariamente igual ao tempo gasto na fase de iniciação de trinca. Uma trinca curta tem, no final do estágio I, um comprimento de 1 até 5 contornos de grão; e esse tamanho de trinca é invisível à olho nu. Uma trinca do final da fase de iniciação (cujo comprimento é $a_{i}$ ) pode ter um comprimento grande o suficiente para ser caracterizada como uma trinca de estágio II. A propósito, geralmente adota-se que $a_{i}$ possui um valor na ordem de milímetros e, portanto, uma trinca de estágio II. Não existe regra que define o momento em que ocorre a transição da fase de iniciação para a de propagação de trinca. Isto depende da escolha do analista. Por exemplo, para um pesquisador equipado com um equipamento microscópico pode querer definir o comprimento de trinca $a_{i}$ como sendo da ordem de um grão no material, alguns grãos ou $0.1 \mathrm{~mm}$. Para um inspetor em campo, entretanto, $a_{i}$ pode ser definida como a menor trinca que é detectada com o seu equipamento de inspeção não-destrutivo. O tamanho de trinca no final da fase de iniciação $\left(a_{i}\right)$ adotado pela indústria geralmente está na faixa de 1 a $2 \mathrm{~mm}$ de comprimento. Entretanto, pode existir casos especiais em que $a_{i}=0.1 \mathrm{~mm}$.

Contudo, a distinção entre a vida de iniciação de trinca e de propagação de trinca é importante. Para baixas amplitudes de deformação, até $90 \%$ da vida em fadiga pode ser ocupada com a fase de iniciação de trinca, enquanto para altas amplitudes a maior parte da vida pode ser gasta na fase de propagação de trinca. Este fato é confirmado por Newman Jr. (1998, pg. 351), que diz:

Schijve mostrou que para superfíces polidas de metais puros e para ligas comerciais, a formação de uma pequena trinca de aproximadamente $100 \mu \mathrm{m}$ de tamanho pode consumir 60 a $80 \%$ da vida em fadiga

E também confirmado por Lee et al. (2005, pg. 352): 
Acoplamento dos métodos $\varepsilon-\mathrm{N}$ e da/dN modelam o processo de dano

$\tau$
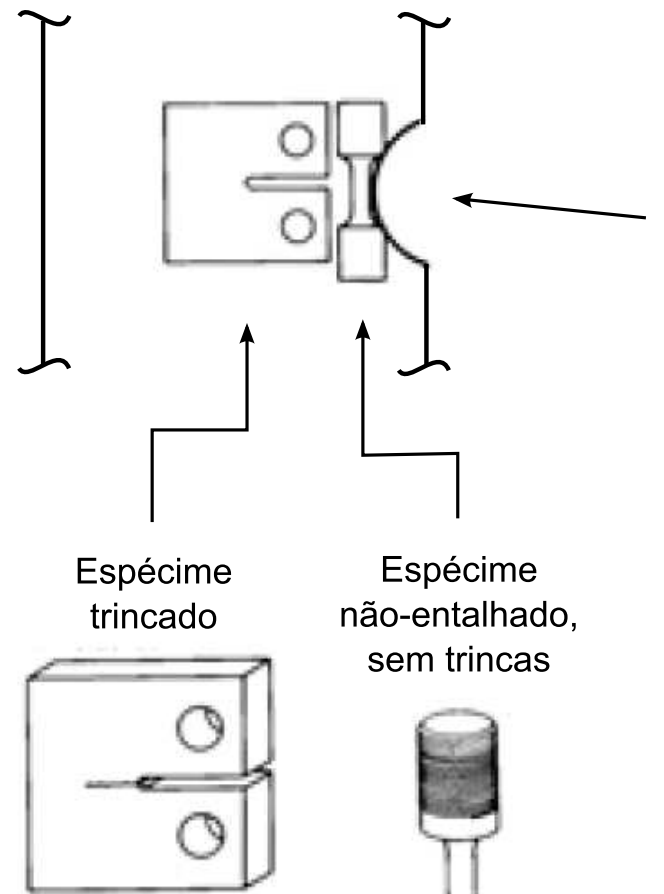

Espécime de teste fadiga para crescimento de trinca

\section{Espécime não-entalhado, sem trincas}

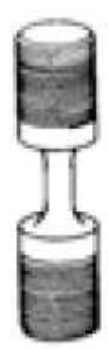

Espécime de teste de fadiga uniaxial baseada em deformação

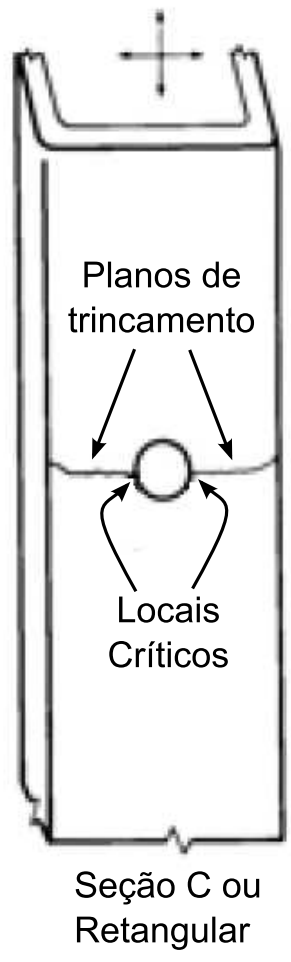

Figura 3.13 Diagrama esquemático ilustrando as duas fases de fadiga (iniciação e propagação de trinca) em um componente de engenharia e os métodos usados para estimar a vida em fadiga (Suresh, 1998). 
Geralmente, a fase de iniciação de trinca representa a maior parte da vida em fadiga de um componente feito de aço, particularmente no regime de fadiga de alto ciclo (aproximadamente $N>10.000$ ciclos). No regime de fadiga de baixo ciclo (aproximadamente $N<10.000$ ciclos), a maior parte da vida em fadiga é gasta na propagação de trinca.

Entretanto, Newman Jr. (1998, pgs. 352-353) relata sobre um importante experimento realizado em 1956 objetivando entender sobre a relação entre a fase de iniciação e de propagação. O experimento utilizou espécimes polidos e não entalhados de alumínio 6061-T6. Este alumínio possui tratamento térmico de endurecimento e possui muitos precipitados em sua matriz. $\mathrm{O}$ experimento mostrou que as primeiras trincas a serem detectadas tinham 0.1 mm de comprimento. Considerando que o tamanho médio dos grãos na liga de um alumínio 2024-T351 é de aproximadamente $0.05 \mathrm{~mm}$, então esta trinca de $0.1 \mathrm{~mm}$ é uma trinca de estágio II O trabalho de 1956 mostrou que em regime de Fadiga de Alto Ciclo, a nucleação e crescimento de uma trinca até $0.1 \mathrm{~mm}$ representou $26 \%$ da vida em fadiga e os outros $74 \%$ foram gastos na propagação de $0.1 \mathrm{~mm}$ até a fratura. Em Fadiga de Baixo Ciclo, a situação foi mais acentuada: o tempo gasto até a trinca chegar a $0.1 \mathrm{~mm}$ foi de $6 \%$ da vida total, contra 94\% do tempo gasto em propagação. Os resultados deste experimento mostraram que metais com grande quantidade de precipitados gastam a maior parte da vida na fase de propagação de trinca de estágio II. Isto acontece tanto em Fadiga de Alto Ciclo quanto em Fadiga de Baixo Ciclo, sendo mais intenso em baixo ciclo. Por este motivo os alumínios envelhecidos (indicados pela têmpera sigla $T$ ) e ferros fundidos dispendem a maior parte da vida em fadiga gasta na propagação de trincas longas. Portanto, de maneira geral, vale a regra da tabela 3.1 para metais:

Tabela 3.1 Distribuição entre fase de iniciação e propagação em metais.

\begin{tabular}{l|l|l}
\hline & \multicolumn{1}{|c|}{$\begin{array}{c}\text { Fadiga de Alto Ciclo } \\
\text { (baixo nível de tensão) }\end{array}$} & \multicolumn{1}{c}{$\begin{array}{c}\text { Fadiga de Baixo Ciclo } \\
\text { (alto nível de tensão) }\end{array}$} \\
\hline $\begin{array}{l}\text { Metais com poucos } \\
\text { precipitados e inclu- } \\
\text { sões }\end{array}$ & $\begin{array}{l}\text { Estágio I representa a maior } \\
\text { parte da vida em fadiga }\end{array}$ & $\begin{array}{l}\text { Estágio II representa a maior } \\
\text { parte da vida em fadiga }\end{array}$ \\
$\begin{array}{l}\text { Metais com mui- } \\
\text { tos precipitados e } \\
\text { inclusões }\end{array}$ & $\begin{array}{l}\text { Estágio II representa a maior } \\
\text { parte da vida em fadiga }\end{array}$ & $\begin{array}{l}\text { Estágio II representa a maior } \\
\text { parte da vida em fadiga }\end{array}$ \\
\hline
\end{tabular}




\subsection{Filosofias de Projeto em Análise de Fadiga}

Em meados de 1970 a força aérea dos Estados Unidos criou a Filosofia de Projeto Tolerante ao Dano (também conhecido como Filosofia DTA 5 , que é uma filosofia na qual a análise pelo método da/dN é utilizada para prever a vida relacionada ao crescimento de trincas e quantificar intervalos de inspeção, sendo a inspeção a principal característica desta filosofia. Esta abordagem é geralmente aplicada a estruturas que são suscetíveis a trincas que crescem com o tempo. Os dois objetivos da análise de tolerância ao dano são:

A) Determinar o efeito das trincas na resistência residual; e

B) Determinar o comportamento do crescimento de trinca em função do tempo.

A análise de tolerância ao dano consiste em vários passos, assim um breve esboço dos passos envolvidos nos cálculos dessa filosofia é apresentado abaixo. Assumindo que o espectro de carregamento de serviço e as propriedades do material (tenacidade à fratura e taxa de crescimento da trinca constantes) são conhecidos:

1. Determine o tamanho do defeito inicial $a_{i}$, através de inspeção não destrutiva (NDI), por exemplo;

2. Calcule o tamanho de trinca crítico $a_{c}$ para o qual a falha irá ocorrer;

3. Integre as equações de propagação por fadiga para determinar o número de ciclos de carregamento (ou blocos de carregamento) necessários para a trinca crescer do seu tamanho inicial $\left(a_{i}\right)$ até o tamanho crítico $\left(a_{c}\right)$ calculado no passo anterior (i.e., deter$\operatorname{minar} N)$;

4. Estabeleça um intervalo de inspeção. Em cada inspeção, o inspetor deve verificar com seu equipamento de inspeção não-destrutiva o tamanho da trinca. Caso a trinca ultrapasse o valor máximo estipulado de $a_{\text {insp }}$, deve-se separar ou trocar o componente de maneira que o mesmo volte a ter uma trinca com tamanho igual ou menor que $a_{i}$ . A imagem 3.14 ilustra esta etapa. Alguns especialistas recomendam que a próxima inspeção seja feita na metade da vida calculada no passo anterior, ou seja, a inspeção seja feita em $50 \% N$; já no exemplo ilustrado na figura 3.14 a inspeção é feita antes da metade da vida calculada, em $40 \% \mathrm{~N}$.

5. Execute o passo $\mathrm{n}^{\circ} 4$ continuamente.

É importante salientar que a existência de um programa de inspeção periódica de trincas é fundamental para que a filosofia de Projeto Tolerante ao Dano possa ser utilizada. Esta filosofia é utilizada frequentemente na área aeronáutica porque é inevitável a existência de trincas em componentes de aviões. Além disso, o projeto estrutural aeronáutico deve sempre prever o caso mais crítico (worst case) e garantir que a aeronave seja capaz de voar mesmo na presença de trincas. Esta filosofia é especialmente aplicável à indústria aeronáutica porque

\footnotetext{
${ }^{5}$ Do inglês, Damage Tolerance Analysis.
} 


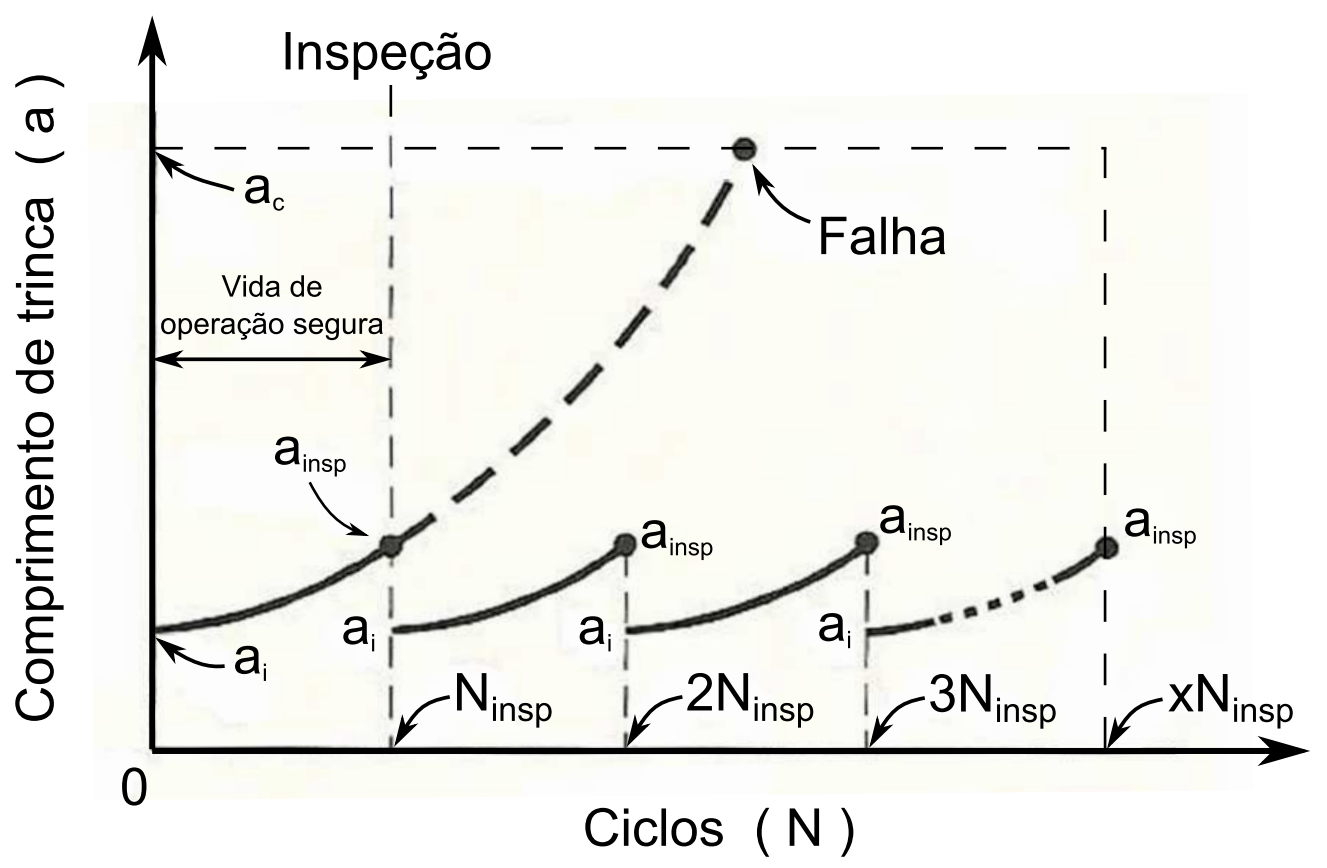

Figura 3.14 Intervalos de inspeção na filosofia de Projeto Tolerante ao Dano.

o número de aeronaves produzidas e vendidas é pequeno e é possível se realizar inspeção em cada uma delas. Este é o motivo que torna impossível a aplicação da mesma na indústria automobilística. Por exemplo, um Boing 777 custa U\$ 250.000.000 enquanto um carro médio novo custa U\$ 25.000. Para cada U\$1 gasto em inspeção e manutenção de um B777 pode-se gastar apenas U\$0.01 em um carro.

A comparação entre as filosofias de Projeto para Tolerância ao Dano (Damage Tolerance) e Projeto para Vida Segura ${ }^{6}$ (Safe-Life) é descrita na tabela 3.2 .

Tabela 3.2 Comparação entre filosofias de projeto.

\begin{tabular}{|c|c|}
\hline $\begin{array}{l}\text { Safe Life } \\
\text { (Vida Total) }\end{array}$ & $\begin{array}{l}\text { Damage Tolerance } \\
\text { (Tolerância ao Dano) }\end{array}$ \\
\hline $\begin{array}{l}\text { Presume-se que a estrutura é livre de } \\
\text { defeitos iniciais }\end{array}$ & $\begin{array}{l}\text { Presume-se que um defeito inicial } \\
\text { existe: igual ao limite da NDI* }\end{array}$ \\
\hline $\begin{array}{l}\text { Nenhuma trinca inicial é admitida na } \\
\text { fase etapa de projeto }\end{array}$ & Inspeção para detectar trinca \\
\hline $\begin{array}{l}\text { A vida de projeto é menor do que a } \\
\text { vida em serviço, com ou sem reparo }\end{array}$ & $\begin{array}{l}\text { É assumido que uma trinca irá cres- } \\
\text { cer até um comprimento crítico em } \\
\text { dois intervalos de inspeção }\end{array}$ \\
\hline
\end{tabular}

Continua na próxima página

\footnotetext{
${ }^{6}$ Aquela utilizada com os métodos $\mathrm{S}-\mathrm{N}$ e $\varepsilon-\mathrm{N}$.
} 
Tabela 3.2 Continuação da página anterior

$\begin{array}{cc}\text { Safe Life } & \text { Damage Tolerance } \\ (\text { Vida Total) } & \text { (Tolerância ao Dano) }\end{array}$

A vida segura é calculado utili- A vida é obtida através do cálculo do zando as curvas $\mathrm{S}-\mathrm{N}$ (ou das curvas crescimento de trinca, determinado varepsilon- $\mathrm{N}$ ) utilizando mecânica da fratura

Uma grande dispersão é inerente ao método, muitas vezes sendo o fator O fator de dispersão é igual à 2 no crescimento de trinca de dispersão de 3-4 aplicado a vida calculada

A probabilidade de falha é $0,001 \quad$ A probabilidade de falha depois de 2 inspeções é 0,001

* Inspeção Não Destrutiva. Do inglês, Non-Destructive Inspection.

\subsection{Conclusões do Capítulo 3}

O processo de projeto de fadiga é um processo iterativo que envolve síntese, análise e testes. Existem quatro métodos de previsão de vida em fadiga que o engenheiro pode utilizar para resolver problemas da área: o Método S-N, o Método $\varepsilon-\mathrm{N}$, o Método da/dN e o Método dos 2 Estágios. Entretanto, estimativas de vida em fadiga computacionais ou analíticas não devem ser consideradas auto-suficientes para tomar uma decisão de projeto, principalmente para situações onde o fator segurança é crítico. Ensaios com produtos inteiros devem sempre ser realizados (de Castro \& Meggiolaro, 2009a; Fatemi, sda; Lee et al., 2011). O engenheiro deve fazer um balanço entre cálculos e ensaios a fim de que a melhor decisão seja escolhida, considerando os fatores custo, tempo de manufatura e confiabilidade do produto. Entretanto, é importante ter em mente que avaliações analíticas/numéricas podem fornecer excelentes protótipos e salvar tempo e recursos.

Em um projeto de produto, o engenheiro deve balancear o custo total de projeto, teste e manufatura contra os custos (em dinheiro, reputação da marca/empresa ou mesmo vidas) de falhas por fadiga. Da mesma forma, o engenheiro nunca deve esquecer as vantagens e limitações do teste acelerado de fadiga nem deve deixar de executá-lo após as análises de fadiga (Fatemi, sda).

A tabela 3.3 conclui o capítulo 3 apresentando as vantagens e desvantagens de cada Método de Previsão de Vida em Fadiga. 


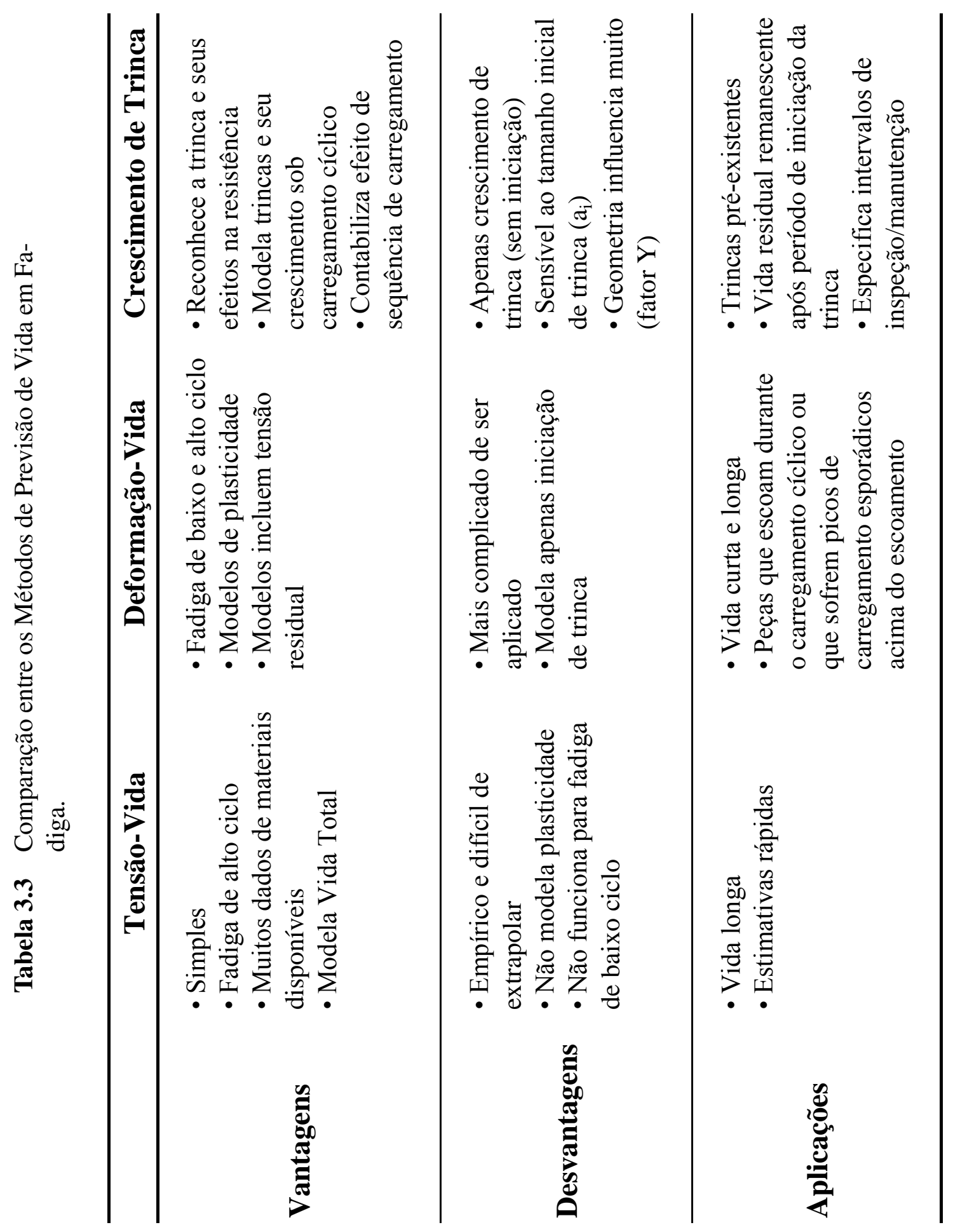




\section{Capítulo 4}

\section{Análise de Fadiga Uniaxial Baseada em Tensão}

\subsection{Introdução}

O capítulo 2 apresentou a explicação de como o mecanismo de fadiga se desenvolve na microestrutura do material. O capítulo 3 apresentou um resumo sobre os principais métodos utilizados para se realizar previsão de vida em fadiga. Este capítulo foca em como estabelecer dados de fadiga e como utilizá-los para se determinar a vida em fadiga utilizando a abordagem S-N.

Desde a metade do século XIX, o método padrão na análise de fadiga tem sido o método $S$-N uniaxial, também conhecido por método tensão-vida uniaxial ou método baseado em tensão uniaxial. A análise de fadiga uniaxial baseada em tensão é usada para estimar a vida em fadiga de componentes sob carregamento cíclico, quando a trinca é nucleada devido à um estado uniaxial de tensões. A vida em fadiga de um componente se refere ao número de ciclos $(N)$ para uma trinca nuclear e crescer até que haja fratura do mesmo.

Este método é válido apenas para componentes e estruturas que estejam sujeitos à níveis baixos de tensão uniaxial, de maneira que não haja (ou haja muito pouca) deformação plástica no componente. Assim, só se deve usar o método S-N quando a tensão máxima no ponto crítico da peça (em geral a raiz de um entalhe) for menor do que a resistência ao escoamento cíclico do material (modelado como se fosse contínuo, homogêneo, isotrópico, elástico e linear) naquele ponto. A análise das tensões que atuam neste ponto crítico é feita num volume fisicamente pequeno, mas grande em relação à dimensão característica da anisotropia intrínseca da microestrutura do material. Este volume, chamado elemento de volume representativo, pode ser 0,1 a $1 \mathrm{~mm}^{3}$ na maioria das ligas metálicas estruturais, cujo tamanho médio de grão é de 10 a $100 \mu \mathrm{m}$. Uma vez que as tensões em cada região do componente 
estão abaixo do limite de escoamento do material $\left(\left[S_{y}\right)\right.$, utiliza-se uma lei constitutiva elástica linear para prever o estado de tensões em cada região do componente.

Há muitos fatores que influenciam localmente a nucleação de trincas por fadiga sob variação de tensões. Os principais fatores são: acabamento superficial, gradiente das tensões (gerado por entalhes), variação microscópica das propriedades mecânicas do material e microtensões residuais (as macro tensões residuais devem ser incluídas nas análises de tensão). Entretanto, é muito difícil gerar modelos precisos para quantificar estes efeitos, que só influem significamente num microscópico volume de material que não é isotrópico, e muitas vezes não homogêneo. Além disso, é muito lento e caro, para qualquer uso prático, medir os parâmetros que afetam a iniciação das trincas, como por exemplo, as direções principais dos grãos próximos do ponto crítico e a geometria detalhada da sua rugosidade superficial. Assim a única opção disponível para o engenheiro estrutural é dimensionar à fadiga quantificando globalmente o efeito de todos os detalhes locais importantes, por meio de fatores semi-empíricos. Esse clássico enfoque de engenharia pode não ser academicamente elegante, pois no mínimo requer muitos testes, mas tem se mostrado eficiente e poderoso na resolução da maioria das aplicações práticas na indústria. Adicionalmente, este método pode gerar resultados confiáveis mesmo quando associado a uma análise de tensões relativamente simples, que demanda pouco esforço computacional e não requer conhecimento acadêmico demasiadamente profundo. Todos os motivos citados acima fazem do método $\mathrm{S}-\mathrm{N}$ o mais utilizado na prática para o dimensionamento mecânico quanto à fadiga.

\subsection{Curva S-N Espécime}

Para entender como um material se comportava sob carregamento variável, deve-se realizar ensaios de fadiga utilizando corpos de prova padronizados. Uma das primeiras máquinas de fadiga utilizadas foi a máquina de R. R. Moore, mostrada na figura 4.2a No ensaio usando esta máquina, um espécime padronizado é acoplado nesta máquina e gira com rotação constante, ao mesmo tempo que um contrapeso produz uma flexão pura no espécime. $\mathrm{O}$ momento fletor no espécime é uniforme ao longo de toda a extensão do corpo de prova.

A norma ASTM-E 466 padroniza o ensaio de fadiga para obtenção de curvas S-N a partir de espécimes padronizados. De acordo com a norma, os espécimes utilizados devem ser iguais, serem cuidadosamente usinados e polidos em uma direção axial, de modo a evitar riscos circunferentes, não podem ter tratamento superficial e devem possuir seção circular. Os espécimes padronizados também não podem possuir entalhes, por isso o espécime deve ter formato de ampulheta para que a fratura por fadiga ocorra na seção de menor diâmetro, diâmetro é igual à $7,62 \mathrm{~mm}(=0,3 \mathrm{in})$. O formato de ampulheta deve ser feito de maneira a garantir que os espécimes não tenham entalhe, i.e., o fator de concetração de tensão causado 
por este formato deve ser muito próximo à 1. A figura 4.1 ilustra o espécime recomendado pela ASTM para ensaios de fadiga tração-compressão.

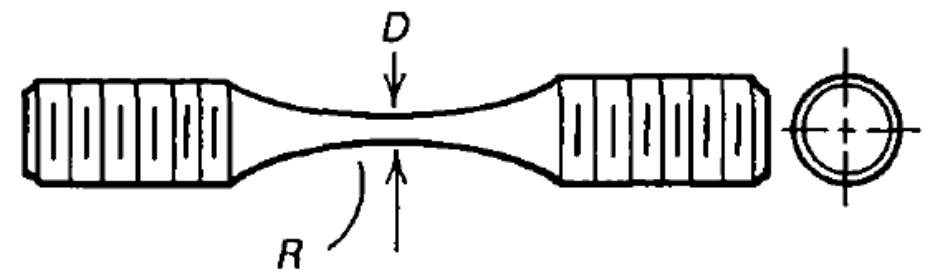

Figura 4.1 Exemplo de espécime para ensaio de fadiga de flexão rotativa.

Durante o ensaio de fadiga, cada ponto da superfície do espécime está sujeito a uma tensão cíclica, uniaxial, que varia senoidalmente. A tensão em um ponto da superfície localizado na região de menor diâmetro pode ser descrita por duas variáveis: tensão máxima $\left(S_{\text {max }}\right)$ e mínima $\left(S_{\text {min }}\right)$. Mas na maioria das vezes é descrita tensão alternada $\left(S_{a}\right)$ e pela tensão média $\left(S_{m}\right)$, conforme a figura 4.3 . O intervalo de tensão $(\Delta S)$ é a diferença entre a tensão máxima e mínima em um ciclo:

$$
\Delta S=S_{\text {max }}-S_{\text {min }}
$$

A tensão alternada é igual à metade do intervalo de tensão:

$$
S_{a}=\frac{\left(S_{\max }-S_{\min }\right)}{2}
$$

E a tensão média é definida como

$$
S_{m}=\frac{\left(S_{\max }+S_{\min }\right)}{2}
$$

Geralmente, para os analistas em fadiga, é conveniente considerar tensões de tração como sendo positivas e tensões de compressão como sendo negativas. Na maioria das vezes utilizase carregamento alternado na obtenção de curvas $\mathrm{S}-\mathrm{N}$, que significa que a tensão cíclica possui tensão média $\left(S_{m}\right)$ igual à zero. Mas existem casos em que os ensaios de fadiga são feitos com tensão média diferente de zero (por exemplo, em uma máquina de fadiga que permite carregamento tração-compressão cíclico onde onde $S_{\text {min }}=0, S_{a}=S_{m}=S_{\text {max }} / 2$ ). A figura 4.3 apresenta os símbolos descritos acima.

Dois outros parâmetros são também utilizados para representar as tensões médias em um componente: a razão de tensão $(R)$ e a razão de amplitudes $(Q)$, definidos respectivamente pelas equações (4.4) e 4.5). A figura 4.4 contém a representação visual dos possíveis valores da razão de tensão.

$$
R=\frac{S_{\min }}{S_{\max }}
$$




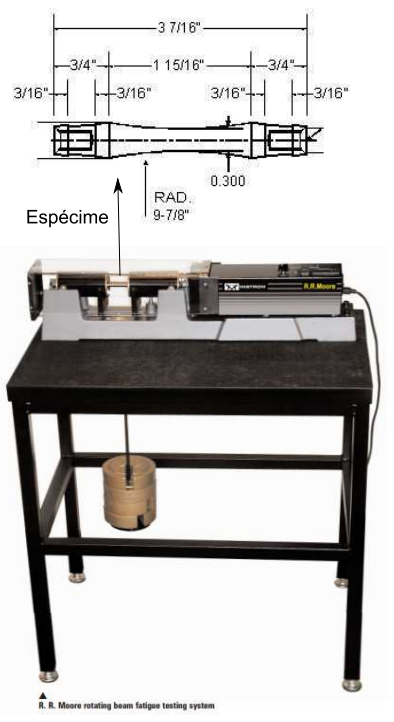

(a) Máquina de fadiga de Moore, com espécime instalado.

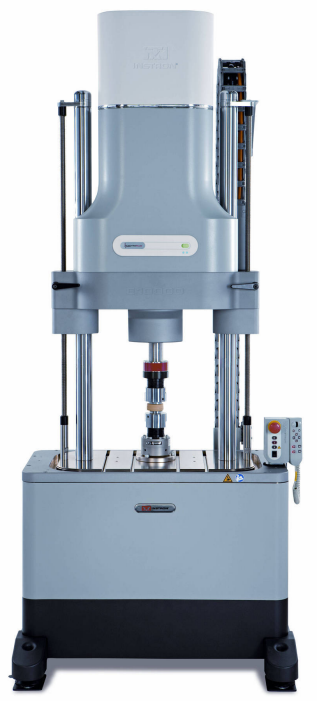

(b) Máquina de fadiga linear-torção, marca Instron.

Figura 4.2 Exemplos de máquinas para realização de ensaios de fadiga (Extraído de Instron (sd))

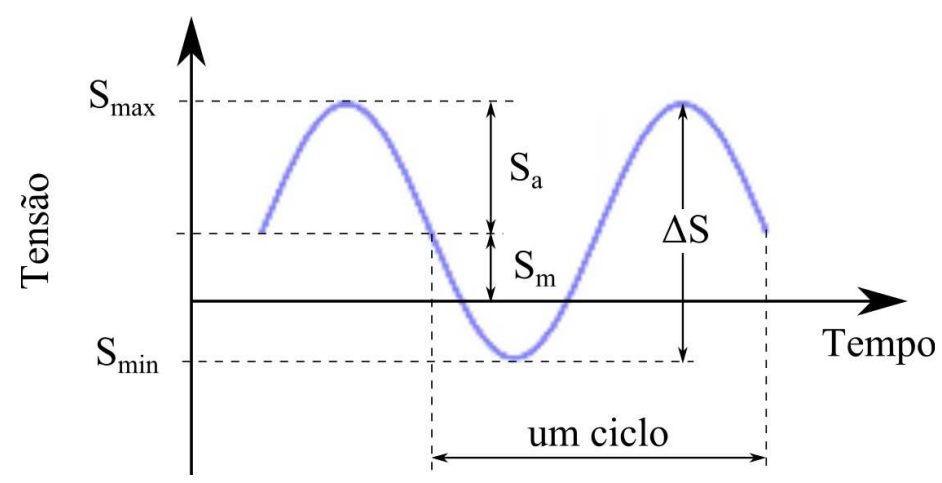

Figura 4.3 Símbolos usados no método S-N.

$$
A=\frac{S_{a}}{S_{m}}=\frac{1-R}{1+R}
$$

No ensaio de fadiga pela máquina R. R. Moore, o espécime continua girando até que ocorra a falha por fadiga, caracterizada pela separação do mesmo em duas partes. Uma vez ocorrida a falha, um ponto é marcado em um gráfico, sendo o valor da ordenada igual à tensão alternada $\left(S_{a}\right)$ e o valor da abscissa igual ao número de cíclos em que ocorreu a ruptura do corpo de prova $(N)$. Espera-se que a fratura ocorra na seção com menor diâmetro. A fratura em qualquer outra região que não seja a de maior nível de tensão indica a presença de defeitos de fabricação do espécime. Nestes casos, o ensaio com este espécime não é válido e os dados obtidos por ele não devem ser utilizados. O primeiro teste é realizado de maneira que o espécime seja submetido a uma tensão um pouco inferior ao limite de 


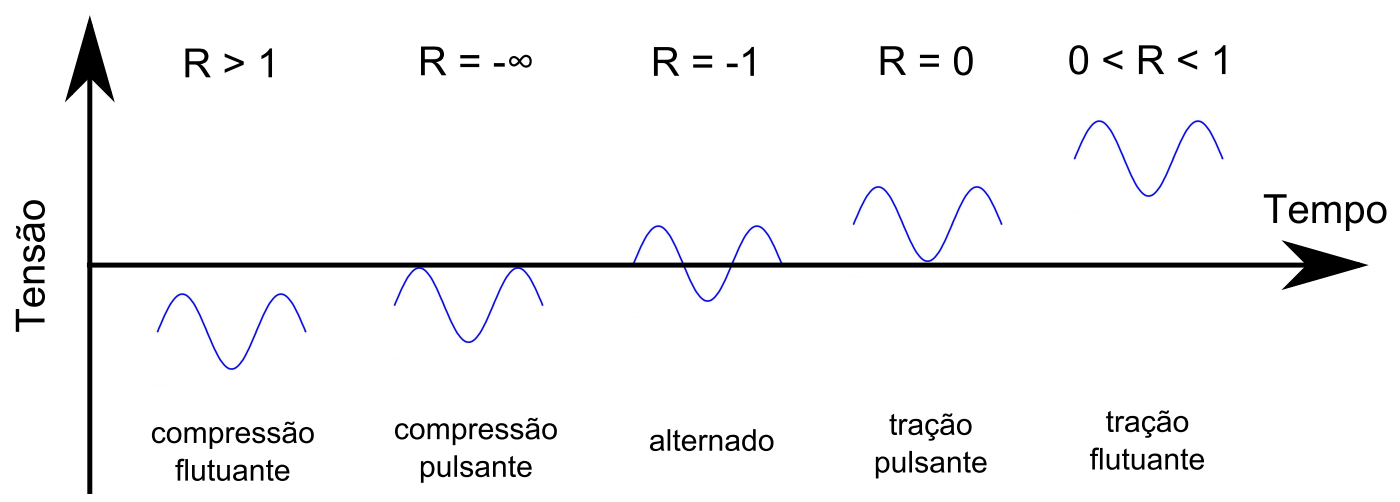

Figura 4.4 Ciclos de tensão com diferentes valores de tensão médias $\left(S_{m}\right)$ e razão de tensão $(R)$.

escoamento do material do corpo de prova. O segundo teste é feito a uma tensão $S_{a}$ menor que aquela utilizada no primeiro. O terceiro teste é feito a uma tensão $S_{a}$ menor do que a do segundo, e assim por diante. Este procedimento é repetido com vários espécimes, cada teste sendo realizado com um valor diferente para $S_{a}$. E, portanto, cada espécime testado irá falhar em um número de ciclos $N$ diferente. Observa-se que quanto mais baixa é a tensão alternada, maior será o número de ciclos para a fratura. A curva que melhor interpola a nuvem de pontos, sendo portanto uma média do fenômeno, chama-se curva S-N. Neste trabalho, para uma melhor compreensão, chamaremos de Curva $S$ - $N$ Espécime uma curva $\mathrm{S}-\mathrm{N}$ obtida com um ensaio padronizado, i.e., utilizando espécimes padronizados, com seção circular, diâmetro de aproximadamente $8 \mathrm{~mm}$ (= 0,3pol), sem entalhes, com superfície polida, sem macro tensões residuais, testados na atmosfera e temperatura ambiente e sob flexão rotativa $(R=-1)$. O termo curva $S$ - $N$ é usado como uma abreviação de curva $S$ - $N$ de amplitude constante, pois na obtenção desta curva, cada espécime foi testado com um valor de $S_{a}$ constante (Lee et al. 2011). A figura 4.5a apresenta a curva S-N obtida de alumínio 7075-T6, obtida com corpos de provas padronizados e para carregamento com $\underline{R}=-1$.

Outras máquinas de ensaio de fadiga estão disponíveis no mercado. Existem máquinas de fadiga por flexão rotativa, que geram flexão alternada (sem rotação), que geram carregamento de tração-compressão uniaxial cíclico, torção cíclica e até máquinas de fadiga multiaxial, que impõe tensões tensões axiais e torcionais combinadas simultaneamente. A figura $4.2 \mathrm{~b}$ apresenta uma das máquinas de fadiga mais modernas do mercado. Este equipamento também realiza ensaios de fadiga multiaxial, onde carregamento axial e torcional são aplicados simultaneamente ao corpo de prova, gerando um estado multiaxial cíclico de tensões. As máquinas de fadiga que não funcionam sob flexão rotativa permitem a aplicação de um carregamento que gere tensão média diferente de zero $\left(S_{m} \neq 0\right)$. Entretanto, as Curvas S-N Espécime são geralmente obtidas com a tensão média $\left(S_{m}\right)$ igual à zero.

De acordo com Schütz (1996), o trabalho pioneiro foi de O. H. Basquin que em 1910 


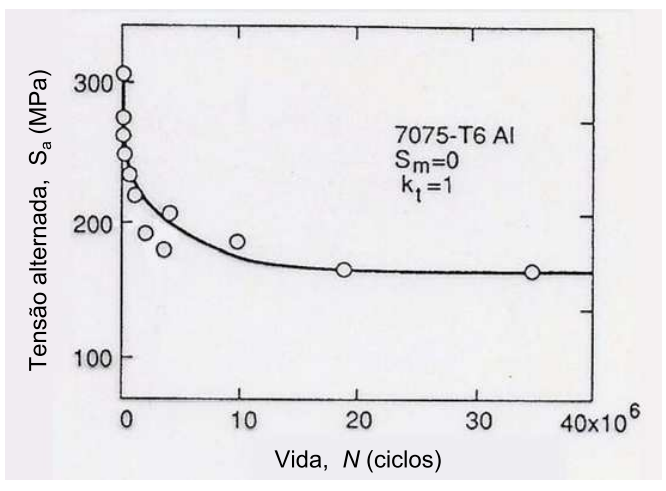

(a) Curva S-N em escala linear (ex) Lopes, 2012).

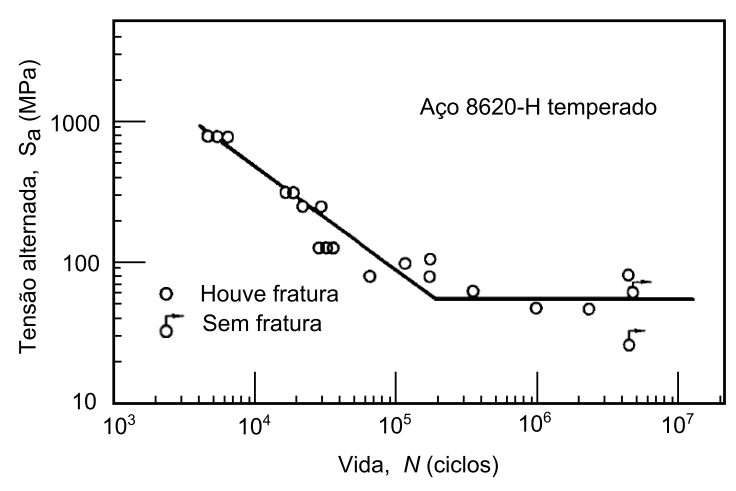

(b) Curva S-N em gráfico dilog (Extraído de (Boyer. 1986))

Figura 4.5 Exemplos de curvas S-N para metais.

percebeu que uma curva S-N segue uma relação potencial e, portanto, se transforma em uma reta quando os dados são exibidos em um gráfico log-log (Schütz, 1996). Por este motivo, uma curva $\mathrm{S}-\mathrm{N}$ de amplitude constante é geralmente plotada como uma linha reta em coordenadas log-log, representando os dados de fadiga no regime de Fadiga de Alto Ciclo, onde o dano por fadiga é devido à pouca (ou nenhuma) deformação plástica. A figura $4.5 \mathrm{~b}$ ilustra a curva S-N obtida do aço $8620-\mathrm{H}$ plotada em um gráfico dilog. Na verdade, a curva S-N consiste em dois regimes lineares distintos quando plotada em coordenadas log-log.

A figura 4.6 apresenta o desenho esquemático de uma Curva $S$-N Espécime, curva tensãovida obtida utilizando espécimes padronizados obtidos com carregamento $R=-1$. O segmento linear com inclinação negativa é chamado de região de vida finita e corresponde ao regime de Fadiga de Alto Ciclo e a linha horizontal é a região de vida infinita. O ponto desta curva S-N em que a curva muda de uma inclinação negativa para uma linha horizontal é chamado de ponto de inflexãd $]^{1}$ cujo valor da ordenada é chamado de limite de fadiga $\left(S_{E}\right)$. August Wöhler foi o primeiro que identificou a existência do limite de fadiga. 2. O limite de fadiga de um componente feito de aço ou ferro fundido pode ser definido como a tensão alternada abaixo da qual não ocorre ruptura por fadiga. A explicação deste fenômeno é dada pela análise sob a ótica da ciência dos materiais. Devido à tensões de operação cíclicas (e de amplitude constante), uma trinca irá nuclear dentro de um grão do material e irá crescer como uma trinca de estágio I até atingir o contorno de grão, que é uma barreira que impede o seu crescimento. Se uma barreira de grão não é resistente o bastante, esta trinca irá continuar

\footnotetext{
${ }^{1}$ Em inglês, knee point.

${ }^{2}$ De acordo com Day \& McNeil (2013), entre 1851 e 1889 Wöhler publicou 42 artigos, escritos em alemão, nos periódicos técnicos da Alemanha, embora a importância destes trabalhos não tenha sido completamente reconhecida em outros países no início. Mais tarde, em 1871, o periódico Engineering publicou uma série de nove artigos de Wöhler, traduzidos para o inglês, que descreviam detalhadamente as descobertas de Wöhler, trazendo elas para a atenção dos engenheiros. A partir de então, Wöhler se popularizou. Os experimentos de Wöhler em fadiga dos metais foram publicados no periódico Engineering em (1867) 2:160; (1871) 11:199-200, 222, 243-4, 261, 299-300, 326-7, 349-50, 397, 439-41 (Day \& McNeil, 2013).
} 
a se propagar no próximo grão, se transformar em uma trinca de estágio II e crescer até a fratura final. Entretanto, se a barreira de grão é muito resistente, a trinca irá ficar presa e se tornar uma trinca não-propagante. A tensão alternada mínima que faz uma trinca superar as barreiras e continuar se propagando é referida como o limite de fadiga.

O levantamento de curvas S-N de espécimes e componentes desde 1870 mostrou experimentalmente que o limite de fadiga existe para a maioria dos aços e cada aço possui um valor de limite de fadiga. Entretanto, Nem todos os metais apresentam este patamar horizontal. Aços ferríticos e martensíticos, ferros fundidos, ferros forjadoł 3 , ligas de titânio e ligas de molibidênio possuem. Outros materiais como ligas de alumínio, de magnésio e ligas de cobre, a maioria dos aços inoxidáveis, alguns aços carbonos de alta resistência e ligas de aço de alta resistência não possuem limite de fadiga. Os metais que não possuem limite de fadiga serão discutidos na seção 4.2.3. No caso dos metais que possuem limite de fadiga, cada metal possui um valor próprio de limite de fadiga, que está muito relacionado à microestrutura do material. Acreditava-se antigamente que era fundamental testar um material para se obter o seu limite de fadiga. Entretanto, o levantamento de curvas S-N de espécimes e componentes desde 1870 mostrou experimentalmente que existem também métodos para estimar o valor desta propriedade sem que seja necessário realizar ensaios de fadiga. Estes métodos serão apresentados nas seções $4.2,4.3 \mathrm{e} 4.4$.

A curva tensão-vida extraída a partir de ensaio com espécimes padronizados e sob condições padronizadas é intitulada Curva $\boldsymbol{S}$ - $\boldsymbol{N}$ Espécime e é tipicamente expressa conforme a equação (4.6), conhecida como relação de Basquim. Um ensaio padronizado é aquele realizado utilizando espécimes padronizados, com seção circular, diâmetro de aproximadamente $8 \mathrm{~mm}(=0,3 \mathrm{pol})$, sem entalhes, com superfície polida, sem macro tensões residuais, testados na atmosfera e temperatura ambiente e sob flexão rotativa $(R=-1)$.

$$
S_{a}=S_{f, s p}^{\prime} \cdot(2 N)^{b_{s p}}
$$

Pode-se notar que um ciclo de tensão $(N=1)$ constitui uma única aplicação e remoção de uma carga em uma direção seguido de outra aplicação e remoção da carga na outra direção. Portanto, $N=1 / 2$ significa que a carga é aplicada uma vez e então retirada, que é exatamente o caso de um teste de tração simples. Sendo $N=1 / 2$ igual a uma reversão, então o coeficiente de resistência à fadiga $\left(S_{f}^{\prime}\right)$ representa a resistência à fadiga em uma reversão.

A função potencial (4.6), que em geral ajusta bem os resultados de muitos testes S-N, não é uma lei física. Por isso, qualquer outra função pode ser utilizada para ajustar os testes. Por exemplo, há autores que preferem curvas S-N linearizáveis em gráficos semi-log onde

\footnotetext{
${ }^{3}$ Do inglês, wrought iron. Também conhecido como ferro pudlado, é o ferro comercialmente puro, o qual possui uma pequena quantidade de carbono (não mais de 0,15\%), mas que geralmente possui escórias. É resistente, maleável, dúctil e facilmente soldável. Todavia, é macio demais para uso em lâminas. Geralmente utilizado em gradil e portões decorados
} 
$S_{a}(N)=a_{1}+a_{2} \log N$, sendo $a_{1}$ e $a_{2}$ constantes que dependem do material (de Castro $\&$ Meggiolaro, 2009a).

Os dois parâmetros utilizados para definir o segmento de reta inclinada de uma curva S-N são as propriedades de fadiga. A inclinação da Curva S-N Espécime no regime HCF é denotado por $b_{s p}$ (a razão entre altura e base) ou por $k_{s p}$ (a razão negativa entre base e altura). $\mathrm{O}$ parâmetro $k_{s p}$ é denominado por fator de inclinação e igual à:

$$
k_{s p}=-\frac{1}{b_{s p}}
$$

A inclinação $b_{s p}$ e o fator de inclinação $k_{s p}$ são determinados utilizando qualquer dois pontos de uma curva S-N $\left(S_{1}, N_{1}\right)$ e $\left(S_{2}, N_{2}\right)$, conforme segue:

$$
\frac{N_{2}}{N_{1}}=\left(\frac{S_{1}}{S_{2}}\right)^{k_{s p}}=\left(\frac{S_{1}}{S_{2}}\right)^{-1 / b_{s p}}
$$

Pesquisas mostraram que as regiões $\mathrm{LCF}, \mathrm{HCF}$ e vida infinita podem ser separadas por dois parâmetros, $N_{B}$ e $N_{E}$. Foi percebido que, de uma maneira geral, o regime de Fadiga de Baixo Ciclo dos metais supracitados se caracteriza com falhas de $N=1 / 2$ ciclo até $N \approx 1000$ ciclos, como indicado na figura 4.6. Já a fadiga de alto ciclo está compreendida entre os ciclos de tensão maiores que $10^{3}$ ciclos. Também é possível perceber uma distinção entre a região de vida finita e a região de vida infinita, conforme a figura 4.6. As fronteiras entre as regiões LCF e HCF e entre vida finita e infinita, caracterizadas pelos parâmetros $N_{B}$ e $N_{E}$, não podem ser precisamente definidas por uma fórmula ou regra para todos os metais, ao menos que se extraia a Curva $S$-N Espécime via experimentos. Entretanto, Juvinall (1967) e outros autores 4 recomendam que seja adotado $10^{5} \leq N_{E} \leq 10^{6}$ ciclos quando o engenheiro está estimando a Curva $S$-N Espécime de aços. 5 A diretriz do Conselho Alemão de Pesquisa em Engenharia (FKM-Guideline, 2003) e Lee et al. (2011) recomendam que seja adotado $N_{E}=10^{6}$ ciclos sempre que o engenheiro não possuir dados experimentais sobre $N_{E}$; de acordo com FKM-Guideline (2003), este valor deve ser utilizado para todos os tipos de aços , ferros fundidos e ligas de alumínio.

A análise de fadiga uniaxial baseada em tensão utiliza curvas S-N para se realizar a previsão de vida em fadiga de um objeto. A relação entre tensão e vida indica a resistência à fadiga de um material. Sempre que o engenheiro estrutural precisar da Curva S-N Espécime, recomenda-se que ele a obtenha realizando seus próprios testes com espécimes

\footnotetext{
${ }^{4}$ Que vieram após Juvinall

${ }^{5}$ É interessante ressaltar que uma maneira racional e detalhada para encontrar este valor é mostrada em análise de fadiga baseada em deformação, mas este assunto não faz parte do escopo desta dissertação e portanto não será visto.

${ }^{6} \mathrm{Na}$ verdade, o capítulo sobre análise de fadiga uniaxial baseada em tensão do livro de Lee et al. (2011) é inteiramente baseado na FKM-Guideline (2003).
} 


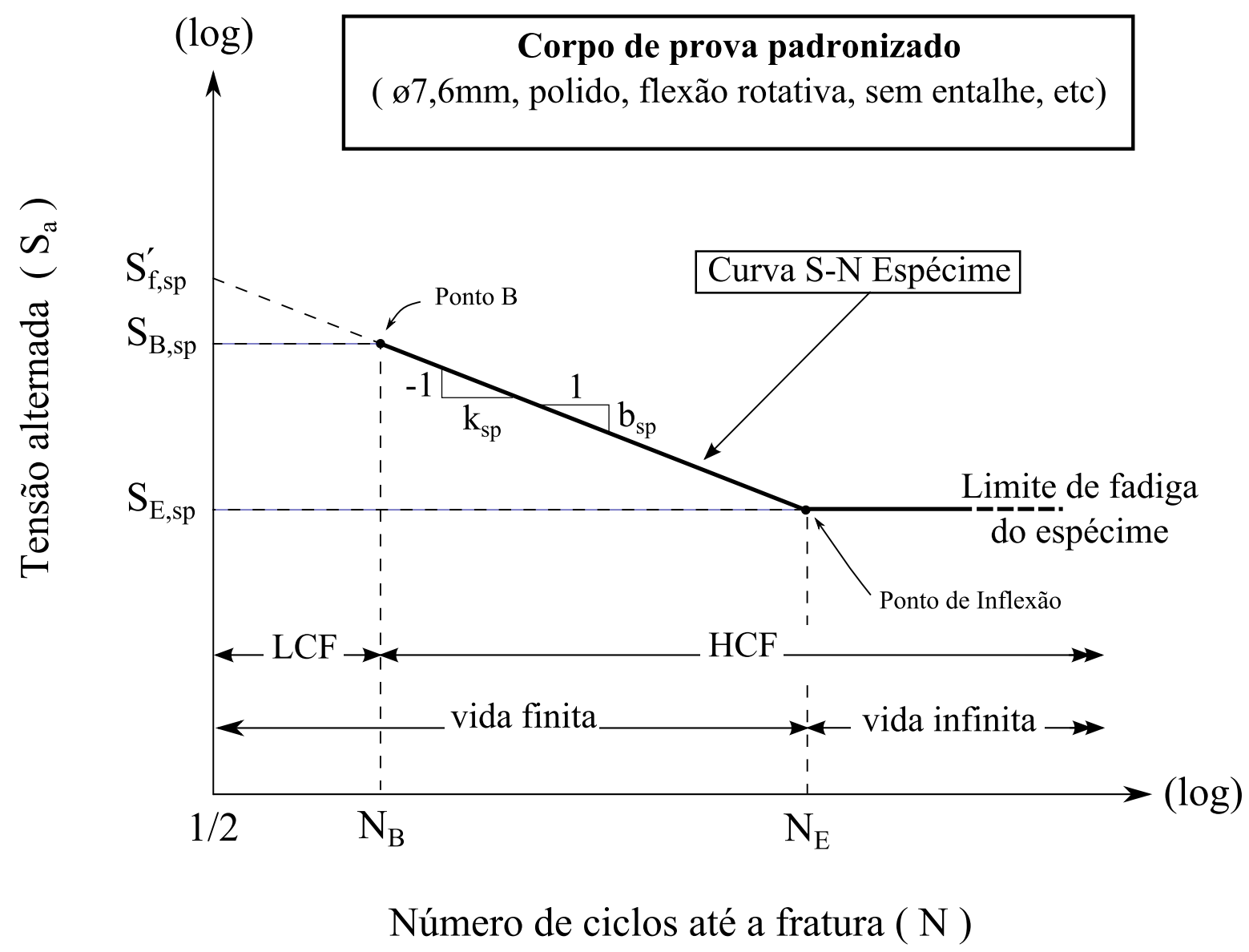

Figura 4.6 Desenho esquemático de Curva $S$-N Espécime para metais que exibem limite de fadiga (ex: aços ferríticos e martensíticos, ferros fundidos, ferros forjados, ligas de titânio e ligas de molibidênio)

Onde

$b_{s p}:$ Expoente de resistência à fadiga do espécime

$k_{s p}:$ Fator de inclinação do espécime

$S_{f, s p}^{\prime}$ : Coeficiente de resistência à fadiga do espécime

$S_{E, s p}:$ Limite de fadiga do espécime

$N_{E} \quad$ : Ciclo do limite de fadiga

$S_{B, s p}$ : Resistência à fadiga para $N_{B}$ ciclos do espécime

$N_{B} \quad$ : Ciclo da fronteira LCF 
padronizados pela ASTM E466-07(2007). Vale lembrar que a Curva S-N Espécime neste trabalho representa uma curva $S$-N obtida com um ensaio padronizado, i.e., utilizando espécimes padronizados, com seção circular, diâmetro de aproximadamente $8 \mathrm{~mm}$, sem entalhes, com superfície polida, sem macro tensões residuais, testados na atmosfera e temperatura ambiente e sob flexão rotativa $(R=-1)$. Entretanto, é comum o engenheiro se deparar com o problema de ausência de dados de fadiga.

Décadas de levantamento de Curvas $S$ - $N$ Espécime de materiais metálicos (em especial aço, ferro fundido e alumínio) possibilitou que pesquisadores pudessem perceber algumas regras que descrevem uma curva S-N. Essas relações empíricas relacionam as propriedades de fadiga com as propriedades mecânicas estáticas. Estas relações não possuem base científica, foram apenas obtidas através de observação dos dados experimentais, mas são ferramentas de engenharia simples e útil para estimar a vida em fadiga de espécimes (Lee et al., 2005). Esta foi a melhor maneira encontrada pela engenharia para resolver problemas relacionados à fadiga e durabilidade (de Castro \& Meggiolaro, 2009a). As seções 4.2.1, 4.2.2 e 4.2 .3 tem o objetivo de fornecer técnicas para estimar a Curva $S$ - $N$ Espécime quando há informações limitadas.

\subsubsection{Estimativa do limite de fadiga $S_{E, s p}$ de aços}

Os experimentos feitos desde 1870 permitiram que fosse proposta uma regra para se estimar o limite de fadiga de espécimes sujeitos à ensaio de flexão rotativa $\left(S_{E, s p}\right)$. Os experimentos mostraram que o limite de fadiga da Curva S-N Espécime $\left(S_{E, s p}\right)$ é igual à uma porcentagem do limite de resistência à tração do material do espécime estado $\left(S_{u}\right)$, conforme representa a equação abaixo e a figura 4.7. O parâmetro $C_{E, \sigma}$ representa esta porcentagem.

$$
S_{E, s p}=C_{E, \sigma}, S_{u}
$$

Juvinall (1967) também apresenta em seu livro um grafico que contém 89 testes de fadiga de diversos espécimes de aço com limite de resistência à tração $S_{u}$ menor que $1400 \mathrm{MPa}$. Este gráfico é apresentado na figura 4.8 e cada ponto representa o teste de um espécime, sob flexão rotativa (entretanto, a fonte não informa quais outras características desses corpos de prova como rugosidade superficial, tamanho, temperatura, microestrutura do aço, etc). Dentre os 89 testes, 6 deles foram terminados sem que houvessem fratura por fadiga. O gráfico influenciou Juvinall à propôr que, na ausência de resultados experimentais confiáveis, se estime a resistência à fadiga de corpos de prova padronizados de aço da seguinte forma:

$$
S_{E, s p}\left(N_{E}=10^{6}\right)= \begin{cases}0,5 \cdot S_{u} & \text { para } S_{u} \leq 1400 \mathrm{MPa} \\ 700 \mathrm{MPa} & \text { para } S_{u}>1400 \mathrm{MPa}\end{cases}
$$




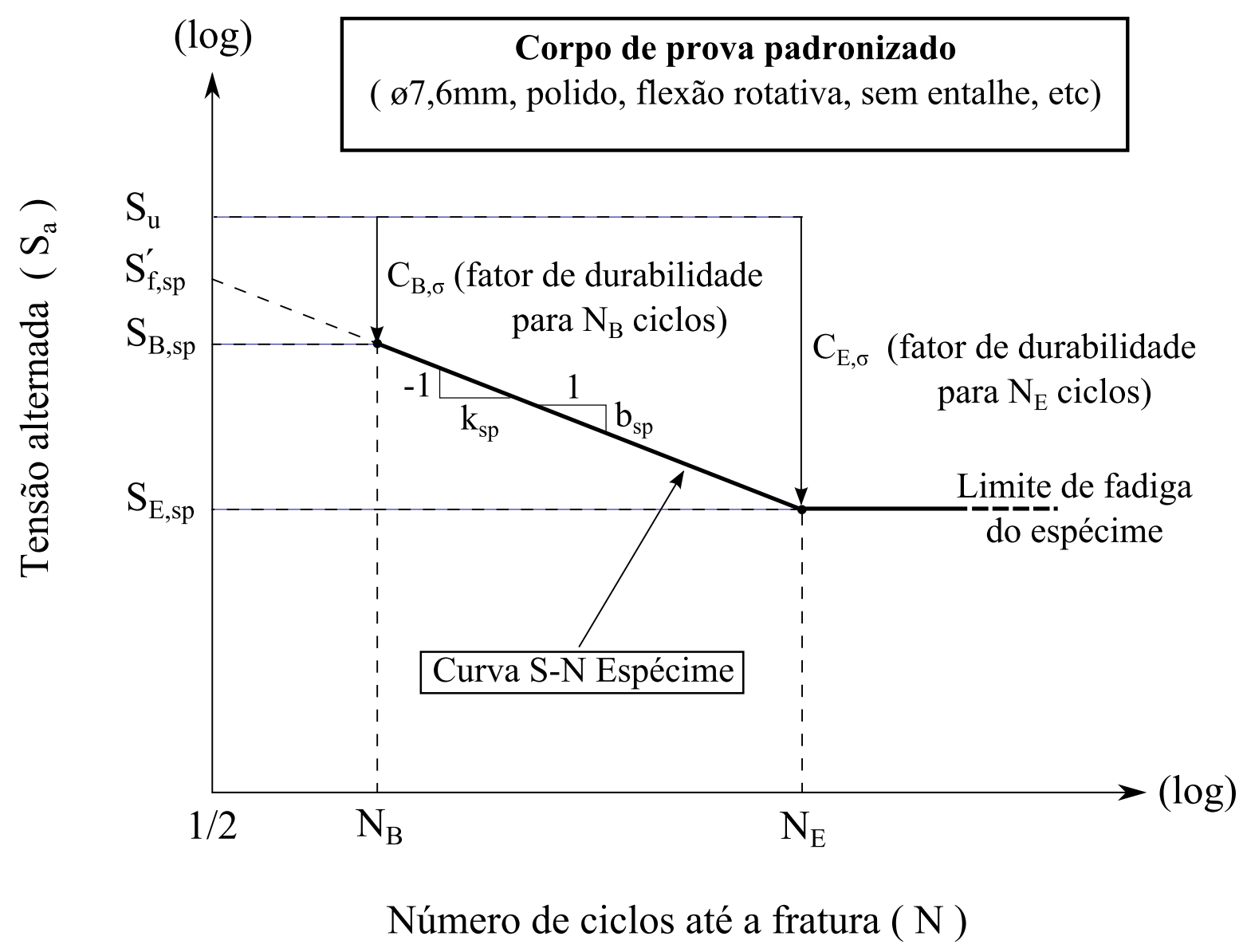

Figura 4.7 Interpretação gráfica dos parâmetros $C_{B, s p}$ e $C_{E, s p}$ em uma Curva S-N Espécime

Onde

$S_{u}$ : Limite de resistência à tração para 50\% de confiabilidade (R50\%), obtido em um ensaio de tração quase-estático para obtenção da curva $\sigma-\varepsilon$

Existe um motivo para que aços com $S_{u}>1400 \mathrm{MPa}$ possuam um limite de resistência à tração em torno de $700 \mathrm{MPa}$. Este fenômeno é explicado através de análise da microestrutura dos metais e pode ser entendido em detalhes nas referências Shigley et al. (2003), Lee et al. (2005, seção 4.3.4) e Norton (2006).

Juvinall (1967) também apresenta em seu livro uma figura que mostra a influência da microestrutura dos aços no limite de fadiga (figura 4.9). Baseado nesta figura, Lee et al. (2005) criaram uma tabela (tabela 4.1) que reune os valores mínimos dos limites de fadiga da figura 4.9. Lee et al. (2005) recomendam a utilização dos dados da figura 4.9 ou da tabela 4.1 no dimensionamento em uma análise de fadiga. Entretanto, de Castro \& Meggiolaro (2009a), que também apresentam esta figura em seu livro, relatam que estes dados são antigos e que

${ }^{7}$ Para confiabilidade de R50\%. 


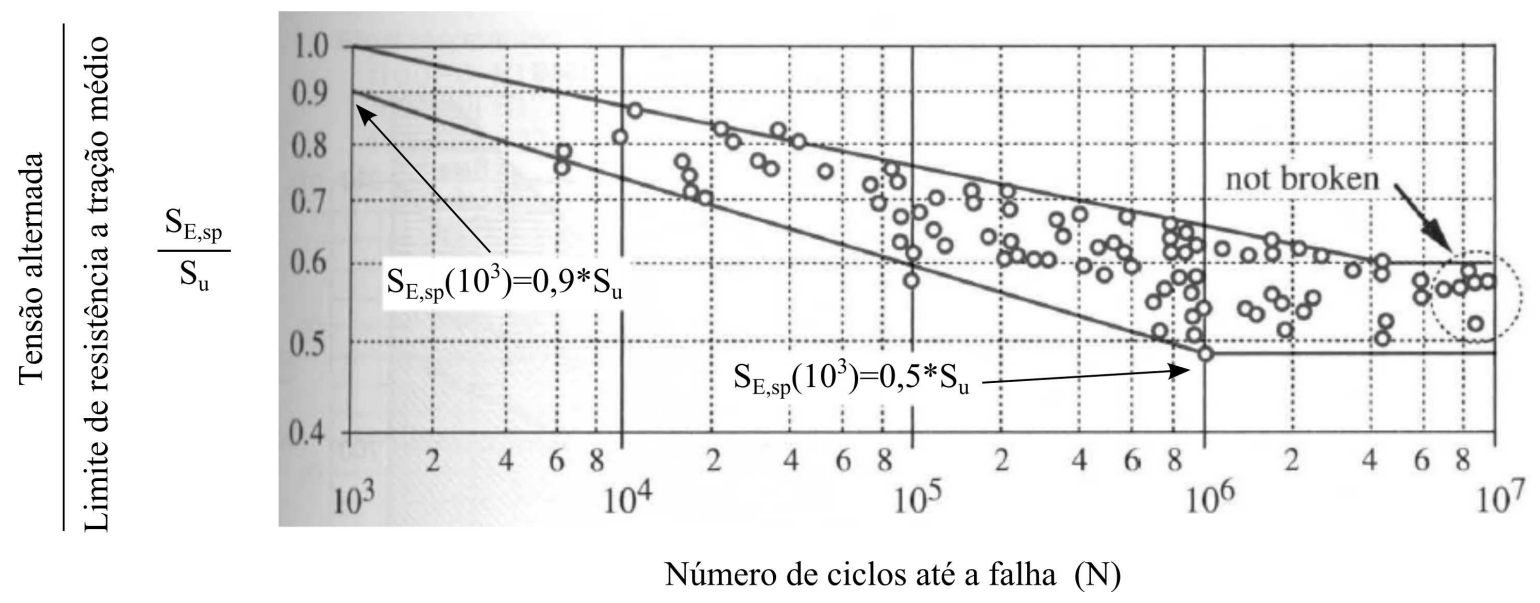

Figura 4.8 Dados de 89 testes de fadiga em aços trabalhados (Do inglês, Wrought Steels) com $S_{u}<1400 \mathrm{MPa}$ usados por Juvinall (1967, pg. 210, fig. 11.7) para justificar a estimativa espressa pela equação (4.10) Juvinall, 1967

não foi possível recuperar a fonte original das medidas usadas nesta figura. Infelizmente, também não se conseguiu dados recentes e modernos para confirmá-los. de Castro \& Meggiolaro (2009a) sugerem que as informações apresentadas nesta figura sejam consideradas apenas como sendo representativas, e devem ser utilizadas com cautela.

Seguir a receita de Juvinall (1967) utilizando $S_{E, s p}=0,5 \cdot S_{u}$ para aços parece ser um procedimento seguro e conservativo quando se olha os dados da figura 4.8, mas esta impressão não significa que esta estimativa esteja sempre correta. O primeiro motivo é porque há muitos aços que possuem $C_{E, \sigma}<0.5$, como pode ser visto na figura 4.9. O segundo motivo vem a seguir: Dowling (1998) e Shigley et al. (2003) apresentam um gráfico do limite de fadiga $\left(S_{E, s p}\right)$ versus o limite de resistência à tração $\left(S_{u}\right)$ de testes feitos em uma grande quantidade de aços e ferros forjados (figura 4.10). As razões de $S_{E} / S_{u}$ de $0,6,0,5$ e 0,4 são mostrados nas linhas sólidas e tracejada. Aços com $S_{u}>1450 \mathrm{MPa}$ tem um limite de fadiga de $S_{E}=724 \mathrm{MPa}$ e um desvio padrão de $93 \mathrm{MPa}$ (e portanto um coeficiente de variação de $\mathrm{COV}=6,4 \%$ ). Como pode ser visto na figura 4.10, muitos testes resultaram em um valor de $S_{E, s p}\left(10^{6}\right)<0,5 \cdot S_{u}$. Enquanto $S_{E, s p}\left(10^{6}\right)=0,5 \cdot S_{u}$ é uma estimativa conservativa para os dados da figura 4.8, ela passa pela média dos dados da figura 4.10, resultando portanto em uma confiabilidade baixa na previsão de $S_{E, s p}$. Socie (2004b) e Norton (2006) também apresentam em suas obras uma figura praticamente idêntica (figura 4.11), ambas retiradas de Forrest (1962), uma publicação de 44 anos antes.

FKM-Guideline (2003) e Lee et al. (2011) recomendam utilizar outros valores para o fator do limite de fadiga $\left(C_{E, s p}\right)$, apresentado na tabela 4.2 .

Diante de toda a informação exposta nesta seção, acredita-se que, na falta de dados experimentais confiáveis, a melhor maneira para se estimar o limite de fadiga de aços seja 


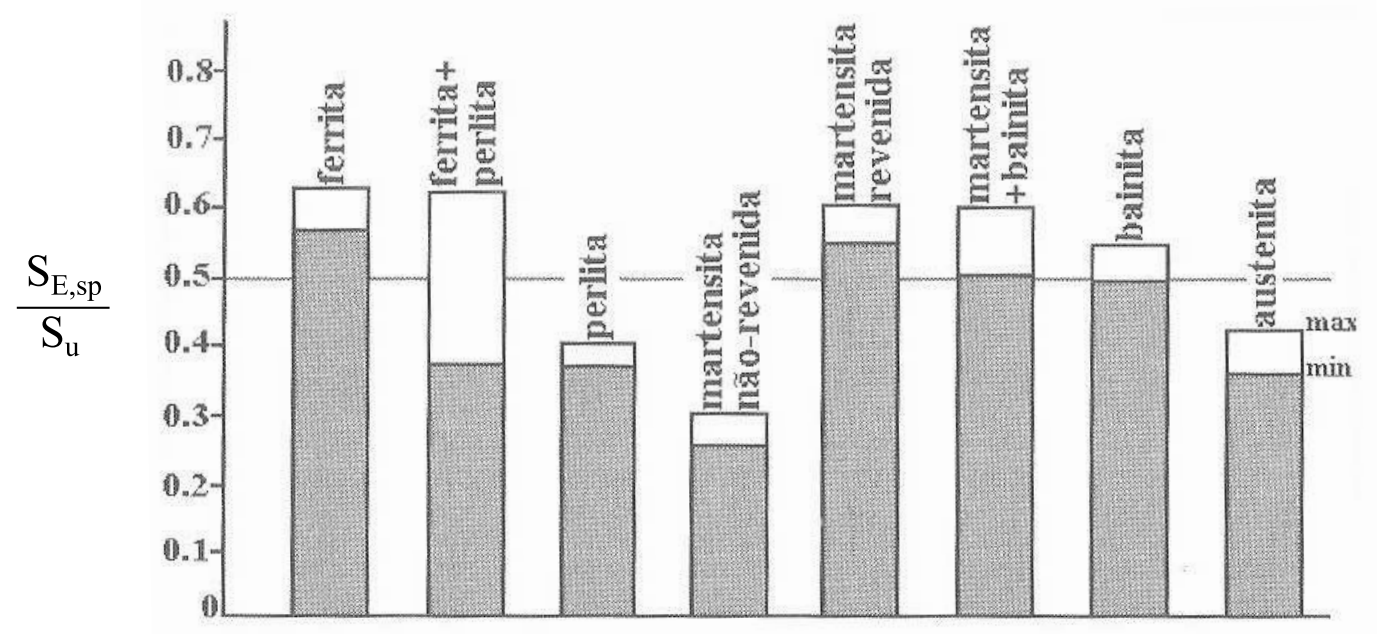

Figura 4.9 Influência da microestrutura no limite de fadiga dos aços (Extraído de Juvinall (1967).

Tabela 4.1 Estimativa do limite de fadiga de espécimes sob flexão rotativa $\left(S_{E, s p}\right)$ para aços (Extraído de Lee et al. (2005).

\begin{tabular}{l|c|c|c|c}
\hline \multicolumn{1}{c|}{ Tipo do Material } & $C_{E, \sigma}$ & $S_{E, s p}$ & $N_{E}$ & Comentários \\
\hline Microestrutura dos aços & & & & \\
Aço (ferrita) & 0,58 & $0,58 \cdot S_{u}$ & $10^{6}$ & \\
Aço (ferrita + perlita) & 0,38 & $0,38 \cdot S_{u}$ & $10^{6}$ & \\
Aço (perlita) & 0,38 & $0,38 \cdot S_{u}$ & $10^{6}$ & \\
Aço (martensita não revenida) & 0,26 & $0,26 \cdot S_{u}$ & $10^{6}$ & \\
Aço (martensita altamente revenida*) & 0,55 & $0,55 \cdot S_{u}$ & $10^{6}$ & \\
Aço (martensita altamente revenida* + & 0,55 & $0,55 \cdot S_{u}$ & $10^{6}$ & \\
bainita revenida) & 0,5 & $0,5 \cdot S_{u}$ & $10^{6}$ & \\
Aço (bainita revenida) & 0,37 & $0,37 \cdot S_{u}$ & $10^{6}$ & \\
Aço (Austenita) & & & & \\
Generalização & $-5,5$ & $0,5 \cdot S_{u}$ & $10^{6}$ & $S_{u} \leq 1400 \mathrm{MPa}$ \\
Aços forjados/trabalhados & - & $700 \mathrm{MPa}$ & $10^{6}$ & $S_{u}>1400 \mathrm{MPa}$ \\
Aços forjados/trabalhados &
\end{tabular}

* Do inglês, Higly tempered martensite

- Do inglês, Wrought steels 


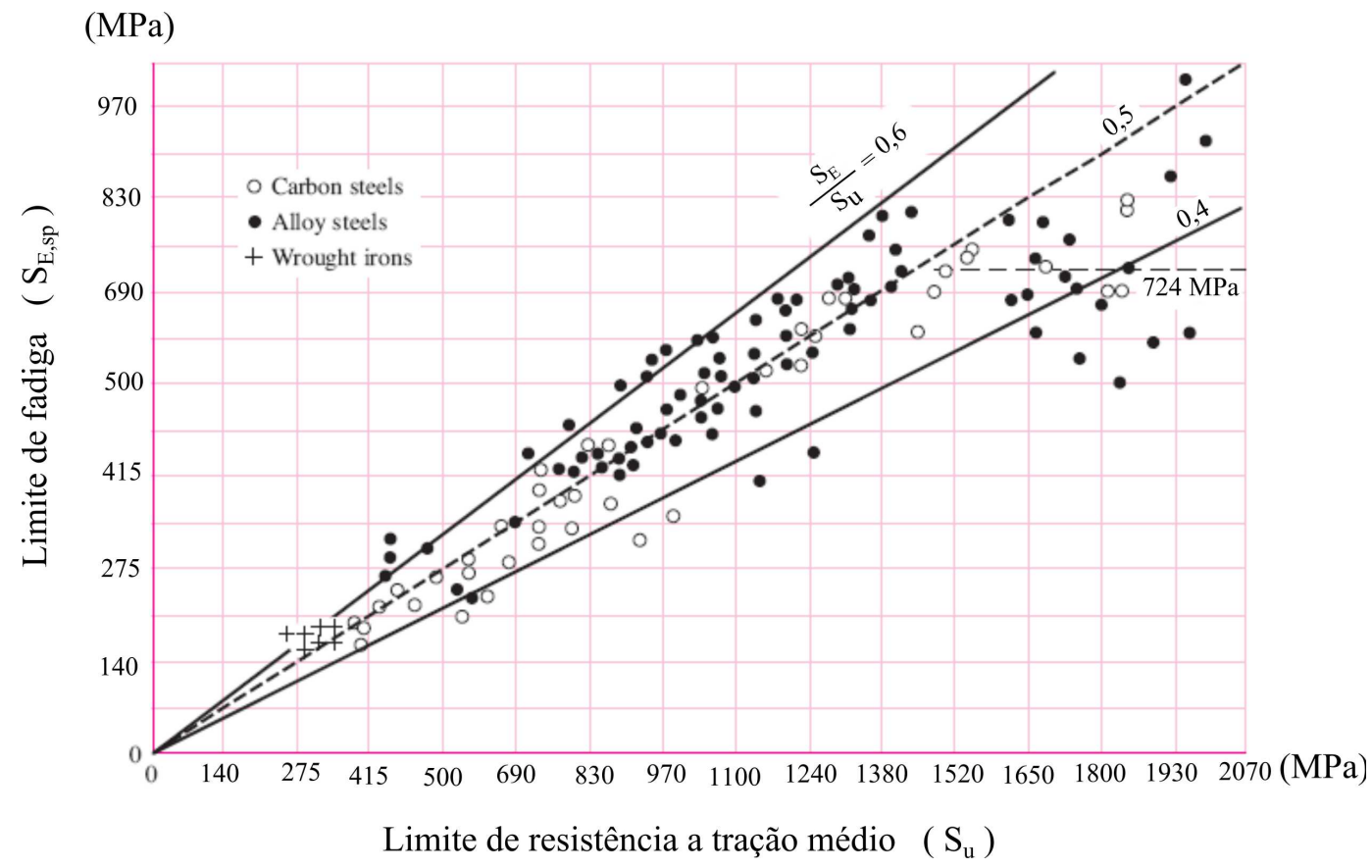

Figura 4.10 Relação entre limite de fadiga para flexão rotativa de espécimes não entalhados versus limite de resistência à tração (Coletado de dados compilados de Grover et al. (1960) e SAE International (1968, pg. 42)).

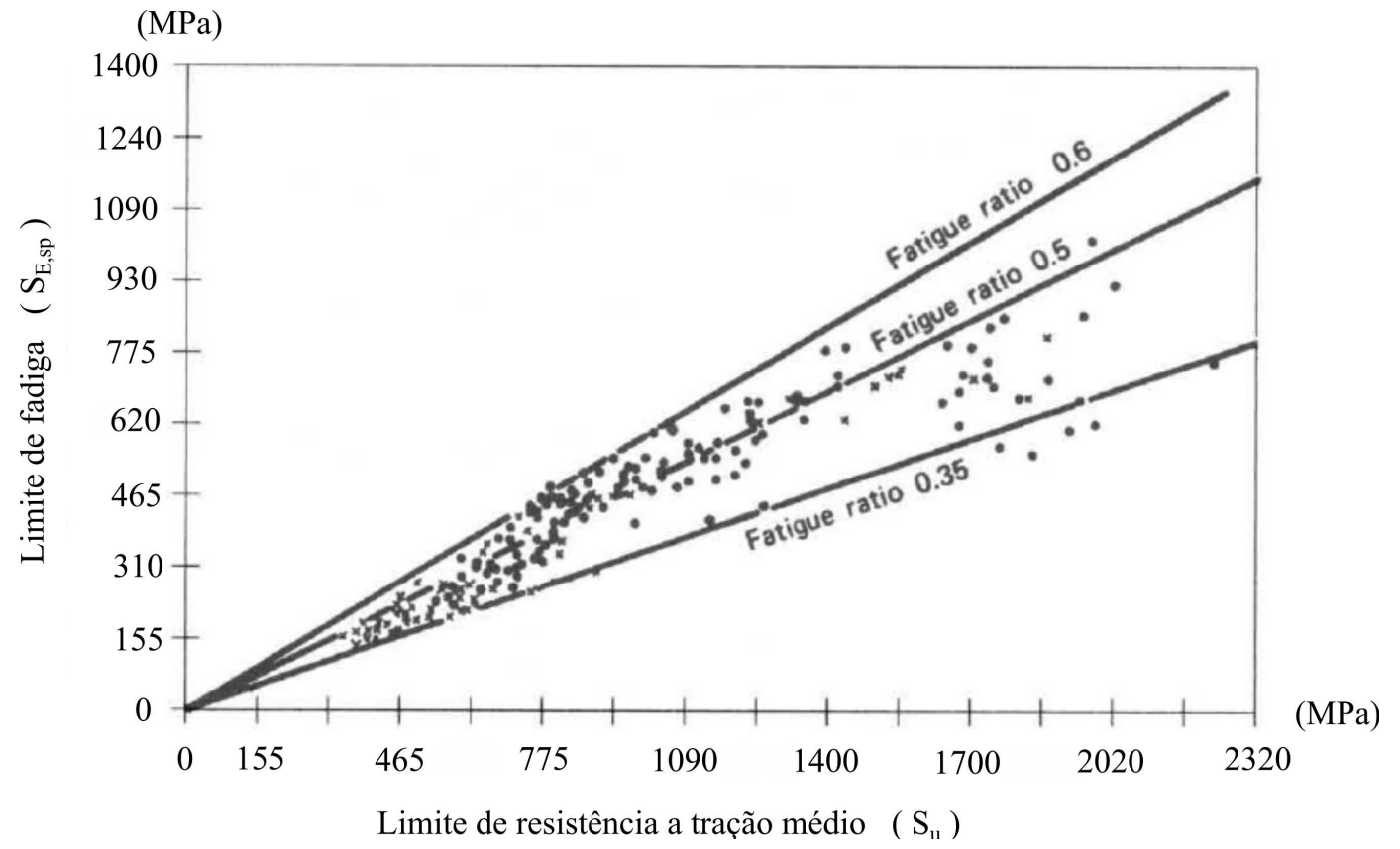

Figura 4.11 Relação entre limite de fadiga para flexão rotativa de espécimes de aço não entalhados versus limite de resistência à tração (Extraído de Forrest (1962)). 
utilizando os dados fornecidos pela FKM-Guideline (2003) ou, no máximo, dados da tabela 4.1 .

Tabela 4.2 Fatores do limite de fadiga para aços (FKM-Guideline, 2003).

\begin{tabular}{l|c|c|c}
\hline \multicolumn{1}{c|}{ Tipo do Material } & $C_{E, \sigma}$ & $S_{E, s p}$ & $N_{E}$ \\
\hline Aço para cementação (case-hardening steel) & 0,40 & $0,40 \cdot S_{u}$ & $10^{6}$ \\
Aço inoxidável (stainless steel) & 0,40 & $0,40 \cdot S_{u}$ & $10^{6}$ \\
Aço para forjamento (forjing steel) & 0,40 & $0,40 \cdot S_{u}$ & $10^{6}$ \\
Outro aço diferente dos tipos acima & 0,45 & $0,45 \cdot S_{u}$ & $10^{6}$ \\
Aço para fundição (steel casting) & 0,34 & $0,34 \cdot S_{u}$ & $10^{6}$ \\
\hline
\end{tabular}

* Aço fundido e aço fundido tratado termicamente para aplicações gerais

Na revisão bibliográfica percebeu-se que Schijve (2008) e Norton (2006) apresentam em seus livros a figura 4.11, a mesma figura apresentada por Forrest em 1962. Curiosamente, mesmo esta figura mostrando que existem aços onde $C_{E, \sigma}<0,5$, ambos os autores recomendam utilizar exatamente a mesma receita criada por Juvinall em 1967, dada pela equação (4.10). Constatou-se também que Dowling (1998) e Shigley et al. (2003) publicaram em seus livros a figura 4.10, cujos dados foram na verdade coletados do relatório técnico da Bureau of Naval Weapons de 1960 (Grover et al., 1960) e do Fatigue Design Handbook da SAE de 1968 (SAE International, 1968). Estranhamente, mesmo esta figura mostrando que existem aços onde $C_{E, \sigma}<0,5$, Dowling (1998) e Shigley et al. (2003) recomendam ambos utilizar a mesma receita criada por Juvinall em 1967, dada pela equação (4.10). Lee et al. (2005, seção 4.3.4) também apresentam em seu livro uma figura praticamente idêntica às figuras $4.10 \mathrm{e}$ 4.11, mas o autor não informa qual a origem dos dados. Diante do exposto, pode-se perceber que os gráficos e tabelas contidas nos livros atuais da área de fadiga provém, na verdade, de testes realizados antes da década de 1970. Além disso, constatou-se que muitos autores de livros/publicações recentes (Shigley et al., 2003; Socie, 2004b; Lee et al., 2005: Norton, 2006; Schijve, 2008) recomendam a utilização da exata receita criada por Juvinall (1967) (equação 4.10), comprovadamente insegura para ser utilizada em projetos mecânicos.

É importante sempre ter em mente que existe uma grande dispersão das razões $C_{E, \sigma}$, conforme mostrado nas figuras 4.8, 4.9, 4.10 e 4.11. Portanto, não se pode afirmar seguramente que a receita sugerida por Juvinall $\mathrm{em} 1967$ (e por diversos autores posteriores baseados nas sugestões do livro dele) através da equação (4.10) seja sempre segura. Desta maneira, é fundamental que o engenheiro estrutural tome cautela na estimativa da Curva S-N Espécime, utilizando um fator de segurança adequado durante a análise de fadiga. 


\subsubsection{Estimativa da resistência à fadiga $S_{B, s p}$ para aços}

O método para se estimar a resistência à fadiga para $N_{B}$ ciclos do espécime $\left(S_{B, s p}\right)$ é similar àquele apresentado na seção 4.2.1. A idéia é estimar esta propriedade como sendo uma porcentagem do limite de resistência à tração $S_{u}$, conforme apresenta a equação abaixo e a figura 4.7 .

$$
S_{B, s p}=C_{B, \sigma} \cdot S_{u}
$$

Juvinall (1967) se baseou nos dados da figura 4.8 para propor que seja utilizado o ciclo da fronteira $L C F$ sendo $N_{B}=10^{3}$ ciclos na ausência de dados experimentais. de Castro \& Meggiolaro (2009a, seção 4.3.4) informam que Juvinall também se basearam nos dados da figura 4.8 e sugeriram que fosse utilizado $S_{B, s p}\left(N_{B}=10^{3}\right)=0,9 \cdot S_{u}$ (i.e., $C_{B, s p}=0,9$ ) para a estimativa de $S_{B, s p}$ para aços. Entretanto, não se sabe por qual motivo esta proposta passou a ser infelizmente recomendada por vários outros autores posteriores à Juvinall (por exemplo Lee et al., 2005) para todos os metais (i.e., todos os tipos de aços, alumínio, ligas de magnésio, cobre, titânio, etc). Nenhum autor pesquisado nesta dissertação, exceto de Castro \& Meggiolaro (2009a), apresentou estudos experimentais que mostram o valor de $C_{B, s p}$ para cada tipo de metal. Portanto, sugerir a utilização desta equação para qualquer metal é bastante perigoso, uma vez que Juvinall (1967) comprovou experimentalmente sua utilização apenas para aços.

O método S-N se baseia em análise de tensões linear elástica e as tensões nos espécimes são calculadas por uma fórmula linear elástica 8 mesmo quando a tensão obtida ultrapassa o limite de escoamento $\left(S_{y}\right)$, como é usual quando a tensão máxima se aproxima de $S_{\text {max }}=S_{a}=0,9 \cdot S_{u}$ (de Castro \& Meggiolaro, 2009a). Uma estimativa do tipo $S_{B, s p}\left(10^{3}\right)=0,9 \cdot S_{u}$ quase sempre implica no escoamento do espécime nas vidas próximas à 1000 ciclos, invalidando assim a linearidade assumina na análise S-N linear elástica (de Castro \& Meggiolaro, 2009a). Portanto, para que o valor de $S_{B, s p}\left(N_{B}=10^{3}\right.$ ) seja obtido corretamente, uma análise de tensão elastoplástica deve ser realizada no espécime, pois a mesma consegue contabilizar o escoamento, caso ele ocorra. O cálculo das tensões elastoplásticas que atuam em corpos de prova cilíndricos de flexão rotativa após seu escoamento não é trivial. O cálculo dessas tensões envolve a análise de fadiga utilizando o método $\varepsilon-\mathrm{N}$ e não será abordada neste trabalho. Entretanto, mais informações sobre este método podem ser encontradas em Lee et al. (2005), Lee et al. (2011) e de Castro \& Meggiolaro (2009a).

de Castro \& Meggiolaro (2009a) analisaram curvas $\varepsilon$-N de 7270 ligas metálicas e constataram que em mais $\mathbf{8 5 \%}$ das ligas analisadas a tensão no espécime $\left(S_{a}=0,9 \cdot S_{u}\right) \mathbf{u l}$ trapassa o limite de escoamento $\left[S_{y}\right.$, quando $N_{B}=10^{3}$ ciclos. de Castro \& Meggiolaro (2009a) também analisaram curvas $\varepsilon-\mathrm{N}$ de 724 aços diferentes com todas as propriedades

\footnotetext{
${ }^{8}$ Por exemplo, no corpo de prova de Moore, $\sigma=32 M / \pi d^{3}$, onde $\mathbf{d}$ é o menor diâmetro do espécime e $\mathbf{M}$ é o menor momento fletor nele aplicado.
} 
medidas. Todos os testes foram feitos sob tração-compressão, não sob flexão rotativa, como é usual em ensaios experimentais baseados em deformação (e consequentemente, não há gradiente de tensão ao longo da espessura no espécime). A análise desses dados permitiu concluir que a resistência à fadiga em 1000 ciclos é na maioria das vezes muito menor do que $0,9 \cdot S_{u}$. Esta análise mostrou que $549 \operatorname{aços}(\mathbf{7 6 \%})$ tinham $S_{u} \leq 1400 \mathrm{MPa}$ e o valor médio da resistência à fadiga em $10^{3}$ ciclos deste grupo era igual à $S_{B, s p}=0,76 \cdot S_{u}$, com coeficiente de variação de $\mathrm{COV}=13 \%$. Adicionalmente, 175 aços $(24 \%)$ tinham $S_{u}>1400$ MPa e possuiam o valor médio $S_{B, s p}=0,67 \cdot S_{u}$ com coeficiente de variação de COV $=10 \%$. A figura 4.12 apresenta a resistência à fadiga $S_{B, s p}$ em aços medida em $N_{B}=10^{3}$ ciclos por de Castro \& Meggiolaro (2009a). de Castro \& Meggiolaro (2009a) relatam que, "apesar da grande dispersão desses dados, não há outra opção a não ser propor que se adote sempre a equação (4.12) para estimar $S_{B, s p}\left(10^{3}\right)$ ".

Diante do exposto, conclui-se que a pesquisa de de Castro \& Meggiolaro (2009a) mostra que a receita $S_{B, s p}\left(10^{3}\right)=0,9 \cdot S_{u}$ recomendada por Juvinall (1967) $)^{9}$ é muito insegura, mesmo para aços, e deve ser evitada ao máximo. Assim, é altamente aconselhável utilizar a equação 4.12 apenas em último caso, quando não houver a possibilidade de se obter a Curva $S$-N Espécime. É importante salientar que o resultado da pesquisa de de Castro \& Meggiolaro (2009a) (equação 4.12) vale apenas para aços. Adicionalmente, o autor lembra que o engenheiro estrutural deve se atentar à dispersão dos resultados mostrados na figura 4.12 para realizar um dimensionamento seguro.

Espécimes padronizados de aço: $\left\{\begin{array}{lll}S_{B, s p}\left(10^{3}\right)=0,76 \cdot S_{u} & \overline{\mathrm{COV}}=13 \%) & @ S_{u} \leq 1400 \mathrm{MPa} \\ S_{B, s p}\left(10^{3}\right)=0,67 \cdot S_{u} & \overline{\mathrm{COV}=10 \%)} & @ S_{u}>1400 \mathrm{MPa}\end{array}\right.$

\subsubsection{Estimativa do limite de fadiga de outras ligas metáli- cas}

Existem poucas literaturas que informam (de uma maneira utilizável em projetos mecânicos) o valor das propriedades de fadiga de outros metais. Inclusive estas poucas publicações trazem informações de maneira bem resumida e sem especificar claramente as condições para o uso daquelas hipóteses.

Segundo Juvinall (1967), o limite de fadiga de ferros fundidos extraídos de testes com corpos de prova pode ser estimado como sendo igual à $S_{E, s p}\left(10^{6}\right)=0,4 \cdot S_{u}$ em um ciclo do limite de fadiga de $N_{E}=10^{6}$ ciclos, provavelmente influenciado pela figura 4.13 publicada por Forrest (1962). Por outro lado, Lee et al. (2005, pg. 133) informam que o limite de fadiga de espécimes padronizados sob flexão rotativa ocorre em $N_{E}=5 \cdot 10^{7}$ ciclos e pode

\footnotetext{
${ }^{9}$ Que Juvinall $(1967)$ recomendou aplicar apenas para aços.
} 


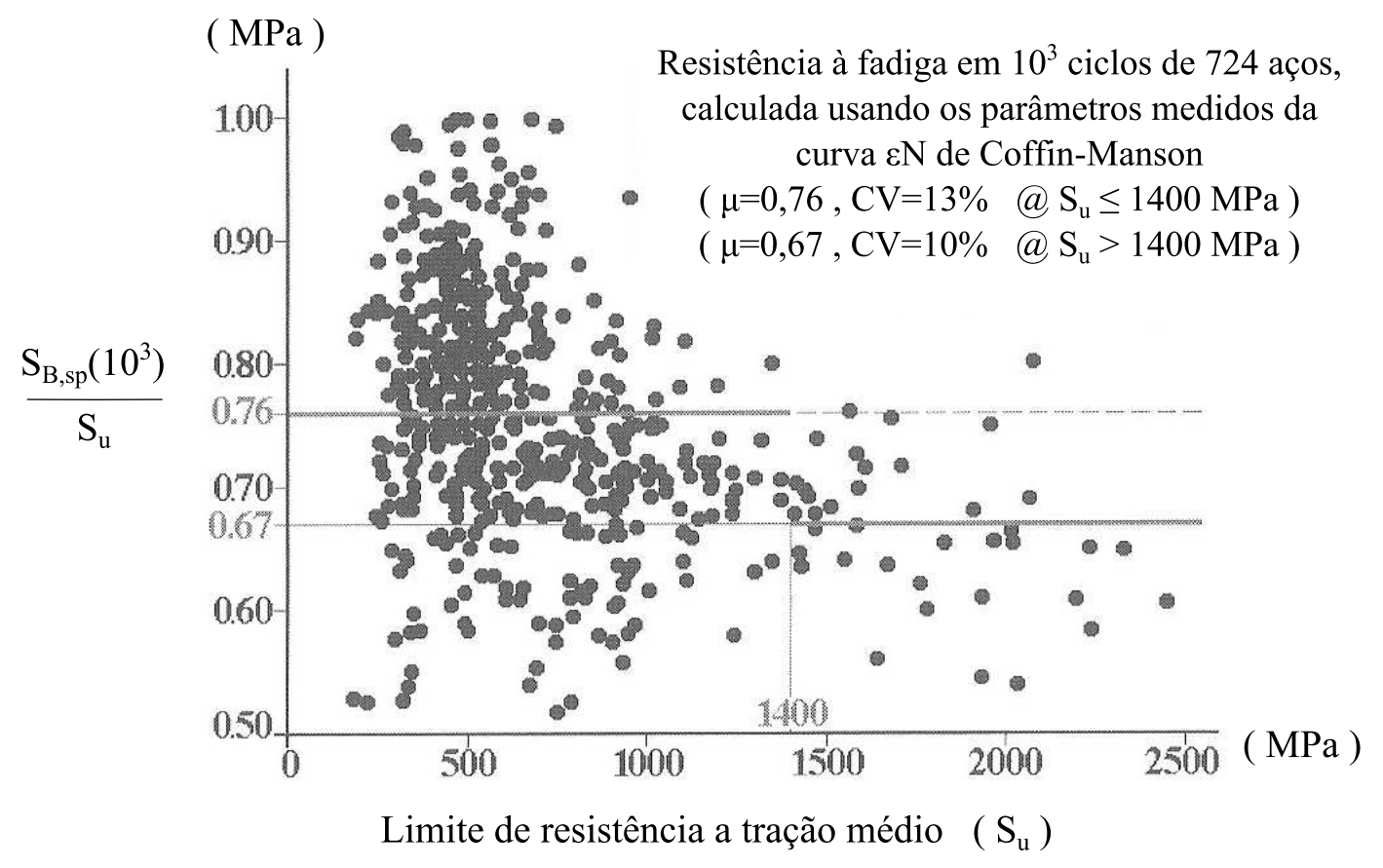

Figura 4.12 Resistência à fadiga $S_{B, s p}$ dos aços em $N=10^{3}$ ciclos (de Castro \& Meggiolaro, 2009a, fig. 4.28).

ser estimado como sendo $S_{E, s p}\left(10^{7}\right)=0,4 \cdot S_{u}$. Forrest (1962) e Norton (2006) apresentam em suas publicações a figura 4.13, que relaciona o limite de resistência à tração como o limite de fadiga de espécimes polidos sob flexão rotativa de ferros fundidos e ferros forjados. As linhas aproximadamente se ajustam às fronteiras superior e inferior; em ferros fundidos com alto limite de resistência à tração, o limite de fadiga tende a estar perto da linha superior. Norton (2006) recomenda utilizar $S_{E, s p} \cong 0,4 \cdot S_{u}$ para $S_{u}<400 \mathrm{MPa}$ e $S_{E, s p} \cong 160 \mathrm{MPa}$ para $S_{u} \geq 400 \mathrm{MPa}$. Ele também que recomenda que o ciclo do limite de fadiga de ferros fundidos é igual ao dos aços e deve ser escolhido como sendo $10^{6} \leq N_{E} \leq 10^{7}$. Diante do exposto pela figura 4.13, também seria possível utilizar a fronteira inferior igual à $S_{E, s p}\left(10^{6}\right)=0,35 \cdot S_{u}$ (independente do valor de $S_{u}$ ) e $N_{E}=10^{6}$ de maneira a prevenir-se contra a dispersão das razões $S_{E, s p} / S_{u}$. FKM-Guideline (2003) e Lee et al. (2011) apresentam valores similares na tabela 4.3 e recomendam que sejam utilizados esses fatores do limite de fadiga. Acreditase que os métodos utilizados pela diretriz do Conselho Alemão de Pesquisa em Engenharia sejam os mais recentes/modernos, por isto recomenda-se a utilização destes dados.

Tabela 4.3 Fatores do limite de fadiga para ferros fundidos (FKMGuideline, 2003).

\begin{tabular}{l|c|c|c}
\hline \multicolumn{1}{c|}{ Tipo do Material } & $C_{E, \sigma}$ & $S_{E, s p}$ & $N_{E}$ \\
\hline Ferro fundido nodular (Ductile iron) & 0,34 & $0,34 \cdot S_{u}$ & $10^{6}$ \\
Ferro fundido maleável (Malleable cast iron) & 0,30 & $0,30 \cdot S_{u}$ & $10^{6}$ \\
Ferro fundido cinzento (Grey cast iron) & 0,30 & $0,30 \cdot S_{u}$ & $10^{6}$ \\
\hline
\end{tabular}




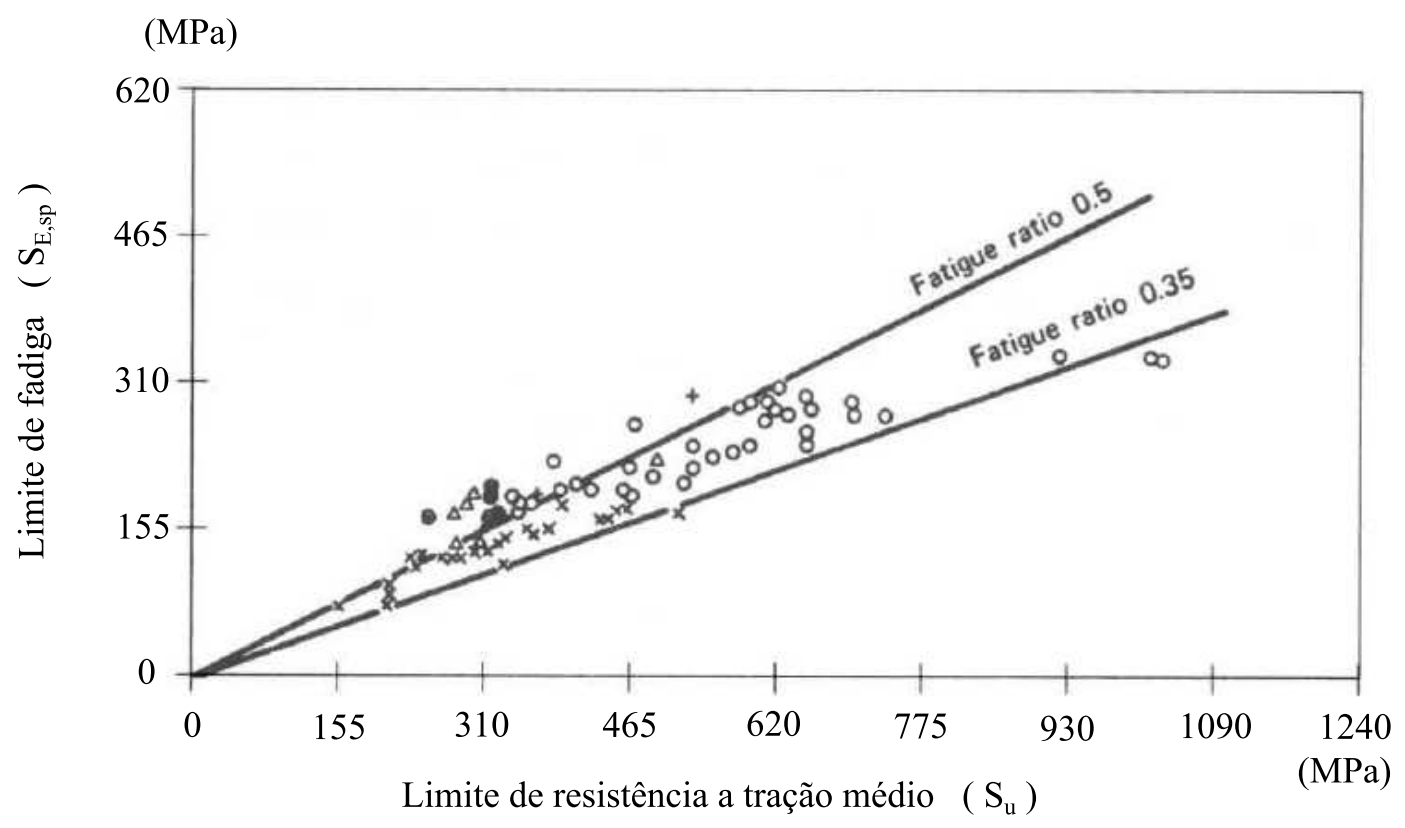

Figura 4.13 Relação entre resistência à fadiga de espécimes nãoentalhados sob flexão rotativa e o limite de resistência à tração de ferros fundidos e ferros forjados (Forrest, 1962).

Nem todos os metais apresentam limite de fadiga. De acordo com Dowling (1998, pg. 418), aços carbono de baixa resistência, ligas de aço de baixa resistência, ferros fundidos, ferros forjados, ligas de titânio e ligas de molibdênio possuem. Outros materiais como ligas de alumínio, de magnésio e de cobre, a maioria dos aços inoxidáveis, alguns aços carbonos de alta resistência e ligas de aço de alta resistência possuem curvas $\mathrm{S}-\mathrm{N}$ que continuam decrescendo com o aumento de $N$, sendo que o fator de inclinação da Curva S-N Espécime se torna menor após aproximadamente $10^{6}-5 \cdot 10^{6}$ ciclos (Sonsino, 2007, tab. 4). Estas curvas geralmente continuam tendo um ponto de inflexão, mas a tensão alternada relativa à este ponto não se chama mais limite de fadigd ${ }^{10}$, mas sim limite de endurance $\underline{11}^{11}\left(S_{K, s p}\right)$, que é a resistência à fadiga para um dado número de ciclos $N_{K}$. De acordo com Lee et al. (2005), o termo limite de fadiga é usado para representar apenas a resistência à fadiga que divide o limiar entre vida finita e vida infinita (para aqueles materiais que possuem vida infinita). Neste trabalho, será utilizado o termo limite de fadiga para se referir à $S_{E, s p}$ e limite de endurance para se referir à $S_{K, s p}$. Da mesma forma, o parâmetro $N_{K}$ será denominado ciclo do limite de endurance e será igual ao número de ciclos em que ocorre o ponto de inflexão.

A região da curva S-N acima do ciclo do limite de endurance $N_{K}$ é chamada de Fadiga de Ultra-Alto Ciclo (UHCF), A figura 4.14a representa um desenho esquemático da Curva S-N Espécime para materiais que não possuem vida infinita e a figura $4.14 \mathrm{~b}$ apresenta Curvas

\footnotetext{
${ }^{10}$ Em inglês, fatigue limit.

${ }^{11}$ Em inglês, endurance limit.
} 
S-N Espécime de alumínio obtidas até o regime de ultra-alto ciclo.

Embora ligas de alumínio não possuam um limite de fadiga real, uma prática comum é adotar a resistência à fadiga em $5 \cdot 10^{8}$ ciclos como o sendo o limite de endurance (Lee et al. 2005). Juvinall (1967), Fuchs \& Stephens (1980), Dieter (1981), Bannantine et al. (1990) e de Castro \& Meggiolaro 2009a) também adotam $N_{K}=5 \cdot 10^{8}$, enquanto que (Sonsino, 2007, tab. 4) adota $10^{6}-5 \cdot 10^{6}$ e a diretriz FKM-Guideline (2003) adota $10^{6}$. Assim:

Ligas de alumínio: $\begin{cases}N_{K}=5 \cdot 10^{8} & \text { (Juvinall, 1967; Fuchs \& Stephens, 1980; } \\ & \text { Dieter, 1981; Bannantine et al., 1990; } \\ & \text { de Castro \& Meggiolaro, 2009a; } \\ N_{K}=10^{6}-5 \cdot 10^{6} & \text { Lee et al., 2005) } \\ N_{K}=10^{6} & \text { (Sonsino, 2007, tab. 4) } \\ \text { (FKM-Guideline, 2003; Lee et al., 2011) }\end{cases}$

Juvinall (1967) apresenta em seu livro a figura 4.15a e se baseia nela para propor que se utilize a equação (4.14) para se estimar o limite de fadiga de ligas de alumínio. Lee et al. (2005), Norton (2006) e de Castro \& Meggiolaro (2009a) propõem a mesma recomendação da (4.14). Adicionalmente, Lee et al. (2005, pg. 133) afirmam que o limite de endurance de ligas de alumínio fundidas em molde permanente é de $S_{K, s p}\left(5 \cdot 10^{8}\right)=80 \mathrm{MPa}$ e o de ligas de alumínio fundidas em molde de areia é de $S_{K, s p}\left(5 \cdot 10^{8}\right)=55 \mathrm{MPa}$.

Ligas de alumínio (Juvinall, 1967): $\begin{cases}S_{K, s p}\left(5 \cdot 10^{8}\right)=0,4 \cdot S_{u} & @ S_{u} \leq 330 \mathrm{MPa} \\ S_{K, s p}\left(5 \cdot 10^{8}\right)=130 \mathrm{MPa} & @ S_{u}>330 \mathrm{MPa}\end{cases}$

Meggiolaro \& de Castro (2002a) analisaram a relação entre a resistência à fadiga à $5 \cdot 10^{8}$ ciclos de 218 ligas de alumínio e corrobaram a receita de Juvinall (vide figura 4.16). As ligas com $S_{u} \leq 325 \mathrm{MPa}$ (142 ligas) possuíam média $\bar{x}\left(S_{K, s p} / S_{u}\right)=C_{E, \sigma}=0,4$, mas os dados são muitos dispersos $\left(\mathrm{COV}=24 \%\right.$ ). A média das ligas com $S_{u}>325 \mathrm{MPa}$ (76 ligas) foi de $\bar{x}\left(S_{K, s p} / S_{u}\right)=C_{E, \sigma}=130 \mathrm{MPa}$ com $\mathrm{COV}=28 \%$. Contudo, sendo a média de todos os dados igual à $\bar{x}\left(S_{K, s p} / S_{u}\right)=C_{E, \sigma}=0,37$ e com $\operatorname{COV}=27 \%$, não há razão para justificar a separação das ligas com $S_{u}>325 \mathrm{MPa}$. Por esta razão, de Castro \& Meggiolaro (2009a) propõem uma outra estimativa para o limite de fadiga das ligas de alumínio:

Ligas de alumínio: $\quad S_{K, s p}\left(5 \cdot 10^{8}\right)=0,35 \cdot S_{u} \quad$ (independente do valor de $S_{u}$ )

Meggiolaro \& de Castro (2002a) informam que os dados da figura 4.16 incluem ligas laminadas ( 3 tipos da série $1 \mathrm{xxx}, 15$ da 2xxx, 2 da 3xxx, 1 da 4xxx, 10 da 5xxx, 13 da 6xxx, 8 da $7 x x x$ e 1 da $8 x x x$ ) e ligas fundidas (6 da série 2xx.0, 12 da 3xx.0, 5 da 4xx.0, 2 da 7xx.0 e 1 da 8xx.0), em várias têmperas diferentes. Consequentemente, esses dados cobrem grande parte das ligas estruturais de alumínio utilizadas na prática.

Não se pode perder de vista que existe uma grande dispersão nos valores de $C_{E, \sigma}$ para o alumínio, conforme nota-se nas figuras $4.15 \mathrm{~b}$ e 4.16 . Não se pode afirmar seguramente que a 


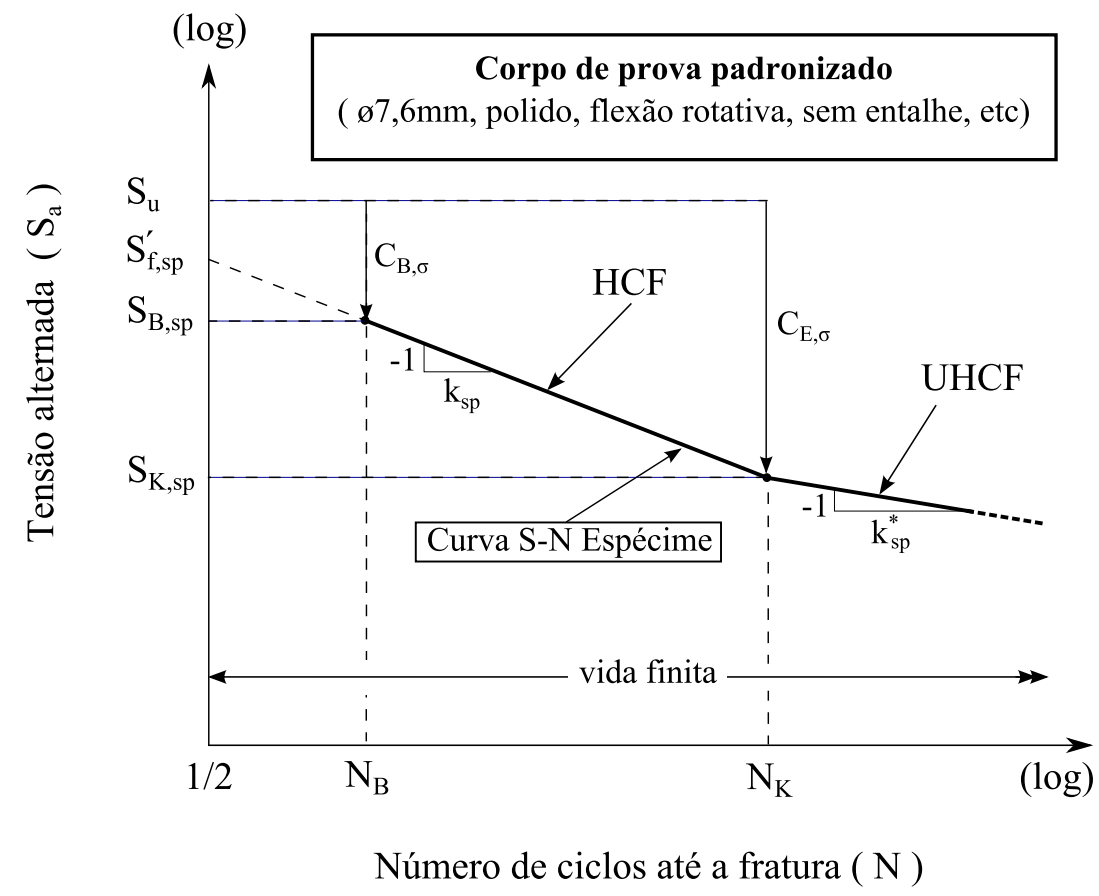

(a) Desenho esquemático de Curva S-N Espécime para metais que não possuem patamar de fadiga.

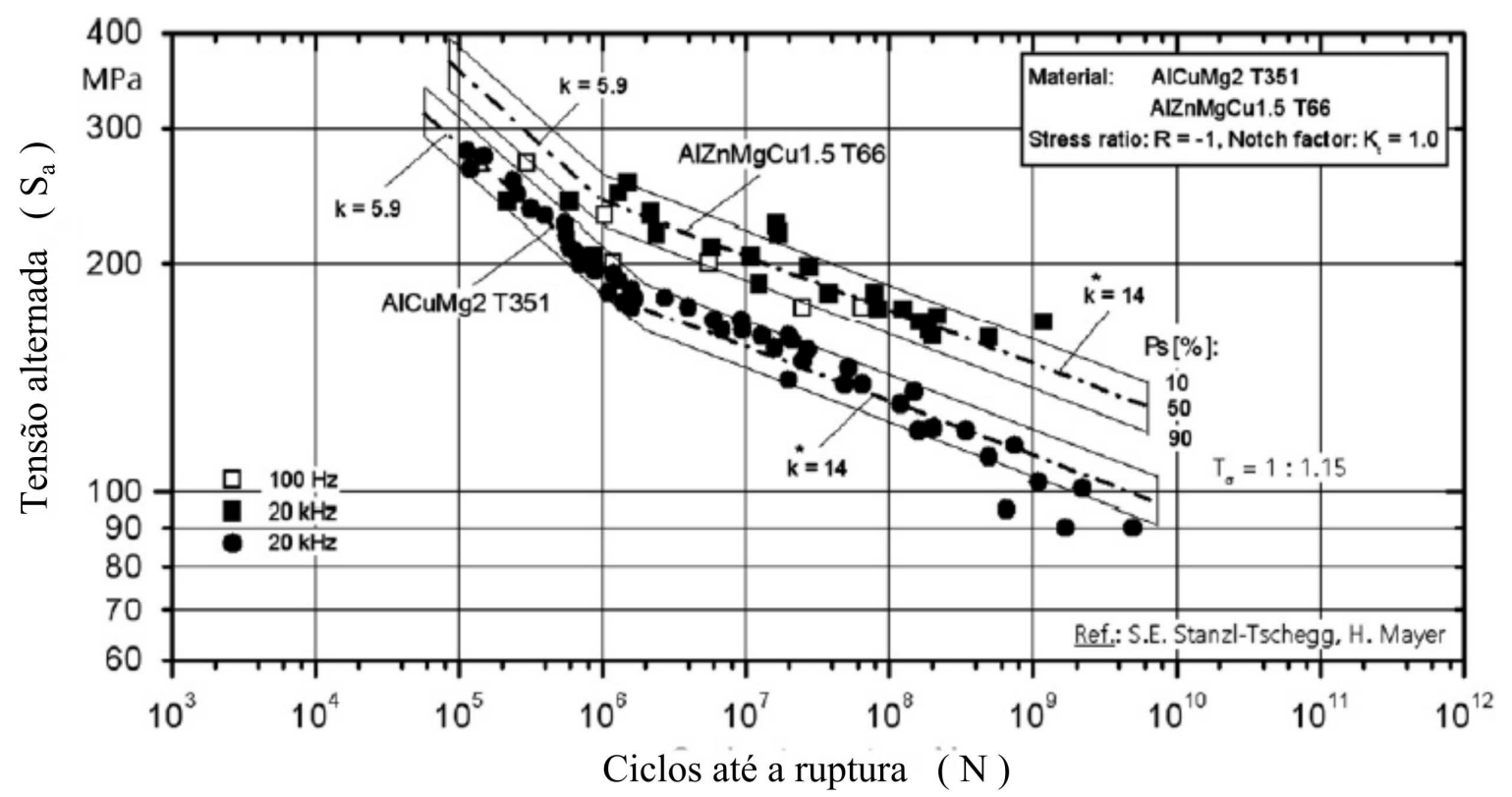

(b) Curva S-N Espécime de duas ligas de alumínio até o regime de ultra-alto ciclo (Sonsino, 2007, fig. 11).

Figura 4.14 Curvas S-N Espécime para metais sem patamar de fadiga. 
Ligas representadas:

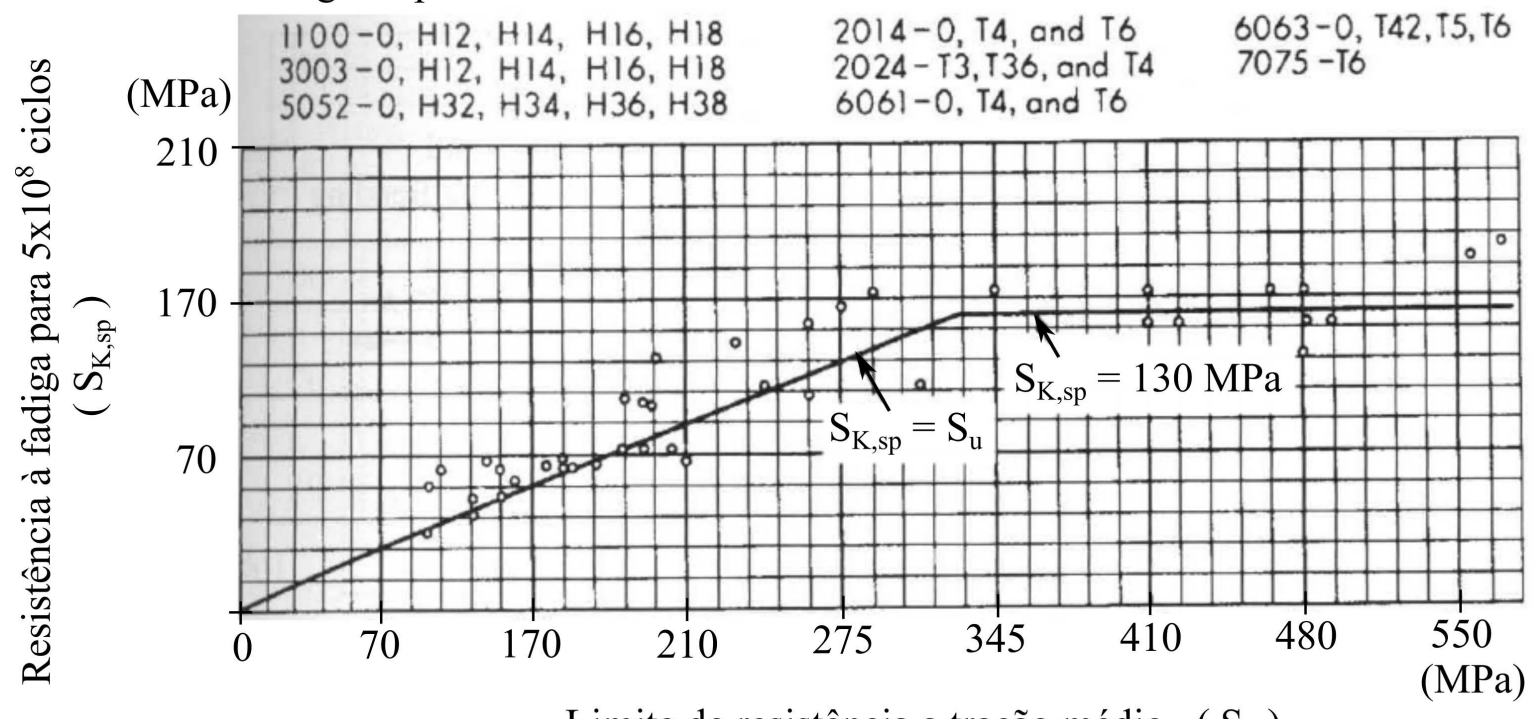

Limite de resistência a tração médio $\left(\mathrm{S}_{\mathrm{u}}\right)$

(a) Resistência à fadiga em $5 \cdot 10^{8}$ ciclos para ligas de alumínio trabalhadas comuns (Juvinall, 1967, pg. 215).

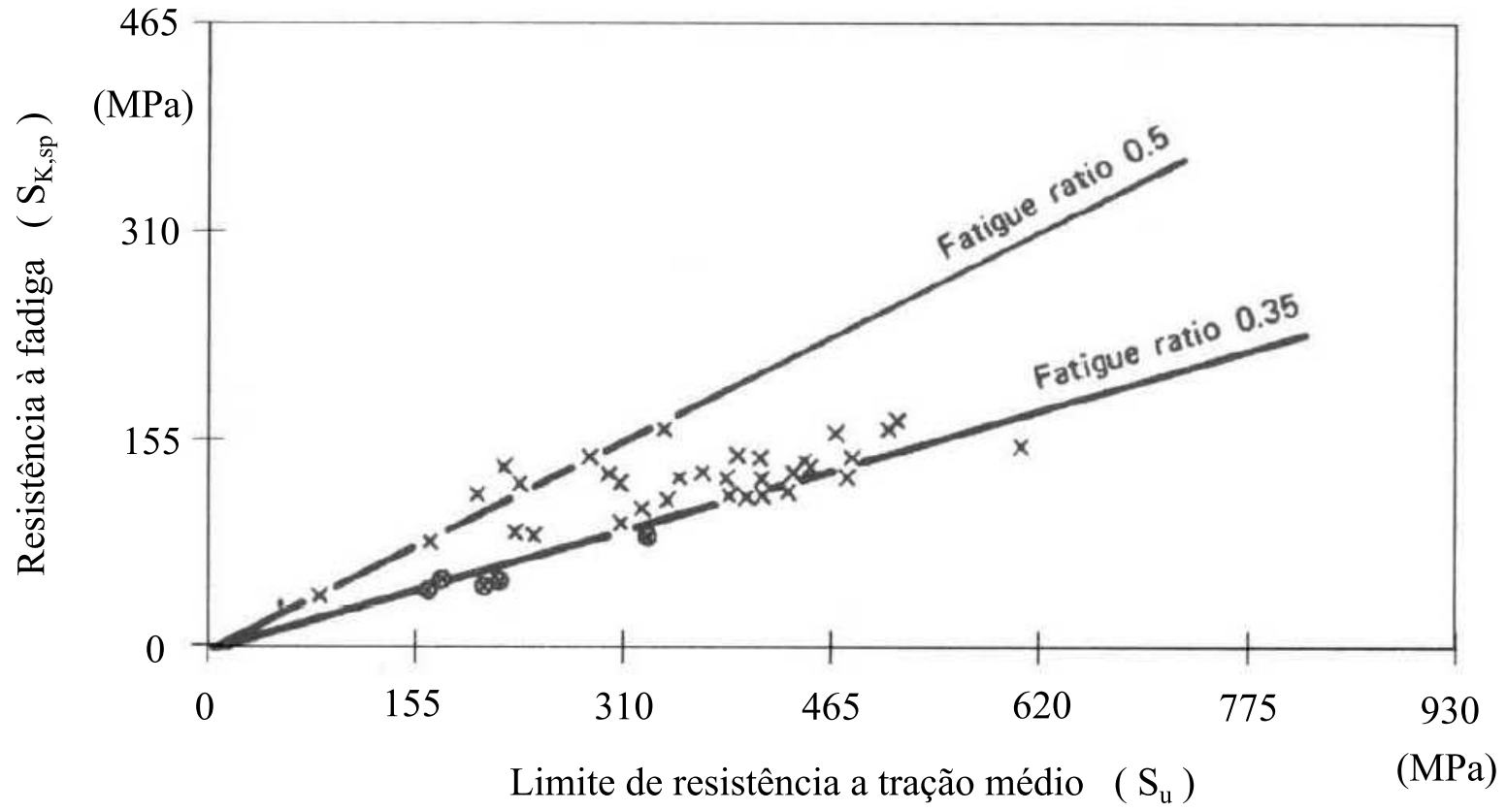

(b) Relação entre resistência à fadiga de espécimes sem entalhe sob flexão rotativa $\left(S_{K, s p}\right)$ e limite de resistência à tração $\left(S_{u}\right)$ em ligas de alumínio (Forrest, 1962$)$.

Figura 4.15 Relação entre $S_{K, s p}$ e $S_{u}$ em ligas de alumínio. 
recomendação sugerida por de Castro \& Meggiolaro (2009a) através da equação (4.15) seja sempre segura, pois a reta representada por esta equação não passa pelos pontos inferiores da figura $4.15 \mathrm{~b}$ nem da figura 4.16 .

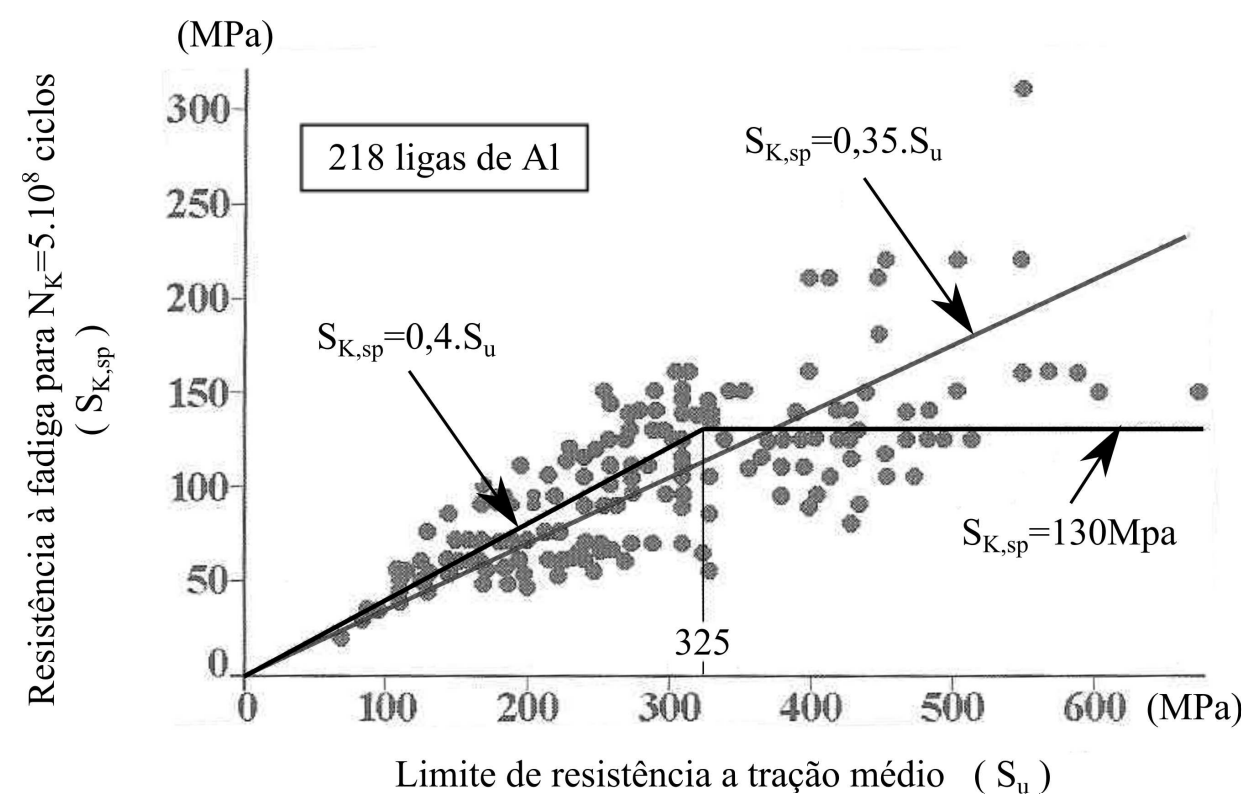

Figura 4.16 Limites de fadiga de 218 ligas de alumínio. Os dados foram coletados da literatura e analisados por de Castro \& Meggiolaro (2009a).

A diretriz FKM-Guideline (2003) também apresenta uma maneira de se estimar o limite de endurance $\left(S_{k, s p}\right)$ através do fator de durabilidade $\left(C_{E, \sigma}\right)$. Este fator deve ser adotado conforme apresenta a tabela 4.4. Sonsino (2007) realizou uma extensa pesquisa na área de fadiga de ultra-alto ciclo e analisou 4 ligas de alumínio: AlCuMg1.5 T66 (equivalente ao 7075-T66), AlCuMg2 T351 (equivalente ao 2024-T351), AlMgSi1 T6 (equivalente ao 6082T6) e G-AlSi5Cu3Mg0.4 T5 (equivalente ao 319-T5). Em seu excelente artigo ele verifica que o fator de inclinação para a região de ultra-alto ciclo $\left(k_{s p}^{*}\right)$ é igual à $k_{s p}^{*}=14$ para as ligas 7075-T66 e 2024-T351, $k_{s p}^{*}=22$ para a liga 6082-T6 e $k_{s p}^{*}=32$ para a liga 319-T5. Estes valores também estão condensados na tabela 4.4 .

Tabela 4.4 Fatores do limite de fadiga $\left(C_{E, s p}\right)$ para ligas de alumínio (adaptado de FKM-Guideline, 2003 e Sonsino, 2007).

\begin{tabular}{l|c|c|c|c}
\hline \multicolumn{1}{c|}{ Tipo do Material } & $C_{E, \sigma}$ & $S_{E, s p}$ & $N_{E}$ & $k_{s p}^{*}$ \\
\hline $\begin{array}{l}\text { Ligas de alumínio trabalhado (wrought alumi- } \\
\text { nium alloys) }\end{array}$ & 0,30 & $0,30 \cdot S_{u}$ & $10^{6}$ & 14 \\
$\begin{array}{l}\text { Ligas de alumínio fundido (cast aluminum al- } \\
\text { loys) }\end{array}$ & 0,30 & $0,30 \cdot S_{u}$ & $10^{6}$ & 32 \\
$\begin{array}{l}\text { Ligas de alumínio sinterizado (sintered alumi- } \\
\text { num alloy) }\end{array}$ & 0,30 & $0,30 \cdot S_{u}$ & $10^{6}$ & 22 \\
\hline
\end{tabular}


Há pouca informação disponível na literatura sobre curvas $\mathrm{S}-\mathrm{N}$ de outras ligas metálicas, como ligas de cobre, titânio, magnésio e níquel. Existe ainda um debate entre pesquisadores sobre o formato da curva S-N para ligas não ferrosas. Há autores que não reconhecem a existência de um limite de fadiga nesses metais e recomendam que a curva $\mathrm{S}-\mathrm{N}$ seja estimada mantendo sua inclinação 4.17(b)) ou no máximo diminuindo um pouco sua inclinação 4.17 (c)) após avaliar $S_{K, s p}\left(N_{K}\right)$ em algum valor alto de vida $N_{K}$.

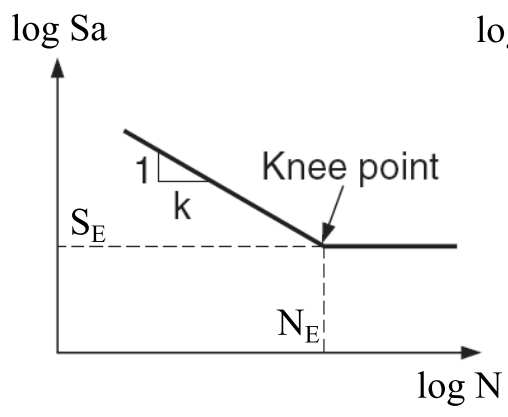

(a)

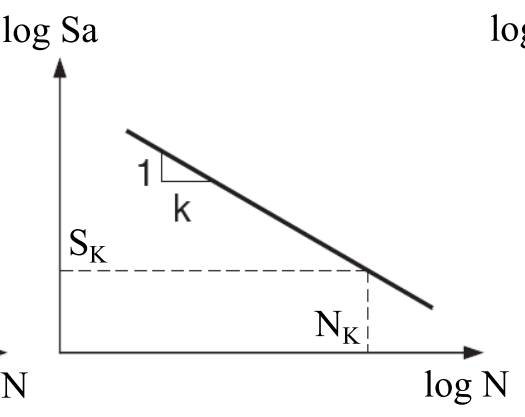

(b)

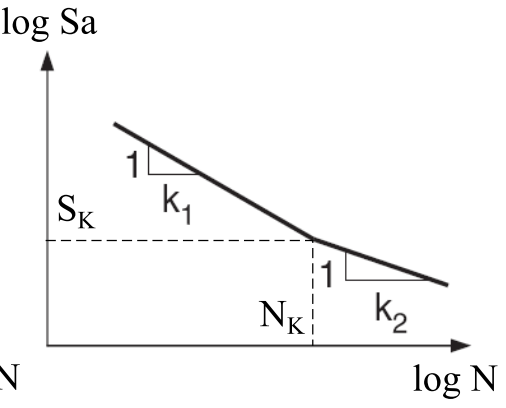

(c)

Figura 4.17 Diferentes comportamentos em fadiga de curvas S-N e definição de limite de fadiga e limite de endurance (Susmel, 2009).

Juvinall (1967) informa que a estimativa da resistência à fadiga do cobre para $N_{K}=10^{8}$ seja igual à apresentada na equação (4.16). Norton (2006) apresenta em seu livro a figura 4.18 (do livro Forrest (1962)) e, baseado nesta figura, propõe que utilizem a equação 4.17) para a estimativa de $S_{K, s p}$. Já o professor Roger J. Hawks, da Universidade de Trine, analizou um grande número de dados de resistência à fadiga de ligas de cobre (inclusive os dados da figura 4.18 de 1962) e afirma que o melhor ajuste aos dados de ligas de cobre ocorre quando a equação (4.18) é utilizada. Entretanto, a análise dos valores do limite de endurance mais atual é realizada por Meggiolaro \& de Castro (2002a) e de Castro \& Meggiolaro (2009a). Os autores investigaram 108 ligas de cobre, que incluem vários tipos de latões e diversos tipos de brozes (figura 4.19) e propõem uma receita aparentemente mais adequada que a citada por Juvinall (1967) (sic), dada pela equação (4.19). É importante ressaltar que nesta análise as ligas com $S_{u}<750 \mathrm{MPa}$ (71 ligas) possuíam média $\bar{x}\left(S_{K, s p}\left(10^{8}\right) / S_{u}\right)=C_{E, \sigma}=0,4$, mas os dados são muitos dispersos $(\overline{C O V}=25 \%$ ) (Meggiolaro \& de Castro, 2002a; de Castro \& Meggiolaro, 2009b, pg. 910). 


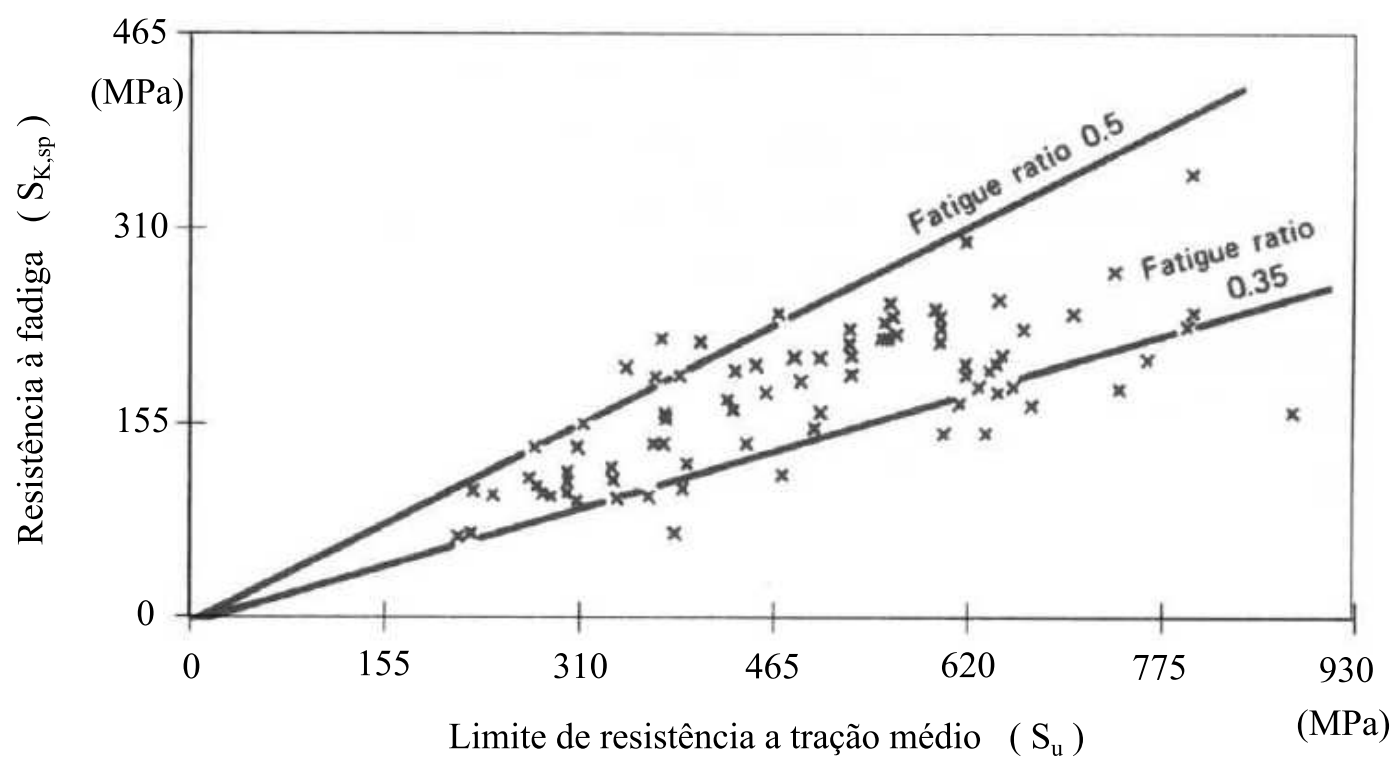

Figura 4.18 Relação entre resistência à fadiga de espécimes sem entalhe sob flexão rotativa $\left(S_{K, s p}\right)$ e limite de resistência à tração $\left(S_{u}\right)$ em ligas de cobre (Forrest, 1962).

Juvinall (1967): $\quad S_{K, s p}\left(10^{8}\right) \quad=\left\{0,25\right.$ a $0,5 \cdot S_{u}$

Norton (2006): $\quad S_{K, s p}\left(5 \cdot 10^{8}\right) \quad= \begin{cases}0,4 \cdot S_{u} & \text { para } S_{u}<280 \mathrm{MPa} \\ 100 \mathrm{MPa} & \text { para } S_{u} \geq 280 \mathrm{MPa}\end{cases}$

Prof. Roger J. Hawks: $S_{K, s p}\left(5 \cdot 10^{8}\right)= \begin{cases}0,37 \cdot S_{u} & \text { para } S_{u}<517 \mathrm{MPa} \\ 193 \mathrm{MPa} & \text { para } S_{u} \geq 517 \mathrm{MPa}\end{cases}$

Pinho de Castro (2009a): $\quad S_{K, s p}\left(10^{8}\right)= \begin{cases}0,4 \cdot S_{u} & \text { para } S_{u}<750 \mathrm{MPa} \\ 300 \mathrm{MPa} & \text { para } S_{u} \geq 750 \mathrm{MPa}\end{cases}$

Com relação à ligas de titânio, Fuchs \& Stephens (1980), Dieter (1981) e Bannantine et al. (1990), de Castro \& Meggiolaro (2009b, pg. 910) afirmam que estas ligas possuem vida infinita após aproximadamente $N_{E}=10^{6}$ ciclos. Juvinall (1967) relata que o ciclo do limite de fadiga ocorre aproximadamente na faixa $10^{6} \leq N_{E} \leq 10^{7}$ e recomenda adotar o limite de fadiga $\left(S_{E, s p}\right)$ conforme a equação (4.20). Entretanto, Meggiolaro \& de Castro (2002a) analizaram o limite de fadiga de 49 ligas de titânio (figura 4.20) e constataram que a média do fator de durabilidade para $N_{E}=10^{6}$ ciclos é $\bar{x}\left(S_{E, s p} / S_{u}\right)=C_{E, \sigma}=0,53$, entretanto os dados são muitos dispersos e possuem um coeficiente de variação de $\overline{C O V}=36 \%$. Os dados analisados estavam entre a faixa $0,1<S_{E, s p} / S_{u}<0,8$ e por serem tão disperos não permitem que se proponha uma estimativa razoável do limite de fadiga a partir do limite de resistência à tração. Em face das razões recomenda-se evitar o uso de estimativas do limite de fadiga em componentes feitos de ligas de titânio.

$$
\text { Juvinall (1967): } \quad S_{E, s p}\left(10^{6}-10^{7}\right)=0,45 \text { a } 0,65 \cdot S_{u}
$$




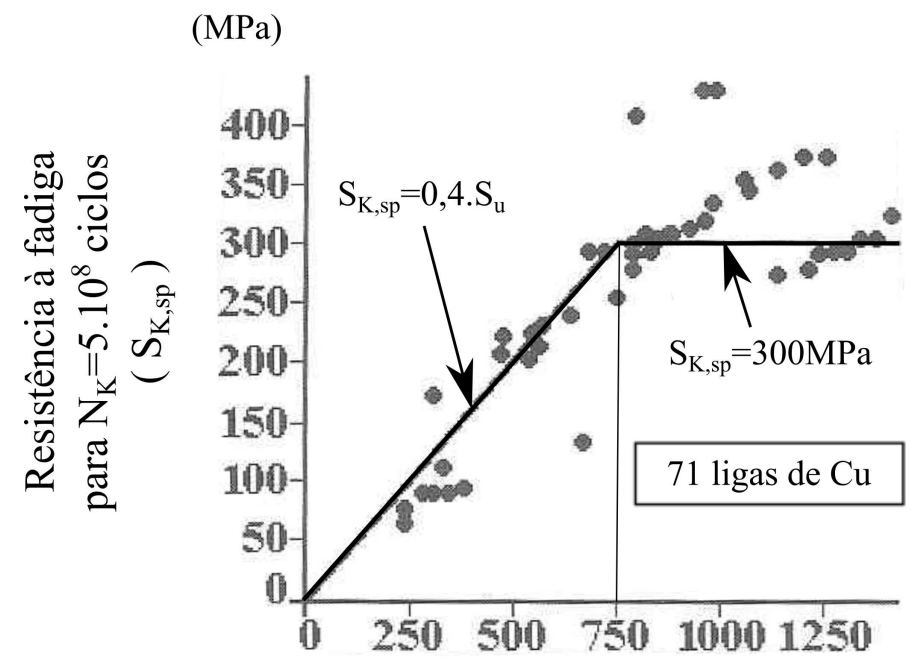

Limite de resistência à tração médio $\left(\mathrm{S}_{\mathrm{u}}\right)$

Figura 4.19 Limite de endurance $\left(S_{K, s p}\right)$ de 71 ligas de bronze (de Castro \& Meggiolaro, 2009a).

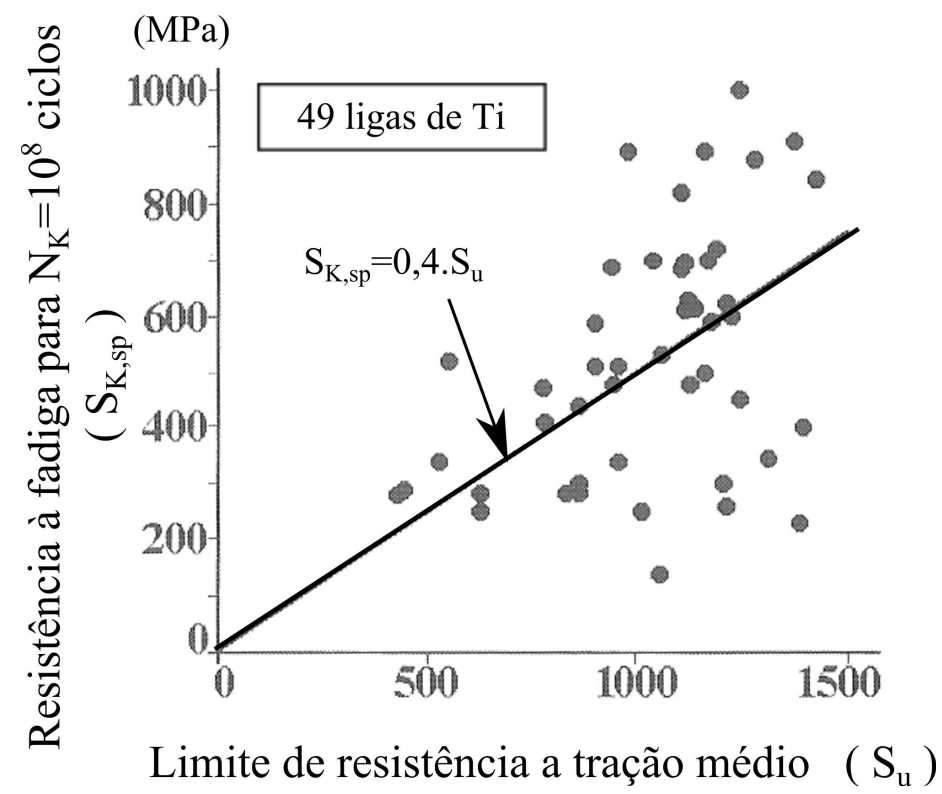

Figura 4.20 Limite de fadiga $\left(S_{E, s p}\right)$ de 49 ligas de titânio (de Castro \& Meggiolaro, 2009a).

Por fim, as equações 4.21), 4.22) e 4.23 representam relações para se estimar (grosseiramente) o limite de fadiga (ou limite de endurance no caso de metais que não apresentam comportamento horizontal após o ponto de inflexão) de ligas de magnésio e de polímeros. A equação (4.21) é recomendação de Juvinall (1967) e as equações 4.22) e 4.23) são propostas de Meggiolaro \& de Castro (2002a). Existe uma grande gama de polímeros no mercado, desde aqueles com baixa resistência à fadiga quanto àqueles com alta. Assim, estimar o limite de fadiga (ou limite de endurance) para todos os polimeros utilizando apenas uma equação (equação 4.23) acarreta em baixa confiabilidade, conforme ilusta a figura 4.21. Por 
tais razões recomenda-se não se estimar as propriedades de fadiga de polímeros a partir do limite de resistência à tração. A maneira mais confiável é utilizar a curva $\mathrm{S}-\mathrm{N}$ própria do material analisado, curva esta obtida através de ensaios experimentais ou da literatura, como por exemplo a figura 4.22 .

$$
\begin{aligned}
S_{K, s p}\left(10^{8}\right) & =0,35 \cdot S_{u} & & (\text { Ligas de Mg }) \\
S_{K, s p}\left(10^{8}\right) & =0,35 \cdot S_{u} & & (32 \text { ligas de Mg, } \mu=0,37, \mathrm{COV}=20 \%) \\
S_{K, s p}\left(10^{6} \text { a } 10^{7}\right) & =0,4 \cdot S_{u} & & \left(x_{50} \text { de } 60 \text { polímeros, } \mu=0,39, \text { COV }=29 \%\right)
\end{aligned}
$$

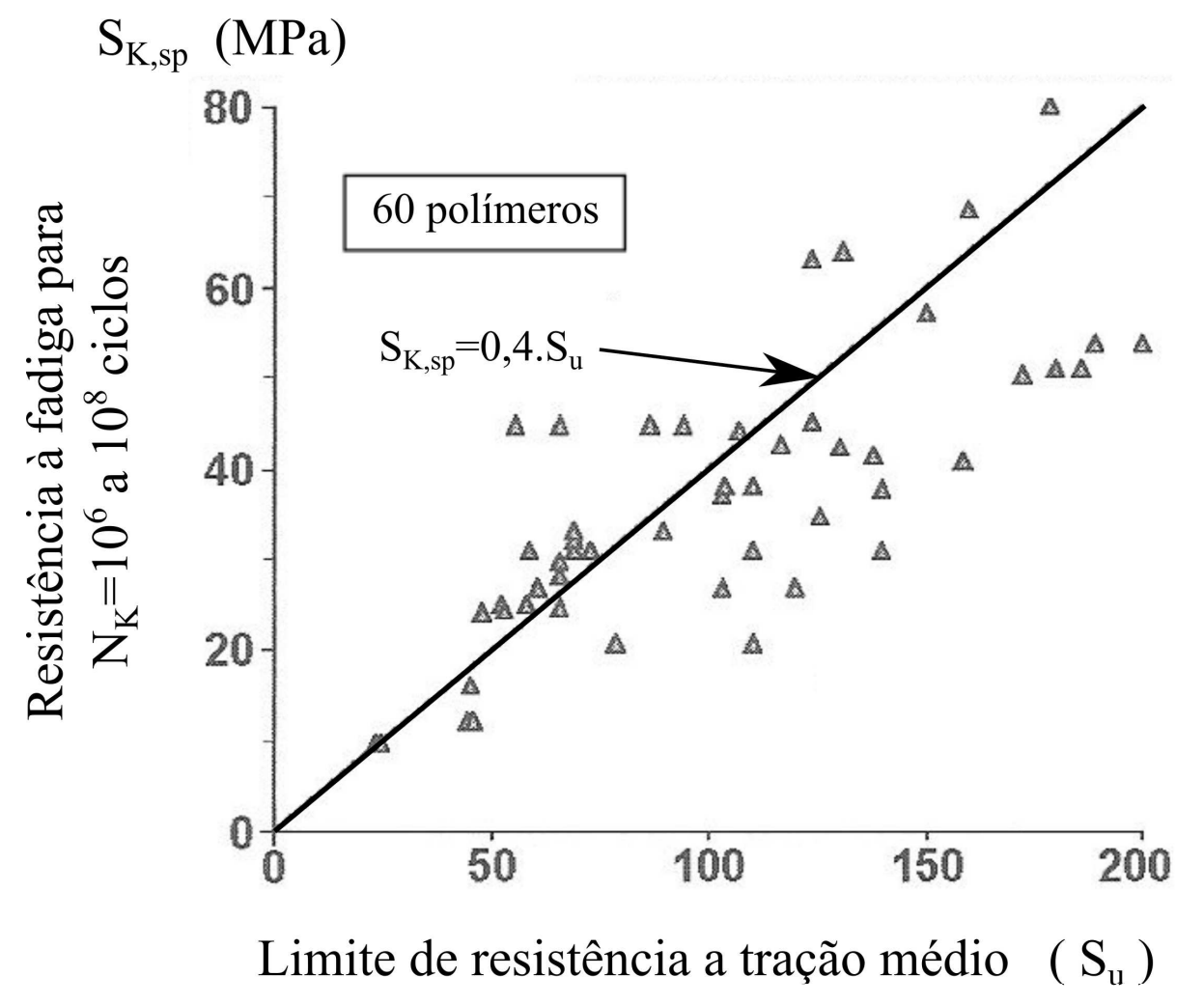

Figura 4.21 Limite de fadiga de 60 polímeros (de Castro \& Meggiolaro, 2009a).

Poucos trabalhos relatam sobre como realizar a estimativa da resistência à fadiga $S_{B, s p}$ de outros metais além do aço, provavelmente pela falta de dados experimentais. Meggiolaro \& de Castro (2002b) realizou uma extensa análise estatística das estimativas dos parâmetros S$\mathrm{N}$ e $\varepsilon$-N e sugere propostas para se estimar o valor de $S_{B, s p}$ de alguns materiais, apresentadas nas seguintes equações:

$$
\begin{aligned}
& S_{B, s p}\left(10^{3}\right)=0,65 \cdot S_{u} \quad \text { (amostra com } 16 \text { ferros fundidos, } C O V=28 \% \text { ) } \\
& S_{B, s p}\left(10^{3}\right)=0,82 \cdot S_{u} \quad(\text { amostra com } 81 \text { ligas de Al, COV }=10 \%) \\
& S_{B, s p}\left(10^{3}\right)=0,89 \cdot S_{u} \quad\left(37 \text { ligas de Al com } S_{u} \geq 325 \mathrm{MPa}, C O V=8 \%\right) \\
& S_{B, s p}\left(10^{3}\right)=0,89 \cdot S_{u} \quad(\text { amostra com } 15 \text { ligas de } \mathbf{T i}, C O V=9 \%) \\
& S_{B, s p}\left(10^{3}\right)=0,76 \cdot S_{u} \quad(\text { amostra com } 9 \text { ligas de Ni, } C O V=31 \%)
\end{aligned}
$$




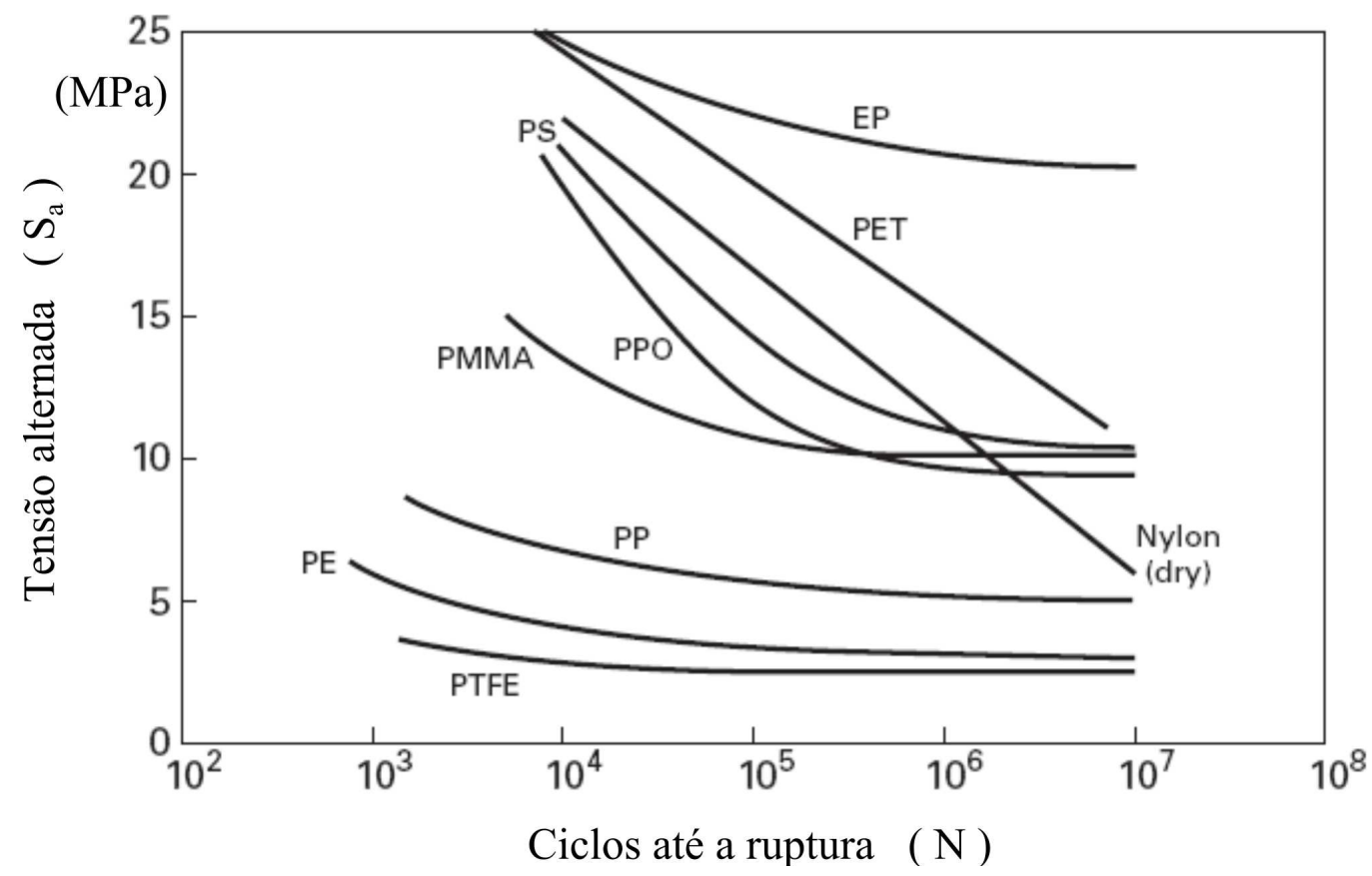

Figura 4.22 Curvas S-N de alguns polímeros (Meyers \& Chawla, 2009, fig. 14.4).

\subsubsection{Estimativa da resistência à fadiga $S_{B, s p}$ de outras ligas metálicas}

Estimar a resistência à fadiga $S_{B, s p}$ para aços utilizando a resistência à tração do material $\left(S_{u}\right)$ é uma abordagem que resulta em baixa confiabilidade no resultado, conforme visto na seção 4.2.2. E isto também é verdade para outros materiais. Por esta razão, Shigley et al. (2003, cap. 6) apresentam um método mais preciso e confiável para se estimar a resistência à fadiga em $10^{3}$ ciclos $\left(S_{B, s p}\right)$. Este método será mostrado à seguir. A experiência tem mostrado que os dados de fadiga de alto ciclo são linearizados por uma transformação logarítimica na tensão e ciclo até a falha. A resistência à fadiga em um número específico de ciclos de um espécime de Moore pode ser escrita como

$$
\left(S_{f}\right)_{@ N}=S_{f, s p}^{\prime} \cdot(2 N)^{b_{s p}}
$$

De acordo com Dieter (1981, cap. 9), a curva tensão-deformação verdadeira $(\sigma-\varepsilon)$ de muitos metais, após o ponto de escoamento, pode ser expressa pela equação (4.30), equação (4.31) (Equação de Ludwik) ou pela equação (4.32) (Equação de Ramberg-Osgood).

$$
\begin{gathered}
\sigma=K \varepsilon^{n} \\
\sigma=\sigma_{y}+K \varepsilon^{n} \\
\varepsilon=\frac{\sigma}{E}+0,002 \cdot\left(\frac{\sigma}{\sigma_{y}}\right)^{n_{2}}
\end{gathered}
$$


Onde

$\sigma \quad:$ Tensão verdadeira

$K \quad$ : Coeficiente de resistência

$\varepsilon \quad:$ Deformação verdadeira

$n$ : Expoente de encruamento

$\sigma_{y} \quad$ : Tensão de escoamento

E : Módulo de Elasticidade

$n_{2}$ : Expoente de encruamento da equação de Ramberg-Osgood

O coeficiente de resistência à fadiga $\left(S_{f, s p}^{\prime}\right)$ é o valor da tensão quando a curva $S-N$ intersepta o eixo das ordenadas. Esta é a tensão que ocorre no espécime durante $1 / 2$ ciclo de carregamento (ou seja, o espécime se rompe durante a tração do primeiro ciclo) e pode-se dizer que seu valor é muito próximo à tensão verdadeira de fratura obtida em ensaio de tração (i.e., $S_{f, s p}^{\prime}=\sigma_{f}$ ). O coeficiente de resistência à fadiga pode ser calculado utilizando a equação (4.30), (4.31) ou (4.32), fazendo $\varepsilon=\varepsilon_{f}$ (onde $\varepsilon_{f}$ é a deformação verdadeira de fratura). Se a equação tensão-deformação verdadeira não for conhecida, a aproximação da American Societ of Materials (1996, pg.2513) para aços com dureza Brinnell $H_{B} \leq 500$ pode ser usada:

$$
\sigma_{f}=S_{u}+345 M P a=S_{f, s p}^{\prime}
$$

Para encontrar o expoente de resistência à fadiga $\left(b_{s p}\right)$, basta substituir o coeficiente de resistência à fadiga $\left(S_{f, s p}^{\prime}\right.$ ) o limite de fadiga $S_{E, s p}$ e o ciclo do limite de fadiga $N_{E}$ (ou o limite de endurance $S_{K, s p}$ e $N_{E}$ ) na equação (4.29) e resolver para $b_{s p}$ conforme a equação abaixo:

$$
b_{s p}=\frac{\log \left(S_{E, s p} / S_{f, s p}^{\prime}\right)}{\log \left(2 N_{E}\right)}
$$

E portanto, a equação da Curva S-N Espécime $\quad\left(S_{f}\right)_{@ N}=S_{f, s p}^{\prime} \cdot(2 N)^{b_{s p}} \quad$ se torna conhecida.

A equação (4.29) para $N=N_{B}=10^{3}$ ciclos resulta em:

$$
\left(S_{f}\right)_{@ 10^{3}}=S_{f, s p}^{\prime} \cdot\left(2 \cdot 10^{3}\right)^{b_{s p}}=C_{B, s p} \cdot S_{u}
$$

Onde $\left(S_{f}^{\prime}\right)_{@ 10^{3} \text { ciclos }}$ é a resistência à fadiga em $10^{3}$ ciclos e $C_{B, s p}$ finalmente pode ser calculado como a seguir:

$$
C_{B, s p}=\frac{S_{f, s p}^{\prime}}{S_{u}}\left(2 \cdot 10^{3}\right)^{b_{s p}}
$$

Após isto, basta utilizar este valor na equação 4.11 para se obter $S_{B, s p}$. Este método permite calcular o valor de $C_{B, s p}$ utilizando os parâmetros $S_{u}, S_{f, s p}^{\prime}, S_{E, s p}$ e $N_{E}$ (ou $S_{u}, S_{f, s p}^{\prime}, S_{K, s p}$ e 
$N_{K}$ no caso de metais sem limite de fadiga) e resulta no cálculo mais preciso de $C_{B, s p}$ quando comparado à metodologia apresentada na seção 4.2.1. Além do mais, esta metodologia possui a vantagem de ser aplicada à qualquer metal.

Outra questão relevante consiste que, se o comportamento em fadiga é controlado pelo modo de iniciação de trinca (ex.: componentes com entalhes suaves, com grandes raios), a Curva S-N Espécime terá uma inclinação mais horizontal $\left(b_{s p} \cong-0,15 ; k_{s p} \cong 7\right.$ ) (Lee et al., 2005). Se o comportamento de fadiga é dominado pelo mecanismo de propagação de trincas (ex.: componentes com entalhes agudos, juntas soldadas, etc) então a Curva S-N Espécime frequentemente terá uma grande inclinação $\left(b_{s p} \cong-0,3 ; k_{s p} \cong 3\right)$. E devido a relação nãolinear entre vida e tensão alternada, um aumento de $10 \%$ na tensão alternada em uma curva $\mathrm{S}-\mathrm{N}$ onde $b_{s p}=-0,15$ acarretará em uma diminuição de $53 \%$ na vida em fadiga.

É preciso insistir também no fato que estimar propriedades mecânicas (principalmente de fadiga) é uma tarefa que exige cautela, devido à dispersão intrínseca do fenômeno. Não se pode perder de vista que existe uma grande dispersão nos valores do limite de fadiga $S_{E, s p}$ e do limite de resistência $S_{B, s p}$ quando estimados utilizando o limite de resistência à tração $S_{u}$. E de uma maneira geral, isto acontece para praticamente todos os materiais. Desta maneira, é necessário que o engenheiro estrutural tome cautela ao estimar a Curva S-N Espécime. $\mathrm{O}$ procedimento mais seguro e que recomenda-se utilizar primeiro é tentar obter o valor das propriedades de fadiga (por exemplo as constantes $b_{s p} \mathrm{e} S_{f, s p}^{\prime}$ ) através de experimentos. Caso isto não seja possível, recomenda-se como segunda opção a obtenção desses valores através de um banco de dados de materiais, podendo ser o apêndice de um livro ou algum site confiável. Apenas em último caso recomenda-se que as propriedades de fadiga sejam estimadas através de $S_{u}$.

Por outro lado, muitas vezes (na verdade, na maioria das vezes) os projetistas precisam estimá-las utilizando $S_{u}$, por simplesmente não terem outra opção. de Castro \& Meggiolaro (2009a) recomendam sempre associar as estimativas de propriedades a alguma variação do erro que ela pode introduzir nas previsões, para que se possam especificar de forma adequada os fatores de segurança a serem utilizados no dimensionamento. Como a previsão dessas propriedades mecânicas possuem grande dispersão, quase sempre decisões subjetivas precisam ser tomadas.

Neste trabalho, foram analizados os procedimentos utilizados por diversos autores para se estimar o valor de $S_{E, s p}, S_{B, s p}, N_{E}$ e $N_{B}$ e encontrou-se algo interessante. Foram analisados 12 obras: Forrest (1962), Juvinall (1967), (Dieter, 1981), Bishop \& Sherratt (2000), Shigley et al. (2003), FKM-Guideline (2003), Lee et al. (2005), Norton (2006), Schijve (2008), de Castro \& Meggiolaro (2009a), Susmel (2009) e Lee et al. (2011). A pesquisa mostrou que todas estas publicações, com exceção de FKM-Guideline (2003) e Lee et al. (2011), utilizaram receitas semelhante ou mesmo idênticas àquelas utilizadas por Forrest (1962) e 
Juvinall (1967), na década de 1960. Ou então utilizaram receitas de livros que utilizaram os métodos e informações desses dois autores. de Castro \& Meggiolaro (2009a pg. 145) também realizam uma extensa análise de 16 obras (Marin, 1962; Heywood, 1962; Forrest, 1962; McClintock \& Argon, 1966; Juvinall, 1967; Lipson \& Sheth, 1973; Duggan \& Byrne, 1977; Dieter, 1981; Moura Branco et al., 1987; SAE International, 1988; Bannantine et al., 1990; Hertzberg, 1996; Frost \& Marsh, 1999; Shigley et al., 2003; Juvinall \& Marshek, 2005; Norton, 2006; Schijve, 2008) e relatam que esses autores analisados também utilizam estratégias similares ou idênticas as utilizadas por Juvinall (1967). A impressão que se tem é que houve pouca evolução neste procedimento desde quando a publicação do livro de Juvinall e que não foram gerados dados mais modernos desde então. Entretanto, não foi possível saber se Juvinall foi quem originalmente propôs esta receita ou se ele teria compilado informações de publicações anteriores.

Em última análise, diante de todo o conteúdo exposto na seção 4.2 , o autor acredita que novas análises estatísticas, semelhantes às utilizadas por de Castro \& Meggiolaro (2009a), sejam necessárias para que seja proposto novas receitas para se estimar o valor de $S_{E, s p} \mathrm{e}$ $S_{B, s p}$ a partir de propriedades mecânicas estáticas. Isto seria necessário para que a estimativa desses dois parâmetros seja feita com maior precisão, em especial com relação ao valor de $S_{B, s p}$, que possui uma dispersão muito maior do que $S_{E, s p \text {. }}$ Por exemplo, estas análises estatísticas poderiam resultar em uma receita/equação que estime $S_{B, s p}$ para cada tipo de aço (igual ao que foi feito na figura 4.9 para $S_{E, s p}$ ). Além do mais, é possível que ligas metálicas desenvolvidas após a década de 1970 possuam valores de $C_{E, s p}$ e $C_{B, s p}$ diferentes das publicadas por Juvinall (1967) e Forrest (1962), tendendo para o lado não conservativo. Portanto, seria interessante que também fossem realizadas análises estatísticas para se verificar se as ligas utilizadas atualmente na indústria ainda possuem o mesmo valor médio e a dispersão do informado na figura 4.9. No caso do alumínio, por exemplo, estas análises estatísticas poderiam ajudar na criação de uma receita diferente para cada família de liga (por exemplo receita "A" para a família $2 \mathrm{xxx}$, receita "B" para a família 7xxx, etc).

\subsection{Curva S-N Unnotched}

\subsubsection{Conceito de Similaridade}

A maneira mais óbvia de se determinar qual a vida em fadiga de uma estrutura completa sujeita a carregamentos reais de serviços é testando-a. Isto pode ser feito colocando a estrutura em um equipamento específico e aplicando os carregamentos na qual ela está sujeita durante seu uso habitual. Mas os testes em escala completa sob cargas reais de serviço são normalmente muito caros, lentos e complexos. Estes testes demandam equipamentos sofisticados e técnicos altamente qualificados para especificá-los, executá-los e interpretá-los. 
Assim, apesar dos seus muitos benefícios e da sua alta confiabilidade, o seu alto custo os torna inviáveis na maioria dos casos práticos. Por este motivo, eles só são usados quando a segurança tem que ser maximizada a qualquer custo, como na indústria aeronáutica, ou quando a produção em larga escala é suficiente para diluir os custos do teste.

Nessas circunstâncias, é bem razoável começar imaginando um caso mais simples em que apenas um componente de uma estrutura complexa é analisado, tendo este componente apenas um ponto crítico facilmente identificável. A quantificação da resistência à fadiga deste componente é feita testando-se este componente sob condições reais de serviço, obtendo como resultado a curva S-N deste componente. A curva S-N fornece a referência dos dados de fadiga de uma dada geometria, processamento de material e condição de carregamento para uso na subsequente análise de resistência e vida em fadiga. Curvas $\mathrm{S}-\mathrm{N}$ de componentes reais representam o verdadeiro comportamento em fadiga de peças manufaturadas incluindo todas as variáveis supracitadas. Apesar dos testes de componentes serem menos caros e menos raros do que os testes de estruturas completas, eles ainda exigem muito tempo, equipamentos sofisticados e técnicos altamente qualificados, o que os torna inviáveis para a grande maioria das indústrias mecânicas. Além do mais, se a geometria mudar, é necessário gerar uma nova curva $\mathrm{S}-\mathrm{N}$ que incorporem os efeitos da mudança; isto adiciona custo e tempo ao processo do projeto de fadiga. Adicionalmente, na fase de projeto, o engenheiro estrutural tem como objetivo estimar (em vez de medir) a resistência à fadiga de componentes que ainda não estão manufaturados. Consequentemente, é inútil realizar testes físicos na fase inicial do projeto, quando a estrutura ainaa não existe.

A terceira opção é medir pelo menos a resistência à fadiga do material do componente, testando apenas pequenos espécimes feitos do mesmo material. Esta solução é mais fácil e barata quando comparada com ensaios em componentes ou estruturas inteiras. Além do mais, ao invés de se tentar reproduzir cargas reais de serviço nestes testes, utiliza-se um carregamento simples (senoidal), que gera um comportamento bastante compreensível. Esta estratégia de abordagem, que teve início com os trabalhos pioneiros de August Wöhler na década de 1860 , permite entender como determinado material se comporta quanto à fadiga. Esta idéia está baseada no importante Conceito de Similaridade ${ }^{12}$ (Socie, 2004b). Este conceito permite engenheiros relacionar o comportamento de espécimes de escala pequena, definidos sob condições cuidadosamente controladas, com a provável performance de estruturas reais sujeitas à cargas de fadiga de amplitude variável sob condições reais de serviço. A figura 4.23 representa este conceito.

O Conceito de Similaridade estipula que, se as cargas instantâneas aplicadas na "estrutura teste" (por exemplo um virabrequim) e no espécime de teste forem as mesmas, e se as características de ambos os objetos testados também forem as mesmas, então a resposta (=vida) em cada caso irá também ser a mesma e pode ser descrita pela curva S-N do material

\footnotetext{
${ }^{12}$ Também chamado de Conceito de Similitude
} 
obtida em ensaio utilizando o espécime de teste (Socie, 2004b). As rotinas usadas no dimensionamento à fadiga pelo método S-N supõe que a vida em fadiga de uma peça, cuja trinca nucleará em um ponto crítico (geralmente na raiz de um entalhe), pode ser reproduzida e que sejam sujeitos ao mesmo histórico de tensões que a solicita em serviço. Em outras palavras, segundo a filosofia S-N, pode-se reproduzir o que acontece em uma estrutura complexa testando adequadamente pequenos corpos de prova muito mais simples e baratos. É por esta razão que os engenheiros conseguem estimar a vida em fadiga de componentes complexos utilizando curvas S-N obtidas com espécimes. Entretanto, para que isso seja possível, é fundamental que os espécimes usados para levantar a curva $\mathrm{S}-\mathrm{N}$ possuam o mesmo material e características (geometria do entalhe, rugosidade superficial, tratamento superficial, temperatura de trabalho, etc) do ponto crítico do componente

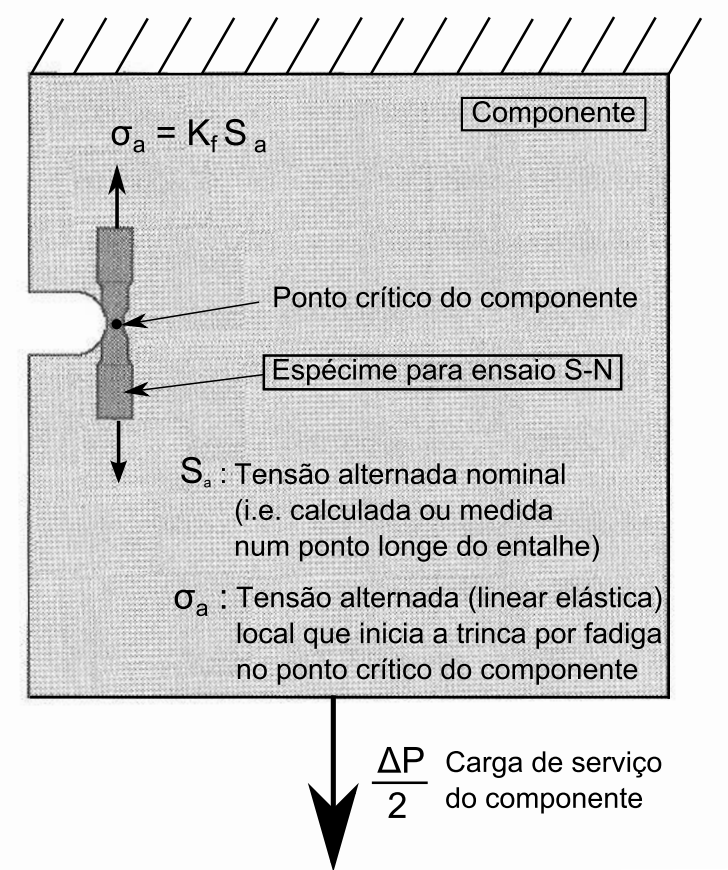

Figura 4.23 Conceito da filosofia do método S-N (adaptado de de Castro \& Meggiolaro, 2009a)
Suponhamos que a curva $\mathrm{S}-\mathrm{N}$ da figura $4.5 b$ foi obtida com o espécime cuja geometria é mostrada na figura 4.23. Suponhamos também que o menor diâmetro do espécime (na região crítica) seja igual à $\varnothing_{s p}$. Assim, a aplicação de uma tensão alternada loca ${ }^{13}$ $\left(\sigma_{a}\right)$ constante de $140 \mathrm{MPa}$ neste espécime (na região de menor diâmetro) irá fazer uma trinca nuclear (na superfície da região de menor diâmetro) e crescer até que haja a fratura deste espécime em aproximadamente 10.000 ciclos. Se uma força alternada for aplicada no componente da figura 4.23 de maneira a gerar uma tensão alternada local $\left(\sigma_{a}\right)$ de $140 \mathrm{MPa}$ no ponto crítico, então uma trinca nucleará na superfície do ponto crítico e irá crescer. Quando a estrutura chegar em 10.000 ciclos, então acredita-se que o comprimento da trinca será aproximada-

mente igual ao diâmetro do espécime $\varnothing_{s p}$. Este é um dos conceitos mais importantes que se deve ter sobre o método de Análise de Fadiga Uniaxial Baseada em Tensão. Portanto, a vida em fadiga (ciclos) em um componente se refere à vida necessária para nuclear e crescer uma trinca até um comprimento de trinca visível $a_{i}$ (ver Lee et al. (2005, pg 106), Lee et al. (2011, pg 116) e de Castro \& Meggiolaro (2009a, pg 137)). Por este motivo alguns autores consideram este método como sendo um método baseado em iniciação de trinca (de Castro \& Meggiolaro, 2009a; Lee et al., 2011, 2005), conforme explicado na seção Idealização do Processo de Fadiga em Fases (3.4).

\footnotetext{
${ }^{13}$ A tensão local é igual à tensão nominal aumentada devido ao concentrador de tensões.
} 
As Curvas S-N Espécime são obtidas em laboratório utilizando espécimes de flexãorotativa padronizados. Obviamente, a maioria dos componentes analisados pelos engenheiros estruturais possuem características bem diferentes das características do espécime utilizado nos ensaios de fadiga. Além disso, as cargas reais de serviço sobre um componente também são diferentes do carregamento do ensaio de fadiga padronizado. Por este motivo, é insensato esperar que uma curva S-N extraída de um componente coincida com aquela extraída utilizando um corpo de prova padronizado. Algumas diferenças citadas por Shigley et al. (2003) são:

- Material: composição, variabilidade;

- Processo de fabricação: método de manufatura, tratamentos térmicos, condições superficiais, concentradores de tensão;

- Geometria: tamanho, formato, concentradores de tensão;

- Ambiente: temperatura, estado de tensões, velocidade de aplicação da carga, corrosão.

Assim, se um componente ou condição de carregamento for diferente daquela utilizada na obtenção da Curva S-N Espécime supramencionada, é necessário "apenas" modificar a Curva S-N Espécime para contabilizar as diferenças. Tais ajustes são obtidos através do uso de fatores modificadores. Este procedimento de estimar uma curva S-N do componente será visto em detalhes na seção 4.3 e 4.4 e é nomeado por Hück, Thrainer \& Schütz (1981) e por Lee et al. (2011) por Método das Curvas $S$ - $N$ Sintéticas ${ }^{14}$.

Não se sabe ao certo quando esta idéia surgiu, talvez no final do século XIX, mas Marin (1962) já menciona este procedimento em seu livro em 1962. Esse mesmo procedimento foi também encontrado em muitas outras publicações (Juvinall, 1967; Fuchs \& Stephens, 1980; Bannantine et al., 1990; Dowling, 1998; Lee et al., 2005; Shigley et al., 2003; de Castro \& Meggiolaro, 2009a; Lee et al. 2011) e é amplamente utilizado em análises de vida em fadiga. Algumas etapas deste procedimento de análise de fadiga diferem de autor para autor, pois houve o aperfeiçoamento de algumas delas ao longo das últimas décadas, de maneira a melhorar os resultados da previsão da vida em fadiga. É o caso de Lee et al. (2011), que apresentam etapas consideravelmente diferentes daquelas utilizadas antes da década de 2000 . O procedimento utilizado por Lee et al. (2011) é o mesmo utilizado por FKM-Guideline (2003), que é a diretriz técnica desenvolvida pelo Conselho Alemão de Pesquisa em Engenharia $F K M$ Esta diretriz contém métodos para a avaliação da resistência de estruturas, tanto para aplicações estáticas quanto para aquelas em que ocorre fadiga. O procedimento para resolução de problemas de fadiga contidos na FKM-Guideline (2003) é o mais atual e moderno conhecido e utiliza a maior parte das etapas e informações contidas nas publicações citadas neste parágrafo. Entretanto, ele também traz métodos inéditos, baseados nas últimas

\footnotetext{
${ }^{14}$ Tradução livre do autor para Synthetic S-N Curves Method.

${ }^{15}$ Do alemão, Forschungskuratorium Maschinenbau.
} 
descobertas científicas e artigos publicados na área de fadiga. Como exemplo, destacam-se o Método do Gradiente de Tensão Relativo para contabilização do efeito de entalhe e o novo método para contabilização do efeito de tamanho em componentes geometricamente complexos, ambos os métodos adequados para serem utilizados em conjunto com FEA. Por este motivo, a FKM-Guideline (2003) tem sido utilizada cada vez mais por engenheiros, inclusive fora da Alemanha devido ao fato desta diretriz ter sido traduzida para o inglês em 2003.

A idéia para a elaboração da FKM-Guideline foi proposta após a queda do muro de berlin, em um encontro do DVM em Berlin, Alemanha, em Maio de 1990, quando especialistas da República Federal da Alemanha se encontraram com especialistas da República Democrática Alemã. O objetivo era combinar as duas normas, a VDI da Alemanha Ocidental e a TGL da Alemanha Oriental, de maneira a se criar uma nova diretriz para previsão de resistência mecânica de componentes e estruturas. Assim nasceu o Forschungskuratorium Maschinenbau (FKM), Conselho Alemão de Pesquisa em Engenharia, Este conselho criou então uma nova diretriz baseada, em particular, nas antigas normas TGL para cálculo de resistência, na diretriz 2226 VDI, na norma DIN 18800, na Eurocode 3 e nas recomendações da IIW. Além disso, reuniram vários especialistas em fadiga da Alemanha afim de criar uma única diretriz para a realização de análises de fadiga, onde foram incluidas as últimas descobertas de pesquisas na área de fadiga de componentes metálicos. Desta maneira nasceu a Diretriz Técnica do FKM (FKM-Guideline),

A diretriz FKM foi desenvolvida para ser utilizada na área da engenharia mecânica e setores industriais associados. A primeira edição, FKM Guideline 183 (Rechnerischer Festigkeitsnachweis für Maschinenbauteile), apareceu em 1994 e em 1998 foi publicada a terceira edição, uma edição completamente retrabalhada e estendida e caracterizada por possuir atualizações mais práticas e uma estrutura mais fácil de ser utilizada pelos engenheiros. A quarta edição, ainda mais extensa, foi publicada em 2002 e incluiu informações novas sobre alumínio e suas ligas. Em 2003 foi lançada a edição em inglês da diretriz FKM, tornando este documento largamente conhecido e utilizado fora da Alemanha, passando a ser considerado como o melhor reflexo do atual estado-da-arte da tecnologia.

Um dos objetivos dessa dissertação, e o foco deste capítulo, é explanar sobre o procedimento mais moderno utilizado para análise de fadiga de componentes, utilizando principalmente métodos da FKM-Guideline (2003). As técnicas usadas para realizar ensaios a fim de obter curvas S-N e para fazer uma análise de dados das propriedades de fadiga estão fora do escopo desta dissertação, e podem ser encontrados em outras referências (ASTM E739-10, 2010; Lee et al., 2005). 


\subsubsection{Método da Curva S-N Sintética}

Frequentemente, a curva S-N de um componente não está disponível para o engenheiro de durabilidade e métodos para estimá-la tornam-se fundamentais no processo de dimensionamento de um componente ou estrutura. As Curvas S-N Espécime são obtidas utilizando corpos de prova padronizados tipo Moore (com superfície polida, diâmetro de aproximadamente $8 \mathrm{~mm}$, sem entalhes, sem macro tensões residuais, testados sob flexão rotativa na atmosfera e temperatura ambientes). Portanto, para estimar a curva $\mathrm{S}-\mathrm{N}$ de componentes reais é fundamental quantificar também os efeitos dos vários detalhes que diferem o espécime do componente real e que podem influenciar localmente a vida em fadiga do seu ponto crítico.

Se um componente ou condições de carregamento se desviam da configuração de teste padronizado na qual foi obtida a Curva S-N Espécime supracitada (ex: tipo de carregamento, tamanho, rugosidade superficial, tratamento superficial, corrosão, confiabilidade, temperatura de operação, presença de tensão média e presença de entalhe), então é necessário modificar a Curva $S$-N Espécime para contabilizar por estas diferenças.

A concentração de tensões induzida por entalhes (como furos, ombros, rasgos, rebaixos) e as macro tensões residuais (que afetam o estado de tensões macroscópicas em torno do ponto crítico) podem e devem ser consideradas na análise das tensões, e por isso não são tratadas como detalhes modificadores da resistência à fadiga de Castro \& Meggiolaro (2009a). Mas os detalhes que atuam numa dimensão pequena, da ordem de tamanho do grão do material (como o acabamento superficial, por exemplo) não são modeláveis pela análise de tensões usada no método S-N (linear, elástica, isotrópica e homogênea). Portanto, esses tipos de efeitos devem ser calibrados empiricamente e são quantificados na prática por constantes chamadas fatores modificadores. Cada fator modificador é responsável por contabilizar o efeito de determinada característica sobre a Curva S-N Espécime e entende-se que esses fatores são independente uns dos outros. A idéia desta metodologia é utilizar a Curva S-N Espécime obtida através de ensaios padronizados (ou de estimativa, como explanado na seção 4.2) para estimar qual seria a curva S-N do componente analisado, uma vez que não é possível obter esta informação através de ensaios de bancada. Esta metodologia se baseia na idéia de que, se fosse possível realizar ensaios de fadiga com o componente real, já fabricado, com os carregamentos que ele sofre e com todas as suas características após sua fabricação (tamanho real, rugosidade superficial, tratamento superficial, efeito de corrosão, temperatura de trabalho e entalhe), obtería-se uma curva S-N que seria idêntica à curva $\mathrm{S}-\mathrm{N}$ estimada através dos fatores modificadores. Na figura 4.24 a curva S-N de um componente não entalhado 16 é estimada através desses fatores, e é nomeada Curva $S$-N Unnotched. É

\footnotetext{
${ }^{16}$ Componente este com todas as suas características após sua manufatura, como tamanho, rugosidade superficial, tratamento superficial, efeito de corrosão e temperatura de trabalho, com exceção do entalhe)
} 
necessário aplicar apneas mais um fator à Curva $S-N$ Unnotched, o fator de entalhe, para que todas as características sejam então contabilizadas.

O ponto crítico em um componente é o primeiro ponto em que ocorrerá a nucleação de uma trinca por fadiga e o crescimento da mesma até ocorrer a fratura da seção transversal do componente. Cada ponto deste componente estará localizado em uma região com características próprias como rugosidade, entalhe, tratamento superficial, tensor de tensões, etc. Por isso, cada ponto da superfície da estrutura (e em uma análise de Elementos Finitos seria cada nó) possuirá uma curva S-N própria, que irá contabilizar todas essas características. A figura 4.25 apresenta a curva tensão-vida de um dos pontos da superfície de um componente, que foi obtida modificando a Curva $S$-N Espécime pelos fatores modificadores. A questão que frequentemente surge em uma análise de fadiga é aquela mostrada na figura 4.26, geralmente não é possível saber qual é o ponto crítico de um componente antes de se realizar uma análise de fadiga. Por esse motivo, deve-se analizar todos os pontos (nós) da superfície da estrutura, afim de verificar onde é o ponto crítico (nó crítico). A figura 4.27 apresenta este conceito aplicado em um componente analisado via o MEF. Para uma melhor compreensão da metodologia exposta neste trabalho, chamaremos de Curva Tensão-Vida Local uma curva S-N obtida após a modificação da Curva $S$-N Espécime através da aplicação de todos os fatores modificadores (inclusive o fator de entalhe, a ser explicado na seção 4.4). Como já foi exposto, acredita-se que, se fosse possível realizar ensaios de fadiga com o componente real, já fabricado, com os carregamentos que ele sofre e com todas as suas características (tamanho, rugosidade superficial, tratamento superficial, entalhes, etc), obtería-se uma curva S-N que seria idêntica à Curva Tensão-Vida Local. E é a Curva Tensão-Vida Local que é utilizada para se calcular a vida do componente analisado.

Este conceito foi desenvolvido e melhorado ao longo dos anos por vários especialistas e é denominado por Hück, Thrainer \& Schütz (1981) e Lee et al. (2011) como o Método da Curva S-N Sintética ${ }^{17}$, por Magna Powertrain (2011) como o Método da Curva S-N Local ${ }^{18}$, por FKM-Guideline (2003) como o Conceito da Tensão Loca ${ }^{19}$ e por Steiner, Steinwender \& Unger (2000) como o Método do Parâmetro de Influência ${ }^{20}$ Portanto, quando se realiza uma análise de fadiga utilizando resultados de uma análise por Elementos Finitos, uma curva tensão-vida é calculada em cada nó do modelo. O cômputo desta Curva Tensão-Vida Local começa com os dados da Curva S-N Espécime e é influenciada por propriedades locais e pelos tensores de tensão do modelo FE linear de carregamentos estáticos e dinâmicos do componente.

O objetivo desta seção (4.3) é mostrar como calcular os fatores modificadores apresentados na figura 4.24 e consequentemente como se obter a curva nomeada Curva S-N Un-

\footnotetext{
${ }^{17}$ Do inglês, Synthetic $S$ - $N$ Method.

${ }^{18}$ Do inglês, Local S-N Curve Method.

${ }^{19}$ Do inglês, Local Stress Concept.

${ }^{20}$ Do inglês, Influence Parameter Method ou Influence Parameter Concept.
} 
notched, que é a curva obtida quando se aplica todos os efeitos/características (i.e., todos os fatores modificadores) com exceção de um: o efeito de entalhe (i.e., fator de entalhe). A Curva Tensão-Vida Local supramencionada é obtida aplicando-se o fator de entalhe na Curva S-N Unnotched. Existem dois tipos de Curva Tensão-Vida Local, a Curva S-N Local (apresentada na figura 4.43) e a Curva $\sigma-N$ Local (apresentada na figura 4.49), e o uso de cada uma dependerá do tipo de metodologia que o especialista em fadiga escolher utilizar. Existem duas metodologias que podem ser utilizadas: a Curva $\boldsymbol{S}-\boldsymbol{N}$ Local é obtida utilizando o fator de entalhe calculado através do Método $K_{f}$ (a ser explicado na seção 4.4.1) enquanto a Curva $\sigma-N$ Local é obtida utilizando o fator de entalhe obtido através do Método do Gradiente de Tensão Relativo (a ser explicado na seção 4.4.2).

Embora existam muitas publicaçõe ${ }^{21}$ que ensinam como obter estes fatores, será utilizada a metodologia apresentada pela FKM-Guideline (2003) na maior parte desta dissertação, por esta apresentar as técnicas mais modernas na área da fadiga.

Não se sabe muito bem ao certo, mas tudo indica que Joseph Marin foi o primeiro a identificar que modifição da Curva S-N Espécime pode ser feita utilizando fatores modificadores. Havia uma dúvida de como os fatores deveriam ser aplicados todos juntos, se de forma aditiva ou multiplicativa. Essa questão foi resolvida por J. Marin através de uma análise estatística extensa de um aço 4340, que resultou em um coeficiente de correlação de 0,85 para a forma multiplicativa e de 0,40 para a forma aditiva Shigley et al. (2003). Por isso, Marin propôs que, quando testes de fadiga não estão disponíveis, uma estima do limite de fadiga da Curva $S$-N Unnotched (figura 4.24) pode ser realizada multiplicando-se os fatores modificadores como se eles atuassem de forma independente, conforme a seguinte equação:

$$
S_{E, \text { un }}=S_{E, s p} \cdot C_{L} \cdot C_{D} \cdot C_{R O} \cdot C_{S T} \cdot C_{C} \cdot C_{R} \cdot C_{T} \cdot C_{m}
$$

Os fatores que transformam a Curva $S$-N Espécime na Curva S-N Unnotched são: fator de carregamento ( $\left.C_{L}\right)$, de tamanho ( $\left.C_{D}\right)$, de acabamento superficial ( $C_{R O}$ ), de tratamento superficial ( $C_{S T}$ ), de corrosão ( $C_{C}$ ), de confiabilidade ( $C_{R}$ ), de temperatura ( $C_{T}$ ) e tensão média $\left(C_{m}\right)$.

A resistência à fadiga para $N_{B}$ ciclos pode ser estimada conforme segue:

$$
S_{B, u n}=S_{B, s p} \cdot C_{C} \cdot C_{R} \cdot C_{T} \cdot C_{m}
$$

É importante ressaltar que o ciclo do limite de fadiga $\left(N_{E}\right)$ e o ciclo da fronteira LCF $\left(N_{B}\right)$ permanecem os mesmos valores. Assim, uma vez conhecido 2 pontos da Curva $S$ - $N$

\footnotetext{
${ }^{21}$ Foram encontradas as seguintes obras que contém tais informações: Juvinall (1967), Fuchs \& Stephens (1980), Moura Branco et al. (1987), Bannantine et al. (1990), Dowling (1998), Shigley et al. (2003), FKMGuideline (2003), Lee et al. (2005), Norton (2006), de Castro \& Meggiolaro (2009a), Lee et al. (2011).
} 


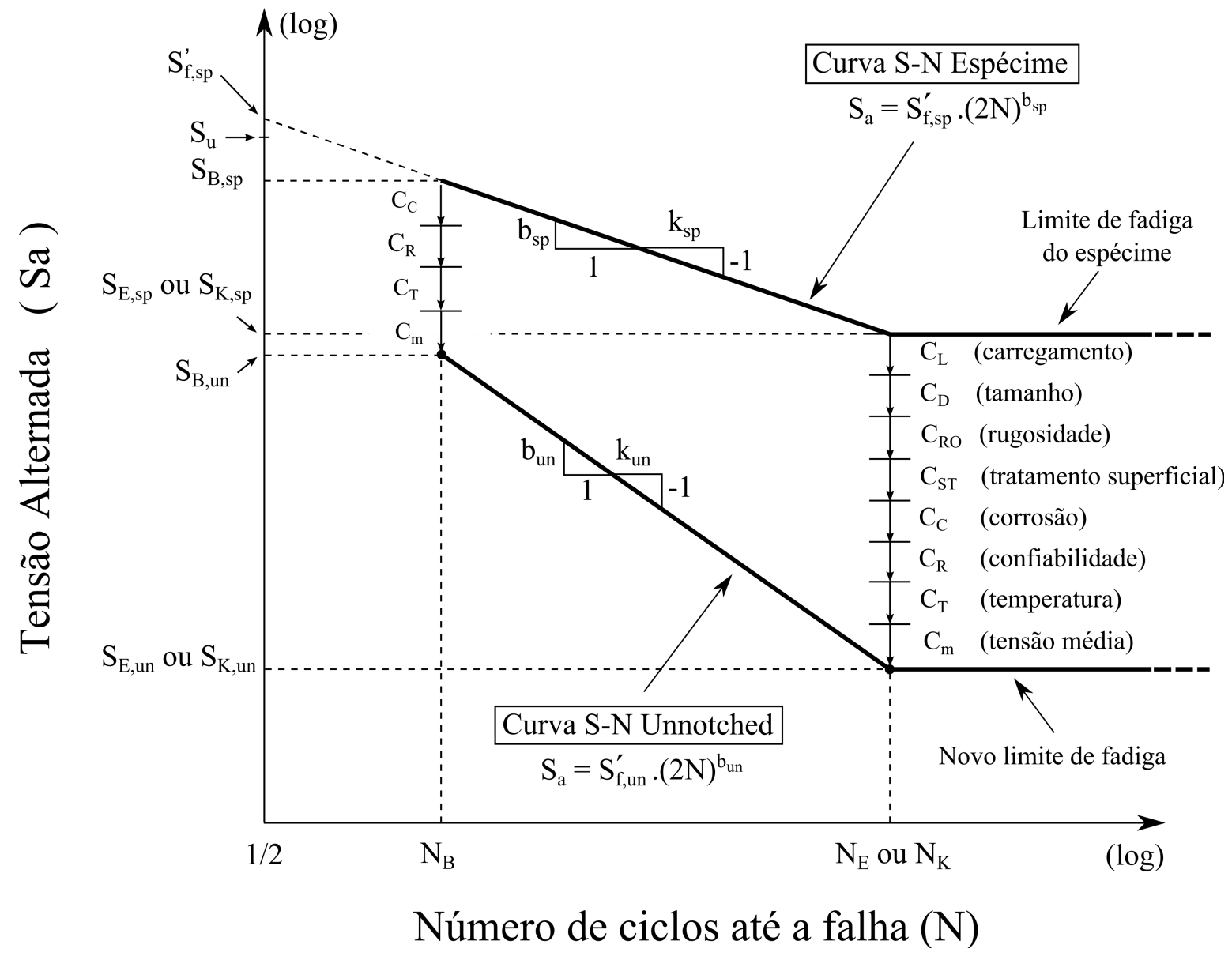

Figura 4.24 Curva S-N obtida através da aplicação dos fatores modificadores.

Onde

$C_{L} \quad: \quad$ Fator modificador de carregamento

$C_{D}:$ Fator modificador de tamanho

$C_{R O}:$ Fator modificador de rugosidade

$C_{S T}:$ Fator modificador de tratamento superficial

$C_{C}:$ Fator modificador de corrosão

$C_{R}:$ Fator modificador de confiabilidade

$C_{T}:$ Fator modificador de temperatura

$C_{m}:$ Fator modificador de tensão média 


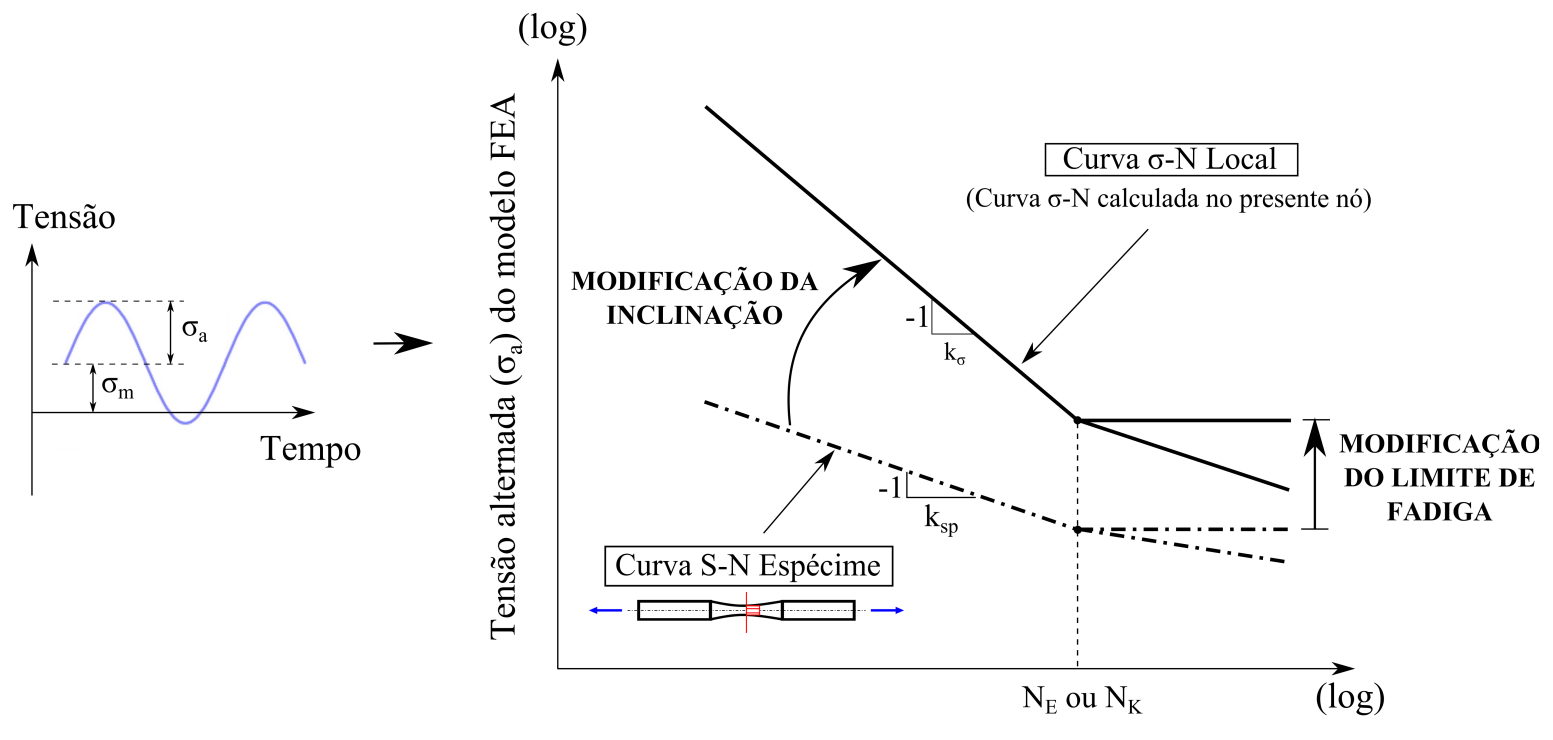

Número de ciclos até a falha $(\mathrm{N})$

Figura 4.25 Curva $\sigma-\mathrm{N}$ Local de um nó FE do componente, obtida com o uso dos fatores modificadores.

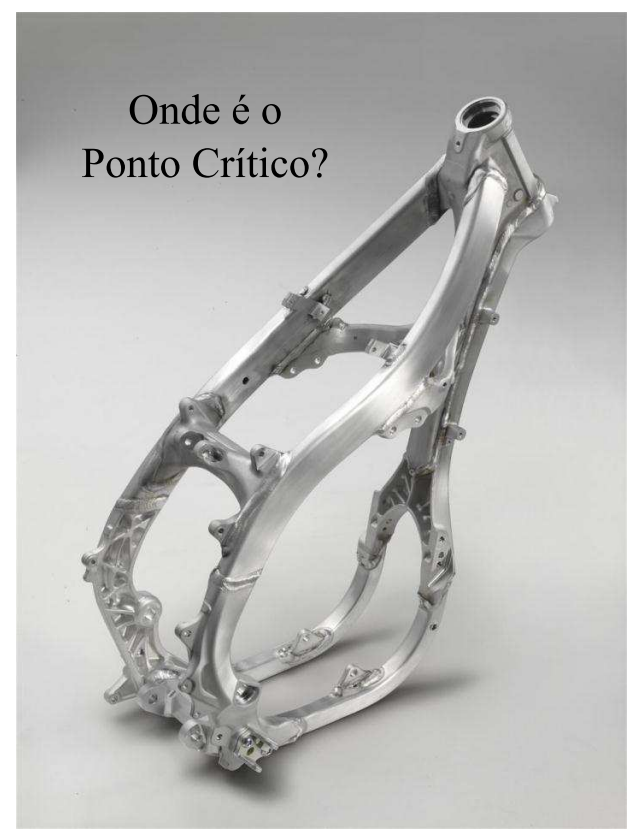

Figura 4.26 Componente mecânico genérico. 


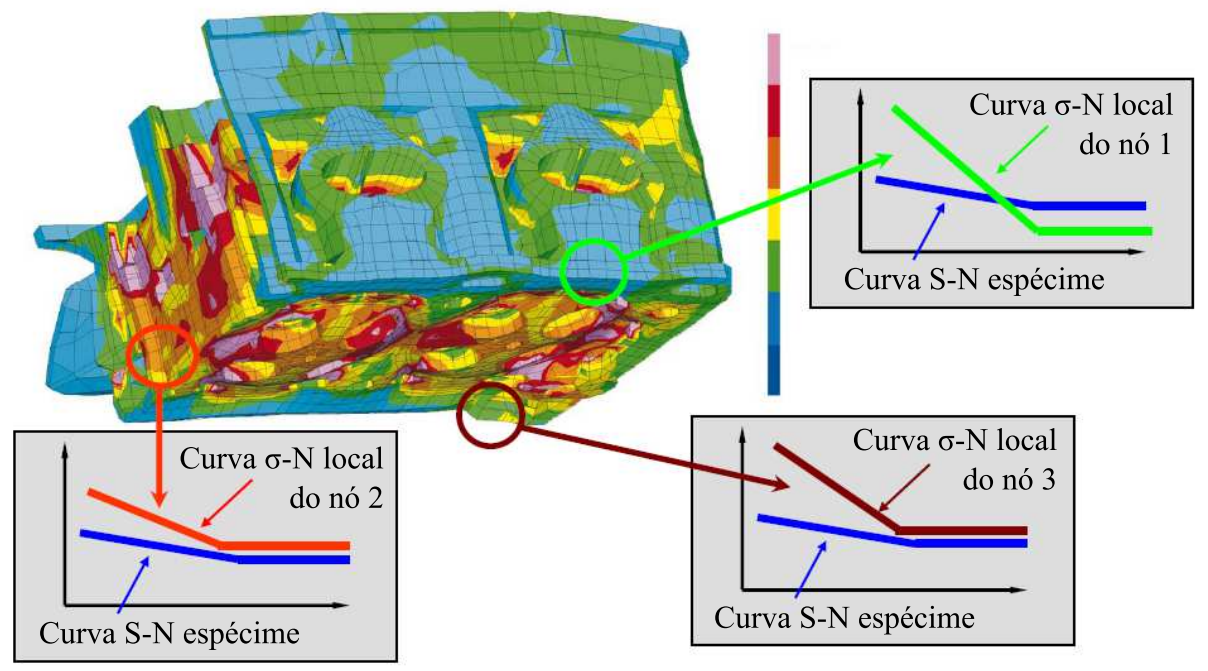

Figura 4.27 Conceito do Método da Curva $\sigma-\mathrm{N}$ Local aplicado em um componente analisado via o MEF (Extraído de Magna Powertrain (2011)).

Unnotched, $\left(N_{E}, S_{E \text {,un }}\right)$ e $\left(N_{B}, S_{B, u n}\right)$, deve-se utilizar a equação (4.8) para obter expoente de resistência à fadiga desta curva $\left(b_{u n}\right)$, conforme descrito abaixo:

$$
b_{\text {un }}=\frac{\log \left(S_{E, \text { un }} / S_{B, \text { un }}\right)}{\log \left(N_{E} / N_{B}\right)}
$$

E em seguida a equação (4.6) avaliada no ponto $\left(N_{E}, S_{E, u n}\right)$ para obter o coeficiente de resistência à fadiga da Curva $S$-N Unnotched $\left(S_{f, u n}^{\prime}\right)$, conforme apresenta a equação abaixo:

$$
S_{f, u n}^{\prime}=\frac{S_{E, u n}}{\left(2 N_{E}\right)^{b_{u n}}}
$$

Desta maneira, a equação que representa a Curva $S-N$ Unnotched é a seguinte:

$$
S_{a}=S_{f, u n}^{\prime} \cdot(2 N)^{b_{u n}}
$$

Shigley et al.(2003) afirmam ser importante relembrar que todos os fatores modificadores são empíricos, conservadores e em sua maioria aplicáveis apenas a aços (pois foram obtidos empiricamente em experimentos geralmente em aços). Eles fornecem pouco ou nenhuma visão do processo de fadiga além de prover tendências aproximadas. Em particular, eles não deveriam ser utilizados em áreas fora da aplicabilidade na qual eles foram medidos. Entretanto, como não há outra opção, tanto a comunidade científica quanto os engenheiros na indústria os utilizam mesmo assim no dimensionamento de estruturas metálicas que não sejam de aço. 


\subsubsection{Fator de Tipo de Carregamento}

Historicamente, as Curvas S-N Espécime têm sido geradas a partir de tensões de flexão completamente reversas. Entretanto, componentes reais como caixas de câmbio, virabrequins e eixos de automóveis estão sujeitos à outras condições de carregamento. Isto requer que o limite de fadiga para flexão rotativa seja modificado para outra condição de carregamento que não seja flexão. O fator modificador de carregamento, denominado $C_{L}$, é determinado considerando-se os efeitos do gradiente de tensão e do tipo de tensão (normal ou de cisalhamento).

Este trabalho utiliza uma nomenclatura específica a fim de facilitar a compreensão do texto. Desta forma, os seguintes símbolos são utilizados neste trabalho:

$S_{E, s p} \quad: \quad$ Limite de fadiga da Curva $S$-N Espécime (ilustrada nas figuras 4.6, 4.14a, 4.24, 4.25 e 4.27), sendo esta curva obtida através de um ensaio padronizado, i.e., utilizando espécimes padronizados, com seção circular, diâmetro de aproximadamente $8 \mathrm{~mm}(=0,3 \mathrm{pol})$, sem entalhes, com superfície polida, sem macro tensões residuais, testados na atmosfera e temperatura ambiente e sob flexão rotativa $(R=-1)$

$\sigma_{E, s p} \quad$ : Limite de fadiga da Curva $S-N$ Espécime, sendo esta curva obtida através de um ensaio padronizado, i.e., utilizando espécimes padronizados, com seção circular, diâmetro de aproximadamente $8 \mathrm{~mm}(=0,3 \mathrm{pol})$, sem entalhes, com superfície polida, sem macro tensões residuais, testados na atmosfera e temperatura ambiente e sob tração-compressão completamente reversa $(R=-1)$

$\tau_{E, s p} \quad$ : Limite de fadiga da Curva $S-N$ Espécime, sendo esta curva obtida através de um ensaio padronizado, i.e., utilizando espécimes padronizados, com seção circular, diâmetro de aproximadamente $8 \mathrm{~mm}(=0,3 \mathrm{pol})$, sem entalhes, com superfície polida, sem macro tensões residuais, testados na atmosfera e temperatura ambiente e sob torção alternada $(R=-1)$

Os parâmetros $S_{E, s p}, \sigma_{E, s p}$ e $\tau_{E, s p}$ sempre serão diferentes entre si. A diferença entre carregamento de axial (i.e., tração-compressão) e de flexão é o resultado dos diferentes gradientes de tensão de cada condição de carregamento. Por exemplo, sob a condição de mesma tensão alternada nominal $S_{a}$, o limite de fadiga de um espécime sob carregamento axial $\left(\sigma_{E, s p}\right)$ é menor do que o limite de fadiga do mesmo espécime sob flexão $\left(S_{E, s p}\right)$. No carregamento axial, toda seção transversal é carregada com um alto nível de tensão (uniforme), o que não acontece na flexão, que possui um alto nível de tensão somente próximo à superfície do espécime. Por isso, além de ser mais provável iniciar uma trinca em carregamento axial, 
esta trinca irá se propagar mais rápido ao longo da seção transversal; por este motivo o limite de fadiga é menor em carregamento axial.

$\mathrm{Na}$ impossibilidade de realizar ensaios de fadiga para a obtenção de $\sigma_{E, s p}$ e $\tau_{E, s p}$, podese estimar estes parâmetros através de relações empíricas entre esses 2 parâmetros e $S_{E, s p}$. Juvinall (1967) e Lee et al. (2005) recomendam que seja adotado um fator modificador de carregamento de $C_{\sigma}=0,9$ para carregamento puramente axial (sem parcela de flexão) e $C_{\sigma}=0,7$ quando houver carregamento axial mas com uma leve parcela de flexão (induzida por desalinhamento, por exemplo). Desta forma, o limite de fadiga de um espécime padronizado sob tração-compressão alternada $\left(\sigma_{E, s p}\right)$ pode ser estimado através da equação (4.41). Ensaios experimentais com aços dúcteis indicam que, em espécimes não entalhados sob torção completamente reversa (i.e. $\operatorname{com} R=-1$ ), o fator modificador de carregamento encontrado foi de $0,5 \leq C_{\tau} \leq 0,6$, que se iguala com os resultados previstos pela teoria de von Mises, onde $C_{\tau}=0,577=1 / \sqrt{3}$ para materiais dúcteis. Portanto, o limite de fadiga de um espécime padronizado sob torção alternada $\left(\sigma_{E, s p}\right)$ pode ser estimado através da equação 4.42). Acredita-se que o limite de fadiga estimado através da equação 4.41 seria igual àquele que obteríamos se pudéssemos realizar o ensaio de fadiga sob tração-compressão alternada. Analogamente, o limite de fadiga estimado através da equação (4.42) seria igual àquele que obteríamos se pudéssemos realizar o ensaio de fadiga sob torção alternada.

$$
\begin{aligned}
& \sigma_{E, s p}=S_{E, s p} \cdot 0,9 \\
& \tau_{E, s p}=S_{E, s p} \cdot C_{\tau}
\end{aligned}
$$

Do exposto, quando o componente sofre um carregamento que gera tensões normais cíclicas, deve-se utilizar o fator de carregamento utilizando a equação 4.43 juntamente com a tabela 4.5. Quando o componente sofre tensões de cisalhamento cíclicas, então devese utilizar a equação (4.44) juntamente com os valores apresentados na tabela 4.6 .

Praticamente todos os autores admitem que o efeito do tipo de carregamento somente afeta o limite de fadiga e é desprezível em vidas baixas (ex: $N_{B}=10^{3}$ ciclos). de Castro \& Meggiolaro (2009a) relatam que esta prática é fisicamente justificável para o fator de tipo de carregamento, pois em uma vida tão curta quanto $N=10^{3}$ ciclos a maioria das ligas metálicas estruturais sofre escoamento cíclico macroscópico no ponto crítico, o qual tende a diminuir o efeito desse fator.

$$
\begin{aligned}
& C_{L}=C_{\sigma} \\
& C_{L}=C_{\tau}
\end{aligned}
$$


Tabela 4.5 Fator de correção em tensão normal $\left(C_{\sigma}\right)($ Lee et al., 2005)

\begin{tabular}{l|c|c}
\hline \multicolumn{1}{c|}{ Tipo de Carregamento } & $C_{\sigma}$ & Comentários \\
\hline Flexão rotativa ou flexão alternada & 1,0 & Todos os metais \\
Carregamento puramente axial & 0,9 & Todos os metais \\
Carregamento axial com leve componente de flexão & 0,70 & Todos os metais \\
\hline
\end{tabular}

Tabela 4.6 Fator de correção de tensão de cisalhamento $\left(C_{\tau}\right)(\overline{\mathrm{FKM}}-$ Guideline, 2003).

\begin{tabular}{l|c|c}
\hline \multicolumn{1}{c|}{ Tipo de Carregamento } & $C_{\tau}$ & Comentários \\
\hline Cisalhamento & $1 / \sqrt{3^{\star}}$ & Aço para cementação (case-hardening steel) \\
Cisalhamento & 0,577 & Aço inoxidável (stainless steel) \\
Cisalhamento & 0,577 & Aço para forjamento (forjing steel) \\
Cisalhamento & 0,577 & Outro aço diferente dos tipos acima \\
Cisalhamento & 0,577 & Aço para fundição (steel casting) \\
Cisalhamento & 0,65 & Ferro fundido nodular (Ductile iron) \\
Cisalhamento & 0,75 & Ferro fundido maleável (Malleable cast iron) \\
Cisalhamento & 0,85 & Ferro fundido cinzento (Grey cast iron) \\
Cisalhamento & 0,577 & Ligas de alumínio trabalhado (wrought aluminium alloys) \\
Cisalhamento & 0,75 & Ligas de alumínio fundido (cast aluminum alloys)
\end{tabular}

* Note que $1 \sqrt{3}=0,577$ é baseado no critério de escoamento de von Mises.

\subsubsection{Fator de Tamanho}

O fator modificador de tamanho $C_{D}$ é utilizado para contabilizar o fato de que a resistência de um componente é reduzida conforme o tamanho do mesmo aumenta com relação ao espécime padronizado de Moore (com diâmetro aproximadamente $8 \mathrm{~mm}=0,3 \mathrm{pol}$ ). Os valores de $C_{D}$ são medidos testando vários corpos de prova que diferem do corpo de prova padrão de Moore apenas pelo diâmetro $\boldsymbol{d}$ (i.e., todas as outras características são mantidas iguais, como polimento, sem entalhes, testados na temperatura ambiente, etc.). Portanto, o fator de tamanho é definido como razão entre o limite de fadiga de um corpo de prova idêntico ao de Moore (exceto pelo diâmetro maior) pelo limite de fadiga do corpo de prova padrão de Moore.

Lee et al. (2005) coletaram dados de Heywood (1962) e Horger (1965) para verificar a relação entre tamanho e limite de fadiga e o resultado é ilustrado na figura 4.28. Esta figura representa ensaios realizados com espécimes de seção transversal circular, sem entalhes, sob carregamentos de flexão e torção. O resultado é que quanto maior o diâmetro do espécime menor é o fator de tamanho; em outras palavras, quanto maior o tamanho do componente menor é o limite de fadiga do componente. Entretanto, foram realizados os mesmos testes com espécimes sujeitos apenas a carregamento axial $\operatorname{com} R=-1$ e constatou-se que este tipo de carregamento gera $C_{D}=1,0$. Em outras palavras, o tamanho do componente não afeta na resistência à fadiga quando o carregamento é axial. 


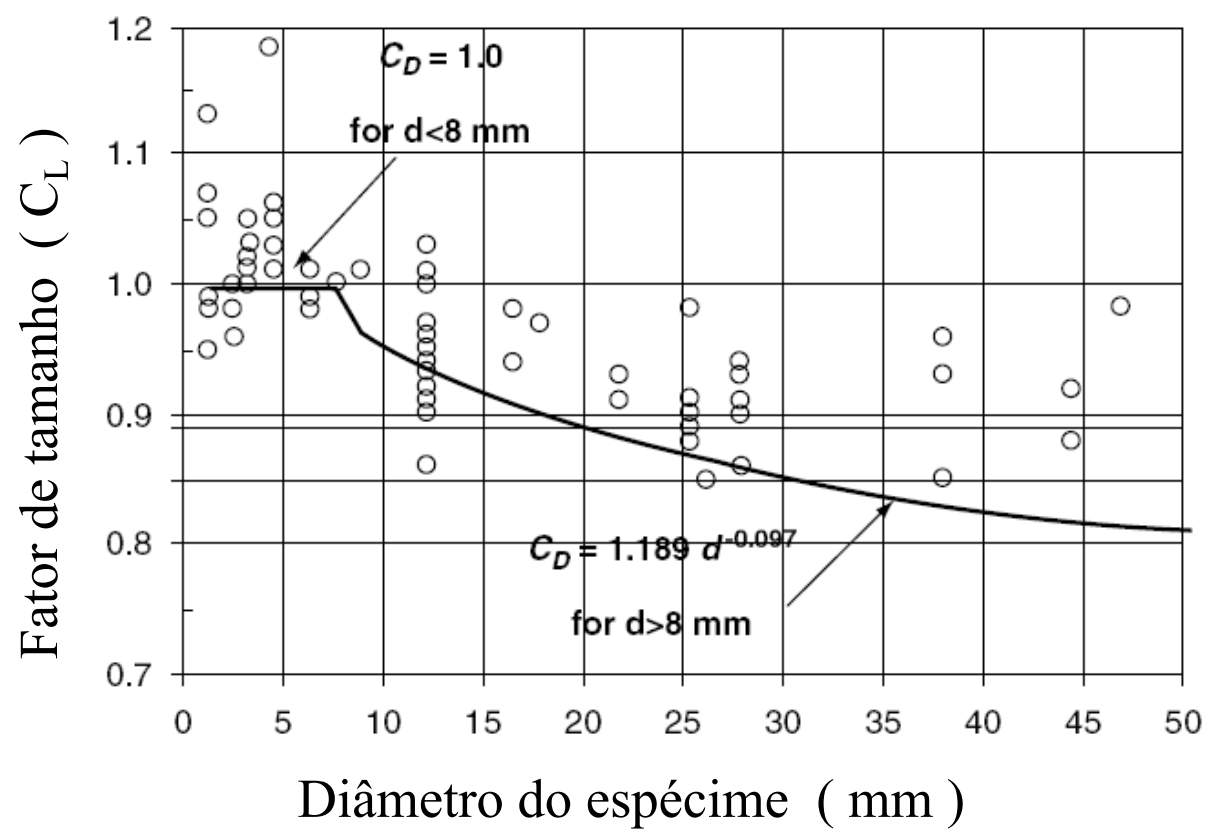

Figura 4.28 Descrição quantitativa do fator de tamanho $C_{L}$ (baseado nos dados de Heywood (1962) e Kuguel (1961)).

Existem justificativas que explicam este fenômeno. A primeira teoria acredita que em peças grandes (lê-se "com grande área superficial") a probabilidade de haver um minúsculo defeito superficial que facilite o início da geração de Bandas de deslizamento persistentes (PSBS) é maior, devido à maior existência de material para haver um defeito. Adicionalmente, como na maioria dos casos as trincas nascem na superfície (ou muito próximo delas), quanto maior a área da superfície exposta à $S_{\max }$, maior a probabilidade de encontrar um grão com planos preferenciais de deslizamento alinhados à tensão de cisalhamento local máxima, conforme explicado na seção 2.1 .

A segunda justificativa é explicada pela teoria do volume crítico postulada pela primeira vez por Kuguel (1961). Acredita-se que o dano por fadiga está diretamente relacionado com o volume crítico, que é o volume de material sujeito à faixa de tensão de $95 \%$ a $100 \%$ da tensão na superfície $S_{a}$ (i.e., o volume crítico é a faixa de material compreendida desde a superfície do componente até a camada onde a tensão é igual à $95 \%$ da tensão da superfície). Seja um componente cilíndrico de diâmetro pequeno e outro idêntico porém com diâmetro muito maior. Seja estes dois componentes sujeitos à mesma tensão alternada $S_{a}$ em suas superfícies. O componente com diâmetro pequeno sob flexão possui um gradiente de tensão grande e por isso a média das tensões deste volume crítico é baixa, quando comparado com o componente de diâmetro grande, que possui um gradiente de tensão menor. Esta teoria está explicada em mais detalhes em de Castro \& Meggiolaro (2009a) e Shigley et al. (2003). Desta maneira, de acordo com de Castro \& Meggiolaro (2009a) e Lee et al. (2005), o gradiente de tensões seria o principal responsável pela diminuição do limite de fadiga: quanto 
maior o gradiente de tensões, menor é o efeito de tamanho, pois $C_{L}$ é mais próximo de 1,0.

Vários autores propuseram diferentes formas de se quantificar o fator de tamanho, que, em suma, são equações que se ajustavam aos dados experimentais mostrados na figura 4.28. Os mais conhecidos são os métodos propostos por Juvinall (1967), Shigley et al. (2003) e Lee et al. (2005),Norton (2006) Pesquisas realizadas recentemente pelo Conselho Alemão de Pesquisa em Engenharia (FKM) resultaram no desenvolvimento de uma técnica inédita para a contabilização do efeito de tamanho em fadiga, publicada na FKM-Guideline (2003). Esta metodologia tornou a contabilização do fator de tamanho mais apurada, pois o fator pode ser agora calculado de maneira diferente para cada tipo de metal e de processo de fabricação. Segundo esta nova metodologia, o fator de tamanho dependente do tamanho da seção transversal e do tipo de material, e pode ser obtido da seguinte maneira:

Tabela 4.7 Constantes usadas para estimar o fator modificador de tamanho (FKM-Guideline, 2003)

\begin{tabular}{l|c|c|c}
\multicolumn{1}{c|}{ Tipo do Material } & $\begin{array}{c}d_{\text {eff,min }} \\
(\mathbf{m m})\end{array}$ & $a_{d}$ & $\begin{array}{c}\text { Caso de } \\
d_{\text {eff }}\end{array}$ \\
\hline Aço & 40 & 0,15 & Caso 2 \\
Aço carbono comum & 70 & 0,2 & Caso2 \\
Aço com granulação refinada & 16 & 0,3 & Caso 2 \\
Aço temperado e revenido & 16 & 0,1 & Caso 2 \\
Aço normalizado & 16 & 0,5 & Caso 1 \\
Aço endurecido superficialmente* & 40 & 0,25 & Caso 1 \\
Aço nitretado, seguido de têmpera e revenimento & 250 & 0,2 & Caso 1 \\
Aço forjado, seguido de têmpera e revenimento & 250 & 0 & Caso 1 \\
Aço forjado, seguido de normalização & & & \\
\hline Aço fundido & 100 & 0,15 & Caso 2 \\
Aço fundido & 200 & 0,15 & Caso 1 \\
Aço fundido, seguido de têmpera e revenimento & & & \\
\hline Ferro Fundido & 60 & 0,15 & Caso 1 \\
Ferro fundido nodular (dúctil) & 15 & 0,15 & Caso 1 \\
Ferro fundido maleável & - & - & Caso 1 \\
Ferro fundido cinzento & - & - & Caso 2 \\
\hline Alumínio & - & - & Caso 2 \\
Alumínio trabalhado & & \\
Alumínio fundido & & & \\
\hline
\end{tabular}

* Através de tratamentos termoquímicos, como cementação, nitretação, carbonitretação boretação ou similares.

- Para ligas de alumínio trabalhado:

$$
C_{D}=1
$$

\footnotetext{
${ }^{22}$ Que na verdade utilizam uma proposta antiga de Shigley e Mitchell.
} 
- Para ligas de alumínio fundido:

$$
\begin{array}{lll}
C_{D}=1,0 & \text { para } & d_{\text {eff }} \leq 12 \mathrm{~mm} \\
C_{D}=1,1\left(\frac{d_{\text {eff }}}{7,5 \mathrm{~mm}}\right)^{-0,2} & \text { para } & 12 \mathrm{~mm}<d_{\text {eff }} \leq 150 \mathrm{~mm} \\
C_{D}=0,6 & \text { para } & d_{\text {eff }} \geq 150 \mathrm{~mm}
\end{array}
$$

- Para ferro fundido cinzento:

$$
\begin{array}{lll}
C_{D}=1,207 & \text { para } & d_{\text {eff }} \leq 7,5 \mathrm{~mm} \\
C_{D}=1,207\left(\frac{d_{\text {eff }}}{7,5 \mathrm{~mm}}\right)^{-0,1922} & \text { para } & d_{\text {eff }}>7,5 \mathrm{~mm}
\end{array}
$$

- Para todo tipo de aço, aço fundido, ferros fundido maleável e ferro fundido nodular (dúctil):

$$
\begin{aligned}
C_{D}= & 1,0 & \text { para } & d_{e f f} \leq d_{e f f, \min } \\
C_{D}= & \frac{1-0,7686 \cdot a_{d} \cdot \log \left(\frac{d_{e f f}}{7,5 \mathrm{~mm}}\right)}{1-0,7686 \cdot a_{d} \cdot \log \left(\frac{d_{\text {eff,min }}}{7,5 \mathrm{~mm}}\right)} & \text { para } & d_{\text {eff }}>d_{\text {eff,min }}
\end{aligned}
$$

Onde

$d_{\text {eff }} \quad$ : Diâmetro efetivo da seção trasversal

$a_{d} \quad:$ Constante informada na tabela 4.7

$d_{e f f, \min }:$ Constante informada na tabela $\overline{4.7}$

Dependendo do tipo de material listado na tabela 4.7, dois casos são necessários ser distintos para determinar $d_{e f f}$. No Caso $1, d_{e f f}$ é definido por

$$
d_{e f f}=\frac{4 V}{O}
$$

onde $\mathrm{V}$ e $\mathrm{O}$ são, respectivamente, o volume e a área superficial da seção transversal do componente que contém o ponto crítico. Componentes feitos de ferro fundido cinzento devem utilizar sempre o Caso 1 para o cálculo de $d_{e f f}$. No Caso $2, d_{e f f}$ é igual ao diâmetro da seção transversal ou à espessura da parede do componente. O $d_{e f f}$ de componentes de alumínio deve ser calculado sempre como sendo o Caso 2. Exemplos do cálculo de $d_{e f f}$ são ilustrados na tabela 4.8 . É curioso notar que o fator de tamanho foi obtido realizando-se ensaios com espécimes de tamanho diferente sob flexão rotativa, mas a literatura recomenda utilizá-los para carregamentos de flexão, tração e também em torção. 
Tabela 4.8 Cálculo do diâmetro efetivo $d_{\text {eff }}($ FKM-Guideline, 2003)

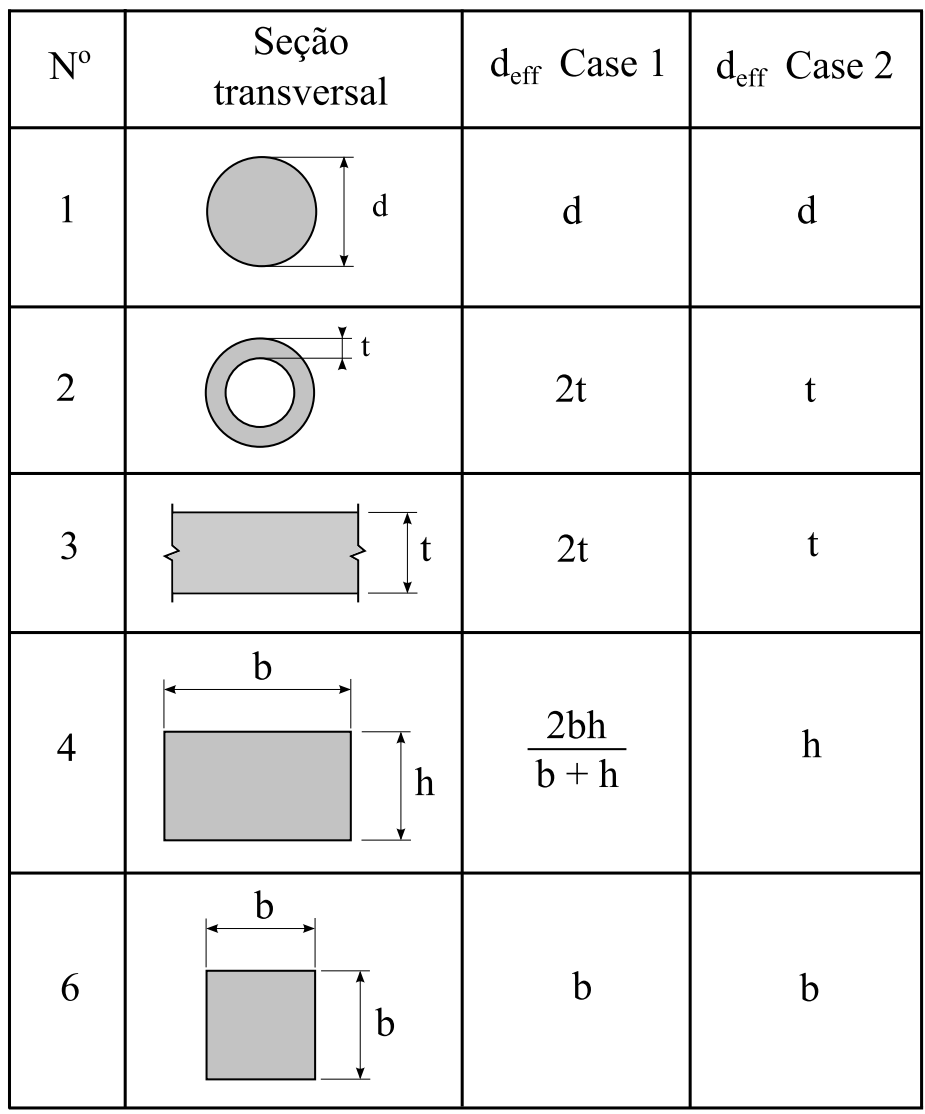

de Castro \& Meggiolaro (2009a) afirmam que é importante observar que o fator de carregamento $C_{L}=0,9$ (proposto para as cargas axiais puras) é o valor para o qual $C_{D}$ tende quando $d \gg 8 \mathrm{~mm}$ em testes de flexão rotativa (figura 4.28). De acordo com os autores, isto indica que:

(i) A causa primária do efeito do diâmetro naqueles testes seria o gradiente de tensões que, como no caso das cargas axiais, tende a zero quando $\mathbf{d}$ tende ao infinito;

(ii) $\mathrm{O}$ fator de carregamento em carga axial pura $\left(C_{\sigma}\right)$ e em carregamento sob flexão $\left(C_{\sigma}\right)$ dependem apenas do gradiente de tensão; e

(iii) Não há justificativa física para separar os efeitos do tamanho e do tipo de carga, pois ambos seriam causados pelo gradiente de tensões.

Assim, o valor proposto por Juvinall (1967) e Lee et al. (2005) de $C_{L}=0,9$ seria justificáveis apenas para componentes sem entalhes sob carregamento axial puro (pois nestes casos o gradiente de tensões é nulo). Entretanto, peças que trabalham sob carga axial pura também possuem entalhes na maioria das vezes, logo possuem gradientes de tensão. 
Pelos motivos supracitados, de Castro \& Meggiolaro (2009a) acreditam que seria mais razoável usar apenas um fator unificado de gradiente de tensões $C_{\Delta}$ que incluísse os efeitos de tamanho e do tipo de carregamento na estimativa do limite de fadiga. E na ausência de dados experimentais específicos, se estimasse $C_{\Delta}=0,9$ no caso de peças sem entalhes sob tensões normais puras (conforme explicado na seção 4.3.3). Já no caso usual de peças entalhadas (seja sob carregamento de flexão ou axial), o parâmetro controlador de $C_{\Delta}$ deveria ser calculado através do gradiente na raiz do entalhe, que é controlado pela geometria do entalhe, e não pelo tamanho da peça. Entretanto, embora os especialistas entendam que de alguma maneira estes 3 fatores ${ }^{23}$ tenham relação entre si, ainda não se sabe como unir os três fatores em um só. Por esta razão, ainda continua sendo recomendado a utilização dos 3 fatores separadamente na prática.

\subsubsection{Fator de Rugosidade}

Irregularidades na superfície de um componente (como riscos, arranhões, puncionamentos, marcas de batidas, etc) atuam como um concentrador de tensão local, no âmbito microestrutural, e são deletérios para a vida em fadiga. Isto ocorre porque estas irregularidades facilitam a formação de bandas de deslizamento persistente (PSV) na superfície do componente e consequentemente a mais rápida iniciação de trincas. Da mesma forma, a rugosidade superficial de um componente também influencia na redução da resistência em fadiga de estruturas. A experiência mostra que a resistência à fadiga diminui com o aumento da rugosidade superficial. Este efeito é mais pronunciado nos materiais com alta tensão de ruptura do que naqueles onde a tensão de ruptura é baixa.

Curvas S-N são extraídas utilizando corpos de prova polidos, portanto qualquer componente que possui rugosidade superficial maior, possuirá menor vida em fadiga. A Curva S-N Espécime deve ser afetada pelo fator modificador de rugosidade $C_{R O}$ para contabilizar o efeito da rugosidade superficial sobre o limite de fadiga $S_{E, s p}$ (ou limite de endurance $S_{K, s p}$ no caso de metais que não apresentam comportamento horizontal após o ponto de inflexão).

O cálculo do fator de rugosidade utilizando o método da FKM-Guideline (2003) é feito utilizando as equações (4.54) para tensão normal e (4.55) para tensão de cisalhamento.

$$
\begin{gathered}
C_{R O}=C_{R O, \sigma}=1-a_{R} \cdot \log \left(R_{Z}\right) \cdot \log \left(\frac{2 S_{u, 97.5}}{S_{u, \min }}\right) \\
C_{R O}=C_{R O, \tau}=1-C_{\tau} \cdot a_{R} \cdot \log \left(R_{Z}\right) \cdot \log \left(\frac{2 S_{u, 97.5}}{S_{u, \min }}\right)
\end{gathered}
$$

Onde

\footnotetext{
${ }^{23}$ Fator de carregamento, fator de tamanho e fator de entalhe
} 
Tabela 4.9 $a_{R}$ e $S_{u, \min }$ para vários metais FKM-Guideline (2003)

\begin{tabular}{l|c|c}
\hline \multicolumn{1}{c|}{ Tipo do Material } & $a_{R}$ & $S_{u, \min } \mathbf{M P a}$ \\
\hline Aço & 0,22 & 400 \\
Aço para fundição & 0,20 & 400 \\
Ferro fundido nodular & 0,16 & 400 \\
Ferro fundido maleável & 0,12 & 350 \\
Ferro fundido cinzento & 0,06 & 100 \\
Ligas de alumínio trabalhado & 0,22 & 133 \\
Ligas de alumínio fundido & 0,20 & 133 \\
\hline
\end{tabular}

$a_{R} \quad: \quad$ Constante de rugosidade listada na tabela 4.9

$R_{Z} \quad$ : Valor médio da rugosidade da superfície (em $\left.\mu \mathrm{m}\right)$

$S_{u, 97.5}:$ Limite de resistência à tração para 97,5\% de confiabilidade (R97,5\%) obtido em um ensaio de tração quase-estático para obtenção da curva $\sigma-\varepsilon$. $S_{u, 97.5}=S_{u} \cdot C_{R}$ sendo $C_{R}$ calculado conforme tabela 4.11 para confiabilidade de $97,5 \%$

$S_{u, \min }$ : Valor mínimo do limite de resistência à tração (em $\mathrm{MPa}$ ), estipulado na tabela 4.9

$C_{\tau} \quad: \quad$ Fator de correção de tensão em cisalhamento, estipulado na tabela 4.6

A figura 4.29 apresenta o valor do fator de rugosidade para tensão normal em aços. Lee et al. (2011) afirmam que uma rugosidade média de $R_{Z}=200 \mu \mathrm{m}$ se aplica à superfícies laminadas, forjadas e superfícies de ferros fundidos. Para aços, o valor de rugosidade de uma superfície retificada varia de $1 \mu \mathrm{m}$ a $12 \mu \mathrm{m}$ e este valor para superfícies usinadas de outras maneiras varia de $6,3 \mu \mathrm{m}$ a $100 \mu \mathrm{m}$. A relação entre o tipo de acabamento superficial e o valor da rugosidade superficial pode ser obtida em várias literaturas, como por exemplo de Castro \& Meggiolaro (2009a, tab. 4.1).

\subsubsection{Fator de Tratamento Superficial}

O início da fratura por fadiga ocorre na superfície ou em uma região próxima à superfície. Assim, a resistência à fadiga pode ser influenciada negativa ou positivamente alterando-se a superfície. A descarbonização da superfície é um exemplo de influência negativa e os processos que endurecem a superfície (através de introdução de tensões internas de compressão na superfície como laminação, nitretação, etc), são exemplos de influência positiva.

O fator de tratamento superficial, $C_{S T}$, que contabiliza o efeito de uma camada superficial tratada na resistência à fadiga de um componente, é definido como a razão entre o limite de fadiga (ou limite de endurance no caso de metais que não apresentam comportamento horizontal após o ponto de inflexão) de um espécime com tratamento superficial pelo limite de 


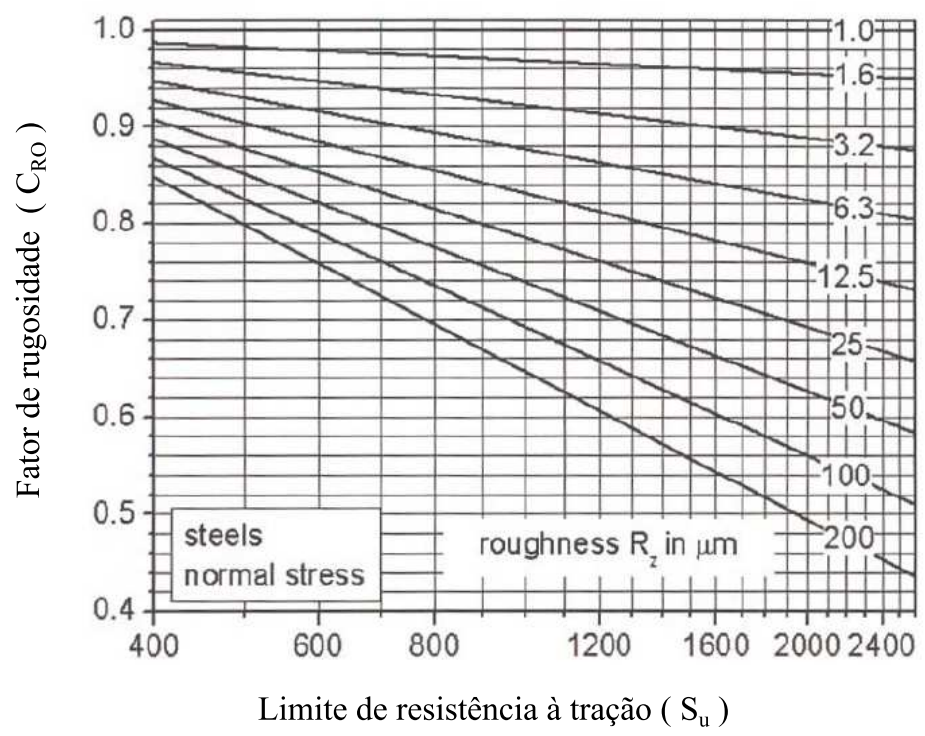

Figura 4.29 Descrição quantitativa do fator de rugosidade $C_{R O}$ para aços sob tensão normal (FKM-Guideline, 2003).

fadiga de um espécime sem tratamento superficial, mantendo todas as outras características do espécime constantes.

De acordo com FKM-Guideline (2003), os limites inferiores e superiores dos fatores de tratamento superficial para aços e ferros fundidos estão tabelados na tabela 4.10. Os valores na tabela foram testados em dois grupos grupos de componentes: o grupo de componentes com diâmetro de 8 à $15 \mathrm{~mm}$ e outro grupo com diâmetro de 30 à 40mm.

Lee et al. (2011) afirmam que o fator $C_{S T}$ também pode contabilizar pelo efeito de um revestimento superficial (como por exemplo os revestimentos anódicos produzidos eletroliticamente), utilizando para isso a seguinte equação:

$$
C_{S T}=1-0,271 \cdot \log t_{c}
$$

Onde

$t_{c} \quad$ : Espessura da camada de revestimento $(\mathrm{em} \mu \mathrm{m})$

É importante notar que, diferente dos outros fatores modificadores, fator modificador de tratamento superficial sempre é maior do que a unidade, significando que tratamentos superficiais sempre aumentam a resistência à fadiga de componentes. Os melhores tratamentos superficiais em termos de custo-benefício são shot peening, endurecimento por indução ou chama, cementação e nitretação, nesta ordem. Por exemplo, é possível obter um aumento de até $150 \%$ na resistência à fadiga de componentes de aços entalhados utilizando 
shot peening, que é um dos tratamentos superficiais mais baratos. Assim, é altamente recomendável se fazer tratamento superficial em componentes que necessitam de alta resistência à fadiga.

Tabela 4.10 Fator de tratamento superficial para vários metais (adaptado de FKM-Guideline, 2003).

\begin{tabular}{|c|c|c|c|c|}
\hline \multirow[t]{2}{*}{ Tratamento Superficial } & \multicolumn{2}{|c|}{$\begin{array}{l}\text { Componentes } \\
\text { não entalhados }\end{array}$} & \multicolumn{2}{|c|}{$\begin{array}{c}\text { Componentes } \\
\text { entalhados }\end{array}$} \\
\hline & 8-15 mm & $30-40 \mathrm{~mm}$ & 8-15 mm & $30-40 \mathrm{~mm}$ \\
\hline \multicolumn{5}{|c|}{ AÇOS } \\
\hline \multicolumn{5}{|c|}{ Tratamentos Termoquímicos } \\
\hline $\begin{array}{l}\text { Nitretação } \\
\text { Profundidade da camada: } 0,1 \text { - 0,4 mm } \\
\text { Dureza superficial: } 700 \text { - } 1000 \text { HV10 }\end{array}$ & $1,15-1,25$ & $1,10-1,15$ & $1,90-3,00$ & $1,30-2,00$ \\
\hline $\begin{array}{l}\text { Cementação } \\
\text { Profundidade da camada: 0,2 - 0,8 mm } \\
\text { Dureza superficial: } 670 \text { - } 750 \text { HV10 }\end{array}$ & $1,20-2,00$ & $1,10-1,50$ & $1,50-2,50$ & $1,20-2,00$ \\
\hline $\begin{array}{l}\text { Carbonitretação } \\
\text { Profundidade da camada: 0,2 - 0,8 mm } \\
\text { Dureza superficial: } 670 \text { - } 750 \text { HV10 }\end{array}$ & 1,80 & & & \\
\hline \multicolumn{5}{|c|}{ Tratamentos Mecânicos } \\
\hline $\begin{array}{l}\text { Laminação à frio } \\
\text { Shot peening }\end{array}$ & $\begin{array}{l}1,20-1,40 \\
1,10-1,30\end{array}$ & $\begin{array}{l}1,10-1,25 \\
1,10-1,20\end{array}$ & $\begin{array}{l}1,50-2,20 \\
1,40-2,50\end{array}$ & $\begin{array}{l}1,30-1,80 \\
1,10-1,50\end{array}$ \\
\hline \multicolumn{5}{|c|}{ Tratamentos Térmicos } \\
\hline $\begin{array}{l}\text { Endurecimento superficial por indução ou } \\
\text { por chama } \\
\quad \text { Profundidade da camada: } 0,9-1,5 \mathrm{~mm} \\
\quad \text { Dureza superficial: } 51-64 \mathrm{HRC}\end{array}$ & $1,30-1,60$ & $1,20-1,50$ & $1,60-2,80$ & $1,50-2,50$ \\
\hline \multicolumn{5}{|c|}{ FERROS FUNDIDOS } \\
\hline $\begin{array}{l}\text { Nitretação } \\
\text { Cementação } \\
\text { Laminação à frio } \\
\text { Shot peening } \\
\text { Endurecimento superficial por indução ou } \\
\text { por chama }\end{array}$ & $\begin{array}{l}1,15 \\
1,2 \\
1,2 \\
1,1 \\
1,3\end{array}$ & $\begin{array}{l}1,1 \\
1,1 \\
1,1 \\
1,1\end{array}$ & $\begin{array}{l}1,9 \\
1,5 \\
1,5 \\
1,4\end{array}$ & $\begin{array}{l}1,3 \\
1,2 \\
1,3 \\
1,1\end{array}$ \\
\hline
\end{tabular}

\subsubsection{Fator de Corrosão}

Há poucos dados disponíveis sobre a influência da corrosão na resistência à fadiga dos metais. Entretanto, é bem sabido que estruturas em contato com a água podem sofrer de corrosão, resultando em uma modificação da curva S-N. A figura 4.30 apresenta o efeito da corrosão de uma liga de alumínio trabalhando em água do mar.

O procedimento contido na diretriz técnica FKM-Guideline (2003) não leva em consi- 


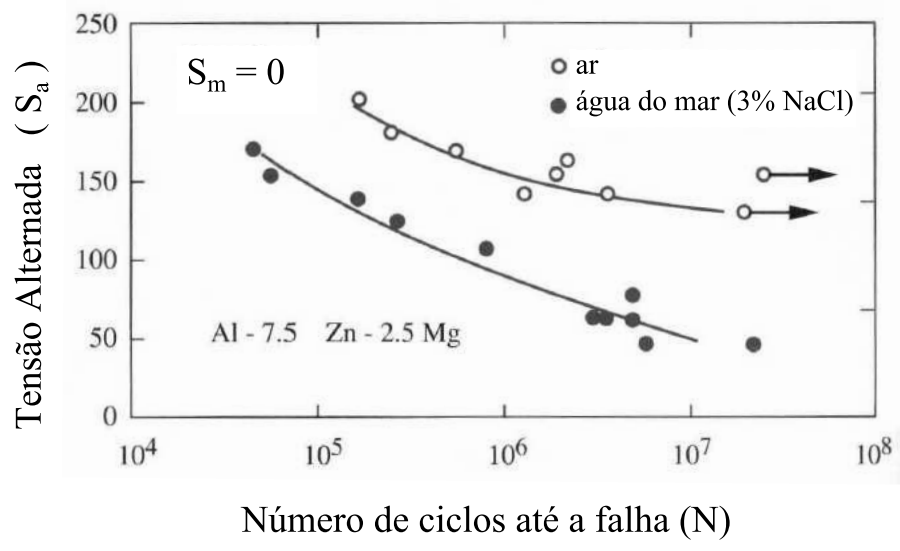

Figura 4.30 Diferença entre curvas $\mathrm{S}-\mathrm{N}$ de alumínio trabalhando ao ar livre e sob água do mar.

deração o fenômeno de corrosão. Entretanto, a Bureau Veritas possui uma norma técnica de 1998 intitulada Fatigue Strength of Welded Ship Structures (Bureau Veritas, 1998) que especifica como deve ser considerado a corrosão em uma análise de fadiga de estruturas navais.

Os efeitos da corrosão nas curvas S-N devem ser levados em consideração. Isto é feito transladando a Curva $S$-N Espécime para baixo por um fator igual à $C_{C}$ e assumindo que não há mudanças na inclinação da curva S-N. O fator de corrosão é dado por:

$$
C_{C}=\frac{1}{2^{b_{s p}}}
$$

E, desta forma, a equação (4.6) é corrigida pelo efeito da corrosão e se transforma em:

$$
S_{a}=\frac{S_{f, s p}^{\prime}}{(2)^{b_{s p}}} \cdot(2 N)^{b_{s p}}
$$

O procedimento proposto pela Bureau Veritas é aplicável à estruturas sob contato com a água salgada, e sem mecanismos de proteção contra corrosão 24 . Entretanto, como a resistência à fadiga diminui mais sob água salgada do que sob água doce, recomenda-se utilizar este procedimento também em estruturas sob corrosão em água doce.

A contabilização do dano cumulativo em fadiga é ligeiramente diferente quando ocorre o fenômeno de corrosão. Uma análise mais profunda sobre a contabilização do dano cumulativo pode ser encontrada em Bureau Veritas (1998).

\footnotetext{
${ }^{24} \mathrm{O}$ ferro, utilizado em cascos de navio, em contato com a água do mar, se oxidaria muito facilmente se não houvesse um metal de sacrifício, normalmente o magnésio. Considerando que substituir plaquetas de magnésio é muito mais barato do que substituir a estrutura de ferro, fica clara a vantagem da sua utilização. A utilização de um metal de sacrifício é um método de proteção catódica.
} 


\subsubsection{Fator de Confiabilidade}

Existem muitas fontes de variabilidade que acabam afetando na precisão na vida em fadiga de estruturas. Dentre elas pode-se citar a variação devido ao material utilizado na fabricação, ao processo de manufatura, à utilização a variação relacionada aos consumidores.

Uma Curva $S$ - $N$ Espécime é apresentada na forma de uma reta no domínio log-log e possui três constantes associadas à ela: $S_{f, s p}^{\prime}, b_{s p}$ e $S_{E, s p}$. Cada curva é obtida utilizando-se 14 ou mais corpos de prova e ela representa a curva média que interpola todos os pontos obtidos. Se uma grande quantidade de espécimes forem testados sob vários níveis de tensão até a fratura, será percebido que os pontos relativos à falha se distribuem conforme uma distribuição gaussiana em gráfico log-log, conforme ilustram as figuras 4.31 e 4.32 . A curva que passa pelo centro dessa distribuição é Curva $S$-N Espécime e possui confiabilidade de $50 \%$, conforme ilustra a figura 4.33 . Um gráfico que mostra curvas S-N para várias probabilidades é chamado de Curva $P-S-N$. Obviamente, o engenheiro deseja que haja o mínimo possível de falhas por fadiga no produto que está projetando, portanto ele não pode utilizar a Curva S-N Espécime, mas sim uma curva S-N com alta confiabilidade.

Se dados de testes de fadiga não estão disponíveis, uma análise estatística rigorosa não pode ser realizada a fim de contabilizar a natureza aleatória das propriedades do material. $\mathrm{Na}$ ausência de dados estatísticos da curva, deve-se transformar a Curva S-N Espécime (que possui $50 \%$ de probabilidade de falha) para se obter uma curva S-N com maior confiabilidade. Há duas maneiras de se calcular a curva S-N com alta confiabilidade. Pode-se transladar a Curva S-N Espécime para a esquerda (conforme ilustrado na figura 4.33. b)) ou transladá-la para baixo (conforme figura 4.33(c)). Mais detalhes sobre cada um desses métodos podem ser encontrados em Lee et al. (2005, cap. 4). Entretanto, a maneira mais usual de se realizar isto é transladando a Curva S-N Espécime para baixo. Isto é feito multiplicando-se a Curva S-N Espécime (e portanto também o seu limite de fadiga $S_{E, s p}$ ) por uma constante, denominada fator modificador de confiabilidade, $C_{R}$. Desta forma, o limite de fadiga médio $\left(\bar{S}_{E, s p}=S_{E, s p}\right)$ é reduzido para um limite de fadiga com nível de confiabilidade específico $S_{E, s p, \%}$. O fator de confiabilidade é definido como

$$
C_{R}=\frac{S_{E, s p, \%}}{\bar{S}_{E, s p}}
$$

Estudos mostram que a curva S-N possui distribuição gaussiana ao longo de toda a região de HCF quando plotada em gráfico log-log (de Castro \& Meggiolaro, 2009a; Lee et al., 2005). Sendo uma variável aleatória para o limite de fadiga denotada por $S_{E, s p}$, então o desvio padrão do limite de fadiga $\left(S T D\left(S_{E, s p}\right)\right)$ é calculado como

$$
\operatorname{STD}\left(S_{E, s p}\right)=\operatorname{COV}\left(S_{E, s p}\right) \cdot \bar{S}_{E, s p}
$$




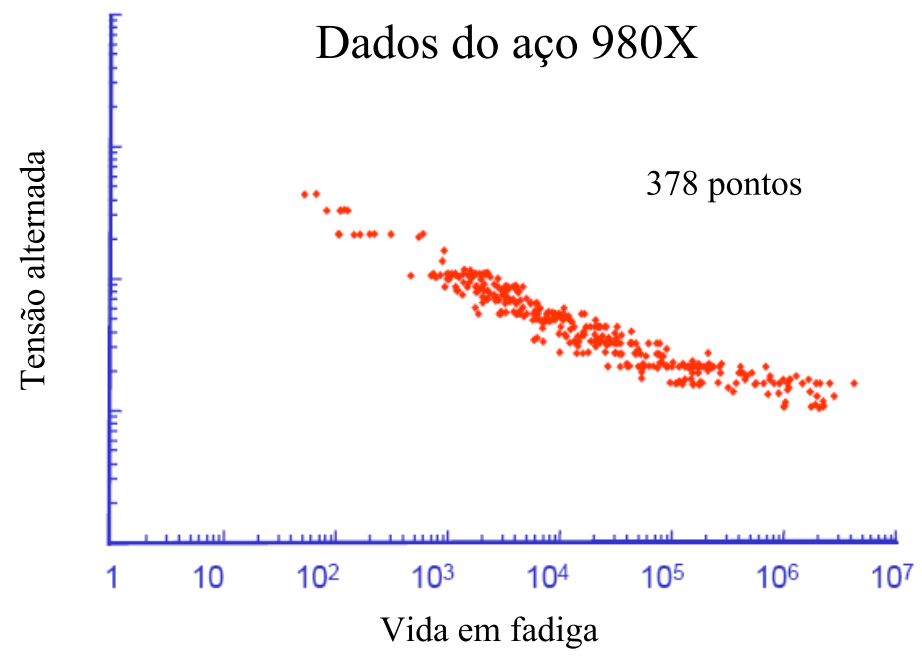

Figura 4.31 Resultado de 378 testes de fadiga do aço 980X para diversos níveis de tensão (Socie, 2002).

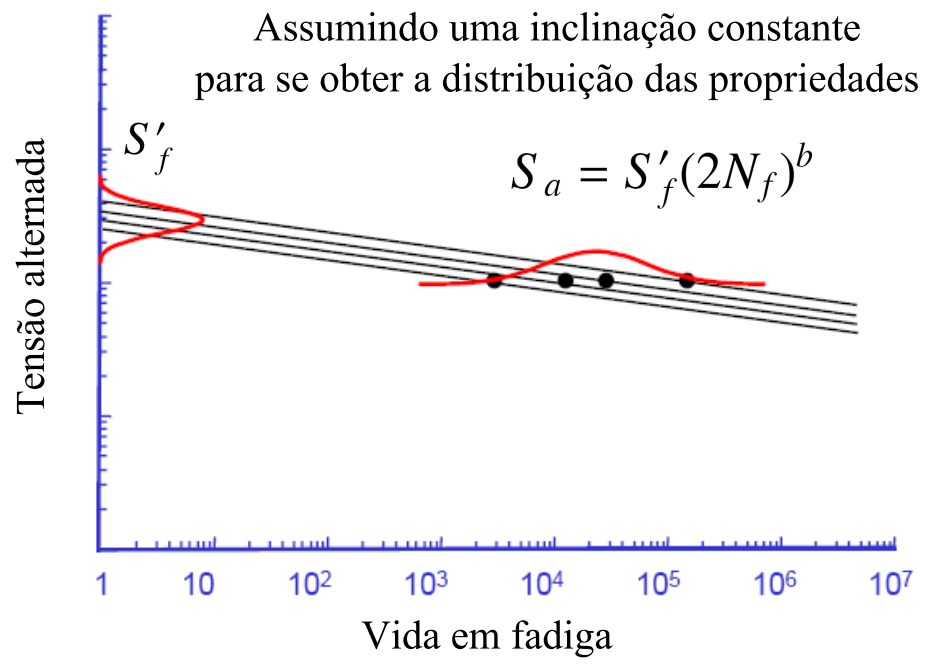

Figura 4.32 Interpolação da curva S-N (Socie, 2002).

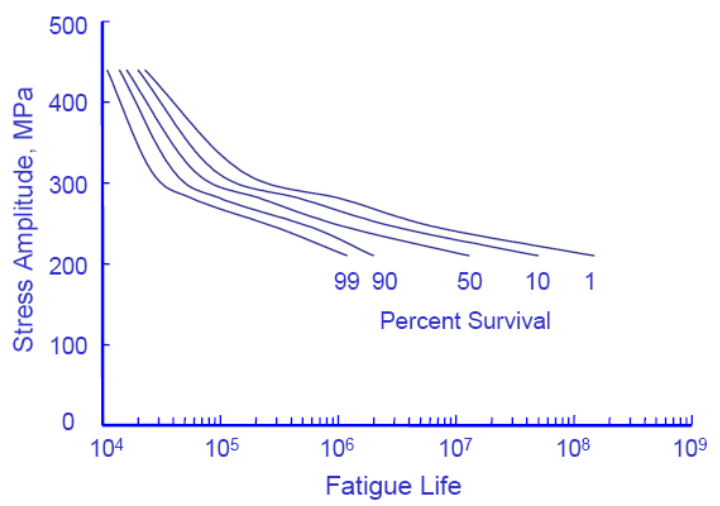

(a)

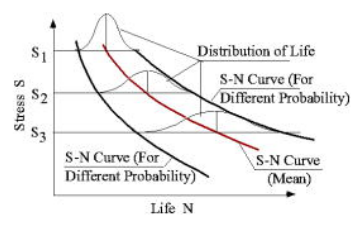

(b)

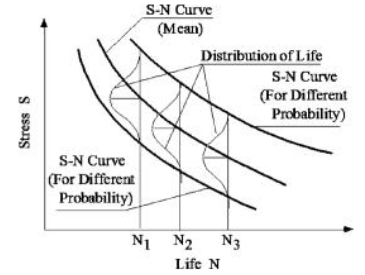

(c)

Figura 4.33 Curvas P-S-N e as duas maneiras de se interpretar uma curva S-N para diferentes probabilidades (Socie, 2002). 
onde $\operatorname{COV}\left(S_{E, s p}\right)$ é o coeficiente de variação de $S_{E, s p}$. Denotando o nível de confiabilidade como $R$ e a propabilidade de falha como

$$
P\left[S_{E, s p, \%}<\bar{S}_{E, s p}\right]=1-R
$$

e introduzindo uma nova variável,

$$
Z=\frac{S_{E, s p, r}-\bar{S}_{E, s p}}{S T D\left(S_{E, s p}\right)}
$$

então a probabilidade do limite de fadiga ser menor do que o limite de fadiga médio $\left(\bar{S}_{E, s p}\right)$ é

$$
P\left[S_{E, s p, \%}<\bar{S}_{E, s p}\right]=-\varphi(Z)=1-R
$$

onde $\varphi(Z)$ é a função densidade de probabilidade da distribuição normal e

$$
Z=-\varphi^{-1}(1-R)
$$

O limite de fadiga com uma confiabilidade de $R$ pode ser escrito como segue:

$$
\begin{aligned}
S_{E, s p, \%} & =\bar{S}_{E, s p}-\varphi^{-1}(1-R) \cdot S T D\left(S_{E, s p}\right) \\
& =\bar{S}_{E, s p}-\varphi^{-1}(1-R) \cdot \operatorname{COV}\left(S_{E, s p}\right) \cdot \bar{S}_{E, s p}
\end{aligned}
$$

resultando em

$$
C_{R}=\frac{S_{E, s p, \%}}{\bar{S}_{E, s p}}=1-\varphi^{-1}(1-R) \cdot \operatorname{COV}\left(S_{E, s p}\right)
$$

Em 1975 Haugein \& Wirsching realizaram uma pesquisa e mostraram que o coeficiente de variação do limite de fadiga $\operatorname{COV}\left(S_{E, s p}\right)$ não ultrapassam $8 \%$ em metais. Desta forma, adimitindo um coeficiente de variação de $\overline{C O V}=8 \%$ para o limite de fadiga e que o coeficiente de variação é o mesmo para toda a região de $\mathrm{HCF}$, obtém-se os valores para o fator de confiabilidade para vários níveis de confiabilidade, apresentados na tabela 4.11 .

É importante ressaltar que os fatores de confiabilidade da tabela 4.11 foram obtidos admitindo-se a hipótese de que função densidade de probabilidade (PDF) da curva S-N possui distribuição normal ao longo de toda a região de $\mathrm{HCF}$ e admitindo-se um coeficiente de variação de $\mathrm{COV}=8 \%$ constante ao longo de toda a curva $\mathrm{S}-\mathrm{N}$. É por esta razão que a literatura estipula utilizar o valor de $C_{R}$ para corrigir tanto $S_{E, s p}$ (ou $S_{K, s p}$ ) quanto $S_{B, s p}$. A FKM-Guideline (2003) especifica que a curva $S-N$ que deve ser utilizada no projeto de fadiga deve ser aquela baseada em uma probabilidade de 97,5\% de confiabilidade, correspondendo à um valor de $C_{R}=0,843$. A comunidade científica também acredita que a hipótese de considerar que a curva S-N segue uma distribuição normal seja verdadeira para qualquer tipo de metal (de Castro \& Meggiolaro, 2009a; Lee et al., 2005). 
Conforme exposto na seção 4.2.1, a hipótese de considerar $\mathrm{COV}=8 \%$ para o limite de fadiga de aços pode ser considerada segura, pois $\operatorname{COV}\left(S_{E, s p}\right)=6,4 \%$ para aços. Entretanto, adotar esta hipótese para corrigir $S_{E, s p}\left(\right.$ ou $S_{K, s p}$ ) de outros metais é altamente insegura em projetos. Isto porque o coeficiente de variação do limite de fadiga de outras ligas metálicas é maior do que $8 \%$, conforme as informações abaixo, provenientes da seção 4.2 .3 .
Ligas de alumínio:
$\operatorname{COV}\left(S_{K, s p}\right)=27 \%$
Ligas de titânio:
$\operatorname{COV}\left(S_{E, s p}\right)=36 \%$
Ligas de cobre:
$\operatorname{COV}\left(S_{E, s p}\right)=25 \%$
Ligas de magnésio:
$\operatorname{COV}\left(S_{E, s p}\right)=20 \%$

Por este motivo, o autor recomenda que não seja utilizado a tabela 4.11, mas sim a tabela 4.12 para a obtenção do fator de confiabilidade, pois esta apresenta o fator de confiabilidade para diferentes valores de coeficiente de variação.

O coeficiente de variação do limite de $S_{B, s p}$, de acordo com a seção 4.2 .3 , são:
Aços:
$\operatorname{COV}\left(S_{B, s p}\right)=13 \%$
Ferros fundidos:
$\operatorname{COV}\left(S_{B, s p}\right)=28 \%$
Ligas de alumínio:
$\operatorname{COV}\left(S_{B, s p}\right)=10 \%$
Ligas de titânio:
$\operatorname{COV}\left(S_{B, s p}\right)=9 \%$
Ligas de níquel:
$\operatorname{COV}\left(S_{B, s p}\right)=31 \%$

Por isso o autor recomenda que seja calculado e utilizado dois valores de $C_{R}$, um para corrigir $S_{E, s p}$ e outro para corrigir $S_{B, s p}$. O fator $C_{R}$ que modificará $S_{E, s p}$ deve ser calculado utilizando a fórmula (4.66) juntamente com o COV relativo à $S_{E, s p}$ (que varia com o material escolhido). Da mesma maneira, o fator $C_{R}$ que modificará $S_{B, s p}$ deve ser calculado utilizando a mesma fórmula mas utilizando o COV relativo à $S_{B, s p}$ (por exemplo aqueles informados na equação (4.12).

As gaussianas são definidas para $-\infty<x<\infty$. Entretanto, segundo de Castro \& Meggiolaro (2009a, pp.171), a equação (4.66) não pode ser usada nos casos onde a confiabilidades ou o COV são altos demais, pois nestes casos o fator $C_{R}$ passa a ser negativo e consequentemente $S_{E, s p}$ também passa a ser negativo, o que não pode ocorrer. Isso significa que as resistências, que são sempre valores positivos, nunca são estritamente gaussianas de Castro \& Meggiolaro, 2009a, pp.171).

\subsubsection{Fator de Temperatura}

Observações de experimentos revelam que o aumento da temperatura causa a redução na resistência à fadiga. Em temperaturas abaixo da ambiente, fratura frágil é uma grande possi- 
Tabela 4.11 Fator de confiabilidade FKM-Guideline (2003).

\begin{tabular}{lccc}
\hline Confiabilidade & Probabilidade de Falha & $\mathbf{Z}$ & $\begin{array}{c}\text { Fator de } \\
\text { Confiabilidade } \\
R\end{array}$ \\
\hline \multicolumn{1}{c}{$1-R$} & $\varphi^{-1}(R-1)$ & $C_{R}$ \\
\hline $50 \%$ & $50 \%$ & 0,000 & 1,000 \\
$90 \%$ & $10 \%$ & 1,282 & 0,897 \\
$95 \%$ & $5 \%$ & 1,645 & 0,868 \\
$97,5 \%$ & $2,5 \%$ & 1,960 & 0,843 \\
$99 \%$ & $1 \%$ & 2,326 & 0,814 \\
$99,9 \%$ & $0,1 \%$ & 3,090 & 0,753 \\
$99,99 \%$ & $0,01 \%$ & 3,719 & 0,702 \\
$99,999 \%$ & $0,001 \%$ & 4,265 & 0,659 \\
$99,9999 \%$ & $0,0001 \%$ & 4,753 & 0,620 \\
\hline
\end{tabular}

Tabela 4.12 Fator de confiabilidade usuais em projeto de fadiga.

\begin{tabular}{|c|c|c|c|c|c|c|c|c|}
\hline \multicolumn{9}{|c|}{ Fator de confiabilidade $C_{R}$ para várias confiabilidades $\left(C_{R}\right)$ e dispersões $(\mathrm{COV})$} \\
\hline \multirow{2}{*}{$\begin{array}{c}\text { Confiabilidade } \\
\mathbf{R}(\%)\end{array}$} & \multirow{2}{*}{$\begin{array}{l}\text { Probabilidade } \\
\text { de Falha (1-R) }\end{array}$} & \multirow{2}{*}{$\mathbf{Z}(\mathbf{R})$} & \multicolumn{6}{|c|}{ Coeficiente de variação: $\operatorname{COV}(S)=\hat{\sigma}[\bar{S}) / \mu(S)$} \\
\hline & & & $7 \%$ & $10 \%$ & $13 \%$ & $15 \%$ & $18 \%$ & $25 \%$ \\
\hline $50 \%$ & $50 \%$ & 0 & 1 & 1 & 1 & 1 & 1 & 1 \\
\hline $90 \%$ & $10 \%$ & 1,282 & 0,910 & 0,872 & 0,833 & 0,808 & 0,769 & 0,680 \\
\hline $95 \%$ & $5 \%$ & 1,645 & 0,885 & 0,836 & 0,786 & 0,753 & 0,704 & 0,589 \\
\hline $97,5 \%$ & $3 \%$ & 1,960 & 0,863 & 0,804 & 0,745 & 0,706 & 0,647 & 0,510 \\
\hline $99 \%$ & $1 \%$ & 2,326 & 0,837 & 0,767 & 0,698 & 0,651 & 0,581 & 0,418 \\
\hline $99,9 \%$ & $0,1 \%$ & 3,090 & 0,784 & 0,691 & 0,598 & 0,536 & 0,444 & 0,227 \\
\hline
\end{tabular}

bilidade e deveria ser investigada primeiro. Quando componentes operam em temperaturas mais altas que a ambiente, escoamento deveria ser investigado primeiro, pois o limite de escoamento cai rapida e continuamente com o aumento da temperatura e, em alguns casos, o modo de falha por escoamento pode ocorrer antes da falha por fadiga. Em temperaturas acima de $50 \%$ da temperatura de fusão absoluta do material, a fluência se torna um fator significante e portanto este fator também precisa ser considerado no projeto de engenharia. A fluência combinada com tensões cíclicas resulta em um complexo mecanismo de dano denominado "fadiga com fluência". O método Tensão-Vida passa a não ser mais válido em altas temperaturas. Por outro lado, a abordagem Deformação-Vida consegue contabilizar os efeitos combinados de fluência e fadiga sob alta temperatura e deve ser usado nestas situações.

Além da resistência à fadiga diminuir e a inclinação da curva S-N (fator de inclinação $k$ ) com o aumento da temperatura, o limite de fadiga passa a não mais existir em altas temperaturas. Assim, o ponto de inflexão desaparece do diagrama $\mathrm{S}-\mathrm{N}$ de maneira que a resistência à fadiga continua a diminuir indefinidamente com o aumento do número de ciclos $N$, conforme ilustrado na figura 4.17(b). Acredita-se que este fenômeno ocorre devido à combinação das tensões cíclicas com o ataque corrosivo acelerado à altas temperaturas, resultando em um mecanismo de dano complexo que é normalmente denominado "fadiga com corrosão". 
Uma das maneiras de medir o decréscimo da resistência à fadiga com a temperatura é utilizando o fator modificador de temperatura, $C_{T}$, definido como sendo a razão entre o limite de fadiga (ou limite de endurance) do espécime à determinada temperatura " $T$ " e o limite de fadiga (ou limite de endurance) à temperatura ambiente, conforme segue:

$$
C_{T}=\frac{S_{E, s p, T}}{S_{E, s p}}
$$

O fator de temperatura é um fator menor do que a unidade e que diminui com o aumento da temperatura. Alguns pesquisadores propuseram equações que relacionam $C_{T}$ e a temperatura, através da interpolação dos dados experimentais por polinômios. Há poucos dados na literatura sobre a influência da temperatura no fator de temperatura e foram encontrados somente duas propostas que contabilizam este fator. Shigley et al. (2003) e Norton (2006) propõem ambos uma equação do $4^{\circ}$ grau para estimar o valor do fator de temperatura, sendo estas duas equações válidas para todos os tipos de metais. Entretanto, essas equações foram obtidas utilizando valores do limite de resistência à tração $\left(S_{u}\right)$ em altas temperaturas, e não o limite de fadiga. A FKM-Guideline (2003), entretanto, apresenta valores para $C_{T}$ obtidos utilizando o limite de fadiga ao invés do limite de resistência à tração.

A queda da resistência à tração depende do material e não pode ser modelada com apenas uma fórmula, válida para todos os metais. A FKM-Guideline (2003) especifica os fatores modificadores de temperatura conforme segue:

- Para aços com granulação fina, onde $T>60^{\circ} \mathrm{C}$

$$
C_{T}=1-10^{-3} \cdot T
$$

- Para todos os aços, excetos os de granulação fina, onde $T>100^{\circ} \mathrm{C}$

$$
C_{T}=1-1,4 \cdot 10^{-3}(T-100)
$$

- Para aços para fundição, onde $T>100^{\circ} \mathrm{C}$

$$
C_{T}=1-1,2 \cdot 10^{-3}(T-100)
$$

- Para ferro fundido nodular, onde $T>100^{\circ} \mathrm{C}$

$$
C_{T}=1-1,6 \cdot 10^{-6} \cdot T^{2}
$$


- Para ferro fundido maleável, onde $T>100{ }^{\circ} \mathrm{C}$

$$
C_{T}=1-1,3 \cdot 10^{-6} \cdot T^{2}
$$

- Para ferro fundido cinzento, onde $T>100^{\circ} \mathrm{C}$

$$
C_{T}=1-10^{-6} \cdot T^{2}
$$

- Para ligas de alumínio, onde $T>50^{\circ} \mathrm{C}$

$$
C_{T}=1-1,2 \cdot 10^{-3}(T-50)
$$

Note que a temperatura precisa ser dada em graus Celsius.

\subsubsection{Fator de Tensão Média}

O dano por fadiga em um componente está fortemente correlacionado com a tensão alternada aplicada $S_{a}$ (ou com o intervalo de tensão $\Delta S$ ), e secundariamente influenciada pela tensão média $S_{m}$. O efeito da tensão média deve ser seriamente considerado em análises de fadiga. No regime de Fadiga de Alto Ciclo, tensões médias normais tem um efeito significativo no comportamento de componentes.

Tensões médias normal $\left(S_{m}\right)$ são responsáveis pelo estado de abrir e fechar de trincas. Como a abertura de trincas acelera a taxa de propagação de trincas e o fechamento retarda o crescimento de trincas, tensões médias normal trativas são deletérias e tensões médias normal compressivas são benéficas em termos da vida em fadiga. De acordo com de Castro \& Meggiolaro (2009a), existe pouco efeito da tensão média no regime de Fadiga de Baixo Ciclo onde grande quantidade de deformação plástica reduz significantemente seu efeito benéfico ou deletério da tensão média.

O efeito da tensão média normal pode ser representada pela tensão média $\left(S_{m}\right)$ ou pela razão de tensão $(R)$, apresentados pelas equações a seguir, já apresentadas na seção 4.1 .

$$
\begin{gathered}
S_{m}=\frac{\left(S_{\max }+S_{\min }\right)}{2} \\
R=\frac{S_{\text {min }}}{S_{\text {max }}}
\end{gathered}
$$

Todos os modelos que contabilizam o efeito da tensão média são empíricos e foram propostos para compensar os efeitos da tensão média normal $\left(S_{m}\right)$ na resistência à fadiga em alto 
ciclo. As representações mais úteis de dados experimentais de fadiga são gráficos de $S_{a}$ versus $S_{m}$, chamados de gráficos de vida constante. Estes gráficos são obtidos obtendo-se várias Curvas S-N Espécime, cada curva sendo obtida com um valor de tensão média $S_{m}$ constante $\left(0, S_{m 1}, S_{m 2}, S_{m 3}\right.$, etc), conforme ilustrado na figura 4.34(a). Após isto, estes dados são passados para um gráfico de $S_{a}$ versus $S_{m}$, conforme apresenta a figura 4.34(b). Na verdade, as figuras 4.34(a) e 4.34(b) podem ser transformadas em um único gráfico, representado pela 4.35. Na Alemanha, o gráfico de vida constante é chamado de diagrama de Haigh, enquanto que nos Estados Unidos é comumente referido como diagrama de Goodman.

Pode-se observar pela figura 4.34(a) que Curvas S-N Espécime obtidas com tensão média maior do que zero terão uma vida em fadiga menor, para um mesmo nível de tensão alternada. Da mesma forma, Curvas S-N Espécime obtidas com tensão média menor do que zero terão uma vida maior. O objetivo principal do diagrama de Haigh é estimar qual seria a Curva $\mathrm{S}-\mathrm{N}$ Espécime obtida com tensão média diferente de zero, utilizando para isso a tensão alternada $\left(S_{a}\right)$ e a tensão média $\left(S_{m}\right)$ aplicadas no componente analisado e também outras propriedades mecânicas.

Na figura 4.34(b), a curva que sai do eixo das abscissas, interpola os pontos e termina no eixo das ordenadas é uma semi-reta. Entretanto, cada metal possui um tipo de curva, que pode ser uma semi-reta, uma parábola ou outro tipo de curva. Muitos pesquisadores propuseram curvas (equações) que visam interpolar estes pontos. Estas curvas propostas se chamam modelos de correção da tensão média. Embora muitos modelos tenham sido desenvolvidos para a contabilização da tensão média na resistência à fadiga, oito deles são mais conhecidos e utilizados: modelo de Gerber (Gerber, 1874, Alemanha), modelo de Soderberg (Soderberg, 1930, USA), modelo de Goodman (Goodman, 1899, Alemanha), modelo de Morrow I (Morrow, 1968), modelo de Morrow II, modelo ASME-Elíptico (também chamado de modelo ASME, modelo elíptico ou modelo quadrático), modelo de SWT (Smith et al., 1970) e modelo de Walker (Walker, 1970). O modelo intitulado nesta dissertação por Morrow I utiliza o coeficiente de resistência à fadiga $\left(S_{f, s p}^{\prime}\right)$ obtido da interseção da curva S-N com o eixo das ordenadas. O modelo intitulado aqui por Morrow II utiliza a tensão verdadeira de fratura $\left(\sigma_{f}\right)$, calculada através da curva tensão-deformação verdadeira.

O fator modificador de tensão média, $C_{m}$, tem a função de contabilizar o efeito da tensão média na vida em fadiga. Este fator translada verticalmente toda a Curva S-N Espécime 25 , conforme ilustrado na figura 4.34(a), transformando-a assim em uma curva S-N com média diferente de zero. O fator de tensão média é definido pela equação (4.75) para metais que

\footnotetext{
${ }^{25}$ Obtida com $S_{m}=0$
} 


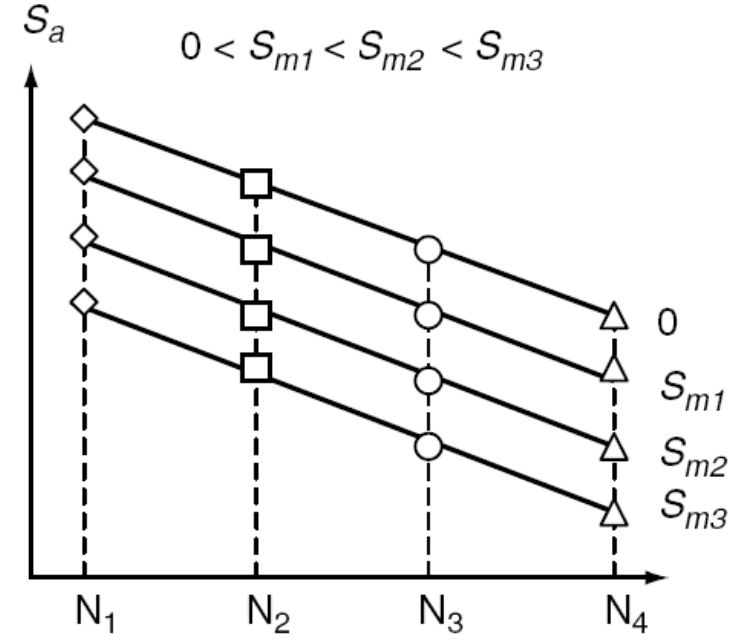

(a)

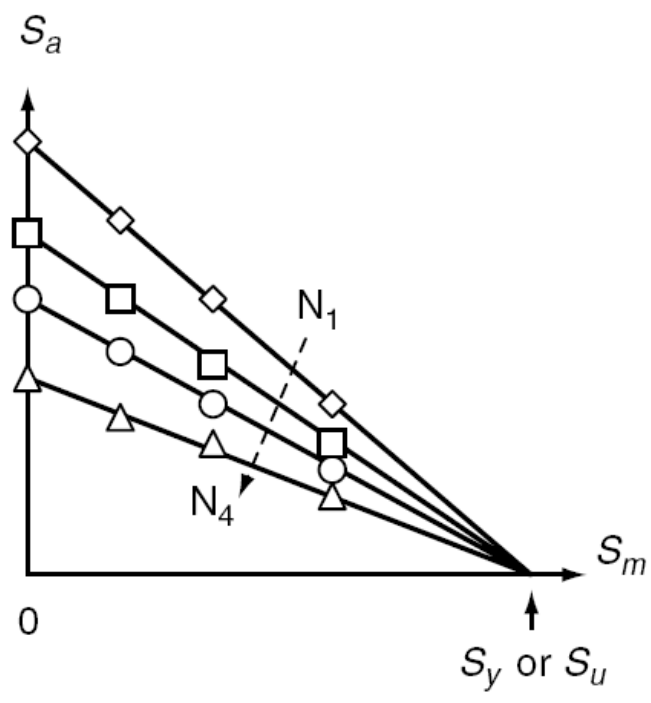

(b)

Figura 4.34 Construção dos gráficos de vida constante para tensão normal nas coordenadas $S_{a}$ e $S_{m}$ (Lee et al., 2011).

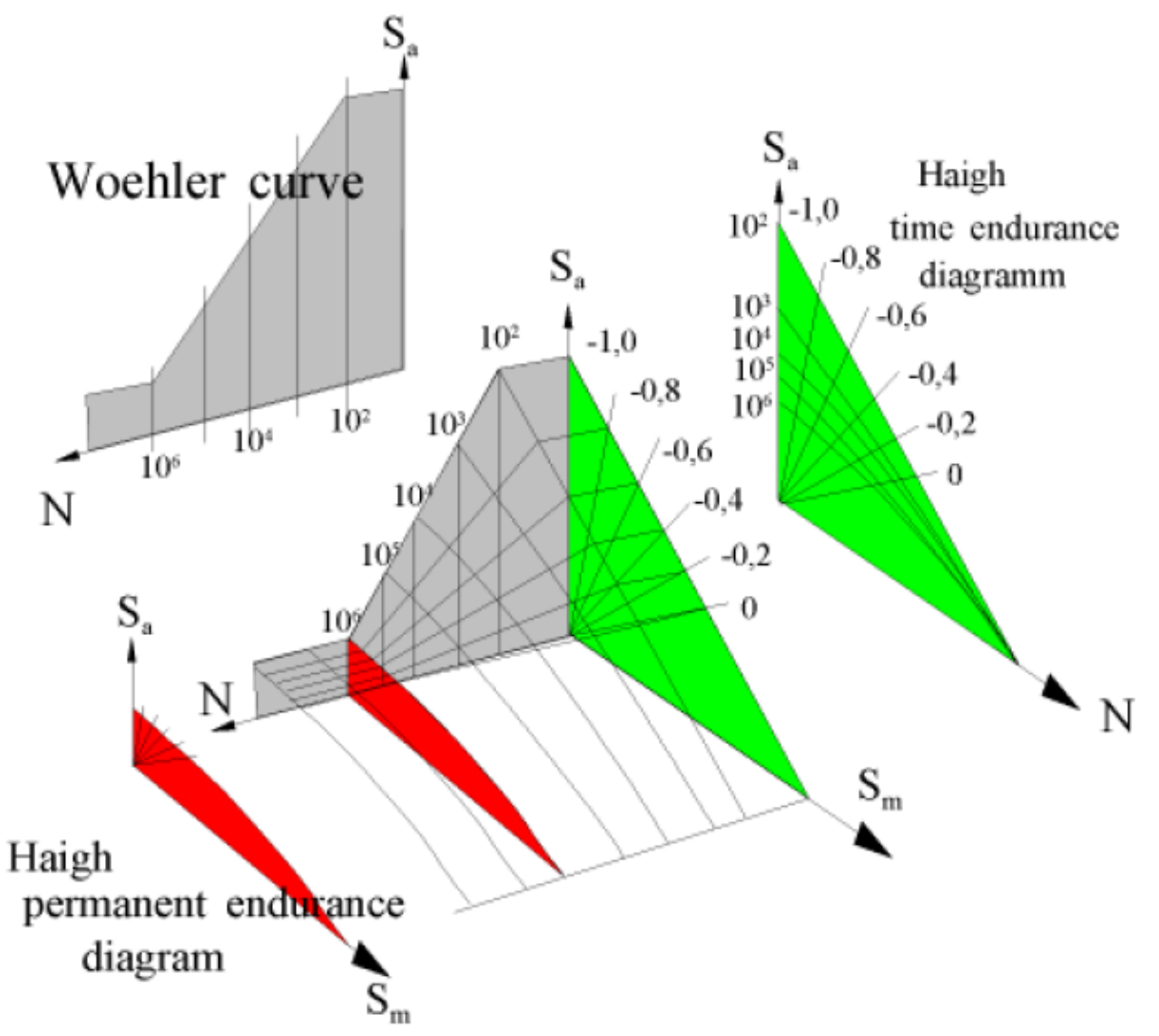

Figura 4.35 Relações entre tensão alternada $\left(S_{a}\right)$, tensão média $\left(S_{m}\right)$ e razão de tensão $(R)$ (Steinbeis $\mathrm{GmbH} \&$ Co, 2013). 
possuem limite de fadiga e pela equação (4.76) para metais que possuem limite de endurance.

$$
\begin{gathered}
C_{m}=\frac{S_{E, s p, R}}{S_{E, s p}} \\
C_{m}=\frac{S_{K, s p, R}}{S_{K, s p}}
\end{gathered}
$$

Onde

$S_{E, s p, R} \quad: \quad$ Limite de fadiga da Curva S-N Espécime obtida com carregamento onde $R \neq-1$ (i.e. $S_{m} \neq 0$ )

$S_{E, s p} \quad$ : Limite de fadiga da Curva $S$-N Espécime obtida com carregamento onde $R=-1$ (i.e. $S_{m}=0$ )

$S_{K, s p, R} \quad$ : Limite de endurance da Curva S-N Espécime obtida com carregamento onde $R \neq-1$ (i.e. $S_{m} \neq 0$ )

$S_{K, s p} \quad:$ Limite de endurance da Curva S-N Espécime obtida com carregamento onde $R=-1$ (i.e. $S_{m}=0$ )

O valor do fator $C_{m}$ depende do modelo de correção da tensão média que o engenheiro escolhe utilizar. Por exemplo, cada um dos oito modelos supracitados irão resultar em um valor específico para $C_{m}$ A diferença entre cada um dos modelos pode ser observada na tabela 4.13. Segundo Lee et al. (2011), todos devem ser utilizados apenas no caso de tensões médias baixas ou moderadas. O modo como o fator $C_{m}$ é calculado também é apresentado nesta tabela.

Shigley et al. (2003, pp. 341) e Schijve (2008, pp. 124) afirmam que para metais dúcteis, sob ciclos de carregamento com tensão média baixa $(\mathrm{R}<0)$, ambas uma parábola (modelo de Gerber) e uma elipse (modelo de ASME-Elíptico) interpolam melhor os dados experimentais e portanto estimam melhor o efeito da tensão média na previsão da vida em fadiga. Contudo, projetistas e engenheiro frequentemente empregam o modelo de Goodman modificado por ter sido o modelo mais mencionado nos livros de engenharia e projeto mecânico ao longo das últimas décadas, mesmo este modelo não possuindo a melhor correlação com ensaios experimentais.

Entretanto, um dos melhores e mais atuais estudos para a verificação da precisão dos modelos de tensão média foi realizado por Dowling (2004), tendo sido mencionado em diversas obras por causa disto (Lee et al., 2011; Papuga, 2005). Dowling (2004) realizou um estudo extensivo com dados experimentais de fadiga de aços, ligas de alumínio e ligas de titânio para carregamento com $-1 \leq R \leq 0,45$. Foram analizados quatro modelos de tensão média na pesquisa de Dowling: Goodman, Morrow I, Morrow II, Smith-Watson-Tooper (SWT) e Walker. Ele concluiu o seguinte: 
- Modelo de Goodman: O modelo de Goodman para correção da tensão média é altamente impreciso, inclusive para aços, e não deve ser utilizado (Dowling, 2004).

- Modelo de Morrow I: O modelo de Morrow I funciona bem para aços e pode ser utilizado para metais em geral, tendo praticamente a mesma precisão que o modelo de Morrow II. Entretanto, o modelo de Morrow I não deve ser utilizado para ligas de alumínio nem ligas de titânio por gerar resultados altamente imprecisos e não conservadores.

- Modelo de Morrow II: Um dos melhores modelos para se utilizar, pois que gera ótimos resultados para diversos metais (tanto para aços quanto para ligas de alumínio e ligas de titânio), sendo ligeiramente mais preciso do que o modelo Morrow I. Entretanto, o modelo Morrow II tem a desvantagem de utilizar o parâmetro $\sigma_{f}{ }^{26}$, geralmente difícil de ser obtido.

- Modelo de SWT: É o modelo recomendado para ligas de alumínio e ligas de titânio por gerar resultados precisos para estas ligas, mais precisos que os modelos de Morrow I e Morrow II para estas ligas. O modelo de SWT também é aceitável para aços e é uma boa escolha para uso geral, mas não tão bom quanto Morrow I e Morrow II para aços.

- Modelo de Walker: Dowling (2004) mostrou que o modelo de Walker é o melhor de todos, para qualquer tipo de metal, pois contém uma constante $\gamma$ que dependente do material analisado, e por isso apresenta uma precisão alta nos casos onde $\gamma$ é conhecido ou pode ser estimado. Como há pouquíssima informação na literatura sobre $\gamma$, praticamente não é possível utilizar este modelo na prática. 
Em resumo, uma análise aos resultados obtidos por Dowling (2004) permite concluir que os modelos de correção da tensão média podem ser ordenados pela precisão dos resultados que eles geram. Desta maneira, para aços e metais em geral:

$\left.1^{\circ}\right)$ Modelo de Walker

$2^{\circ}$ ) Modelo de Morrow I ou Morrow II

$\left.3^{\circ}\right)$ Modelo de $S W T$

E para ligas de alumínio e ligas de titânio:

$1^{\circ}$ ) Modelo de Walker

$2^{\circ}$ ) Modelo de $S W T$

$3^{\circ}$ ) Modelo de Morrow II

O modelo Morrow I não deve ser utilizado para ligas de alumínio nem titânio por ser bastante impreciso (Dowling, 2004).

Tabela 4.13 Métodos para a determinação de $C_{m}$ (adaptado de Lee et al. (2011), Dowling (2004), Susmel (2009) e Papuga (2005))

\begin{tabular}{|c|c|c|c|}
\hline Autor & Fórmula & & Uso recomendado \\
\hline Gerber & $\begin{array}{l}S_{a, R=-1}=\frac{S_{a}}{1-\left(\frac{S_{m}}{S_{u}}\right)^{2}} \\
C_{m}=1-\left(\frac{S_{m}}{S_{u}}\right)^{2} \\
\text { i.e. } S_{E, s p, R=0}=\frac{S_{u}^{2}}{2 S_{E, s p}}\left[\sqrt{1+\left(\frac{2 S_{E, s p}}{S_{u}}\right)^{2}}-1\right.\end{array}$ & $(4.77)$ & $\begin{array}{l}\text { Metais dúcteis (Papuga, } \\
\text { 2005). Recomendado por } \\
\text { Shigley et al. (2003, } \\
\text { pp.298). Mas não teve bons } \\
\text { resultados ao ser aplicado } \\
\text { para o aço ASTM A743 } \\
\text { AC6NM em da Silva et al. } \\
(2010) \text {. }\end{array}$ \\
\hline Soderberg & $\begin{array}{l}S_{a, R=-1}=\frac{S_{a}}{1-\frac{S_{m}}{S_{y}}} \\
C_{m}=1-\frac{S_{m}}{S_{y}} \\
\text { i.e. } \quad S_{E, s p, R=0}=\frac{S_{y} \cdot S_{E, s p}}{S_{y}+S_{E, s p}}\end{array}$ & $(4.78)$ & 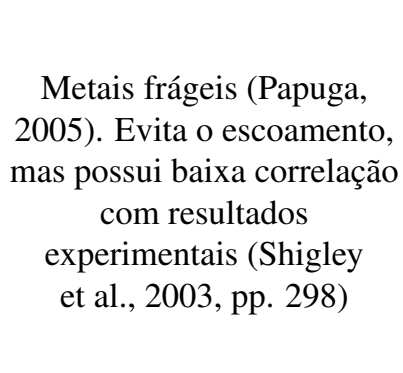 \\
\hline
\end{tabular}


Tabela 4.13 Continuação da página anterior

\begin{tabular}{|c|c|c|c|}
\hline Autor & Fórmula & & Uso recomendado \\
\hline Goodman & $\begin{array}{l}S_{a, R=-1}=\frac{S_{a}}{1-\frac{S_{m}}{S_{u}}} \\
C_{m}=1-\frac{S_{m}}{S_{u}} \\
\text { i.e. } S_{E, s p, R=0}=\frac{S_{u} \cdot S_{E, s p}}{S_{u}+S_{E, s p}}\end{array}$ & $(4.79)$ & $\begin{array}{l}\text { Modelo impreciso } \\
\text { (inclusive para aço e } \\
\text { alumínio), sendo } \\
\text { excessivamente conservador } \\
\text { para tensões médias trativas. } \\
\text { Não recomendado por } \\
\text { Dowling (2004). }\end{array}$ \\
\hline Morrow I & $\begin{array}{l}S_{a, R=-1}=\frac{S_{a}}{1-\frac{S_{m}}{S_{f, s p}^{\prime}}} \\
C_{m}=1-\frac{S_{m}}{S_{f, s p}^{\prime}} \\
\text { i.e. } S_{E, s p, R=0}=\frac{S_{f, s p}^{\prime} \cdot S_{E, s p}}{S_{f, s p}^{\prime}+S_{E, s p}}\end{array}$ & $(4.80)$ & $\begin{array}{l}\text { Funciona bem para aços (e } \\
\text { metais em geral), mas não } \\
\text { deve ser utilizado em ligas } \\
\text { de alumínio e de titânio por } \\
\text { ser altamente impreciso e } \\
\text { não conservador (Dowling, } \\
2004 \text { ). }\end{array}$ \\
\hline Morrow II & $\begin{array}{l}S_{a, R=-1}=\frac{S_{a}}{1-\frac{S_{m}}{\sigma_{f}}} \\
C_{m}=1-\frac{S_{m}}{\sigma_{f}} \\
\text { i.e. } S_{E, s p, R=0}=\frac{\sigma_{f} \cdot S_{E, s p}}{\sigma_{f}+S_{E, s p}}\end{array}$ & $(4.81)$ & $\begin{array}{l}\text { Ótimos resultados para } \\
\text { maioria dos metais } \\
\text { (inclusive aços, ligas de } \\
\text { alumínio e de titânio) e é } \\
\text { ligeiramente melhor do que } \\
\text { a equação } 4.80 \text {. } \\
\text { Entretanto, tem a } \\
\text { desvantagem de que os } \\
\text { valores de } \sigma_{f} \text { não estão } \\
\text { sempre disponíveis } \\
\text { (Dowling, 2004). }\end{array}$ \\
\hline $\begin{array}{l}\text { ASME- } \\
\text { Elíptico }\end{array}$ & $\begin{array}{l}S_{a, R=-1}=\frac{S_{a}}{\sqrt{1-\left(\frac{S_{m}}{S_{y}}\right)^{2}}} \\
C_{m}=\sqrt{1-\left(\frac{S_{m}}{S_{y}}\right)^{2}} \\
\text { i.e. } S_{E, s p, R=0}=\frac{S_{y} \cdot S_{E, s p}}{\sqrt{S_{y}^{2}+S_{E, s p}^{2}}}\end{array}$ & $(4.82)$ & $\begin{array}{l}\text { Metais dúcteis (Shigley } \\
\text { et al. 2003). Melhor do que } \\
\text { a equação } 4.77 \text {, pois } \\
\text { considera que a falha } \\
\text { estática acontece no } \\
\text { escoamento. Recomendado } \\
\text { por Shigley et al. (2003, pp. } \\
\text { 298); Não analisado por } \\
\text { Dowling (2004). }\end{array}$ \\
\hline SWT & $\begin{array}{l}S_{a, R=-1}=\sqrt{S_{\text {max }} \cdot S_{a}}=\sqrt{S_{a} \cdot\left(S_{a}+S_{m}\right)} \\
C_{m}=\sqrt{\frac{S_{a}}{S_{a}+S_{m}}}=\sqrt{\frac{1-R}{2}} \\
\text { i.e. } S_{E, s p, R=0}=\frac{S_{E, s p}}{\sqrt{2}}\end{array}$ & $(4.83)$ & $\begin{array}{l}\text { É a melhor opção para ligas } \\
\text { de alumínio e de titânio } \\
\text { (perdendo apenas para o } \\
\text { modelo de Walker) } \\
\text { (Dowling, 2004). Lee et al. } \\
\text { (2011) recomenda-o como } \\
\text { uso geral para metais } \\
\text { dúcteis. }\end{array}$ \\
\hline
\end{tabular}


Tabela 4.13 Continuação da página anterior

\begin{tabular}{c|c|c}
\hline Autor & Fórmula & Uso recomendado \\
\hline Walker & $C_{m}=\left(\frac{S_{a}}{S_{a}+S_{m}}\right)^{1-\gamma}=\left(\frac{1-R}{2}\right)^{1-\gamma}$ & $\begin{array}{c}\text { Graças ao parâmetro de } \\
\text { material } \gamma \text { fornece } \\
\text { resultados superiores à } \\
\text { qualquer outro modelo, para } \\
\text { qualquer tipo de metal } \\
\text { i.e. } \quad S_{E, s p, R=0}=S_{E, s p} \cdot 2^{\gamma-1}\end{array}$ \\
$\begin{array}{c}\text { (Dowling, 2004). Entretanto } \\
\text { isto é verdade apenas se } \gamma \text { é } \\
\text { disponível. }\end{array}$ \\
\hline
\end{tabular}

Lee et al. (2011) afirmam que, se não há dados experimentais disponíveis para o material analisado ou se a razão de tensão $R$ está fora da faixa $-2 \leq R \leq 0,45$, então a correção da tensão média deve necessariamente ser realizada utilizando a diretriz técnica alemã FKMGuideline (2003). A FKM-Guideline (2003) apresenta uma maneira mais moderna de se contabilizar o efeito da tensão média e, na verdade, esta maneira pode ser utilizada para qualquer faixa de razão de tensão $R$. Por isso, a contabilização do efeito da tensão média utilizando a metodologia da FKM-Guideline (2003) tem sido cada vez mais utilizada e recomendada, estando incluída nos softwares de análise de fadiga comerciais $n$ Code Design Life (HBM), FEMFAT (Magna Powertrain), MSC Nastran Embedded Fatigue (MSC.Software), o fe-safe (Dassault Systèmes), o winLIFE (Steinbeis Foundation) e o Fatiga (Fatec Engineering).

Para contabilizar o efeito da tensão média, a FKM-Guideline (2003) introduz um parâmetro para auxiliar na construção do diagrama de Haigh, o fator de sensibilidade à tensão média, $M_{\sigma}$, que é a inclinação do gráfico de vida constante. O fator $M_{\sigma}$ depende do tipo de material e da condição de carregamento. Por exemplo, um componente sujeito à tensão cíclica normal terá um diagrama de Haigh diferente do mesmo componente sujeito à tensão cíclica cisalhante.

De acordo com a FKM-Guideline (2003), o diagrama de Haigh para tensão normal pode ser classificado como possuindo 4 regimes, conforme mostrado na figura 4.36 e sumarizado a seguir:

\section{- Regime I: $R>1$}

É aplicado para um carregamento com razão de tensão $R>1$ onde as tensões máxima e mínima são negativas (compressão).

- Regime II: $-\infty \leq R \leq 0$

É aplicável para o caso onde $-\infty \leq R \leq 0 . R=-\infty$ significa que a tensão máxima é $S_{\max }=0 ; R=-1$ representa o estado de tensão totalmente reversa; $R=0$ representa tensão de tração pulsante. 
- Regime III: $0<R \leq 0,5$

É representado por $0<R<0,5$ onde as tensões máxima e mínima são positivas.

- Regime IV: $R>0,5$

Ocorre quando para $R \geq 0,5$, caracterizado por um regime de alta tensão, onde $S_{m}>$ $S_{a}$.

A FKM-Guideline (2003) informa que o fator de sensibilidade à tensão média $\left(M_{\sigma}\right)$ é obtido através da equação (4.85) quando há apenas de tensão normal presente. Esta diretriz permite calcular o fator de tensão média $C_{m}$ para diversos metais, bastando alterar os parâmetros $a_{C_{m}}$ e $b_{C_{m}}$, apresentados na tabela 4.14

$$
M_{\sigma}=a_{C_{m}} \cdot S_{u, 97.5}+b_{C_{m}}
$$

Onde

$$
\begin{array}{ll}
a_{C_{m}} \text { e } b_{C_{m}}: & \text { Parâmetros de material listados na tabela } 4.14 \\
S_{u, 97.5} & : \begin{array}{l}
\text { Limite de resistência à tração para } 97,5 \% \text { de confiabilidade (R97,5\%) ob- } \\
\text { tido em um ensaio de tração quase-estático para obtenção da curva } \sigma-\varepsilon .
\end{array} \\
& \begin{array}{l}
S_{u, 97.5}=S_{u} \cdot C_{R} \text { sendo } C_{R} \text { calculado conforme tabela } 4.11 \text { para confiabili- } \\
\text { dade de } 97,5 \%
\end{array}
\end{array}
$$

Tabela 4.14 Fatores $a_{C_{m}}$ e $b_{C_{m}}$ para vários materiais (em temperatura ambiente) FKM-Guideline (2003).

\begin{tabular}{lll}
\hline \multicolumn{1}{c}{ Materiais } & \multicolumn{1}{c}{$a_{c_{m}}$} & $b_{c_{m}}$ \\
\hline Aço & 0,00035 & $-0,1$ \\
Aço para fundição & 0,00035 & 0,05 \\
Ferro fundido nodular & 0,00035 & 0,08 \\
Ferro fundido maleável & 0,00035 & 0,13 \\
Ferro fundido cinzento & 0 & 0,5 \\
Ligas de alumínio trabalhado & 0,001 & $-0,04$ \\
Ligas de alumínio fundido & 0,001 & 0,2 \\
\hline
\end{tabular}

Assim, de acordo com a diretriz técnica alemã FKM-Guideline (2003), o fator de tensão média $\left(C_{m}\right)$ é calculado conforme as equações abaixo, para cada um dos quatro regimes: 


$$
\begin{aligned}
& \text { Regime I: } \quad R>1 \quad C_{m}=\frac{1}{1-M_{\sigma}} \\
& \text { Regime II: } \quad-\infty \leq R \leq 0 \quad C_{m}=\frac{1}{1+M_{\sigma} \cdot \frac{1+R}{1-R}} \\
& \text { Regime III: } \quad 0<R \leq 0,5 \quad C_{m}=\frac{\frac{1+\left(M_{\sigma} / 3\right)}{1+M_{\sigma}}}{1+\left(M_{\sigma} / 3\right) \cdot\left(\frac{1+R}{1-R}\right)} \\
& \text { Regime IV: } \quad R>0,5 \quad C_{m}=\frac{1+\left(M_{\sigma} / 3\right)}{\left(1+M_{\sigma}\right)^{2}}
\end{aligned}
$$

Para projetos mecânicos, Wilson \& Haigh (1923) introduziram a linha de escoamento, também chamada de linha de Langer (linha tracejada vermelha das figuras 4.36 e 4.39), como uma restrição de projeto adicional para materiais. Toda vez que um carregamento caracterizado por um ponto nesta figura $\left(S_{a}, S_{m}\right)$ estiver abaixo desta linha então não haverá escoamento. No caso de carregamentos com amplitude variável, deve-se verificar se cada ciclo de carregamento $\left(S_{a, j}, S_{m, j}\right)$ ultrapassa a linha de Langer para garantir que não haja escoamento em nenhum momento da operação do componente (Shigley et al., 2003). Isto deve ser feito principalmente para carregamentos com tensão média alta (i.e., $R>0$ ) e para metais dúcteis (que possuem limite de escoamento bem abaixo do limite de resistência à tração).

A linha preta espessa da figura 4.36 é utilizada para o cálculo da tensão $S_{E, s p, R}$. Esta linha é considerada a linha do projeto seguro por considerar tanto a resistência à fadiga quanto a resistência ao escoamento.

Em metais frágeis, como o ferro fundido, o limite de escoamento à tração (YTS) e à compressão (YCS) são muito próximos ao limite de resistência à tração e à compressão, respectivamente. Por isso, nestes metais, é comum substituir os parâmetros YTS e YCS da figura 4.36 por UTS ${ }^{27}$ (Limite de Resistência à Tração) e UCS ${ }^{28}$ (Limite de Resistência à Compressão), respectivamente. Além do mais, metais frágeis apresentam UCS é muito maior do que UTS, o faz com que o diagrama de Haigh seja assimétrico para estes metais. Quanto maior a diferença entre o limite de resistência à tração $\left(S_{u}=U T S\right)$ e o limite de resistência à

\footnotetext{
${ }^{27}$ Em inglês, Ultimate Tensile Strength

${ }^{28}$ Em inglês, Ultimate Compressive Strength
} 
compressão $\left(S_{u, c}=U C S\right)$ mais assimétrico é o diagrama. As figuras 4.37 e 4.38 apresentam o diagrama de Haigh para ferro fundido nodular e cinzento, respectivamente, utilizadas no software de fadiga comercial FEMFAT 29 .

O diagrama de Haigh mostrado nas figuras 4.36, 4.37 e 4.38 foi construído para ser utilizado apenas quando o componente está sujeito à tensão normal. Na presença de tensão de cisalhamento (sem componente de tensão normal), o diagrama de Haigh muda de forma e passa a ter apenas três regimes, conforme ilustra a figura 4.39. Nos casos onde há apenas tensão cisalhante, o fator de sensibilidade à tensão média $\left(M_{\tau}\right)$ é calculado conforme a equação (4.90).

$$
M_{\tau}=C_{\tau} \cdot M_{\sigma}
$$

Onde

$C_{\tau} \quad: \quad$ Fator de correção de tensão em cisalhamento, estipulado na tabela 4.6 .

\subsubsection{Efeito da Frequência do Carregamento}

A influência da frequência no comportamento S-N dos metais é complicado por causa dos efeitos sinergéticos da temperatura, corrosão ambiental, sensividade da relação tensãodeformação com a taxa de deformação, e frequência de excitação. Independentemente, tanto a temperatura elevada quanto a corrosão são detrimentais à resistência à fadiga. Quando um espécime metálico é ciclado com um carregamento com alta frequência a temperatura do mesmo aumenta devido à histerese de amortecimento interno do material, e portanto a alta temperatura passa também a gerar uma mudança na curva S-N obtida. E isto acontece principalmente em metais de baixa resistência mecânica. A geração de calor devido ao carregamento cíclico depende do volume de material altamente tensionado. Portanto, carregamento axial em espécimes grandes irão produzir mais calor do que em espécimes pequenos sob flexão ou do que espécimes entalhados, e portanto os efeitos de frequência poderiam ser diferentes nestas situações. Se os efeitos do calor são negligenciados devido a várias técnicas de resfriamento e/ou devido à baixas tensões alternadas durante o teste, e os efeitos de corrosão são também negligenciados, então os efeitos da frequência podem ser mensurados. Sob as condições supracitadas e utilizando espécimes padronizados sob tensão axial ou flexão, carregamentos com frequência menores que $1 \mathrm{~Hz}$ até $200 \mathrm{~Hz}$ tem tido apenas um pequeno efeito sobre Curva S-N Espécime para a maioria dos metais estruturais (Stephens et al., 2000). Em altas frequências (mas ainda menores que $200 \mathrm{~Hz}$ ), a resistência à fadiga em

\footnotetext{
${ }^{29}$ Este software calcula o diagrama de Haigh de uma maneira um pouco diferente da diretriz FKM-Guideline (2003)
} 


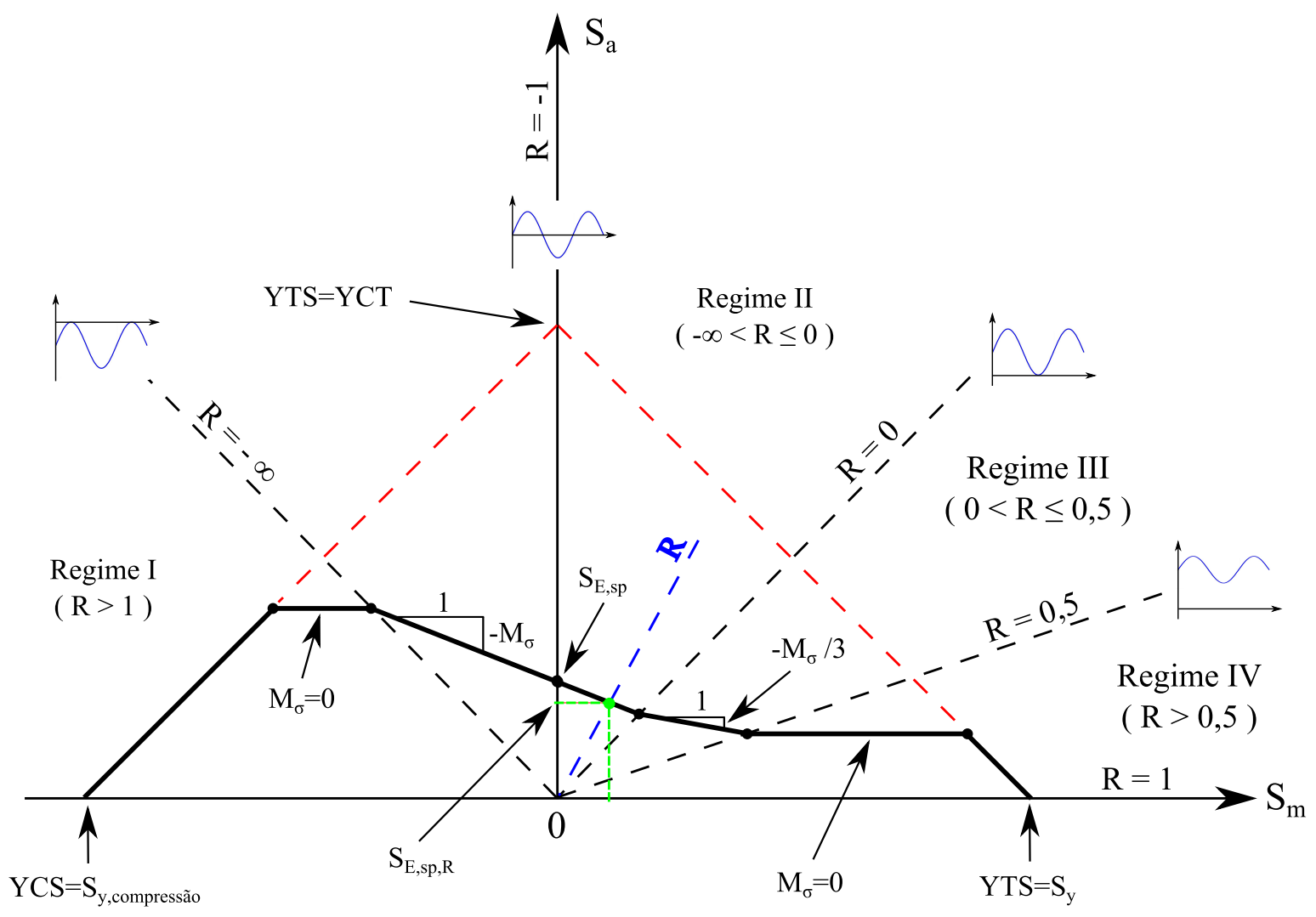

Figura 4.36 Diagrama de Haigh para contabilização do efeito da tensão média sob Tensão Cíclica Normal

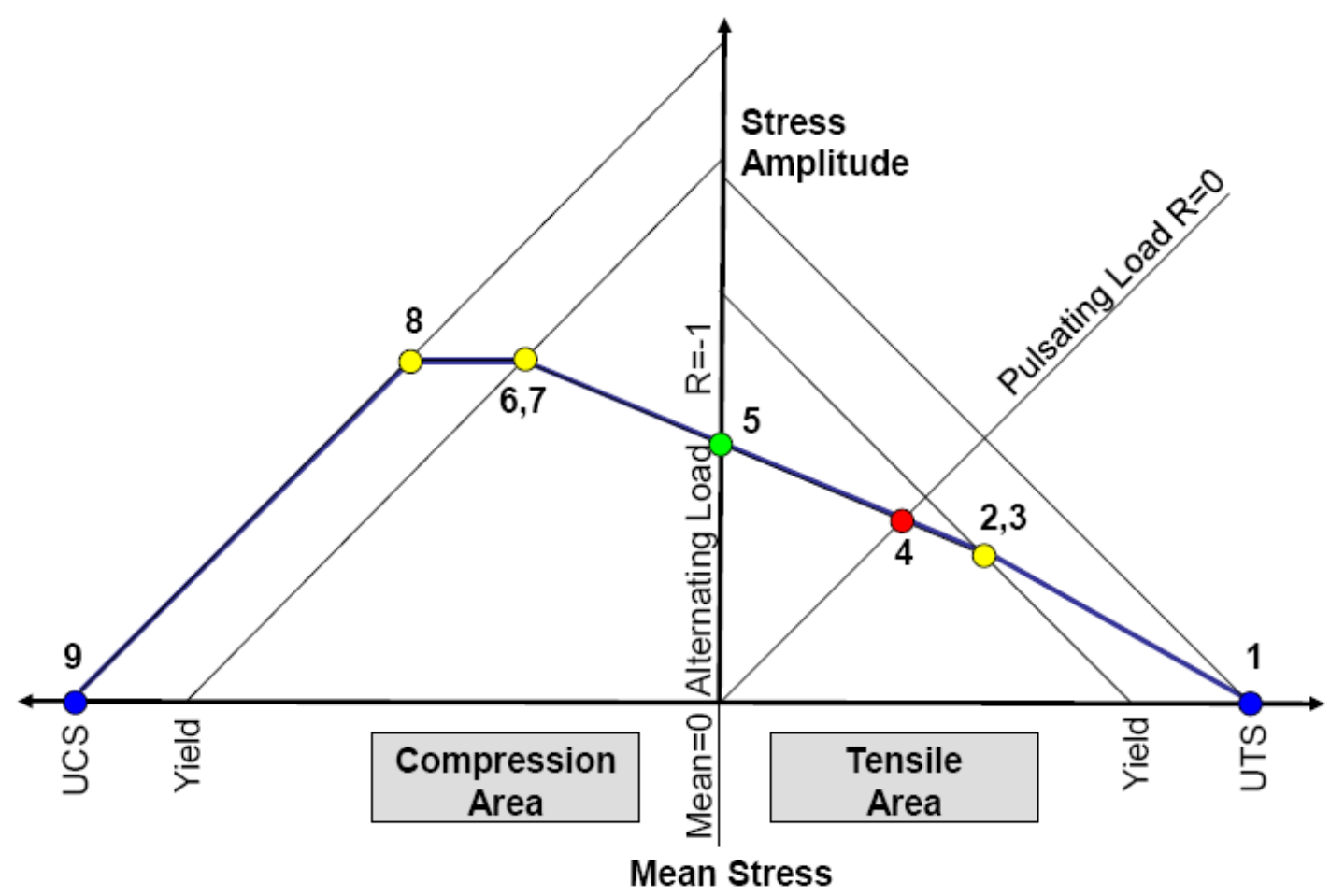

Figura 4.37 Construção do diagrama de Haigh para ferro fundido nodular (Magna Powertrain, 2011). 
$2 \bullet \mathrm{S}_{\mathrm{m}}=0,88 . \mathrm{S}_{\mathrm{uts}} \& \mathrm{~S}_{\mathrm{a}}=0,34 . \mathrm{S}_{\mathrm{a}, \mathrm{R}=-1}$

3० $S_{m}=0,76 . S_{\text {uts }} \& S_{a}=0,48 \cdot S_{a, R=-1}$

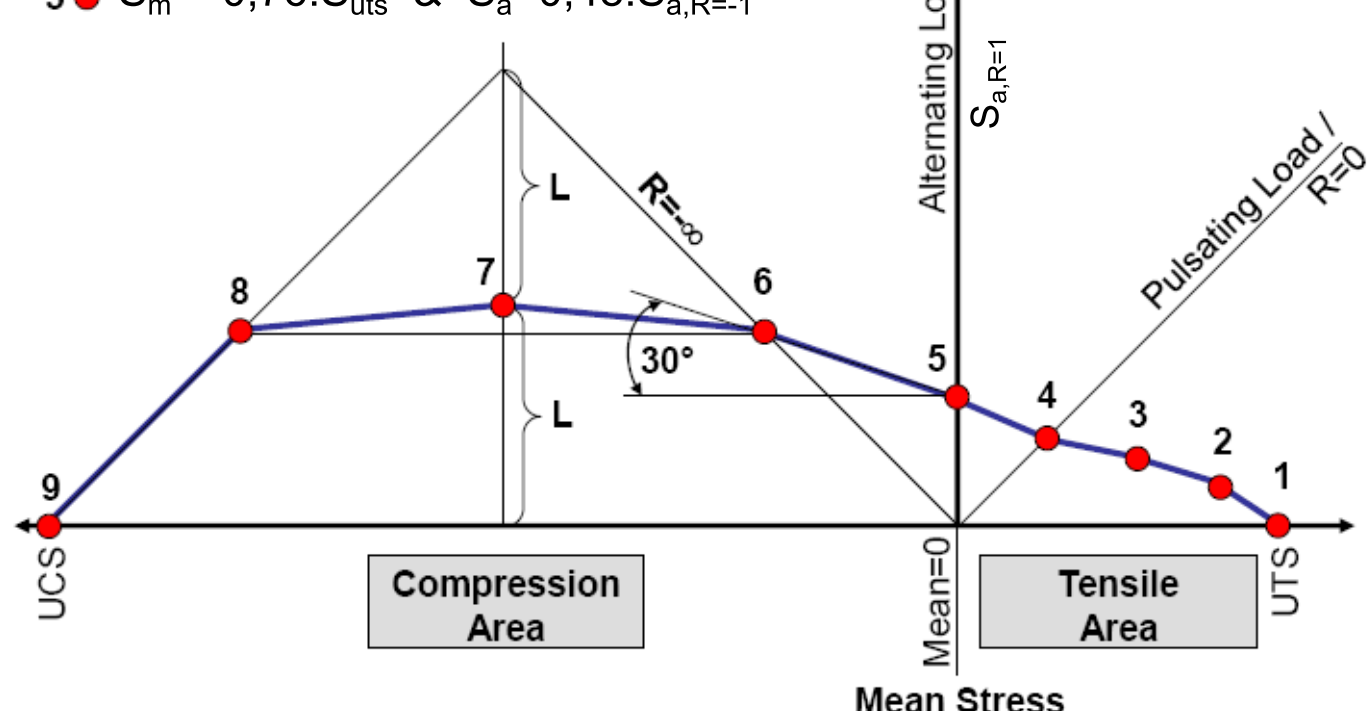

Figura 4.38 Construção do diagrama de Haigh para ferro fundido cinzento (Magna Powertrain, 2011).

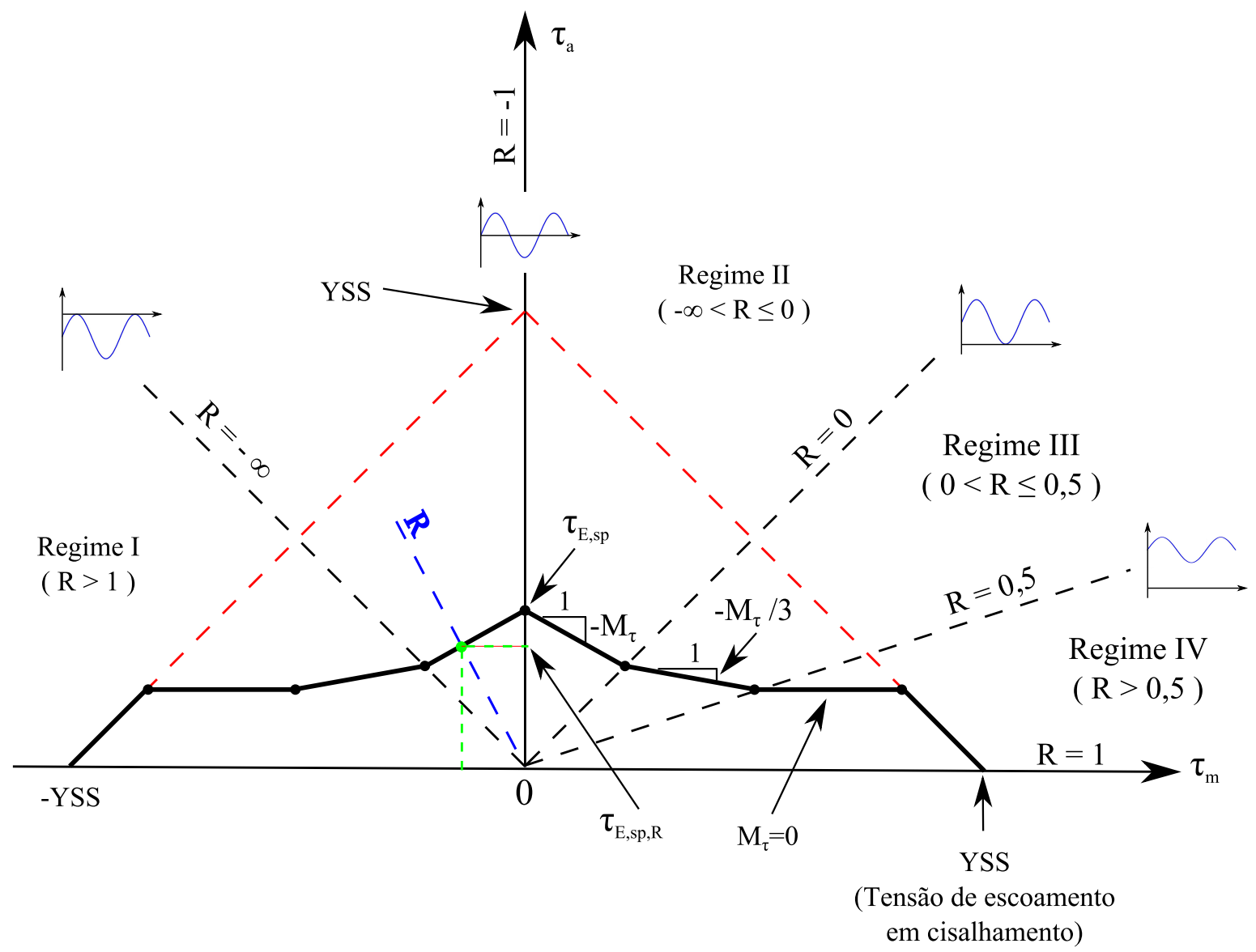

Figura 4.39 Diagrama de Haigh para contabilização do efeito da tensão média sob Tensão Cíclica Cisalhante 
$10^{6}$ até $10^{8}$ ciclos tem mostrado um aumento de zero até $10 \%$ Forrest, 1962, Stephens et al., 2000). Em tensões alternadas altas, um pequeno aumento na vida em fadiga também ocorreu; entretanto uma análise estatística mostrou que, na maioria dos casos, esta mudança na vida é devido à própria dispersão intrínseca em uma dada frequência. Praticamente em nenhum caso houve diminuição da resistência à fadiga devido ao aumento da frequência. Baseado nas informações supracitadas, com o conhecimento da ausência dos efeitos de temperatura e corrosão, os efeitos de frequência de até $200 \mathrm{~Hz}$ têm sido geralmente ignorados no projeto de fadiga e em seus testes físicos. É importante lembrar que a chave destas conclusões estão baseadas na ausência do aumento de temperatura e da corrosão.

$\mathrm{Na}$ faixa de frequência na ordem de $\mathrm{kHz}$, mudanças maiores na resistência à fadiga tem ocorrido, comparado com aquelas em menos que $200 \mathrm{~Hz}$. A temperatura aumentam muito nessas frequências (1 à $25 \mathrm{kHz}$ ) e são mais difíceis de controlar. Nestas condições os espécimes são resfriados por ar, água, água com inibidores ou óleos especiais que fazem contato com a superfície do espécime (Stephens et al., 2000). Testes intermitentes também tem sido usados para manter condições isotérmicas. Máquinas de fadiga de ultra alta frequência $(\mathrm{kHz})$ são pneumátcas, piezoelétricas ou magnéticas, e os espécimes testados nestas condições podem ser não entalhados, entalhados ou até mesmo pré-trincados. Os limites de fadiga obtidos nestes testes ficam entre $10^{6}$ à $10^{8}$ ciclos. O valor do limite de fadiga em frequências $\mathrm{kHz}$ aumentam em um fator 1 até 2,6, comparado com testes abaixo de $20 \mathrm{~Hz}$ (Stephens et al. 2000). Entretanto, apesar das muitas tendências em direção ao aumento da resistência à fadiga em frequências $\mathrm{kHz}$, é ainda difícil fazer uma generalização devido ao grande número de variáveis de testes/materiais complexos envolvidos (Stephens et al., 2000).

Carregamentos abaixo de $10 \mathrm{~Hz}$ geralmente não causam aquecimento significativo em componentes de plástico e por isso a frequência de carregamento pode ser ignorada nesses casos Unger (2011).

\subsection{Curva Tensão-Vida Local}

Durante o projeto de um componente o engenheiro de durabilidade frequentemente se depara com um problema: a ausência das propriedades de fadiga do material. Mais ainda, é quase certo que a curva S-N do componente analisado não existirá. Nestes casos, métodos para estimar a curva S-N do componente a partir da Curva $S-N$ Espécime se tornam úteis e cruciais no processo de desenvolvimento de produtos. A seção 4.3 mostrou como utilizar a Curva $S$-N Espécime para estimar a Curva $S$-N Unnotched. Isto é feito através dos fatores modificadores, que contabilizam as características que diferem o componente mecânico analisado do espécime padronizado de Moore. Praticamente todos os fatores foram considerados na seção 4.3, com exceção de um: o fator de entalhe. Assim, falta apenas ser aplicado o fator de entalhe na Curva S-N Unnotched para se obter a Curva Tensão-Vida Local. 
É importante lembrar que existem dois tipos de Curva Tensão-Vida Local: a Curva $\mathbf{S}-\boldsymbol{N}$ Local (apresentada na figura 4.43) e a Curva $\sigma-N$ Local (apresentada na figura 4.49), e o uso de cada uma dependerá do tipo de metodologia que o especialista em fadiga escolher utilizar. Existem duas metodologias que podem ser utilizadas: a Curva $\mathbf{S}-\boldsymbol{N}$ Local é obtida utilizando o fator de entalhe calculado através do Método $K_{f}$ (a ser explicado na seção 4.4.1) enquanto a Curva $\sigma-N$ Local é obtida utilizando o fator de entalhe obtido através do Método do Gradiente de Tensão Relativo (a ser explicado na seção 4.4.2).

É importante que fique bastante claro que cada ponto (ou nó, caso a análise de fadiga esteja utilizando resultados de Análise por Elementos Finitos da superfície do componente possui uma Curva $S$ - $N$ Local, pois cada curva foi obtida utilizando-se fatores modificadores que geralmente diferem de ponto para ponto do componente, conforme ilustra a figura 4.27. Como exemplo pode-se citar o fator de tamanho. Este fator possibilita prever como o aumento da área da seção transversal do espécime influencia na vida em fadiga. Foi mostrado que quanto maior for o diâmetro do objeto ciclado, quando comparado com o espécime padronizado de $7,5 \mathrm{~mm}$, menor será a vida em fadiga deste objetd 20 Um componente pode ter geometria complexa e várias seções transversais, cada seção possuindo uma área transversal diferente uma das outras. Desta maneira, tendo em mente o conceito de fator de tamanho, sabemos que cada ponto da superfície do componente poderá nuclear uma trinca e cada trinca demorará um número de ciclos para se propagar pela seção transversal até a ruptura. Em outras palavras, cada ponto da superfície pertence a uma seção transversal e portanto existe uma curva S-N associada àquele ponto e a seção transveral que passa por ele. Adicionalmente, um componente possui curvas (mudança de geometria) como entalhes que geram aumento de tensão localmente, que por sua vez estão associados com um fator de concentração de tensão $\left(K_{t}\right)$. Experimentos com espécimes não entalhados e entalhados mostraram que entalhes causam uma redução na vida em fadiga. Portanto, como um componente mecânico típico possui vários entalhes em sua superfície, cada ponto na superfície está associado a uma Curva Tensão-Vida. E este é exatamente o conceito da fundamental por trás do Método da Curva Tensão-Vida Local, apresentado no início da seção 4.3.2 e nas figuras 4.25, 4.26 e 4.27.

Trincas por fadiga tipicamente nucleiam na superfície (ou em inclusões/precipitados localizados ligeiramente abaixo dela) de um componente, principalmente na superfície da raíz de um entalhe onde o nível de tensão é amplificado devido ao efeito de concentração de tensão.

Análise estrutural utilizando o Método dos Elementos Finitos já é uma realidade na indústria e na área acadêmica. Isto acontece porque esta ferramenta facilita a solução de problemas reais, que na maioria das vezes possuem geometria, materiais e condições de con-

\footnotetext{
${ }^{30} E$ É interessante notar que o componente maior quebrará mais rápido, mesmo possuindo uma área da seção transversal maior e tendo mais material para a trinca romper.
} 
torno complexas. Adicionalmente, análises de fadiga utilizando os resultados de análises de Elementos Finitos têm sido cada vez mais realizadas, devido à facilidade, rapidez e precisão na previsão de vida quando o computador é utilizado.

Para que a análise estrutural numérica tivesse um custo computacional baixo, muitas técnicas de análise de entalhe foram desenvolvidas para estimar as respostas de tensãodeformação locais baseadas nos resultados de Análise por Elementos Finitos elástica, linear (Neuber (1961), Molsky \& Glinka (1981), Hoffmann \& Seeger (1989), Barkey et al. (1994), Lee et al. (1995), Moftakhar et al. (1995), Gu \& Lee (1997), Lee \& Gu (1999), Buczynski \& Glinka (2000) ). De acordo com Lee et al. (2011, pg. 61 e 162), a tensão calculada neste tipo de análise é denominada por pseudo tensão ou tensão fictícid ${ }^{31}$, cujo símbolo é “ $\sigma^{e}$ ”, para diferenciar da tensão verdadeira " $\sigma$ " quando ocorre plasticidade. Obviamente, quando os níveis de tensão são baixos e não ocorre plasticidade, $\sigma^{e}=\sigma$.

O cálculo das pseudo tensões se torna um passo crucial na análise de entalhes para estimar as respostas de tensão-deformação verdadeira $(\sigma-\varepsilon)$ local. A análise de tensão estática e a análise dinâmica linear por superposição modal são as duas técnicas mais comuns para análise de pseudo tensão (Lee et al., 2011, pg. 61). Em uma análise estática, as pseudo tensões podem ser obtidas por superposição de todas as influências de pseudo tensões das cargas aplicadas em cada intervalo de tensão (time step). Na análise dinâmica linear por superposição modal, as pseudo tensões podem ser calculadas através da soma das tensões dos modos normais e coordenadas modais. Se a fadiga devido à ressonância é o problema principal, a análise dinâmica linear por superposição modal é recomendada; fora isso, a análise estática poderia ser a escolha principal.

Para um componente com um entalhe superficial, a tensão elástica na raiz do entalhe $\left(\sigma^{e}\right)$ pode ser determinada pelo produto da tensão nominal $(\mathrm{S})$ e o fator de concentração de tensão elástico $\left(K_{t}\right)^{32}$,

$$
\sigma^{e}=K_{t} \cdot S
$$

A pseudo tensão $\sigma^{e}$ pode ser calculada através de uma Análise por Elementos Finitos. Seja a figura 4.40. A tensão nominal $(S)$ é calculada como sendo a força sobre o componente $(F)$ dividida pela área da seção transversal crítiç ${ }^{33}\left(A_{\text {notched }}\right)$. O fator de concentração de tensão elástico é uma função da geometria do entalhe e do tipo de carregamento. Para os casos onde a geometria do componenete é relativamente simples e a tensão nominal pode ser facilmente definida, os fatores de concentração de tensão estão geralmente disponíveis na literatura. Entretanto, devido às complexidades da geometria e carregamento na maior parte

\footnotetext{
${ }^{31}$ Tradução livre do autor para pseudo stress e fictitious stress, respectivamente. Referência: Lee et al. (2011).

${ }^{32}$ Também intitulado fator de concentração de tensão geométrico ou apenas fator de concentração de tensão.

${ }^{33}$ Do inglês, net section.
} 
dos componentes reais, o valor de $\sigma^{e}$ somente pode ser obtido diretamente através de análise por Elementos Finitos.

Sejam os espécimes da figura 4.41 a serem submetidos à um teste de fadiga sob força axial de amplitude $F_{a}=\frac{F_{\max }-F_{\min }}{2}$. Cada espécime possui um valor diferente de fator de concentração de tensão $\left(K_{t}\right)$, mas possuem a mesma área da seção transversal crítica (cujo diâmetro é $\varnothing_{s p}=1 / 4 \mathrm{pol}$ ), e portanto possuem a mesma tensão alternada nominal $\left(S_{a}\right)$ se submetidos à mesma força cíclica. $\mathrm{O}$ espécime da figura 4.41a possui um raio muito grande e portanto $K_{t} \approx 1$, portanto considera-se este espécime como sendo um espécime não entalhado. Experimentos com espécimes semelhantes ao da figura 4.41 mostrou que o limite de fadiga de um espécime entalhado é menor do que o limite de fadiga do espécime sem entalhe, sob o mesmo valor de tensão alternada nominal $\left(S_{a}\right)$. A figura 4.42 apresenta este experimento. Quanto mais agudo era o entalhe, menor era o valor do limite de fadiga.

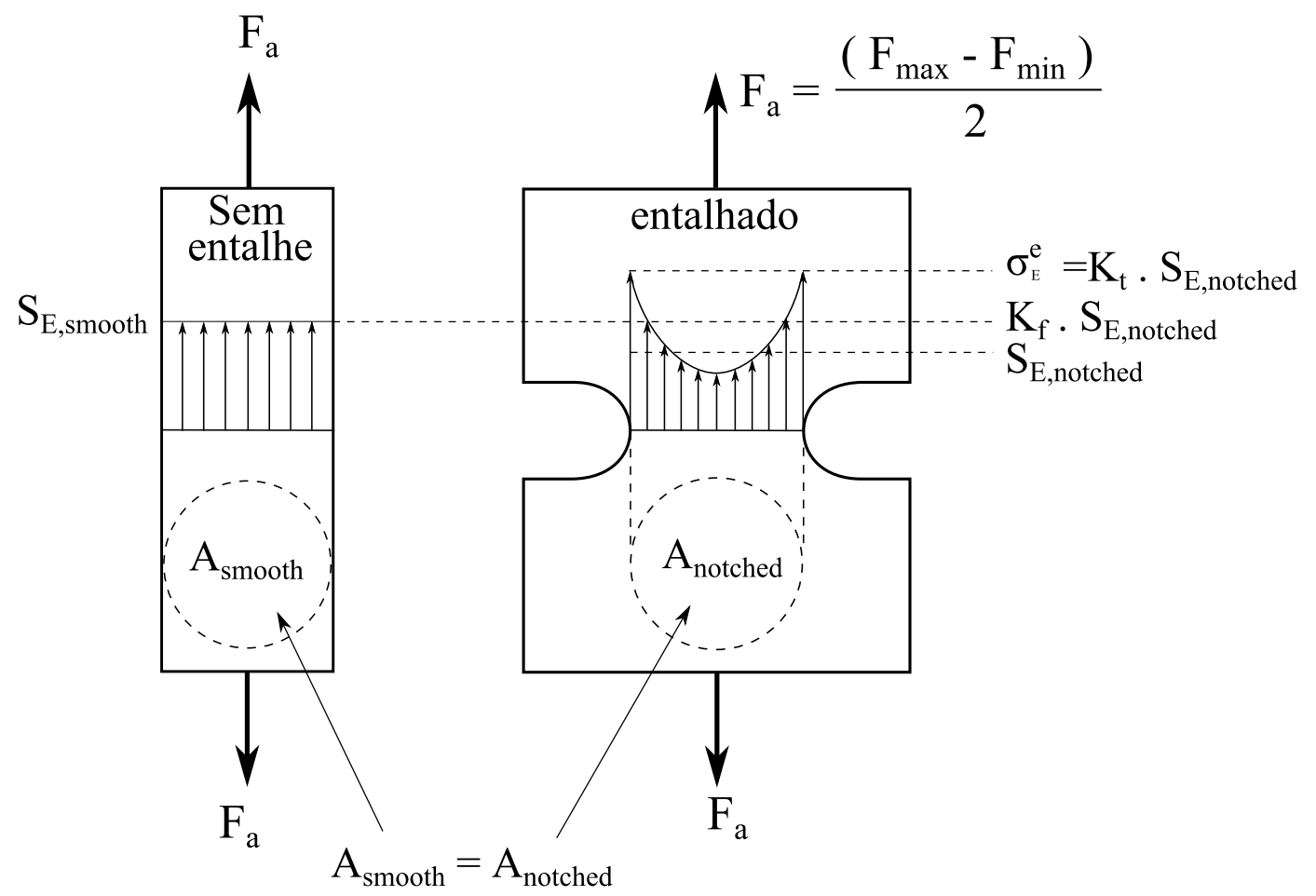

Figura 4.40 Componentes entalhado e não entalhado com a mesma vida em fadiga.

Antigamente acreditava-se que o limite de fadiga de um espécime não entalhado era reduzido pelo fator de concentração de entalhes $K_{t}$. Entretanto, experimentos mostraram que o limite de fadiga do espécime não entalhado é reduzido por um fator $K_{f}$, chamado fator de entalhe em fadiga ou fator de redução de resistência em fadiga. Este fator, representado pela equação (4.92), é definido como a razão do limite de fadiga de um espécime não entalhado pelo limite de fadiga de um espécime entalhado (ambos possuindo a mesma área transversal crítica). A figura 4.40 ilustra o conceito do fator de entalhe em fadiga. O fator $K_{f}$ é quase sempre menor do que $K_{t}$. A figura 4.42 apresenta a diferença entre o limite de fadiga de um 


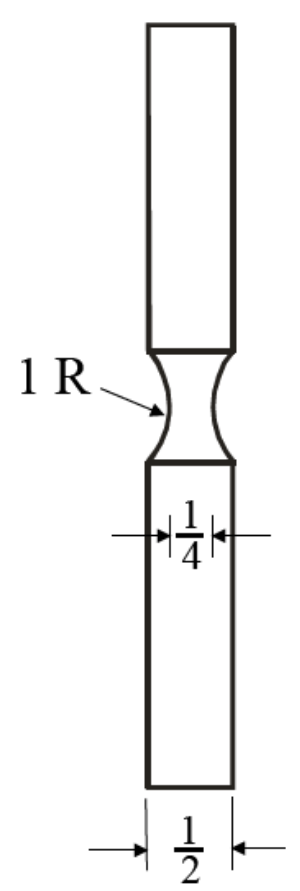

(a)

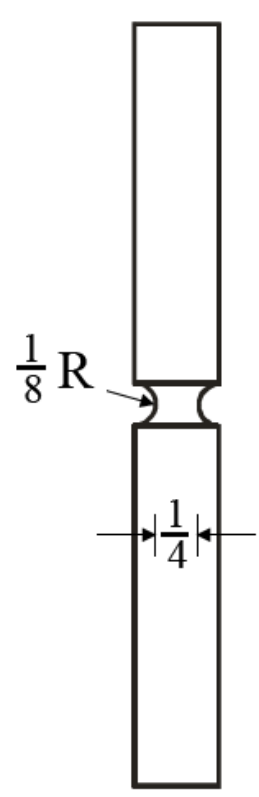

(b)

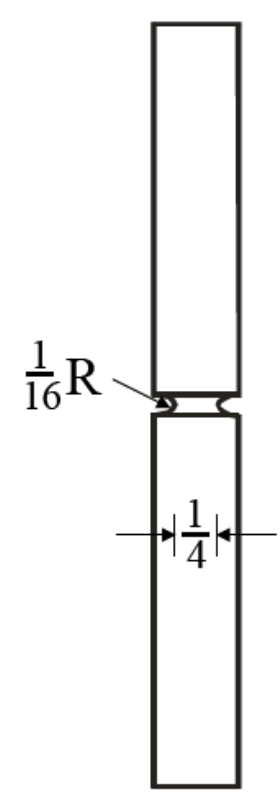

(c)

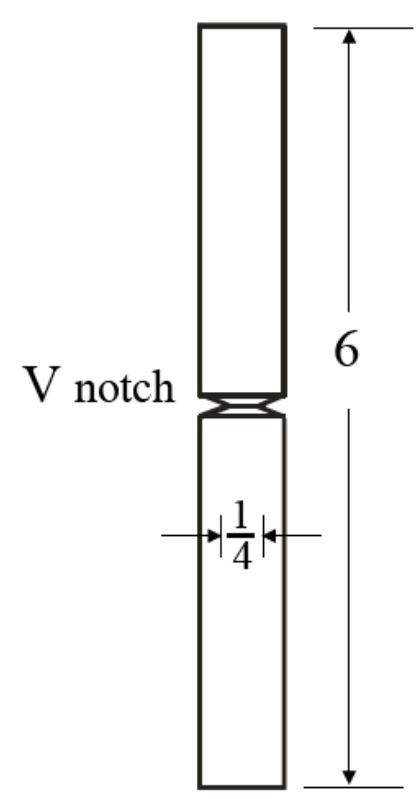

(d)

Figura 4.41 Espécimes de fadiga com diferentes tipos de entalhes.

espécime não entalhado dividido pelo fator $K_{f}$ (i.e. $\frac{S_{E, s p}}{K_{f}}$ ) e o limite de fadiga de um espécime não entalhado dividido pelo fator $K_{t}$ (i.e. $\frac{S_{E, s p}}{K_{t}}$ ).

$$
K_{f}=\frac{S_{E, \text { un }}}{S_{E, \text { notched }}}
$$

Onde

$S_{E, \text { un }} \quad: \quad$ Limite de fadiga de um espécime não entalhado

$S_{\text {Enotched }}$ : Limite de fadiga de um espécime entalhado

Para aplicações em engenharia, o fator de entalhe em fadiga pode ser empiricamente relacionado ao fator de concentração de tensão através do fator de sensibilidade ao entalhe $q$ conforme a equação seguinte:

$$
q=\frac{K_{f}-1}{K_{t}-1} \quad 0 \leq q \leq 1
$$

A equação 4.93 pode ser escrita de uma forma mais prática:

$$
K_{f}=1+\left(K_{t}-1\right) \cdot q
$$

O fator $K_{f}$ pode ser igual ou menor do que $K_{t}$, embora seja menor na maioria das situações. A diferença entre $K_{f}$ e $K_{t}$ aumenta quanto menor for o raio do entalhe ou quanto 


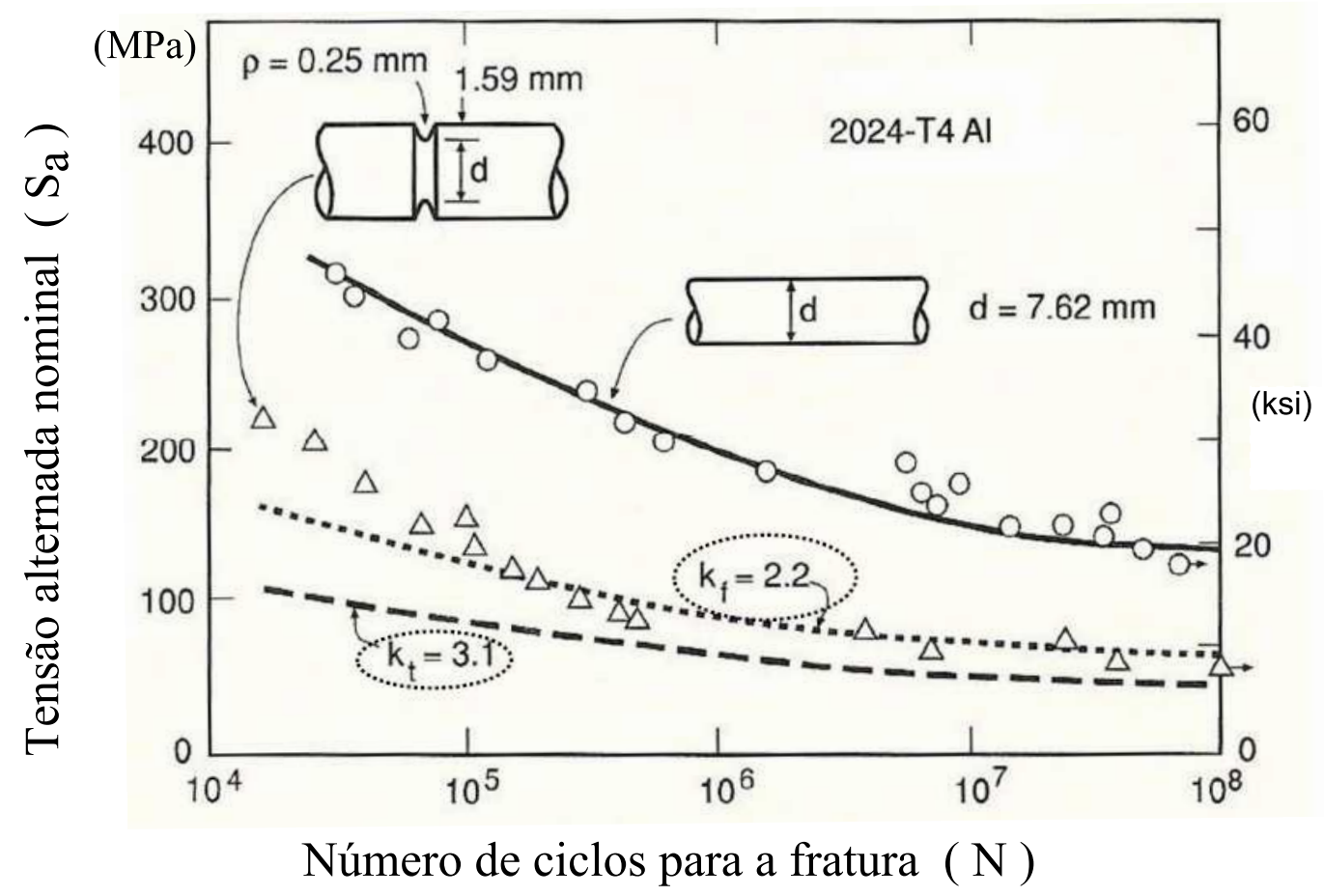

Figura 4.42 Efeito de um entalhe no comportamento Tensão-Vida de metais em regime de Fadiga de Alto Ciclo (Extraído de Lopes (2012)).

maior o limite de resistência à tração do metal Lee et al. (2005). Se $q=1$ então $K_{f}=K_{t}$ e o material é considerado como sendo completamente sensível ao entalhe. Entretanto, se $q=0$ então $K_{f}=1$ e o material é considerado não sensitivo ao entalhe. Metais com grãos pequenos e uniformes possuem alta sensibilidade à presença de entalhe (i.e., $q \rightarrow 1$ ) enquanto ferros fundidos são materiais que possuem $q \rightarrow 0$ porque a grafita lamelar age como um entalhe microscópico interno, nucleando facilmente trincas internas e reduzindo significamente o efeito dos entalhes externos macroscópicos. Shigley et al. (2003, pp. 329) afirmam que, sempre quando não houver dados disponíveis sobre $q$ do material analisado ou quando houver dúvida com relação ao valor real de $q$, recomenda-se utilizar $K_{f}=K_{t}($ i.e. $q=1)$, sendo essa uma atitude conservadora.

É importante ressaltar que, na obtenção de $K_{f}$ através da equação 4.92, os limites de fadiga são calculados utilizando dois tipos de espécimes. Os dois tipos de espécime possuem as mesmas características quanto à matéria prima, acabamento superficial, área da seção transversal crítica, tratamento superficial, temperatura e tipo de carregamento durante o ensaio de fadiga; a única diferença entre os dois é a presença do entalhe em um dos espécimes, conforme ilustrado na figura 4.40. Adicionalmente, também é importante que fique claro que as tensões da fórmula (4.92) são tensões nominais, medidas na seção crítica do corpo de prova.

A tensão média tem mais efeito em componente entalhados do que nos não entalha- 
dos.Tensão média compressiva pode reduzir significamente ou mesmo eliminar os efeitos da concentração de tensão em fadiga. Tensões residuais compressivas devido a tratamento superficial ou trabalho mecânico em um componente fazem com que haja tensão média compressiva. Estas tensões são muito maiores do que as tensões médias causadas pelas cargas externas. Por este motivo, shot peening e outros tratamentos que geram tensões residuais compressivas no componente ${ }^{34}$ são muito recomendáveis em componentes entalhados que estarão sujeitos à fadiga, principalmente naqueles que serão submetidos a tensão média positiva (Fatemi, sdb). O tratamento para incluir tensão residual compressiva não precisa ser realizado em todo o componente, basta apenas realizar na superfície dos entalhes. Isto é feito em virabrequins de motores a combustão interna e engrenagens, por exemplo.

Conforme mencionado no início da seção 4.4, resta apenas contabilizar o efeito do entalhe para que a Curva Tensão-Vida Local seja obtida. O efeito de entalhe pode ser contabilizado basicamente de 2 maneiras: através do Método $K_{f}$ e do Método do Gradiente de Tensão Relativo. Estes métodos serão vistos a seguir.

\subsubsection{Fator de Entalhe via Método $K_{f}$}

Neste método o fator de entalhe em fadiga $K_{f}$ é calculado utilizando a equação (4.94), após o fator $K_{t}$ e o $q$ terem sido calculados. O fator $K_{t}$ é obtido através da mecânica dos sólidos. Já o fator $q$ é calculado utilizando o método proposto por Neuber (1961) ou por Peterson (1959) Em seguida a Curva S-N Local é finalmente obtida a partir da Curva $S-N$ Unnotched com a aplicação do fator de entalhe $K_{f}$. A figura 4.43 apresenta a proposta de Collins (1993) para se estimar a Curva $S$-N Local da seção analisada do componente metálico. Na proposta de Collins (1993) o parâmetro $S_{f}^{\prime}$ não se altera e portanto

$$
S_{f}^{\prime}=S_{f, u n}^{\prime}
$$

O expoente de resistência à fadiga da Curva $S-N$ Local, $b$, é obtido utilizando os pontos $\left(N_{E}\right.$, $\left.S_{E}\right)$ e $\left(1 / 2, S_{f}^{\prime}\right)$ na equação 4.8 , conforme descrito abaixo:

$$
b=\frac{\log \left(S_{E} / S_{f}^{\prime}\right)}{\log \left(2 N_{E}\right)}
$$

Portanto, a equação da Curva S-N Local é dada por:

$$
S_{a}=S_{f}^{\prime} \cdot(2 N)^{b}
$$

\footnotetext{
${ }^{34}$ Pelo menos na superfície, onde as tensões devido às cargas externas tendem a ser maiores por causa do gradiente de tensões na flexão e na torção.

${ }^{35}$ Ambos os métodos geram resultados similares na prátcia.
} 
Há duas maneiras de calcular o fator de entalhe $K_{f}$ : através do Método de Neuber e do Método de Peterson. Nesta dissertação não será explicado em detalhes o cálculo do fator de entalhe pelo Método $K_{f}$, embora método possa ainda representar uma abordagem confiável. Na verdade, o Método $K_{f}$ não será explicado em detalhes porque possui a desvantagem de não poder ser utilizado em uma análise de fadiga baseada em Elementos Finitos. Outro método, mais poderoso, será o enfoque desta dissertação e será apresentado na seção 4.4.2. O leitor poderá encontrar mais informações sobre o Método $K_{f}$ em Lee et al. (2005, cap. 4), de Castro \& Meggiolaro (2009a, cap. 4) e Lee et al. (2011, cap. 4).

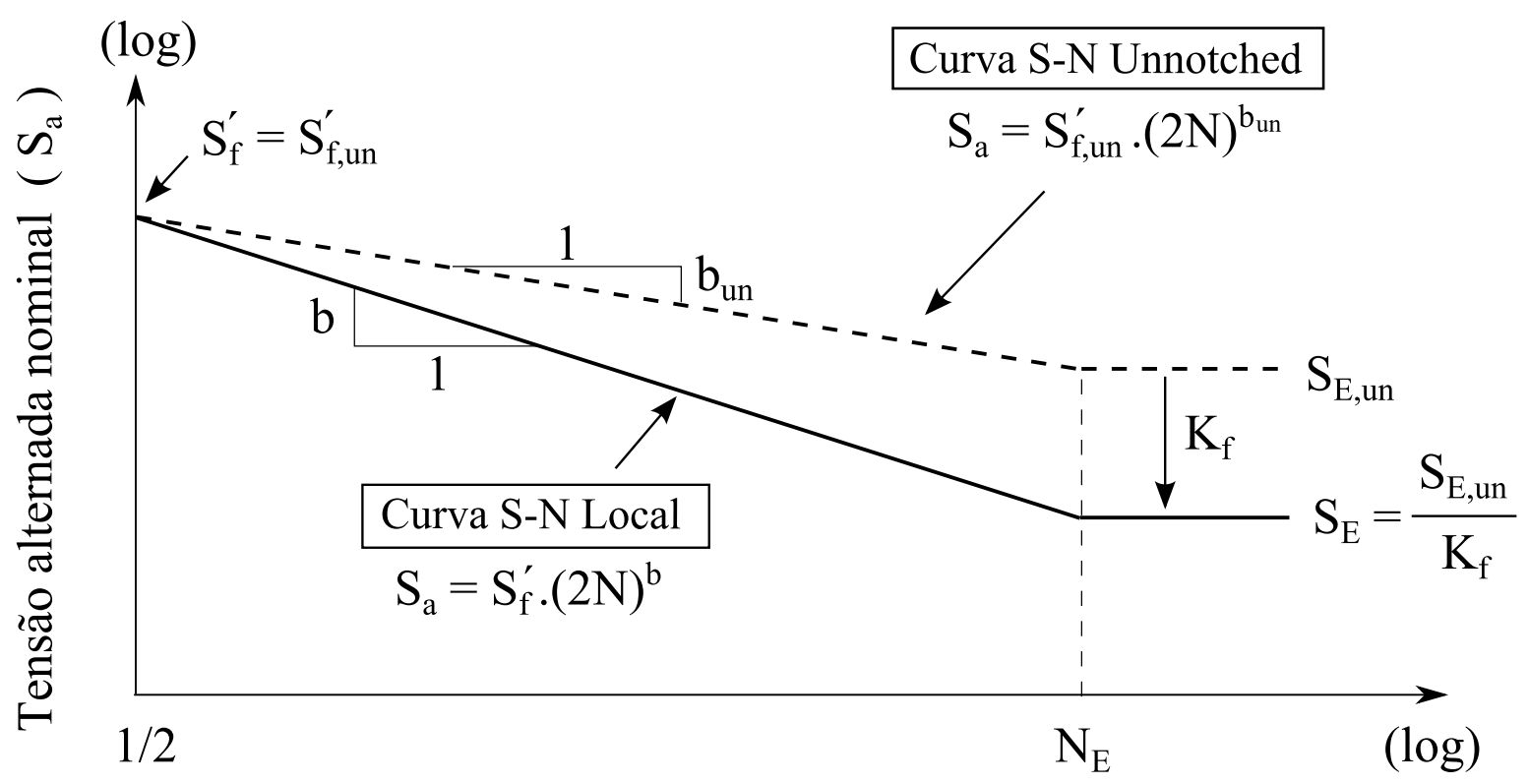

Ciclos até a falha $(\mathrm{N})$

Figura 4.43 Curva S-N Local de amplitude constante para um componente entalhado de aço.

É muito importante entender que a variável tensão alternada $\left(S_{a}\right)$ que aparece na equação 4.97) (i.e., a coordenada " $y$ " da figura 4.43, representa a tensão alternada nominal presente na seção transversal crítica do componente entalhado. Por exemplo, a tensão alternada nominal do componente entalhado da figura 4.40 que está sujeito a uma força alternada $F_{a}$ é igual à $S_{a}=\frac{F_{a}}{A_{\text {notched }}}$. Sejam dois componentes, um entalhado e um não entalhado, que possuem área da seção crítica iguais, conforme a figura 4.40, sendo estes componentes sujeitos ao mesmo carregamento externo $F_{a}$, então ambos possuirão a mesma tensão alternada nominal $S_{a}$. Entretanto, embora ambos possuam mesma $S_{a}$, a vida em fadiga do componente não entalhado será obtida através da Curva $S$-N Unnotched (equação 4.40 e a vida do componente entalhado será obtida através da Curva $S$ - $N$ Local (equação 4.97).

Grande parte das análises estruturais são realizadas utilizando o $\mathrm{MEF}$ devido aos compo- 
nentes e estruturas possuirem geometrias complexas, difíceis de serem analizadas através de cálculos analíticos. Desta maneira, é impossível determinar qual a tensão alternada nominal $\left(S_{a}\right)$ de um componente entalhado geometricamente complexo como o da figura 4.27, pois não há seção transversal nominal definível em uma análise por Elementos Finitos (Eichlseder, 2000a; Steiner et al., 2000). Para a utilização do Método $K_{f}$ (equação 4.94), faz-se necessário que se conheça o fator de concentração de tensão $K_{t}$ do ponto analisado do componente. Entretanto, a maior parte dos componentes mecânicos do mundo real, encontrados em automóveis, aeronaves e máquinas em geral, possuem geometria complexa e concentradores de tensão não convencionais, cujo valor de $K_{t}$ não pode ser determinado analiticamente. Assim sendo, não é possível utilizar o Método $K_{f}$ para a contabilização do efeito de entalhe em análise de fadiga de componentes com geometrias complexas (Eichlseder, 2000a; Lee et al., 2011; Mentley \& Pompetzki, 2006; Steiner et al., 2000).

Existe um procedimento que contorna este problema, baseado no Gradiente de Tensão (de uma análise por Elementos Finitos por exemplo). Este é o procedimento que será visto a seguir.

\subsubsection{Fator de Entalhe via o Método do Gradiente de Ten- são Relativo}

O Método do Gradiente de Tensão Relative 36 também chamado de Método do Fator de Suporte por Spaggiari et al. (2011), utiliza o gradiente de tensões do componente para determinar o efeito de entalhe em fadiga. Ao invés de utilizar o raio do entalhe, o método utiliza o valor do gradiente de tensão ao longo da profundidade do componente para se calcular o valor do fator de entalhe em fadiga.

Siebel \& Stieler (1955) propuseram um novo parâmetro $\left(\chi^{\prime}\right)$ em unidade de $1 / \mathrm{mm}$, intitulado gradiente de tensão relativo ${ }^{37}(\mathrm{RSG})$, que é definido para componentes sujeitos à tensão normal conforme segue:

$$
\chi_{\sigma}^{\prime}=\frac{\left(\chi_{\sigma}\right)_{x=0}}{\sigma_{\max }^{e}}=\frac{1}{\sigma_{\max }^{e}}\left(\frac{\mathrm{d} \sigma^{e}(x)}{\mathrm{d} x}\right)_{x=0}
$$

Onde

\footnotetext{
${ }^{36}$ Tradução livre do autor para Relative Stress Gradient

${ }^{37}$ Também conhecido como gradiente de tensão normalizado
} 
$x \quad$ : Distância a partir da raiz do entalhe, perpendicular à superfície do mesmo.

$\chi^{\prime} \quad$ : Gradiente de tensão ao longo de $\mathrm{x}$.

$\sigma_{\max }^{e} \quad$ : Pseudo tensão máxima (tensão normal elástica máxima) existente na raiz do entalhe.

$\sigma^{e}(x)$ : Distribuição da pseudo tensão calculada ao longo de x.

A figura 4.44 ilustra os parâmetros que definem a equação (4.98), comparando o gradiente de tensão relativo obtido em um componente não entalhado sob flexão com um componente entalhado sob carregamento axial.

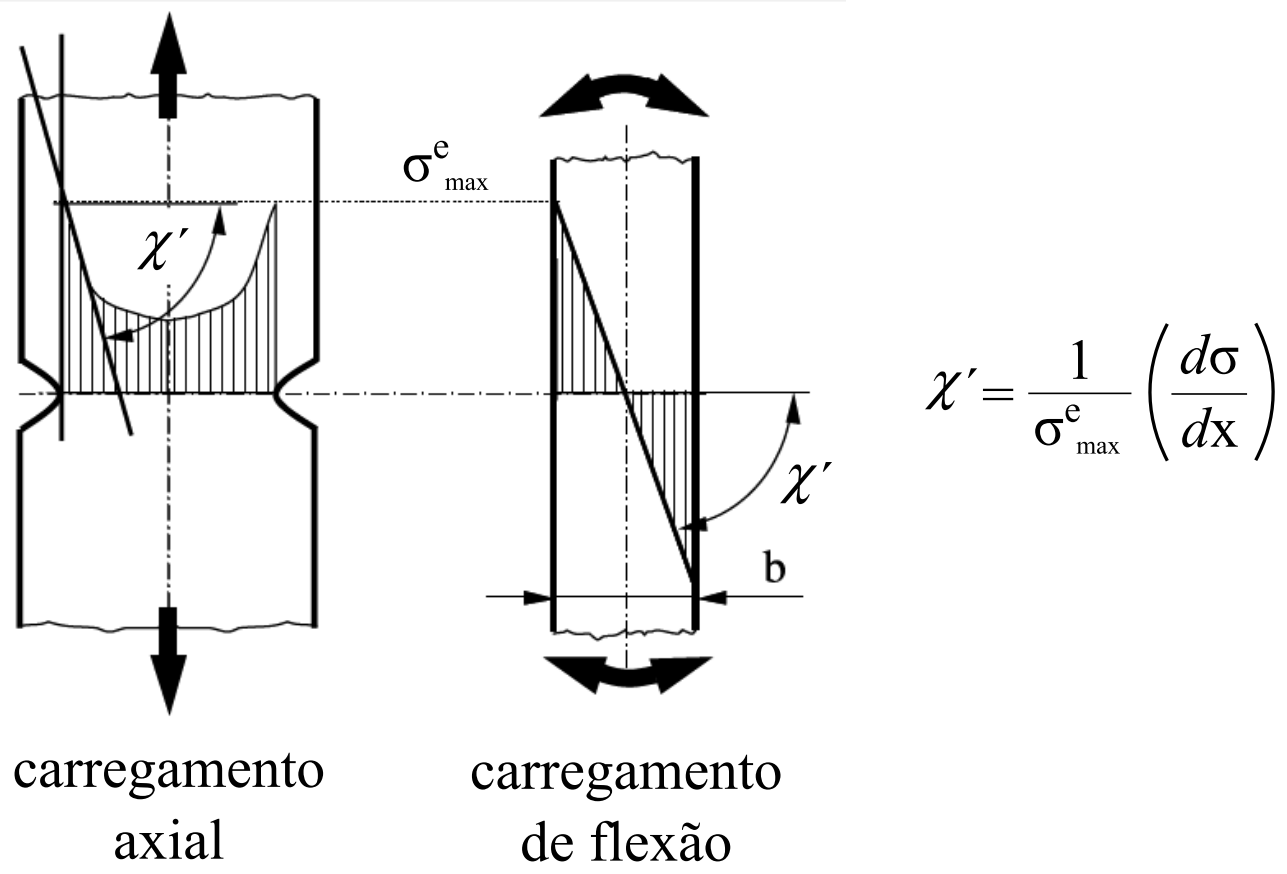

Figura 4.44 Distribuição de pseudo tensão e gradiente de tensão na raiz de um entalhe (adaptado de Eichlseder (2000a)).

Experimentos com vários componentes, com e sem entalhes, permitiram gerar uma série de curvas empíricas que relacionam a razão $\frac{K_{t}}{K_{f}}$ (medida no ciclo do limite de fadiga $N_{E}=$ $2 \cdot 10^{7}$ ) com o parâmetro $\chi^{\prime}$ para vários materiais, utilizando o limite de resistência à tração $S_{u}$ e o limite de escoamento $S_{y}$. Estas curvas empíricas são ilustradas nas figuras 4.45 até 4.46 para vários materiais. Desta forma, o fator de entalhe " $n_{K}$ " calculado pelo método do gradiente de tensão relativo é expressa pela seguinte fórmula genérica:

$$
n_{K}=\frac{K_{t}}{K_{f}}=1+\sqrt{a_{s s} \cdot \chi^{\prime}}
$$

Onde

$a_{s s} \quad$ : Parâmetro de material de Siebel e Stieler. 


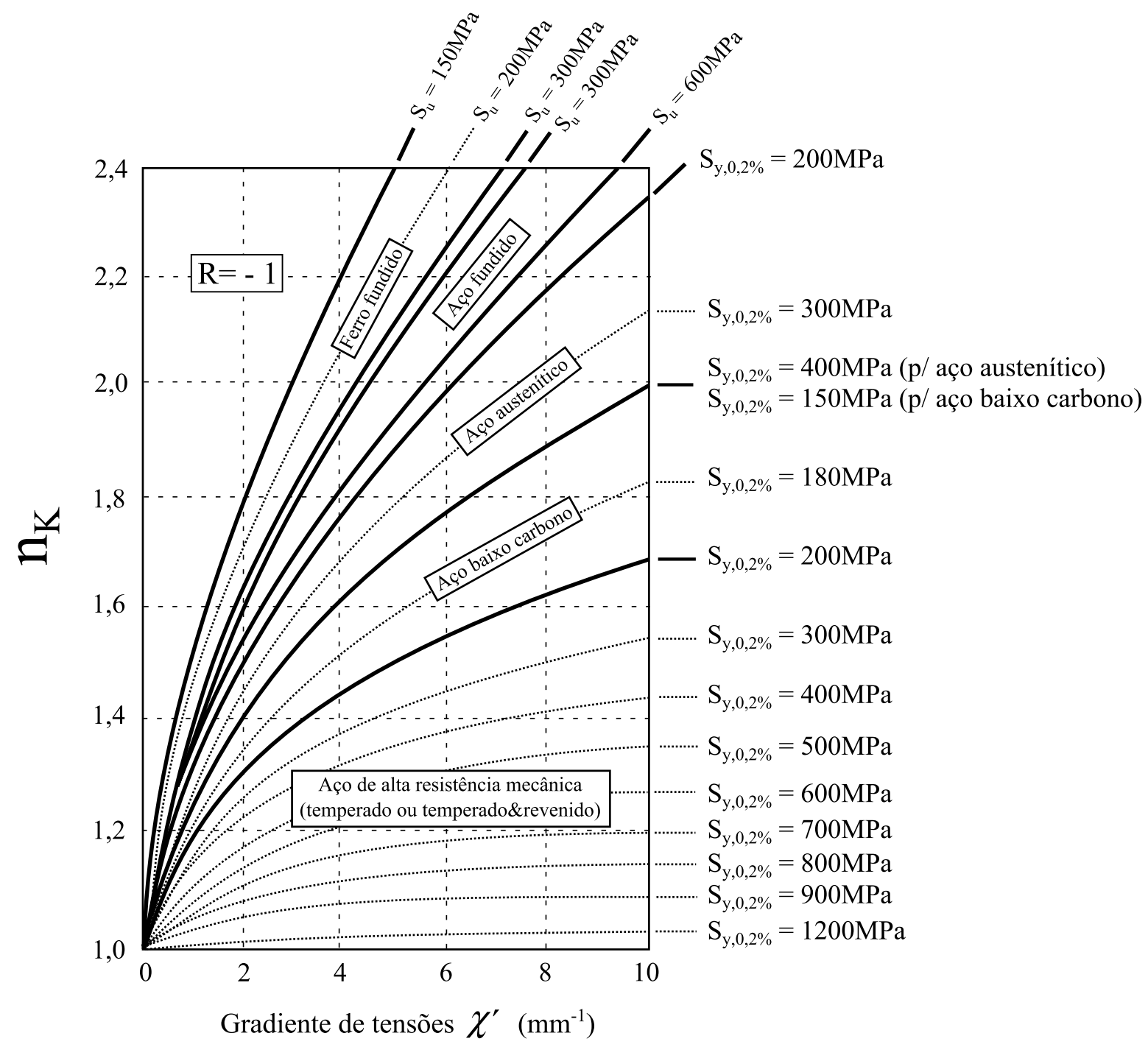

Figura 4.45 Efeito do gradiente de tensão relativo na razão $n_{K}=$ $K_{t} / K_{f}$ para vários materiais em termos da resistência mecânica.

O Conselho Alemão de Pesquisa em Engenharia (FKM-Guideline, 2003), baseado no conceito de Siebel \& Stieler (1955), propôs um método para contabilizar fator de entalhe em fadiga. O método da FKM possui vantagem sobre o método de Siebel \& Stieler (1955) por possibilitar o cálculo do fator de entalhe tanto para carregamentos que geram tensões normais $(\sigma)$ quanto para aqueles que geram tensões de cisalhamento $(\tau)$ no componente. Adicionalmente, o método apresenta melhorias quanto à contabilização do efeito de entalhe para ferro fundido e ligas de alumínio. De acordo com FKM-Guideline (2003), o fator de 


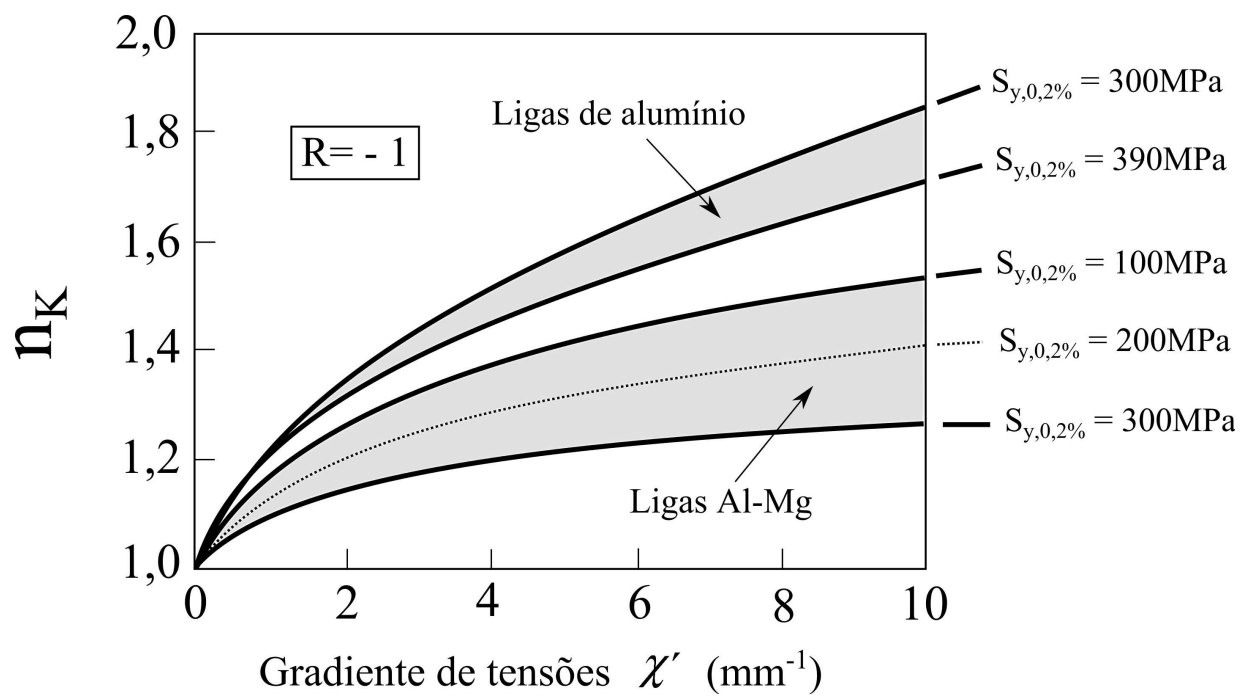

(a) Ligas de alumínio e Al-Mg.

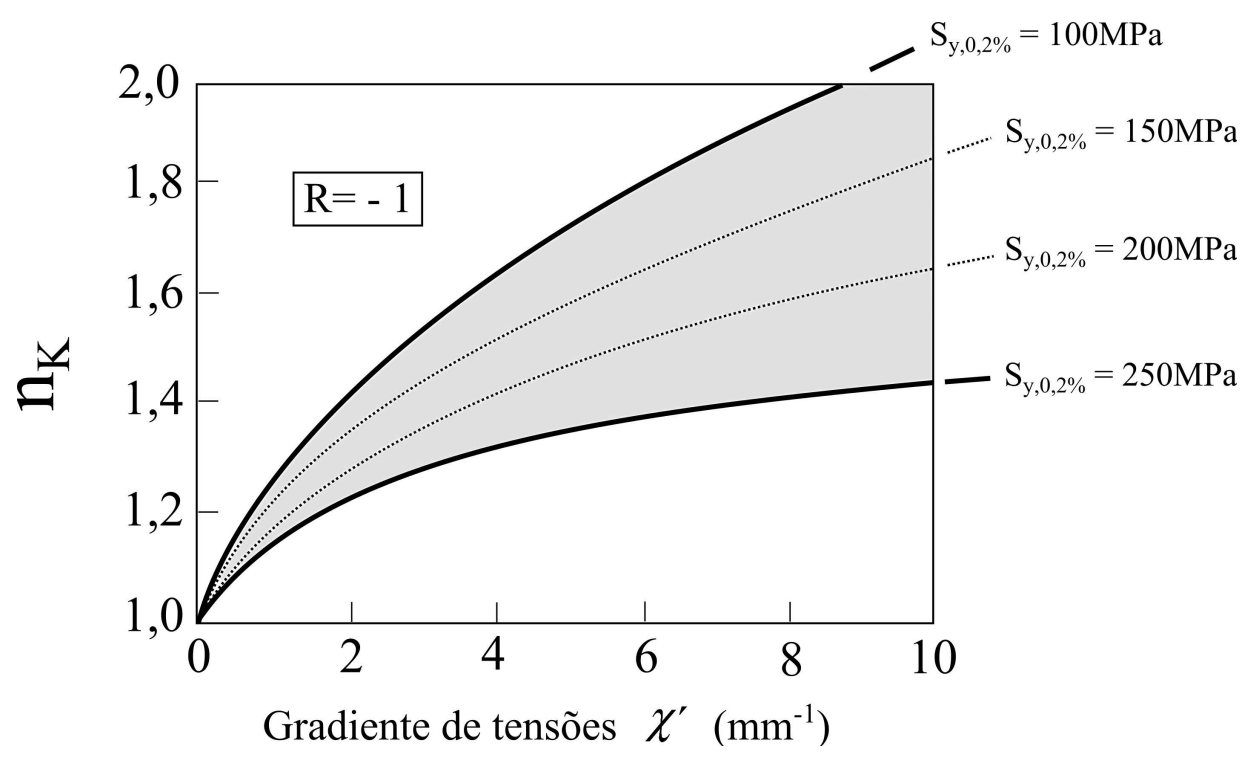

(b) Latão.

Figura 4.46 Efeito do gradiente de tensão relativo na razão $n_{K}=$ $K t / K f$ para ligas de alumínio e latão (adaptado de Santus (2007) e de Moraes Filho (2007)). 
entalhe para tensão normal é calculado conforme segue:

$$
\begin{array}{lll}
n_{K, \sigma}=1+\chi_{\sigma}^{\prime} \cdot 10^{-\left(a_{G}-0,5+\frac{s_{u, 97.5}}{b_{G}}\right)} & \text { para } & \chi_{\sigma}^{\prime} \leq 0,1 \mathrm{~mm}^{-1} \\
n_{K, \sigma}=1+\sqrt{\chi_{\sigma}^{\prime}} \cdot 10^{-\left(a_{G}+\frac{s_{u, 97.5}}{b_{G}}\right)} & \text { para } & 0,1 \mathrm{~mm}^{-1} \leq \chi_{\sigma}^{\prime} \leq 1 \mathrm{~mm}^{-1} \\
n_{K, \sigma}=1+\sqrt[4]{\chi_{\sigma}^{\prime}} \cdot 10^{-\left(a_{G}+\frac{s_{u, 97.5}}{b_{G}}\right)} & \text { para } & 1 \mathrm{~mm}^{-} 1 \leq \chi_{\sigma}^{\prime} \leq 100 \mathrm{~mm}^{-} 1
\end{array}
$$

Sendo o gradiente de tensão relativo sob tensão normal calculado conforme a equação (4.98). Analogamente, o gradiente de tensão relativo sob tensão de cisalhamento é calculado utilizando a seguinte equação:

$$
\chi_{\tau}^{\prime}=\frac{\left(\chi_{\tau}\right)_{x=0}}{\tau_{\max }^{e}}=\frac{1}{\tau_{\max }^{e}}\left(\frac{\mathrm{d} \tau^{e}(x)}{\mathrm{d} x}\right)_{x=0}
$$

E o fator de entalhe $n_{K, \tau}=\frac{K_{t}}{K_{f}}$ para tensão cisalhante é calculado a partir do gradiente de tensão relativo cisalhante conforme segue:

$$
\begin{array}{lll}
n_{K, \tau}=1+\chi_{\tau}^{\prime} \cdot 10^{-\left(a_{G}-0,5+C_{\tau} \frac{s_{u, 97.5}}{b_{G}}\right)} & \text { para } & \chi_{\tau}^{\prime} \leq 0,1 \mathrm{~mm}^{-1} \\
n_{K, \tau}=1+\sqrt{\chi_{\tau}^{\prime}} \cdot 10^{-\left(a_{G}+C_{\tau} \frac{s_{u, 97.5}}{b_{G}}\right)} & \text { para } & 0,1 \mathrm{~mm}^{-1} \leq \chi_{\tau}^{\prime} \leq 1 \mathrm{~mm}^{-1} \\
n_{K, \tau}=1+\sqrt[4]{\chi_{\tau}^{\prime}} \cdot 10^{-\left(a_{G}+C_{\tau} \frac{s_{u, 97.5}}{b_{G}}\right)} & \text { para } & 1 \mathrm{~mm}^{-} 1 \leq \chi_{\tau}^{\prime} \leq 100 \mathrm{~mm}^{-} 1
\end{array}
$$

Onde

$S_{u, 97.5}$ : Limite de resistência à tração para 97,5\% de confiabilidade (R97,5\%) obtido em um ensaio de tração quase-estático para obtenção da curva $\sigma-\varepsilon$.

$C_{\tau} \quad:$ Fator de correção de tensão em cisalhamento, estipulado na tabela 4.6

$a_{G}$ e $b_{G} \quad$ : Constantes de material, listadas na tabela 4.15

Tabela 4.15 Fatores $a_{G}$ e $b_{G}$ para vários materiais (FKM-Guideline, 2003).

\begin{tabular}{lcc}
\hline \multicolumn{1}{c}{ Material } & $a_{G}$ & \multicolumn{1}{c}{$b_{G}$} \\
\hline Aço inoxidável & 0,4 & 2400 \\
Aço trabalhado (exceto aço inoxidável) & 0,50 & 2700 \\
Aços para fundição & 0,25 & 2000 \\
Ferro fundido nodular & 0,05 & 3200 \\
Ferro fundido maleável & $-0,05$ & 3200 \\
Ferro fundido cinzento & $-0,05$ & 3200 \\
Ligas de alumínio trabalhado & 0,05 & 850 \\
Ligas de alumínio fundido & $-0,05$ & 3200 \\
\hline
\end{tabular}

A figura 4.47 mostra a relação entre o fator de entalhe e o gradiente de tensão relativo $\chi^{\prime}$ na direção normal à superfície para aços e ferros fundidos de várias resistências. 


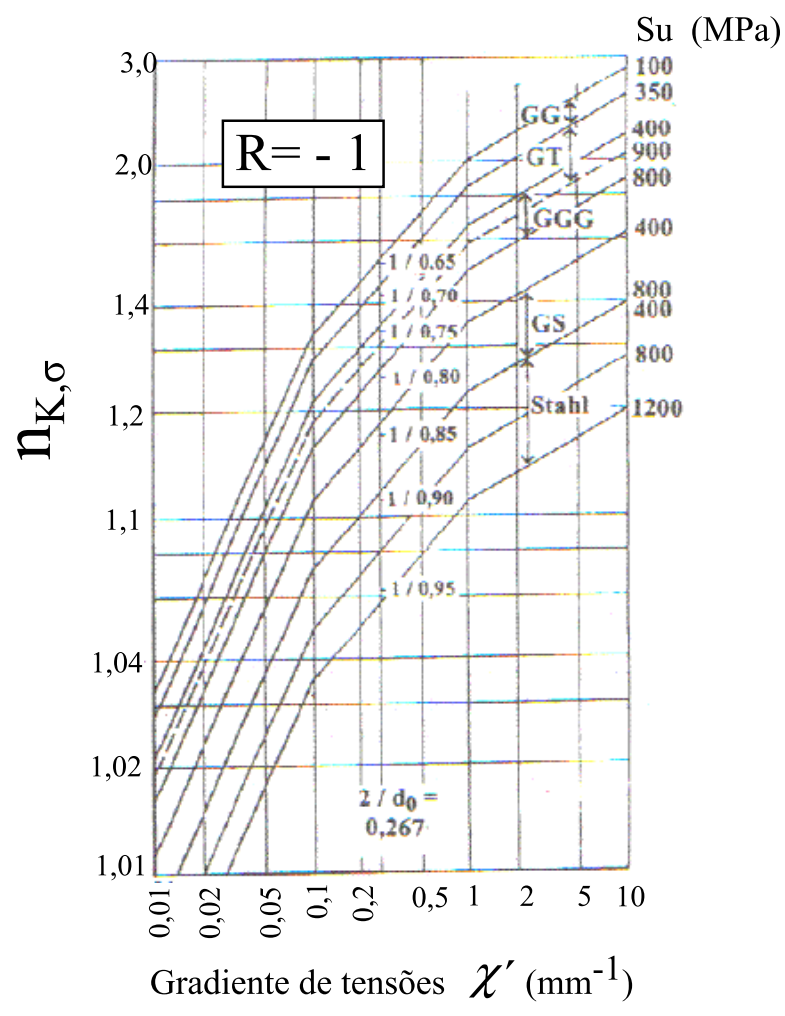

Figura 4.47 Razão $\frac{K_{t}}{K_{f}}$ para tensão normal como função do gradiente de tensão relativo (FKM-Guideline, 2003).

O cálculo do fator de entalhe $n_{K, \tau}$ através do Método do Gradiente de Tensão Relativo pode ser perfeitamente utilizado em conjunto com Análise por Elementos Finitos, pois o gradiente de tensão relativo $\chi^{\prime}$ pode ser calculado de maneira fácil utilizando as tensões nos nós dos elementos da superfície do componente. Na raíz de um entalhe sempre há um gradiente de tensão perpendicular à superfície, e quanto mais agudo é o entalhe, maior será o gradiente de tensão. E quanto mais agudo é o gradiente de tensões, maior a razão $\frac{K_{t}}{K_{f}}$.

A Curva $\sigma-N$ Local de um componente entalhado é preferida se a tensão local é determinada por uma análise por Elementos Finitos linear elástica. Esta curva apresentada na figura 4.49 e a seção 4.4.2 apresenta o método para transformar a Curva S-N Unnotched na Curva $\sigma-N$ Local. Há basicamente duas formas de construir a curva tensão-vida utilizando o Método do Gradiente de Tensão Relativo. A forma mais utilizada é a proposta pela FKM-Guideline (2003) (Analytical Strength Assessment of Components in Mechanical Engineering).

Seja a próxima equação S-N válida:

$$
N \cdot S^{k}=N_{E} \cdot S_{E}^{k}=\text { constante }
$$


O pseudo limite de fadiga da Curva $\sigma-N$ Local é representado conforme segue:

$$
\sigma_{E}^{e}=K_{t} \cdot S_{E, \text { notched }}
$$

E seja também as próximas equações válidas:

$$
\begin{array}{r}
K_{f}=\frac{S_{E, \text { un }}}{S_{E, \text { notched }}} \\
n_{K}=\frac{K_{t}}{K_{f}}
\end{array}
$$

Onde

$\sigma_{E}^{e} \quad:$ Pseudo limite de fadiga

$n_{K} \quad:$ Fator de entalhe

$S_{E, \text { un }} \quad$ : Limite de fadiga de um componente não entalhado, calculado através da seção 4.3 , considerando todos os fatores modificadores e considerando $K_{f}=1$

$S_{E, \text { notched }} \quad$ : Limite de fadiga de um componente entalhado, calculado através da seção 4.3. considerando todos os fatores modificadores e considerando $K_{f}>1$

A substituição das equações (4.92) e (4.99) na equação 4.108) resulta em:

$$
\sigma_{E}^{e}=n_{K} \cdot S_{E, \text { un }}
$$

O termo " $\sigma_{E}^{e}$ " é denominado pseudo limite de fadiga e é a tensão alternada elástica (obtida em análise por Elementos Finitos linear elástica) que surge na raiz do entalhe de um componente e que está relacionada ao ciclo do limite de fadiga $N_{E}$. A equação 4.109) representa a obtenção do pseudo limite de fadiga $\left(\sigma_{E}^{e}\right)$ a partir do limite de fadiga do componente não entalhado $\left(S_{E, u n}\right)$, através da aplicação do efeito de entalhe. A representação gráfica deste processo é apresentado na figura 4.48 .

FKM-Guideline (2003) e Lee et al. (2011) especificam que a inclinação da Curva $\sigma-N$ Local $\left(k_{\sigma}\right)$ seja assumida igual a inclinação da Curva S-N Local, obtida através do Método $K_{f}$. Assim, a Curva $\sigma-N$ Local seria igual à curva azul da figura 4.48, O fator de inclinação $k$ mostrado nesta figura é conhecido apenas se $K_{f}$ for conhecido, conforme apresenta a figura 4.43 (lembrando que $k=-1 / b$ ); entretanto, como não há seção transversal nominal definível em componentes com geometrias complexas, é impossível determinar $K_{f}$ (Eichlseder, 2000a; Steiner et al., 2000). Por este motivo, o autor recomenda que se adote o fator de inclinação da Curva $\sigma-N$ Local como sendo igual ao fator de inclinação da Curva S-N Unnotched (ou seja, $k_{\sigma}=k_{u n}$ ). Desta maneira, pode-se entender então que a Curva $\sigma-N$ Local é obtida, na verdade, através da translação para cima da Curva S-N Unnotched, conforme 
apresentado na figura 4.49. Portanto, a curva que deve ser utilizada na análise de fadiga baseada em Elementos Finitos é a Curva $\sigma-N$ Local, representada pela curva azul da figura 4.49 e pela equação (4.110). O fato de considerar o fator de inclinação da Curva $\sigma-N$ Local igual à Curva $S-N$ Unnotched faz com que previsões sejam mais conservadoras quanto menor for a vida calculada. Entretanto, não são tão conservadoras quanto previsões feitas sem utilizar o fator de entalhe $n_{K}$. Alguns softwares de análise de fadiga baseados em Elementos Finitos tem a opção de desabilitar o uso do fator de entalhe $n_{K}$ na análise de durabilidade (i.e. faz-se $n_{K}=1$ ). Nestes casos, a Curva $\sigma$-N Local se torna idêntica à Curva $S$ - $N$ Unnotched. Entretanto, isto causa um superdimensionamento da estrutura analisada, por isso o autor recomenda que sempre se utilize o fator de entalhe $n_{k}$.

$$
\sigma_{a}^{e}=\sigma_{f}^{\prime} \cdot(2 N)^{b_{\sigma}}
$$

Onde $\sigma_{f}^{\prime}$ é o pseudo coeficiente de resistência à fadiga, definido pela equação 4.111) e $b_{\sigma}$ é o pseudo expoente de resistência à fadiga representada pela equação (4.112).

$$
\begin{aligned}
& \sigma_{f}^{\prime}=n_{K} \cdot S_{f, u n}^{\prime} \\
& b_{\sigma}=b_{u n}
\end{aligned}
$$

É importante ressaltar que a tensão alternada “ $\sigma_{a}^{e}$ " da Curva $\sigma-N$ Local, representada no eixo das ordenadas, representa a tensão alternada na raiz do entalhe, obtida por exemplo por um strain gauge colocado na raiz do entalhe. Obviamente, $\sigma_{a}^{e}$ também poderia ser obtida através de análise linear por Elementos Finitos. Esta pseudo tensão alternada é expressa como

$$
\sigma_{a}^{e}=\frac{\left(\sigma_{\max }^{e}-\sigma_{\min }^{e}\right)}{2}
$$

E a pseudo tensão média é expressa como

$$
\sigma_{m}^{e}=\frac{\left(\sigma_{\max }^{e}+\sigma_{\min }^{e}\right)}{2}
$$

As equações 4.92, 4.107), 4.108) e 4.109), assim como as figuras 4.48 e 4.49, foram apresentadas aqui para um material que possui limite de fadiga $\left(S_{E}\right)$. A mesma analogia vale para metais que possuem limite de endurance $\left(S_{K}\right)$ (ex: alumínio), bastando substituir $S_{E}$ por $S_{K}$ nestas equações e figuras.

O software FEMFAT utiliza uma metodologia ligeiramente diferente daquela ilustrada na figura 4.25, para o cálculo da Curva $\sigma-N$ Local. A metodologia utilizada no FEMFAT é baseado nas pesquisas de Hück et al. (1981), Eichlseder (2000b) e Eichlseder (2000a) e funciona de maneira que, além da Curva $S$-N Espécime da figura 4.25 ser transladada para cima e sua inclinação ser modificada, o ciclo do limite de fadiga $\left(N_{E}\right)$ também é modificado 


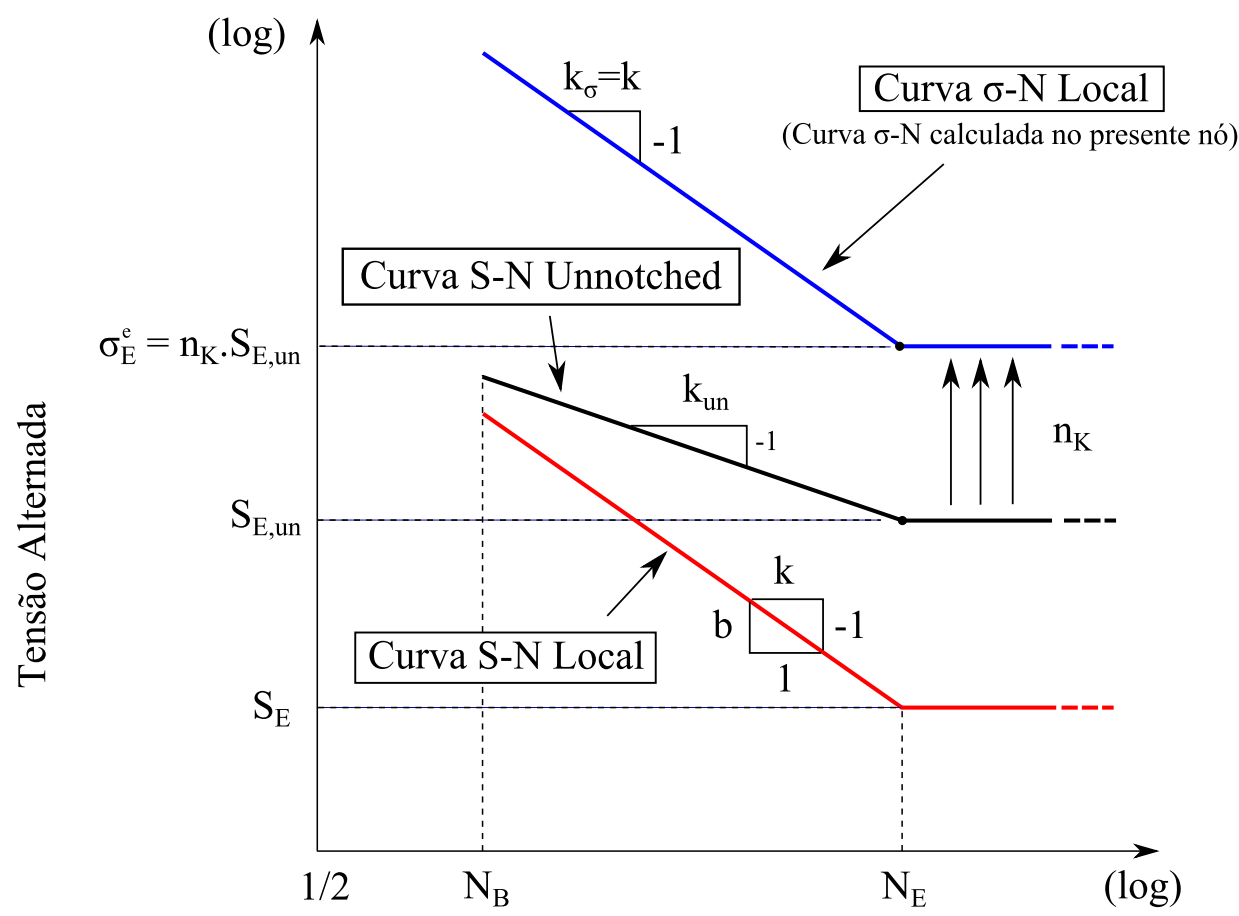

Número de ciclos até a falha $(\mathrm{N})$

Figura 4.48 Obtenção da Curva $\sigma$-N Local de um componente entalhado metálico (que possui limite de fadiga).

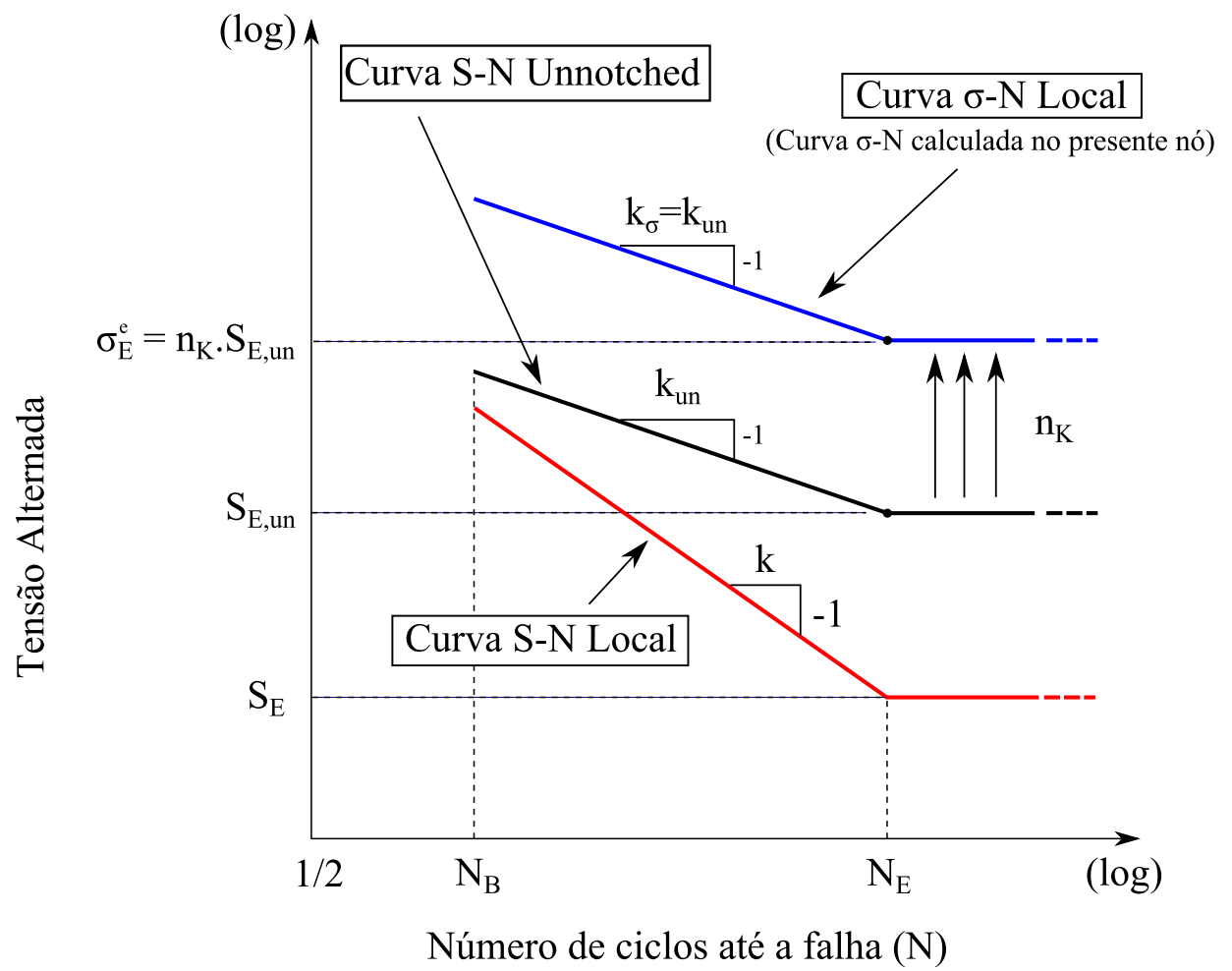

Figura 4.49 Obtenção da Curva $\sigma$-N Local de um componente entalhado metálico utilizando a inclinação $k_{u n}$. 
(i.e. a curva também é transladada para a direita ou esquerda). Mais informações sobre a metodologia utilizada no software FEMFAT pode ser encontrado em Magna Powertrain (2011) e Christian Gaier (2010).

Há componentes mecânicos em que as 6 componentes do tensor tensão de Cauchy de um ponto (nó em FEA) podem variar simultaneamente. A seção 5.3 do capítulo 5 mostrará como o efeito de entalhe é contabilizado considerando a variação das 6 componentes de tensão de cada nó de uma análise por Elementos Finitos.

\subsection{Carregamento de Amplitude Variável e Dano por Fadiga}

Os procedimentos mostrados neste capítulo até então foram construídos considerando que o carregamento aplicado no componente possuía tensão alternada e tensão média constantes. Assim, se o método da FKM for escolhido, por exemplo, a pseudo tensão alternada $\left(\sigma_{a}^{e}\right)$ constante era aplicada na Curva $\sigma-\mathrm{N}$ Local (equação 4.110 e figura 4.49) para a determinação do número de ciclos de carregamento em que ocorrerá a falha por fadiga.

É muito comum encontrar estruturas sujeitas à cargas cíclicas com amplitude variável. Na verdade, grande parte das estruturas mecânicas estão submetidas à carregamento de amplitude variável. Como exemplo temos: componentes de suspensão automotiva, chassis e monobloco de veículos, componentes da asa de aviões, navios e estruturas navais, estruturas sujeitas à carregamento marítmo e devido ao vento e componentes sujeitos à vibração no geral. Este tipo de carregamento gera tensões também de amplitude variáve 38 ; a figura 5.19 (a) apresenta o histórico de tensão em um componente sujeito à carregamentos de amplitude variável. Desta forma, é necessário um método que transforme o carregamento de amplitude variável, aleatório, em blocos de carregamentos com amplitude constante. Existem vários métodos que fazem isto, mas o Método de Rainflow é o método mais conhecido, eficiente e simples. Ele foi proposto pela primeira vez em 1968 por Endo e Matsuishi (Matsuishi \& Endo, 1968) e desde então foi aperfeiçoado algumas vezes. Atualmente, a ASTM e outras instituições de padronização adotam o Método de Rainflow por gerar resultados com boa correlação com experimentos controlados em laboratório de fadiga sob tensão variável. O Método de Rainflow lê o histórico de tensão e conta os picos e vales deste histórico de tensão aleatório e o substitui um novo histórico, representado por blocos de tensão. Cada bloco de tensão está associado a um valor de carregamento (que tem um determinado valor de tensão alternada e um valor de tensão média) e a um determinado número de ciclos que este carregamento é aplicado. O método se baseia na hipótese de que a aplicação deste novo

\footnotetext{
${ }^{38}$ Todas as seis componentes do tensor de tensões de cada ponto do componente podem variar quando há carregamento variável.
} 
histórico de tensão irá gerar a mesma vida em fadiga que o histórico aleatório geraria. A figura 4.50 exemplifica a transformação de um histórico de tensão de amplitude variável em vários blocos de tensão com amplitude constante. É comum também este novo histórico ser expresso utilizando a matriz de Rainflow, ilustrada na figura 4.51. Esta matriz é identificada por um gráfico tridimensional. Cada coluna vertical representa um bloco; o eixo vertical (eixo z) indica número de ciclos que o par tensão alternada $\sigma_{a}^{e}$ (eixo x) e tensão média $\sigma_{m}^{e}$ (eixo y) é aplicado naquele ponto do componente (ou nó, pensando em uma análise FE). É importante ressaltar que existe uma matriz de Rainflow para cada nó da superfície de uma malha de Elementos Finitos.

O algoritimo do Método de Rainflow não será apresentado por este não ser o enfoque principal desta dissertação. Mais informações sobre o Método de Rainflow podem ser encontradas em Lee et al. (2011) e de Castro \& Meggiolaro (2009a).

Uma vez que o Método de Rainflow é aplicado à cada um dos nós superficiais de um modelo FE e a matriz de Rainflow de cada nó tiver sido computada, é necessário calcular o dano por fadiga causado por cada bloco de carregamento. A maneira mais simples, prática, e rápida de se fazer esta soma é utilizando a regra de Palmgren-Miner. Palmgren e Miner (Miner, 1945; Palmgren, 1924) propuseram uma variável chamada dano que contabiliza a vida em fadiga de estruturas sujeitas à tensão de amplitude variável. Esta regra assume que cada bloco de carregamento causa um dano $d_{j}$ ao componente, de maneira que o componente falha por fadiga quando a variável dano alcançar um valor crítico $\left(D_{P M}\right)$ :

$$
D=\sum_{1}^{m} d_{j}=\sum_{1}^{m} \frac{n_{j}}{N_{j}} \geq D_{P M}
$$

Onde

$m \quad$ : Número de blocos existentes na matriz de Rainflow.

$n_{j} \quad: \quad$ Número de ciclos de tensão alternada constante que atua no nó analisado.

$N_{j} \quad$ : Número total de ciclos para ocorrer a falha sob a tensão alternada supracitada.

$D_{P M} \quad$ : Valor crítico do dano, em que ocorre a falha por fadiga.

Palmgren e Miner encontraram que o valor crítico do dano é $D_{P M}=1,0$ em suas pesquisas. Mas estudos realizados por outros pesquisadores após Palmgren e Miner mostraram que o valor crítico de dano é uma variável aleatória que varia de 0,15 à 1,06 (Lee et al., 2011). A (FKM-Guideline, 2003) recomenda adotar para projetos mecânicos os seguintes valores críticos:

- $D_{P M}=0,3$ para aços, aços para fundição e ligas de alumínio; e 


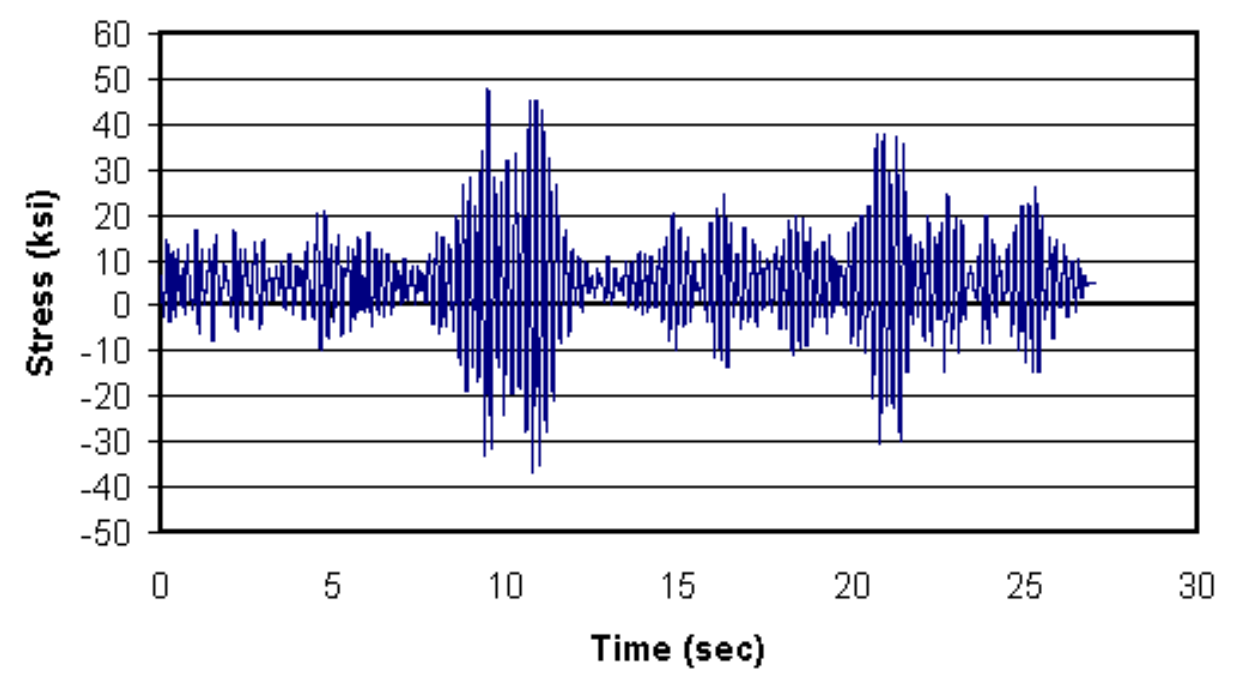

(a) Histórico de tensão de amplitude variável (extraído de Technology (2005)).

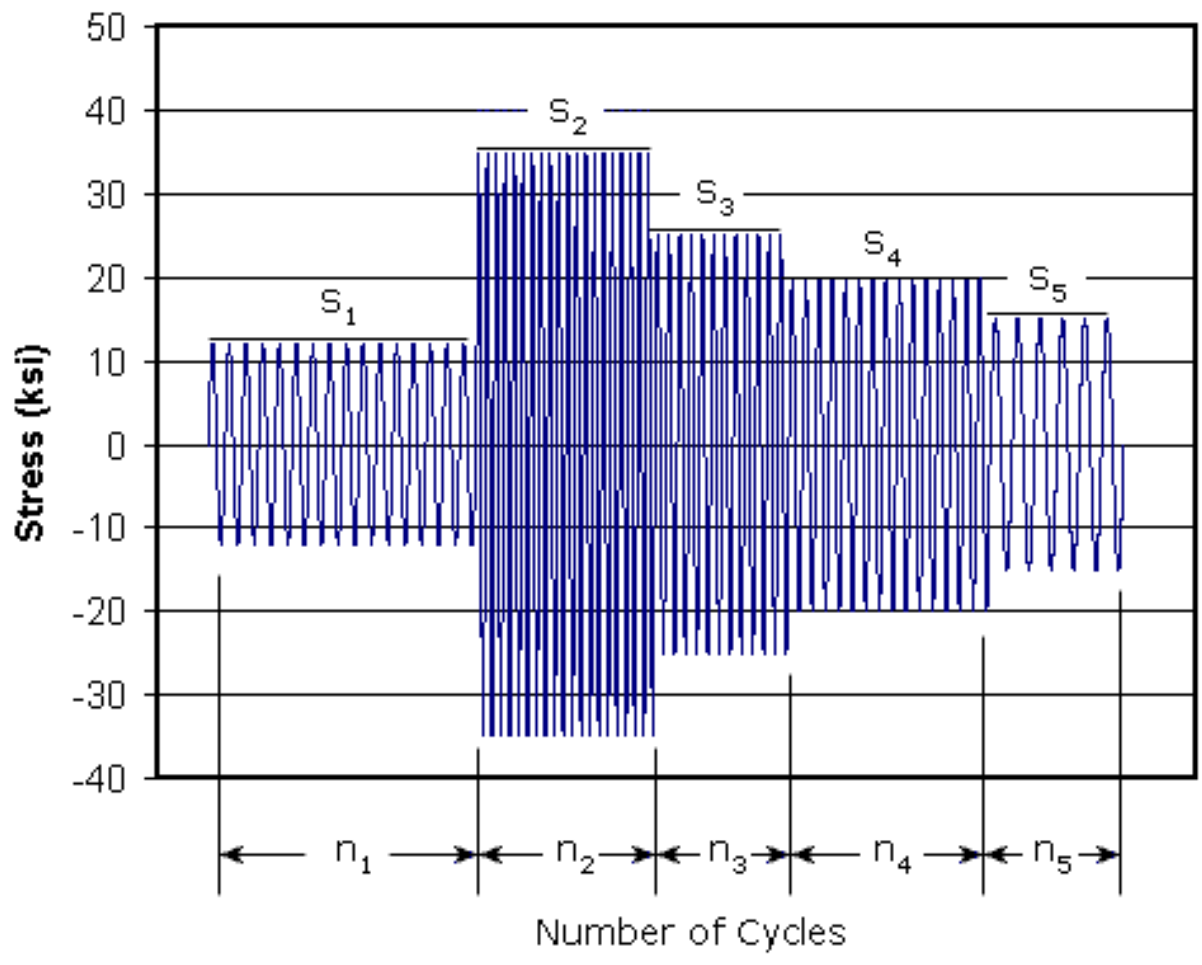

(b) Blocos de tensão alternada e média constantes (extraído de Technology (2005)).

Figura 4.50 Aplicação do Método de Rainflow em um histórico de tensões variável . 


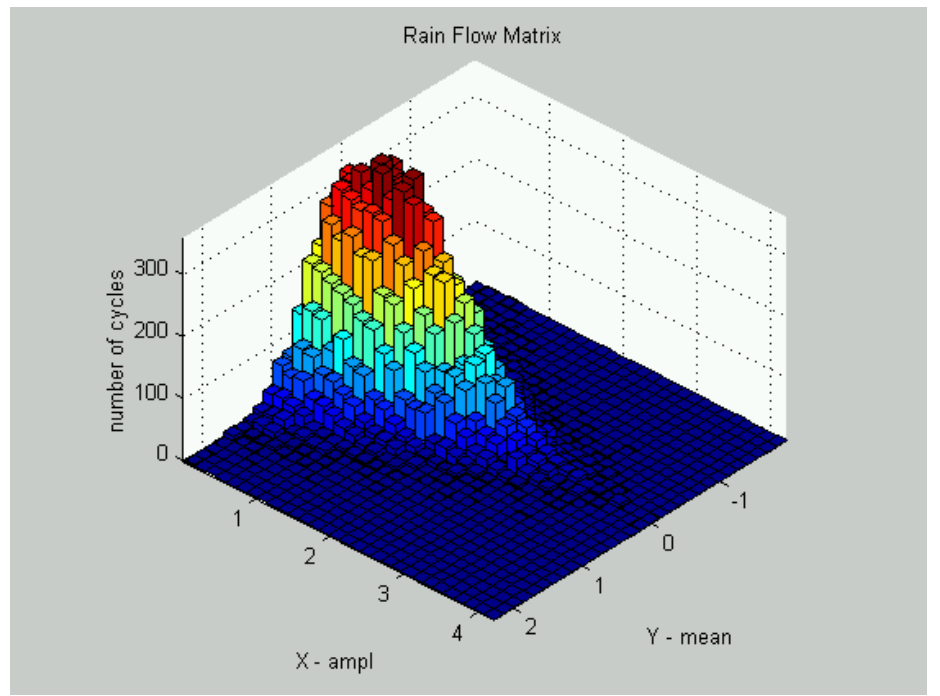

Figura 4.51 Matriz de Rainflow no nó $n_{i}$ localizado na superfície do modelo de Elementos Finitos (extraído de MathWorks (2010)).

- $D_{P M}=1,0$ para ferros fundidos nodulares, ferros fundidos maleáveis e ferros fundidos cinzentos;

Muitos materiais exibem um limite de fadiga sob testes de amplitude constante, como o aços por exemplo. Entretanto, o limite de fadiga desses materiais desaparece (Lee et al. 2011) em carregamento de amplitude variável quando ocorrem sobrecargas periódicas. Isto acontece porque, uma tensão alternada baixa, que não teria energia suficiente para nuclear uma trinca, possui energia suficiente para propagá-la porque tensões alternadas altas periódicas já conseguiram fazer a trinca de estágio I passar pela barreira de grão e se transformar em trinca de estágio II. Haibach (1970) propôs um dos melhores modelos para contabilizar o efeito de sobrecargas periódicas no comportamento de ciclos de tensão abaixo do limite de fadiga original. Este modelo, intitulado Miner-Haibach, estende a curva tensão-vida original abaixo do limite de fadiga original utilizando um fator de inclinação igual à $2 k-1$. (Stanzl et al., 1986) encontrou uma boa correlação entre resultados medidos e calculados utilizando o modelo de Miner-Haibach. De acordo com este modelo, a curva tensão-vida (seja a Curva $S$-N Local ou a Curva $\sigma$-N Local) continua a decrescer após o ponto de inflexão até tensão alternada igual à zero (Lee et al., 2011). Entretanto, a contabilização de tensões alternadas muito baixas tem alto custo computacional e não aumenta a variável dano $D$, por isso é prática comum adotar um limite de fadiga sob amplitude variável como sendo igual a $25 \%$ do limite de fadiga sob amplitude constante (Draper, sdb). A figura 4.52 ilustra a Curva $S-N$ Local (equação 4.97) que deve ser utilizada sob carregamento de amplitude variável e a figura 4.53 apresenta a Curva $\sigma-N$ Local (equação 4.110) que se deve utilizar quando também há carregamento de amplitude variável. 
É importante muito importante contabilizar o dano por fadiga causado por carregamento de amplitude variável abaixo de $\sigma_{E}^{e}$. Foi realizado uma pesquisa onde o histórico de deformação foi medido em um braço de direção de um caminhão utilizando strain gages (Draper, sdb). O sinal possuia amplitude variável, devido à vibração durante o tráfego do veículo e às curvas aleatórias feitas pelo motorista. Realizaram a técnica de Rainflow sobre o sinal medido e eliminaram todos os os ciclos que tinham amplitude menor do que o limite de fadiga sob amplitude constante $\left(\sigma_{E}^{e}\right)$. Também fizeram uma análise utilizando a regra de MinerHaibach e considerando o dano causado por tensões abaixo de $\sigma_{E}^{e}$. Surpreendentemente, a análise de fadiga utilizando o sinal completo resultou uma vida em fadiga 9 vezes menor do que a análise utilizando o sinal truncado. Este experimento mostra como ciclos com tensão alternada menor do que o limite de fadiga $\sigma_{E}^{e}$ também causam dano em um ambiente de carregamento de amplitude variável onde ocorrem sobrecargas periódicas.

\subsection{Informações sobre Fadiga Computacional}

\subsubsection{Sobre o Cálculo do Fator de Tensão Média em Fadiga Computacional}

Todas as equações da seção 4.3 .10 foram formuladas no passado para serem utilizadas com tensões alternadas nominais $\left(S_{a}\right)$ e tensões médias nominais $\left(S_{m}\right)$. Da mesma maneira, o diagrama de Haigh também foi criado para ser utilizado com tensões nominais. Entretanto, frequentemente não temos o valor das tensões nominais quando a análise de fadiga é feita em problemas do mundo real, em componentes e estruturas com geometria e condições de contorno complexas. Em uma análise de fadiga baseada em $\overline{F E A}$ o que se tem é a pseudo tensão alternada ( $\sigma_{a}^{e}$, equação 4.113 ) e a pseudo tensão média $\left(\sigma_{m}^{e}\right.$, equação 4.114), que são tensões locais medidas na raiz dos entalhes da estrutura.

Não foi encontrado na revisão bibliográfica realizada neste trabalho material que relatasse como o engenheiro deve proceder nas condições supracitadas. Por este motivo o autor realizou análises sobre este assunto e concluiu que a pseudo tensão alternada $\left(\sigma_{a}^{e}\right)$ e a pseudo tensão média $\left(\sigma_{m}^{e}\right)$ devem ser utilizadas nas fórmulas da seção 4.3 .10 (ou no diagrama de Haigh) ao invés da tensão alternada nominal $\left(S_{a}\right)$ e da tensão média nominal $\left(S_{m}\right)$, uma vez que não há outra alternativa para se efetuar a correção da tensão média quando se utiliza tensões provenientes de FEA em análises de fadiga.

Foi realizado neste trabalho uma extensa série de análises para entender qual o resultado de se utilizar as pseudo tensões $\sigma_{a}^{e}$ e $\sigma_{m}^{e}$ nos modelos de correção da tensão média expostos na seção 4.3.10, ao invés das tensões nominais $S_{a}$ e $S_{m}$. Estas análises são importantes porque 


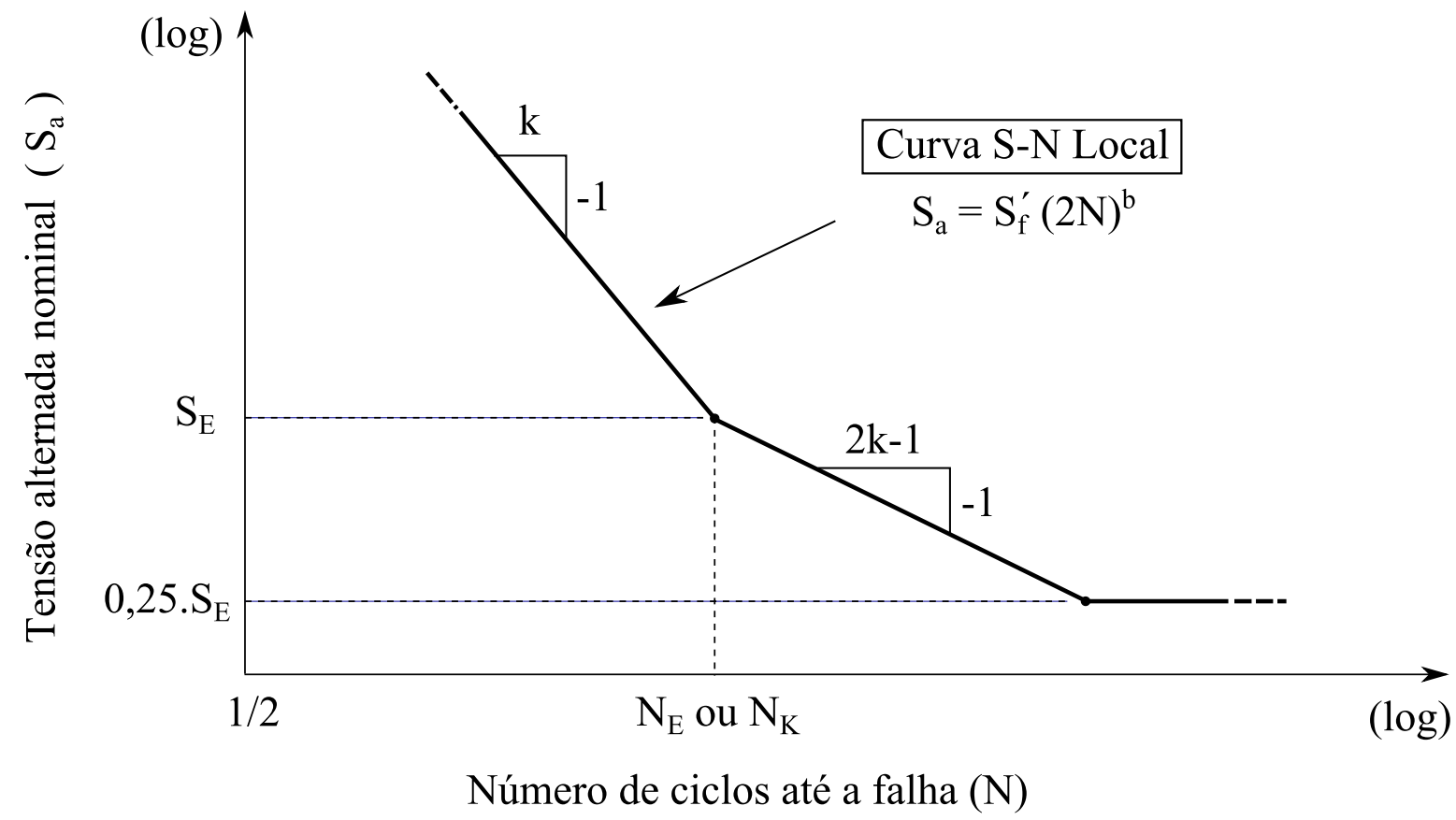

Figura 4.52 Curva S-N Local de um componente entalhado modificada para contabilizar carregamento de amplitude variável.

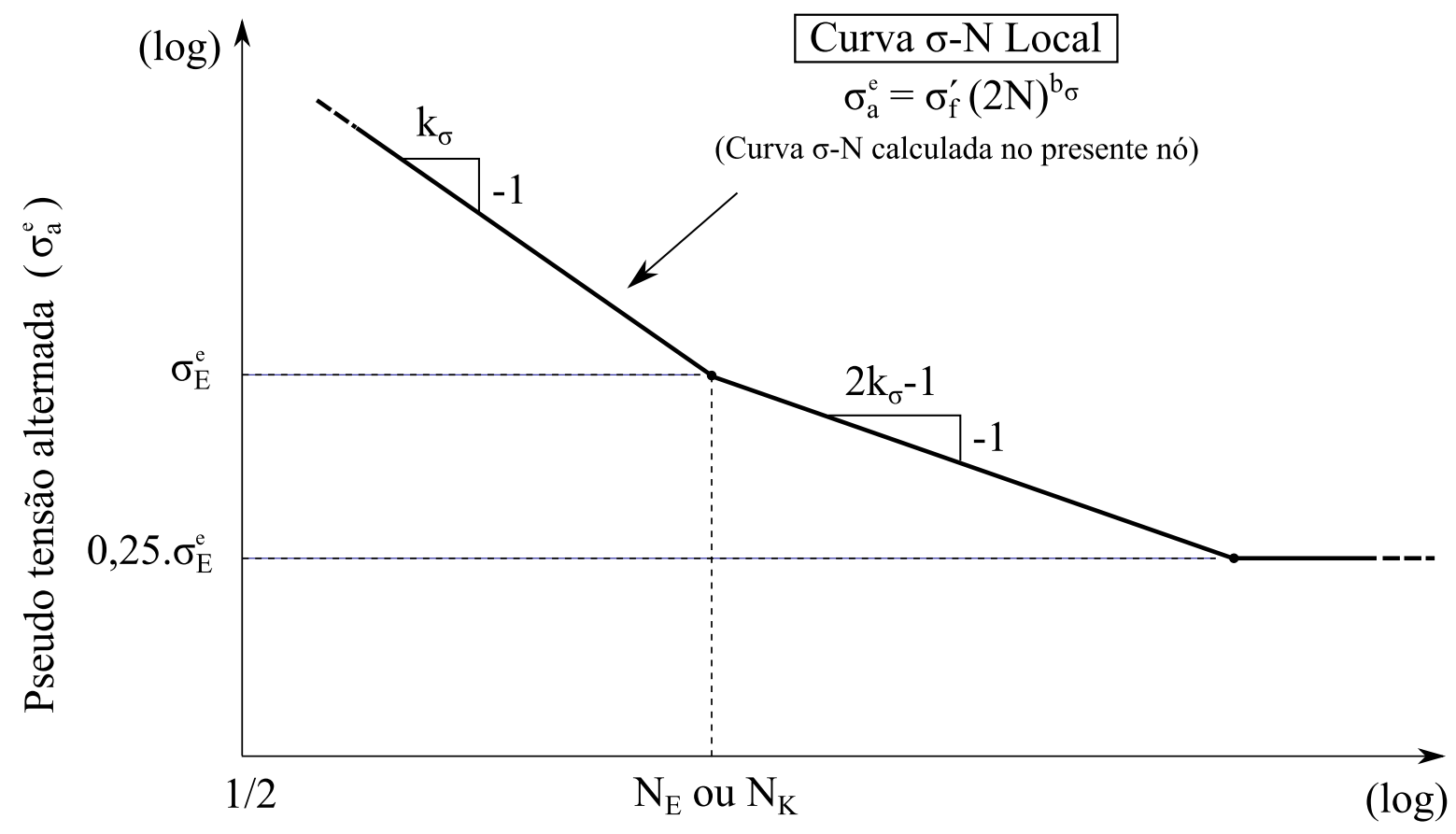

Número de ciclos até a falha $(\mathrm{N})$

Figura 4.53 Curva $\sigma^{e}$-N Local de um componente entalhado modificada para contabilizar carregamento de amplitude variável. 
não se sabe, a princípio, se a utilização de pseudo tensões iria gerar resultados conservadores ou inseguros. Existem 4 parâmetros que podem influenciar nos resultados das análises: a pseudo tensão média $\left(\sigma_{m}^{e}\right)$, a pseudo tensão alternada $\left(\sigma_{a}^{e}\right)$, a resistência mecânica do material $\left(S_{y},, S_{u}, S_{f, s p}^{\prime}, \sigma_{f}\right.$ ou $\left.\gamma\right\rangle$ e o fator de concentração de tensão elástico $\left(K_{t}\right)$.

Como foi visto na seção 4.3.10, o efeito da tensão média é contabilizado transladando a Curva Tensão-Vida verticalmente através da aplicação do parâmetro $C_{m}$, calculado utilizando as equações de (4.77) à 4.84). Quando a tensão média é positiva o modelo deveria transladar a Curva Tensão-Vida para baixo (matematicamente isto significa que $C_{m}<1$ ) e quando é negativa transladá-la para cima (i.e., $C_{m}>1$ ). Assim, a equação da Curva S-N já corrigida para um determinado valor de tensão média nominal é dada por:

$$
S_{a}=C_{m} \cdot S_{f, s p}^{\prime} \cdot(2 N)^{b_{s p}}
$$

O objetivo das análises feitas aqui é determinar o quão discrepante é o resultado gerado pela utilização das pseudo tensões ao se calcular $C_{m}$, quando comparado com o valor de $C_{m}$ calculado utilizando as tensões nominais. Para isto foi criado um parâmetro novo, $C_{m, \sigma^{e}}$. Este parâmetro é calculado utilizando as equações de 4.121) à (4.127), utilizando as pseudo tensões nesses modelos. Assim, a equação da Curva $\mathrm{S}-\mathrm{N}$ já corrigida para um determinado valor de pseudo tensão média é dada por:

$$
S_{a}^{\prime}=C_{m, \sigma^{e}} \cdot S_{f, s p}^{\prime} \cdot(2 N)^{b_{s p}}
$$

Foram análisados 7 modelos de correção da tensão média: modelo de Gerber, de Soderberg, de Goodman, de Morrow I, ASME-Elíptico, SWT e de Walker. O erro relativo de $C_{m}$, calculado pela equação 4.118, representa o quanto o fator de tensão média calculado através das pseudo tensões médias $\left(C_{m, \sigma^{e}}\right)$ diferem do fator de tensão média calculado através das tensões médias nominais $\left(C_{m}\right)$. Obviamente, quanto mais próximo de zero for $\epsilon_{C_{m}}$, melhor.

$$
\epsilon_{C_{m}}=\frac{C_{m, \sigma^{e}}-C_{m}}{C_{m}}
$$

As análises foram feitas utilizando as propriedades do seguinte aço:

Especificação do material: AISI 4340

Liga do material: 4340

Processo do material: Temperado e Revenido

Dureza Brinell: $B N H=409$

Módulo de elasticidade: $E=200.000 \mathrm{MPa}$

Limite de resistência à tração: $S_{u}=1.468 \mathrm{MPa}$ 
Coeficiente de resistência à fadiga da Curva S-N Espécime: $S_{f, s p}^{\prime}=1.770 \mathrm{MPa}$

Expoente de resistência à fadiga da Curva S-N Espécime: $b_{s p}=-0,086$

Limite de fadiga: $S_{E}=539 \mathrm{MPa}$

Ciclo do limite de fadiga: $N_{E}=10^{6}$ ciclos ${ }^{40}$

Informações Adicionais: Curva S-N Espécime obtida através de carregamento com amplitude constante

Fonte: www.efatigue.com

As análises foram realizadas em um espécime de geometria simples, como os da figura 4.41, pois assim tanto as tensões nominais quanto as pseudo tensões poderiam ser calculadas. Vale lembrar que seguintes relações são válidas:

$$
\begin{gathered}
S_{a}=\frac{\left(S_{\text {max }}-S_{\text {min }}\right)}{2} \\
S_{m}=\frac{\left(S_{\text {max }}+S_{\text {min }}\right)}{2} \\
\sigma_{a}^{e}=\frac{\left(\sigma_{\text {max }}^{e}-\sigma_{\text {min }}^{e}\right)}{2} \\
\sigma_{m}^{e}=\frac{\left(\sigma_{\text {max }}^{e}+\sigma_{\text {min }}^{e}\right)}{2} \\
\sigma_{a}^{e}=K_{t} \cdot S_{a} \\
\sigma_{m}^{e}=K_{t} \cdot S_{m}
\end{gathered}
$$

A figura 4.57 apresenta as equações 4.116 e 4.117) calculadas para um espécime entalhado com $K_{t}=3,0$ através do modelo de Morrow I, para 4 valores de tensão média nominal: $S_{m}=-50 \mathrm{MPa}, S_{m}=0, S_{m}=50 \mathrm{MPa}$ e $S_{m}=100 \mathrm{MPa}$. Nesta figura, as curvas tracejadas representam a a equação (4.116) (sendo $C_{m}$ calculado conforme a tabela 4.13 ) e a curvas contínuas são obtidas utilizando a equação 4.117) (sendo $C_{m, \sigma^{e}}$ calculado conforme a tabela 4.16). O resultado desta análise mostrou que se $\sigma_{m}^{e}=0$ (e consequentemente $S_{m}=0$ ) então as Curvas S-N obtidas pelas equações 4.116 e 4.117) são idênticas e o resultado obtido é igual ao que seria obtido se utilizássemos a tensão média nominal $S_{m}$ na correção da tensão média, para qualquer um destes modelos. Quando $\sigma_{m}^{e}>0$ (e consequentemente $S_{m}>0$ ), então começa a haver uma discrepância entre as curvas. Nestes casos, o valor de $\epsilon_{C_{m}}$ é negativo e decresce cada vez mais com o aumento da tensão média. Em outras palavras, o valor de $C_{m, \sigma^{e}}$ é menor do que deveria ser, fazendo com que a Curva S-N esteja

\footnotetext{
${ }^{39}$ Valor estimado pela fonte www.efatigue.com.br

${ }^{40}$ Valor estimado pela fonte www.efatigue.com.br
} 
mais transladada para baixo do que deveria estar. Este fenômeno não é ao todo ruim, pois faz com que a previsão da vida em fadiga de uma estrutura utilizando a pseudo tensão média no cálculo do efeito de entalhe seja conservadora, a favor da segurança. Este tipo de fenômeno acontece também nos modelos de Soderberg e Goodman, conforme pode ser visto nas figuras 4.55 e 4.56, respectivamente. Entretanto, quando $\sigma_{m}^{e}<0$ (e consequentemente $\left.S_{m}<0\right)$ nos modelos de Morrow I, Soderberg e Goodman ${ }^{41}$, então $\epsilon_{C_{m}}$ é positivo e seu valor aumenta com a diminuição da tensão média. Em outras palavras, o valor de $C_{m, \sigma^{e}}$ é maior do que deveria ser, fazendo com que a Curva S-N esteja mais transladada para cima do que deveria estar. Esta situação é ruim, pois faz com que a previsão de vida em fadiga seja não conservadora. Nestes casos, o engenheiro deve aplicar um fator de segurança adequado para contornar este problema.

As figuras de 4.54 à 4.60 representam as equações 4.116) e 4.117) calculadas para um espécime entalhado com $K_{t}=3,0$ para todos os 7 modelos analisados.

Tabela 4.16 Modelos de correção da tensão média utilizando pseudo tensões

\begin{tabular}{|c|c|c|}
\hline Autor & Fórmula & \\
\hline Gerber & $C_{m, \sigma^{e}}=1-\left(\frac{\sigma_{m}^{e}}{S_{u}}\right)^{2}$ & $(4.121)$ \\
\hline Soderberg & $C_{m, \sigma^{e}}=1-\frac{\sigma_{m}^{e}}{S_{y}}$ & $(4.122)$ \\
\hline Goodman & $C_{m, \sigma^{e}}=1-\frac{\sigma_{m}^{e}}{S_{u}}$ & $(4.123)$ \\
\hline Morrow I & $C_{m, \sigma^{e}}=1-\frac{\sigma_{m}^{e}}{S_{f, s p}^{\prime}}$ & $(4.124)$ \\
\hline $\begin{array}{l}\text { ASME- } \\
\text { Elíptico }\end{array}$ & $C_{m, \sigma^{e}}=\sqrt{1-\left(\frac{\sigma_{m}^{e}}{S_{y}}\right)^{2}}$ & $(4.125)$ \\
\hline SWT & $C_{m, \sigma^{e}}=\sqrt{\frac{\sigma_{a}^{e}}{\sigma_{a}^{e}+\sigma_{m}^{e}}}=\sqrt{\frac{1-R}{2}}$ & $(4.126)$ \\
\hline Walker & $C_{m, \sigma^{e}}=\left(\frac{\sigma_{a}^{e}}{\sigma_{a}^{e}+\sigma_{m}^{e}}\right)^{1-\gamma}=\left(\frac{1-R}{2}\right)^{1-\gamma}$ & $(4.127)$ \\
\hline
\end{tabular}

\footnotetext{
${ }^{41} \mathrm{O}$ modelo de Morrow II não foi analisado por que não conseguiu-se obter a tensão verdadeira de fratura $\left(\sigma_{f}\right.$ ) do aço AISI 4340. Entretanto, pode-se prever pela forma da equação (4.81) que este modelo consegue contabilizar o efeito benéfico das tensões médias compressivas e se comporta de maneira similar ao Modelo de Morrow I.
} 


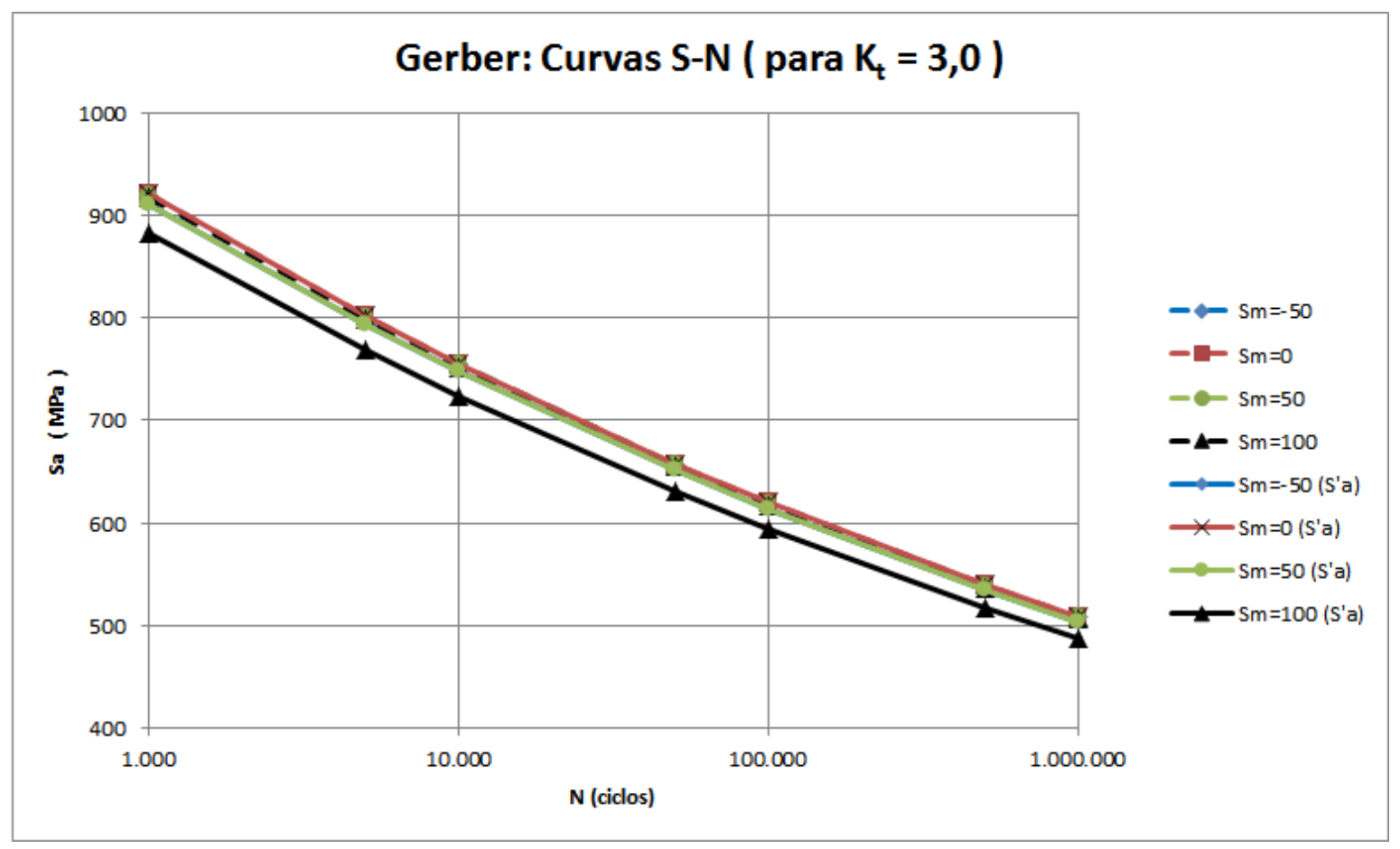

Figura 4.54 Curvas S-N já corrigidas pelo efeito da tensão média utilizando o modelo de Gerber.

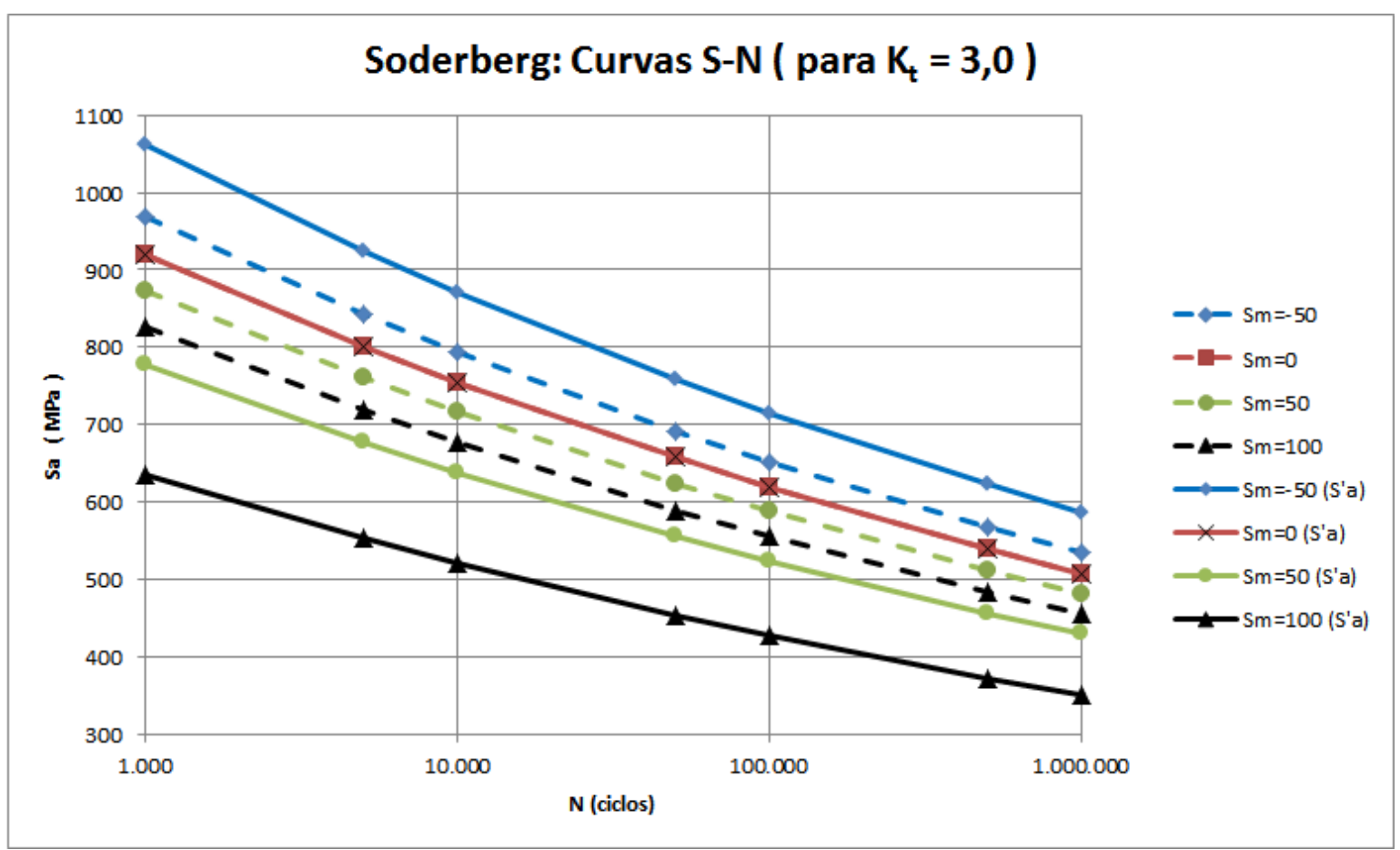

Figura 4.55 Curvas S-N já corrigidas pelo efeito da tensão média utilizando o modelo de Soderberg. 


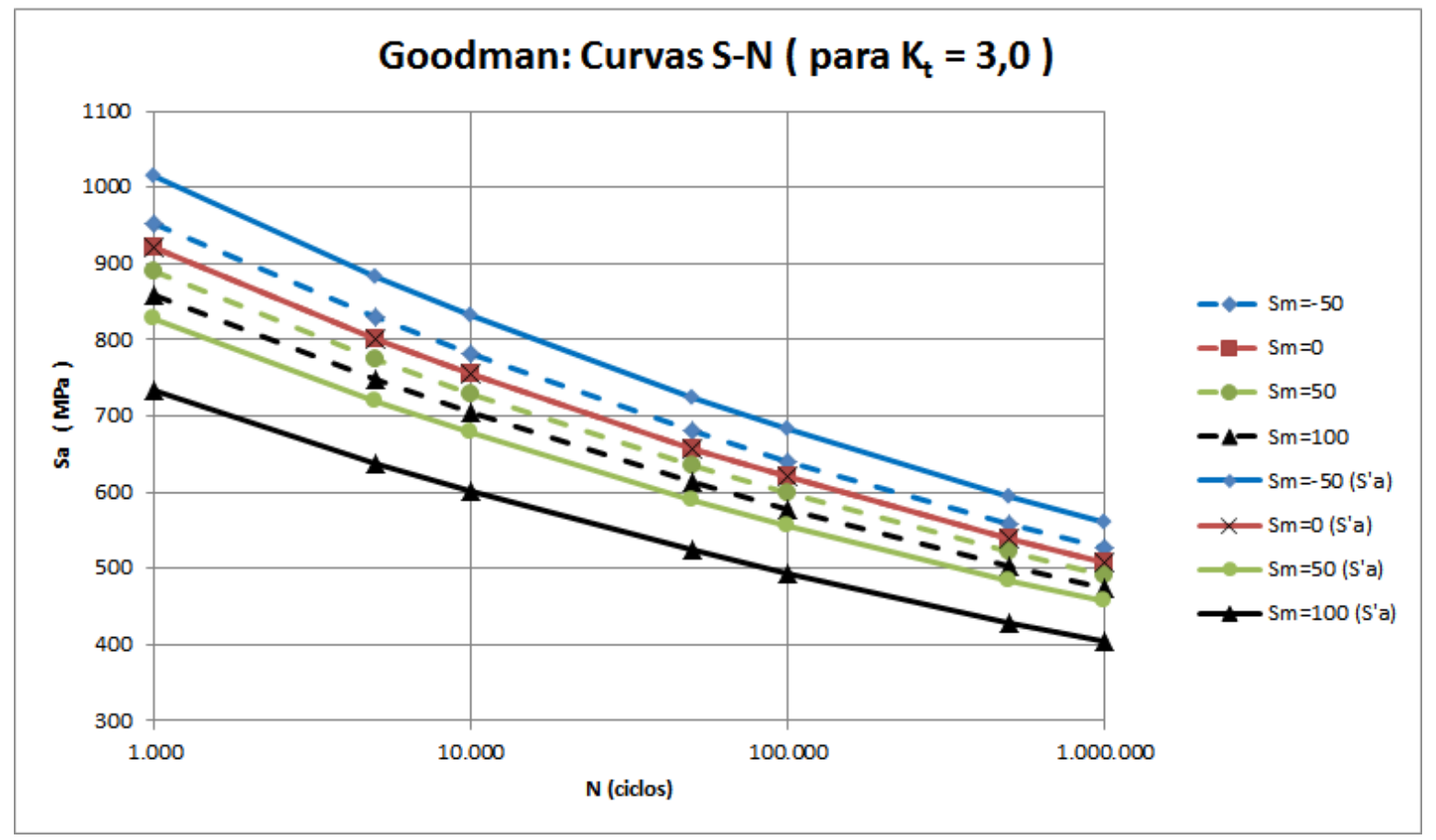

Figura 4.56 Curvas $\mathrm{S}-\mathrm{N}$ já corrigidas pelo efeito da tensão média utilizando o modelo de Goodman.

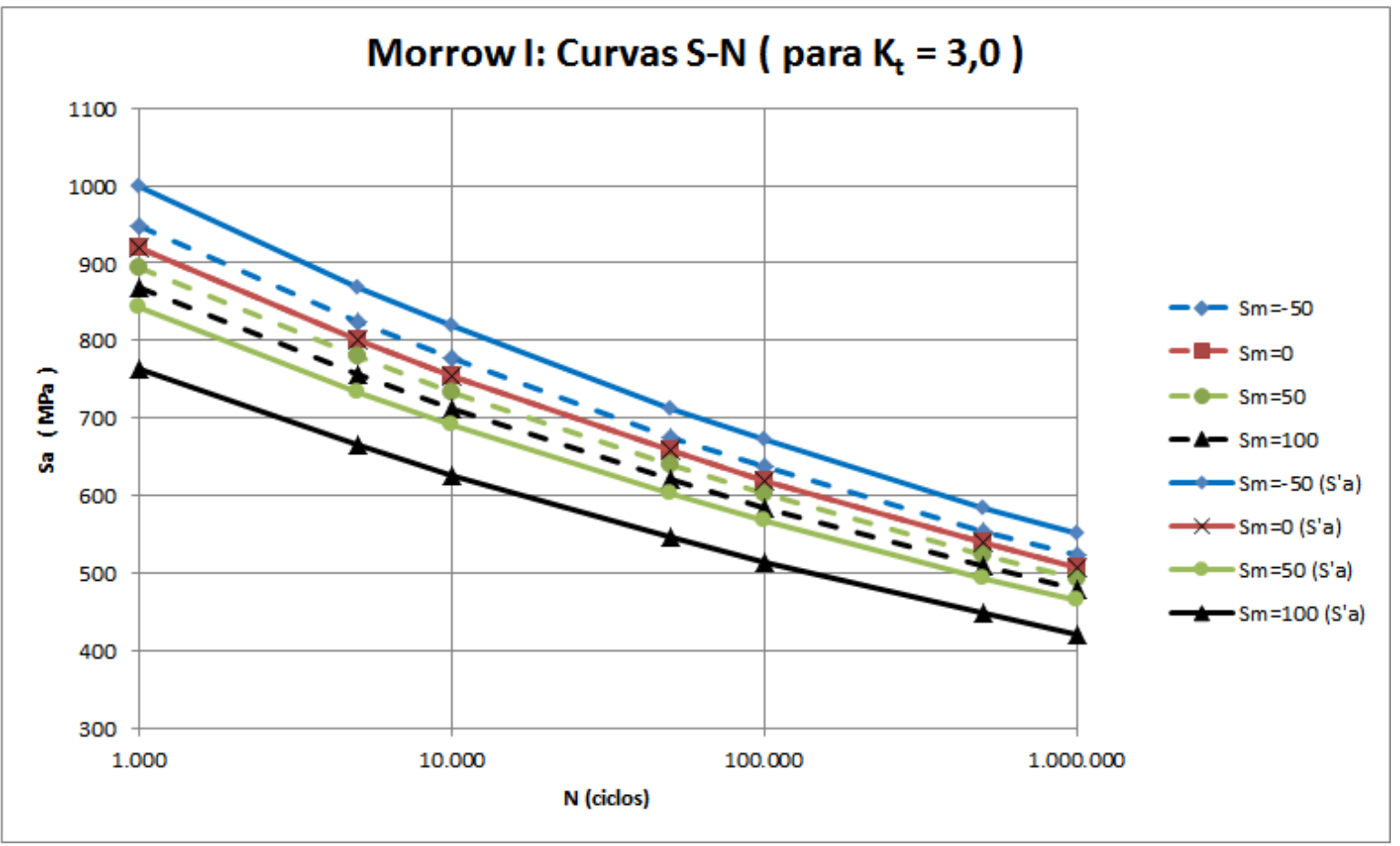

Figura 4.57 Curvas S-N já corrigidas pelo efeito da tensão média utilizando o modelo de Morrow I. 


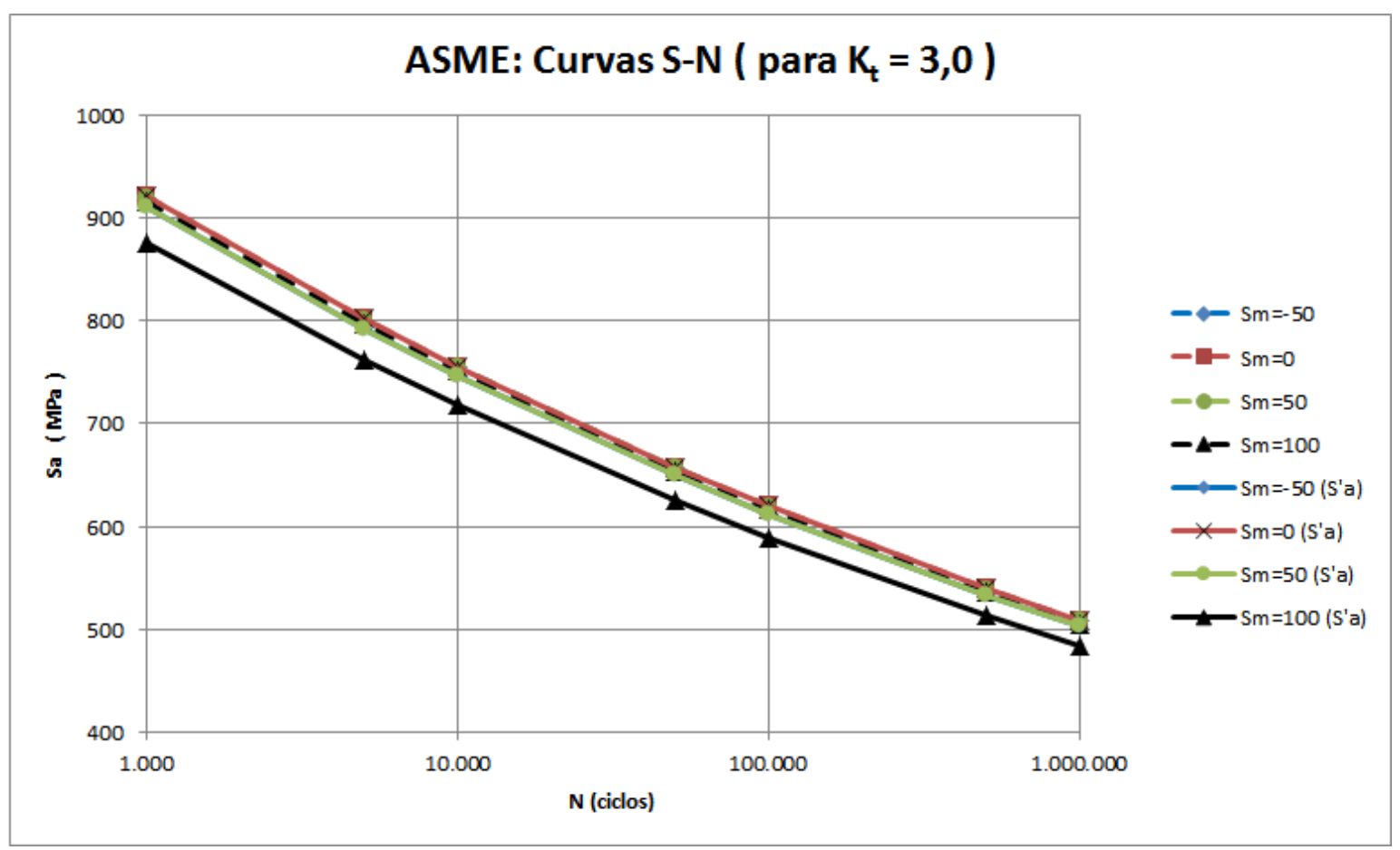

Figura 4.58 Curvas S-N já corrigidas pelo efeito da tensão média utilizando o modelo ASME-Elíptico.

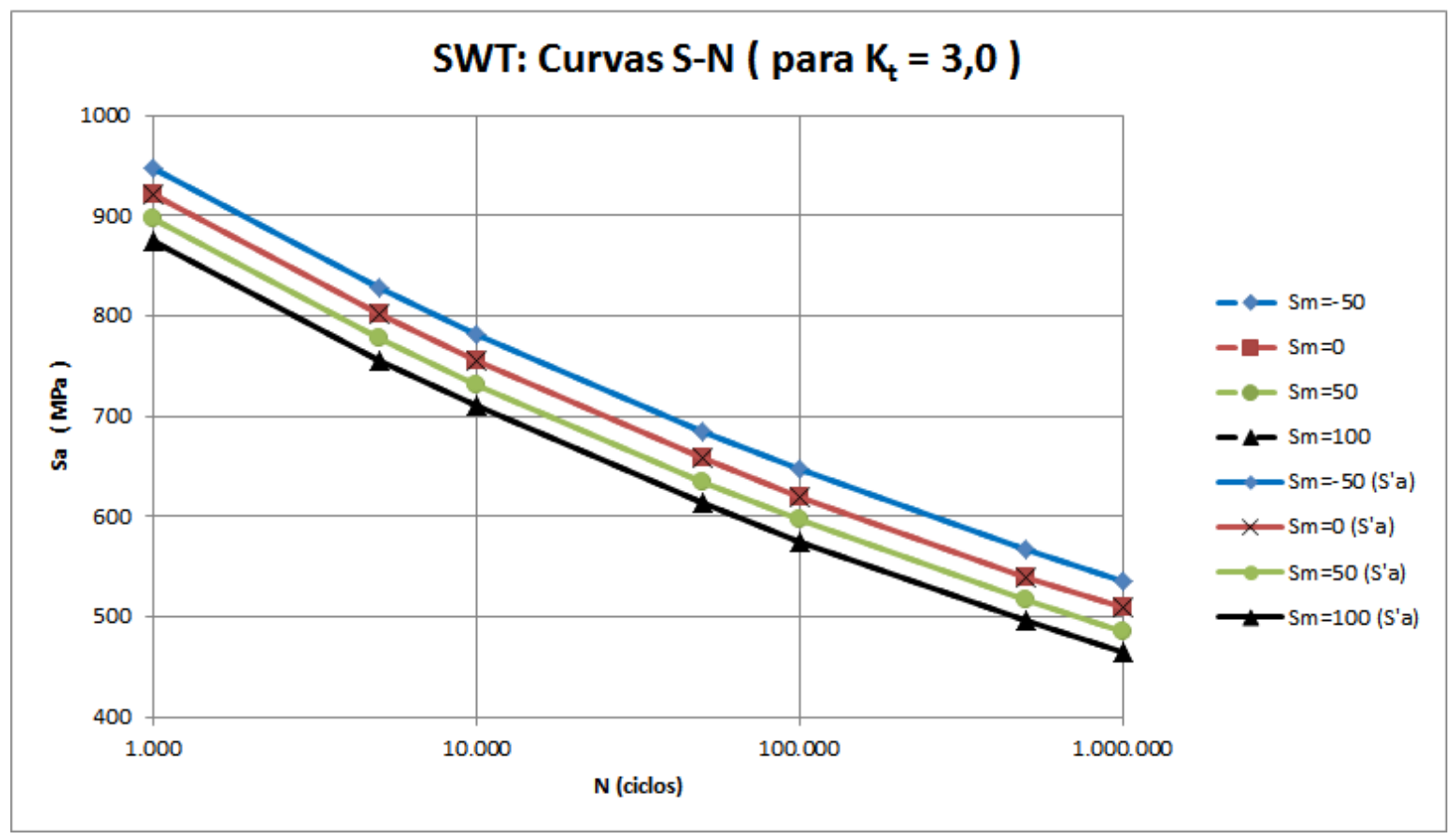

Figura 4.59 Curvas $\mathrm{S}-\mathrm{N}$ já corrigidas pelo efeito da tensão média utilizando o modelo SWT. 


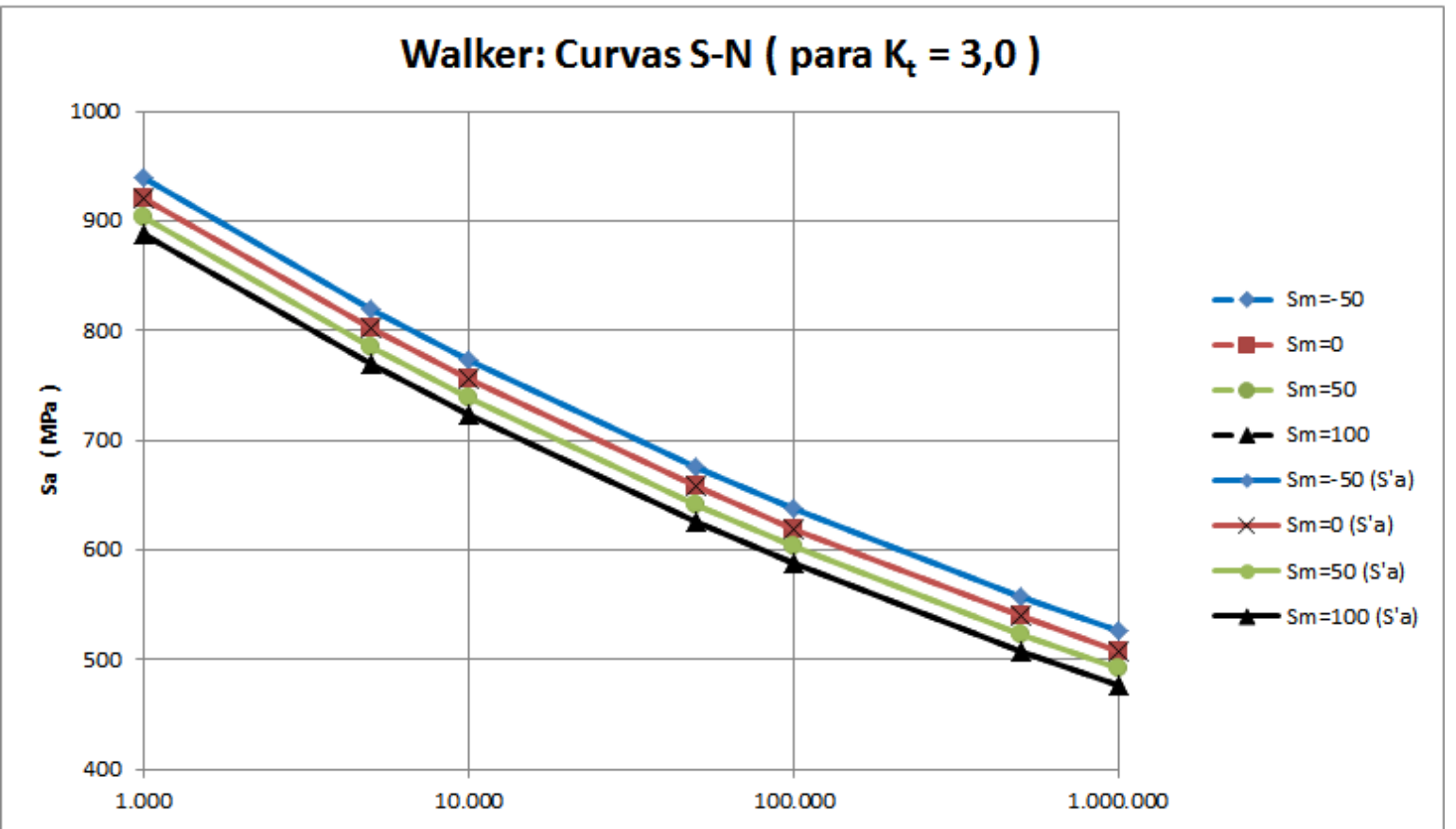

Figura 4.60 Curvas S-N já corrigidas pelo efeito da tensão média utilizando o modelo de Walker.

Experimentos com corpos de prova comprovaram que tensões médias positivas basicamente transladam a Curva S-N Espécime para baixo, enquanto tensões médias negativas transladam a Curva S-N Espécime para cima. Este fenômeno pode ser observado na figura 4.34(a). Os modelos de Soderberg, Goodman, Morrow I, Morrow II, SWT e Walker conseguem representar este fenômeno porque, nesses modelos, a tensão média negativa resulta em um fator modificador de tensão média $C_{m}>1$, que matematicamente significa transladar a Curva S-N Espécime para cima. Entretanto, o modelo de Gerber e ASME-Elíptico não conseguem contabilizar o efeito benéfico da tensão média negativa, pois a tensão média está elevada ao quadrado. Desta forma, tensões médias negativas sempre resultarão em $C_{m}<1$ nesses modelos e a Curva S-N resultante sempre será transladada para baixo, mesmo quando há tensões médias negativas. Isto pode ser percebido comparando-se as figuras $4.54 \mathrm{e} 4.58$ com as figuras 4.55, 4.56, 4.57, $4.59 \mathrm{e} 4.60$.

Conforme mencionado, o ideal é que o parâmetro $\epsilon_{C_{m}}$ seja o mais próximo de zero. Quando este parâmetro é positivo então a contabilização do efeito da tensão média é conservador, e quando é negativo resulta em uma estimativa insegura. Este parâmetro foi calculado para os 7 modelos de correção da tensão média supracitados, para tensões médias de $-50 \leq S_{m} \leq 175 \mathrm{MPa}$ e para diversos valores de $K_{t}$. Os resultados das análises são apresentados nas figuras de 4.61 à 4.67

Os modelos que possuem relações quadráticas, como o modelo de Gerber e ASME- 
Elíptico, possuem outra peculiaridade. Os termos elevados ao quadrado ${ }^{42}$ resultam em números menores que a unidade na maior parte das vezes. Isto acontece porque, mesmo a pseudo tensão média $\left(\sigma_{m}^{e}\right)$ sendo maior que a tensão média nominal $\left(S_{m}\right)$, pois $\sigma_{m}^{e}=K_{t} \cdot S_{m}$, a pseudo tensão média continua sendo menor do que a tensão de escoamento $\left(S_{y}\right)$ na maior parte das vezes ${ }^{43}$ Isto faz com que o termo elevado ao quadrado, menor do que um, seja ainda menor quando elevado ao quadrado. Por este motivo, o valor de $\epsilon_{C_{m}}$ dos modelos quadráticos são menores do que os dos outros modelos. Isto pode ser comprovado comparando-se o erro $\epsilon_{C_{m}}$ do modelo de Gerber (figura 4.61) com o do modelo de Goodman (figura 4.63).

O engenheiro deve tomar bastante cuidado ao utilizar pseudo tensões nos modelos de correção da tensão média. A pseudo tensão média na raiz de entalhes agudos de componentes pode ser tão alta que que $C_{m, \sigma^{e}}$ pode se tornar negativo. Isto não tem nenhum significado físico, apenas é uma característica matemática que surge ao utilizar a pseudo tensão média ao invés da tensão média nominal nas fórmulas. Portanto, o engenheiro deve certificar que o fator $C_{m, \sigma^{e}}$ seja sempre maior que zero.

Os modelos SWT e de Walker possuem uma característica bastante interessante. A formulação desses modelos fazem com que $C_{m}=C_{m, \sigma^{e}}$ sempre, independente do valor da tensão média, da tensão alternada, das propriedades mecânicas do material ou do fator de concentração de tensão elástico. Isto ocorre porque tanto o numerador quanto o denominador das equações desses modelos aumentam de maneira proporcional, conforme pode ser observado pelas equações 4.128) e 4.129). Este fenômeno pode ser comprovado pelas figuras 4.59 e 4.60, que mostram as curvas contínuas sobrepostas sobre as curvas tracejadas. Assim, o modelo SWT e de Walker geram erro $\epsilon_{C_{m}}=0$, conforme mostra as figuras 4.66 4.67, e são excelentes para serem utilizados quando se realiza análise de fadiga baseada em Elementos Finitos. Estes dois modelos não superdimensionam nem subdimensionam a estrutura.

$$
\begin{gathered}
C_{m, \sigma^{e}}=\sqrt{\frac{\sigma_{a}^{e}}{\sigma_{a}^{e}+\sigma_{m}^{e}}}=\sqrt{\frac{K_{t} \cdot S_{a}}{K_{t} \cdot S_{a}+K_{t} \cdot S_{m}}}=\sqrt{\frac{S_{a}}{S_{a}+S_{m}}}=C_{m} \\
C_{m, \sigma^{e}}=\left(\frac{\sigma_{a}^{e}}{\sigma_{a}^{e}+\sigma_{m}^{e}}\right)^{1-\gamma}=\left(\frac{K_{t} \cdot S_{a}}{K_{t} \cdot S_{a}+K_{t} \cdot S_{m}}\right)^{1-\gamma}=\left(\frac{S_{a}}{S_{a}+S_{m}}\right)^{1-\gamma}=C_{m}
\end{gathered}
$$

Constatou-se também que a discripância entre os resultados aumenta quanto maior o fator de concentração de tensão $K_{t}$, conforme observado nas figuras de 4.61 à 4.67. A figura 4.68 apresenta uma comparação entre o erro $\epsilon_{C_{m}}$ gerado por cada modelo analisado, para um

\footnotetext{
${ }^{42} \sigma_{m}^{e} / S_{u}$ no modelo de Gerber e $\sigma_{m}^{e} / S_{y}$ no modelo ASME-Elíptico.

${ }^{43}$ Isto ocorre em regiões onde o fator de concentração de tensão elástico $K_{t}$ não é muito alto.
} 
componente com fator de concentração de tensão elástico de $K_{t}=1,5$. As figuras de 4.69 à 4.71 apresentam o mesmo resultado, mas para $K_{t}=2,0, K_{t}=3,0$ e $K_{t}=4,0$. Os modelos SWT e de Walker geram o menor erro e sua utilização em análise de fadiga baseada em Elementos Finitos não geram resultados conservadores nem inseguros.

O modelo de Gerber é o terceiro menos sensível à utilização da pseudo tensão média, seguido do modelo ASME, Morrow I, Goodman e por último o modelo de Soderberg. neste último modelo, um pequeno aumento de $\sigma_{m}^{e}$ resulta em um alto coeficiente de segurança (superdimensionamento da estrutura) enquanto $\sigma_{m}^{e}$ levemente negativa gera um resultado bastante não conservador (subdimensiona a estrutura). Esta ordem se mantém independente do fator $K_{t}$.

Em resumo, a escolha do modelo de correção de tensão média a ser utilizado em uma análise de fadiga baseada em Elementos Finitos deve levar em consideração o que foi relatado na seção 4.3 .10 e nesta seção. A estrutura ficará superdimensionada utilizando as pseudo tensões alternada $\left(\sigma_{a}^{e}\right)$ e média $\left(\sigma_{m}^{e}\right)^{44}$ quando as tensões médias são maiores que zero, entretanto o engenheiro não tem outra escolha a não ser aceitar isto, uma vez que é impossível obter o valor das tensões nominais alternada $\left(S_{a}\right)$ e média $\left(S_{m}\right)$ em análises de estruturas com geometria complexas.

\subsubsection{Sobre Carregamento de Amplitude Variável em Fa- diga Computacional}

A Curva Tensão-Vida de amplitude constante (seja a Curva S-N Local ou a Curva $\sigma$ $\mathrm{N}$ Local) necessita ser utilizada para prever a vida em fadiga de um componente para uma dada tensão alternada constante e tensão média constante. Quando um carregamento de amplitude variável é aplicado em um componente a mesma regra da seção 4.5 é aplicada. A figura 4.72 apresenta esta metodologia para quando se realiza uma análise de fadiga baseada em Elementos Finitos. O seguinte procedimento deve ser seguido para se realizar o cálculo da vida em fadiga do componente utilizando Elementos Finitos:

1) Primeiramente o Método de Rainflow deve ser aplicado em todos os nós da superfície do modelo de EF, e desta forma cada nó terá uma matriz de Rainflow associada à ele.

2) Deve-se escolher um nó superficial para analisar, intitulado nó $n_{i}$. Para cada nó $i$, executar os próximos passos:

i. A matriz de Rainflow possui vários blocos que devem ser aplicados em sequência para a contabilização do dano por fadiga. Para cada bloco, numerado pelo subíndice “ $j ”$, deve-se efetuar as seguintes etapas:

\footnotetext{
${ }^{44}$ Provenientes de FEA
} 


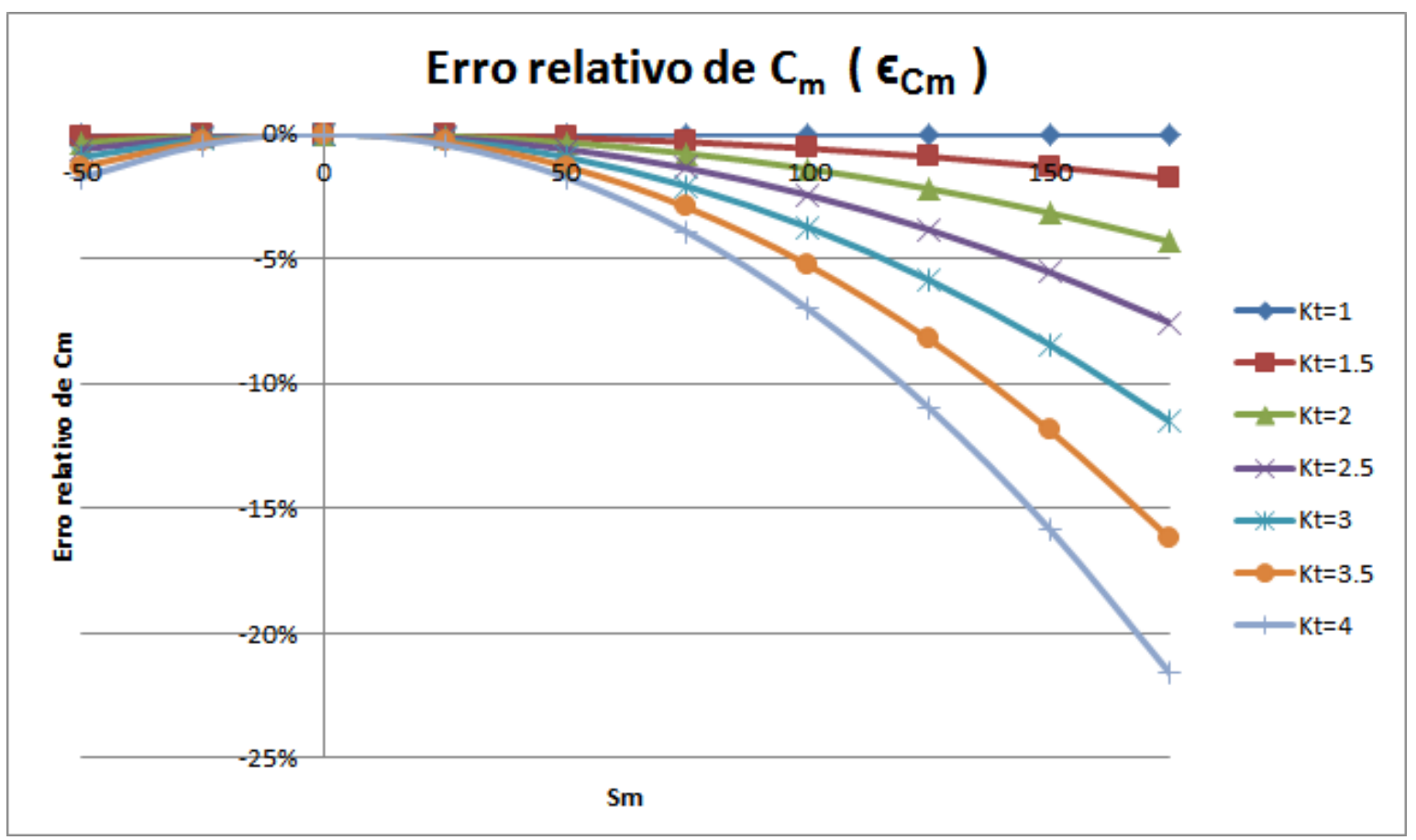

Figura 4.61 Parâmetro $\epsilon_{C_{m}}$ para o modelo de Gerber.

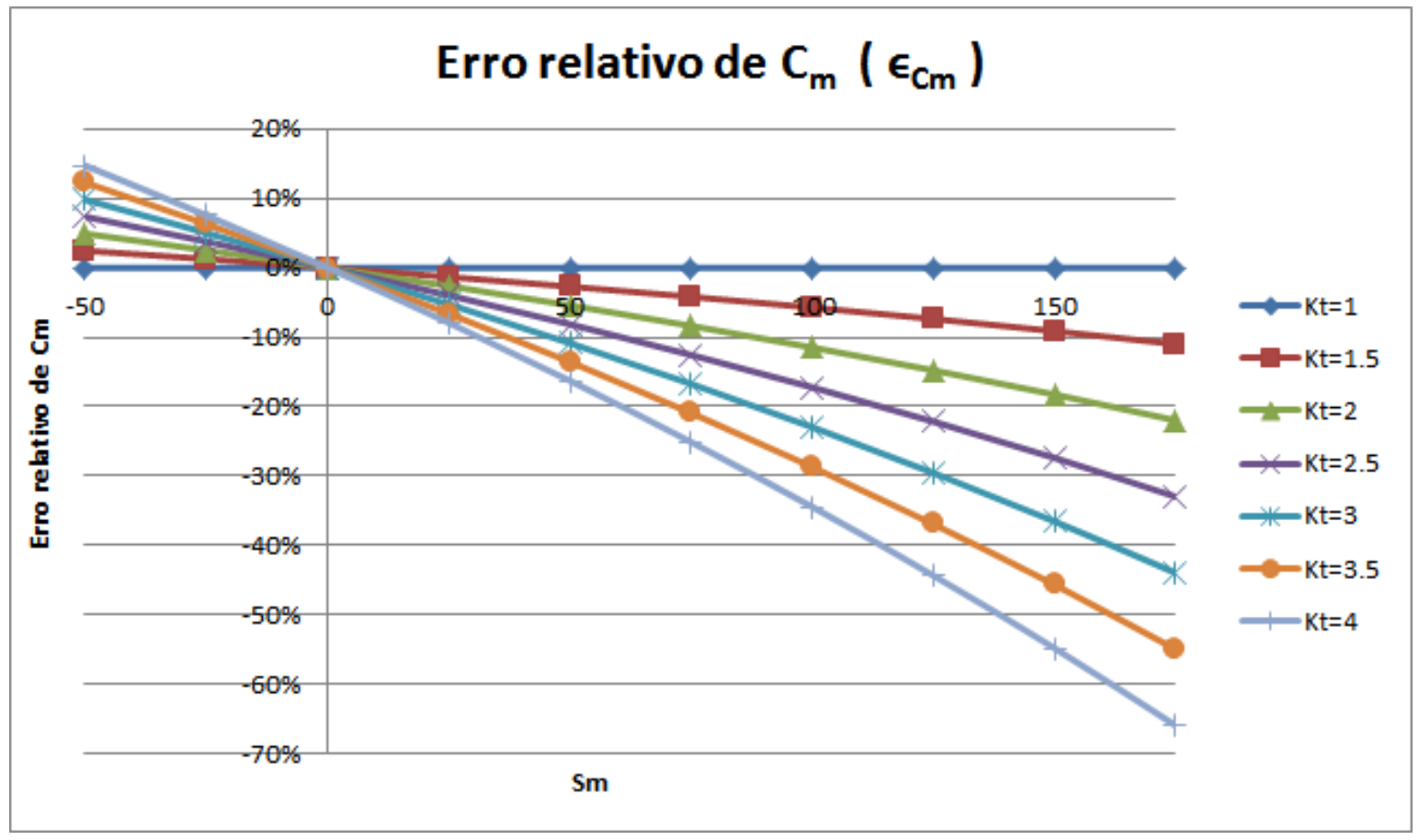

Figura 4.62 Parâmetro $\epsilon_{C_{m}}$ para o modelo de Soderberg. 


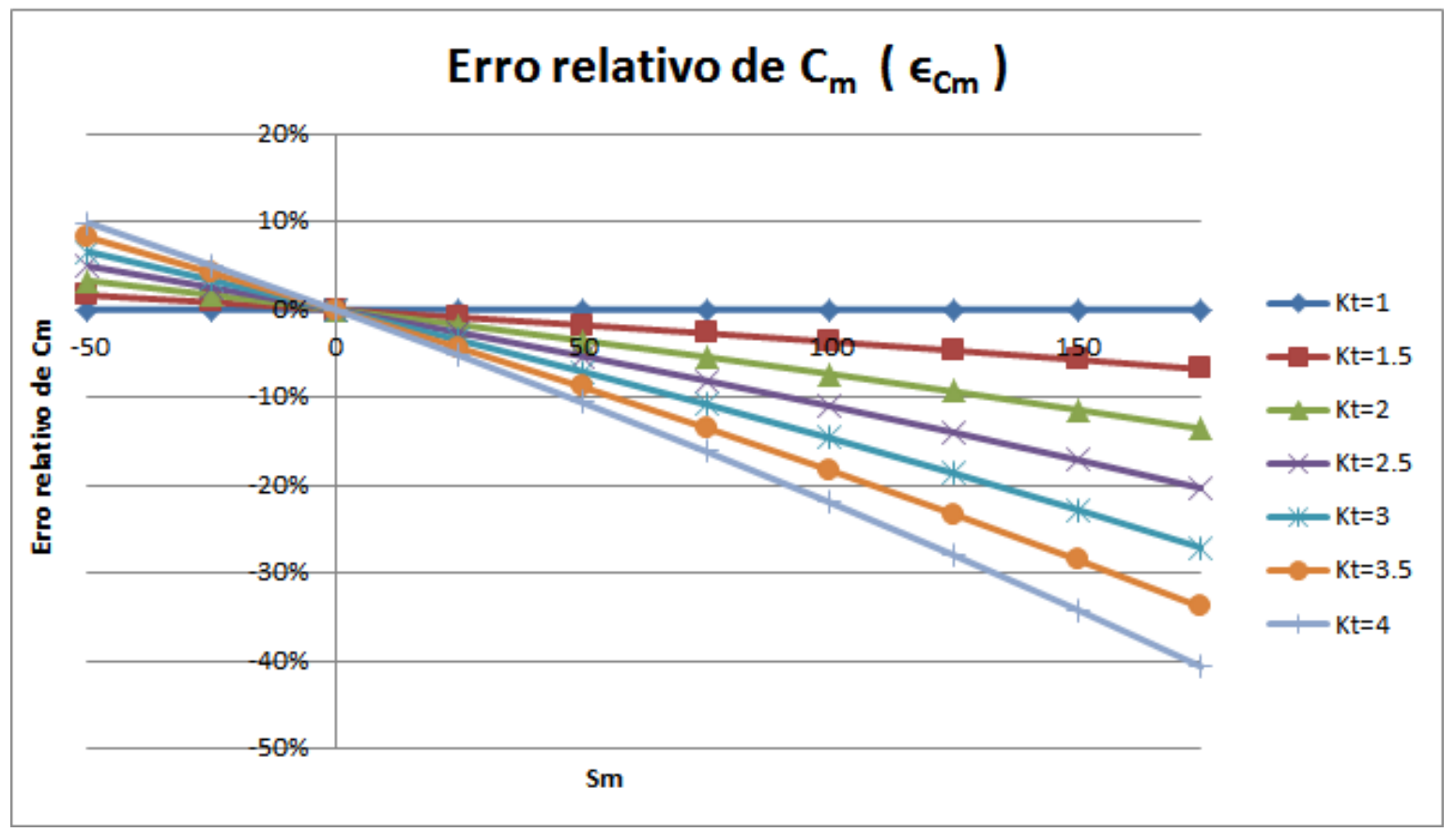

Figura 4.63 Parâmetro $\epsilon_{C_{m}}$ para o modelo de Goodman.

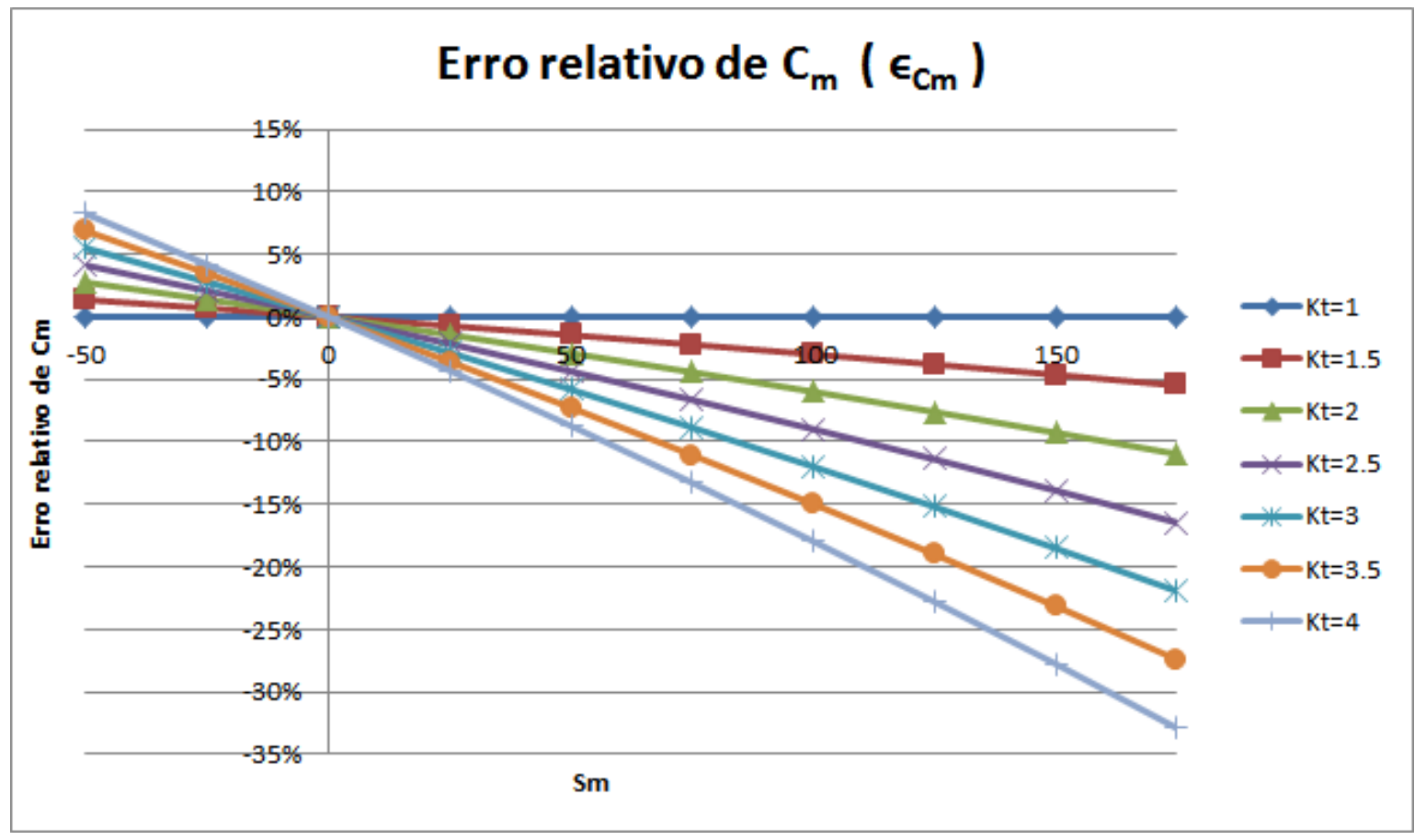

Figura 4.64 Parâmetro $\epsilon_{C_{m}}$ para o modelo de Morrow I. 


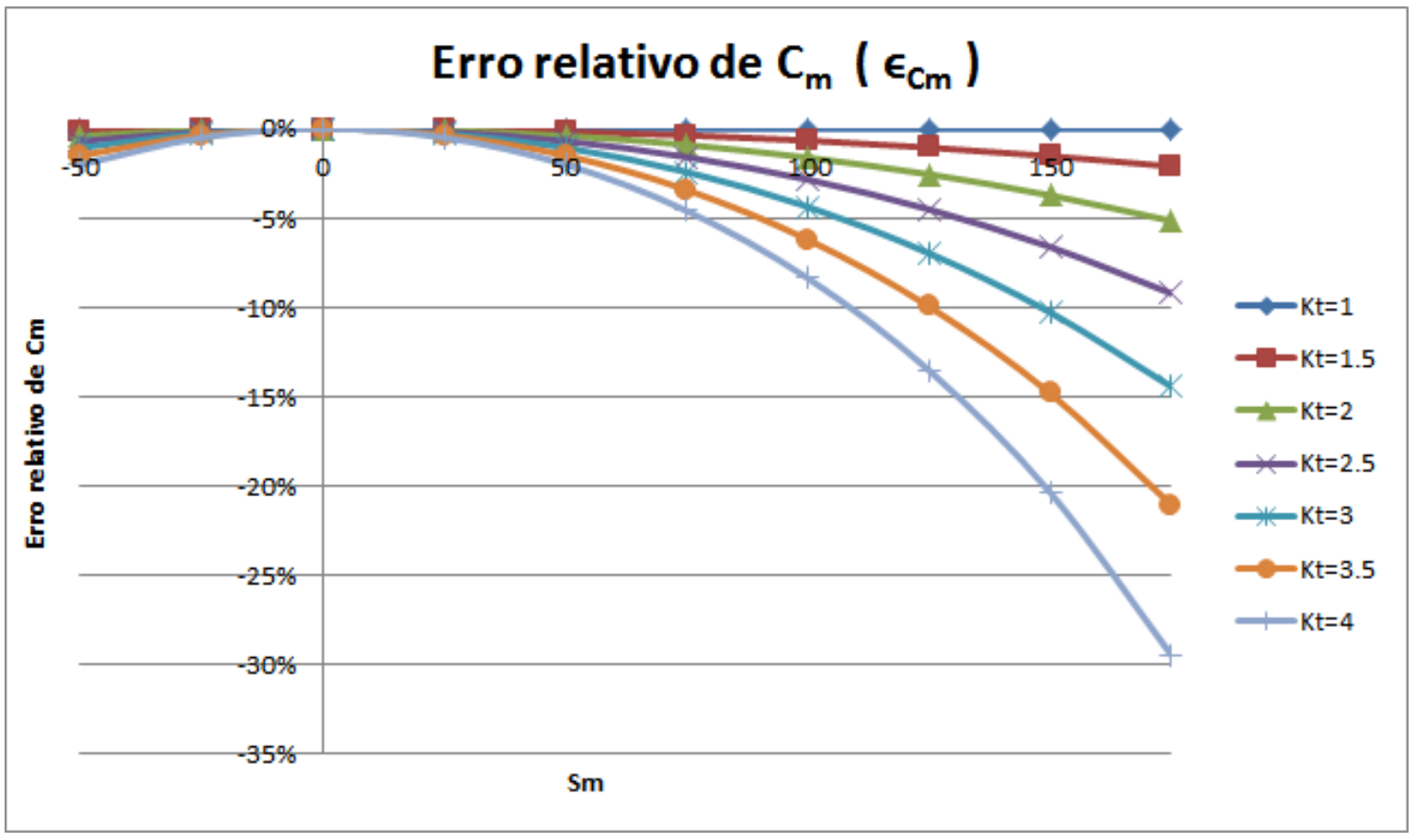

Figura 4.65 Parâmetro $\epsilon_{C_{m}}$ para o modelo ASME-Elíptico.

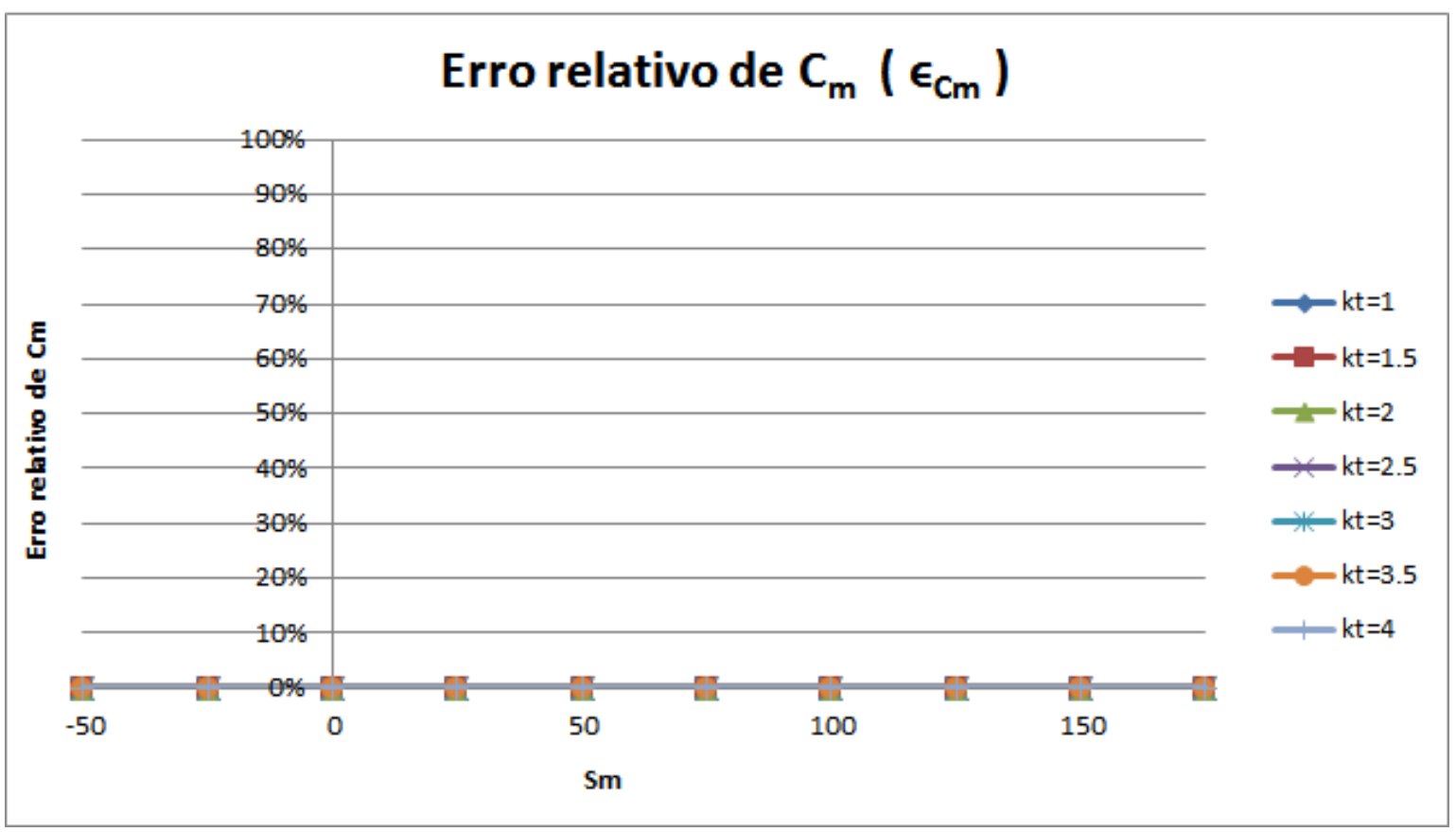

Figura 4.66 Parâmetro $\epsilon_{C_{m}}$ para o modelo SWT. 


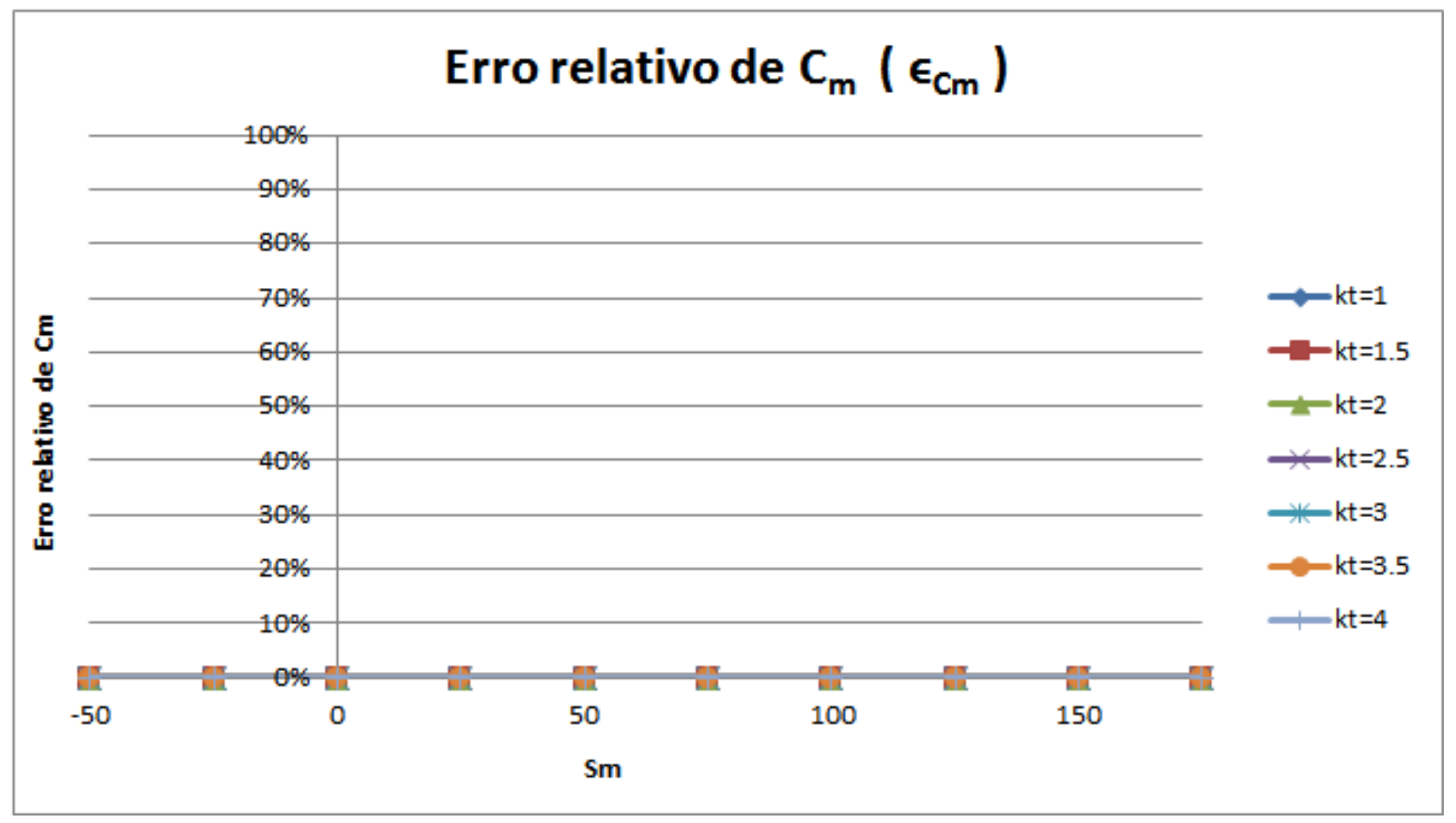

Figura 4.67 Parâmetro $\epsilon_{C_{m}}$ para o modelo de Walker.

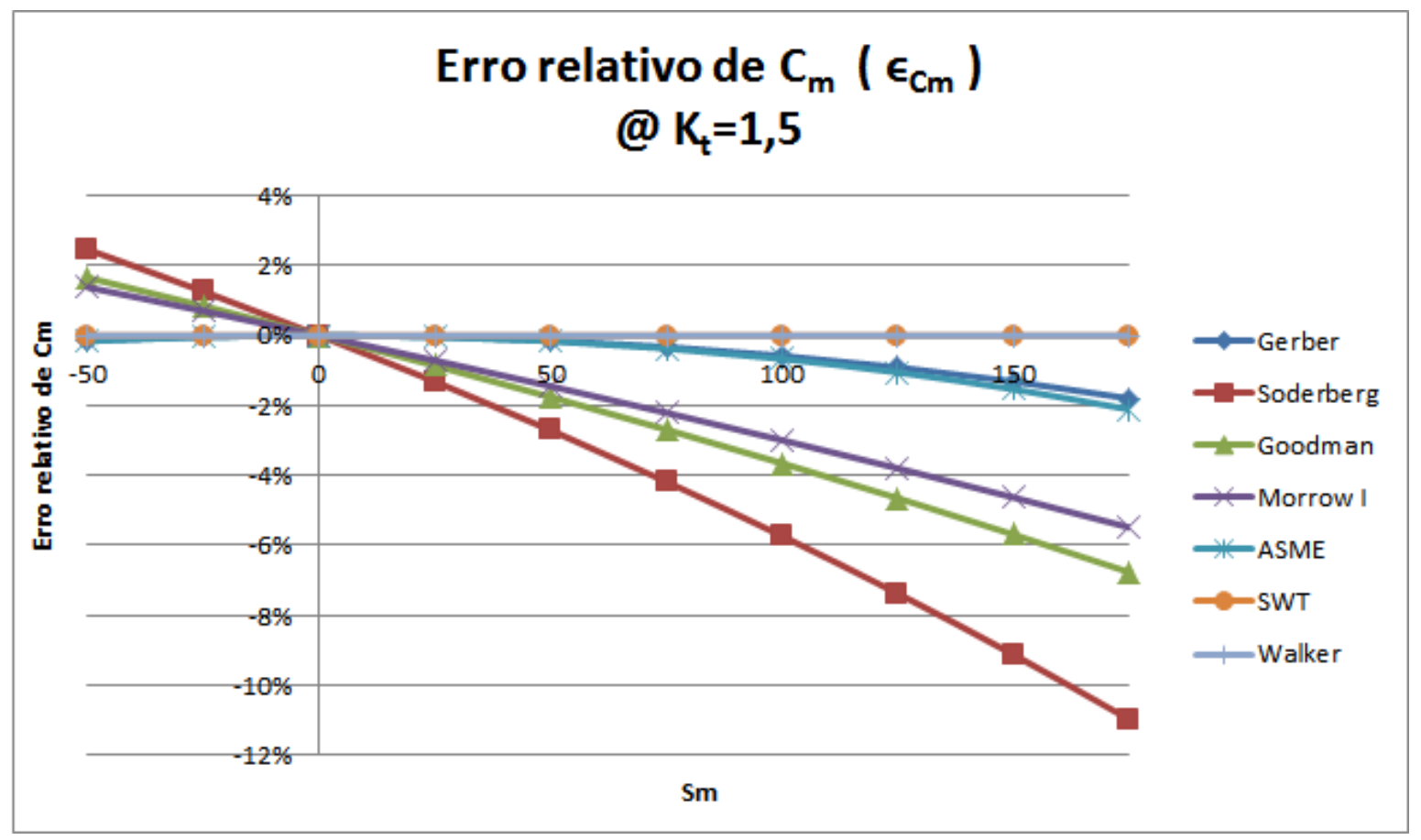

Figura 4.68 Parâmetro $\epsilon_{C_{m}}$ de todos os modelos de correção de tensão média, medido em um componente com $K_{t}=1,5$. 


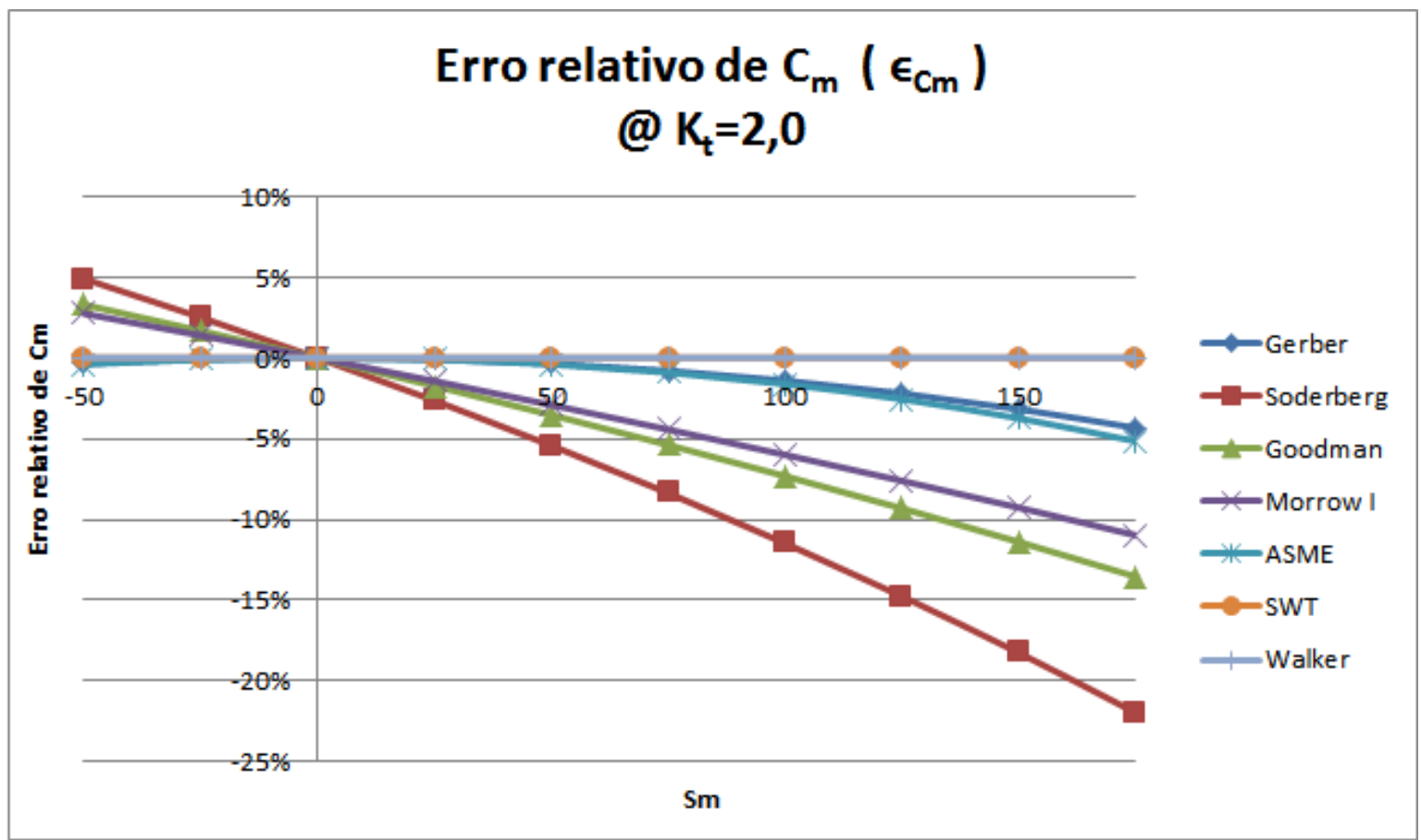

Figura 4.69 Parâmetro $\epsilon_{C_{m}}$ de todos os modelos de correção de tensão média, medido em um componente com $K_{t}=2,0$.

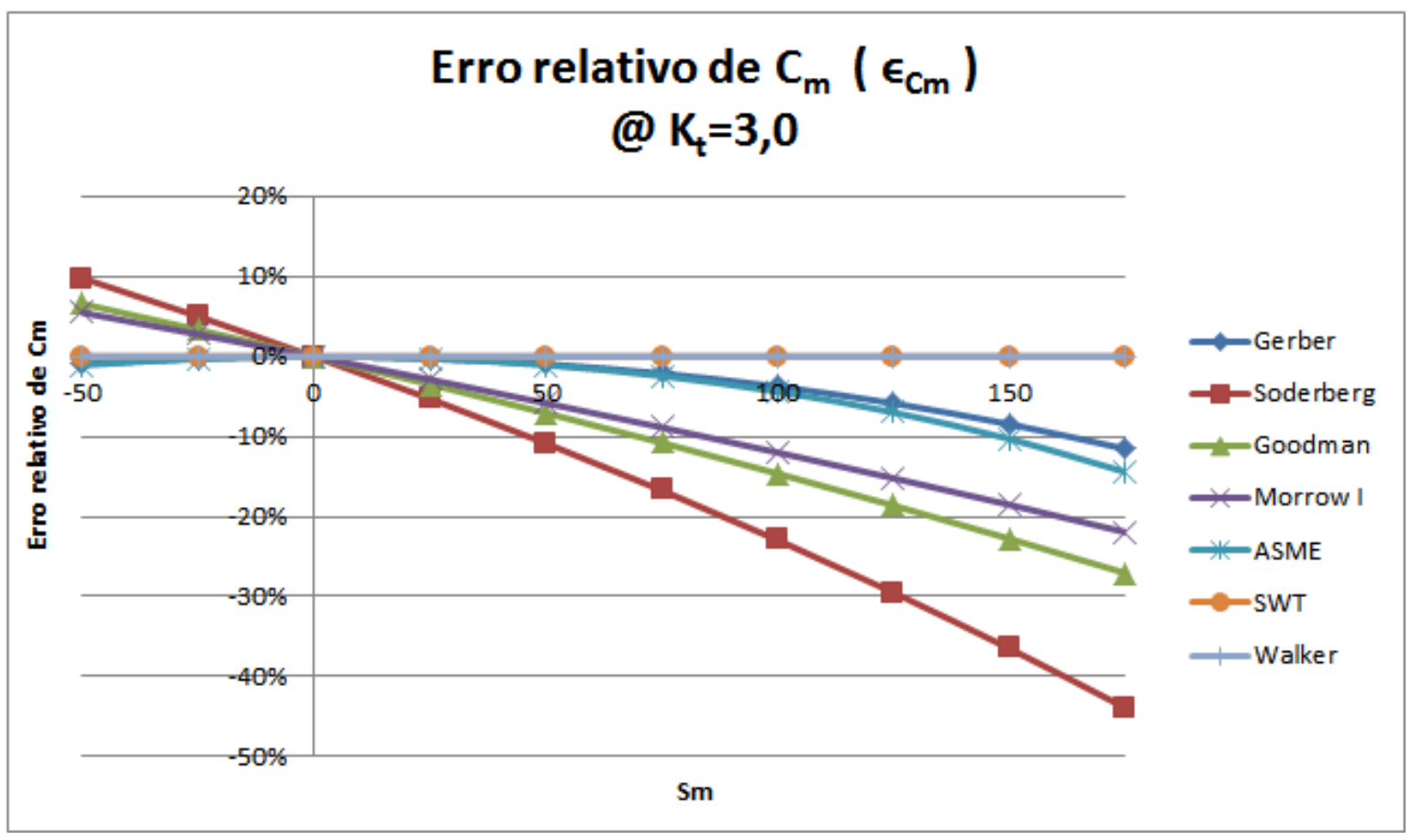

Figura 4.70 Parâmetro $\epsilon_{C_{m}}$ de todos os modelos de correção de tensão média, medido em um componente com $K_{t}=3,0$. 


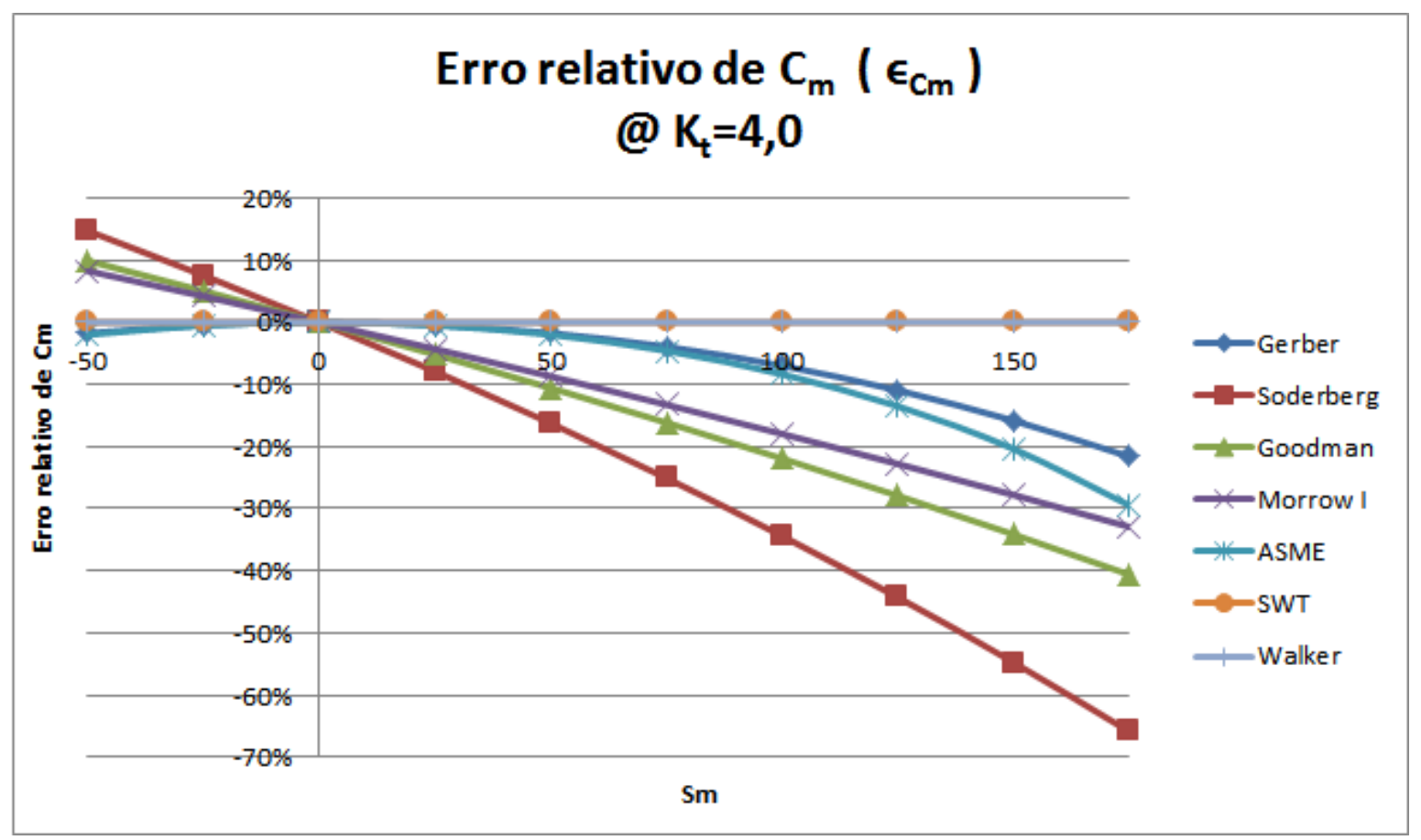

Figura 4.71 Parâmetro $\epsilon_{C_{m}}$ de todos os modelos de correção de tensão média, medido em um componente com $K_{t}=4,0$.

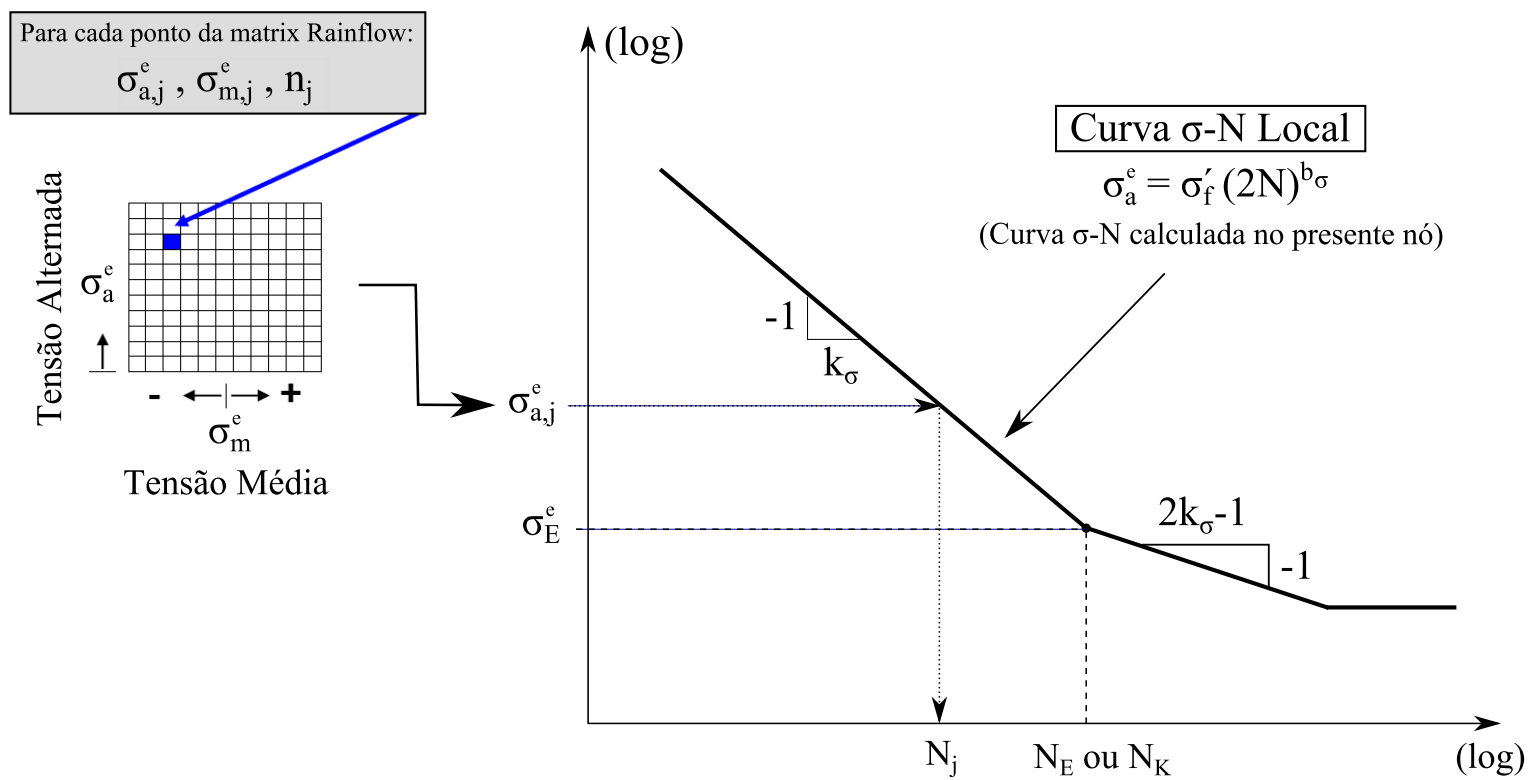

Número de ciclos até a falha $(\mathrm{N})$

Figura 4.72 Contabilização da matriz de Rainflow na curva $\sigma^{e}$-N Local de um componente entalhado. 
a) Cada bloco “ $j$ " tem uma pseudo tensão alternada $\left(\sigma_{a, j}^{e}\right)$ e uma pseudo tensão média $\left(\sigma_{m, j}^{e}\right)$ associados à ele, que são aplicados por $n_{j}$ ciclos.

b) Todos os fatores modificadores apresentados na seção 4.3 devem ser calculados e a Curva $\sigma-N$ Local deve ser obtida. O fator $C_{m, \sigma^{e}}$ deve ser calculado nesta etapa, utilizando a pseudo tensão média $\left(\sigma_{m, i}^{e}\right)$ da etapa (2.i.a). Esta tensão será utilizada em uma das equações da seção 4.6.1 para que $\left(C_{m, \sigma^{e}}\right)$ seja contabilizado. Isto fará com que a Curva $\sigma-N$ Local translade verticalmente e fará com que o efeito da tensão média seja contabilizado;

c) O próximo passo é utilizar a pseudo tensão alternada $\left(\sigma_{a, j}^{e}\right)$ na Curva $\sigma-N$ Local, conforme ilustra a figura 4.72, para obter o número de ciclos $N_{j}$.

d) A seguir, deve-se calcular o parâmetro de dano $d_{j}$ que o bloco $j$ causa, utilizando a equação 4.115).

ii. Nesta etapa todos os blocos da matriz de Rainflow foram contabilizados para o nó $i$ e portanto o dano total $D_{P M, i}$ está contabilizado para este nó.

3) Nesta etapa o dano $D_{P M}$ de cada nó $i$ foi contabilizado. O nó que possui o maior valor de $D_{P M}$ é nomeado ponto/nó crítico, onde espera-se ser o primeiro ponto em que haverá nucleação da trinca e subsequente crescimento da mesma.

Uma análise de fadiga via Elementos Finitos também apresenta plots 3D coloridos. Os resultados são apresentados igual acontece em uma análise estrutural. O usuário especifica qual variável ele quer verificar e pede para plotá-la para cada nó do componente. A figura 4.73 apresenta o perfil de dano por fadiga para um componente de suspensão automotiva. $\mathrm{O}$ dano mostrado na figura foi calculado utilizando a equação (4.115). Entretanto, o perfil pode ser de qualquer outra variável como vida em fadiga, fator de segurança, razão de biaxialidade e a tensão de Findley (estes dois últimos serão explicados no capítulo 5).

\subsubsection{Densidade da Malha de Elementos Finitos em Fadiga Computacional}

A análise de fadiga baseada em Elementos Finitos é relativamente um assunto novo e as regras para a densidade de malha não estão completamente definidas ainda. Entretanto, sabe-se que a precisão dos resultados de fadiga depende diretamente da informação de tensão do modelo FEA pois como uma curva tensão-vida apresenta uma relação logarítimica entre a tensão e a vida, um erro de $5 \%$ na tensão pode resultar em um erro de $200 \%$ na vida em fadiga prevista (Draper, $\mathrm{sdb}$ ). 


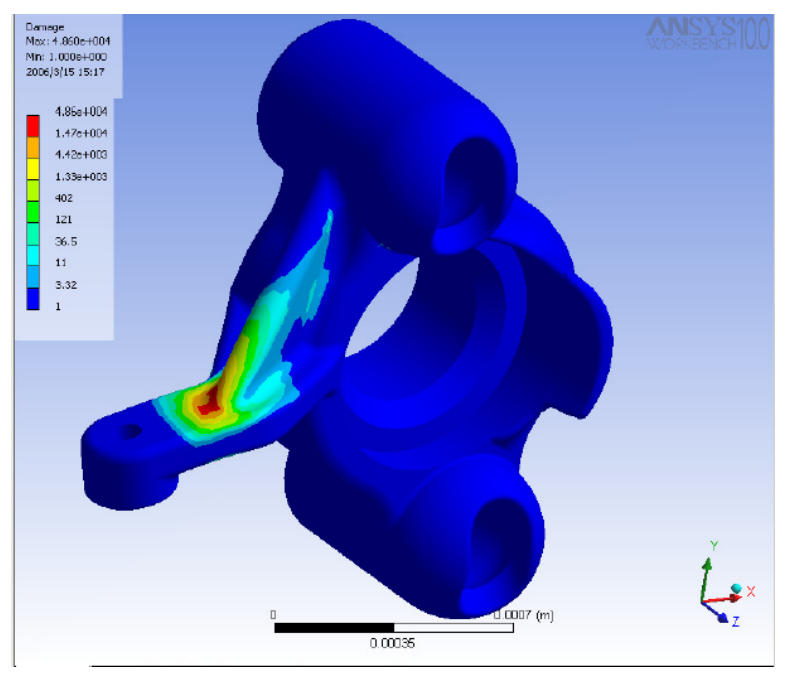

Figura 4.73 Perfil de dano por fadiga em todo o modelo FE.

Uma das melhores maneiras de se verificar se os resultados de tensão estão adequados para serem utilizados para previsão de vida em fadiga é comparar a tensão elemental ${ }^{45}$ com a tensão nodal ${ }^{46}$ Draper recomenda, baseado em sua experiência de anos na área de fadiga, que a vida em fadiga deveria ser calculada a partir de tensões nodais, ao invés das tensões nos pontos de integração, pois trincas de fadiga geralmente se iniciam na superfície do componente. Por isso, recomenda-se que o analista de fadiga realize a análise de previsão de vida utilizando uma malha mais refinada do que aquela geralmente utilizada em análise de tensões convencionais. Adicionalmente, recomenda-se que o analista compare o perfil de tensão nodal com o perfil de tensão elemental. Draper ( $(\mathrm{sdb})$ afirma que a diferença de mais $10 \%$ entre a tensão nodal e a tensão elemental poderia indicar uma malha inadquada para o cálculo da vida em fadiga. Esta é uma análise de sensitividade simples mas muito valiosa.

Em modelos grandes recomenda-se a utilização de malha relativamente grosseira no modelo e a utilização de submodelos com malha refinada, a fim de alcançar o refinamento de malha necessário para a análise de fadiga. Adicionalmente, uma malha simples e grosseria nas localizações críticas quase sempre resultam em estimativas de vida não conservadoras (Draper, sda).

\footnotetext{
${ }^{45}$ Comumente chamada de elemental stress.

${ }^{46}$ Comumente chamadas de nodal stress. Assim, cada nó possui um valor de tensão associado à ele; esta tensão nodal geralmente é a média simples das tensões nos elementos calculadas na posição (x,y,z) deste nó. Entretanto, a tensão nodal também podem ser a média de valores extrapolados a partir dos pontos de integração usando polinômios de ordem reduzida, procedimentos de suavização contínua e discreta global, procedimentos baseados em patch utilizando um conjunto de elementos vizinhos (chamado de método superconvergente), entre outros.
} 


\subsection{Conclusões do Capítulo 4}

Este capítulo descreveu como realiar uma análise de fadiga utilizando o método baseado em tensão. Embora este método tenha surgido em meados da década de 1860, ele ainda continua sendo o método mais utilizado em análise de fadiga devido às seguintes características:

1 O parâmetro governante para a falha por fadiga são as tensões, que são fáceis de serem obtidas em uma análise linear utilizando desde ferramentas simples como equações da resistência dos materiais até métodos sofisticados como o MEF.

2 A trinca por fadiga é nucleada devido ao estado de tensões cíclico e portanto parte-se do princípio que não existem trincas no início da utilização do componente, coincidindo com o que acontece com grande parte das estruturas;

3 Os ciclos de carregamento causam nenhuma (ou no máximo pouca) deformação plástica, que também frequentemente acontece em componentes mecânicos.

Uma grande revisão bibliográfica foi feita neste capítulo tendo sido analisadas 11 obras pelo autor desta dissertação e mais 16 obras por outros pesquisadores, resultando em uma análise de 27 obras que tratam do assunto fadiga sob a ótica do projeto mecânico. Concluiuse que os métodos existentes para estimar Curvas S-N Espécime e os fatores modificadores provém da década de 1960, principalmente dos trabalhos de Forrest (1962) e Juvinall (1967). Desta maneira, entende-se que houve pouca evolução na metodologia de análise de fadiga. Muitos metais foram desenvolvidos desde a década de 1960, principalmente metais de altíssima resistência mecânica. Isto foi possível graças ao melhoramento da microestrutura e dos processos de fabricação diferenciados. Como o fenômeno de nucleação e propagação de trinca está diretamente ligado à microestrutura, acredita-se que seja importante realizar uma revisão na metodologia de análise de fadiga para verificar se os fatores modificadores continuam aplicáveis aos novos metais.

Na seção 4.2 foi visto que existem casos onde há considerável dispersão ao se estimar as propriedades de fadiga a partir de propriedades estáticas, principalmente quando se tenta estimar $S_{b, s p}$. Por tal razão, o engenheiro deve tentar obter a Curva S-N Espécime primeiramente, seja através de banco de dados de materiais, catálogos ou através de seus próprios ensaios de bancada. A estimativa da curva Curva S-N Espécime deve ser feita apenas em último caso, quando o engenheiro realmente não consegue obter os parâmetros da curva de outra forma.

Na seção 4.3 foi introduzido o conceito de fator modificador. Estes fatores foram retirados de diversas literaturas, pois não foi encontrado uma obra que contivesse todos os fatores incluídos. O efeito da frequência de aplicação do carregamento é pequeno apenas quando corrosão, temperatura e efeitos ambientais agressivos estão ausentes. Acabamento superficial tem uma influência significativa na resistência à fadiga, principalmente em vidas 
longas e ultra longas. Tensões médias compressivas e tensões residuais compressivas são uma das melhores maneiras para aumentar a vida em fadiga de uma estrutura; por exemplo, o tratamento superficial por indução pode aumentar em mais de $150 \%$ o limite de fadiga de componentes entalhados, conforme apresenta a tabela 4.10. Do mesmo modo, não se pode negligenciar o efeito detrimental de tensões médias de tração ou das tensões residuais trativas no decréscimo da vida em fadiga. Neste capítulo foi apresentado dois métodos para contabilização do efeito de entalhe: o método $K_{f}$ e o método $R S G G^{47}$. O método $K_{f}$ utiliza as equações de Neuber ou Peterson, entretanto este método não consegue ser aplicado em análises de fadiga baseadas em Elementos Finitos. Apenas o método RSG é capaz de ser utilizado para contabilizar a influência de qualquer geometria de entalhe (Steiner et al., 2000). Além do mais, este método é o único capaz de ser utilizado automatizadamente em análises de fadiga de componentes com geometria complexa utilizando FEA. Este tipo de análise é recente na área de $\mathrm{CAE}$ e tem ganhado cada vez mais visibilidade e importância nos últimos anos sob o nome de FE-Based Fatigue Analysis.

A maneira de se contabilizar o efeito da tensão média nesta dissertação difere da maioria livros conhecidos da área de fadiga. Nesta dissertação, o efeito da tensão média foi considerado na modificação da Curva S-N Unnotched através do fator $C_{m}$, enquanto que na maioria dos livros de fadiga este efeito é contabilizado nas tensões. Foram apresentados 8 modelos para se contabilizar o efeito da tensão média. Entretanto, todos estes modelos foram formulados/criados para funcionar com tensão cíclica nominal $\left(S_{a}\right.$ e $\left.S_{m}\right)$.

Um novo método foi proposto nesta dissertação para a contabilização do efeito da tensão média para quando a análise de fadiga por Elementos Finitos é realizada e não for possível calcular as tensões nominais. Este método utiliza as pseudo tensões alternada $\left(\sigma_{a}^{e}\right)$ e média $\left(\sigma_{m}^{e}\right)$ para contabilizar o efeito da tensão média, através fator modificador $C_{m, \sigma^{e}}$. As vantagens e consequências deste método proposto foram apresentadas e discutidas.

Foi visto também que ciclos de baixa amplitude também causam dano em componentes sujeitos a carregamentos de amplitude variável com sobrecargas periódicas. Nestes casos a curva tensão-vida deve ser modificada novamente e passa a ter 2 inclinações. O final do capítulo também tratou sobre os aspéctos relacionados ao refinamento da malha de Elementos Finitos em uma FE-Based Fatigue Analysis.

É muito importante considerar uma ampla faixa de testes de espécimes em ensaios de fadiga, sendo que os testes podem abranger desde espécimes pequenos, altamente polidos e padronizados até estruturas em escala total ${ }^{48}$. O engenheiro deve se lembrar que o coeficiente de resistência a fadiga de componentes, $S_{f}^{\prime}$, pode variar de 1 a $70 \%$ do limite de resistência à tração e que o engenheiro pode influenciar substancialmente este valor através de decisões

\footnotetext{
${ }^{47}$ Método do Gradiente de Tensão Relativo

${ }^{48}$ Em inglês, full-scale tests of large structures.
} 
adequadas de projeto e manufatura. É também importante lembrar que os efeitos de frequência são geralmente pequenos apenas quando os efeitos de temperatura, corrosão ou outros agentes ambientais são ausentes. Também é importante lembrar que a rugosidade superficial é um dos principais fatores que influenciam na vida de estruturas com vidas longas (i.e., com baixa tensão alternada aplicada). O engenheiro nunca deve negligenciar o efeito deletério causado por tensões médias ou tensões residuais trativas e que modelos estão disponíveis para contabilizar estes efeitos. Da mesma maneira, o engenheiro deve sempre se beneficiar das vantagens de tensões médias e tensões residuais compressivas no aumento da vida em fadiga da estrutura objeto de análise. Adicionalmente, e talvez o mais importante, deve-se evitar sempre que possível concentração de tensões, que diminuem drasticamente a vida à fadiga de um componente.

Muitas estruturas podem ser projetadas de forma segura, associando rotinas de cálculo à fatores de segurança generosos, corrobados pela experiência acumulada em projetos similares ou obtidos através de normas técnicas. Todavia, fatores de segurança generosos não podem ser usados na análise de falhas, nem na maioria das avaliações de vida residual, muito menos se a minimização de peso ou custo da estrutura for fator crítico (de Castro \& Meggiolaro, 2009a). Assim, é preciso melhorar constantemente as rotinas de cálculo para aumentar a sua confiabilidade. E isto também vale para a análise de fadiga baseada em Elementos Finitos.

Entretanto, ainda não existe nenhuma rotina de dimensionamento capaz de prever precisamente o dano à fadiga em todos os casos práticos. Mesmo tarefas menos ambiciosas como prever a localização dos pontos críticos de uma estrutura muito complexa podem ser muito difíceis. Por isso, é altamente recomendável que o engenheiro de durabilidade valide a análise de fadiga computacional através de testes com a estrutura utilizando carregamentos iguais às condições de serviço reais, mesmo que isto requeira equipamentos sofisticados, como o mostrado na figura 1.3 .

O papel dos cálculos de fadiga variam de acordo com o componente, o carregamento e a situação na qual o componente será utilizado. Um componente com geometria e carregamentos simples, que será utilizado em uma situação onde uma falha causaria apenas transtornos simples, pode ser fabricado e colocado em serviço apenas com base nos cálculos de projeto. Isto é verdade principalmente se apenas um número pequeno de componentes forem fabricados. Se os prejuizos para uma estimativa errada são altos, então a verificação dos cálculos através de testes físicos se torna de extrema importância. Testes físicos com geometria e carregamento simplificados podem ser às vezes sulficientes para se avaliar vida em fadiga. Entretanto, há casos onde ensaios de fadiga de componente inteiro, sob condições de carregamento próximas à do esperado em serviço, necessitam ser realizados, conforme apresenta a figura 1.3. Este último tipo de ensaio possui alto custo financeiro. Além do mais, uma desvantagem significante com este tipo de teste é que ele não pode ser feito até que um 
protótipo exista, tornando o processo ainda mais trabalhoso e caro.

Quanto mais preciso e confiável se torna o processo de previsão de vida em fadiga, menos prováveis serão o número de modificações necessárias a serem realizadas no futuro. A principal contribuição das análises de fadiga baseada em resultados de análises por Elementos Finitos (também chamada de FE-Based Fatigue Analysis) é permitir cálculos de vida em fadiga confiáveis ainda na fase do desenvolvimento do produto, muito antes de testes físicos serem possíveis, reduzindo os custos diretos e indiretos. Especialistas da área de fadiga acreditam que, em um futuro próximo, simulações computacionais de problemas complexos de durabilidade gerarão resultados muito confiáveis e serão realizadas de maneira fácil e rápida por engenheiros. Por este motivo, testes físicos praticamente não serão mais necessários. Apenas um ou alguns poucos ensaios com o produto inteiro serão realizados para a validação das análises computacionais feitas na fase de projeto. Curiosamente, isto já ocorre em estruturas aeronáuticas atualmente. 


\section{Capítulo 5}

\section{Análise de Fadiga Multiaxial Baseada em Tensão}

\subsection{Introdução}

O capítulo 4 apresentou métodos para previsão de vida em fadiga de estruturas sujeitas a estado uniaxial de tensão. O modelo de Goodman, Gerber, Morrow, ASME-Elíptica e todos os outros modelos de correção da tensão média vistos na seção 4.3 .10 foram criados no passado utilizando ensaios sob carregamento uniaxial e, teoricamente, somente deveriam ser utilizados apenas em casos onde há tensão cíclica uniaxial. Adicionalmente, o método Rainflow para contagem de ciclos de carregamento variável, apresentado na seção 4.5, também foi criado para ser utilizado em casos de tensão uniaxial cíclica de amplitude variável, e só pode ser utilizado neste contexto.

Estruturas reais sob carregamentos cíclicos estão frequentemente sujeitas a estados de tensões multiaxiais cíclicas e também falham por fadiga. $\mathrm{O}$ estado de tensão nos entalhes de um componente é frequentemente multiaxial e diferente do estado de tensão longe do entalhe, no componente em geral. Por exemplo, na raiz de uma rosca o estado de tensão é biaxial, embora a ele possa ser uniaxial no corpo principal do parafuso (Fatemi, sdc). Desta forma, estados de tensão multiaxial são muito comuns e difíceis de evitar. Alguns exemplos de componentes sujeitos a este estado de tensão são: virabrequins sujeitos à torção e flexão, flexão de placas em mais de um eixo, tubulações sujeitas a ciclos de pressurização combinadas com torção constante, eixos sujeitos a torção e flexão cíclicas combinadas, blocos de motores, manga e ponta de eixo, bandeja de suspensão, carcaças de máquinas no geral, dentre outros. A área que estuda e a falha por fadiga de estruturas sujeitas à tensões multiaxiais cíclicas chama-se fadiga multiaxial.

A utilização dos critérios de falha de fadiga uniaxial na estimativa da vida em fadiga de componentes sujeitos à fadiga multiaxial leva à resultados consideravelmente errados na 
maioria das vezes, para o lado não conservador (de Castro \& Meggiolaro, 2009a; Lee et al., 2011; Papuga, 2005; Socie \& Marquis, 2000). Portanto, componentes sujeitos à tensões multiaxiais cíclicas devem necessariamente ser analisados utilizando a teoria de fadiga multiaxial. A previsão da vida em fadiga em um problema de fadiga multiaxial é mais difícil do que em um problema de fadiga uniaxialfaz-se necessário o entendimento e a utilização de modelos de fadiga multiaxia ${ }^{1}$ para uma correta previsão de vida em fadiga. Este capítulo tem o objetivo de apresentar a teoria sobre fadiga multiaxial, assim como os mais importantes critérios de fadiga multiaxial baseados em tensão. Critérios de fadiga baseados em tensão devem ser utilizados quando não ocorre plasticidade significante no componente objeto de análise.

Grande parte dos produtos e componentes mecânicos, como automóveis, aviões e máquinas em geral, são tridimensionais e possuem geometria complexa. Este é o principal motivo de se utilizar análise por Elementos Finitos para calcular as tensões (e deformações) nos locais concentradores de tensão em estruturas complexas. FEA têm sido utilizado amplamente para análise estrutural de componentes, pois fornece resultados de tensão consideravelmente precisos e é favorável para ser utilizado em situações de carregamentos, materiais e condições de contorno complexos.

Há três estragégias para se realizar a análise de fadiga de um componente utilizando resultados de FEA(Lee et al., 2011). A escolha de qual estratégia utilizar depende da aplicação e da necessidade. A primeira estratégia é a realização de uma análise por Elementos Finitos não-linear elasto-visco-plástica se escoamento no material é esperado, como no caso de uma estimativa de fadiga térmica-mecânica ou de componentes sujeitos à tensões cíclica acima do escoamento (Lee et al., 2011). Entretanto, não é nada prático utilizar esta abordagem em estruturas sob longo histórico de carregamento multiaxial de amplitude variável devido ao enorme tempo computacional exigido pela análise.

Como segunda estratégia, pode-se ser empregada uma análise linear elástica por Elementos Finitos a fim de se obter a história de tensões e deformações nos entalhes. Essas são as pseudo tensões $\left(\sigma^{e}\right)$ e pseudo deformações $\left(\varepsilon^{e}\right)$ citadas no capítulo 4. Em casos onde ocorre plastificação na raiz de entalhes, a regra de Neuber multiaxia| $\left.\right|^{2}$ é então aplicada sobre estas histórias de tensões e deformações para estimar as tensões verdadeiras $(\sigma)$ e deformações verdadeiras $(\varepsilon)$ no entalhe quando tensões multiaxiais estão presentes (Lee et al., 2011). Tradicionalmente, esta abordagem tem sido utilizada em análise de fadiga multiaxial baseada em deformação.

A última estratégia está baseada na hipótese de que há pouquíssima deformação plástica no regime de fadiga de alto ciclo, inclusive nas regiões dos entalhes (Lee et al., 2011) e

\footnotetext{
${ }^{1}$ Também chamados por alguns autores de critérios de fadiga multiaxial (Bishop \& Sherratt, 2000, Lee et al. 2011; Papuga, 2005; Socie \& Marquis, 2000)

${ }^{2}$ Também chamada de multiaxial notch stress-strain analysis (Lee et al. 2011. pp.162)
} 
portanto as pseudo tensões (6 componentes do tensor de tensões de Cauchy), são calculados a partir de uma análise linear elástica por Elementos Finitos e são empregados para para prever a vida de componentes através da Curva $\sigma-N$ Local, conforme descrito no capítulo 4 . Como não há deformação plástica no componente em nenhum momento, inclusive nos entalhes, não há necessidade de aplicar a regra de Neuber multiaxial nos entalhes e os critérios de fadiga multiaxial baseados em tensão podem então ser utilizados. Esta última abordagem é a mais eficiente análise de fadiga para ser utilizada no regime HCF e será a abordagem utilizada nesta dissertação.

As duas últimas estratégias são as utilizadas em ferramentas comerciais de análise de fadiga como os softwares $n$ Code Design Life (HBM), o MSC.Fatigue (MSC.Software), o fe-safe (Dassault Systèmes), o FEMFAT (Magna Powertrain), o NX Durability (Siemens) e o winLIFE (Steinbeis Foundation).

Tensões multiaxiais cíclicas em regiões em entalhes são comumente encontradas em estruturas reais, tanto sob carregamento cíclico multiaxial quanto uniaxial. Isto acontece porque a restrição geométrica de um entalhe faz com que ocorram tensões multiaxiais na raiz do mesmo, mesmo que o componente como um todo esteja sob estado de tensão uniaxial (Lee et al., 2011; Socie \& Marquis, 2000).

No geral, um carregamento cíclico multiaxial pode ser classificado em duas categorias: carregamento proporcional e carregamento não proporcional. Carregamento não proporcional é um caminho de carregamento multiaxial que faz com que os eixos das tensões principais de cada ponto da estrutura rotacionem com o passar do tempo, com relação a um sistema de coordenadas local com origem no ponto. Consequentemente, este tipo de carregamento faz com que os eixos da tensão de cisalhamento máxima absoluta também rotacionem com o tempo. Por outro lado, um carregamento proporcional irá fazer com que os eixos principais e os eixo da tensão cisalhante máxima permaneçam estacionário em qualquer ponto da estrutura. É importante ressaltar que carregamentos proporcionais podem fazer com que os valores das tensões principais variem ao longo do tempo, entretanto estes carregamentos não fazem os eixos principais rotacionarem.

Seja o elemento infinitesimal na superfície de um eixo ciclíndrico sujeito à tração e torção representado na figura 5.1. A figura 5.2a apresenta um caso onde as tensões nesse eixo variam proporcionalmente. Nesta imagem, o eixo é solicitado simultaneamente a uma carga axial cíclica de amplitude $P_{a}=100 \mathrm{MPa}$ e a uma torção cíclica de amplitude $T_{a}=60 \mathrm{MPa}$. Este carregamento está em fase (IP), pois ambos atingem o valor máximo ao mesmo tempo e, neste tipo de carregamento, a direção das tensões principais máxima e mínima não rotacionam durante o tempo, conforme apresenta a figura 5.3. Por outro lado, a figura $5.2 \mathrm{~b}$ apresenta um carregamento diferente sobre este mesmo eixo. Neste caso, o componente é solicitado por esforço de tração e torção cíclicas, ambas com a mesma forma de onda 
(frequência), porém com uma defasagem de $90^{\circ}$ entre as duas ondas. Este tipo de carregamento recebe o nome de carregamento fora de fase. Em todo o carregamento fora de fase os valores extremos de canais diferentes não ocorrem ao mesmo tempo. Particularmente os carregamentos que possuem ondas defasadas em $90^{\circ}$ costumam ser chamados de carregamento OP (Shamsaei \& Fatemi, 2010b; Socie \& Marquis, 2000).

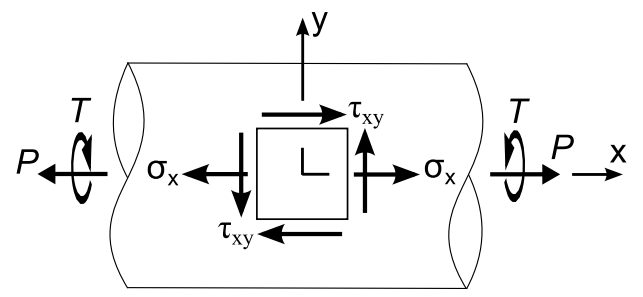

Figura 5.1 Elemento infinitesimal na superfície de um eixo cilíndrico.

A figura 5.4 apresenta o comportamento do elemento infinitesimal durante todo o ciclo de carregamento. Pode-se perceber que os eixos principais rotacionam com o tempo, voltando à mesma posição quando no ponto $\mathrm{M}$. A figura $5.5 \mathrm{a}$ apresenta um diagrama $\sigma \times \tau$ para carregamento IO e a figura $5.5 \mathrm{~b}$ apresenta o mesmo diagrama para carregamento OP.

Estudos na área de fadiga multiaxial ao longo das últimas décadas mostraram que a redução da vida em fadiga multiaxial é causada basicamente por dois motivos: o grau de não-proporcionalidade do carregamento a sensibilidade do material ao carregamento não proporcional. Esses dois fenômenos serão explicados a seguir:

Estudos na metade da década de 90 mostraram que caminhos de carregamento não proporcional diferentes produzem diferentes graus de encruamento não-proporcional, no qual o caminho de carregamento fora de fase em $90^{\circ}$ graus gera o maior grau de encruamento não proporcional e, portanto, menor vida em fadiga (Lee et al., 2011; Shamsaei \& Fatemi, 2010a). Desta maneira, um critério de fadiga confiável deve ser capaz de estimar valores

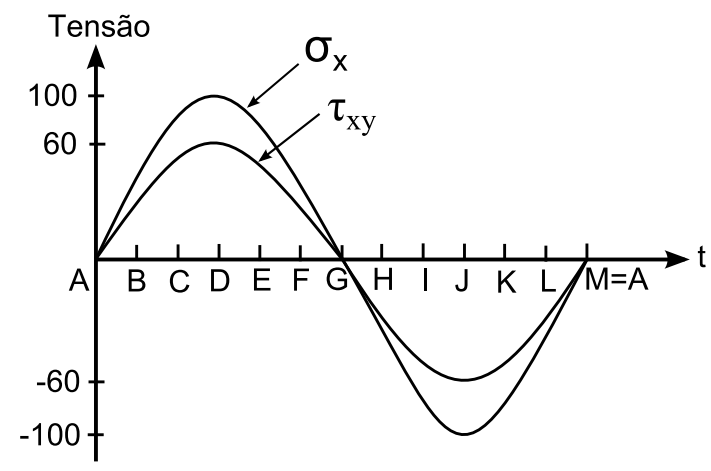

(a) Carregamento em fase (IP).

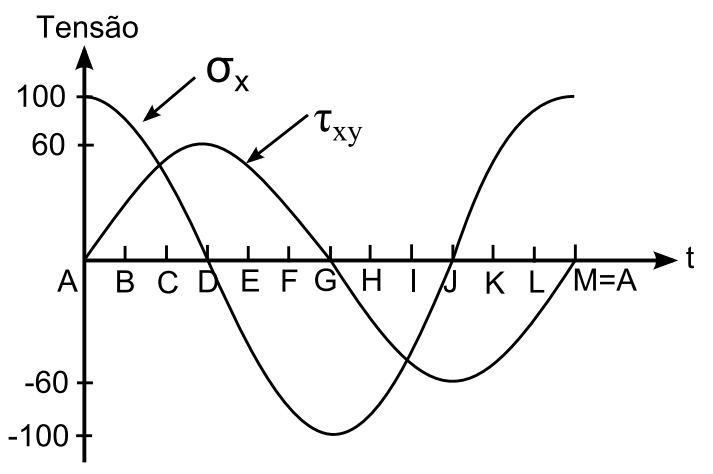

(b) Carregamento $90^{\circ}$ fora de fase (OP).

Figura 5.2 Histórico de tensão normal e cisalhante na superfície do eixo. 


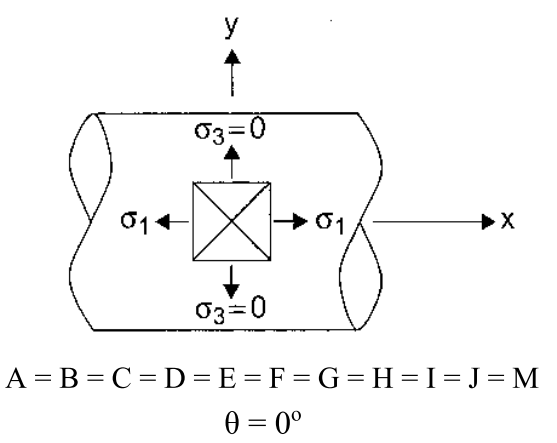

Figura 5.3 Tensões principais máxima e mínima com relação ao eixo local $\mathrm{x}$, nos intervalos de tensão A até $\mathrm{M}$, para carregamento proporcional.

de dano por fadiga maiores para carregamentos não-proporcionais. De maneira geral, estudos mostraram que um carregamento não proporcional causa um dano igual ou maior do que um carregamento proporcional de mesma tensão alternada equivalente (Findley, 1959, Lee et al., 2011; McDiarmid, 1994; Socie \& Marquis, 2000). A causa deste fenômeno tem sido explicada pelo adicional encruamento não proporcional causado pelo aumento das interações entre os sistemas de deslizamento e pela maior criação e movimentação de discordâncias (Lee et al., 2011; Socie \& Marquis, 2000). Maiores detalhes sobre este fenômeno podem ser encontrados em Socie \& Marquis (2000) e Itoh et al. (1995). A figura 5.6 apresenta duas curvas $\mathrm{S}-\mathrm{N}$ obtidas utilizando carregamento proporcional e não proporcional. $\mathrm{O}$ eixo das ordenadas representa a tensão equivalente, que geralmente é calculada utilizando a equação para obtenção da tensão de von Mises. Pode-se observar que, para um mesmo valor de tensão equivalente, a vida para carregamento $90^{\circ}$ fora de fase $\left(N_{O P}\right)$ é menor do que para carregamentos em fase $\left(N_{I P}\right)$.

É possível se criar dezenas de histórias de carregamentos não proporcionais apenas combinando-se o histórico de tensão normal com o histórico de tensão de cisalhamento. A figura 5.7 apresenta diversos tipos de carregamento, tanto proporcionais quanto não proporcionais, apresentados nos diagramas de fases. ${ }^{3}$. A tabela 5.1 apresenta o resultado o valor dos intervalos de tensão $(\Delta \varepsilon, \Delta \gamma, \Delta \sigma, \Delta \tau)$, a tensão equivalente $\left(\sigma_{e q}\right)$ e vida em fadiga $(N)$ de cada de cada tipo de carregamento testado.

Quanto maior o grau de não proporcionalidade de um carregamento menor será a vida em fadiga. O parâmetro que mede o quanto uma história de carregamento é não proporcional é o fator de não-proporcionalidade $F_{N P}$ (Lee et al., 2011; Socie \& Marquis, 2000). A determinação do grau de não proporcionalidade pode ser visualizada desenhando-se o histórico do carregamento no diagrama de fase, com a deformação normal no eixo das abscissas e a deformação de cisalhamento no eixo das ordenadas, conforme mostrado na figura 5.8 .

${ }^{3}$ Chamados de stress path quando é um diagrama $\sigma-\tau$ e strain path quando representa $\varepsilon-\gamma$ Araújo et al. 


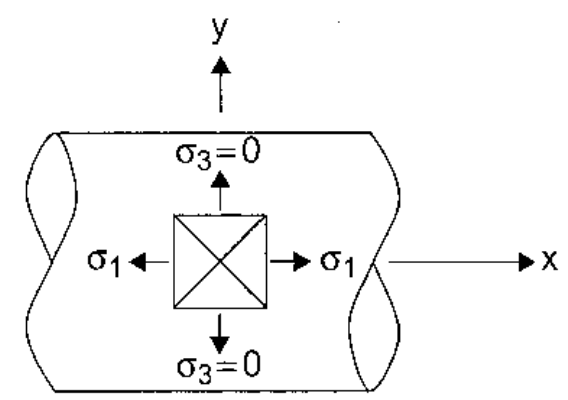

Point $\mathrm{A}, \theta_{1}=0$

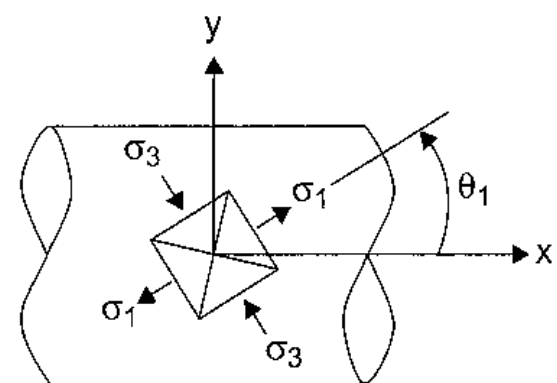

Point $\mathrm{C}, \theta_{1}=32^{\circ}$

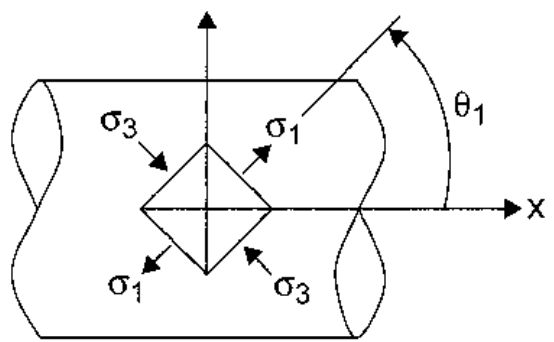

Point $\mathrm{D}, \theta_{1}=45^{\circ}$

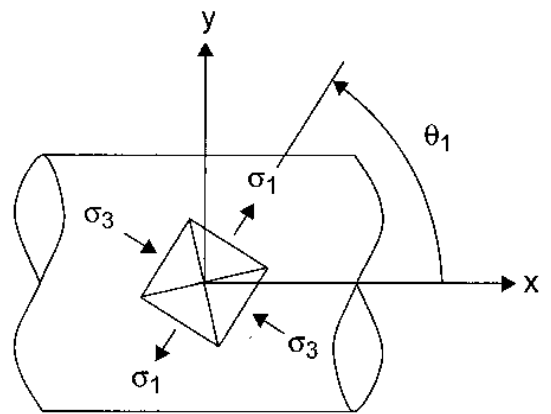

Point $E, \theta_{1}=58^{\circ}$

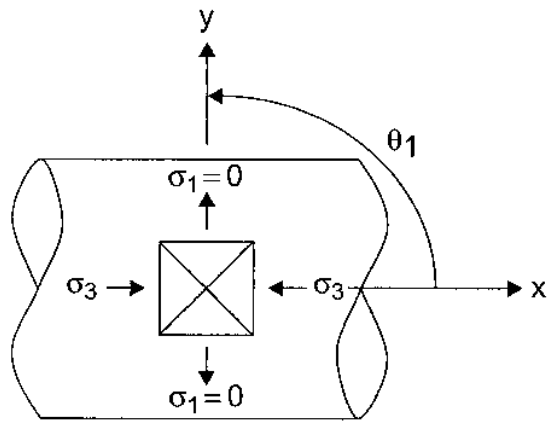

Point G, $\theta_{1}=90^{\circ}$

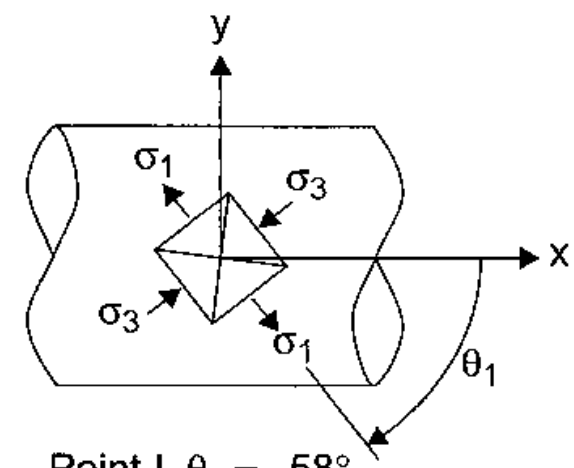

Point $\mathrm{I}, \theta_{1}=-58^{\circ}$

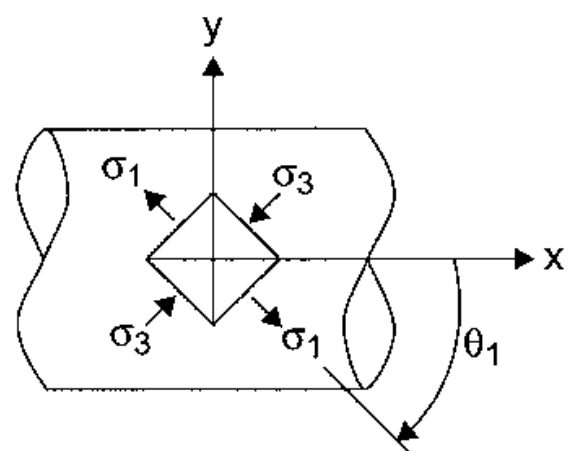

Point $\mathrm{J}, \theta_{1}=-45^{\circ}$

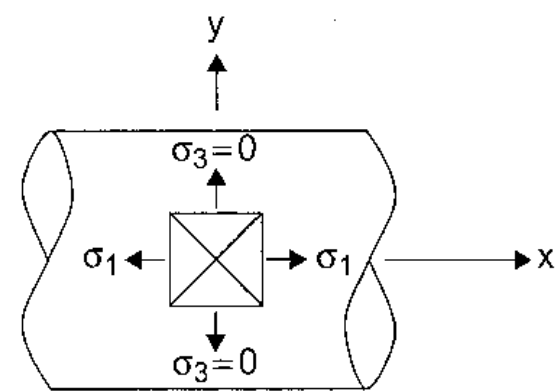

Point M, $\theta_{1}=0^{\circ}$

Figura 5.4 Tensões principais máxima e mínima com relação ao eixo local $\mathrm{x}$, nos intervalos de tensão $\mathrm{A}$ até $\mathrm{M}$, para carregamento não proporcional. 


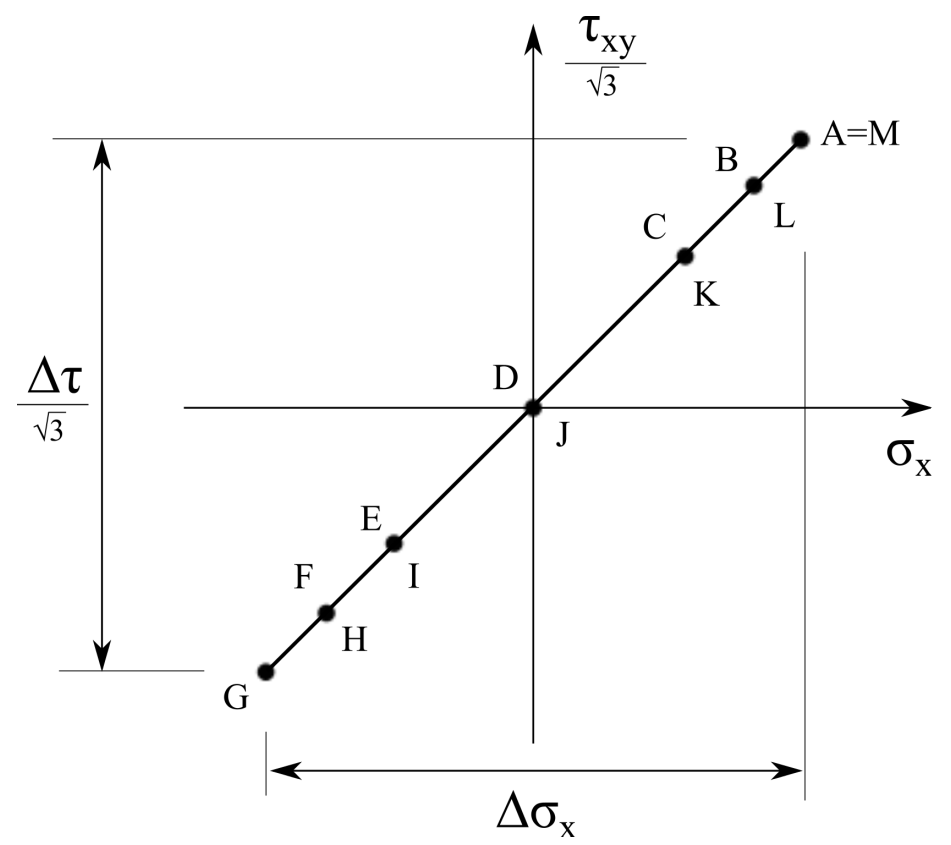

(a) Carregamento em fase (IP) representado no diagrama de fases

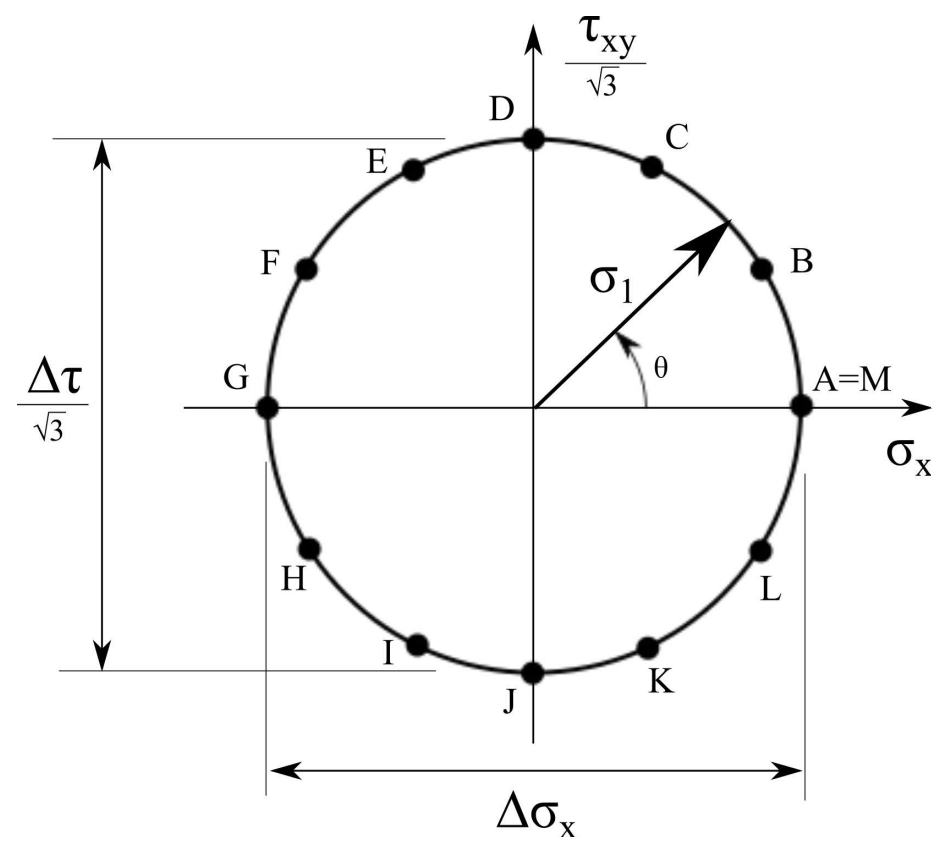

(b) Carregamento $90^{\circ}$ fora de fase (OP) representado no diagrama de fases

Figura 5.5 Diagrama de fases dos dois tipos de carregamentos sobre o eixo. 


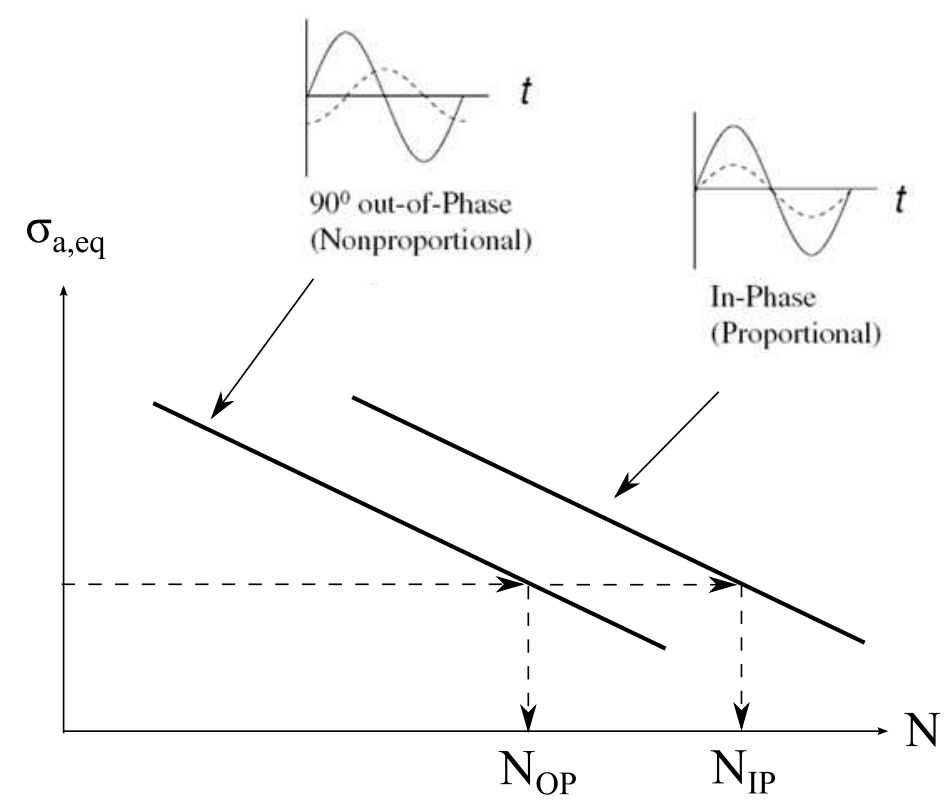

Figura 5.6 Efeito do tipo de carregamento na vida em fadiga.

de Castro \& Meggiolaro (2009a) afirmam que o fator de não-proporcionalidade da carga, $F_{N P}$, é medido pela forma da elipse que envolve a história das deformações normais $\varepsilon$ e cisalhantes $\gamma$ no diagrama de fase. Sendo $a$ e $b$ ( $b \leq a$ sempre) os semi-eixos da elipse envoltória, o fator de não-proporcionalidade é definido por

$$
F_{N P}=\frac{b}{a} \quad \text { Sendo } \quad 0 \leq F_{N P} \leq 1
$$

Todos os carregamentos proporcionais têm deformações de cisalhamento $\gamma$ proporcionais às normais $\varepsilon, \operatorname{com} F_{N P}=0$ e uma trajetória reta no diagrama $\varepsilon \times \gamma / \sqrt{3}$. Por outro lado, carregamentos $90^{\circ}$ sempre resultam em vidas menores (Lee et al., 2011; Shamsaei \& Fatemi, 2010a).

Nos parágrafos anteriores foi visto como o grau de não-proporcionalidade do carregamento, medido através do fator de proporcionalidade, afeta na vida em fadiga. Entretanto, existe mais um fator que afeta na vida: a sensibilidade do material ao carregamento não proporcional. A curva $\sigma-\varepsilon$, geralmente obtida em ensaio de tração, pode ser obtida através de ensaios cíclicos de fadiga, e passa a se chamar curva $\sigma-\varepsilon$ cíclica ${ }^{4}$. Esta curva é obtida submetendo os espécimes a estado uniaxial de tensão cíclico. Entretanto, também é possível obter esta curva aplicando nos espécimes um estado de tensão multiaxial (geralmente biaxial, com tração e torção simultâneas). Nestes casos, o eixo das ordenadas representa a tensão equivalente e o eixo das abscissas representa a deformação equivalente (ambas calculadas utilizando a fórmula da tensão/deformação de von Mises). Quando espécimes são submetidos a carregamento não proporcional variável, alguns materiais podem encruar muito

\footnotetext{
${ }^{4}$ Mais informações sobre esta curva pode ser encontrada em (Lee et al., 2005, cap. 5)
} 

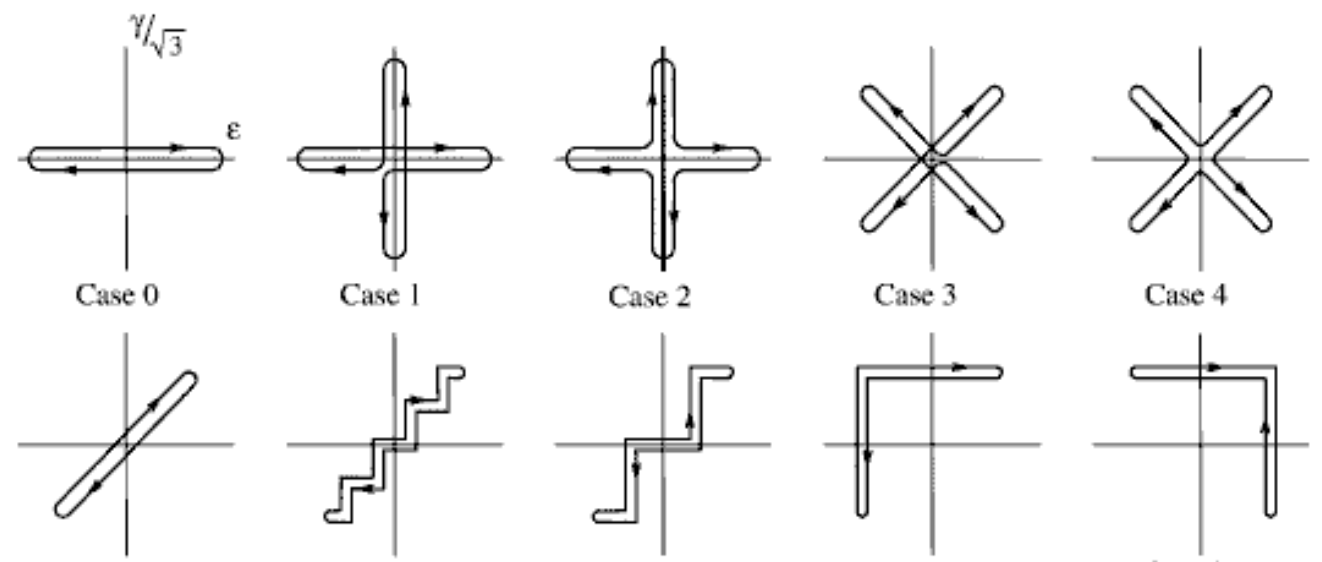

Case 3

Case 4

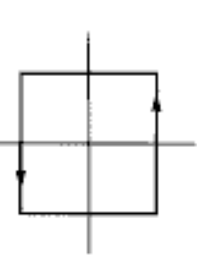

Case 6

Case 7
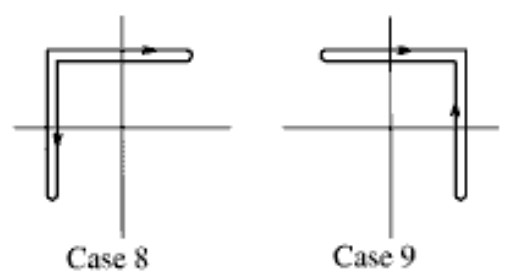

Case 10

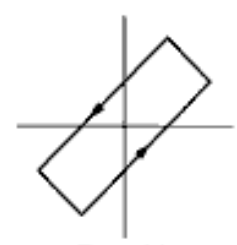

Case 11

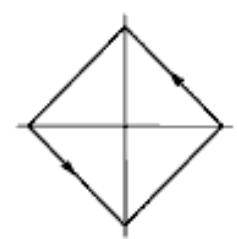

Case 12

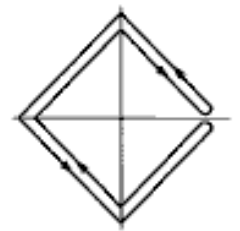

Case 13

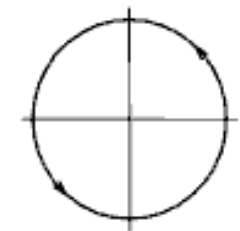

Case 14

Figura 5.7 Históricos de carregamentos proporcionais e não proporcionais (Itoh et al., 1995).

Carga proporcional

$\mathrm{F}_{\mathrm{NP}}=0$

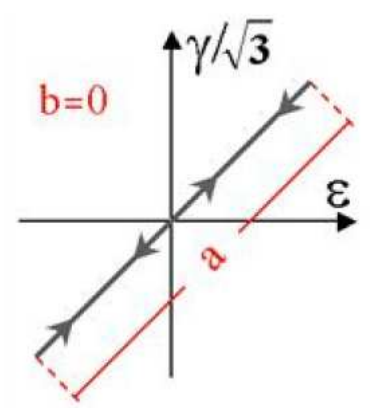

Carga não proporcional

$$
\mathrm{F}_{\mathrm{NP}}=1
$$

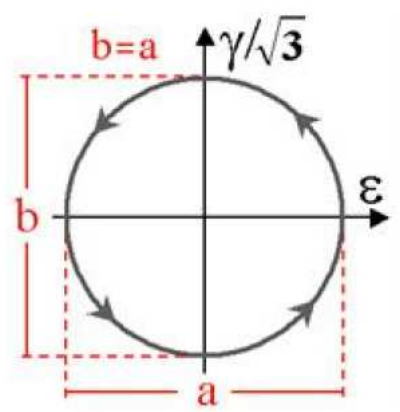

Carga genérica

$$
\mathrm{F}_{\mathrm{NP}}=\mathrm{b} / \mathrm{a}
$$

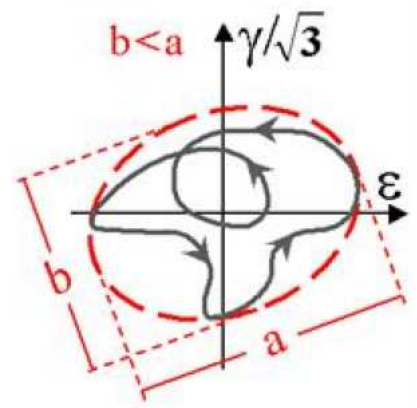

Figura 5.8 Definição do fator de proporcionalidade $\left(F_{N P}\right)$ a partir da história de deformações (Meggiolaro \& de Castro, 2005). 
Tabela 5.1 Influência do caminho de carregamento na vida em fadiga.

\begin{tabular}{c|c|c|c|c|cc}
\hline $\begin{array}{c}\text { Caminho de } \\
\text { Deformação }\end{array}$ & $\begin{array}{c}\text { Deformação } \\
\text { Normal } \\
\Delta \varepsilon\end{array}$ & $\begin{array}{c}\text { Deformação } \\
\text { Cisalhante }\end{array}$ & $\begin{array}{c}\text { Tensão } \\
\text { Normal } \\
\Delta \gamma\end{array}$ & $\begin{array}{c}\text { Tensão } \\
\text { Cisalhante } \\
\Delta \tau\end{array}$ & $\begin{array}{c}\text { Tensão } \\
\text { Equivalente } \\
\sigma_{e q}\end{array}$ & $\begin{array}{c}\text { Vida } \\
N\end{array}$ \\
\hline 0 & 1,13 & 0 & 730 & 0 & 730 & 1.700 \\
1 & 0,8 & 1,39 & 950 & 530 & 960 & 1.400 \\
2 & 0,8 & 1,39 & 860 & 490 & 860 & 2.100 \\
3 & 0,8 & 1,39 & 975 & 545 & 1.237 & 820 \\
4 & 0,8 & 1,39 & 1.10 & 520 & 1.114 & 900 \\
5 & 0,8 & 1,39 & 590 & 250 & 732 & 3.200 \\
6 & 0,8 & 1,39 & 670 & 320 & 770 & 2.600 \\
7 & 0,8 & 1,39 & 735 & 390 & 822 & 1.700 \\
8 & 0,8 & 1,39 & 1.055 & 560 & 1.046 & 470 \\
9 & 0,8 & 1,39 & 1.075 & 600 & 1.070 & 660 \\
10 & 0,8 & 1,38 & 1.060 & 555 & 1.172 & 320 \\
11 & 0,8 & 1,39 & 850 & 500 & 924 & 1.200 \\
12 & 0,8 & 1,39 & 940 & 510 & 960 & 710 \\
13 & 0,8 & 1,39 & 965 & 550 & 1.025 & 1.000 \\
\hline
\end{tabular}

mais do que previsto na curva $\sigma-\varepsilon$ cíclica obtida com carga uniaxial. Já outros, acabam encruando menos (Socie \& Marquis, 2000). Portanto, este tipo de comportamento influencia na previsão de vida em fadiga e deve ser reconhecido nas rotinas de dimensionamento à fadiga (de Castro \& Meggiolaro, 2009a).

Conforme ilustra a figura 5.9, o efeito do carregamento não proporcional pode ser verificado em um gráfico tensão VS deformação equivalente. A relação em fase é representada pelo modelo de Ramberg-Osgood,

$$
\varepsilon=\frac{\sigma}{E}+\left(\frac{\sigma}{H_{C, N P}}\right)^{n_{2}}
$$

Onde

$\varepsilon_{e q}:$ Deformação equivalente

$\sigma_{e q}:$ Tensão equivalente

E : Módulo de Elasticidade

$n_{2}$ : Expoente de encruamento da equação de Ramberg-Osgood

$H_{C, N P}$ : Coeficiente da curva Ramberg-Osgood multiaxial

O novo coeficiente é denominado:

$$
H_{C, N P}=H_{C} \cdot\left(1+\alpha_{N P} \cdot F_{N P}\right)
$$


e contabiliza tanto a sensibilidade do material à cargas não proporcionais $\left(\alpha_{N P}\right)$ quanto ao grau de não proporcionalidade da carga $\left(F_{N P}\right)$. Em carregamento proporcional o coeficiente vale:

$$
H_{C, N P}=H_{C}
$$

$\mathrm{O}$ maior encruamento não proporcional ocorre quando $F_{N P}=1$. De acordo com Lee et al. (2011), a sensibilidade do material à carregamento não proporcional é descrito pelo parâmetro $\alpha_{N P}$, definido pela equação abaixo:

$$
\alpha_{N P}=\frac{\sigma_{a, V M}\left(\phi=90^{\circ}\right)}{\sigma_{a, V M}\left(\phi=0^{\circ}\right)}-1
$$

Onde

$\sigma_{a, V M}\left(\phi=90^{\circ}\right)$ : Tensão alternada de von Mises para um carregamento $90^{\circ}$ fora de fase;

$\sigma_{a, V M}\left(\phi=0^{\circ}\right)$ : Tensão alternada de von Mises para um carregamento em fase, para a mesma deformação alternada $\left(\varepsilon_{a, V M}\right)$

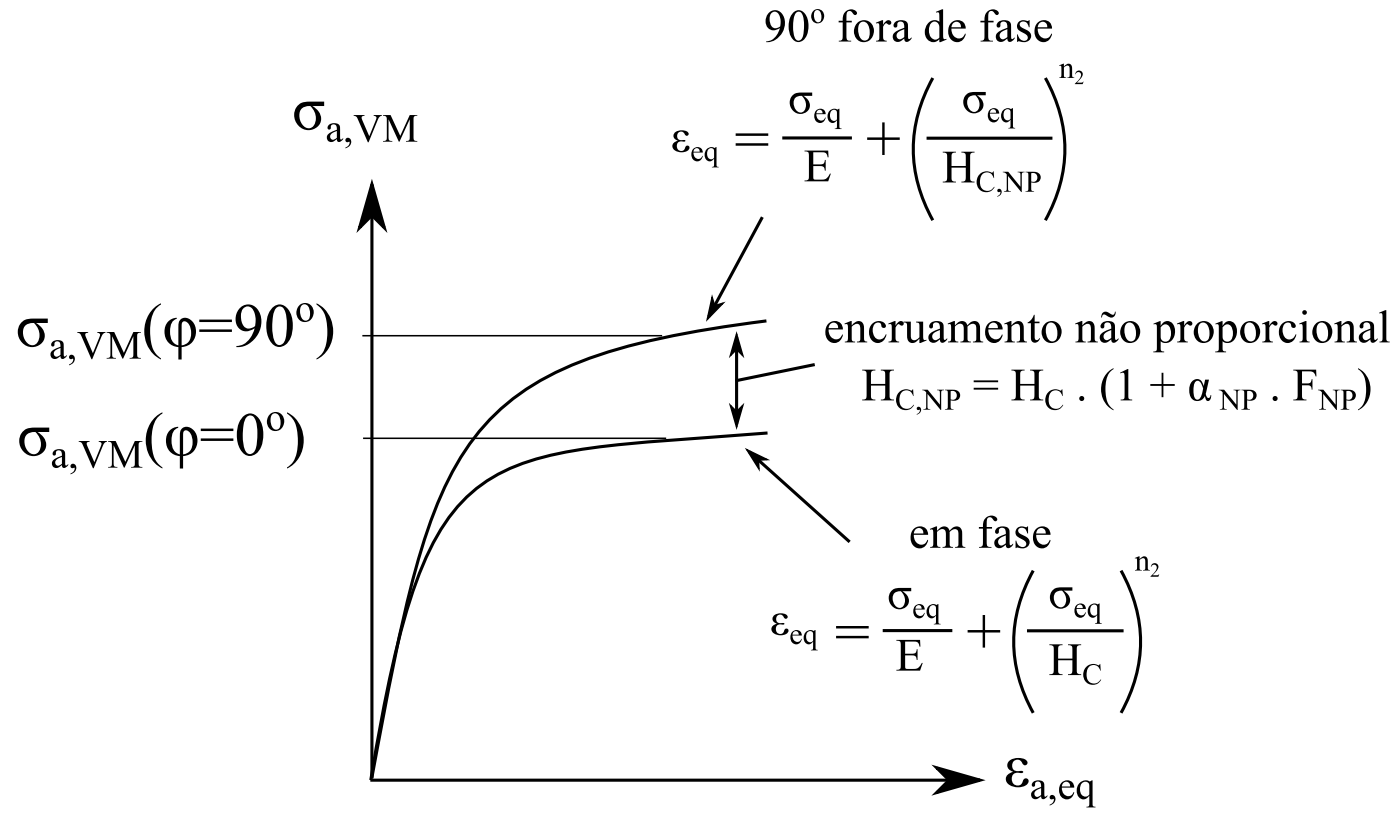

Figura 5.9 Comparação de curva $\sigma-\varepsilon$ cíclicas para o mesmo material sob carregamentos em fase e $90^{\circ}$ fora de fase.

Lee et al. (2011) e Socie \& Marquis (2000) afirmam que a severidade do encruamento não proporcional depende do tipo de material (i.e. da facilidade dos sistemas de deslizamento interagirem), da temperatura e do caminho de carregamento, como pode ser observado pela equação (5.2). A tabela 5.2 apresenta valores do coeficiente de encruamento não proporcional $\left(\alpha_{N P}\right)$ para vários metais, obtidos através da equação (5.3). 
Tabela 5.2 Coeficiente de encruamento não proporcional para vários metais (Socie \& Marquis, 2000)

\begin{tabular}{c|c}
\hline Material & $\alpha_{N P}$ \\
\hline Aço 1045 & 0,3 \\
Aço inoxidável 304 & $0,5-1,0$ \\
Aço inoxidável 304 à $650^{\circ} \mathrm{C}$ & 0,3 \\
Aço inoxidável 316 & 1,0 \\
Aço inoxidável 316 à 550 $\mathrm{C}$ & 0,37 \\
Aço Inconel 718 & 0,2 \\
Aço 42 Cr-Mo & 0,15 \\
Aço 1\% Cr-Mo-V & 0,14 \\
Alumínio 6061-T6 & 0,2 \\
En15R & 0,14 \\
\hline
\end{tabular}

\subsection{Avaliação do Tipo de Carregamento}

Além do fator de não proporcionalidade $\left(F_{N P}\right)$, existe outra maneira de se determinar o quão não proporcional é um carregamento. Isto é feito através de um parâmetro chamado razão de biaxialidade, definida pela equação a seguir:

$$
a=\frac{\sigma_{2}}{\sigma_{1}}
$$

Onde

$\sigma_{1} \quad$ : Tensão principal máxima (em estado plano de tensões)

$\sigma_{2} \quad$ : Tensão principal mínima (em estado plano de tensões)

Em uma placa fina sob um carregamento variável " $F$ " aplicado apenas em uma direção, onde $\left|\sigma_{1}\right| \geq\left|\sigma_{2}\right|$, a tensão principal maior está alinhada na direção do carregamento $\mathrm{P}$, conforme ilustra a figura 5.10(a). Este tipo de carregamento é proporcional e a razão de biaxialidade é igual a

$$
a=\frac{\sigma_{2}}{\sigma_{1}}=0=\text { cte }
$$

Em um vaso de pressão como o mostrado na figura 5.10(b) a tensão de membrana é igual em todas as direções. Este tipo de carregamento é proporcional e resulta em uma razão de biaxialidade igual a

$$
a=\frac{\sigma_{2}}{\sigma_{1}}=1=\text { cte }
$$


Um eixo sujeito apenas à torção sob um torque T está sujeito a um estado puro de cisalhamento e as tensões principais estão inclinadas à $45^{\circ}$, conforme ilustra a figura 5.10(c). Este tipo de carregamento também é proporcional e possui uma razão de biaxialidade igual a

$$
a=\frac{\sigma_{2}}{\sigma_{1}}=-1=\text { cte }
$$

Entretanto, em um eixo sujeito simultaneamente à tração e torção variáveis, igual ao da figura 5.10 (d), a magnitude e a direção das tensões principais irão variar. Neste caso, o carregamento será não proporcional e a razão de biaxialidade será

$$
-1 \leq a \leq 0
$$
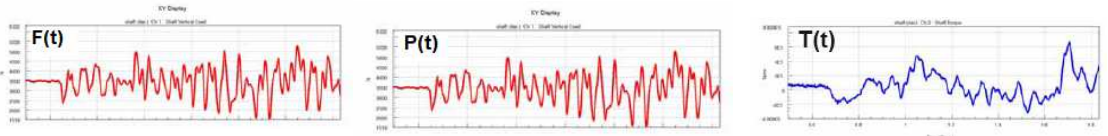

Força F variável

Pressão P variável

Torção T variável

uniaxial

$a=\frac{\sigma_{2}}{\sigma_{1}}=0=$ cte

Carregamento proporcional

(a)

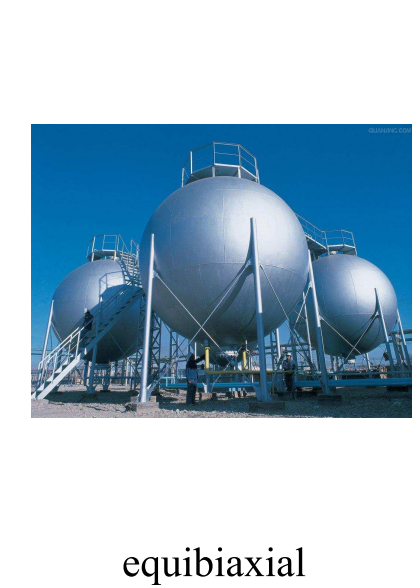

$a=\frac{\sigma_{2}}{\sigma_{1}}=1=$ cte

Carregamento proporcional (c)
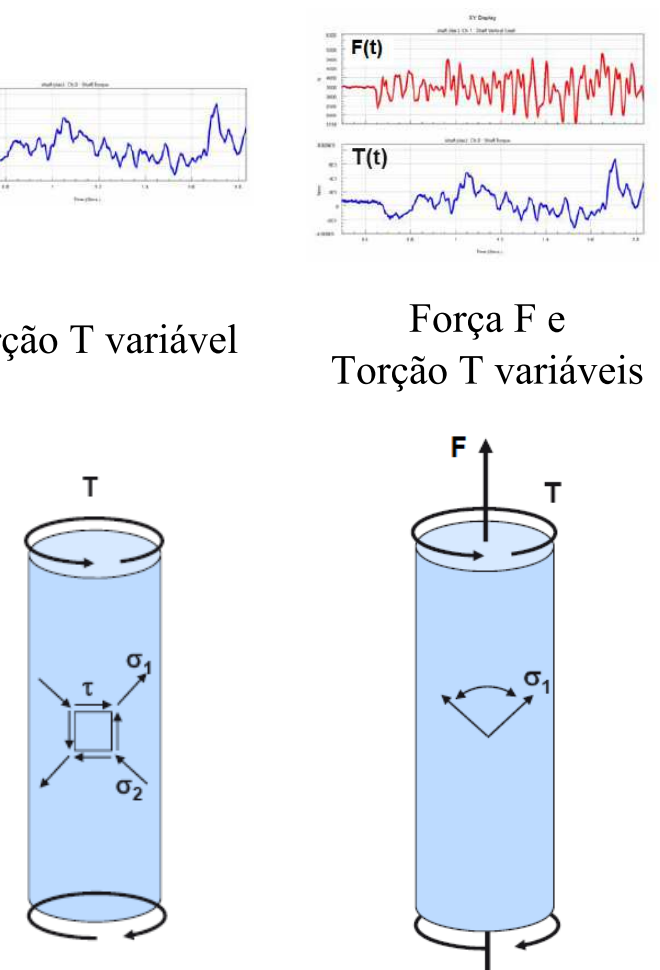

Força $\mathrm{F}$ e Torção T variáveis

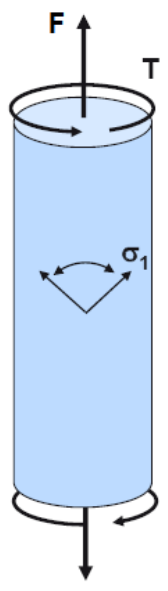

cisalhamento puro $a=\frac{\sigma_{2}}{\sigma_{1}}=-1=$ cte

Carregamento proporcional

$$
\begin{gathered}
a=\frac{\sigma_{2}}{\sigma_{1}} \neq \text { cte } \\
-1 \leq a \leq 0
\end{gathered}
$$

Carregamento não proporcional (e)

Figura 5.10 Razão de biaxialidade para vários casos de carregamento (adaptado de Heyes (2011)).

As tensões principais de cada ponto de um componente 3D são determinadas através da 
equação abaixo:

$$
\sigma^{3}-I_{1} \sigma^{2}+I_{2} \sigma-I_{3}=0
$$

Os valores dos invariantes de tensão são obtidos através das três equações seguintes, onde as 9 componentes do tensor tensão provém de um nó uma análise estrutural por Elementos Finitos, conforme apresenta a figura $5.11(\mathrm{a})$.

$$
\begin{aligned}
& I_{1}=\sigma_{x}^{e}+\sigma_{y}^{e}+\sigma_{z}^{e} \\
& I_{2}=\sigma_{x}^{e} \sigma_{y}^{e}+\sigma_{y}^{e} \sigma_{z}^{e}+\sigma_{z}^{e} \sigma_{x}^{e}-\left(\tau_{x y}^{e}\right)^{2}-\left(\tau_{y z}^{e}\right)^{2}-\left(\tau_{z x}^{e}\right)^{2} \\
& I_{3}=\sigma_{x}^{e} \sigma_{y}^{e} \sigma_{z}^{e}+2 \tau_{x y}^{e} \tau_{y z}^{e} \tau_{x z}^{e}-\sigma_{x}^{e}\left(\tau_{y z}^{e}\right)^{2}-\sigma_{y}^{e}\left(\tau_{x z}^{e}\right)^{2}-\sigma_{z}^{e}\left(\tau_{x y}^{e}\right)^{2}
\end{aligned}
$$

Entretanto, quando não há pressão externa aplicada na superfície do componente, cada ponto na superfície está sob estado de tensão biaxial. Nestes casos, a equação (5.4) continua sendo válida e a seguinte convenção é adotada:

$$
\left|\sigma_{1}\right| \geq\left|\sigma_{2}\right|
$$

Em uma análise estrutural de um componente 3D (por exemplo via Elementos Finitos) que não possui pressão externa aplicada na superfície, a tensão normal à superfície em um ponto localizado também na superfície (ou em um nó superficial, no caso de FEA) possuirá um valor diferente de zero. Por isso, para avaliar o valor da razão de biaxialidade a partir de resultados FEA, é comum reduzir o tensor de tensão 3D do nó superficial para um tensor $2 \mathrm{D}$, através de uma rotação. As tensões são rotacionadas para um sistema de coordenadas local, orientado de maneira que o eixo " $z$ " fica perpendicular à superfície daquele nó, conforme apresenta a figura 5.11(b), e o tensor de tensão 2D passa então a ser aquele mostrado nas figuras 5.11(c) e 5.11(d). A figura 5.12 representa o estado plano de tensão em um nó localizado na superfície de uma malha de Elementos Finitos, sendo $\phi_{p}$ chamado orientação da tensão principal máxima, o ângulo que a tensão principal máxima faz com um eixo local paralelo à superfície $\left(x^{*}\right)$. Assim, baseado nas figuras 5.11 e 5.12, a tensão principal máxima $\left(\sigma_{1}\right)$ e mínima $\left(\sigma_{2}\right)$ são calculadas conforme as equações (5.14) e (5.15), respectivamente, e a razão de biaxialidade $(a)$ continua sendo calculada pela equação (5.4).

$$
\begin{aligned}
& \sigma_{1}=\frac{\sigma_{x^{*}}^{e}+\sigma_{y^{*}}^{e}}{2}+\sqrt{\left(\frac{\sigma_{x^{*}}^{e}-\sigma_{y^{*}}^{e}}{2}\right)^{2}+\left(\tau_{x^{*} y^{*}}^{e}\right)^{2}} \\
& \sigma_{2}=\frac{\sigma_{x^{*}}^{e}+\sigma_{y^{*}}^{e}}{2}-\sqrt{\left(\frac{\sigma_{x^{*}}^{e}-\sigma_{y^{*}}^{e}}{2}\right)^{2}+\left(\tau_{x^{*} y^{*}}^{e}\right)^{2}}
\end{aligned}
$$


E a direção da tensão principal máxima é calculada conforme segue:

$$
\phi_{p}=\frac{1}{2} \arctan \left(\frac{2 \tau_{x^{*} y^{*}}^{e}}{\sigma_{x^{*}}^{e}-\sigma_{y^{*}}^{e}}\right)
$$

Portanto, a seguinte regra é verdadeira para se definir se um ponto está sob carregamento não proporcional:

- Se $\phi_{p} \mathbf{E}$ a forem constantes então o carregamento é proporcional;

- Se $a=0$ e $\phi_{p}=$ cte, então ocorre estado de tensão uniaxial.

- Se $a=$ cte $\neq 0$ e $\phi_{p}=$ cte, então ocorre estado de tensão multiaxial.

- Se $\phi_{p} \mathbf{E} / \mathbf{O U}$ a $a$ variarem no tempo, então ocorre estado de tensão multiaxial e o carregamento é não proporcional.

Lembrando alguns casos especiais de carregamento proporcional:

$$
\begin{aligned}
a=0 & \text { Uniaxial } \\
a=-1 & \text { Cisalhamento puro } \\
a=1 & \text { Equi-biaxial }
\end{aligned}
$$

A figura 5.13a apresenta a deformação $\varepsilon_{x^{*}}^{e}, \varepsilon_{y^{*}}^{e}$ e $\gamma_{x^{*} y^{*}}^{e}$ ao longo do tempo, medido em um nó da superfície da malha de um componente, após uma análise estrutural por Elementos Finitos. Em nenhum instante de tempo houve plasticidade. A tensão principal máxima $\left(\sigma_{1}\right)$, a razão de biaxialidade ( $a$ ) foram calculadas para cada intervalo de tensão (intitulado time step em FEA da figura 5.13a e plotados na figura 5.13b. A orientação da tensão principal máxima $\left(\phi_{p}\right)$ também foi calculada para cada intervalo de tensão (time step) e plotada na figura $5.13 \mathrm{c}$. A figura 5.13b indica que o carregamento exemplo da figura 5.13a gera uma razão de biaxialidade aproximadamente fixa no valor de $-0,1$, especialmente se tensões principais de valor baixo forem ignoradas 5 . A figura $5.13 \mathrm{c}$ mostra que a orientação das tensões principais também é aproximadamente fixa no valor de $-55^{\circ}$. Portanto, é sensato considerar este carregamento como sendo proporcional.

A figura $5.14 \mathrm{a}$ apresenta outro tipo de carregamento sobre o mesmo componente, medido no mesmo nó que aquele da figura 5.13. As figuras $5.14 \mathrm{~b}$ e $5.14 \mathrm{c}$ indicam que a razão de biaxialidade e a orientação de $\sigma_{1}$ (e consequentemente de $\sigma_{2}$ ) variam consideravelmente ao longo do tempo. Portanto, este carregamento é certamente não proporcional.

A razão de biaxialidade ( $a$ ) também pode ser plotada no modelo 3D do componente, conforme apresenta a figura 5.15, da mesma maneira que o dano por fadiga $(D)$, apresentado pela figura 5.16. A observação da figura 5.15 revela que a maior parte deste modelo está

\footnotetext{
${ }^{5}$ As tensões/deformações que causam maior dano por fadiga, $D$, são aquelas que possuem alto valor.
} 

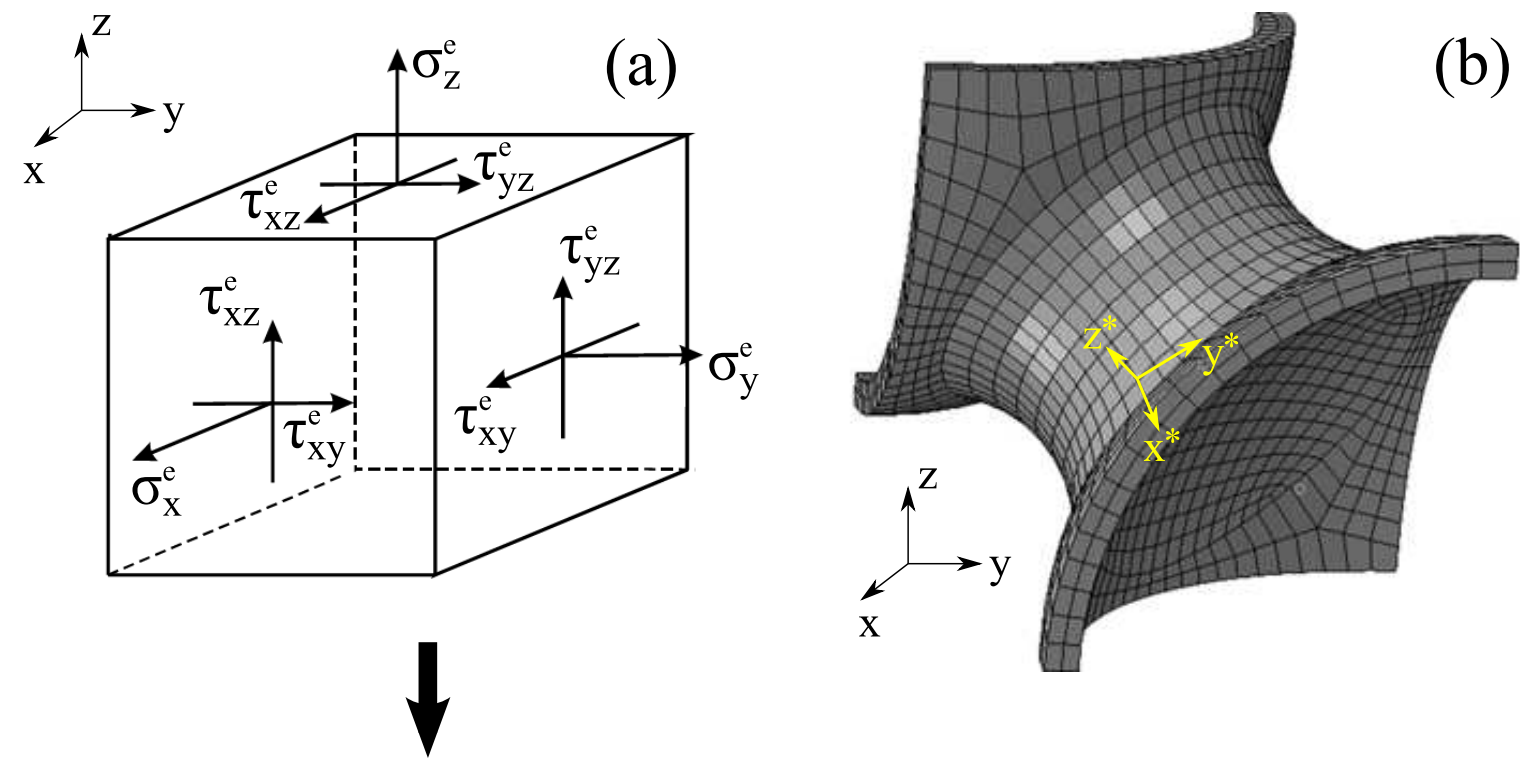

(c)

(d)
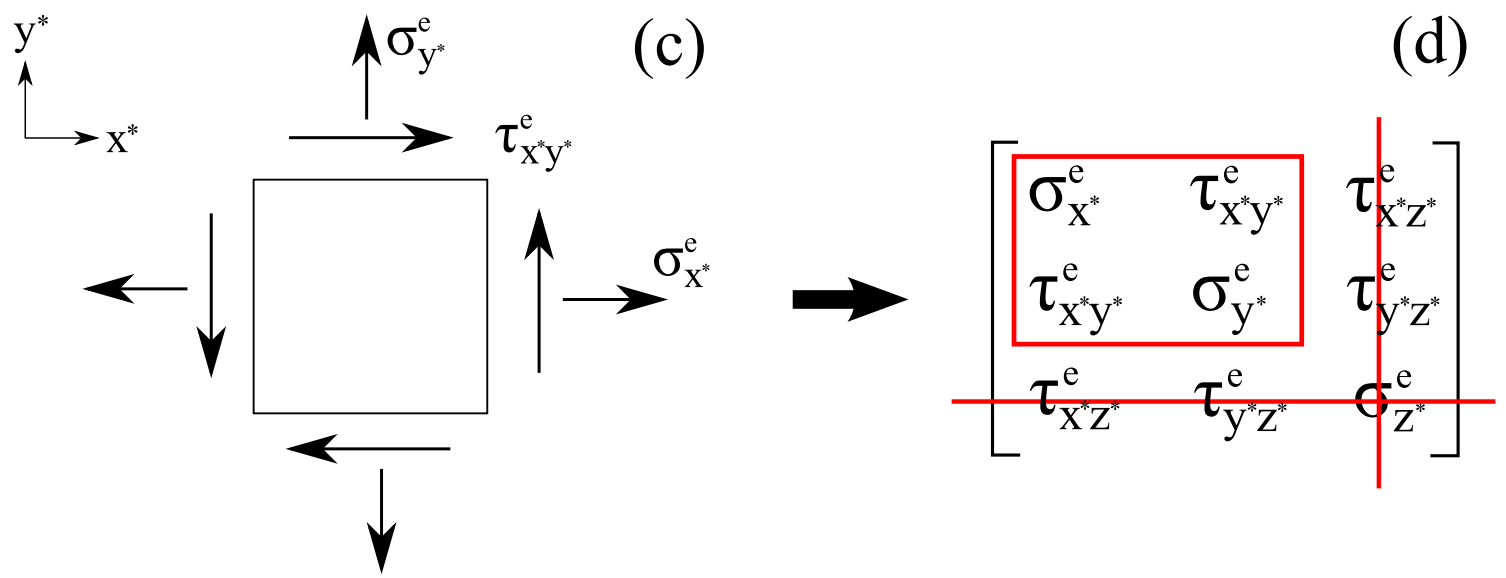

Figura 5.11 Transformação do tensor de tensão 3D dos nós superficiais em estado plano de tensões.

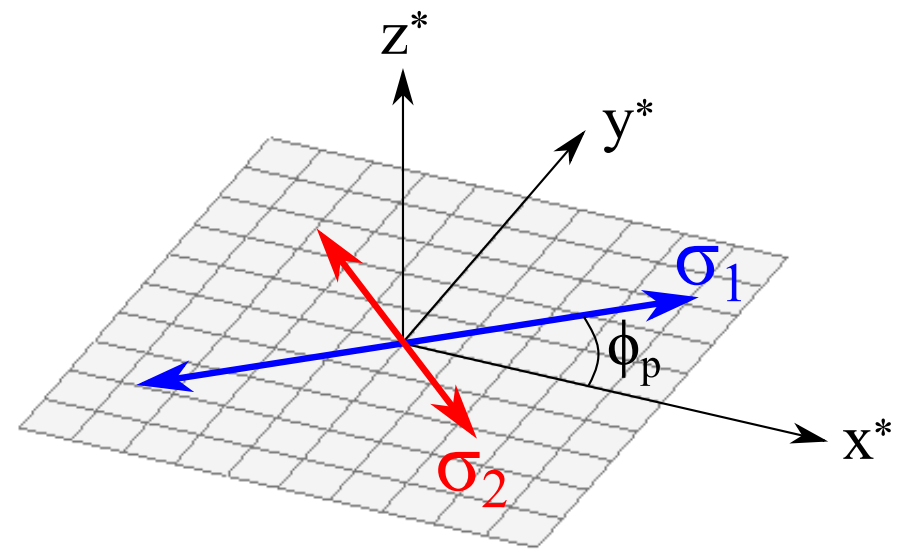

Figura 5.12 Estado plano de tensões na superfície de um componente em uma malha de Elementos Finitos. 


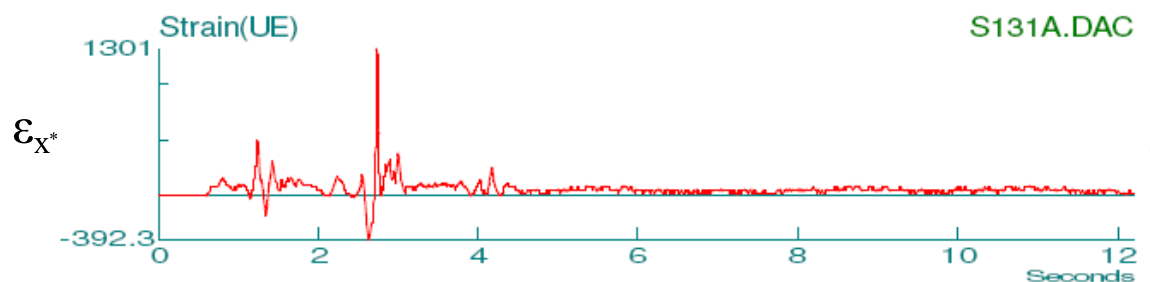

Sample $=409.6$

Npts $=9446$

Max $Y=1301$

Min $Y=-392.3$

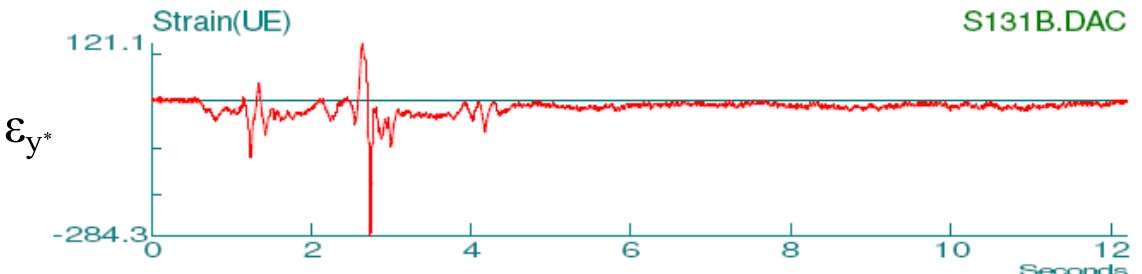

Sample $=409.6$

Npts $=9446$

Max $Y=121.1$

Min $Y=-284.3$

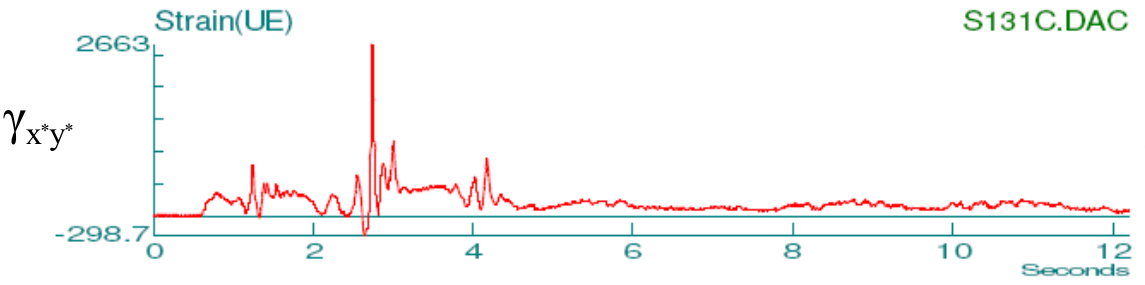

Sample $=409.6$

Npts $=9446$

Max $Y=2663$

Min $Y=-298.7$

(a) Tensor de tensão 2D em um nó da superfície de uma malha de um componente.

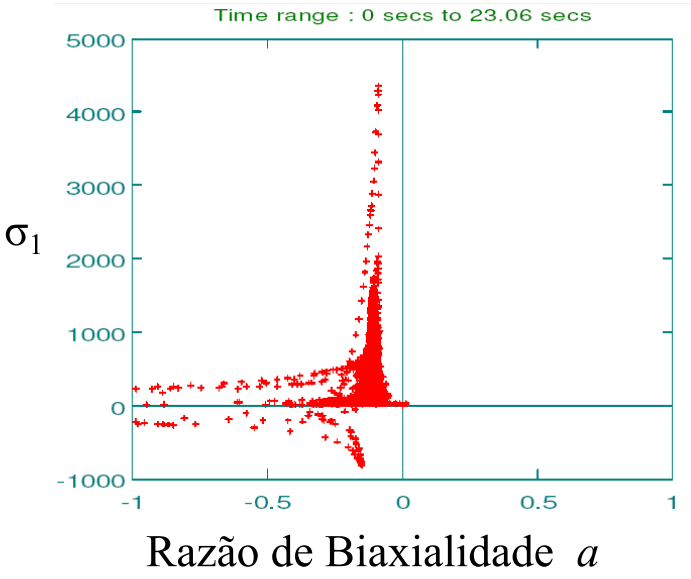

(b) $a \mathrm{VS} \sigma_{1}$

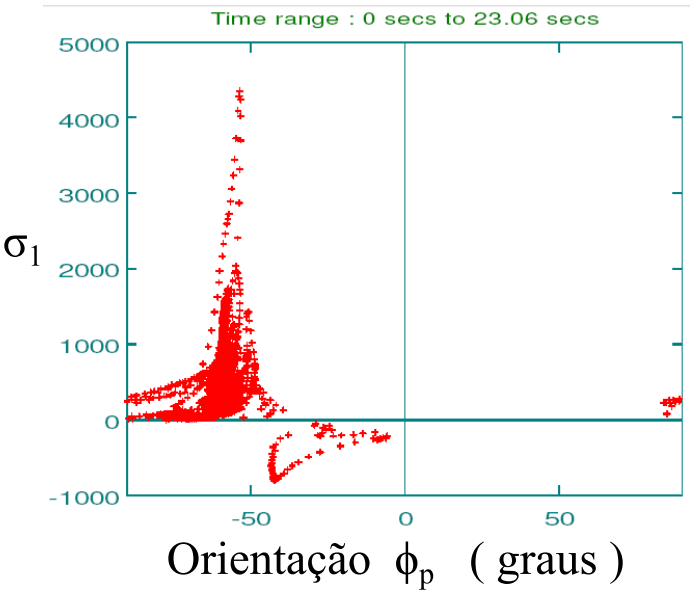

(c) $\phi_{p} \mathrm{VS} \sigma_{1}$

Figura 5.13 Exemplo de carregamento proporcional (MSC.Software, 2008). 


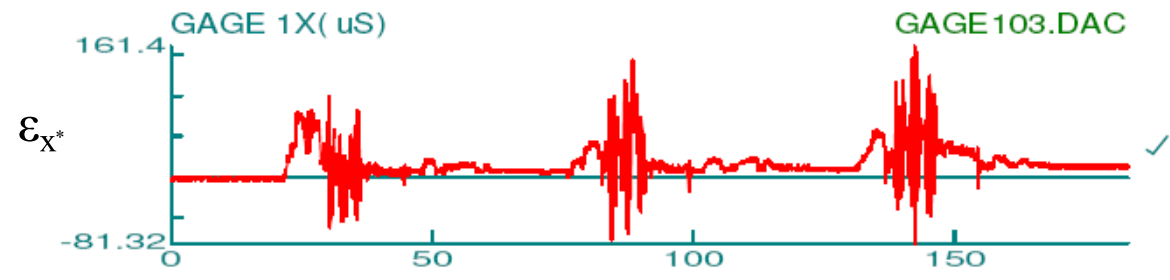

Sample $=200$

Npts $=3.672 \mathrm{E} 4$

$\operatorname{Max} Y=161.4$

Min $Y=-81.32$

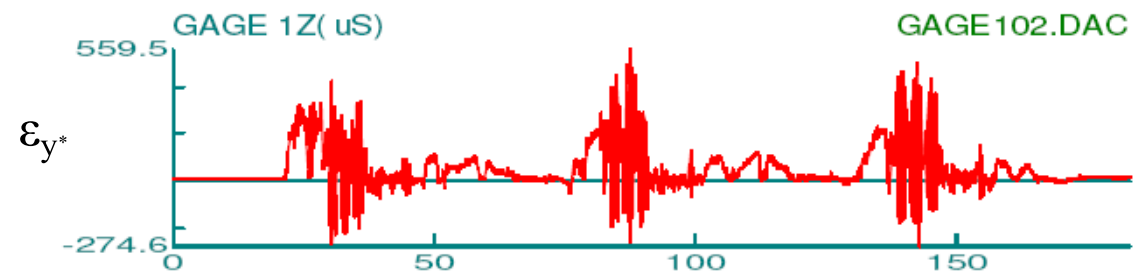

Sample $=200$

Npts $=3.672 \mathrm{E} 4$

$\operatorname{Max} Y=559.5$

Min $Y=-274.6$

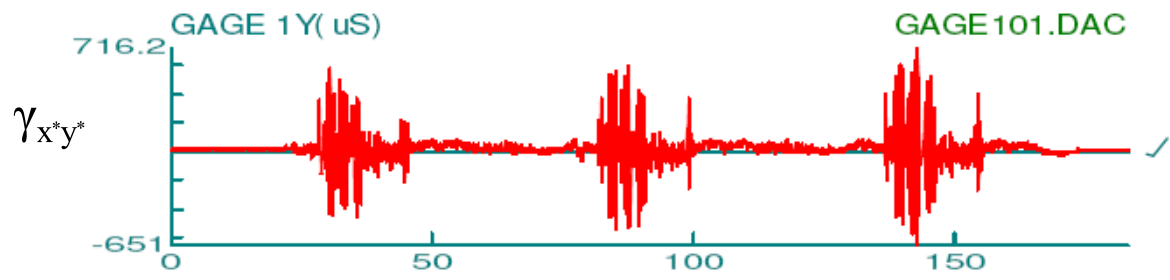

Sample $=200$

Npts $=3.672 \mathrm{E} 4$

$\operatorname{Max} Y=716.2$

Min $Y=-651$

(a) Tensor de tensão 2D em um nó da superfície de uma malha de um componente.

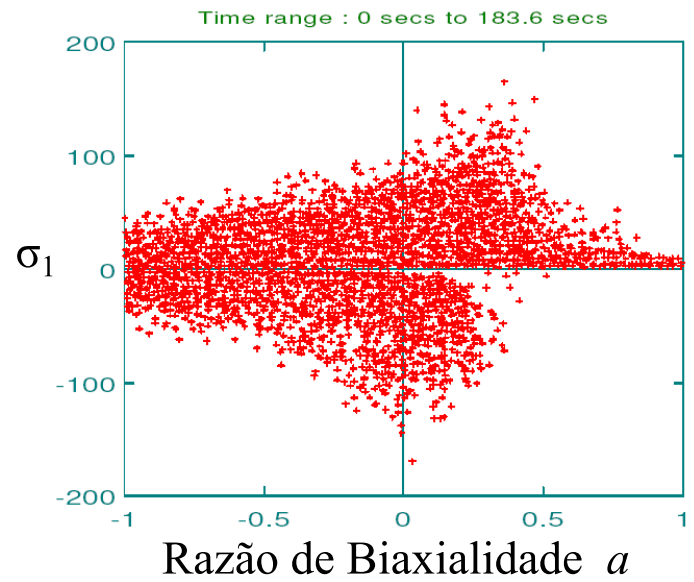

(b) $a \mathrm{VS} \sigma_{1}$

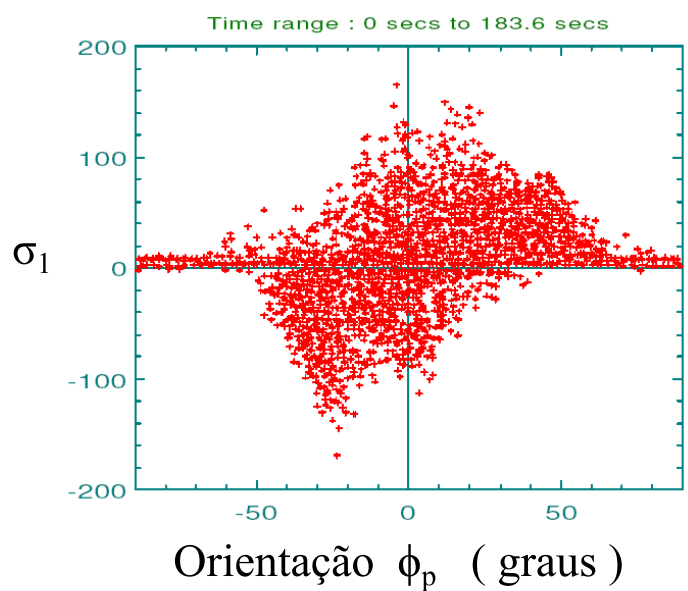

(c) $\phi_{p} \mathrm{VS} \sigma_{1}$

Figura 5.14 Exemplo de carregamento não proporcional (MSC.Software, 2008). 
sujeita à tensão uniaxial pura, com poucas partes sujeitas a estado de cisalhamento puro e a estado biaxial de tensões. Comparando o perfil de biaxialidade com o de dano percebese que o nó com maior dano (e toda a seção transversal que passa por este nó) está sujeito a um estado de tensão essencialmente uniaxial $(a \approx 0)$. Considerando que os resultados mostrados nestas duas figuras foram obtidos de um componente sujeito à um carregamento proporcional, então a razão de biaxialidade em cada nó se manterá constante ao longo de toda a vida do componente. Neste caso, é sensato portanto utilizar um critério de fadiga uniaxial, apresentados na seção 4.3.10, utilizando as pseudo tensões alternada $\left(\sigma_{a}^{e}\right)$ e média $\left(\sigma_{m}^{e}\right)$ da superfície do modelo FE juntamente com a Curva $\sigma-N$ Local. Se o ponto de maior dano estivesse sob tensão de cisalhamento pura $(a=-1)$, então seria necessário utilizar a Curva $\tau-N$ Local, que é aquela obtida utilizando os mesmos fatores modificadores utilizados na Curva $\sigma-N$ Local, exceto o fator de carregamento que deve ser igual a $C_{L}=C_{\tau}$.

Se caso o carregamento deste modelo for não proporcional, então o estado de tensão será múltiplo e haverão diversos valores de razão de biaxialidade para cada nó. Nestes casos, é fundamental que o software de análise de fadiga gere ao usuário gráficos de razão de biaxialidade " $a$ " (figura 5.14b) e orientação da tensão principal máxima " $\phi_{p}$ " (figura 5.14c) para a determinação do quão não proporcional é o carregamento. É altamente interessante se a ferramenta de fadiga pude-se também informar o valor da média e do desvio padrão para cada um destes dois gráficos, assim o usuário teria um embasamento objetivo para determinar se o carregamento é ou não proporcional, ao invés de tomar uma decisão baseada apenas em uma análise visual. Isto torna-se mais importante ainda em carregamento de amplitude variável.

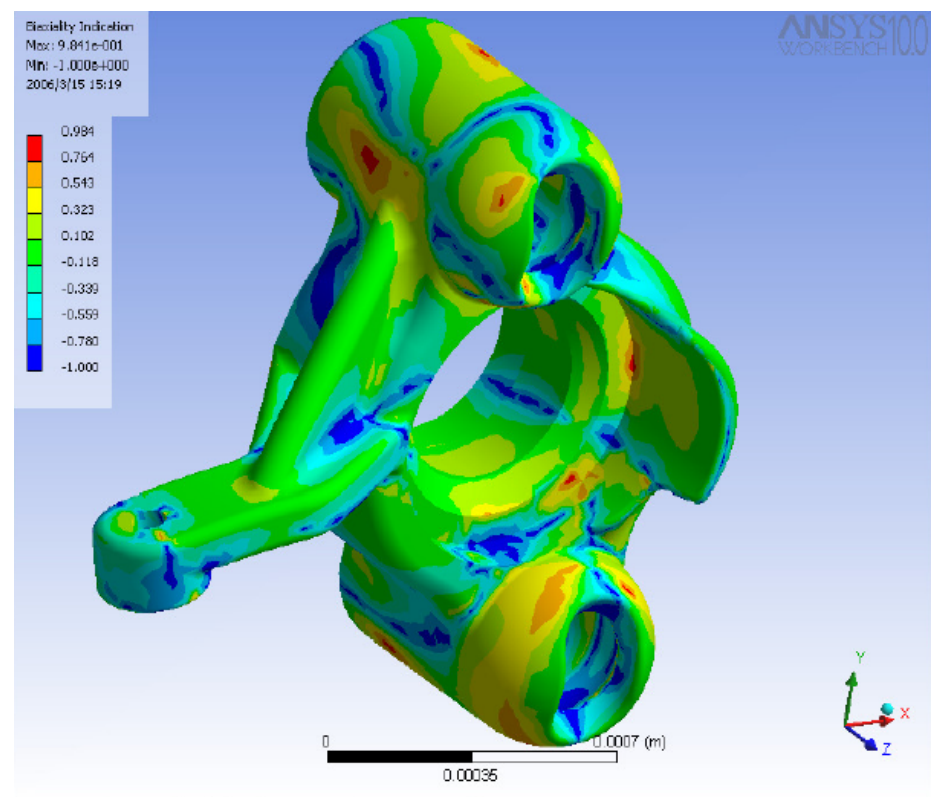

Figura 5.15 Perfil da razão de biaxialidade em todo o modelo.

Para concluir, a figura 5.17 apresenta um resumo sobre o procedimento para se determi- 


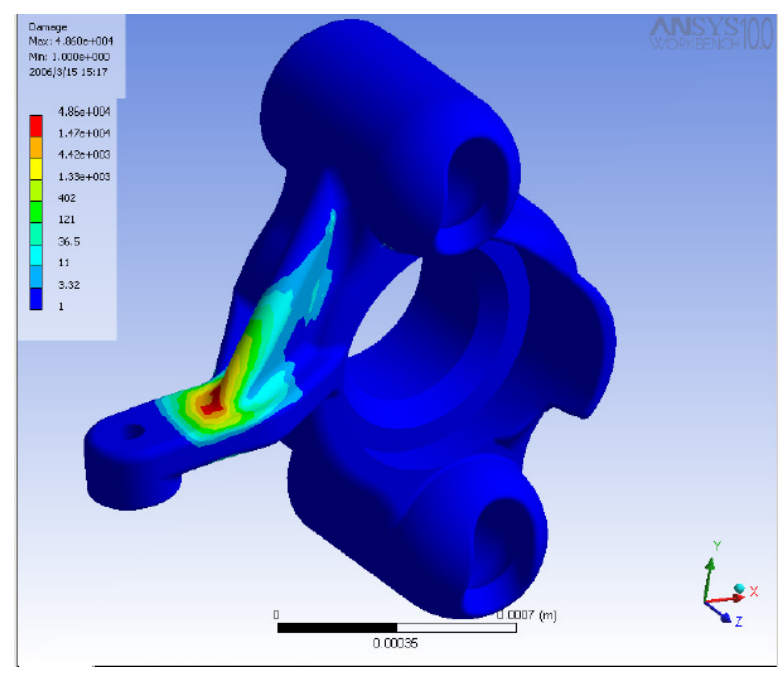

Figura 5.16 Perfil de dano por fadiga em todo o modelo FE.

nar qual o tipo de carregamento que está ocorrendo em cada nó. Se a seção mais crítica $2^{6}$ de um componente possuir $\phi_{p} \cong c t e$ e $a \cong 0$ (conforme apresenta as figuras 5.15e 5.16) então o engenheiro pode prever a vida da estrutura utilizando a metodologia de fadiga uniaxial apresentada no capítulo 4. Por outro lado, se esta seção inteira possuir $\phi_{p} \cong$ cte e $a=c t e \neq 0$ (conforme apresenta as figuras 5.13b e 5.13c) então há um problema de fadiga multiaxial ocorrendo nesta seção do componente e o carregamento é proporcional; será necessário utilizar um modelo de fadiga multiaxial para resolução do problema, a serem apresentados na seção 5.5. Entretanto, se na seção mais crítica do componente ocorre que $\phi_{p} \neq$ cte e $a \neq c t e$, então orientação das tensões principais varia com o tempo e por isso modelos de dano em fadiga multiaxial baseados em plano crítico devem necessariamente ser utilizados, a serem apresentados na seção 5.5.2 (Gaier \& Dannbauer, 2008; Lee et al., 2011; Papadopoulos et al., 1997; Socie \& Marquis, 2000).

É importante lembrar que, conforme apresentado na seção 4.6 .3 , uma densidade de malha adequada é necessária para definir níveis de tensão e razão de biaxialidade, principalmente em entalhes. Compensar uma malha com densidade inadequada com o uso de fatores de concentração de tensões calculados manualmente não irá produzir campos de tensão corretos e certamente a razão de biaxialidade será calculada de maneira errada, gerando resultados de vida muito incorretos.

Conforme visto nos parágrafos anteriores, diferentes caminhos de carregamentos não proporcionais produzem diferentes graus de encruamento não proporcional, entre os quais o caminho de carregamento $90^{\circ}$ produz o maior grau de encruamento não proporcional e, portanto, a menor vida em fadiga. Portanto, a redução da vida em fadiga de um material sob carregamento não proporcional está fortemente associada ao grau de não proporcionalidade do carregamento $\left(F_{N P}\right)$ e do tipo de material $\left(\alpha_{N P}\right)$.

\footnotetext{
${ }^{6}$ Seção transversal do componente que passa pelo ponto (nó) que possui o maior valor de dano $D$.
} 


\begin{tabular}{l|c|c|}
\multicolumn{1}{c}{$\phi_{\mathrm{p}}$} & \multicolumn{1}{c}{$a$} \\
\cline { 2 - 3 } $\begin{array}{l}\text { Uniaxial } \\
\begin{array}{l}\text { Multiaxial } \\
\text { proporcional }\end{array}\end{array}$ & $\begin{array}{l}a=\text { cte }=0 \\
\begin{array}{l}\text { Multiaxial } \\
\text { não proporcional }\end{array}\end{array}$ & $\begin{array}{l}a=\text { cte } \neq 0 \\
-1 \leq a \leq 1\end{array}$ \\
\cline { 2 - 3 } & $\begin{array}{l}\text { Aumentando } \\
\text { dificuldade } \\
\& \\
\begin{array}{l}\text { Diminuindo } \\
\text { confiabilidade }\end{array}\end{array}$ \\
\cline { 2 - 3 }
\end{tabular}

Figura 5.17 Resumo para verificação do tipo de carregamento.

Por tais razões, um modelo de fadiga deve ser capaz de avaliar diferentes valores de dano por fadiga para carregamentos proporcionais e não proporcionais. Alguns modelos de fadiga multiaxial baseados em tensão serão revisados na seção 5.5 .

\subsection{Fator de Entalhe $\left(n_{K}\right)$ Aplicado em Fadiga Mul- tiaxial}

Em fadiga uniaxial se utiliza apenas uma componente do tensor de tensões de Cauchy para se avaliar a vida em fadiga. Se o carregamento produz apenas tensão normal, então a pseudo tensão normal $\left(\sigma^{e}\right)$ é utilizada em conjunto com a Curva $\sigma-N$ Local para se estimar a vida em fadiga. Se o carregamento produz apenas tensão cisalhante, então a pseudo tensão cisalhante $\left(\tau^{e}\right)$ é utilizada em conjunto com a Curva $\tau-N$ Local 7 . Por outro lado, os critérios de fadiga multiaxial utilizam as 6 componentes do tensor de tensões de Cauchy para se estimar a vida em fadiga. Desta maneira, é necessário entender como os fatores modificadores são aplicados quando carregamentos multiaxiais cíclicos estão presentes. Este é o objetivo desta seção.

O Método do Gradiente de Tensão Relativo apresentado na seção 4.4.2 para cálculo do fator de entalhe $n_{K}$, nomeado também por Método $R S G$ Uniaxial, pode ser implementado computacionalmente, de maneira a ser possível calcular o efeito de entalhe em componentes geometricamente complexos, a partir de resultados de análises linear por Elementos Finitos. O método descrito naquela seção foi extraído da FKM-Guideline (2003) e permite calcular o gradiente de tensão relativo $\left(\chi^{\prime}\right)$ apenas para casos em que há tensão normal ou de cisalhamento atuando separadamente. Entretanto, a FKM-Guideline (2003) não especifica como o método poderia ser aplicado a um caso geral onde as 6 componentes do tensor de tensões são cíclicas (i.e. em fadiga multiaxial). Adicionalmente, Siebel \& Stieler (1955),

\footnotetext{
${ }^{7}$ Que é aquela obtida utilizando os mesmos fatores modificadores utilizados na Curva $\sigma-N$ Local, exceto o fator de carregamento que deve ser igual a $C_{L}=C_{\tau}$
} 
FKM-Guideline (2003) e Lee et al. (2011) apresentam o cálculo do gradiente de tensão relativo apenas para casos onde a pseudo tensão média $\left(\sigma_{m}^{e}\right)$ é igual à zero e a pseudo tensão alternada $\left(\sigma_{a}^{e}\right)$ é constante ao longo do tempo, mas não relatam como este método poderia ser aplicado para os casos mais gerais onde a tensão média é diferente de zero, nem para os casos onde há carregamento de amplitude variável.

Mentley \& Pompetzki (2006), MSC.Software (sd) e Steinbeis GmbH \& Co (2013, seção 16.2) relatam sobre um método utilizado para contabilizar o efeito de entalhe para os casos supracitados, utilizando para isso o Método do Gradiente de Tensão Relativo. Mentley \& Pompetzki (2006) também apresenta um estudo de caso que confirma a correlação entre os resultados obtidos através deste método e resultados experimentais. Neste método, o Gradiente de Tensão Relativo pode ser calculado em casos onde há tensões cíclicas normais e cisalhantes atuando simultaneamente, inclusive para os casos onde todas as 6 componentes do tensor de tensão variam ao longo do tempo. Adicionalmente, este método pode ser utilizado juntamente à metodologia apresentada no capítulo 4. Este método será chamado nesta dissertação de Método RSG Multiaxial.

No caso mais geral (3D), há 6 gradientes de tensão que poderiam ser calculados, que podem todos variar com o tempo e são independente uns dos outros. Acredita-se que para contabilizar o gradiente de tensão a partir de uma análise linear por Elementos Finitos devese:

1) Para cada nó localizado na superfície da malha, determinar 6 gradientes de tensão relativos, um para cada componente de tensão $\left(\sigma_{x}^{e}, \sigma_{y}^{e}, \sigma_{z}^{e}, \tau_{x y}^{e}, \tau_{y z}^{e}, \tau_{x z}^{e}\right)$. Em seguida, utilizar estes valores para calcular 6 fatores de entalhe $\left(n_{K, \sigma x}, n_{K, \sigma y}, n_{K, \sigma z}, n_{K, \tau x y}, n_{K, \tau y z}, n_{K, \tau x z}\right)$; $\mathrm{ou}$

2) Para cada nó localizado na superfície da malha, calcular um único gradiente de tensão relativo utilizando a tensão de von Mises, obtendo assim $\chi_{V M}^{\prime}$. Após isto, calcula-se um único fator de entalhe $n_{K}$.

Quando se desenvolve um software para análise de fadiga baseado em resultados de FEA linear, a segunda opção se torna mais vantajosa por ser mais fácil ser implementada computacionalmente. Assim, recomenda-se aplicar o procedimento a seguir em cada nó $n_{i}$ da superfície da malha de Elementos Finitos para que o gradiente de tensão relativo do nó $n_{i}$ seja calculado:

1) Escolher um nó da superfície da malha de Elementos Finitos (nó $n_{i}$ );

2) Identificar os nós vizinhos ao nó $n_{i}$ e que estejam na superfície. No caso da figura 5.18 , há 8 nós vizinhos ao nó $P_{0}$;

3) Para cada nó vizinho superficial, efetuar o produto vetorial afim de determinar o vetor perpendicular. No caso da figura 5.18 , haverão 8 produtos vetoriais;

4) Efetuar o produto escalar de todos os vetores criados no item anterior. No caso da figura 5.18, será um produto escalar de 8 vetores. Isso vai gerar um vetor equivalente; 
5) O nó mais perto da ponta deste vetor equivalente é escolhido e chamado de nó $n_{j}$;

6) Calcular a tensão de von Mises nos nós $n_{i}$ e $n_{j}$;

7) Calcular o gradiente de tensão relativo utilizando as tensões calculadas no passo anterior, utilizando a equação (5.17).

$$
\chi_{V M}^{\prime}=\frac{\left(\chi_{V M}\right)_{x=0}}{\sigma_{V M, i}^{e}}=\frac{1}{\sigma_{V M, i}^{e}}\left(\frac{\sigma_{V M, i}^{e}-\sigma_{V M, j}^{e}}{\sqrt{\left(x_{j}-x_{i}\right)^{2}+\left(y_{j}-y_{i}\right)^{2}+\left(z_{j}-z_{i}\right)^{2}}}\right)
$$

Então os fatores de entalhe $n_{K}$ para cada nó são calculados utilizando as seguintes equações:

$$
\begin{array}{lll}
n_{K}=1+\chi_{V M}^{\prime} \cdot 10^{-\left(a_{G}-0,5+\frac{s_{u, 97.5}}{b_{G}}\right)} & \text { para } & \chi_{V M}^{\prime} \leq 0,1 \mathrm{~mm}^{-1} \\
n_{K}=1+\sqrt{\chi_{V M}^{\prime}} \cdot 10^{-\left(a_{G}+\frac{s_{u, 97.5}}{b_{G}}\right)} & \text { para } & 0,1 \mathrm{~mm}^{-1} \leq \chi_{V M}^{\prime} \leq 1 \mathrm{~mm}^{-1} \\
n_{K}=1+\sqrt[4]{\chi_{V M}^{\prime}} \cdot 10^{-\left(a_{G}+\frac{s_{u, 97.5}}{b_{G}}\right)} & \text { para } & 1 \mathrm{~mm}^{-} 1 \leq \chi_{V M}^{\prime} \leq 100 \mathrm{~mm}^{-} 1
\end{array}
$$

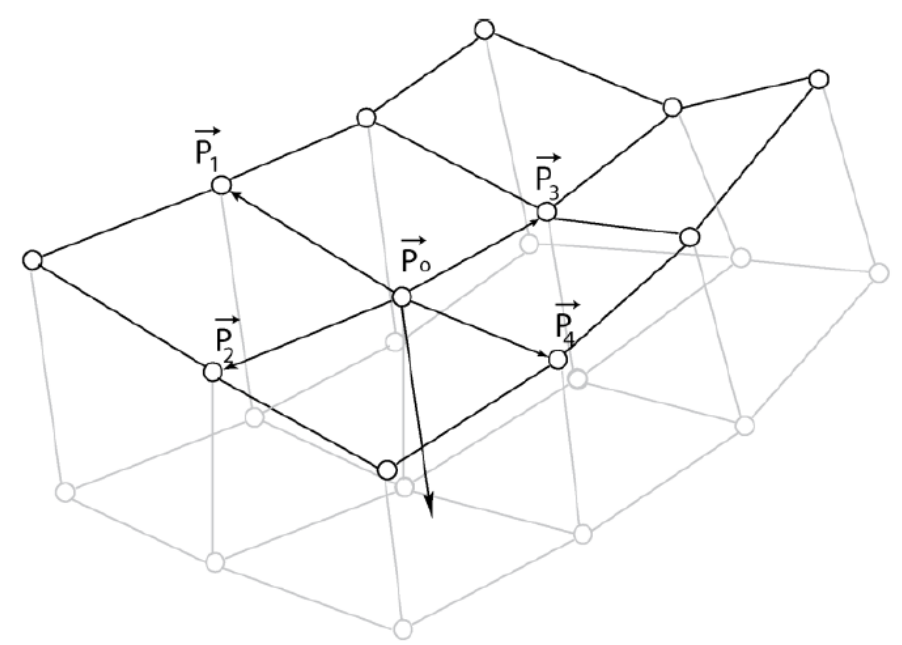

Figura 5.18 Exemplo de cálculo do gradiente de tensão relativo em uma malha de Elementos Finitos (Steinbeis GmbH \& Co 2013).

O fator de entalhe $n_{K}$ deve ser calculado para cada um dos nós da superfície da malha de Elementos Finitos. Deve-se utilizar o procedimento a seguir para a contabilização do fator de entalhe em componentes entalhados sob fadiga multiaxial, onde as 6 componentes do tensor de tensões variam simultaneamente:

1) Em uma análise por Elementos Finitos, cada um dos nós superficiais possui 6 histórias de tensão $\left(\sigma_{x}^{e}, \sigma_{y}^{e}, \sigma_{z}^{e}, \tau_{x y}^{e}, \tau_{y z}^{e}\right.$ e $\left.\tau_{x z}^{e}\right)$; a figura 5.19(a) representa o exemplo de um das 6 componentes do tensor de tensões variando no tempo. Deve-se calcular o gradiente de tensão relativo $\left(\chi_{V M}^{\prime}\right)$ para cada time step, através da equação (5.17), conforme apresenta a figura $5.19(\mathrm{~b})$; 
2) Para cada nó, calcular o fator de entalhe $n_{K}$ para cada intervalo de tempo (time step) utilizando as equações (5.18), (5.19) ou (5.20), conforme indicado pela figura 5.19.(c).

3) Dividir cada um das 6 componentes do tensor de tensões pelo fator de entalhe $n_{K}$, conforme a equação (5.21). Assim o histórico de tensão corrigido é construido conforme ilustra a figura 5.19 (d). A figura 5.20 apresenta a diferença entre um histórico de tensão não corrigido e o mesmo corrigido.

$$
\begin{array}{lll}
\sigma_{x}=\frac{\sigma_{x}^{e}}{n_{K}} & \sigma_{y}=\frac{\sigma_{y}^{e}}{n_{K}} & \sigma_{z}=\frac{\sigma_{z}^{e}}{n_{K}} \\
\tau_{x y}=\frac{\tau_{x y}^{e}}{n_{K}} & \tau_{y z}=\frac{\tau_{y z}^{e}}{n_{K}} & \tau_{x z}=\frac{\tau_{x z}^{e}}{n_{K}}
\end{array}
$$

A correção realizada pela equação (5.21) representa o procedimento inverso da equação (4.109) e, na verdade, transforma a pseudo tensão, calculada via Elementos Finitos, em uma tensão nominal equivalente. Perceba que a equação (5.21) é similar à equação (4.109) para um carregamento uniaxial que gera uma pseudo tensão alternada na raiz do entalhe igual ao limite de fadiga, sendo $\sigma_{x, a}^{e}=\sigma_{E}^{e}$ e $\sigma_{x, a}=S_{E, u n}$. Em outras palavras, no capítulo 4 o efeito do entalhe foi contabilizado através da modificação da Curva Tensão-Tida, através da multiplicação do fator de entalhe " $n_{K}$ " com a Curva S-N Unnotched (transladando-a para cima conforme a figura 4.49p. Por outro lado, em problemas onde há tensões cíclicas em mais de uma direção (fadiga multiaxial), o procedimento é inverso: o efeito do entalhe é contabilizado na história de carregamento, através da divisão da história de carregamento de cada um dos 6 componentes do tensor de tensões pelo fator de entalhe " $n_{K}$ ".

Assim, deve-se utilizar as 6 componentes corrigidas do tensor de tensões $\left(\sigma_{x}, \sigma_{y}\right.$, $\sigma_{z}, \tau_{x y}, \tau_{y z}, \tau_{x z}$ ) da equação (5.21) nos modelos de fadiga multiaxial apresentados na seção 5.5 deste capítulo. É importante enfatizar que o procedimento de rotacionar as tensões apresentado na seção 5.2 e figura 5.11 somente se aplica para a contabilização da razão de biaxialidade " $a$ " e da orientação da tensão principal máxima " $\phi_{p}$ ". As tensões que devem ser utilizadas em qualquer modelo/critério de fadiga multiaxial são aquelas que não foram rotacionadas representadas pela equação (5.21): $\sigma_{x}, \sigma_{y}, \sigma_{z}, \tau_{x y}, \tau_{y z}, \tau_{x z}$. 


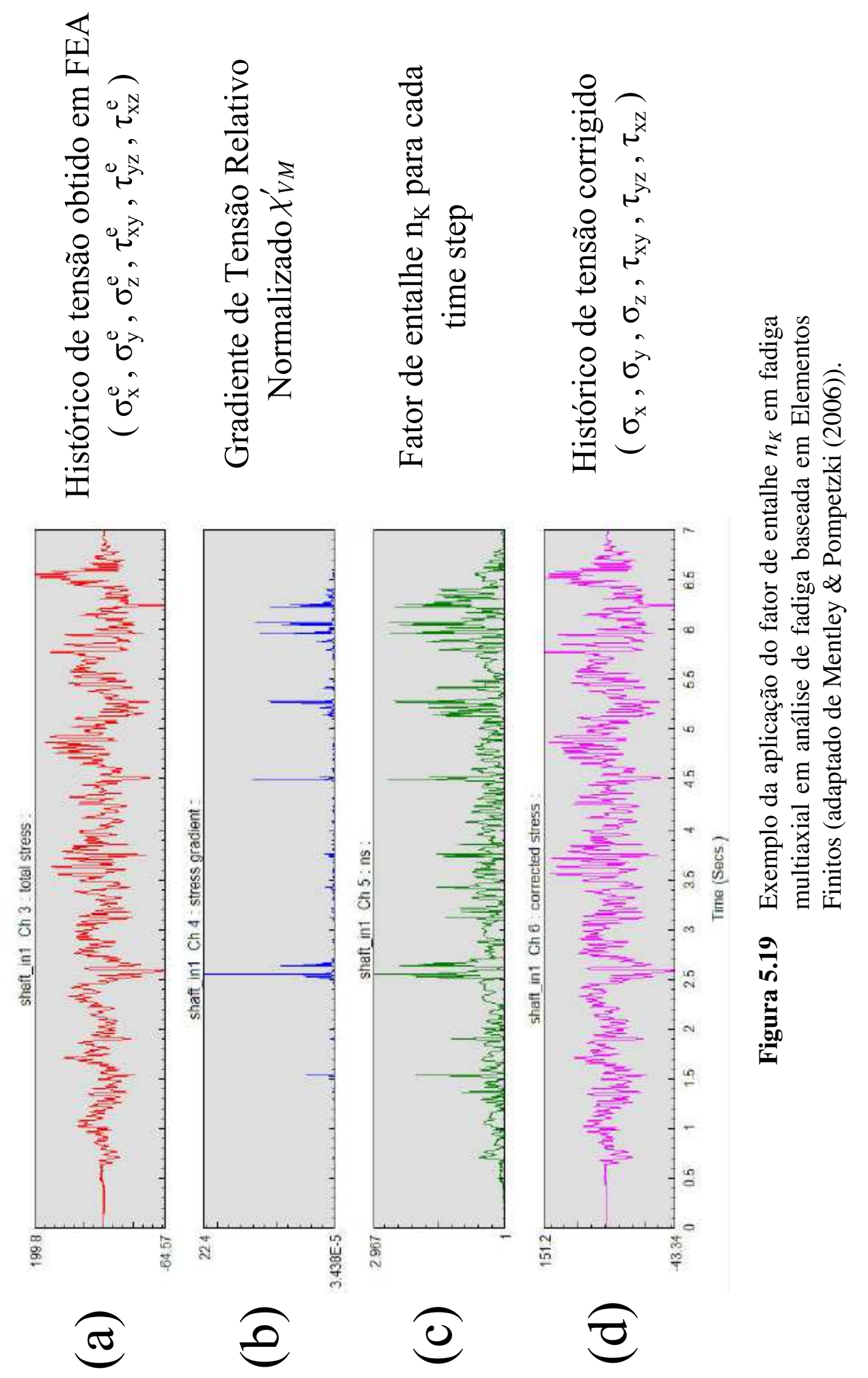




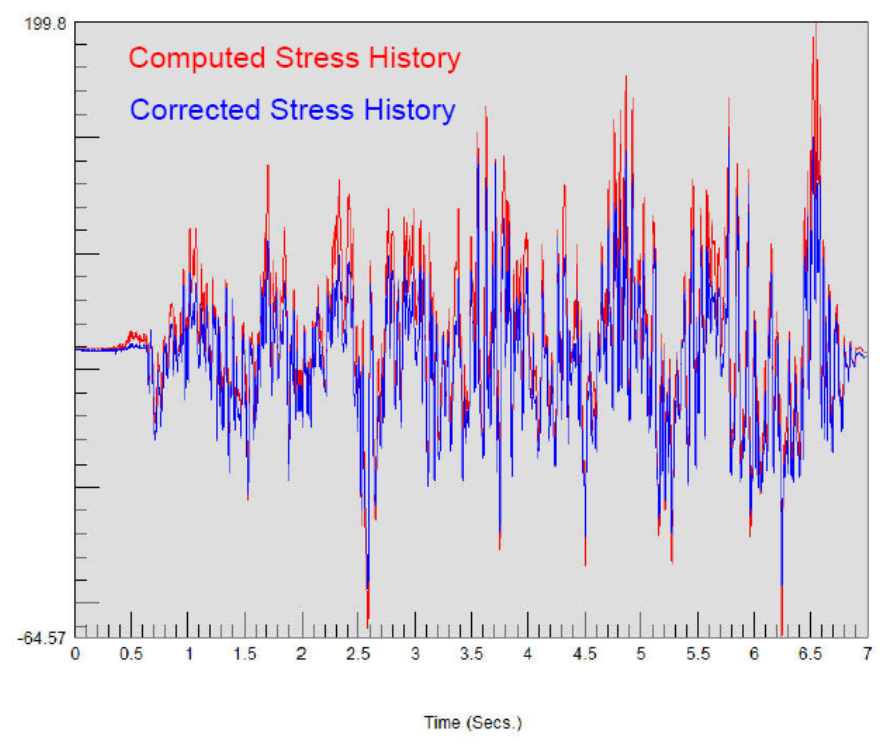

Figura 5.20 Histórico de tensão corrigido pelo fator de entalhe $\left(n_{K}\right)$ em análise de fadiga baseada em Elementos Finitos (adaptado de Mentley \& Pompetzki (2006)).

De uma maneira geral, todos os modelos de fadiga multiaxial transformam os 6 componentes de tensão da equação 5.21 em uma tensão equivalente alternada " $\sigma_{e q, a}$ ", também chamada de parâmetro de dano. Portanto, a vida relativa ao nó " $n_{i}$ " deve ser calculada aplicando esta tensão alternada equivalente na Curva S-N Unnotched, conforme apresenta a equação (5.22) e a figura 5.21. Aliás, é interessante notar semelhança da equação 5.22) com a equação 4.40). É fundamental que o engenheiro tenha sempre em mente que a vida relativa ao nó " $n_{i}$ ", conforme mencionado acima, é na verdade, o número de ciclos " $N$ " que demorará para uma trinca nuclear no nó " $n_{i}$ " e se propagar por toda a seção transversal que contém este nó até que ocorra a ruptura do componente em duas ou mais partes.

$$
\sigma_{e q, a}=S_{f, u n}^{\prime} \cdot(2 N)^{b_{u n}}
$$

O método supracitado, para cálculo do fator de entalhe $n_{K}$ em carregamento multiaxial cíclico, é utilizado na maioria dos softwares comerciais de fadiga baseados em Elementos Finitos, dentre eles o nCode Design Life (HBM), o FEMFAT (Magna Powertrain), o MSC Nastran Embedded Fatigue (MSC.Software) e o winLIFE (Steinbeis Foundation), O FEMFAT (Magna Powertrain) utiliza uma metodologia ligeiramente diferente do Método RSG Multiaxial supracitado; mais informações podem ser encontrados em Magna Powertrain (2011) e Christian Gaier (2010). Este software também calcula o gradiente de tensão relativo conforme a equação (5.17), entretanto utiliza outra fórmula para o cálculo do fator de entalhe $n_{K}$, que pode ser encontrada em Magna Powertrain (2011, pp.73) e Christian Gaier (2010, pp.11). O software fe-safe (Dassault Systèmes) analisa o efeito de entalhe utilizando outro método, a Teoria das Distâncias Críticas (mais informações em Santus (2007) e Susmel 


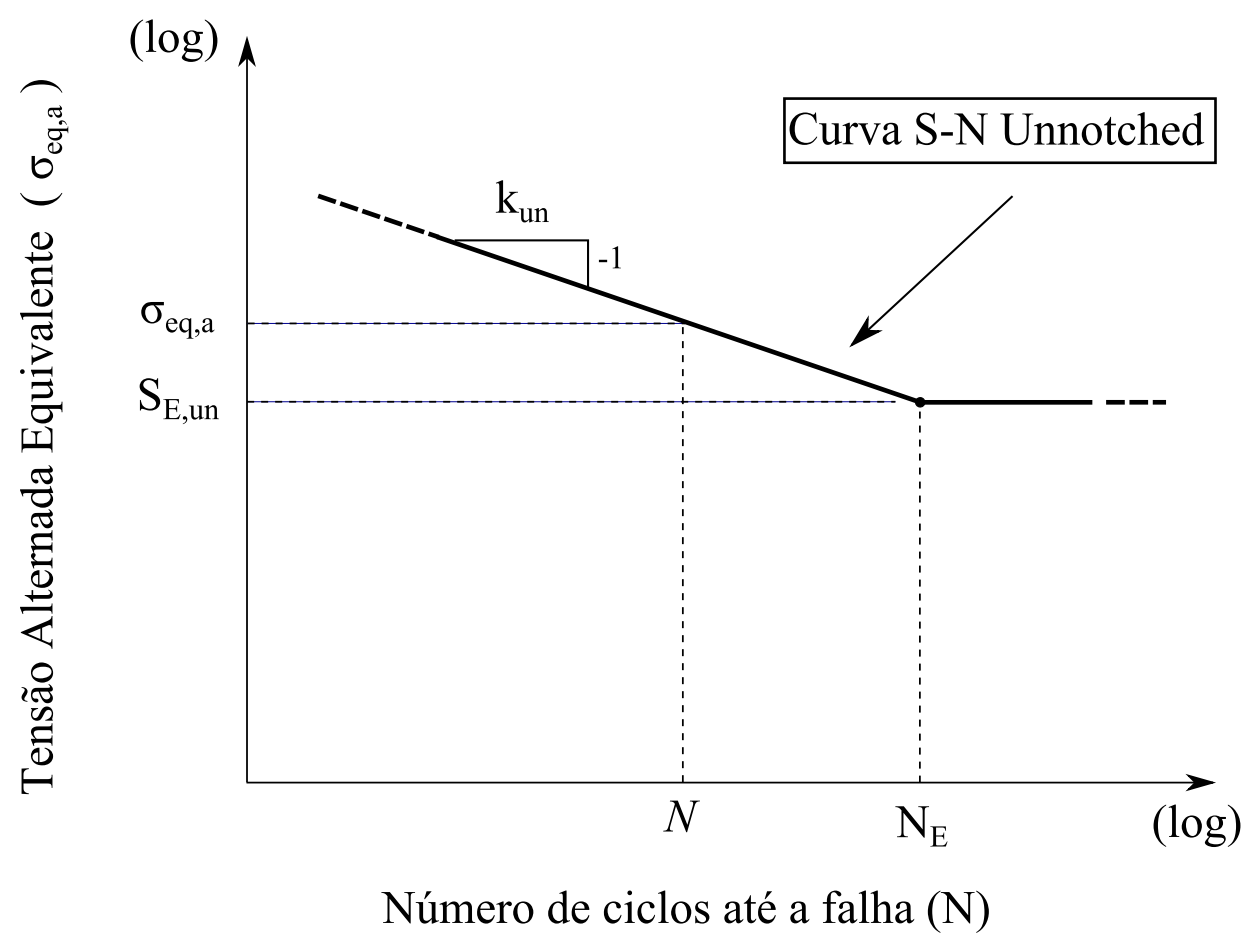

Figura 5.21 Cálculo da vida de um componente sob fadiga multiaxial.

(2009)) e é o único FE-Based Fatigue Analysis Software a utilizar esta metodologia. O método da Distância Crítica também utiliza tensões subsuperficiais provenientes de FEA para contabilizar os efeitos do gradiente de tensão. Os dados são lidos de um modelo FE pelo fe-safe e o método pode ser aplicado a apenas alguns nós (selecionados pelo usuário) ou a todo o modelo.

Recomenda-se que o software de análise de fadiga utilize o Método RSG Multiaxial (ou algum outro método semelhante que calcule automaticamente o efeito de entalhe), desta maneira o efeito de entalhe será calculado automaticamente na análise. O Método RSG Multiaxial também pode ser perfeitamente utilizado em componentes não entalhados sob carregamento multiaxial, pois neste caso, o procedimento irá calcular automaticamente o fator de entalhe $\left(n_{K}\right)$ como sendo igual à 1 . Este procedimento também funciona quando há apenas tensão em uma direção (fadiga uniaxial), seja sob tensão normal ou de cisalhamento, tanto para componentes entalhados quanto para não entalhados. Nos casos onde o componente está sob tensão uniaxial (fadiga uniaxial), o Método RSG Multiaxial produz exatamente o mesmo resultado daquele obtido pelo Método do Gradiente de Tensão Relativo (seção 4.4.2). 


\subsection{Carregamento de Amplitude Variável e Dano por Fadiga em Fadiga Multiaxial}

O Método de Rainflow uniaxial não pode ser utilizado para a contagem de ciclos quando há carregamento não proporcional presente no componente. Há basicamente dois métodos que de contagem de ciclos adequados para este tipo de carregamento, geralmente chamados de Método de Rainflow Multiaxial: o Método de Bannantine \& Socie ((Bannantine, 1989), (Bannantine \& Socie, 1991)) e o Método de Wang \& Brown (Wang \& Brown, 1996). O segundo é provavelmente o mais conhecido e utilizado. Na verdade o Método de Wang \& Brown é muito parecido com o Método de Rainflow uniaxial, entretanto aquele extrai reversões de uma história de tensão (ou deformação) multiaxial de amplitude variável. É importante lembrar que uma reversão (também chamado de semi-ciclo) é igual à meio ciclo.

Os Métodos de Rainflow Multiaxiais, diferentemente do Método de Rainflow Uniaxial, não contabiliza uma matriz igual aquela ilustrada na figura 4.51. Nestes métodos, uma tabela intitulada tabela Rainflow é criada. A primeira coluna desta tabela representa o ponto inicial do ciclo, a segunda coluna representa o ponto final do ciclo e a terceira coluna representa o número de ciclos que ocorre em toda o histórico de tensão/deformação. A figura 5.22 ilustra um exemplo de um carregamento não proporcional e a tabela 5.3 é a tabela Rainflow relativa à esta figura, resultado da contagem de reversão multiaxial utilizando o Método de Wang \& Brown. Para um melhor entendimento sobre o Método de Wang \& Brown ver de Castro \& Meggiolaro (2009a, seções 7.9/7.10), Lee et al. (2011, cap. 3) e/ou Socie \& Marquis (2000, seção 8.4.2.3).

Uma vez que o Método de Rainflow Multiaxial é aplicado à cada um dos nós superficiais de um modelo FE e a tabela Rainflow de cada nó tiver sido computada, é necessário calcular o dano por fadiga causado por cada linha da tabela Rainflow. A maneira mais simples, prática, e rápida de se fazer esta soma é utilizando a regra de Palmgren-Miner. Cada linha da tabela Rainflow (i.e. cada reversão) causa um dano $d_{j}$ ao componente, de maneira que o componente falha por fadiga quando a variável dano alcançar um valor crítico $\left(D_{P M}\right)$ :

$$
D=\sum_{1}^{m} d_{j}=\sum_{1}^{m} \frac{n_{j}}{N_{j}} \geq D_{P M}
$$

Onde

$m \quad$ : Número de linhas existente na da tabela Rainflow.

$n_{j} \quad$ : Número de ciclos relativo à linha analisada que atua no nó analisado.

$N_{j} \quad$ : Número total de ciclos para ocorrer a falha sob a tensão alternada supracitada.

$D_{P M} \quad$ : Valor crítico do dano, em que ocorre a falha por fadiga. 
Palmgren e Miner encontraram que o valor crítico do dano é $D_{P M}=1,0$ em suas pesquisas com carregamento uniaxial de amplitude variável. Mas estudos realizados por outros pesquisadores após Palmgren e Miner mostraram que o valor crítico de dano é uma variável aleatória que varia de 0,15 à 1,06 (Lee et al., 2011). A (FKM-Guideline, 2003) recomenda adotar para projetos mecânicos os seguintes valores críticos para carregamento uniaxial:

- $D_{P M}=0,3$ para aços, aços para fundição e ligas de alumínio; e

- $D_{P M}=1,0$ para ferros fundidos nodulares, ferros fundidos maleáveis e ferros fundidos cinzentos;

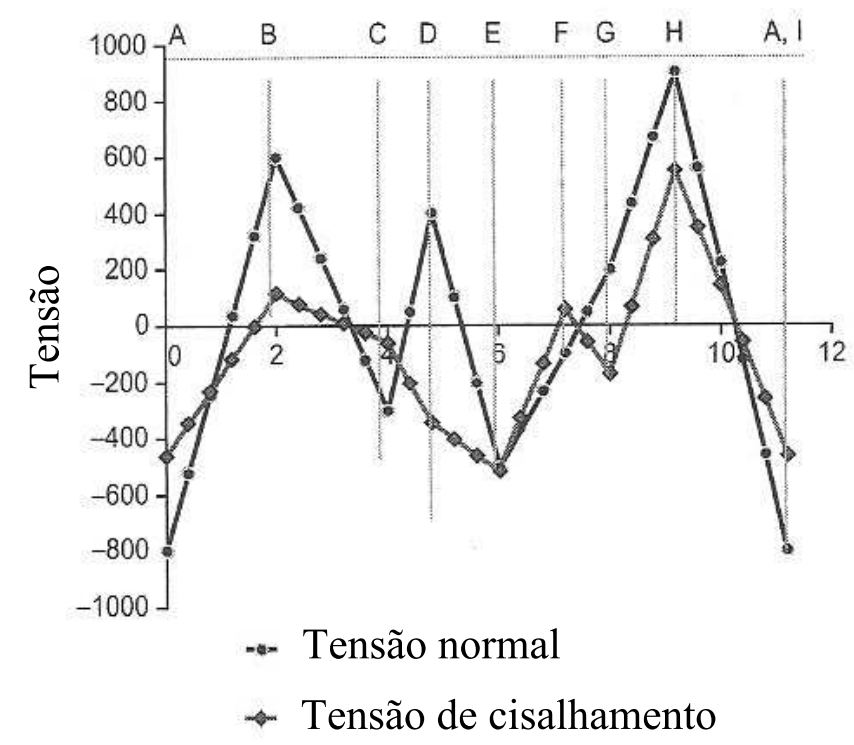

Figura 5.22 Ilustração do Método de Rainflow Multiaxial: histórico de tensão normal e de cisalhamento (extraído de Lee et al. (2011)).

Tabela 5.3 Resultado da Contagem de Reversão Multiaxial

\begin{tabular}{c|c|c}
\hline $\begin{array}{c}\text { Ponto inicial } \\
\text { do ciclo }\end{array}$ & $\begin{array}{c}\text { Ponto final do } \\
\text { ciclo }\end{array}$ & No. de ciclos \\
\hline A & H & 0,5 \\
\hline B & E & 0,5 \\
\hline C & C $~$ & 0,5 \\
\hline E & B & 0,5 \\
\hline F & F* & 0,5 \\
\hline H & I & 0,5 \\
\hline
\end{tabular}




\subsection{Modelos de Dano por Fadiga}

Os primeiros modelos de dano em fadiga multiaxial, também chamados de critérios de fadiga multiaxial, foram baseados em estimativas elásticas das tensões aplicadas combinadas. O objetivo desses critérios era estimar o limite de fadiga de materiais sujeitos a cargas combinadas de flexão e torção aplicadas simultaneamente. No início da década de 1970 muitos esforços estavam direcionados à modelos de fadiga mutiaxial baseados em deformação, que são úteis em análise de fadiga de baixo ciclo. Entretanto, modelos de fadiga multiaxial baseados em tensão continuam mais abrangentes e adequados para a grande classe de componentes que operam com níveis de tensão bem abaixo do limite de escoamento, com tensões um pouco acima do limite de fadiga (Lee et al., 2011). Adicionalmente, muitos modelos de fadiga multiaxial baseados em tensão podem ser utilizados com sucesso no regime fadiga de alto ciclo (vida finita), quando as tensões aplicadas são maiores do que o limite de fadiga, desde que deformações plásticas sejam nulas ou muito pequenas. Papuga (2005) comenta que a utilização deste tipo de modelo em ciclos abaixo de 50.000 deveria ser bastante cautelosa. Muitos são os modelos de fadiga multiaxial propostos e a lista abaixo apresenta alguns deles:

- Modelo de Gough \& Pollard (1935, 1950, 1951)

- Modelo da Tensão Principal Sinalizada

- Modelo da Tensão de Cisalhamento Sinalizada (Modelo de Tresca)

- Modelo de von Mises Sinalizado

- Modelo de Sines (1955, 1959)

- Modelo de Findley (1959)

- Modelo de Crossland (1956)

- Modelo de Dang Van (1973, 1982, 1993)

- Modelo de Matake (1977)

- Modelo de Dietmann (1973a, 1973b)

- Modelo de Lee (1985)

- Modelo de McDiarmid (1987)

- Modelo de Lee \& Chiang (1991)

- Modelo de Fogue (1996)

- Modelo de Robert (1996)

- Modelo de Kenmeugne et al. (1996)

- Modelo de Papadopoulos (1987, 1993, 1994, 1997)

- Modelo de Sonsino (1995)

- Modelo de Zenner \& Liu (1993, 2000)

- Modelo de Morel (1997|1998 2000 2002)

- Modelo de Carpinteri \& Spagnoli (2001,2001) 
- Modelo de Gaier e Dannbauer (2003, 2008)

- Modelo de Gonçalves, Araújo \& Mamiya (2005)

- Modelo de Papuga (2005)

- Modelo de Liu \& Mahadevan (2005, 2006)

- Modelo de Ninic $(2006,2007)$

Pode-se dividir basicamente em três grupos os modelos baseados em tensão apresentados neste trabalho: modelos baseados em tensão equivalente, modelos baseados em planos críticos e modelos baseados em tensão mesoscópica.

- Modelos baseados em tensão equivalente: Este tipo de modelo é baseado tanto na teoria de escoamento de von Mises quanto de Tresca e foi originalmente desenvolvido para a determinação do limite de fadiga para vários metais sobre carregamento proporcional. Com o passar do tempo, algumas formulações foram desenvolvidas através da modificação da tensão alternada de von Mises para a contabilização do efeito de encruamento não proporcional.

- Modelos baseados em plano crítico: Este tipo de modelo fornece uma interpretação física para o processo de iniciação de dano e geralmente geram resultados mais precisos que o tipo anterior, principalmente em carregamentos nã̃o proporcionais. A orientação da trinca pode ser identificada através da procura pelo plano de maior dano, entre os inúmeros potenciais planos de iniciação de trinca. Um parâmetro de dano é utilizado para contabilizar o dano em fadiga e posteriormente a vida da estrutura. Este parâmetro de dano é geralmente uma combinação entre tensão de cisalhamento e tensão normal atuante nesse plano crítico.

- Modelos baseados em tensão mesoscópica: Estes tipos de modelos utilizam um conceito totalmente diferente do que historicamente tinha sido utilizado para prever a falha por fadiga. Estes tipos de modelos utilizam tensões mesoscópicas, que são tensões medidas dentro de um grão cristalino de um metal, diferente das tensões macroscópicas que são computadas em um volume que é muitas vezes maior do que um grão cristalino.

Estes modelos foram desenvolvidos utilizando-se espécimes polidos e sem entalhes, sob carregamentos multiaxiais (geralmente tração e torção cíclicas, aplicadas em fase ou fora de fase). Portanto, como os espécimes não possuem entalhe, as tensões atuantes na superfície destes espécimes são equivalentes às tensões nominais " $S$ " relatadas no capítulo 4, sem a aplicação do fator de entalhe. Entretanto, como o assunto fadiga multiaxial exige a manipulação constante dos 6 componentes do tensor de tensões, será utilizado neste capítulo a nomenclatura $\sigma_{x}, \sigma_{y}, \sigma_{z}, \tau_{x y}, \tau_{y z}$ e $\tau_{x z}$ para se referir às tensões aplicadas no espécime; entretanto, deve-se ficar entendido que estas são equivalentes às tensões nominais "S".

Métodos apropriados para análise de geometrias complexas, onde a localização das áreas críticas não são conhecidas a priori, deveriam satisfazer vários requisitos:

- Ser capaz de prever com boa acuracidade a vida em fadiga do componente sob cargas cíclicas de tração-compressão combinadas à cargas cíclicas de torção, para vários tipos de metais (dúctil, semi-dúctil ou frágil); 
- Independencia do sistema de coordenadas. Isto pode ser alcançado com a aplicação de modelos de plano crítico, por exemplo;

- Ser capaz de prever a vida em fadiga de componentes sujeitos tanto à carregamentos proporcionais quanto à não proporcionais;

- Poder ser utilizado em carregamento de amplitude constante quanto variável. Portanto, deve ser adequado para ser utilizado juntamente com um procedimento de contagem de ciclos (ex: Método Rainflow Multiaxial);

- Sob um ponto de vista prático, o tempo de cálculo de vida em fadiga para grandes modelos de Elementos Finitos, com milhares de nós e com vários histórias de carregamento, cada um com centenas de pontos de amostragem, não deveria exceder uma noite.

Serão apresentados neste capítulo alguns dos modelos de fadiga multiaxial baseados em tensão que ganharam ampla aceitação e que satisfazem os requisitos acima. Não é o objetivo deste trabalho rever todos os modelos que têm sido propostos até então. Uma análise mais detalhada sobre as equações e a precisão de cada modelo pode ser encontrada em $\mathrm{Pa}-$ puga (2005), Papuga (2011), Fojtík (2011) e Papadopoulos et al. (1997). Os modelos de fadiga multiaxial apresentados a seguir estão incluídos nos softwares comerciais de fadiga apresentados na seção 6.2

\subsubsection{Modelos Baseados em Tensão Equivalente}

Existem vários critérios utilizados para a determinação do escoamento estático sob estados de tensão complexos, como o critério de von Mises, de Tresca e da Máxima Tensão Normal, por exemplo. Muitos cientistas tentaram correlacionar dados de ensaios de fadiga multiaxial utilizando parâmetros inicialmente desenvolvidos para a determinação de escoamento estático sob estados de tensão complexos. Este tipo de abordagem teria a vantagem de que simples testes uniaxiais seriam suficientes para descrever completamente o comportamento em fadiga de um componente sob carregamentos complexos. Aliás, como dano por fadiga é controlado pela deformação plástica local, é razoável de se pensar que os critérios de escoamento que descrevem a deformação plástica também podem descrever o comportamento em fadiga. Adicionalmente, os modelos baseado em tensão equivalente partem do princípio que a tensão equivalente causam um dano equivalente ao dano causado pela tensão uniaxial em um ensado de fadiga uniaxial.

Há basicamente três modelos que lidam com carregamentos multiaxiais que são baseados em extensões de critérios de falha estática. Estes modelos são chamados de modelos baseados em tensão equivalente. Os modelos baseados em tensão equivalente foram inicialmente criados para prever a falha por fadiga em condições de carregamento proporcional. Este tipo de critério não contabiliza o efeito de encruamento não proporcional causado por carregamento não proporcional e, desta forma, não conseguem estimar adequadamente a vida em 
fadiga para este tipo de carregamento (Lee et al., 2011; Socie \& Marquis, 2000). Portanto, modelos baseados em tensão equivalente não devem ser utilizados em componentes sujeitos à carregamento não proporcional (Lee et al., 2011; Socie \& Marquis, 2000). Para fins de projeto mecânico, deve-se utilizar modelos baseados no plano crítico em problemas contendo carregamentos não proporcionais. Esta seção informará sobre a utilização dos principais modelos de fadiga multiaxial baseados em tensão equivalente.

Neste capítulo será utilizado uma nomenclatura específica a fim de facilitar a compreensão do texto. Esta nomenclatura também se comunica com àquela utilizada nos capítulos anteriores. Desta forma, os seguintes parâmetros são utilizados neste capítulo:

\begin{tabular}{|c|c|}
\hline$S_{E, s p}$ & $\begin{array}{l}\text { Limite de fadiga da Curva } S-N \text { Espécime (ilustrada nas figuras } 4.6,4.14 \mathrm{a} \\
4.24,4.25 \text { e } 4.27) \text {, sendo esta curva obtida através de um ensaio padro- } \\
\text { nizado, i.e., utilizando espécimes padronizados, com seção circular, diâ- } \\
\text { metro de aproximadamente } 8 \mathrm{~mm}(=0,3 \text { pol), sem entalhes, com superfície } \\
\text { polida, sem macro tensões residuais, testados na atmosfera e temperatura } \\
\text { ambiente e sob flexão rotativa }(R=-1)\end{array}$ \\
\hline$\sigma_{E, s p}$ & $\begin{array}{l}\text { Limite de fadiga da Curva } S-N \text { Espécime, sendo esta curva obtida atra- } \\
\text { vés de um ensaio padronizado, i.e., utilizando espécimes padronizados, } \\
\text { com seção circular, diâmetro de aproximadamente } 8 \mathrm{~mm}(=0,3 \text { pol }) \text {, sem } \\
\text { entalhes, com superfície polida, sem macro tensões residuais, testados na } \\
\text { atmosfera e temperatura ambiente e sob tração-compressão completa- } \\
\text { mente reversa }(R=-1)\end{array}$ \\
\hline$\tau_{E, s p}$ & $\begin{array}{l}\text { Limite de fadiga da Curva } S \text { - } N \text { Espécime, sendo esta curva obtida atra- } \\
\text { vés de um ensaio padronizado, i.e., utilizando espécimes padronizados, } \\
\text { com seção circular, diâmetro de aproximadamente } 8 \mathrm{~mm}(=0,3 \text { pol }) \text {, sem } \\
\text { entalhes, com superfície polida, sem macro tensões residuais, testados na } \\
\text { atmosfera e temperatura ambiente e sob torção completamente reversa } \\
(R=-1)\end{array}$ \\
\hline
\end{tabular}

$\mathrm{Na}$ impossibilidade de realizar ensaios de fadiga para a obtenção de $\sigma_{E, s p}$ e $\tau_{E, s p}$, pode-se estimar estes parâmetros através das equações abaixo, conforme explicado na seção 4.3.3.

$$
\begin{array}{ll}
\sigma_{E, s p}=S_{E, s p} \cdot 0,9 & 4.41 \text { revisitada) } \\
\tau_{E, s p}=S_{E, s p} \cdot C_{\tau} & 4.42 \text { revisitada) }
\end{array}
$$

Outros símbolos também utilizados para facilitar a compreensão deste capítulo são indicados abaixo: 
$A_{-1} \quad$ : Limite de fadiga do componente não entalhado*, obtido com carregamento axial (tração-compressão) alternado $(R=-1)$

$A_{0} \quad$ : Limite de fadiga do componente não entalhado*, obtido com carregamento axial (tração-compressão) pulsante $R=0$ )

$A_{0,5} \quad$ : Limite de fadiga do componente não entalhado*, obtido com carregamento axial (tração-compressão) $\operatorname{com} R=0,5$

$A_{E, \text { un }}:$ Limite de fadiga do componente não entalhado*, obtido com carregamento axial (tração-compressão), obtido com um determinado valor de Razão de Tensões $R$

$T_{-1} \quad$ : Limite de fadiga do componente não entalhado*, obtido com torção alternada $R=-1)$

$T_{0} \quad$ : Limite de fadiga do componente não entalhado*, obtido com torção pulsante $R=0)$

$T_{E, \text { un }} \quad$ : Limite de fadiga do componente não entalhado*, obtido com torção, sob um determinado valor de Razão de Tensões $(R)$

* Na verdade, o limite de fadiga medido na seção transversal analisada do componente, considerando todos os fatores modificadores apresentados na figura 4.24 (exceto o efeito de entalhe, que já foi considerado ao se alterar o carregamento, conforme explicado na seção 5.3).

Na impossibilidade de realizar ensaios de fadiga para a obtenção dos parâmetros supracitados, pode-se estimá-los através das equações abaixo, conforme explicado no capítulo 4.

$$
\begin{aligned}
& \begin{aligned}
A_{-1} & =S_{E, \text { un }}\left(@ C_{L}=0,9 \mathrm{e} R=-1\right) \\
& =\sigma_{E, s p} \cdot C_{R O} \cdot C_{S T} \cdot C_{C} \cdot C_{R} \cdot C_{T} \\
A_{0}= & S_{E, \text { un }}\left(@ C_{L}=0,9 \mathrm{e} R=0\right) \\
& =\sigma_{E, s p} \cdot C_{R O} \cdot C_{S T} \cdot C_{C} \cdot C_{R} \cdot C_{T} \cdot C_{m, \sigma^{e}}(@ R=0) \\
A_{0,5} & =S_{E, \text { un }}\left(@ C_{L}=0,9 \mathrm{e} R=0,5\right) \\
& =\sigma_{E, s p} \cdot C_{R O} \cdot C_{S T} \cdot C_{C} \cdot C_{R} \cdot C_{T} \cdot C_{m, \sigma^{e}}(@ R=0,5) \\
A_{E, \text { un }} & =S_{E, \text { un }}\left(@ C_{L}=0,9\right) \\
& =\sigma_{E, s p} \cdot C_{R O} \cdot C_{S T} \cdot C_{C} \cdot C_{R} \cdot C_{T} \cdot C_{m, \sigma^{e}}
\end{aligned}
\end{aligned}
$$




$$
\begin{aligned}
& \begin{aligned}
T_{-1} & =S_{E, u n}\left(@ C_{L}=C_{\tau} \text { e } R=-1\right) \\
& =\tau_{E, s p} \cdot C_{R O} \cdot C_{S T} \cdot C_{C} \cdot C_{R} \cdot C_{T}
\end{aligned} \\
& T_{0}=S_{E, u n}\left(@ C_{L}=C_{\tau} \mathrm{e} R=0\right) \\
& =\tau_{E, s p} \cdot C_{R O} \cdot C_{S T} \cdot C_{C} \cdot C_{R} \cdot C_{T} \cdot C_{m, \sigma^{e}}(@ R=0) \\
& T_{E, \text { un }}=S_{E, u n}\left(@ C_{L}=C_{\tau}\right) \\
& =\tau_{E, s p} \cdot C_{R O} \cdot C_{S T} \cdot C_{C} \cdot C_{R} \cdot C_{T} \cdot C_{m, \sigma^{e}}
\end{aligned}
$$

\subsubsection{Modelo da Tensão Principal Sinalizada}

Quando o carregamento é uniaxial, é usual basear a estimativa de vida em fadiga em valores de tensão normal $\left(\sigma_{x}\right)$. Quando há multiaxialidade no carregamento, é possível substituir a tensão axial em um componente por uma tensão equivalente, que é então utilizada na Curva Tensão-Vida (obtida utilizando conforme explicado anteriormente) para se calcular a vida em fadiga.

O Modelo da Tensão Principal Sinalizada, também conhecido como Modelo da Tensão Principal Sinalizadd $\unlhd^{8}$ utiliza a tensão principal máxima sinalizada $\unlhd^{9}\left(\sigma_{1, \text { signed }}\right)$ ao invés da tensão principal máxima $\left(\sigma_{1}\right)$, porque esta última gera truncamento nos ciclos (MSC.Software, sd). Isto é explicado em detalhes a seguir.

Seja um componente entalhado sujeito à carregamento axial completamente reverso de amplitude constante, ilustrado na figura 5.23. As tensões mostradas nesta figura são as tensões lidas no ponto onde ocorre o máximo valor de tensão, i.e. na superfície da seção de menor diâmetro. Aqui, as tensões principais são ordenadas no modo convencional, onde $\sigma_{1} \geq \sigma_{2} \geq \sigma_{3}$. Em cada instante de tempo há um valor diferente para as seis componentes de tensão. Os círculos de Mohr para cinco instantes de tempo estão exibidos nesta figura para o carregamento de tensão e compressão cíclico. A presença do entalhe faz com que haja tensões em outras direções além da direção X, principalmente o surgimento da tensão $\sigma_{y}$. Há na verdade um estado biaxial de tensões na superfície do entalhe, pois não há tensão normal à superfície. $\mathrm{O}$ entalhe também faz com que a tensão principal média $\left(\sigma_{2}\right)$ seja diferente de zero.

\footnotetext{
${ }^{8}$ Em inglês, Absolute Maximum Principal Stress

${ }^{9}$ Também intitulada tensão principal máxima sinalizada
} 
Conforme pode ser visto na figura 5.24a, a tensão principal máxima $\left(\sigma_{1}\right)$ é sempre positiva ou zero e a metade de baixo dos ciclos é truncada. Por outro lado, a tensão principal mínima $\left(\sigma_{3}\right)$ é sempre zero ou negativa e a metade de cima também é truncada. Pode-se perceber claramente que não é possível utilizar a tensão principal máxima da figura $5.24 \mathrm{~b}$ nem a tensão principal mínima da figura 5.24c para propósitos de análise de fadiga, pois muitos ciclos possuiriam valores errados. Por isso, há a necessidade de um parâmetro que reflete a natureza reversa do carregamento e nos dá uma representação do carregamento reverso, incluindo valor de tensão alternada e média e números de ciclos (MSC.Software, sd). Isto é feito utilizando a tensão principal máxima sinalizada $\left(\sigma_{1, \text { signed }}\right)$ como parâmetro de dano por fadiga (MSC.Software, sd). Esta tensão é calculada conforme a equação (5.31) para cada time step e apresentada na figura $5.24 \mathrm{~d}$.

$$
\sigma_{1, \text { signed }}= \begin{cases}\sigma_{1} & \text { se } \sigma_{1}>0 \\ \sigma_{3} & \text { se } \sigma_{1} \leq 0\end{cases}
$$

As tensões principais $\sigma_{1}, \sigma_{2}$ e $\sigma_{3}$ devem ser calculadas utilizando 6 componentes de tensão obtidas na equação (5.21) $\left(\sigma_{x}, \sigma_{y}, \sigma_{z}, \tau_{x y}, \tau_{y z}, \tau_{x z}\right)$ conforme as quatro equações abaixo, lembrando que $\sigma_{1} \geq \sigma_{2} \geq \sigma_{3}$ :

$$
\begin{gathered}
\sigma^{3}-I_{1} \sigma^{2}+I_{2} \sigma-I_{3}=0 \\
I_{1}=\sigma_{x}+\sigma_{y}+\sigma_{z} \\
I_{2}=\sigma_{x} \sigma_{y}+\sigma_{y} \sigma_{z}+\sigma_{z} \sigma_{x}-\left(\tau_{x y}\right)^{2}-\left(\tau_{y z}\right)^{2}-\left(\tau_{x z}\right)^{2} \\
I_{3}=\sigma_{x} \sigma_{y} \sigma_{z}+2 \tau_{x y} \tau_{y z} \tau_{x z}-\sigma_{x}\left(\tau_{y z}\right)^{2}-\sigma_{y}\left(\tau_{x z}\right)^{2}-\sigma_{z}\left(\tau_{x y}\right)^{2}
\end{gathered}
$$

De acordo com MSC.Software (sd), no Modelo da Tensão Principal Sinalizada, o parâmetro de dano é contabilizado através do uso do Método de Rainflow uniaxial mostrado na seção 4.5, aplicando este método no histórico da tensão principal máxima sinalizada $\left(\sigma_{1, \text { signed }}\right)$. A amplitude da tensão principal máxima sinalizada e a média da tensão principal máxima sinalizada de cada bloco de amplitude constante da Matriz de Rainflow são calculadas conforme segue:

$$
\begin{aligned}
\sigma_{1, \text { signed }, a} & =\frac{\max \left(\sigma_{1, \text { signed }}\right)-\min \left(\sigma_{1, \text { signed }}\right)}{2} \\
\sigma_{1, \text { signed }, m} & =\frac{\max \left(\sigma_{1, \text { signed }}\right)+\min \left(\sigma_{1, \text { signed }}\right)}{2}
\end{aligned}
$$



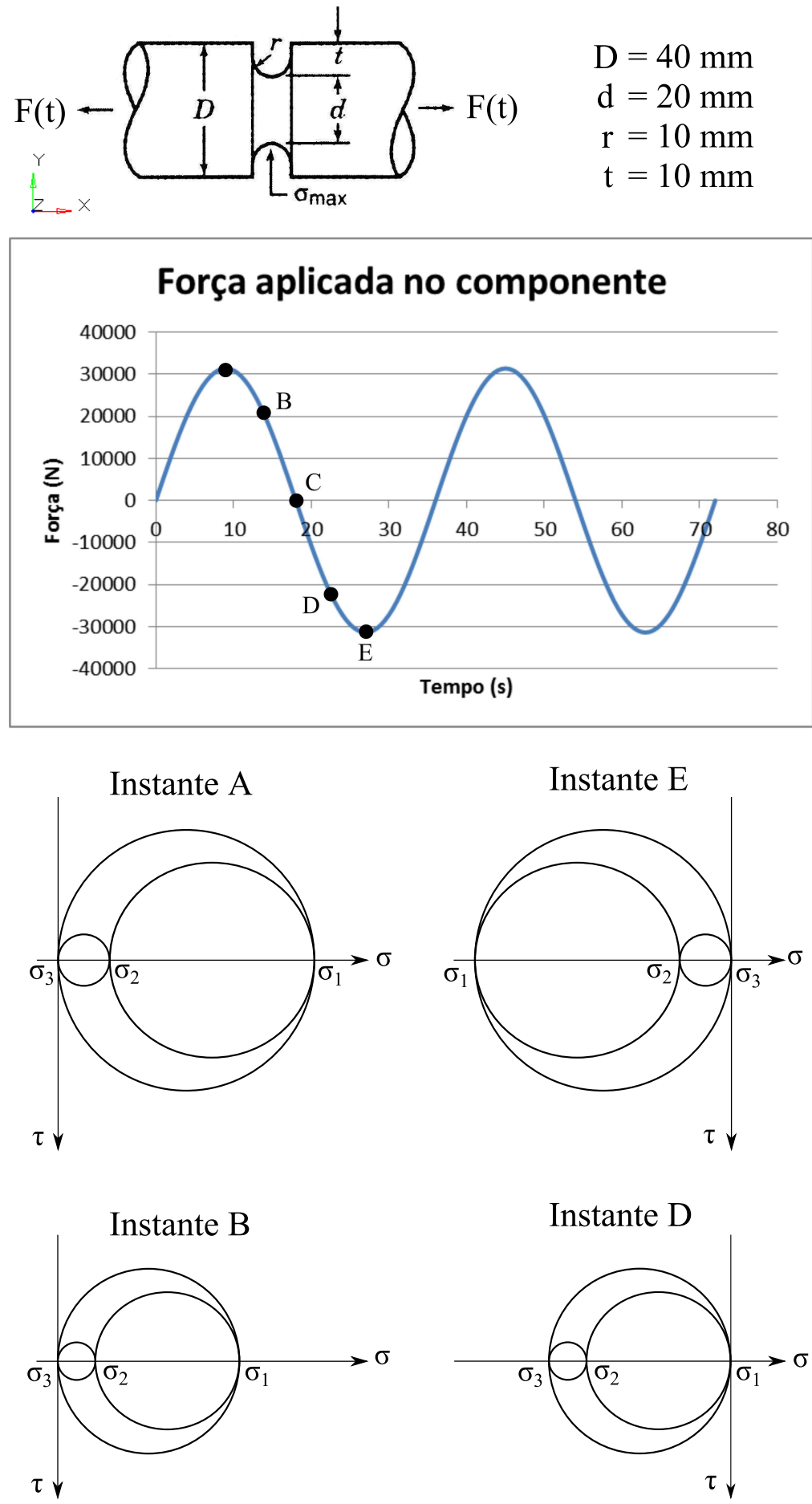

Instante C

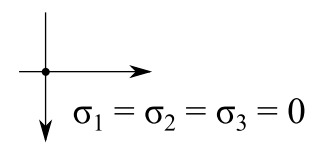

Figura 5.23 Exemplo de componente entalhado. 

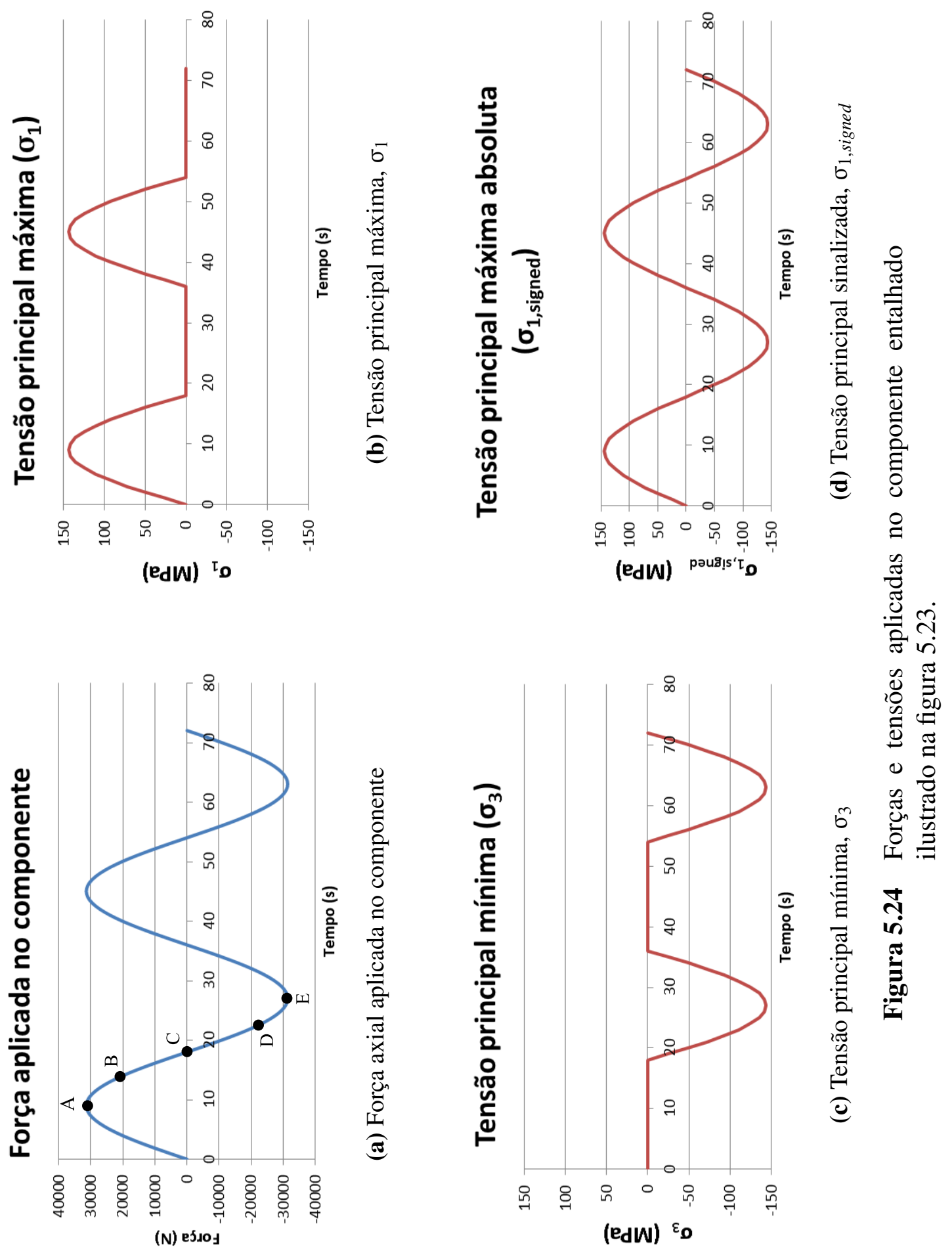
De acordo com Lee et al. (2011), Socie \& Marquis (2000), Karolczuk \& Macha (2005), MSC.Software (2008) e MSC.Software(sd), o Critério da Tensão Principal Sinalizada prevê que a falha por fadiga no espécime padronizado ocorrerá se:

$$
\sigma_{1, \text { signed,a }} \geq \sigma_{E, s p}
$$

As primeiras tentativas de analizar fadiga sob tensões biaxiais foram baseadas nas tensões principais, utilizando uma curva S-N convencional, obtida pelo mesmo procedimento apresentado no capítulo 4 (Fatemi, sdc). A amplitude da tensão principal máxima $\left(\sigma_{1, a}\right)$ era comparada com a Curva Tensão-Vida Local obtida utilizando espécimes sob carregamento axial. A (falsa) hipótese neste procedimento é que a vida em fadiga é sempre determinada pela $\sigma_{1, a}$ e portanto a segunda tensão principal $\left(\sigma_{2, a}\right)$ não tem efeito na vida em fadiga (Draper, sdb).

Um eixo circular submetido à torção pura de $\pm \tau_{x y}$ possuirá uma tensão principal de $\pm \sigma_{1}=$ $\pm \tau_{x y}$. A utilização da tensão principal portanto prevê que a resistência à fadiga em torção é idêntica que a resistência à fadiga para carregamento axial. Entretanto, isto não é confirmado por experimentos. Conforme é sabido, o limite de fadiga sob torção é aproximadamente $57 \%$ do limite de fadiga sob flexão em aços e aproximadamente $64 \%$ do limite de fadiga sob tração-compressão em aços. Portanto, a utilização deste critério em casos de torção pura em aços origina resultados altamente não conservadores.

Neste modelo, o plano que ocorrerá a fratura (plano crítico) é assumido como sendo o plano com a maior amplitude da tensão principal máxima sinalizada $\left(\sigma_{1, \text { signed,a }}\right)$ (Karolczuk \& Macha, 2005).

Todas as publicações lidas e analisadas ao longo do desenvolvimento desta dissertação e que falam sobre este critério explicam como aplicá-lo para prever a falha de um espécime padronizado. Não foi encontrado na revisão bibliográfica desta dissertação referências que relatam como este critério de falha multiaxial pode ser expandido para ser aplicado em componentes de geometria/características ${ }^{11}$ complexas, diferentes do espécime. Também não foi encontrado como utilizar este modelo em conjunto com análises por Elementos Finitos.

Desta forma, o autor acredita que o conceito de similaridade continuaria sendo válido também em fadiga multiaxial e, portanto, continuaria sendo válido utilizar os fatores modificadores apresentados no capítulo 4 também em fadiga multiaxial. Desta forma, o autor acredita que o Modelo da Tensão Principal Sinalizada pode ser utilizado em um componente entalhado ou não entalhado, com características diferentes do espécime padronizado, utilizando o limite de fadiga $A_{E, u n}$, que já consideraria todas as características da seção transversal analisada (pois todos os fatores modificadores apresentados na figura 4.24 já foram

\footnotetext{
${ }^{10}$ Ver tabela 4.6

${ }^{11}$ Geometria do entalhado, rugosidade superficial, tratamento superficial, temperatura de trabalho, etc.
} 
considerados no cálculo de $A_{E, \text { un }}$, exceto o fator de entalhe, que já foi considerado ao se alterar o carregamento, conforme explicado na seção 5.3). Portanto, estima-se que a falha por fadiga do componente ${ }^{12}$ ocorrerá quando a relação abaixo for satisfeita:

$$
\begin{aligned}
\sigma_{1, \text { signed, } a} & \geq A_{E, \text { un }} \\
& \geq \sigma_{E, s p} \cdot C_{R O} \cdot C_{S T} \cdot C_{C} \cdot C_{R} \cdot C_{T} \cdot C_{m, \sigma^{e}} \\
& \geq S_{E, s p} \cdot 0,9 \cdot C_{R O} \cdot C_{S T} \cdot C_{C} \cdot C_{R} \cdot C_{T} \cdot C_{m, \sigma^{e}}
\end{aligned}
$$

Note que o efeito da rugosidade superficial $\left(C_{R O}\right)$, tratamento superficial $\left(C_{S T}\right)$, corrosão $\left(C_{C}\right)$, confiabilidade $\left(C_{R}\right)$, temperatura $\left(C_{T}\right)$ e tensão média $\left(C_{m, \sigma^{\circ}}\right)$ são contabilizados modificando a Curva $S$-N Espécime conforme explicado nas seções $4.3 \mathrm{e} 4.6 .1$.

Socie \& Marquis (2000) também relatam que o Modelo da Tensão Principal Sinalizada pode ser utilizado em quaisquer outros modelos de correção de tensão média apresentados na seção 4.6.1 ou no diagrama de Haigh para incorporar o efeito da tensão média. Assim, o fator modificador de tensão média $\left(C_{m, \sigma^{e}}\right)$ aplicado nas equações (5.25), (5.26), (5.27), (5.29) e (5.30) é calculado utilizando as tensões equivalentes calculadas pelas equações (5.36) e 5.37) em algum modelo de correção de tensão média da seção 4.6.1 (ou no diagrama de Haigh).

Acredita-se que o efeito de tamanho não deve ser considerado porque todos os modelos de fadiga multiaxial são modelos de iniciação de trinca e seriam validados para estruturas com o tamanho/diâmetro do espécime padronizado (Lee et al., 2011).

O efeito de entalhe não é considerado na Curva Tensão-Vida, mas sim é contabilizado dividindo as 6 componentes do tensor de tensões de cada nó pelo fator de entalhe $n_{K}$, conforme explicado na seção 5.3 . É importante lembrar que a tensão $\sigma_{1, \text { signed }}$ (equação 5.31) é calculada utilizando as tensões obtidas na equação (5.21) $\left(\sigma_{x}, \sigma_{y}, \sigma_{z}, \tau_{x y}, \tau_{y z}, \tau_{x z}\right)$. É por este motivo que não se considera o efeito do entalhe nas equações de 5.24 à 5.30 .

Grande parte das publicações (Karolczuk \& Macha, 2005; Lee et al., 2011; Socie \& Marquis, 2000) apresentam os modelos de fadiga multiaxial como sendo um critério do tipo “passa ou não passa”, conforme apresentado pela equação (5.38) e (5.39). Este tipo de apresentação não permite saber em qual ciclo ocorreria a falha por fadiga, caso a tensão equivalente ${ }^{13}$ (lado esquerdo das equações dos critérios de falha) seja maior do que o limite de fadiga (lado direito). Existem poucas referências que relatam como utilizar os critérios de fadiga multiaxial de maneira a obter o número de ciclos em que ocorrerá a falha por fadiga. Foram encontradas apenas três referências que relatam isto na revisão bibliográfica desta dissertação: Socie \& Marquis (2000), Karolczuk \& Macha (2005) e MSC.Software (2008). Entretanto, estas 3 referências apresentam equações para se calcular o número de

\footnotetext{
${ }^{12} \mathrm{Na}$ verdade, a vida em fadiga daquela seção transversal analisada.

${ }^{13}$ Parâmetro de dano.
} 
ciclos em que ocorrerá a fratura em um espécime padronizado. Não foi encontrado na revisão bibliográfica desta dissertação referências que relatam como os critérios multiaxiais podem ser expandidos para prever o número de ciclo que ocorrerá a falha de componentes de geometria/características $\sqrt{14}$ complexas, diferentes do espécime.

Assim, o autor também acredita que o Modelo da Tensão Principal Sinalizada pode ser utilizado para calcular o número de ciclos em que a fratura por fadiga ocorrerá em um componente entalhado ou não entalhado, com características diferentes do espécime padronizado, utilizando uma Curva Tensão-Vida, de maneira similar ao apresentado no capítulo 4. A Curva Tensão-Vida que deveria ser utilizada seria a Curva S-N Unnotched (equação 4.40 e figura 4.24) do lado direito da equação (5.39). Assim, a vida do componente poderia ser estimada utilizando a seguinte equação:

$$
\sigma_{1, \text { signed }, a}=S_{f, \text { un }}^{\prime} \cdot(2 N)^{b_{u n}}
$$

Onde

$S_{f, u n}^{\prime} \quad$ : Coeficiente de resistência à fadiga da Curva $S$-N Unnotched

$b_{u n} \quad:$ Expoente de resistência à fadiga da Curva $S$-N Unnotched

A resistência à fadiga para $N_{B}$ ciclos do componente é estimada conforme a equação abaixo (similar à equação 4.37):

$$
S_{B, u n}=S_{B, s p} \cdot C_{C} \cdot C_{R} \cdot C_{T} \cdot C_{m, \sigma^{e}}
$$

Uma vez conhecido 2 pontos da curva, $\left(N_{E}, A_{E, \text { un }}\right)$ e $\left(N_{B}, S_{B, \text { un }}\right)$, deve-se utilizar a equação (5.42) para obter o expoente de resistência à fadiga $\left(b_{u n}\right)$ e em seguida a equação (5.43) para obter o coeficiente de resistência à fadiga $\left(S_{f, u n}^{\prime}\right)$. É importante ter em mente que $A_{E, \text { un }}$ é o limite de fadiga da Curva Tensão-Vida referente à seção transversal analisada do componente (lado direito da equação 5.40).

$$
\begin{gathered}
b_{u n}=\frac{\log \left(A_{E, \text { un }} / S_{B, \text { un }}\right)}{\log \left(N_{E} / N_{B}\right)} \\
S_{f, \text { un }}^{\prime}=\frac{A_{E, \text { un }}}{\left(2 N_{E}\right)^{b_{u n}}}
\end{gathered}
$$

As figuras $5.25 \mathrm{e}$ 5.26 ilustram didaticamente como este critério de fadiga multiaxial deve ser utilizado.

\footnotetext{
${ }^{14}$ Geometria do entalhe, rugosidade superficial, tratamento superficial, temperatura de trabalho, etc.
} 


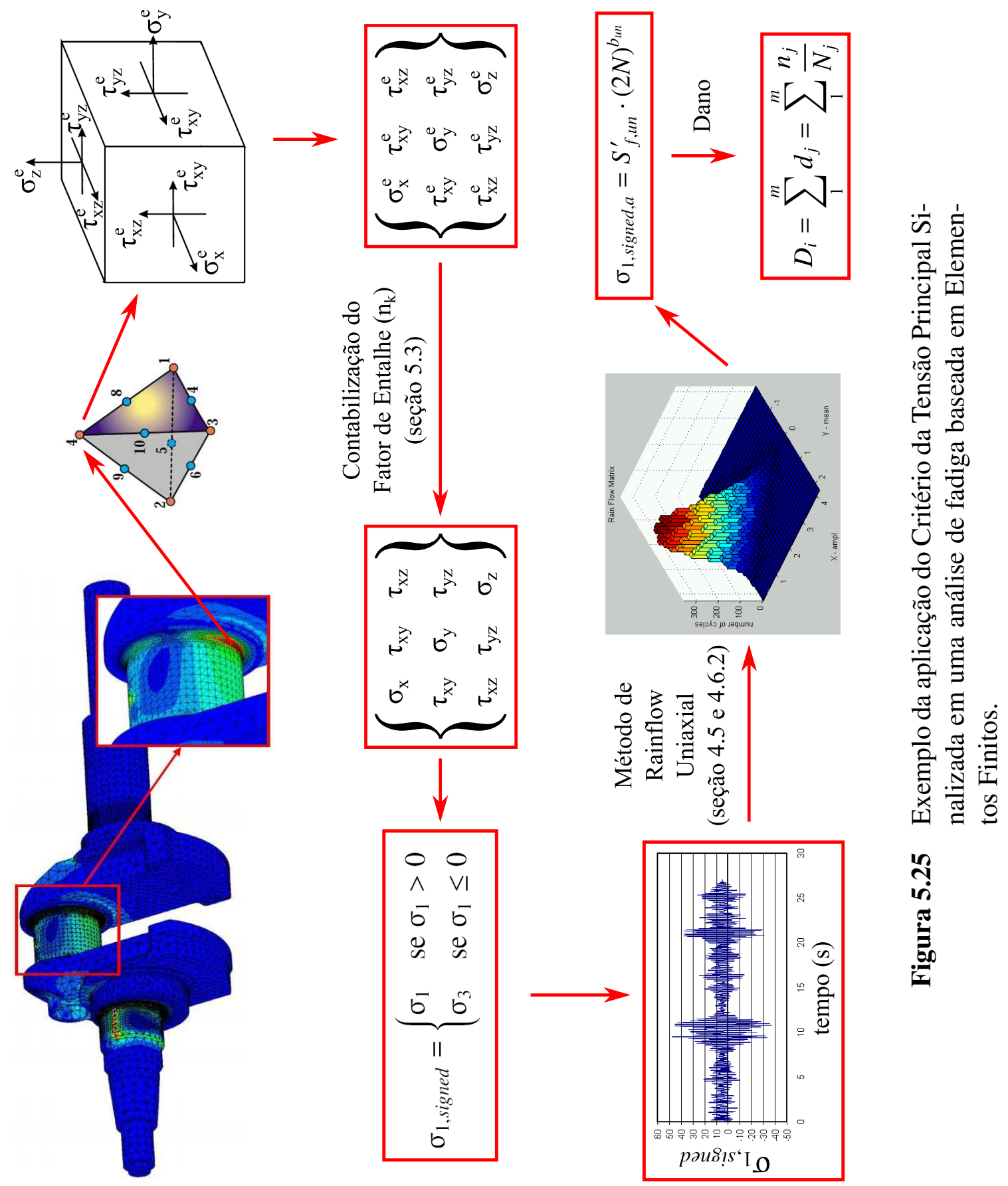




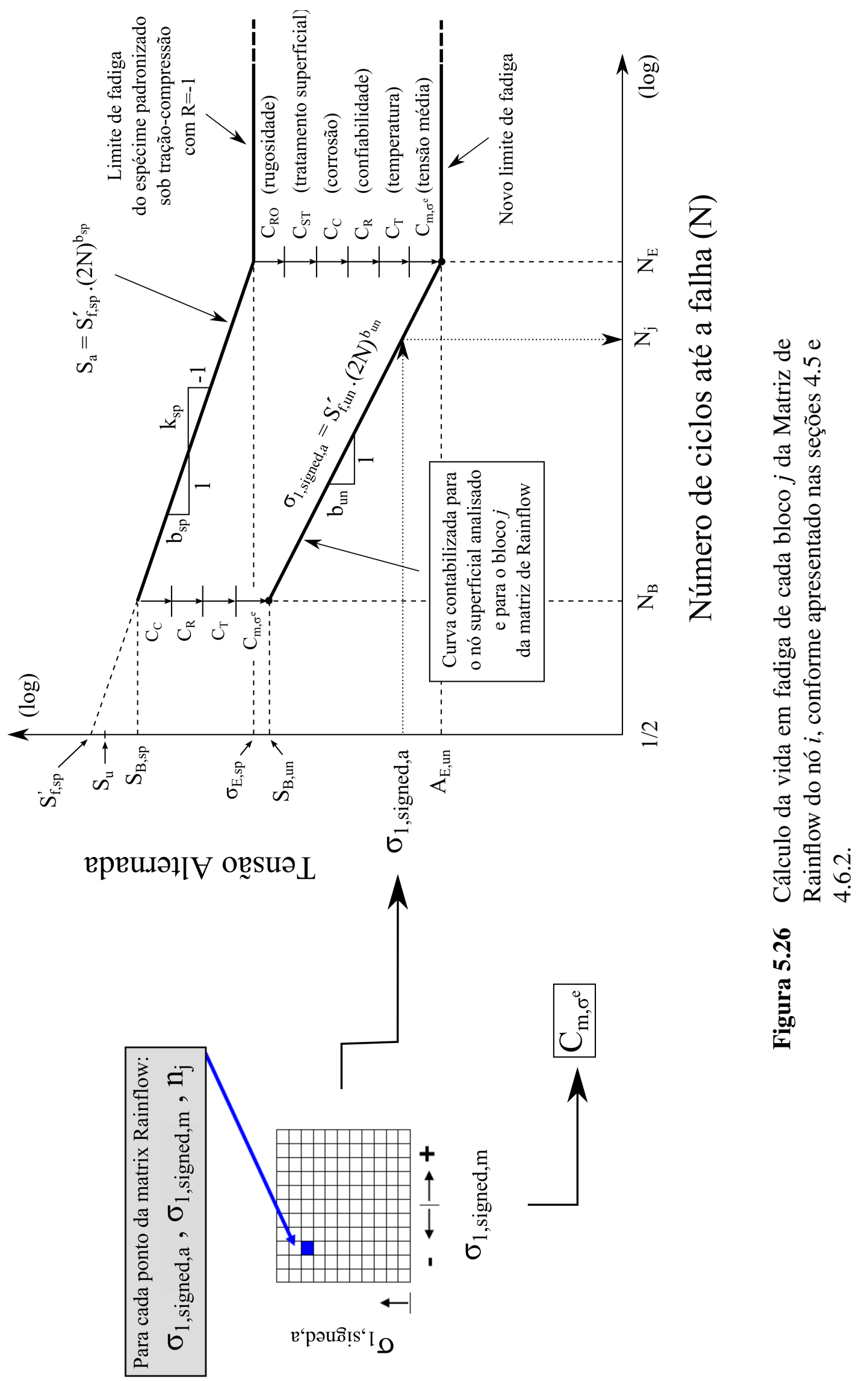


Lee et al. (2011, pp.193), Gaier \& Dannbauer (2003), Draper (sdb) e Fatemi (sdc) relatam que este critério deve ser utilizado apenas para análise de fadiga de metais frágeis como ferros fundidos e alguns aços de ultra-alta resistência mecânica. A análise de fadiga utilizando tensões principais tende a gerar previsões de vida muito inseguras quanto mais dúctil for o metal, como é o caso das ligas de aço e de alumínio mais comumente utilizadas. É muito importante ter em mente que este critério poderá ser utilizado apenas para componentes sujeitos à carregamento proporcional (Lee et al., 2011; Socie \& Marquis, 2000).

Este modelo de fadiga multiaxial está incluso em praticamente todos os FE-Based Fatigue Analysis Softwares, inclusive nos descritos na seção 6.2 .

\subsubsection{Modelo da Tensão de Cisalhamento Sinalizada (Modelo de Tresca)}

O Modelo da Tensão de Cisalhamento Sinalizada, também conhecido como Modelo de Tresca Sinalizadd ${ }^{15}$ utiliza a tensão de cisalhamento sinalizada $\left(\tau_{\text {signed }}\right)$ para prever a falha por fadiga. A tensão de cisalhamento sinalizada é a tensão de cisalhamento máxima ${ }^{16}$, utilizando o sinal da tensão principal máxima $\left(\sigma_{1}\right)$ ou o sinal da tensão principal mínima $\left(\sigma_{3}\right)$. Isto é necessário porque a tensão de cisalhamento máxima, calculada pela fórmula de Tresca, é sempre positiva e portanto gera truncamento nos ciclos, conforme apresentado pela figura 5.27a (MSC.Software, sd). Isto será explicado em detalhes a seguir.

Seja o componente entalhado sujeito à carregamento axial completamente reverso de amplitude constante, ilustrado na figura 5.24a. Aqui, as tensões principais são ordenadas no modo convencional, onde $\sigma_{1} \geq \sigma_{2} \geq \sigma_{3}$. Conforme pode ser visto nesta figura, a tensão de cisalhamento máxima $(\tau)$ é sempre positiva quando calculada através da fórmula de Tresca, conforme apresenta a figura 5.27a. Por este motivo, este tipo de tensão não consegue caracterizar o comportamento cíclico relacionado à fadiga. Por isso, há a necessidade de se criar um parâmetro que reflete a natureza reversa do carregamento e nos dá uma representação do carregamento reverso (MSC.Software, sd). Isto é feito utilizando a tensão de cisalhamento máxima sinalizadd ${ }^{17}\left(\tau_{\text {signed }}\right)$ como parâmetro de dano por fadiga (MSC.Software, sd). Esta tensão é calculada conforme a equação (5.44) para cada time step e apresentada na figura $5.27 \mathrm{~b}$.

$$
\tau_{\text {signed }}= \begin{cases}\left(\frac{\sigma_{1}-\sigma_{3}}{2}\right) \cdot \frac{\sigma_{1}}{\left|\sigma_{1}\right|} & \text { se } \sigma_{1} \neq 0 \\ \left(\frac{\sigma_{1}-\sigma_{3}}{2}\right) \cdot \frac{\sigma_{3}}{\left|\sigma_{3}\right|} & \text { se } \sigma_{1}=0 \text { e } \sigma_{3} \neq 0 \\ 0 & \text { se } \sigma_{1}=0 \text { e } \sigma_{3}=0\end{cases}
$$

\footnotetext{
${ }^{15}$ Em inglês, Signed Tresca Model

${ }^{16}$ Que é a tensão cisalhante máxima no circulo de Mohr, calculada pela equação de Tresca $\left(\frac{\sigma_{1}-\sigma_{3}}{2}\right)$

${ }^{17}$ Em inglês, signed tresca stress.
} 
As tensões principais $\sigma_{1}, \sigma_{2}$ e $\sigma_{3}$ devem ser calculadas utilizando 6 componentes de tensão obtidas na equação (5.21) $\left(\sigma_{x}, \sigma_{y}, \sigma_{z}, \tau_{x y}, \tau_{y z}, \tau_{x z}\right)$ conforme as quatro equações abaixo, lembrando que $\sigma_{1} \geq \sigma_{2} \geq \sigma_{3}$ :

$$
\begin{gathered}
\sigma^{3}-I_{1} \sigma^{2}+I_{2} \sigma-I_{3}=0 \\
I_{1}=\sigma_{x}+\sigma_{y}+\sigma_{z} \\
I_{2}=\sigma_{x} \sigma_{y}+\sigma_{y} \sigma_{z}+\sigma_{z} \sigma_{x}-\left(\tau_{x y}\right)^{2}-\left(\tau_{y z}\right)^{2}-\left(\tau_{x z}\right)^{2} \\
I_{3}=\sigma_{x} \sigma_{y} \sigma_{z}+2 \tau_{x y} \tau_{y z} \tau_{x z}-\sigma_{x}\left(\tau_{y z}\right)^{2}-\sigma_{y}\left(\tau_{x z}\right)^{2}-\sigma_{z}\left(\tau_{x y}\right)^{2}
\end{gathered}
$$

De acordo com MSC.Software (sd), no Modelo de Tresca, o parâmetro de dano é contabilizado através do Método de Rainflow uniaxial mostrado na seção 4.5, aplicando este método no histórico da tensão de cisalhamento sinalizada $\left(\tau_{\text {signed }}\right)$. A amplitude da tensão de cisalhamento sinalizada $\left(\tau_{\text {signed,a }}\right)$ e a média da tensão de cisalhamento sinalizada $\left(\tau_{\text {signed,m }}\right)$ de cada bloco de amplitude constante da Matriz de Rainflow são calculadas conforme segue:

$$
\begin{aligned}
\tau_{\text {signed, } a} & =\frac{\max \left(\tau_{\text {signed }}\right)-\min \left(\tau_{\text {signed }}\right)}{2} \\
\tau_{\text {signed, } m}= & \frac{\max \left(\tau_{\text {signed }}\right)+\min \left(\tau_{\text {signed }}\right)}{2}
\end{aligned}
$$

De acordo com Lee et al. (2011), Socie \& Marquis (2000), Karolczuk \& Macha (2005), MSC.Software (2008) e MSC.Software(sd), o Critério de Tresca prevê que a falha por fadiga no espécime padronizado ocorrerá se a equação abaixo for satisfeita:

$$
\tau_{\text {signed,a }} \geq \tau_{E, s p}
$$

Todas as publicações lidas e analisadas ao longo do desenvolvimento desta dissertação e que falam sobre este critério explicam como aplicá-lo para prever a falha de um espécime padronizado. Não foi encontrado na revisão bibliográfica desta dissertação referências que relatam como este critério de falha multiaxial pode ser expandido para ser aplicado em componentes de geometria/características ${ }^{18}$ complexas, diferentes do espécime. Também não foi encontrado como utilizar este modelo em conjunto com análises por Elementos Finitos.

Desta forma, o autor acredita que o conceito de similaridade continuaria sendo válido também em fadiga multiaxial e, portanto, continuaria sendo válido utilizar os fatores modificadores apresentados no capítulo 4 também em fadiga multiaxial. Desta forma, o autor

\footnotetext{
${ }^{18}$ Geometria do entalhado, rugosidade superficial, tratamento superficial, temperatura de trabalho, etc.
} 


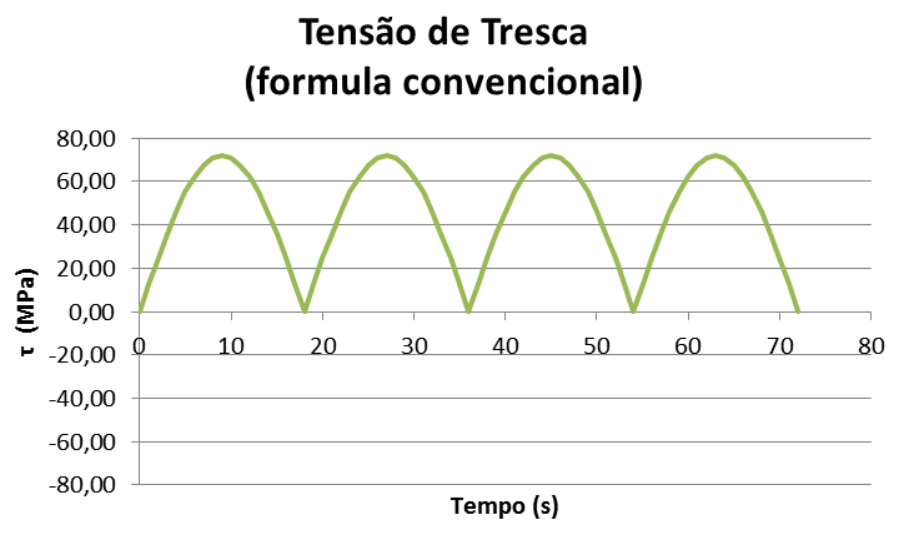

(a) Tensão de cisalhamento máxima, $\tau$

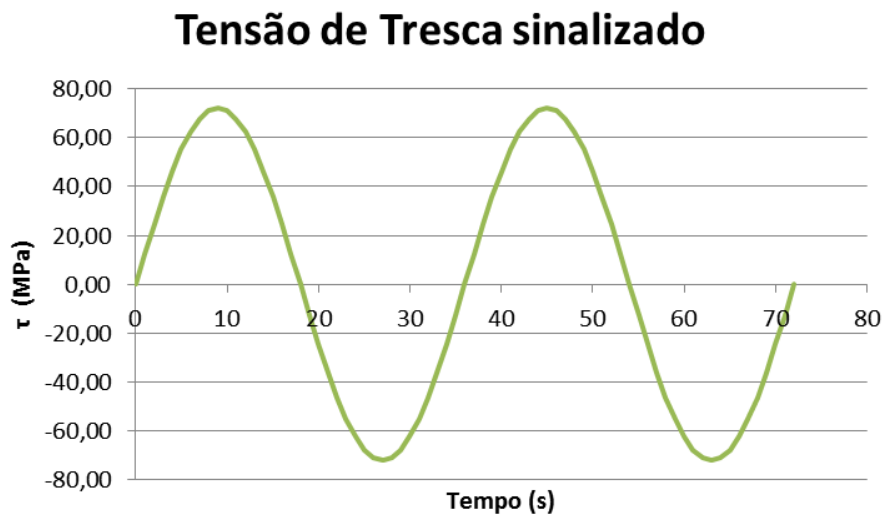

(b) Tensão de cisalhamento sinalizada, $\sigma_{3}$

Figura 5.27 Tensões aplicadas no componente entalhado ilustrado na figura $5.24 \mathrm{a}$.

acredita que o Modelo da Tensão de Cisalhamento Sinalizada pode ser utilizado em um componente entalhado ou não entalhado, com características diferentes do espécime padronizado, utilizando o limite de fadiga $T_{E, u n}$, que já consideraria todas as características da seção transversal analisada (pois todos os fatores modificadores apresentados na figura 4.24 já foram considerados no cálculo de $T_{E, u n}$, exceto o fator de entalhe, que já foi considerado ao se alterar o carregamento, conforme explicado na seção 5.3. Portanto, estima-se que a falha por fadiga do componente ${ }^{19}$ ocorrerá quando a relação abaixo for satisfeita:

$$
\begin{aligned}
\tau_{\text {signed, } a} & \geq T_{E, \text { un }} \\
& \geq \tau_{E, s p} \cdot C_{R O} \cdot C_{S T} \cdot C_{C} \cdot C_{R} \cdot C_{T} \cdot C_{m, \sigma^{e}} \\
& \geq S_{E, s p} \cdot C_{\tau} \cdot C_{R O} \cdot C_{S T} \cdot C_{C} \cdot C_{R} \cdot C_{T} \cdot C_{m, \sigma^{e}}
\end{aligned}
$$

O efeito da rugosidade superficial $\left(C_{R O}\right)$, tratamento superficial $\left(C_{S T}\right)$, corrosão $\left(C_{C}\right)$,

\footnotetext{
${ }^{19} \mathrm{Na}$ verdade, a vida em fadiga daquela seção transversal analisada.
} 
confiabilidade $\left(C_{R}\right)$, temperatura $\left(C_{T}\right)$ e tensão média $\left(C_{m, \sigma^{e}}\right)$ modificam a Curva $S$ - $N$ Espécime conforme explicado na seção 4.3 .

Não foi encontrado na revisão bibliográfica desta dissertação referências que relatam como contabilizar o efeito da tensão média no Modelo da Tensão de Cisalhamento Sinalizada. Entretanto, o autor acredita que pode-se utilizar o Diagrama de Haigh mostrado na figura 4.39 para contabilizar o efeito da tensão média no Modelo da Tensão de Cisalhamento Sinalizada. Assim, o fator modificador de tensão média $\left(C_{m, \sigma^{e}}\right)$ aplicado nas equações (5.29) e (5.30) deveria ser calculado utilizando as tensões equivalentes calculadas pelas equações (5.49) e 5.50) no Diagrama de Haigh mostrado na figura 4.39.

Acredita-se que o efeito de tamanho não deve ser considerado porque todos os modelos de fadiga multiaxial são modelos de iniciação de trinca e seriam validados para estruturas com o tamanho/diâmetro do espécime padronizado (Lee et al., 2011).

O efeito de entalhe não é considerado na Curva Tensão-Vida, mas sim é contabilizado dividindo as 6 componentes do tensor de tensões de cada nó pelo fator de entalhe $n_{K}$, conforme explicado na seção 5.3. É importante lembrar que a tensão $\tau_{\text {signed }}$ (equação 5.44) é calculada utilizando as tensões obtidas na equação (5.21) $\left(\sigma_{x}, \sigma_{y}, \sigma_{z}, \tau_{x y}, \tau_{y z}, \tau_{x z}\right)$. É por este motivo que não se considera o efeito do entalhe nas equações de 5.24 à 5.30 .

Grande parte das publicações (Karolczuk \& Macha, 2005; Lee et al., 2011; Socie \& Marquis, 2000) apresentam os modelos de fadiga multiaxial como sendo um critério do tipo "passa ou não passa", conforme apresentado pela equação (5.51) e (5.52). Este tipo de apresentação não permite saber em qual ciclo ocorreria a falha por fadiga, caso a tensão equivalente ${ }^{20}$ (lado esquerdo das equações dos critérios de falha) seja maior do que o limite de fadiga (lado direito). Existem poucas referências que relatam como utilizar os critérios de fadiga multiaxial de maneira a obter o número de ciclos em que ocorrerá a falha por fadiga. Foram encontradas apenas três referências que relatam isto na revisão bibliográfica desta dissertação: Socie \& Marquis (2000), Karolczuk \& Macha (2005) e MSC.Software (2008). Entretanto, estas 3 referências apresentam equações para se calcular o número de ciclos em que ocorrerá a fratura em um espécime padronizado. Não foi encontrado na revisão bibliográfica desta dissertação referências que relatam como os critérios multiaxiais podem ser expandidos para prever o número de ciclo que ocorrerá a falha de componentes de geometria/características ${ }^{21}$ complexas, diferentes do espécime.

Assim, o autor também acredita que o Modelo da Tensão de Cisalhamento Sinalizada pode ser utilizado para calcular o número de ciclos em que a fratura por fadiga ocorrerá em um componente entalhado ou não entalhado, com características diferentes do espécime padronizado, utilizando uma Curva Tensão-Vida, de maneira similar ao apresentado no capítulo

\footnotetext{
${ }^{20}$ Parâmetro de dano.

${ }^{21}$ Geometria do entalhe, rugosidade superficial, tratamento superficial, temperatura de trabalho, etc.
} 
4. A Curva Tensão-Vida que deveria ser utilizada seria a Curva S-N Unnotched (equação 4.40 e figura 4.24 do lado direito da equação (5.52). Assim, a vida do componente poderia ser estimada utilizando a seguinte equação:

$$
\tau_{\text {signed,a }}=\tau_{f, u n}^{\prime} \cdot(2 N)^{b_{u n}}
$$

Onde

$\tau_{f, u n}^{\prime} \quad$ : Coeficiente de resistência à fadiga da Curva $S-N$ Unnotched

$b_{u n} \quad:$ Expoente de resistência à fadiga da Curva S-N Unnotched

A resistência à fadiga para $N_{B}$ ciclos do componente é estimada conforme a equação abaixo (similar à equação 4.37):

$$
S_{B, \text { un }}=S_{B, s p} \cdot C_{C} \cdot C_{R} \cdot C_{T} \cdot C_{m, \sigma^{e}}
$$

Uma vez conhecido 2 pontos da curva, $\left(N_{E}, T_{E, \text { un }}\right)$ e $\left(N_{B}, S_{B, \text { un }}\right)$, deve-se utilizar a equação (5.55) para obter o expoente de resistência à fadiga $\left(b_{u n}\right)$ e em seguida a equação (5.56) para obter o coeficiente de resistência à fadiga $\left(\tau_{f, \text { un }}^{\prime}\right)$. É importante ter em mente que $T_{E, \text { un }}$ é o limite de fadiga da Curva Tensão-Vida referente à seção transversal analisada do componente (lado direito da equação 5.53).

$$
\begin{gathered}
b_{u n}=\frac{\log \left(T_{E, \text { un }} / S_{B, \text { un }}\right)}{\log \left(N_{E} / N_{B}\right)} \\
\tau_{f, \text { un }}^{\prime}=\frac{T_{E, \text { un }}}{\left(2 N_{E}\right)^{b_{u n}}}
\end{gathered}
$$

As figuras 5.28 e 5.29 ilustram didaticamente como este critério de fadiga multiaxial deve ser utilizado.

É muito importante ter em mente que este critério poderá ser utilizado apenas para componentes sujeitos à carregamento proporcional (Lee et al., 2011; Socie \& Marquis, 2000). Este modelo de fadiga multiaxial está incluso em praticamente todos os FE-Based Fatigue Analysis Softwares, inclusive nos descritos na seção 6.2. 

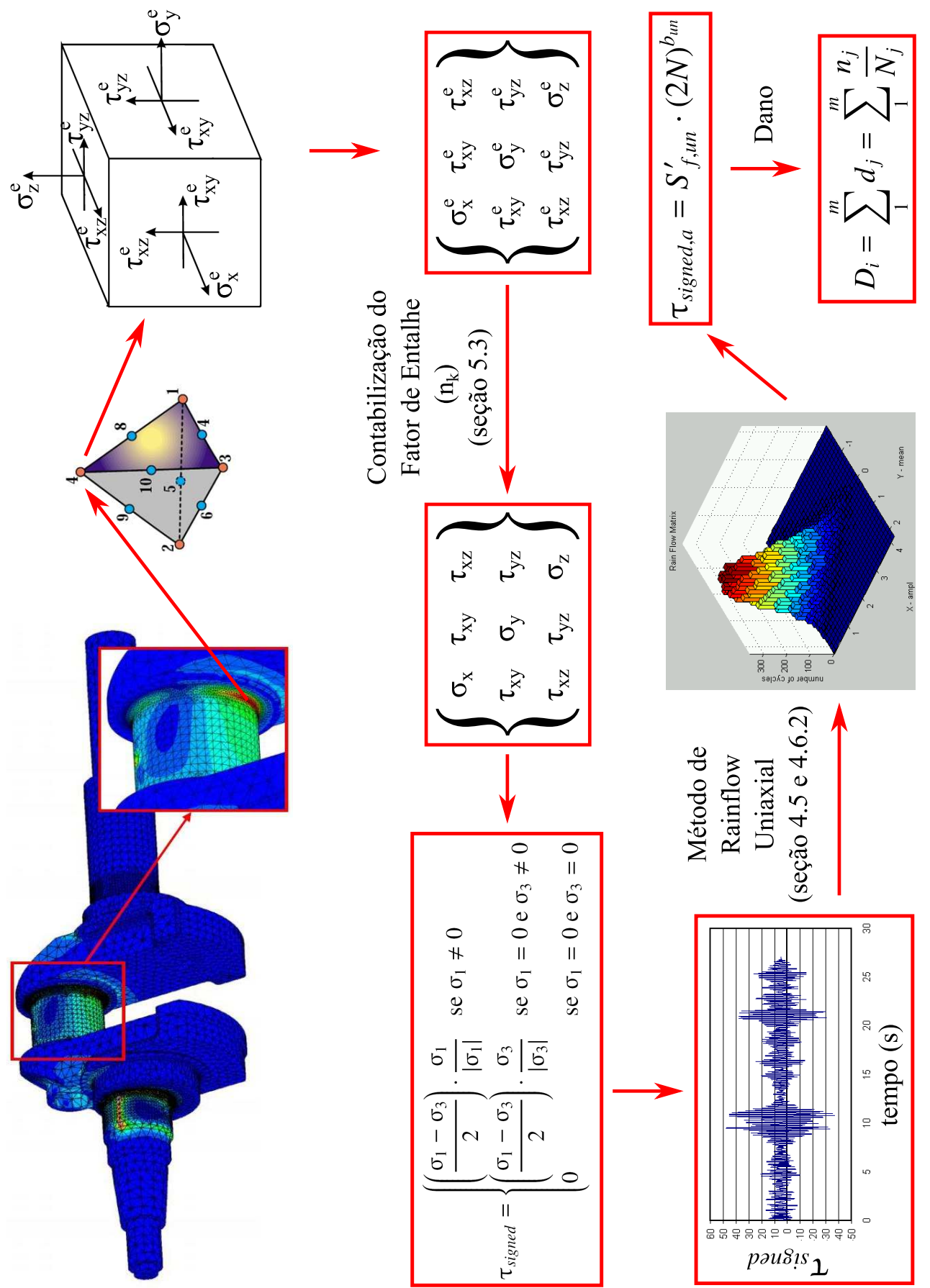

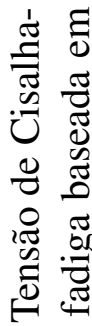

중 8

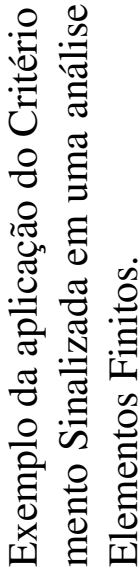
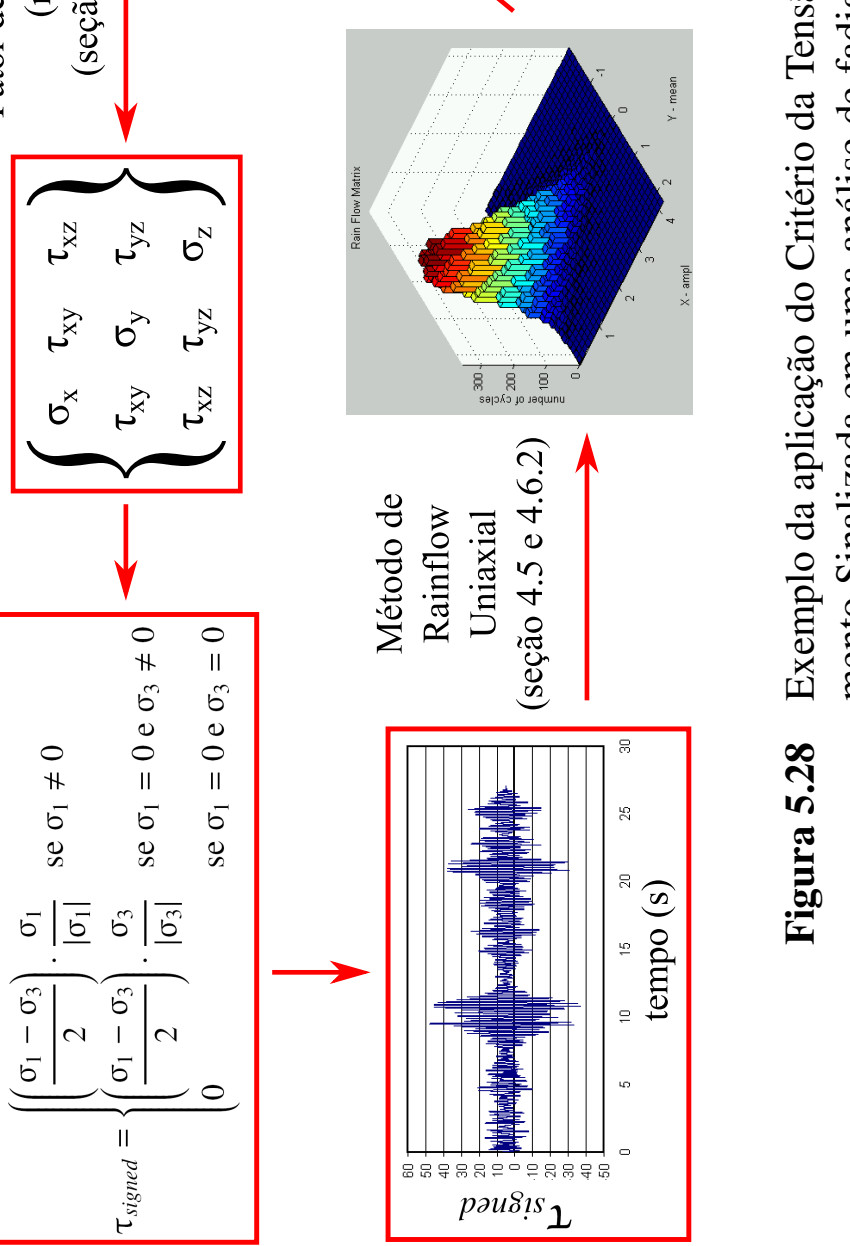
. 


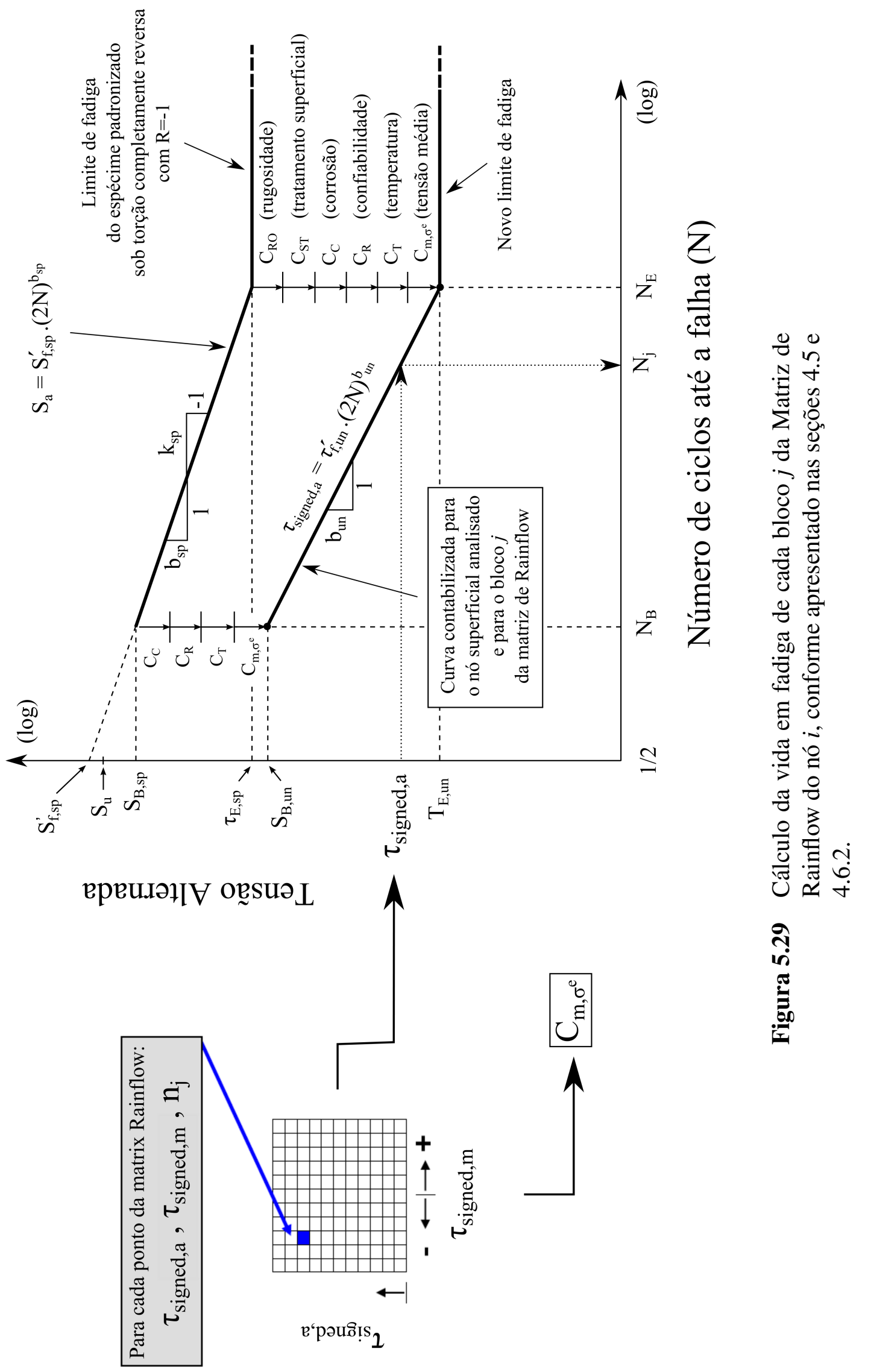




\subsubsection{Modelo de von Mises Sinalizado}

O Modelo de von Mises Sinalizadd 22 também conhecido como Modelo de von Mises Modificad ${ }^{23}$ ou Modelo da Tensão de Cisalhamento Octaédrica, é o modelo baseado em tensão mais conhecido e utilizado (Fatemi,, sdc $)$. As componentes de tensão alternada podem ser convertidas em uma única tensão alternada equivalente, que é comparada com um valor de tensão uniaxial experimental. Esta tensão equivalente é obtida utilizando a teoria de von Mises.

De acordo com Lee et al. (2011), neste modelo a tensão alternada equivalente é calculada por:

$$
\sigma_{V M, a}=\frac{1}{\sqrt{2}} \sqrt{\left(\sigma_{x, a}-\sigma_{y, a}\right)^{2}+\left(\sigma_{y, a}-\sigma_{z, a}\right)^{2}+\left(\sigma_{x, a}-\sigma_{z, a}\right)^{2}+6\left(\tau_{x y, a}^{2}+\tau_{y z, a}^{2}+\tau_{x z, a}^{2}\right)}
$$

E a tensão média equivalente é calculada conforme segue:

$$
\sigma_{V M, m}=\frac{1}{\sqrt{2}} \sqrt{\left(\sigma_{x, m}-\sigma_{y, m}\right)^{2}+\left(\sigma_{y, m}-\sigma_{z, m}\right)^{2}+\left(\sigma_{x, m}-\sigma_{z, m}\right)^{2}+6\left(\tau_{x y, m}^{2}+\tau_{y z, m}^{2}+\tau_{x z, m}^{2}\right)}
$$

A equação acima fornece apenas valores positivos de tensão média e não consegue contabilizar o efeito benéfico das tensões compressivas em fadiga. Desta forma, Fatemi (sdc) recomenda que os efeitos benéficos da tensão média compressiva e os efeitos prejudiciais da tensão média positiva sejam levados em consideração adequadamente calculando a tensão média equivalente de acordo com as recomendações de Sines (1959), conforme a equação (5.59). Entretanto, esta equação falha em alguns casos porque o efeito da tensão média compressiva em uma direção pode ser cancelado pelo efeito da tensão média trativa em outra direção, o que nem sempre está de acordo com as evidências experimentais.

$$
\sigma_{V M, m}=\frac{\sigma_{x, m}+\sigma_{y, m}+\sigma_{z, m}}{3}=\frac{\sigma_{1, m}+\sigma_{2, m}+\sigma_{3, m}}{3}
$$

Onde

Índices $\mathrm{x}, \mathrm{y}$ e $\mathrm{z}$ : Eixos de coordenada locais

Índices 1,2 e 3 : Eixos das tensões principais

Seja um carregamento multiaxial proporcional. Quando se calcula a tensão de von Mises em cada time step, $\sigma_{V M \text {,signed, }}$, esta tensão é sempre igual ou maior que zero, devido à construção da equação de von Mises. Isto pode ser visualizado na figura 5.30a. Desta forma,

\footnotetext{
${ }^{22}$ Em inglês, Signed von Mises model

${ }^{23} \mathrm{Em}$ inglês, Modified von Mises criterion
} 
tensões normais compressivas resultarão em tensões de von Mises positivas. Desta forma, não é possível utilizar a equação de von Mises convencional em problemas de fadiga. Este problema pode ser contornado utilizando a tensão de von Mises sinalizada, calculada utilizando a fórmula de von Mises mas com o sinal da tensão principal máxima sinalizada (MSC.Software, sd). Isto é muito útil para identificar quaisquer tensões médias compressivas, uma vez que tensões compressivas e trativas geram resultados diferentes na estrutura quanto à fadiga. Esta tensão é calculada conforme a equação (5.60) para cada time step e apresentada na figura 5.30b. É importante lembrar que $\sigma_{1} \geq \sigma_{2} \geq \sigma_{3}$.

$$
\sigma_{V M, \text { signed }}= \begin{cases}\frac{\sigma_{1}}{\left|\sigma_{1}\right|} \cdot \sqrt{\frac{\left(\sigma_{x}-\sigma_{y}\right)^{2}+\left(\sigma_{y}-\sigma_{z}\right)^{2}+\left(\sigma_{x}-\sigma_{z}\right)^{2}+6\left(\tau_{x y}^{2}+\tau_{y z}^{2}+\tau_{x z}^{2}\right)}{2}} & \text { se } \sigma_{1} \neq 0 \\ \frac{\sigma_{3}}{\left|\sigma_{3}\right|} \cdot \sqrt{\frac{\left(\sigma_{x}-\sigma_{y}\right)^{2}+\left(\sigma_{y}-\sigma_{z}\right)^{2}+\left(\sigma_{x}-\sigma_{z}\right)^{2}+6\left(\tau_{x y}^{2}+\tau_{y z}^{2}+\tau_{x z}^{2}\right)}{2}} & \text { se } \sigma_{1}=0 \text { e } \sigma_{3} \neq 0 \\ 0 & \text { se } \sigma_{1}=0 \text { e } \sigma_{3}=0\end{cases}
$$

De acordo com MSC.Software (sd), no Modelo de von Mises Sinalizado, o parâmetro de dano é contabilizado através do uso do Método de Rainflow uniaxial mostrado na seção 4.5. aplicando este método no histórico da tensão de von Mises sinalizada $\left(\sigma_{V M, \text { signed }}\right)$. A amplitude da tensão de von Mises sinalizada e a média da tensão de von Mises sinalizada de cada bloco de amplitude constante da Matriz de Rainflow são calculadas conforme segue:

$$
\begin{aligned}
\sigma_{V M, a} & =\frac{\max \left(\sigma_{V M, \text { signed }}\right)-\min \left(\sigma_{V M, \text { signed }}\right)}{2} \\
\sigma_{V M, m} & =\frac{\max \left(\sigma_{V M, \text { signed }}\right)+\min \left(\sigma_{V M, \text { signed }}\right)}{2}
\end{aligned}
$$

De acordo com Lee et al. (2011), Socie \& Marquis (2000), Karolczuk \& Macha (2005), MSC.Software (2008) e MSC.Software (sd), o Critério de von Mises Sinalizado prevê que a falha por fadiga no espécime padronizado ocorrerá se:

$$
\sigma_{V M, a} \geq \sigma_{E, s p}
$$

Todas as publicações lidas e analisadas ao longo do desenvolvimento desta dissertação e que falam sobre este critério explicam como aplicá-lo para prever a falha de um espécime padronizado. Não foi encontrado na revisão bibliográfica desta dissertação referências que relatam como este critério de falha multiaxial pode ser expandido para ser aplicado em componentes de geometria/característica $\$^{24}$ complexas, diferentes do espécime. Também não foi encontrado como utilizar este modelo em conjunto com análises por Elementos Finitos.

\footnotetext{
${ }^{24}$ Geometria do entalhado, rugosidade superficial, tratamento superficial, temperatura de trabalho, etc.
} 


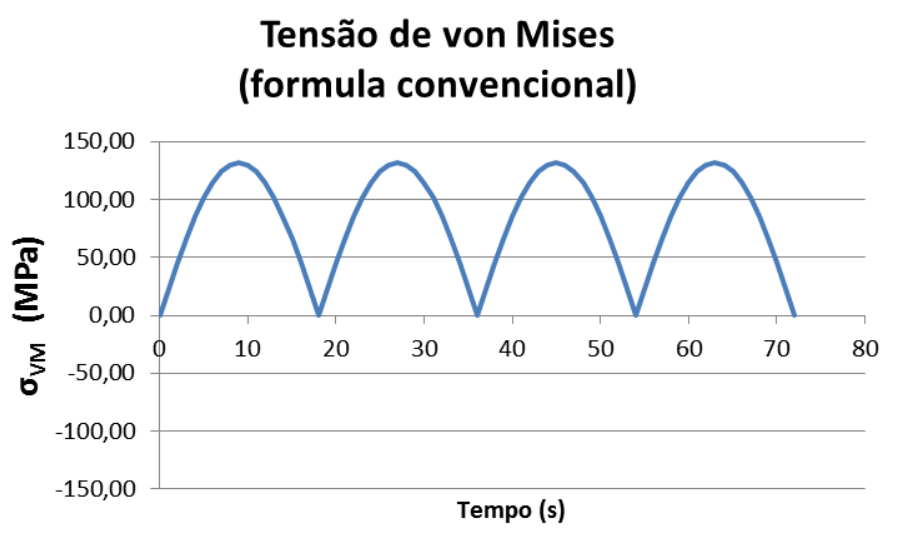

(a) Tensão de von Mises, $\sigma_{V M, \text { signed }}$

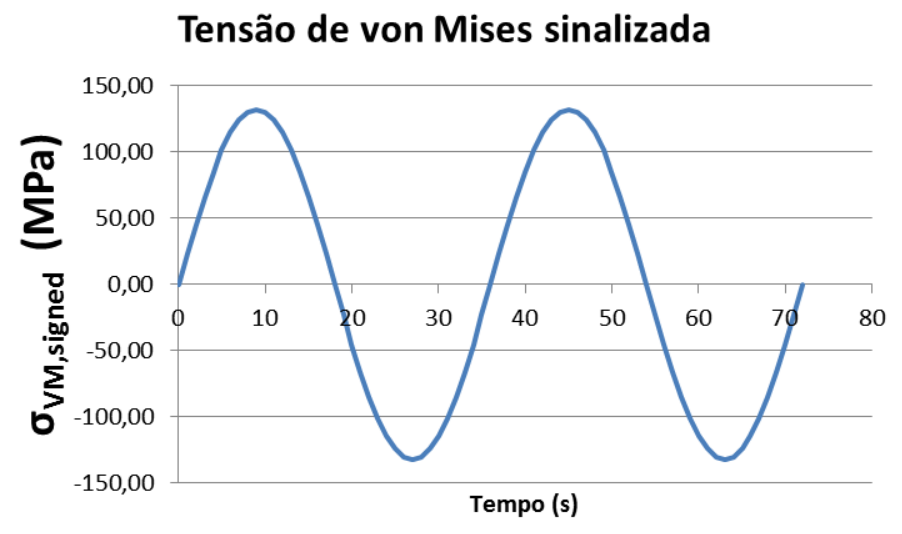

(b) Tensão de von Mises sinalizada, $\sigma_{V M, \text { signed }}$

Figura 5.30 Tensões aplicadas no componente entalhado ilustrado na figura 5.23 .

Desta forma, o autor acredita que o conceito de similaridade continuaria sendo válido também em fadiga multiaxial e, portanto, continuaria sendo válido utilizar os fatores modificadores apresentados no capítulo 4 também em fadiga multiaxial. Desta forma, o autor acredita que o Modelo de von Mises Sinalizado pode ser utilizado em um componente entalhado ou não entalhado, com características diferentes do espécime padronizado, utilizando o limite de fadiga $A_{E, u n}$, que já consideraria todas as características da seção transversal analisada (pois todos os fatores modificadores apresentados na figura 4.24já foram considerados no cálculo de $A_{E, \text { un }}$, exceto o fator de entalhe, que já foi considerado ao se alterar o carregamento, conforme explicado na seção 5.3. Portanto, estima-se que a falha por fadiga do componente $\mathrm{e}^{25}$ ocorrerá quando a relação abaixo for satisfeita:

$$
\begin{aligned}
\sigma_{V M, a} & \geq A_{E, u n} \\
& \geq \sigma_{E, s p} \cdot C_{R O} \cdot C_{S T} \cdot C_{C} \cdot C_{R} \cdot C_{T} \cdot C_{m, \sigma^{e}} \\
& \geq S_{E, s p} \cdot 0,9 \cdot C_{R O} \cdot C_{S T} \cdot C_{C} \cdot C_{R} \cdot C_{T} \cdot C_{m, \sigma^{e}}
\end{aligned}
$$

\footnotetext{
${ }^{25} \mathrm{Na}$ verdade, a vida em fadiga daquela seção transversal analisada.
} 
Note que o efeito da rugosidade superficial $\left(C_{R O}\right)$, tratamento superficial $\left(C_{S T}\right)$, corrosão $\left(C_{C}\right)$, confiabilidade $\left(C_{R}\right)$, temperatura $\left(C_{T}\right)$ e tensão média $\left(C_{m, \sigma^{e}}\right)$ são contabilizados modificando a Curva $S$ - $N$ Espécime conforme visto nas seções $4.3 \mathrm{e} 4.6 .1$.

Socie \& Marquis (2000) também relatam que o Modelo de von Mises Sinalizado pode ser utilizado em quaisquer outros modelos de correção de tensão média apresentados na seção 4.6.1 ou no diagrama de Haigh para incorporar o efeito da tensão média. Assim, o fator modificador de tensão média $\left(C_{m, \sigma^{e}}\right)$ aplicado nas equações (5.25), (5.26), (5.27), (5.29) e (5.30) é calculado utilizando as tensões equivalentes calculadas pelas equações (5.61) e (5.62) em algum modelo de correção de tensão média da seção 4.6.1 (ou no diagrama de Haigh).

Acredita-se que o efeito de tamanho não deve ser considerado porque todos os modelos de fadiga multiaxial são modelos de iniciação de trinca e seriam validados para estruturas com o tamanho/diâmetro do espécime padronizado (Lee et al., 2011).

O efeito de entalhe não é considerado na Curva Tensão-Vida, mas sim é contabilizado dividindo as 6 componentes do tensor de tensões de cada nó pelo fator de entalhe $n_{K}$, conforme explicado na seção 5.3. É importante lembrar que a tensão $\sigma_{V M \text {,signed }}$ (equação 5.60) é calculada utilizando as tensões obtidas na equação (5.21) $\left(\sigma_{x}, \sigma_{y}, \sigma_{z}, \tau_{x y}, \tau_{y z}, \tau_{x z}\right)$. É por este motivo que não se considera o efeito do entalhe nas equações de 5.24 à 5.30.

Grande parte das publicações (Karolczuk \& Macha, 2005; Lee et al., 2011; Socie \& Marquis, 2000) apresentam os modelos de fadiga multiaxial como sendo um critério do tipo "passa ou não passa", conforme apresentado pela equação (5.63) e (5.64). Este tipo de apresentação não permite saber em qual ciclo ocorreria a falha por fadiga, caso a tensão equivalente ${ }^{26}$ (lado esquerdo das equações dos critérios de falha) seja maior do que o limite de fadiga (lado direito). Existem poucas referências que relatam como utilizar os critérios de fadiga multiaxial de maneira a obter o número de ciclos em que ocorrerá a falha por fadiga. Foram encontradas apenas três referências que relatam isto na revisão bibliográfica desta dissertação: Socie \& Marquis (2000), Karolczuk \& Macha (2005) e MSC.Software (2008). Entretanto, estas 3 referências apresentam equações para se calcular o número de ciclos em que ocorrerá a fratura em um espécime padronizado. Não foi encontrado na revisão bibliográfica desta dissertação referências que relatam como os critérios multiaxiais podem ser expandidos para prever o número de ciclo que ocorrerá a falha de componentes de geometria/características ${ }^{27}$ complexas, diferentes do espécime.

Assim, o autor também acredita que o Modelo de von Mises Sinalizado pode ser utilizado para calcular o número de ciclos em que a fratura por fadiga ocorrerá em um componente

\footnotetext{
${ }^{26}$ Parâmetro de dano.

${ }^{27}$ Geometria do entalhe, rugosidade superficial, tratamento superficial, temperatura de trabalho, etc.
} 
entalhado ou não entalhado, com características diferentes do espécime padronizado, utilizando uma Curva Tensão-Vida, de maneira similar ao apresentado no capítulo 4 . A Curva Tensão-Vida que deveria ser utilizada seria a Curva S-N Unnotched (equação 4.40 e figura 4.24) do lado direito da equação (5.64). Assim, a vida do componente poderia ser estimada utilizando a seguinte equação:

$$
\sigma_{V M, a}=S_{f, u n}^{\prime} \cdot(2 N)^{b_{u n}}
$$

Onde

$S_{f, \text { un }}^{\prime} \quad$ : Coeficiente de resistência à fadiga da Curva $S$-N Unnotched

$b_{u n} \quad:$ Expoente de resistência à fadiga da Curva $S$-N Unnotched

A resistência à fadiga para $N_{B}$ ciclos do componente é estimada conforme a equação abaixo (similar à equação 4.37):

$$
S_{B, u n}=S_{B, s p} \cdot C_{C} \cdot C_{R} \cdot C_{T} \cdot C_{m, \sigma^{e}}
$$

Uma vez conhecido 2 pontos da curva, $\left(N_{E}, A_{E, u n}\right)$ e $\left(N_{B}, S_{B, u n}\right)$, deve-se utilizar a equação (5.67) para obter o expoente de resistência à fadiga $\left(b_{u n}\right)$ e em seguida a equação (5.68) para obter o coeficiente de resistência à fadiga $\left(S_{f, u n}^{\prime}\right)$. É importante ter em mente que $A_{E, \text { un }}$ é o limite de fadiga da Curva Tensão-Vida referente à seção transversal analisada do componente (lado direito da equação 5.65 ).

$$
\begin{gathered}
b_{u n}=\frac{\log \left(A_{E, \text { un }} / S_{B, \text { un }}\right)}{\log \left(N_{E} / N_{B}\right)} \\
S_{f, \text { un }}^{\prime}=\frac{A_{E, \text { un }}}{\left(2 N_{E}\right)^{b_{u n}}}
\end{gathered}
$$

As figuras 5.31 e 5.32 ilustram didaticamente como este critério de fadiga multiaxial deve ser utilizado. 

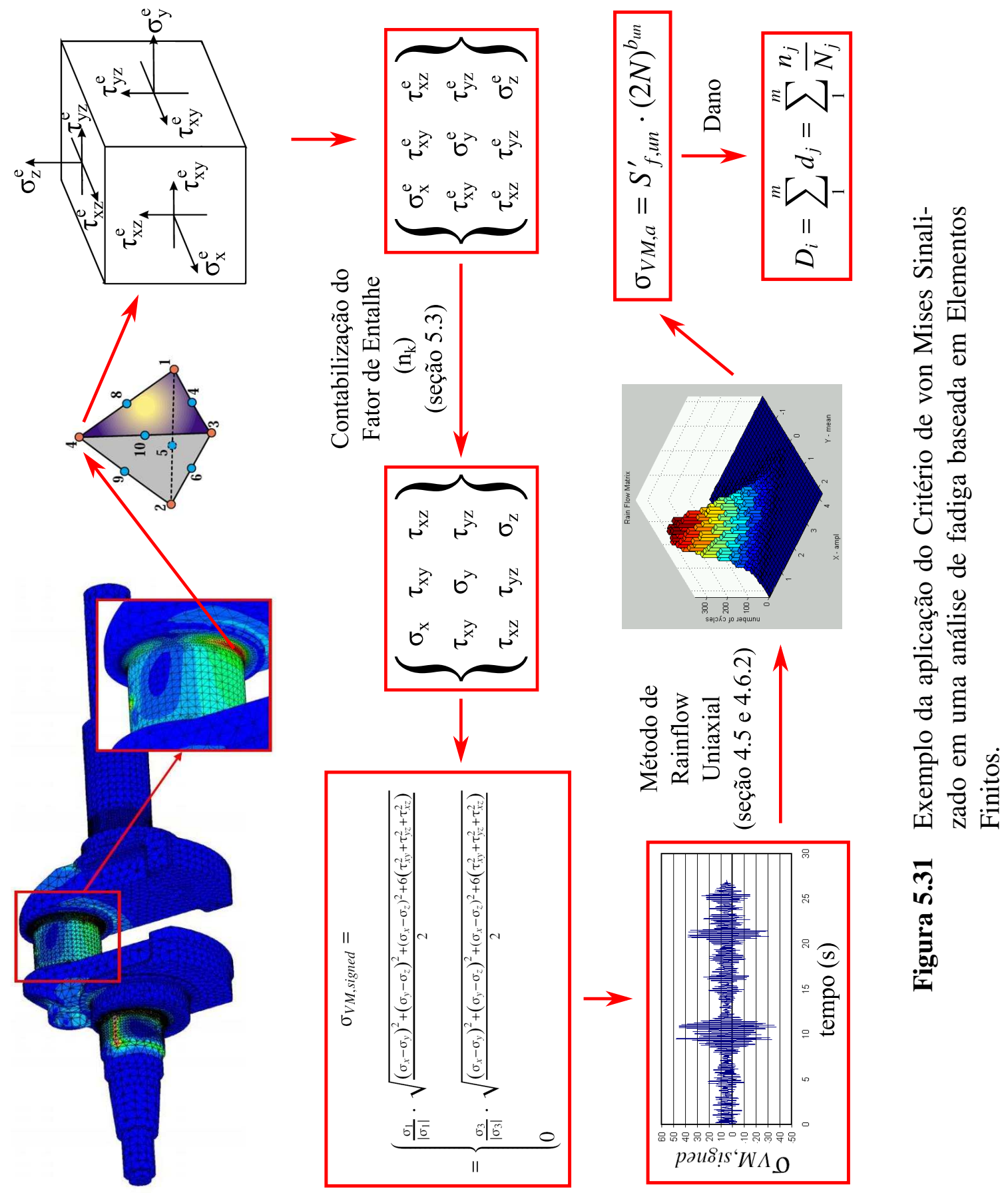


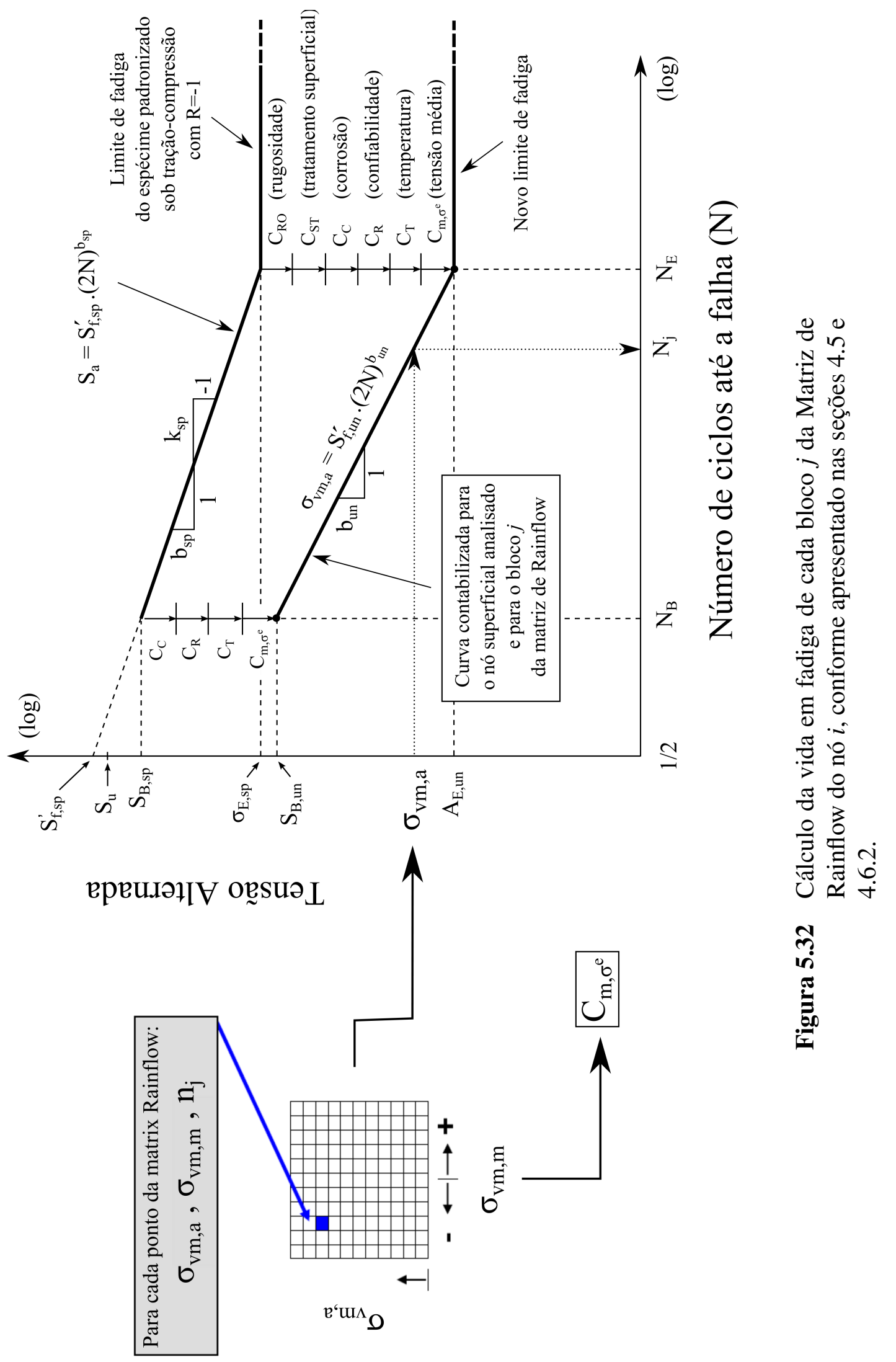


Socie \& Marquis (2000) e Lee et al. (2011) afirmam que o modelo de von Mises sinalizado não consegue contabilizar o efeito de encruamento não proporcional e portanto não consegue calcular corretamente a vida em fadiga em componentes sob carregamento não proporcional. Portanto, eles e muitos outros autores (Lee et al., 2005, de Castro \& Meggiolaro, 2009a, , Shigley et al., 2003, Norton, 2006, Bishop \& Sherratt, 2000) recomendam o uso deste modelo apenas para carregamentos proporcionais. Adicionalmente, Socie \& Marquis (2000, pp.132) relatam que o Modelo de von Mises Sinalizado tem maior correlação com dados experimentais quando a trinca por fadiga nucleiam devido à tensão de cisalhamento. Portanto, este modelo deve ser utilizado apenas em metais dúcteis (Socie \& Marquis, 2000, pp.132).

É interessante notar que, embora todos os autores supracitados recomendem a utilização do modelo de von Mises, Shamsaei \& Fatemi (2010b) enfatizam que a previsão de vida em fadiga utilizando o modelo de von Mises é muito ruim e não conservadora, mesmo em carregamentos proporcionais. Diante do exposto, o critério de von Mises sinalizado não deve ser utilizado para previsões de vida em fadiga, mesmo quando os blocos de carregamento constituem-se apenas de ciclos proporcionais (Shamsaei \& Fatemi, 2010b). A figura 5.33 apresenta os resultados obtidos por Shamsaei \& Fatemi (2010b) sobre o modelo de von Mises, testado para diversos tipos de carregamento. Este modelo gera resultados não conservadores para a maioria dos tipos de carregamentos proporcionais e não proporcionais, principalmente para carregamentos $90^{\circ}$ fora de fase (ponto vermelho). Uma análise mais profunda sobre a análise do critério de von Mises pode ser encontrada em Shamsaei \& Fatemi (2010b).

Este modelo de fadiga multiaxial está incluso em muitos FE-Based Fatigue Analysis Softwares, inclusive em alguns descritos na seção 6.2 .

\subsubsection{Modelo de Sines}

Sines publicou o seu trabalho no início da segunda metade do século XX. O Critério de Sines é muito parecido com o de von Mises, entretanto utiliza a tensão de cisalhamento octaédrica alternada $\left(\tau_{\text {oct,a }}\right)$ e a componente hidrostática das tensões médias $\left(\sigma_{h, m}\right)$. Sines descobriu que a tensão cisalhante média não tem efeito significativo na vida em fadiga de componentes sujeitos à tensão normal e cisalhante alternadas (contanto que a máxima tensão cisalhante não ultrapasse o limite de escoamento) (Fatemi, sdc). Adicionalmente, experimentos no passado revelaram que a vida em fadiga é sensível à tensão hidrostática (Fatemi, sdc; Socie \& Marquis, 2000). Portanto, para que os efeitos benéficos da tensão média compressiva e os efeitos prejudiciais da tensão média positiva sejam levados em consideração adequadamente, Sines recomendou contabilizar o efeito da tensão média utilizando a tensão hidrostática, conforme apresentado abaixo. Entretanto, a equação (5.70) falha em alguns 


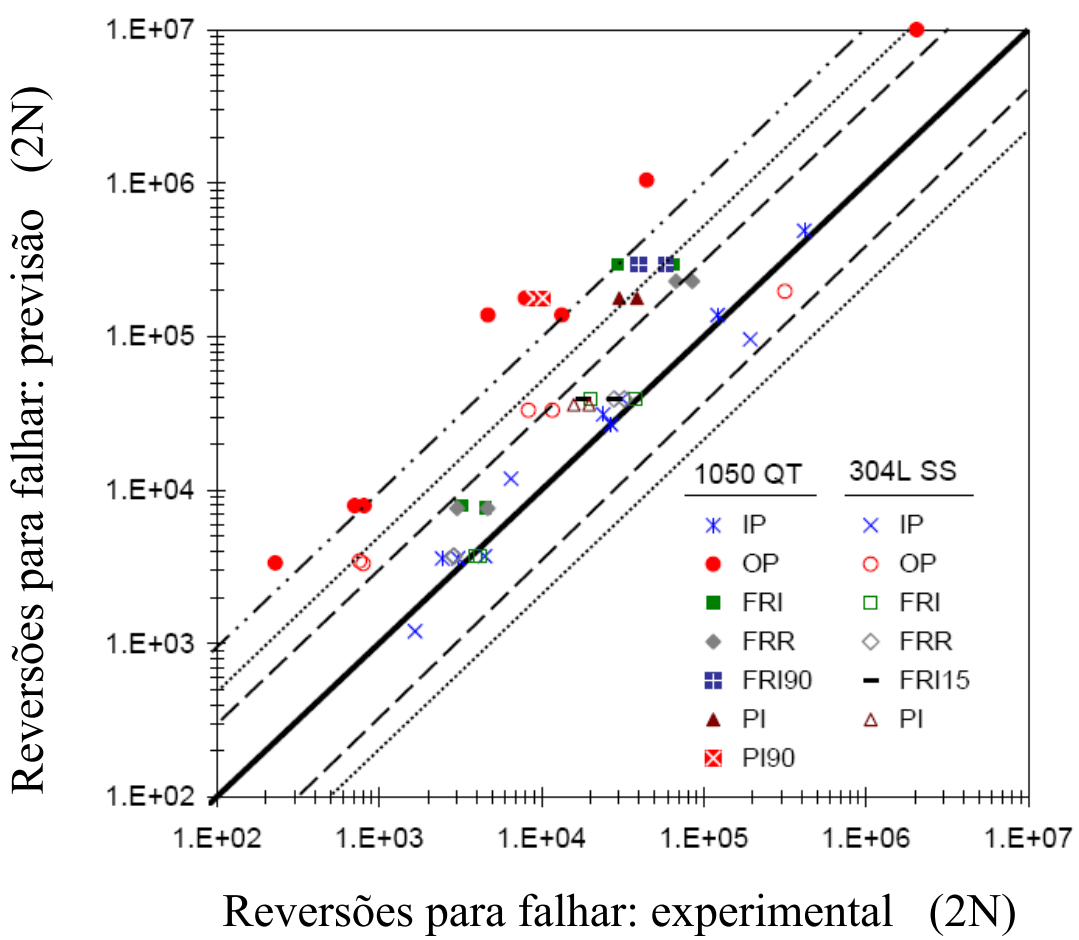

Figura 5.33 Modelo de von Mises como o critério de fadiga multiaxial mais utilizado (Shamsaei \& Fatemi, 2010b).

casos porque o efeito da tensão média compressiva em uma direção pode ser cancelado pelo efeito da tensão média trativa em outra direção, o que nem sempre está de acordo com as evidências experimentais.

De acordo com Socie \& Marquis (2000) e Lee et al. (2011), o Modelo de Sines prevê que a falha por fadiga no espécime padronizado ocorrerá se:

$$
\begin{aligned}
\tau_{\text {sines }, a} & \geq \beta_{s} \\
\tau_{\text {oct }, a}+\alpha_{s} \cdot\left(3 \sigma_{h, m}\right) & \geq \beta_{s}
\end{aligned}
$$

Após o processo de contagem de ciclos explicado na seção 5.4, deve-se calcular a tensão octaédrica de cisalhamento alternada $\left(\tau_{\text {oct,a }}\right)$, a componente hidrostática das tensões médias $\left(\sigma_{h, m}\right)$ e a tensão de sines $\left(\tau_{\text {sines,a }}\right)$ para cada linha da tabela Rainflow (seção 5.4) conforme segue:

$$
\begin{aligned}
\tau_{o c t, a} & =\frac{1}{3} \sqrt{\left(\sigma_{x, a}-\sigma_{y, a}\right)^{2}+\left(\sigma_{y, a}-\sigma_{z, a}\right)^{2}+\left(\sigma_{x, a}-\sigma_{z, a}\right)^{2}+6\left(\tau_{x y, a}^{2}+\tau_{y z, a}^{2}+\tau_{x z, a}^{2}\right)} \\
\sigma_{h, m} & =\frac{1}{3}\left(\sigma_{x, m}+\sigma_{y, m}+\sigma_{z, m}\right)=\frac{1}{3}\left(\sigma_{1, m}+\sigma_{2, m}+\sigma_{3, m}\right)
\end{aligned}
$$

Onde

Índices $\mathrm{x}, \mathrm{y}$ e z : Eixos de coordenada locais Índices 1, 2 e 3 : Eixos das tensões principais 
A constante $\alpha_{s}$ é o fator de sensibilidade à tensão normal de Sines e representa o quanto a tensão hidrostática afeta na falha por fadiga. A constante $\beta_{s}$ representa o limite de fadiga sob fadiga multiaxial, pois se o parâmetro de dano (lado esquerdo da equação 5.69) estiver abaixo de $\beta_{s}$ não haverá falha por fadiga. Socie \& Marquis (2000) afirmam que as constantes $\alpha_{s}$ e $\beta_{s}$ devem ser encontradas através da avaliação da equação (5.69) em dois estados de tensão, conforme descrito a seguir. Primeiro estado de tensão: em um espécime padronizado sujeito à tração-compressão completamente reversa $(\mathrm{R}=-1)$, no limite de fadiga ocorre:

$$
\begin{aligned}
\tau_{o c t, a} & =\frac{1}{3} \sqrt{\left(\sigma_{x, a}-0\right)^{2}+(0-0)^{2}+\left(\sigma_{x, a}-0\right)^{2}+6(0)}=\frac{\sqrt{2}}{3} \cdot \sigma_{x, a}=\frac{\sqrt{2}}{3} \cdot \sigma_{E, s p} \\
\sigma_{h, m} & =\frac{1}{3} \cdot(0+0+0)=0
\end{aligned}
$$

Assim:

$$
\tau_{o c t, a}+\alpha_{s} \cdot\left(3 \sigma_{h, m}\right)=\frac{\sqrt{2}}{3} \cdot \sigma_{E, s p}+\alpha_{s} \cdot 0=\beta_{s}
$$

E portanto:

$$
\beta_{s}=\frac{\sqrt{2}}{3} \cdot \sigma_{E, s p}
$$

Segundo estado de tensão: em um espécime padronizado sujeito à carregamento axial pulsante $(\mathrm{R}=0)$, no limite de fadiga ocorre:

$$
\begin{aligned}
\tau_{o c t, a} & =\frac{1}{3} \sqrt{\left(\sigma_{x, a}-0\right)^{2}+(0-0)^{2}+\left(\sigma_{x, a}-0\right)^{2}+6(0)}=\frac{\sqrt{2}}{3} \cdot \sigma_{x, a}=\frac{\sqrt{2}}{3} \cdot \sigma_{E, s p, R=0} \\
\sigma_{h, m} & =\frac{1}{3} \cdot\left(\sigma_{x, m}+0+0\right)=\frac{1}{3} \cdot \sigma_{E, s p, R=0}
\end{aligned}
$$

Assim:

$$
\tau_{o c t, a}+\alpha_{s} \cdot\left(3 \sigma_{h, m}\right)=\frac{\sqrt{2}}{3} \cdot \sigma_{E, s p, R=0}+\alpha_{s} \cdot\left(\sigma_{E, s p, R=0}\right)=\beta_{s}
$$

Substituindo a equação (5.72) na equação (5.73) tem-se:

$$
\alpha_{s}=\frac{\sqrt{2}}{3} \cdot\left(\frac{\sigma_{E, s p}-\sigma_{E, s p, R=0}}{\sigma_{E, s p, R=0}}\right)
$$

O limite de fadiga do espécime padronizado em carregamento axial pulsante $\sigma_{E, s p, R=0}$ pode não estar disponível para o engenheiro. Nestes casos, recomenda-se que este seja estimado utilizando a constante $C_{m, \sigma^{2}}{ }^{28}$ calculada para $\mathrm{R}=0$ (i.e., $\sigma_{m}=\sigma_{a}$ ):

$$
\sigma_{E, s p, R=0}=\sigma_{E, s p} \cdot C_{m, \sigma^{e}}(@ R=0)
$$

\footnotetext{
${ }^{28}$ Calculada conforme explicado na seção 4.6 .1
} 
Lee et al. (2011) menciona que a constante $\beta_{s}$ seria igual ao limite de fadiga em torção completamente reversa $\tau_{E, s p}$ obtido sob carregamento de torção completamente reversa $(\mathrm{R}=-1)$, e que poderia ser calculado conforme a equação (4.42). Entretanto, isto é apenas uma aproximação que resulta em um erro relativo de aproximadamente $+22 \%$ para metais dúcteis. É recomendável obter o limite de fadiga $\beta_{s}$ utilizando a equação (5.72).

Todas as publicações lidas e analisadas ao longo do desenvolvimento desta dissertação e que falam sobre este critério explicam como aplicá-lo para prever a falha de um espécime padronizado. Não foi encontrado na revisão bibliográfica desta dissertação referências que relatam como este critério de falha multiaxial pode ser expandido para ser aplicado em componentes de geometria/características ${ }^{29}$ complexas, diferentes do espécime. Também não foi encontrado como utilizar este modelo em conjunto com análises por Elementos Finitos.

Desta forma, o autor acredita que o conceito de similaridade continuaria sendo válido também em fadiga multiaxial e, portanto, continuaria sendo válido utilizar os fatores modificadores apresentados no capítulo 4 também em fadiga multiaxial. Desta forma, o autor acredita que o Modelo de Sines pode ser utilizado em um componente entalhado ou não entalhado, com características diferentes do espécime padronizado, utilizando o limite de fadiga $A_{E, u n}$, que já consideraria todas as características da seção transversal analisada (pois todos os fatores modificadores apresentados na figura 4.24 já foram considerados no cálculo de $A_{E, u n}$, exceto o fator de entalhe, que já foi considerado ao se alterar o carregamento, conforme explicado na seção 5.3.

Assim, as equações (5.72) e (5.74) seriam obtidas utilizando os limites de fadiga do componente obtido com carregamento axial (tração-compressão) alternado $\left(A_{-1}\right)$ e obtido com carregamento axial (tração-compressão) pulsante $\left(A_{0}\right)$, conforme apresentado abaixo:

$$
\begin{gathered}
\beta_{s}=\frac{\sqrt{2}}{3} \cdot A_{-1} \\
\alpha_{s}=\frac{\sqrt{2}}{3} \cdot\left(\frac{A_{-1}-A_{0}}{A_{0}}\right)
\end{gathered}
$$

Portanto, estima-se que a falha por fadiga do componente ${ }^{30}$ ocorrerá quando a relação

\footnotetext{
${ }^{29}$ Geometria do entalhado, rugosidade superficial, tratamento superficial, temperatura de trabalho, etc.

${ }^{30} \mathrm{Na}$ verdade, a vida em fadiga daquela seção transversal analisada.
} 
abaixo for satisfeita:

$$
\begin{aligned}
\tau_{o c t, a}+\alpha_{s} \cdot\left(3 \sigma_{h, m}\right) & \geq \beta_{s} \\
& \geq \frac{\sqrt{2}}{3} \cdot A_{-1} \\
& \geq \frac{\sqrt{2}}{3} \cdot \sigma_{E, s p} \cdot C_{R O} \cdot C_{S T} \cdot C_{C} \cdot C_{R} \cdot C_{T} \\
& \geq \frac{\sqrt{2}}{3} \cdot S_{E, s p} \cdot 0,9 \cdot C_{R O} \cdot C_{S T} \cdot C_{C} \cdot C_{R} \cdot C_{T}
\end{aligned}
$$

Note que o efeito da rugosidade superficial $\left(C_{R O}\right)$, tratamento superficial $\left(C_{S T}\right)$, corrosão $\left(C_{C}\right)$, confiabilidade $\left(C_{R}\right)$ e temperatura $\left(C_{T}\right)$ são contabilizados modificando a Curva $S-N$ Espécime conforme explicado nas seções $4.3 \mathrm{e} 4.6 .1$.

É importante relatar que o efeito da tensão média não é considerado através da modificação da Curva Tesão-Vida utilizando o fator modificador de tensão média $\left(C_{m, \sigma^{e}}\right)$, pois o Critério de Sines já considera o efeito da tensão média no cálculo da tensão de equivalente $\left(\tau_{\text {sines }, a}\right)$ através da parcela relativa à tensão hidrostática $\left(\alpha_{s} \cdot 3 \sigma_{h, m}\right)$ (Lee et al., 2011; Socie \& Marquis, 2000). Há um entendimento na literatura que a tensão cisalhante média não altera a resistência à fadiga, por este motivo não tem sido incluída como uma variável importante nos modelos multiaxiais, principalmente em alto número de ciclos. Entretanto, em regime de baixo número de ciclos ainda há dúvidas sobre o efeito da tensão cisalhante média.

Acredita-se que o efeito de tamanho não deve ser considerado porque todos os modelos de fadiga multiaxial são modelos de iniciação de trinca e seriam validados para estruturas com o tamanho/diâmetro do espécime padronizado (Lee et al., 2011).

O efeito de entalhe não é considerado na Curva Tensão-Vida, mas sim é contabilizado dividindo as 6 componentes do tensor de tensões de cada nó pelo fator de entalhe $n_{K}$, conforme explicado na seção 5.3 . É importante lembrar que a tensão $\tau_{\text {sines,a }}$ (equação 5.69 é é calculada utilizando as tensões obtidas na equação (5.21) $\left(\sigma_{x}, \sigma_{y}, \sigma_{z}, \tau_{x y}, \tau_{y z}, \tau_{x z}\right)$. É por este motivo que não se considera o efeito do entalhe nas equações de 5.24 à 5.30 .

Grande parte das publicações (Karolczuk \& Macha, 2005; Lee et al., 2011; Socie \& Marquis, 2000) apresentam os modelos de fadiga multiaxial como sendo um critério do tipo "passa ou não passa”, conforme apresentado pela equação (5.69) e (5.78). Este tipo de apresentação não permite saber em qual ciclo ocorreria a falha por fadiga, caso a tensão equivalente ${ }^{31}$ (lado esquerdo das equações dos critérios de falha) seja maior do que o limite de fadiga (lado direito). Existem poucas referências que relatam como utilizar os critérios de fadiga multiaxial de maneira a obter o número de ciclos em que ocorrerá a falha por fadiga. Foram encontradas apenas três referências que relatam isto na revisão bibliográfica

\footnotetext{
${ }^{31}$ Parâmetro de dano.
} 
desta dissertação: Socie \& Marquis (2000), Karolczuk \& Macha (2005) e MSC.Software (2008). Entretanto, estas 3 referências apresentam equações para se calcular o número de ciclos em que ocorrerá a fratura em um espécime padronizado. Não foi encontrado na revisão bibliográfica desta dissertação referências que relatam como os critérios multiaxiais podem ser expandidos para prever o número de ciclo que ocorrerá a falha de componentes de geometria/características $\sqrt{32}$ complexas, diferentes do espécime.

Assim, o autor também acredita que o Modelo da Tensão Principal Absoluta pode ser utilizado para calcular o número de ciclos em que a fratura por fadiga ocorrerá em um componente entalhado com características diferentes do espécime padronizado utilizando uma Curva Tensão-Vida, de maneira similar ao apresentado no capítulo 4. A Curva Tensão-Vida que deveria ser utilizada seria a Curva S-N Unnotched (equação 4.40 e figura 4.24) do lado direito da equação (5.78). Assim, a vida do componente poderia ser calculada utilizando a seguinte equação:

$$
\begin{aligned}
\tau_{\text {sines }, a} & =\tau_{f, u n}^{\prime} \cdot(2 N)^{b_{u n}} \\
\tau_{\text {oct }, a}+\alpha_{s} \cdot\left(3 \sigma_{h, m}\right) & =\tau_{f, u n}^{\prime} \cdot(2 N)^{b_{u n}}
\end{aligned}
$$

Onde

$\tau_{f, u n}^{\prime} \quad$ : Coeficiente de resistência à fadiga da Curva $S$-N Unnotched

$b_{u n} \quad:$ Expoente de resistência à fadiga da Curva $S$-N Unnotched

A resistência à fadiga para $N_{B}$ ciclos do componente é estimada conforme a equação abaixo (similar à equação 4.37):

$$
S_{B, u n}=S_{B, s p} \cdot C_{C} \cdot C_{R} \cdot C_{T}
$$

Uma vez conhecido 2 pontos da curva, $\left(N_{E}, \beta_{s}\right)$ e $\left(N_{B}, S_{B, \text { un }}\right)$, deve-se utilizar a equação (5.81) para obter o expoente de resistência à fadiga $\left(b_{u n}\right)$ e em seguida a equação (5.82) para obter o coeficiente de resistência à fadiga $\left(\tau_{f, u n}^{\prime}\right)$. É importante ter em mente que $\beta_{s}$ é o limite de fadiga da Curva Tensão-Vida referente à seção transversal analisada do componente (lado direito da equação 5.79).

$$
\begin{gathered}
b_{u n}=\frac{\log \left(\beta_{s} / S_{B, u n}\right)}{\log \left(N_{E} / N_{B}\right)} \\
\tau_{f, u n}^{\prime}=\frac{\beta_{s}}{\left(2 N_{E}\right)^{b_{u n}}}
\end{gathered}
$$

\footnotetext{
${ }^{32}$ Geometria do entalhe, rugosidade superficial, tratamento superficial, temperatura de trabalho, etc.
} 
O critério de Sines possui boa correlação e deve ser aplicado apenas em metais dúcteis e em componentes sujeitos à carregamento poporcional, onde a direção dos eixos das tensões principais permanecem fixas em cada ciclo de carregamento (Lee et al., 2011; Socie \& Marquis, 2000).

Seja um componente sob carregamento de amplitude variável. A análise de fadiga baseada em Elementos Finitos deste componente, utilizando o Critério de Sines, deve ser realizada da seguinte forma:

1) Escolher um nó superficial para analisar, intitulado nó $n_{i}$. Para cada nó $n_{i}$, executar os próximos passos:

a) Contabilizar o efeito de entalhe através do cálculo e utilização das 6 componentes do tensor de tensões $\left(\sigma_{x}, \sigma_{y}, \sigma_{z}, \tau_{x y}, \tau_{x z}, \tau_{y z}\right)$ para cada time step, utilizando a equação (5.21);

b) Executar um Método de Rainflow Multiaxial e obter a tabela Rainflow para o nó $n_{i}$ analisado. Para cada linha da tabela, numerada pelo subíndice “ $j$ ”, deve-se efetuar as seguintes etapas:

i. Calcular a tensão octaédrica de cisalhamento alternada $\left(\tau_{\text {oct,a }}\right)$ e a componente hidrostática das tensões médias $\left(\sigma_{h, m}\right)$ para cada time step, utilizando a equação 5.70;

ii. Calcular a tensão de sines $\left(\tau_{\text {sines,a }}\right.$ ) para cada time step (lado esquerdo da equação (5.79);

iii. Todos os fatores modificadores mencionados nesta seção devem ser calculados, assim como os parâmetros $\beta_{s}, S_{B, u n}, b_{u n}$ e $\tau_{f, u n}^{\prime}$. Após isto, a curva Curva $S-N$ Unnotched (lado direito da equação 5.79) deve ser obtida;

iv. Utilizar $\tau_{\text {sines,a }}$ na Curva $S-N$ Unnotched, calculada no item anterior, conforme ilustra a figura 5.35, para obter o número de ciclos $N_{j}$.

v. A seguir, deve-se calcular o parâmetro de dano $d_{j}$ que a linha $j$ causa utilizando a equação (5.23).

c) Nesta etapa de cálculo, todas as linhas da tabela Rainflow foram contabilizadas e sabe-se agora qual é o dano total do nó $n_{i}$, intitulado $D_{i}=f(i)$.

2) Nesta etapa de cálculo, o dano $D_{i}$ de cada nó $n_{i}$ do modelo FE foi contabilizado. O nó que possuir o maior valor de dano é nomeado ponto/nó crítico, onde espera-se ser o primeiro ponto em que haverá nucleação da trinca e subsequente crescimento da mesma. 


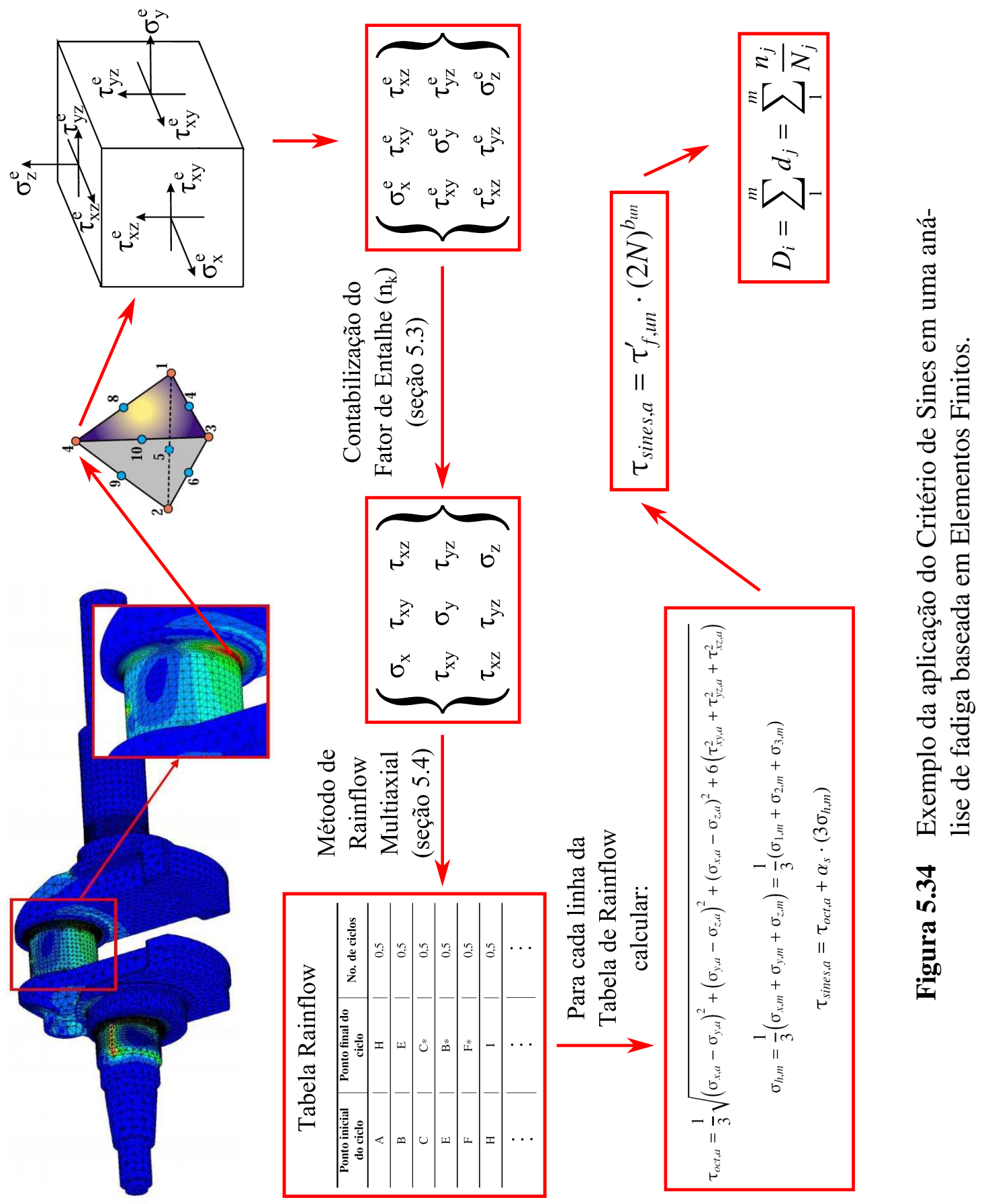




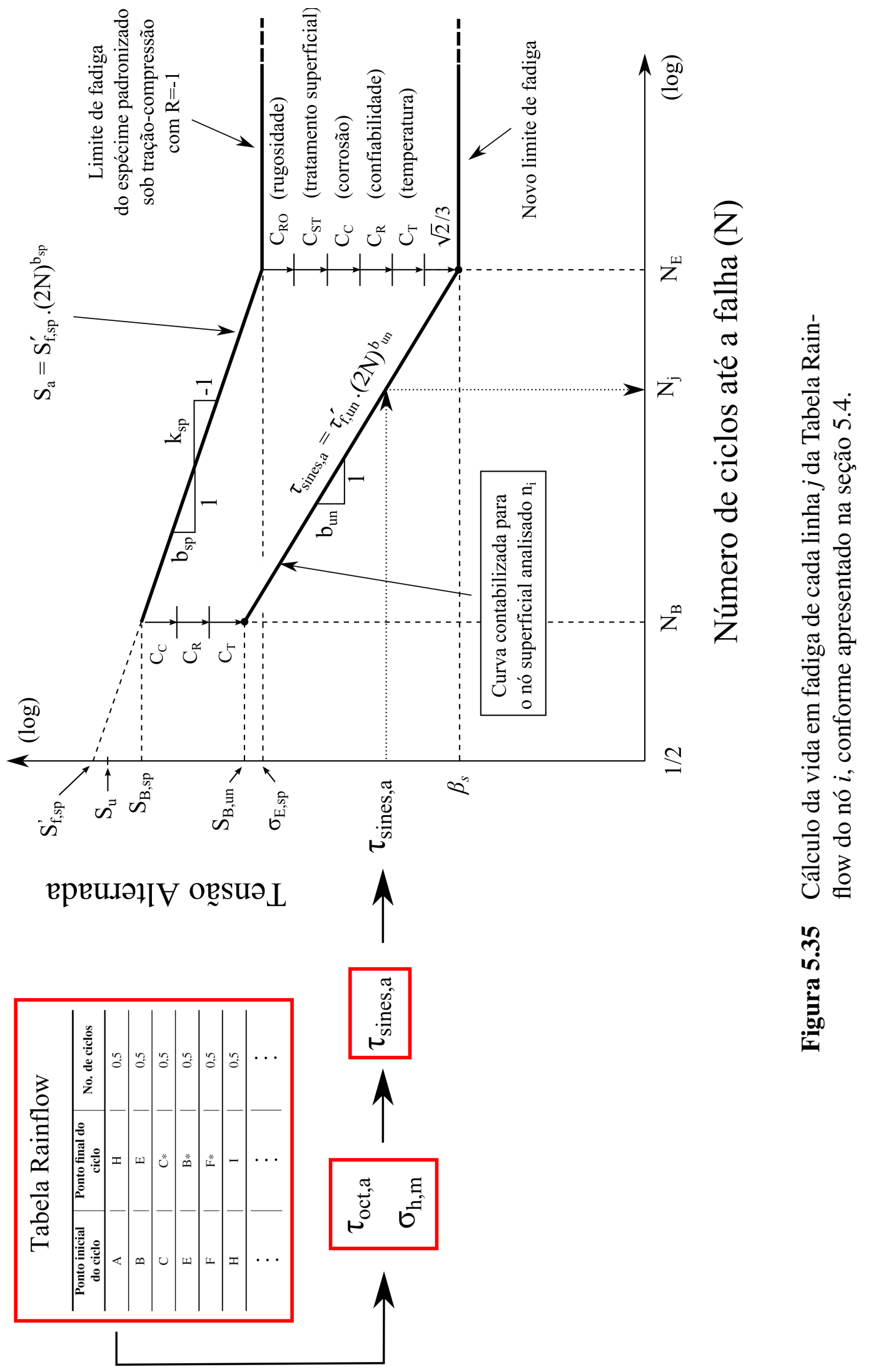




\subsubsection{Modelos Baseados no Plano Crítico}

Modelos baseados na idéia do plano crítico estão entre os que conseguem realizar as melhores previsões de vida para componentes sob carregamento não proporcional.

Draper (sda) relata que em um projeto estrutural de um virabrequim de motor, a análise por Elementos Finitos é utilizada para gerar soluções de tensão. É prática comum dividir a análise de maneira que o virabrequim gire $5^{\circ} \mathrm{em}$ cada intervalo de tensão (time step), onde a análise termina em 2 ou 3 revoluções do mesmo. A análise EF mostra que as tensões principais mudam sua magnitude e orientação durante o ciclo de carregamento aplicado em um virabrequim (Draper, sda). Ensaios em virabrequins sob flexão e torção combinadas mostraram que a trinca não se iniciou no ponto de máxima tensão de von Mises (Draper, sda). Isto é um importante resultado, porque a tensão de von Mises obtida através de FEA costuma ser utilizada para identificar os pontos críticos em fadiga. Da mesma forma, a tensão principal máxima geralmente falha para identificar a localização crítica e principalmente a vida em fadiga em componentes onde as tensões nos pontos críticos são particularmente não proporcionais (Draper, sda).

A abordagem pelo plano crítico tem sido uma das técnicas mais utilizadas no dimensionamento de componentes estruturais, devido aos resultados promissores, principalmente em estruturas sujeitas à carregamentos multiaxiais, não-proporcionais e de amplitude variável. Seja um ponto na superfície de um espécime que possui 6 componentes de tensão variando no tempo, conforme representado pela figura 5.36b. Fazendo um corte neste cubo infinitesimal, representado pelos ângulos $\theta$ e $\phi$, surgirá uma tensão de cisalhamento aternada $\left(\tau_{a}\right)$ neste plano e também uma tensão normal à ele $\left(\sigma_{n}\right)$ (figura 5.36b). O valor de $\tau_{a}$ e $\sigma_{n}$ irá variar conforme o plano de corte escolhido. Pode-se definir um parâmetro de dano como sendo uma função da tensão de cisalhamento alternada $\left(\tau_{a}\right)$ e da tensão normal a este plano $\left(\sigma_{n}\right)$. Portanto, o parâmetro de dano também possui um valor diferente para cada plano analizado. Este parâmetro é representado pelo lado esquerdo da equação (5.83). De uma maneira geral, os critérios de plano crítico consideram que uma trinca nucleará na superfície do material e em certa orientação onde o parâmetro de dano por fadiga, simbolizado pelo lado esquedo da equação 5.83, for maximizado. Neste método, objetiva-se encontrar, através de técnicas de busca, a orientação do plano que maximize o lado esquerdo da equação (5.83). Após encontrar o plano de maior dano, chamado plano crítico, deve-se comparar o parâmetro de dano com a resistência à fadiga do material, à direita da equação (5.83), e desta forma calcular a vida em fadiga do componente.

É importante ressaltar que os modelos de plano crítico fornecem informações sobre o plano em que a trinca se inicia, o que não quer dizer que a propagação ocorrerá naquela direção. Tratam-se de critérios de iniciação de trinca. A Mecânica da Fratura fornece me- 
lhores informações referentes à direção da propagação da trinca até a fratura total.

$$
a \cdot f\left(\tau_{a}\right)+b \cdot g\left(\sigma_{n}\right) \leq A_{-1}
$$

Onde os parâmetros $a$ e $b$ são constantes obtidas a partir de dois limites de fadiga (por exemplo $T_{-1}$ e $A_{-1}$ ). A combinação linear mostrada nesta equação pode ser substituida por uma versão quadrática também. Critérios de fadiga de alto ciclos são completamente dominados pela avaliação de tensões. Assim, como uma resposta completamente elástica é esperada, deformações também podem ser utilizadas utilizando o módulo de elasticidade. A tensão cisalhante alternada $\tau_{a}$ domina o processo de dano, enquanto a componente normal $\sigma_{n}$ tem um efeito secundário.

A seção 5.5.2.1 discursará sobre como obter a tensão de cisalhamento alternada $\left(\tau_{a}\right)$ e da tensão normal ao plano $\left(\sigma_{n}\right)$ para serem utilizadas nos critérios de plano crítico.

\subsubsection{Amplitude da Tensão Cisalhante e Tensão Normal no Plano Crítico}

Uma análise computacional de fadiga utiliza resultados de uma análise por Elementos Finitos, sendo os resultados os valores das seis componentes do tensor de tensões de cada nó da superfície do modelo, em cada instante de tempo.

Seja uma estrutura submetida a um carregamento periótico onde para um determinado ponto material observa-se um estado de tensão descrito utilizando conforme a figura $5.36 \mathrm{~b}$. Considere que as tensões provenientes da análise FE estão calculados com base no sistema de coordenadas X-Y-Z, que é o mesmo sistema das tensões da equação (5.21). As tensões podem ser obtidas em um sistema de coordenadas diferente chamado $X^{\prime}$-Y'-Z' utilizando a equação (5.84). O sistema de coordenadas auxiliar X'-Y' $X^{\prime}$ ' pode ser visto na figura $5.36 \mathrm{~b}$. É importante ressaltar que o vetor da direita da equação 5.84 provém da equação (5.21).

$$
\left[\begin{array}{c}
\sigma_{x}^{\prime} \\
\sigma_{y}^{\prime} \\
\sigma_{z}^{\prime} \\
\tau_{x y}^{\prime} \\
\tau_{x z}^{\prime} \\
\tau_{y z}^{\prime}
\end{array}\right]=\left[\begin{array}{cccccc}
T_{11}^{2} & T_{12}^{2} & T_{13}^{2} & 2 T_{11} T_{12} & 2 T_{11} T_{13} & 2 T_{13} T_{12} \\
T_{21}^{2} & T_{22}^{2} & T_{23}^{2} & 2 T_{21} T_{22} & 2 T_{21} T_{23} & 2 T_{23} T_{22} \\
T_{31}^{2} & T_{32}^{2} & T_{33}^{2} & 2 T_{31} T_{32} & 2 T_{31} T_{33} & 2 T_{33} T_{32} \\
T_{11} T_{21} & T_{12} T_{22} & T_{13} T_{23} & \left(T_{11} T_{22}+T_{12} T_{21}\right) & \left(T_{13} T_{21}+T_{11} T_{23}\right) & \left(T_{12} T_{23}+T_{13} T_{23}\right) \\
T_{11} T_{31} & T_{12} T_{32} & T_{13} T_{33} & \left(T_{11} T_{32}+T_{12} T_{31}\right) & \left(T_{13} T_{31}+T_{11} T_{33}\right) & \left(T_{13} T_{32}+T_{12} T_{33}\right) \\
T_{21} T_{31} & T_{22} T_{32} & T_{23} T_{33} & \left(T_{21} T_{32}+T_{22} T_{31}\right) & \left(T_{23} T_{31}+T_{21} T_{33}\right) & \left(T_{22} T_{33}+T_{23} T_{32}\right)
\end{array}\right]\left[\begin{array}{c}
\sigma_{x} \\
\sigma_{y} \\
\sigma_{z} \\
\tau_{x y} \\
\tau_{x z} \\
\tau_{y z}
\end{array}\right]
$$




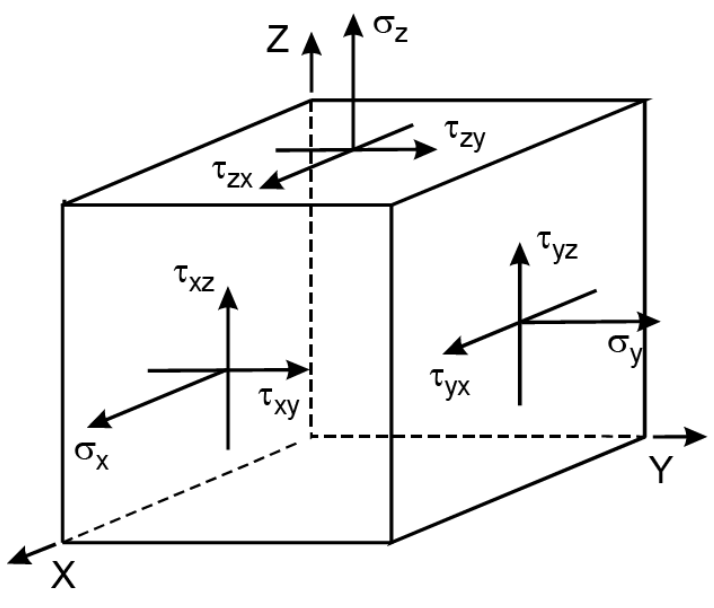

(a) Tensor de tensão em um nó.

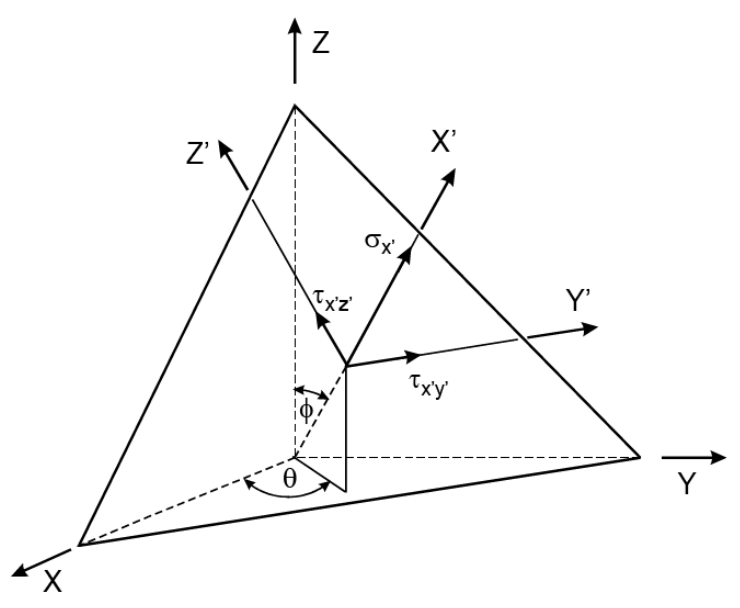

(b) Transformação das tensões em um nó.

Figura 5.36 Sistema de coordenadas auxiliar $X^{\prime}-Y^{\prime}-Z^{\prime}$ e transformação do tensor de tensão.

É mais conveniente definir a direção dos cossenos diretores em termos de dois ângulos, $\theta$ e $\phi$. As constantes utilizadas na equação (5.84) são definidas por:

$$
\begin{array}{lll}
T_{11}=\cos \theta \cdot \sin \phi & T_{12}=\sin \theta \cdot \sin \phi & T_{13}=\cos \phi \\
T_{21}=-\sin \theta & T_{22}=\cos \theta & T_{23}=0 \\
T_{31}=-\cos \theta \cdot \cos \phi & T_{32}=-\sin \theta \cdot \cos \phi & T_{33}=\sin \phi
\end{array}
$$

Seja o versor $\hat{n}$ da figura 5.37 com mesma direção e sentido que o eixo $X^{\prime}$ da figura 5.36b. O caminho $\Phi$ da figura 5.37 representa o caminho de tensão durante 1 (hum) ciclo de carregamento, descrito pelo vetor $\vec{t}(t)$ da figura 5.37. De acordo com a figura 5.37, o vetor tensão normal $\sigma_{x}^{\prime} \hat{n}$ em um instante de tempo é a projeção do vetor $\vec{t}$ sobre a direção de $\hat{n}$, sendo $\hat{n}$ um versor perpendicular ao plano $\Delta$, ou seja, o versor $\hat{n}$ possui a mesma direção e sentido que o versor $X^{\prime}$. A máxima tensão normal perpendicular à este plano é dada pela equação (5.86, sendo " $P$ " o período de tempo em que ocorre um ciclo.

$$
\sigma_{n, \max }=\max _{t \in P}\left\{\sigma_{x}^{\prime}(t)\right\}
$$

A obtenção da tensão de cisalhamento alternada $\tau_{a}$ a ser utilizada nos modelos de plano crítico (i.e., na equação 5.83) é mais difícil de se obter. Ela depende da orientação do plano em avaliação, isto é, é uma função dos ângulos $\theta, \phi$ e $\varphi$. (indicados nas figuras 5.37(b) e $5.38 \mathrm{c}$.

Ao longo da história foram propostos vários métodos para o cômputo da amplitude da tensão cisalhante para histórias de tensões complexas, entre as quais destacam-se o Método da Maior Corda, o Método da Maior Projeção, o Método do Mínimo Círculo Circunscrito 


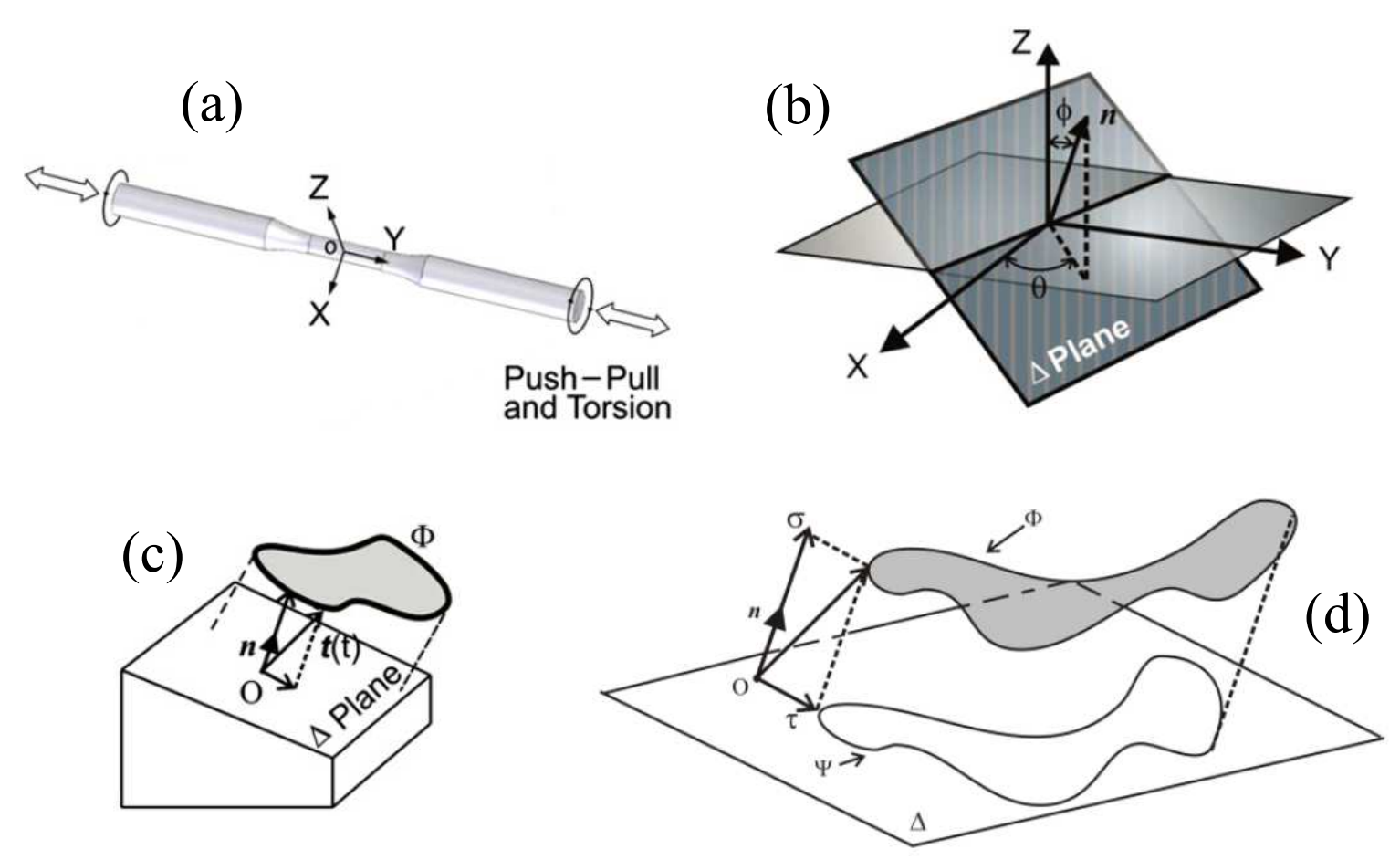

Figura 5.37 (a) Espécime sob carregamento multiaxial; (b) Plano de corte no material intitulado $\Delta$; (c) Vetor tensão $\mathbf{t}(\mathrm{t})$ atuando em um ponto do material $\mathbf{O}$ e descrevendo um caminho de tensão $\Phi$; (d) Projeção do vetor tensão $\mathbf{t}(\mathrm{t})$ em um plano material $\Delta$ para um período de um ciclo de carregamento complexo gerando uma curva fechada $\Phi$ (adaptado de Araújo et al., 2011).

(MMC) e o Método do Máximo Envelope Retangular Circunscrito (MERC). Araújo et al. (2011) demonstraram que o MERC é o método que gera melhores resultados, conseguindo ser capaz de diferenciar claramente o maior dano causado por carregamento não proporcional quando comparado com carregamento proporcional, o que não ocorre com os outros métodos. Ademais, o MERC é extremamente rápido e não precisa de algorítimos sofisticados para ser implementados como o MMC. Por este motivo, este é o método utilizado neste trabalho. A figura 5.38 ajuda a entender o MERC.

A máxima amplitude da tensão cisalhante no plano $\Delta$, intitulada de $\tau_{a}$, é igual à diagonal do máximo envelope retangular que circunscreve o caminho do carregamento $(\Phi)$ durante 1 (hum) ciclo de carregamento; isto é realizado calculando a diagonal do máximo envelope retangular para vários valores de $\varphi$, conforme ilustra a figura 5.38. Assim, deve-se escolher um plano de corte $(\theta, \phi)$ e calcular as 6 componentes do tensor de tensões pertencentes à este plano, conforme a equação (5.84). Após isto, baseado na figura 5.38, pode-se calcular os parâmetros abaixo:

$$
\begin{aligned}
& \tau_{1}^{\prime}=\tau_{x y}^{\prime} \cdot \cos \varphi+\tau_{x z}^{\prime} \cdot \sin \varphi \\
& \tau_{2}^{\prime}=\tau_{x z}^{\prime} \cdot \cos \varphi-\tau_{x y}^{\prime} \cdot \sin \varphi
\end{aligned}
$$


Os semi lados do envelope retangular com orientação $\varphi$ que tangencia a história de tensões cisalhantes $\Phi$ podem ser definidos como:

$$
\begin{aligned}
& a_{1}(\varphi)=\frac{1}{2}\left(\max _{t \in P} \tau_{1}^{\prime}(\varphi, t)-\min _{t \in P} \tau_{1}^{\prime}(\varphi, t)\right) \\
& a_{2}(\varphi)=\frac{1}{2}\left(\max _{t \in P} \tau_{2}^{\prime}(\varphi, t)-\min _{t \in P} \tau_{2}^{\prime}(\varphi, t)\right)
\end{aligned}
$$

Para cada envelope retangular com orientação $\varphi$, pode-se definir a tensão de cisalhamento alternada como sendo:

$$
\tau_{a, \varphi}(\varphi)=\sqrt{a_{1}^{2}(\varphi)+a_{2}^{2}(\varphi)}
$$

Finalmente, a máxima amplitude da tensão de cisalhamento ${ }^{33}$ no plano $\Delta$, é aquela que maximiza a equação (5.89), sendo expressa pela seguinte relação:

$$
\begin{aligned}
\tau_{a} & =\max _{\varphi}\left(\tau_{a, \varphi}(\varphi)\right) \\
& =\max _{\varphi}\left(\sqrt{a_{1}^{2}(\varphi)+a_{2}^{2}(\varphi)}\right)
\end{aligned}
$$

A tensão $\tau_{a}$ é aquela que deve ser utilizada nos critérios de plano crítico (na equação 5.83). Uma análise mais profunda sobre os métodos para cálculo da amplitude de tensão cisalhante $\tau_{a}$ pode ser encontrada em Araújo et al. (2011).

É importante ressaltar que não é necessário o cálculo da tensão de cisalhamento média $\left(\tau_{m}\right)$, pois os critérios baseados no plano crítico consideram o efeito da tensão média por meio da tensão normal observada no plano crítico (por exemplo através de $\sigma_{n, \text { max }}$ ). Há um entendimento na literatura que a tensão cisalhante média não altera a resistência à fadiga, por este motivo não tem sido incluída como uma variável importante nos modelos multiaxiais, principalmente em alto número de ciclos. Entretanto, em regime de baixo número de ciclos ainda há dúvidas sobre o efeito desta tensão cisalhante média.

A utilização de critérios de Fadiga Multiaxial baseados em Plano Crítico implicam em quantificação do parâmetro de dano ${ }^{34}$ em diversos planos. Lee et al. (2011) afirmam que para identificar o plano de maior dano é necessário avaliar o parâmetro de dano em cada plano de corte, variando-se o ângulo $\theta$ de $0^{\circ}$ à $179,9^{\circ}$ em um passo de $5^{\circ}$ e também variandose o ângulo $\phi$ de $0^{\circ}$ à $179,9^{\circ}$ em um passo também de $5^{\circ}$. A utilização de um passo de $5^{\circ}$ resulta na avaliação de um total de 1.225 planos $\left(=\left(\frac{180^{\circ}-5^{\circ}}{5^{\circ}}\right) \times\left(\frac{180^{\circ}-5^{\circ}}{5^{\circ}}\right)=\frac{175}{5} \times \frac{175}{5}=35 \times 35\right)$. De acordo com Lee et al. (2011), a utilização do passo de $5^{\circ}$ é uma prática comum e pode ser escolhida a critério do engenheiro, lembrando sempre que a adoção de um passo grande poderia conduzir a erros de discretização em alguns casos. Lee et al. também afirma que o passo de $5^{\circ}$ também pode levar à erros em alguns casos por ser grande demais.

\footnotetext{
${ }^{33}$ Também chamada de máxima tensão de cisalhamento alternada

${ }^{34}$ Também chamado por alguns autores de tensão equivalente " $\sigma_{e q, a}$ "
} 


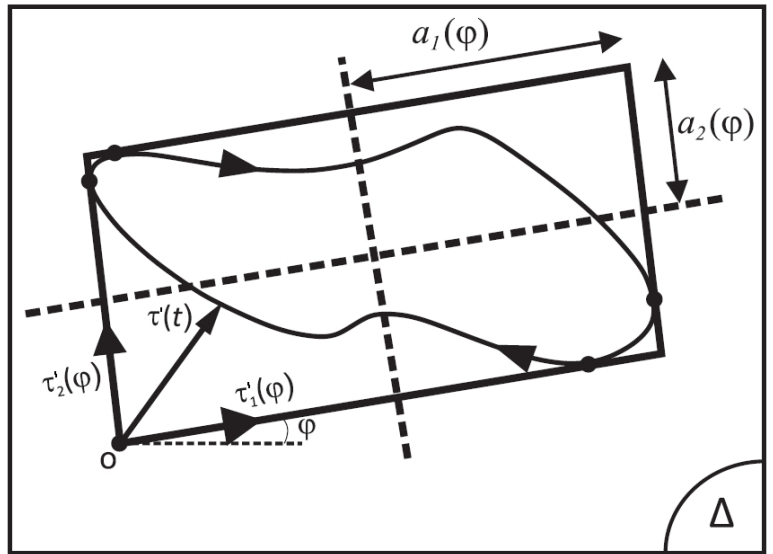

(a) Semi lados $a_{1}(\varphi)$ e $a_{2}(\varphi)$ de um envelope retangular com orientação $\varphi$ tangenciando o caminho da tensão de cisalhamento $\Phi$ em um plano material $\Delta$.

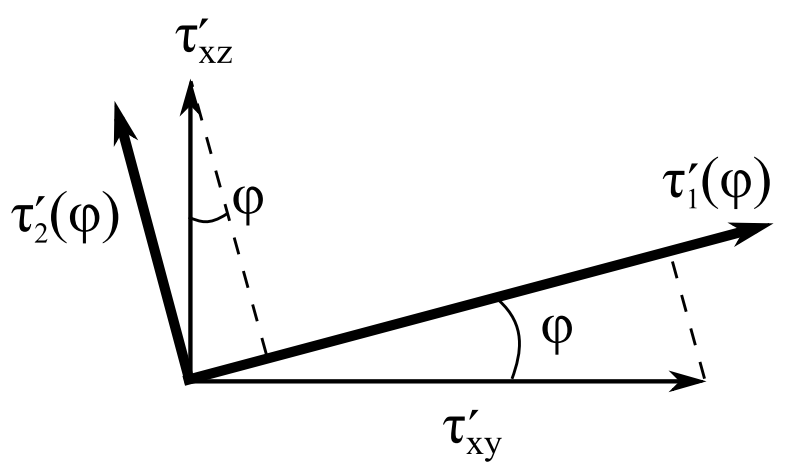

(b) Transformação de coordenadas.

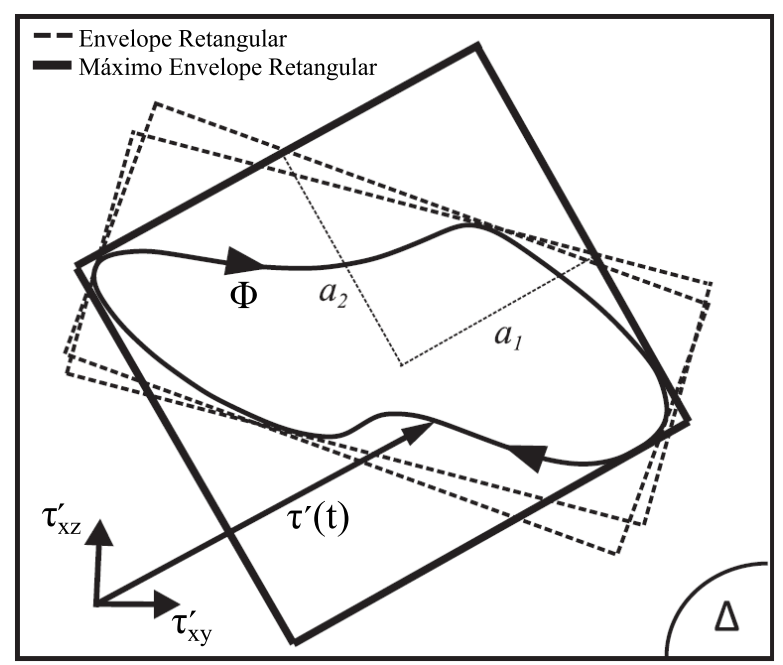

(c) Máximo Envelope Retangular Circunscrito para o caminho $\Phi$.

Figura 5.38 Cálculo do Máximo Envelope Retangular Circunscrito (MERC) no Plano $\Delta$ (adaptado de Araújo et al. (2011)). 


\subsubsection{Modelo de Findley}

Findley (1959) revisou muitos dados experimentais também estudados por Sines, mas gerou um modelo de fadiga diferente (Socie \& Marquis, 2000). Ele foi o primeiro a propor o conceito de plano crítico, por isto é o modelo de fadiga multiaxial mais conhecido e relatado em todos os livros de fadiga multiaxiais. Findley propôs que a falha no espécime ocorrerá quando o valor do parâmetro de dano por fadiga (lado esquerdo da equação 5.91) atinge o limite $\beta_{F}$ :

$$
\max _{\theta, \phi}\left\{\tau_{\text {findley,a }}\right\} \geq \beta_{F}
$$

Sendo $\tau_{\text {findley, } a}$ intitulada tensão de Findley, calculada no plano $\Delta(\theta, \phi)$ :

$$
\tau_{\text {findley }, a}=\tau_{\text {findley }, a}(\theta, \phi)=\tau_{a}+k_{F} \cdot \sigma_{n, \max }
$$

A constante $k_{F}$ é chamada de fator de sensibilidade à tensão normal de Findley, representando a influência da máxima tensão normal no dano em fadiga.

O Critério de Findley está baseado na idéia de que a tensão cisalhante alternada $\left(\tau_{a}\right)$ é a principal responsável pela falha por fadiga e a máxima tensão normal $\left(\sigma_{n, \max }\right)$, medida no plano que contém $\tau_{a}$ (plano $\Delta$ ), possui uma influência secundária (Socie \& Marquis, 2000). Findley investigou também relações parabólicas, mas concluiu que a forma linear era suficiente para descrever os dados experimentais (Socie \& Marquis, 2000).

Cada plano de corte analisado $\Delta$, identificado por $\theta$ e $\phi$, resultará um valor de $\sigma_{n, \text { max }}$ e um valor para $\tau_{a}$ para um ciclo de carregamento 5 . Portanto, o máximo valor do parâmetro de dano (lado esquerdo da equação 5.91) é obtido através do seguinte procedimento:

1) Escolha um valor para $\theta$ e $\phi$;

2) Calcule as 6 componentes do tensor de tensões utilizando a equação (5.21) para contabilizar o efeito de entalhe no cálculo de fadiga;

3) Calcule as 6 componentes do tensor de tensões $\left(\sigma_{x}^{\prime}, \sigma_{y}^{\prime}, \sigma_{z}^{\prime}, \tau_{x y}^{\prime}, \tau_{x z}^{\prime}, \tau_{y z}^{\prime}\right)$ utilizando a equação (5.84);

4) Utilize o MERC e calcule o valor de $\tau_{a}$ após analisar os vários ângulos $\varphi$, conforme equação (5.90);

5) Calcule a máxima tensão normal ao plano material $\Delta\left(\sigma_{n, \max }\right)$ utilizando a equação 5.86;

\footnotetext{
${ }^{35} \mathrm{~A}$ ser identificado através de técnicas de contagem de ciclos, conforme será apresentado na seção 5.4
} 
6) Calcule o valor da tensão de Findley, medida no plano $\Delta$, utilizando a equação (5.92).

7) Repita os procedimentos de 1 até 5 e calcule o valor do parâmetro de dano $\left(\tau_{\text {findley, } a}\right)$ variando os ângulos $\theta$ e $\phi$. O maior valor de $\tau_{\text {findley, } a}$ deve ser utilizado para comparar com a ressitência à fadiga do material (representada pelo lado direito da equação 5.91).

Considera-se o par ordenado $\left(\theta^{*}, \phi^{*}\right)$ como os valores de $\theta$ e $\phi$ que geram o maior valor da tensão de Findley $\left(\tau_{\text {findley,a }}\right)$. Este par ordenado $\left(\theta^{*}, \phi^{*}\right)$ define o plano critico, representado pelo símbolo $\Delta^{*}$.

A constante $\beta_{F}$ representa o limite de fadiga sob tensões multiaxiais, pois se o parâmetro de dano (lado esquerdo da equação 5.91) estiver abaixo de $\beta_{F}$ não haverá falha por fadiga.

Socie \& Marquis (2000) afirmam que as constantes $\alpha_{F}$ e $\beta_{F}$ devem ser encontradas através da avaliação da equação (5.91) em dois estados distintos de tensão, conforme descrito a seguir. Socie \& Marquis (2000) afirmam que, através de manipulações matemáticas, é possível mostrar que, no limite de fadiga sob torção completamente reversa $(\mathrm{R}=-1)$, a equação (5.91) se transforma em:

$$
\beta_{F}=\sqrt{1+k_{F}^{2}} \cdot \tau_{a}
$$

E no limite de fadiga sob carregamento uniaxial de tração-compressão torção completamente reverso ( $\mathrm{R}=-1)$, a equação (5.91) se transforma em:

$$
\beta_{F}=\frac{\sqrt{\sigma_{a}^{2}+\left(k_{F} \cdot \sigma_{\max }\right)^{2}}+k_{F} \cdot \sigma_{\max }}{2}
$$

Karolczuk \& Macha (2005) afirmam que este critério pode ser utilizado para metais dúcteis e frágeis. Os autores também relatam que a constante $k_{F}$ possui um valor baixo para metais dúcteis, sendo o plano crítico próximo ao plano $\Delta$ onde a tensão de cisalhamento é maximizada (i.e., no plano onde $\max _{\theta, \phi}\left\{\tau_{a}(\theta, \phi)\right\}$ ). Socie \& Marquis (2000, pp.140) afirmam que $k_{F}$ tipicamente varia entre 0,2 e 0,3 para materiais dúcteis. Por outro lado, metais frágeis possuem $k_{F}$ alto e nestes casos o plano crítico se aproxima do plano perpendicular à amplitude da tensão principal máxima sinalizada $\left(\sigma_{1, \text { signed,a }}\right)$.

De acordo com Socie \& Marquis (2000), existem 3 maneiras de se encontrar a constante de Findley $k_{F}$ e o limite de fadiga $\beta_{F}$. A primeira é ter em mãos o limite de fadiga do componente ${ }^{36}$ obtido com carregamento axial (tração-compressão) alternado $\left(A_{-1}\right)$ e o limite de fadiga do componente obtido com torção alternada $\left(T_{-1}\right)$. Se este for o caso, deve-se utilizar a equação (5.95) para encontrar o valor de $k_{F}$. Após isto utiliza-se o valor de $k_{F}$ na

\footnotetext{
${ }^{36} \mathrm{Na}$ verdade, da seção transversal analisada.
} 
equação (5.94) para encontrar $\beta_{F}$, sendo $\sigma_{a}=A_{-1}$ e $\sigma_{\max }=A_{-1}$. É importante relatar que, para metais dúcteis, a relação $\frac{T_{-1}}{A_{-1}}$ costuma resultar em um valor diferente de $C_{\tau}$. Geralmente $\frac{T_{-1}}{A_{-1}}>C_{\tau}$ e isto acontece por que as tensões cíclicas multiaxiais alteram esta relação.

A segunda maneira é ter em mãos $A_{-1}$ juntamente com o limite de fadiga do componente obtido com carregamento axial (tração-compressão) pulsante $\left(A_{0}\right)$. Se este for o caso, devese utilizar a equação (5.96) para encontrar o valor de $k_{F}$. Após isto utiliza-se o valor de $k_{F}$ na equação 5.94) para encontrar $\beta_{F}$, sendo $\sigma_{a}=A_{0}$ e $\sigma_{\max }=2 A_{0}$.

A terceira e última maneira é ter em mãos $A_{-1}$ juntamente com o limite de fadiga do componente obtido com carregamento axial (tração-compressão) com $\mathrm{R}=0,5\left(A_{0,5}\right)$. Se este for o caso, deve-se utilizar a equação (5.97) para encontrar o valor de $k_{F}$. Após isto utiliza-se o valor de $k_{F}$ na equação (5.94) para encontrar $\beta_{F}$, sendo $\sigma_{a}=A_{0,5}$ e $\sigma_{\max }=4 A_{0,5}$.

$$
\begin{gathered}
\frac{k_{F}+\sqrt{1+\left(k_{F}\right)^{2}}}{2 \cdot \sqrt{1+\left(k_{F}\right)^{2}}}=\frac{T_{-1}}{A_{-1}} \\
\frac{k_{F}+\sqrt{1+\left(k_{F}\right)^{2}}}{2 k_{F}+\sqrt{1+\left(2 k_{F}\right)^{2}}}=\frac{A_{0}}{A_{-1}} \\
\frac{k_{F}+\sqrt{1+\left(k_{F}\right)^{2}}}{4 k_{F}+\sqrt{1+\left(4 k_{F}\right)^{2}}}=\frac{A_{0,5}}{A_{-1}}
\end{gathered}
$$

Note que o efeito da rugosidade superficial $\left(C_{R O}\right)$, tratamento superficial $\left(C_{S T}\right)$, corrosão $\left(C_{C}\right)$, confiabilidade $\left(C_{R}\right)$ e temperatura $\left(C_{T}\right)$ são contabilizados ao se calcular $A_{-1}, A_{0}, A_{0,5}$ e $T_{-1}$.

É importante relatar que o efeito da tensão normal média $\left(\sigma_{m}\right)$ não é considerado através do fator modificador de tensão média $\left(C_{m, \sigma^{e}}\right)$, mas sim contabilizadas automaticamente no cálculo da tensão de equivalente $\left(\tau_{\text {findley,a }}\right)$, através da parcela relativa à máxima tensão normal ao plano material $\Delta\left(k_{F} \cdot \sigma_{n, \max }\right)$ (Lee et al., 2011; Socie \& Marquis, 2000). A tensão cisalhante média $\left(\tau_{m}\right)$ pode ser obtida pelo centro do máximo envelope retangular circunscrito. Entretanto, há um entendimento na literatura que a tensão cisalhante média não altera a resistência à fadiga, por este motivo não tem sido incluída como uma variável importante nos modelos multiaxiais, principalmente em alto número de ciclos. Entretanto, em regime de baixo número de ciclos ainda há dúvidas sobre o efeito da tensão cisalhante média. Em resumo, o modelo de Findley consegue automaticamente contabilizar o efeito das tensões médias através do lado esquerdo da equação (5.98), por isso não há necessidade de utilizar o fator modificador de tensão média $\left(C_{m}\right)$ no modelo de Findley. 
Acredita-se que o efeito de tamanho não deve ser considerado porque todos os modelos de fadiga multiaxial são modelos de iniciação de trinca e seriam validados para estruturas com o tamanho/diâmetro do espécime padronizado (Lee et al., 2011).

O efeito de entalhe não é considerado na Curva Tensão-Vida, mas sim é contabilizado dividindo as 6 componentes do tensor de tensões de cada nó pelo fator de entalhe $n_{K}$, conforme explicado na seção 5.3. É importante lembrar que a tensão $\tau_{\text {findley,a }}$ (equação 5.92) é calculada utilizando as tensões obtidas na equação (5.21) $\left(\sigma_{x}, \sigma_{y}, \sigma_{z}, \tau_{x y}, \tau_{y z}, \tau_{x z}\right)$. É por este motivo que não se considera o efeito do entalhe nas equações de 5.24 à 5.30 .

Grande parte das publicações (Karolczuk \& Macha, 2005; Lee et al., 2011; Socie \& Marquis, 2000) apresentam os modelos de fadiga multiaxial como sendo um critério do tipo "passa ou não passa", conforme apresentado pela equação (5.91). Este tipo de apresentação não permite saber em qual ciclo ocorreria a falha por fadiga, caso a tensão equivalente ${ }^{37}$ (lado esquerdo das equações dos critérios de falha) seja maior do que o limite de fadiga (lado direito). Existem poucas referências que relatam como utilizar os critérios de fadiga multiaxial de maneira a obter o número de ciclos em que ocorrerá a falha por fadiga. Foram encontradas apenas três referências que relatam isto na revisão bibliográfica desta dissertação: Socie \& Marquis (2000), Karolczuk \& Macha (2005) e MSC.Software (2008). Entretanto, estas 3 referências apresentam equações para se calcular o número de ciclos em que ocorrerá a fratura em um espécime padronizado. Não foi encontrado na revisão bibliográfica desta dissertação referências que relatam como os critérios multiaxiais podem ser expandidos para prever o número de ciclo que ocorrerá a falha de componentes de geometria/características ${ }^{38}$ complexas, diferentes do espécime.

Assim, o autor também acredita que o Modelo de Findley pode ser utilizado para calcular o número de ciclos em que a fratura por fadiga ocorrerá em um componente entalhado com características diferentes do espécime padronizado utilizando uma Curva Tensão-Vida, de maneira similar ao apresentado no capítulo 4. A Curva Tensão-Vida que deveria ser utilizada seria a Curva S-N Unnotched (equação 4.40 e figura 4.24) do lado direito da equação (5.91). Portanto, estima-se que a falha por fadiga do componente ${ }^{39}$ ocorrerá quando a relação abaixo for satisfeita:

$$
\begin{array}{r}
\max _{\theta, \phi}\left\{\tau_{\text {findley, } a}\right\}=\tau_{f, \text { un }}^{\prime} \cdot(2 N)^{b_{u n}} \\
\max _{\theta, \phi}\left\{\tau_{a}+k_{F} \cdot \sigma_{n, \text { max }}\right\}=\tau_{f, \text { un }}^{\prime} \cdot(2 N)^{b_{u n}}
\end{array}
$$

Onde

\footnotetext{
${ }^{37}$ Parâmetro de dano.

${ }^{38}$ Geometria do entalhe, rugosidade superficial, tratamento superficial, temperatura de trabalho, etc.

${ }^{39} \mathrm{Na}$ verdade, a vida em fadiga daquela seção transversal analisada.
} 
$\tau_{f, \text { un }}^{\prime} \quad$ : Coeficiente de resistência à fadiga da Curva $S$-N Unnotched

$b_{u n} \quad$ : Expoente de resistência à fadiga da Curva S-N Unnotched

O parâmetro $\beta_{F}$ é muito importante porque ele representa o limite de fadiga da Curva Tensão-Vida representada pelo lado direito da equação (5.98). Portanto, se a tensão de Findley avaliada no plano crítico $\left(\max _{\theta, \phi}\left\{\tau_{\text {findley,a }}\right\}\right)$ é menor do que $\beta_{F}$, então não haverá falha por fadiga.

A resistência à fadiga para $N_{B}$ ciclos do componente é estimada conforme a equação abaixo (similar à equação 4.37):

$$
S_{B, u n}=S_{B, s p} \cdot C_{C} \cdot C_{R} \cdot C_{T}
$$

Uma vez conhecido 2 pontos da curva, $\left(N_{E}, \beta_{F}\right)$ e $\left(N_{B}, S_{B, u n}\right)$, deve-se utilizar a equação (5.100) para obter o expoente de resistência à fadiga $\left(b_{u n}\right)$ e em seguida a equação 5.101) para obter o coeficiente de resistência à fadiga $\left(\tau_{f, u n}^{\prime}\right)$. É importante ter em mente que $\beta_{F}$ é o limite de fadiga da Curva Tensão-Vida referente à seção transversal analisada do componente (lado direito da equação 5.98).

$$
\begin{gathered}
b_{u n}=\frac{\log \left(\beta_{F} / S_{B, u n}\right)}{\log \left(N_{E} / N_{B}\right)} \\
\tau_{f, u n}^{\prime}=\frac{\beta_{F}}{\left(2 N_{E}\right)^{b_{u n}}}
\end{gathered}
$$

O modelo de Findley é um dos mais conhecidos na comunidade científica, por ser um modelo bastante antigo (1959) e por gerar resultados satisfatórios. Este modelo está incluso no Módulo Fadiga do software COMSOL.

Seja um componente sob carregamento de amplitude variável. A análise de fadiga baseada em Elementos Finitos deste componente, utilizando o Critério de Findley, deve ser realizada da seguinte forma:

1) Escolher um nó superficial para analisar, intitulado nó $n_{i}$. Para cada nó $n_{i}$, executar os próximos passos:

I. Contabilizar o efeito de entalhe através do cálculo e utilização das 6 componentes do tensor de tensões $\left(\sigma_{x}, \sigma_{y}, \sigma_{z}, \tau_{x y}, \tau_{x z}, \tau_{y z}\right)$ para cada time step, utilizando a equação (5.21);

II. Executar um Método de Rainflow Multiaxial e obter a tabela Rainflow para o nó $n_{i}$ analisado. 
III. Escolher um plano de corte para análise, intitulado plano $\Delta_{q}\left(\theta_{q}, \phi_{q}\right)$. Para cada plano $\left(\theta_{q}, \phi_{q}\right)$ executar os próximos passos:

a) Calcular as 6 componentes do tensor de tensões $\left(\sigma_{x}^{\prime}, \sigma_{y}^{\prime}, \sigma_{z}^{\prime}, \tau_{x y}^{\prime}, \tau_{x z}^{\prime}, \tau_{y z}^{\prime}\right)$ para cada time step, utilizando a equação (5.84);

b) Para cada linha “ $j$ ”da tabela, numerada pelo subíndice “ $j ”$, deve-se:

i. Calcular a tensão de Findley $\left(\tau_{\text {findley, },}\right)$ para a linha “ $j$ ” da Tabela Rainflow, utilizando a equação 5.92;

ii. Todos os fatores modificadores mencionados nesta seção devem ser calculados, assim como os parâmetros $\beta_{F}, S_{B, u n}, b_{u n}$ e $\tau_{f, u n}^{\prime}$. Após isto, a curva Curva S-N Unnotched (lado direito da equação 5.98) deve ser obtida.

iii. Utilizar a tensão de Findley $\left(\tau_{\text {findley, },}\right)$ na Curva $S-N$ Unnotched calculada no item anterior, conforme ilustra a figura 5.40 , para obter o número de ciclos $N_{j}$.

iv. Calcular o parâmetro de dano $d_{j}$ que a linha $j$ causa utilizando a equação 4.115.

c) Nesta etapa de cálculo, todas as linhas da Tabela Rainflow foram contabilizadas para o plano de corte analisado $\left(\theta_{q}, \phi_{q}\right)$ e o dano total para este plano está contabilizado, intitulado $D_{i, q}$.

IV. Nesta etapa de cálculo, o dano total foi calculado para todos os planos analisados. O plano que gera o maior dano total é intitulado plano crítico, cujo símbolo é $\Delta^{*}$ $\left(\theta^{*}, \phi^{*}\right)$ e o dano no plano crítico no nó $n_{i}$ é intitulado $D_{i}$.

2) Nesta etapa de cálculo, o dano $D_{i}$ de cada nó $n_{i}$ do modelo FE foi contabilizado. O nó que possuir o maior valor de dano é nomeado ponto/nó crítico, onde espera-se ser o primeiro ponto em que haverá nucleação da trinca e subsequente crescimento da mesma. 

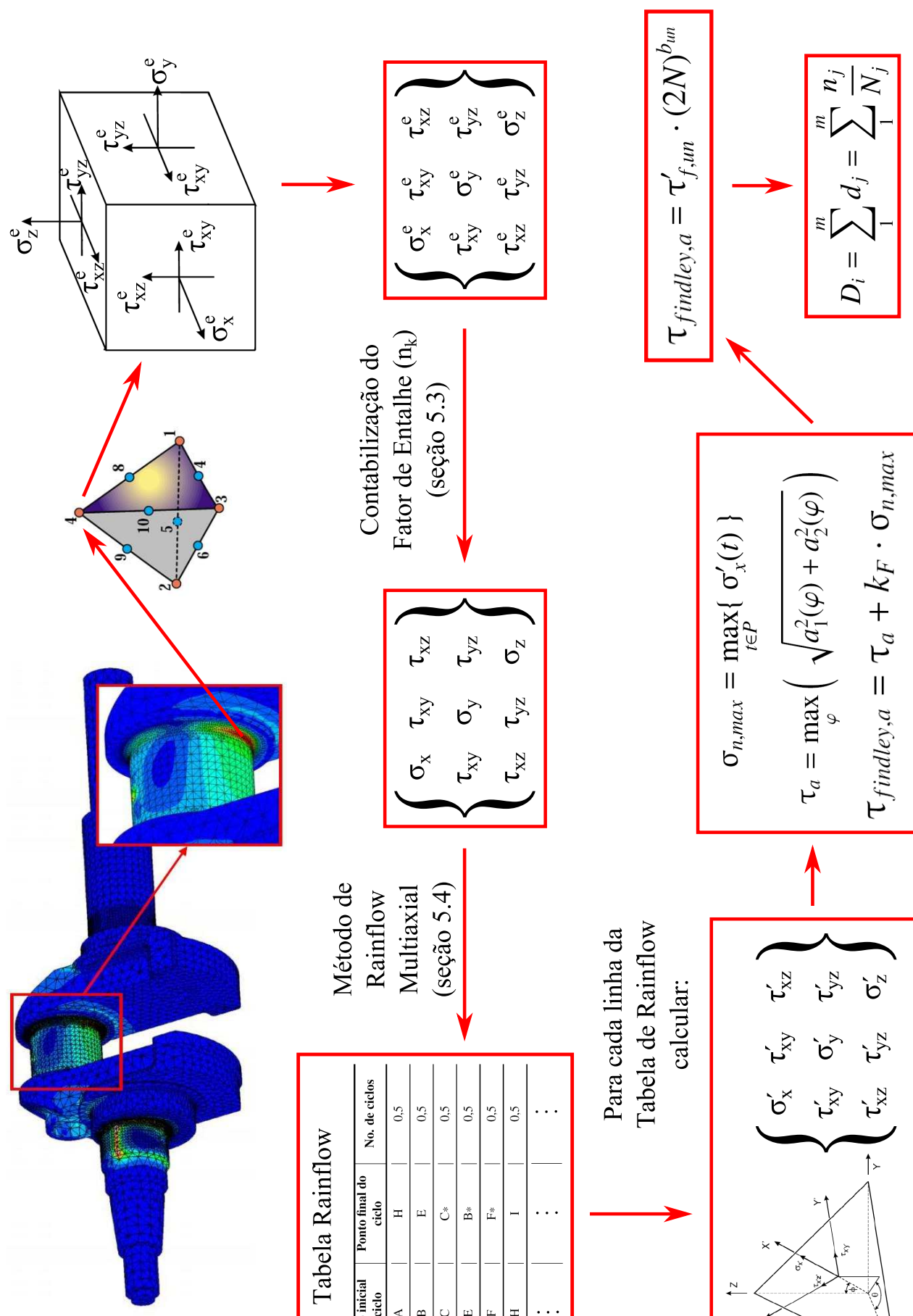

ఏ
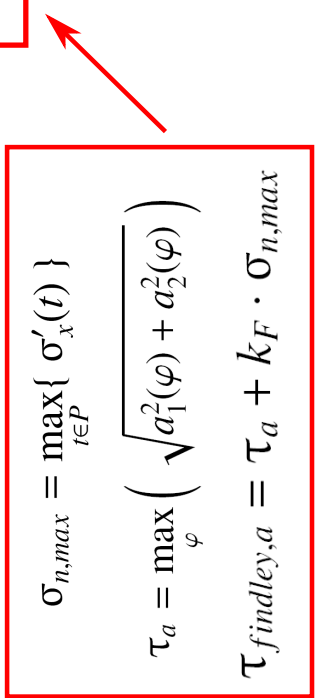

वิ)

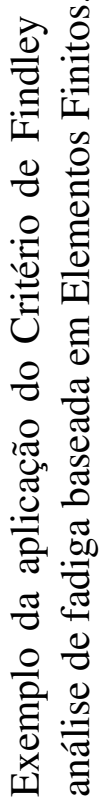

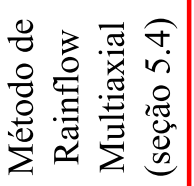
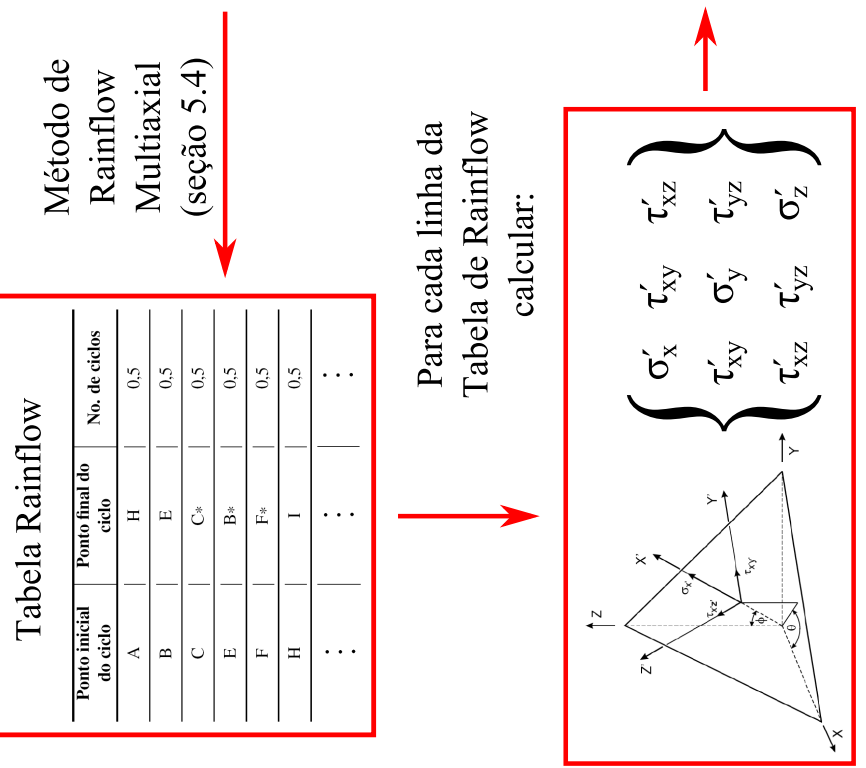

ले. 


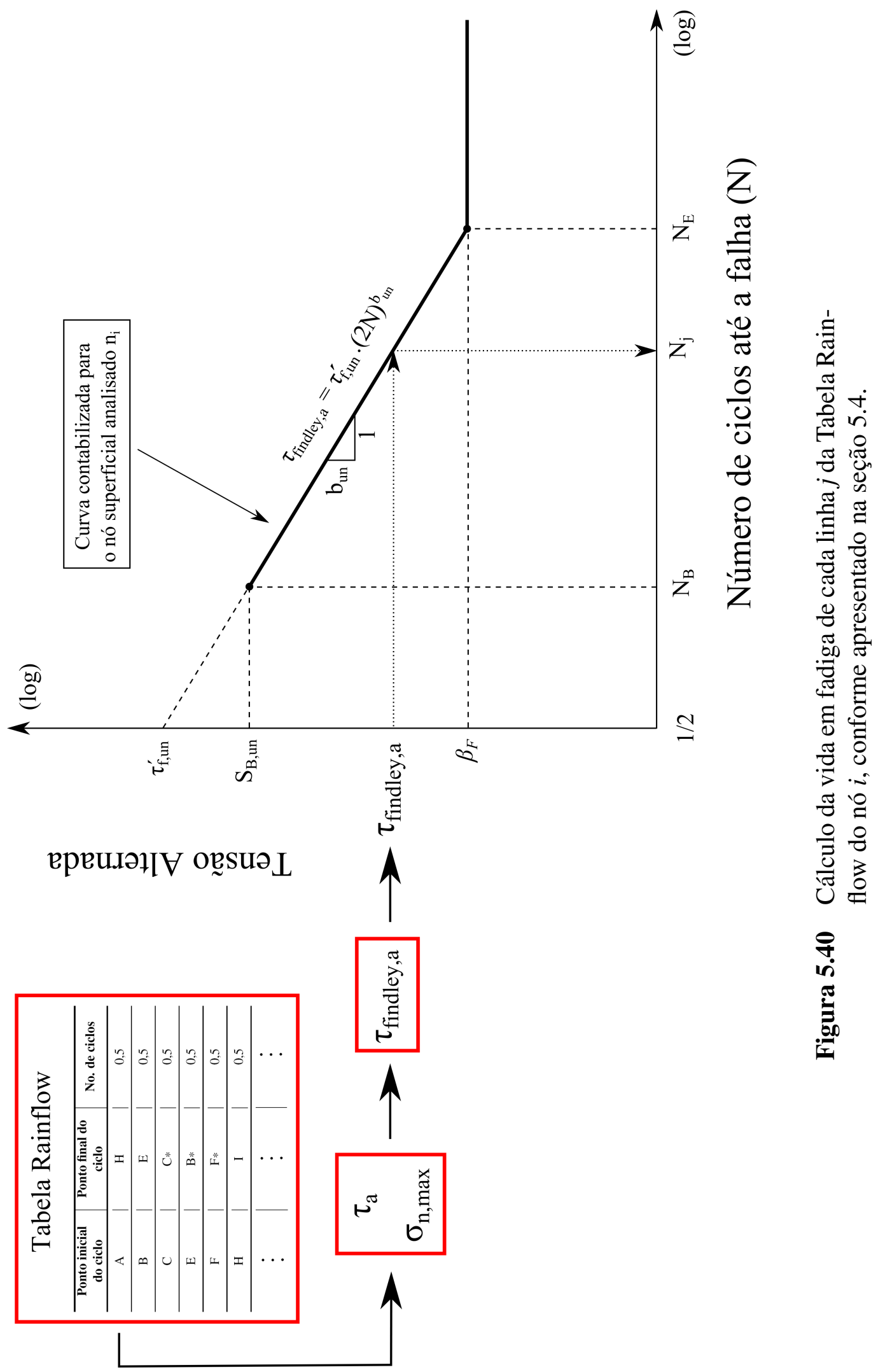




\subsubsection{Modelo de Gaier e Dannbauer}

Depois de rever os dados experimentais de Gough para flexão e torção combinados, Gaier \& Dannbauer (2003, 2008) proporam que uma trinca por fadiga irá provavelmente iniciar no plano onde a tensão de Gaier e Dannbauer $\left(\sigma_{G D}\right)$ é máxima. A tensão de Gaier e Dannbauer é calculada da seguinte maneira:

$$
\sigma_{G D}=\alpha_{G D} \cdot \sigma_{x}^{\prime}
$$

Sendo

$$
\alpha_{G D}=1+(1-k) V
$$

Onde

$\sigma_{G D}:$ Tensão de Gaier e Dannbauer

$\alpha_{G D}:$ Fator de tensão normal ajustada

$\sigma_{x}^{\prime} \quad$ : Tensão normal no plano de corte $\Delta$

$k \quad: \quad \frac{\sigma_{E, s p}}{\tau_{E, s p}}=\frac{1}{C_{\tau}}$

$V \quad$ : Razão entre a tensão principal mínima e máxima, definido como $V=\frac{\sigma_{3}}{\sigma_{1}}$

$$
\text { para }\left|\sigma_{1}\right|>\left|\sigma_{3}\right| \text { e como } V=\frac{\sigma_{1}}{\sigma_{3}} \text { para }\left|\sigma_{3}\right|>\left|\sigma_{1}\right|
$$

Lee et al. (2011) relatam que o valor do parâmetro $k$ é geralmente igual à 2,0 para metais dúcteis e 1,0 para metais frágeis. O parâmetro $V$ varia entre $-1 \mathrm{e}+1$, sendo $V=-1$ para carregamento de cisalhamento onde $\sigma_{3}=-\sigma_{1}, V=0$ para carregamento de flexão e tensãocompressão onde $\sigma_{3}=0$, e $V=+1$ para carregamento hidrostático onde $\sigma_{1}=\sigma_{2}=\sigma_{3}$. $\mathrm{O}$ parâmetro $\sigma_{x}^{\prime}$ é a tensão normal ao plano de avaliação $\Delta^{40}$, obtida pela equação (5.84).

Seja um espécime padronizado sob carregamento de amplitude constante. Neste caso, a amplitude da tensão de Gaier e Dannbauer $\left(\sigma_{G D, a}\right)$ e a média da tensão de Gaier e Dannbauer $\left(\sigma_{G D, m}\right)$ calculada para este ciclo de amplitude constante e calculada para um determinado plano material $\Delta$ (dependente de $\theta$ e $\phi$ ) é calculada conforme segue:

$$
\begin{aligned}
\sigma_{G D, a} & =\frac{\max \left(\sigma_{G D}\right)-\min \left(\sigma_{G D}\right)}{2} \\
\sigma_{G D, m} & =\frac{\max \left(\sigma_{G D}\right)+\min \left(\sigma_{G D}\right)}{2}
\end{aligned}
$$

\footnotetext{
${ }^{40}$ Plano ilustrado na figura $5.36 \mathrm{~b} e \sqrt{5.37}(\mathrm{~b})$
} 
De acordo com o Modelo de Gaier e Dannbauer, deve-se calcular a tensão $\sigma_{G D, a}$ para vários planos de análise $\Delta$. A falha em um espécime padronizado é prevista quando a maior tensão encontrada for maior do que o limite de fadiga do espécime padronizado:

$$
\begin{aligned}
\sigma_{e q} & \geq \sigma_{E, s p} \\
\max _{\theta, \phi}\left\{\sigma_{G D, a}\right\} & \geq \sigma_{E, s p}
\end{aligned}
$$

O critério de Gaier e Dannbauer é um critério de plano crítico, desta forma deve-se utilizar o maior valor da tensão $\sigma_{G D, a}$ na equação (5.106), variando-se para isto os ângulos $\theta$ e $\phi$. Gaier \& Dannbauer (2008) afirmam que, para as superfícies, onde o estado de tensão é biaxial, o método pode considerar apenas os planos perpendiculares à superfície, conforme ilustrado na figura 5.41(a). Para um estado triaxial de tensões, que ocorre em superfícies sob pressão (por exemplo rolamentos) ou dentro de componentes, mais planos devem ser analisados conforme ilustra a figura 5.41 (b). Gaier \& Dannbauer (2008) afirmam que varrer ângulos a cada $10^{\circ}$ seria um valor que resulta em bom equilíbrio entre precisão dos resultados e tempo de processamento.

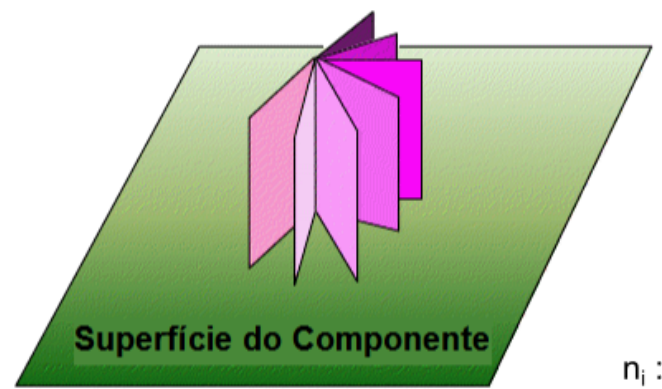

(a)

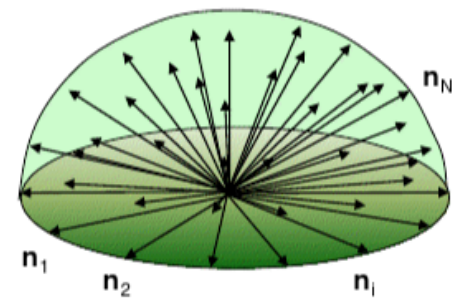

$\mathrm{n}_{\mathrm{i}}$ : vetores normais as planos de corte $i=1,2,3, \ldots, N-1, N$

Figura 5.41 Exemplo de varredura de planos no modelo de Gaier e Dannbauer.

Todas as publicações lidas e analisadas ao longo do desenvolvimento desta dissertação e que falam sobre este critério explicam como aplicá-lo para prever a falha de um espécime padronizado. Não foi encontrado na revisão bibliográfica desta dissertação referências que relatam como este critério de falha multiaxial pode ser expandido para ser aplicado em componentes de geometria/características ${ }^{41}$ complexas, diferentes do espécime. Também não foi encontrado como utilizar este modelo em conjunto com análises por Elementos Finitos.

Desta forma, o autor acredita que o conceito de similaridade continuaria sendo válido também em fadiga multiaxial e, portanto, continuaria sendo válido utilizar os fatores modificadores apresentados no capítulo 4 também em fadiga multiaxial. Desta forma, o autor

\footnotetext{
${ }^{41}$ Geometria do entalhado, rugosidade superficial, tratamento superficial, temperatura de trabalho, etc.
} 
acredita que o Modelo de Gaier e Dannbauer pode ser utilizado em um componente entalhado ou não entalhado, com características diferentes do espécime padronizado, utilizando o limite de fadiga $A_{E, u n}$, que já consideraria todas as características da seção transversal analisada (pois todos os fatores modificadores apresentados na figura 4.24 já foram considerados no cálculo de $A_{E, u n}$, exceto o fator de entalhe, que já foi considerado ao se alterar o carregamento, conforme explicado na seção 5.3. Portanto, estima-se que a falha por fadiga do componente $\mathrm{e}^{42}$ ocorrerá quando a relação abaixo for satisfeita:

$$
\begin{aligned}
\max _{\theta, \phi}\left\{\sigma_{G D, a}\right\} & \geq A_{E, \text { un }} \\
& \geq \sigma_{E, s p} \cdot C_{R O} \cdot C_{S T} \cdot C_{C} \cdot C_{R} \cdot C_{T} \cdot C_{m, \sigma^{e}} \\
& \geq S_{E, s p} \cdot 0,9 \cdot C_{R O} \cdot C_{S T} \cdot C_{C} \cdot C_{R} \cdot C_{T} \cdot C_{m, \sigma^{e}}
\end{aligned}
$$

Note que o efeito da rugosidade superficial $\left(C_{R O}\right)$, tratamento superficial $\left(C_{S T}\right)$, corrosão $\left(C_{C}\right)$, confiabilidade $\left(C_{R}\right)$, temperatura $\left(C_{T}\right)$ e tensão média $\left(C_{m, \sigma^{e}}\right)$ são contabilizados modificando a Curva S-N Espécime conforme explicado nas seções $4.3 \mathrm{e} 4.6 .1$.

Gaier \& Dannbauer (2003, 2008) relatam que o Modelo de Gaier e Dannbauer pode ser utilizado em quaisquer outros modelos de correção de tensão média apresentados na seção 4.6.1 ou no diagrama de Haigh para incorporar o efeito da tensão média. Assim, o fator modificador de tensão média $\left(C_{m, \sigma^{e}}\right)$ aplicado nas equações (5.25), (5.26), (5.27), (5.29) e (5.30) é calculado utilizando as tensões equivalentes calculadas pelas equações (5.104) e (5.105) em algum modelo de correção de tensão média da seção 4.6.1 (ou no diagrama de Haigh).

Acredita-se que o efeito de tamanho não deve ser considerado porque todos os modelos de fadiga multiaxial são modelos de iniciação de trinca e seriam validados para estruturas com o tamanho/diâmetro do espécime padronizado (Lee et al., 2011).

O efeito de entalhe não é considerado na Curva Tensão-Vida, mas sim é contabilizado dividindo as 6 componentes do tensor de tensões de cada nó pelo fator de entalhe $n_{K}$, conforme explicado na seção 5.3. É importante lembrar que a tensão $\sigma_{G D}$ (equação 5.102 é calculada utilizando a tensão obtida na equação (5.84) $\left(\sigma_{x}^{\prime}\right)$. É por este motivo que não se considera o efeito do entalhe nas equações de 5.24 à 5.30 .

Grande parte das publicações (Karolczuk \& Macha, 2005; Lee et al., 2011; Socie \& Marquis, 2000) apresentam os modelos de fadiga multiaxial como sendo um critério do tipo "passa ou não passa", conforme apresentado pela equação (5.106 e (5.107). Este tipo de apresentação não permite saber em qual ciclo ocorreria a falha por fadiga, caso a tensão equivalente ${ }^{43}$ (lado esquerdo das equações dos critérios de falha) seja maior do que o limite

\footnotetext{
${ }^{42} \mathrm{Na}$ verdade, a vida em fadiga daquela seção transversal analisada.

${ }^{43}$ Parâmetro de dano.
} 
de fadiga (lado direito). Existem poucas referências que relatam como utilizar os critérios de fadiga multiaxial de maneira a obter o número de ciclos em que ocorrerá a falha por fadiga. Foram encontradas apenas três referências que relatam isto na revisão bibliográfica desta dissertação: Socie \& Marquis (2000), Karolczuk \& Macha (2005) e MSC.Software (2008). Entretanto, estas 3 referências apresentam equações para se calcular o número de ciclos em que ocorrerá a fratura em um espécime padronizado. Não foi encontrado na revisão bibliográfica desta dissertação referências que relatam como os critérios multiaxiais podem ser expandidos para prever o número de ciclo que ocorrerá a falha de componentes de geometria/características ${ }^{44}$ complexas, diferentes do espécime.

Assim, o autor também acredita que o Modelo de Gaier e Dannbauer pode ser utilizado para calcular o número de ciclos em que a fratura por fadiga ocorrerá em um componente entalhado ou não entalhado, com características diferentes do espécime padronizado, utilizando uma Curva Tensão-Vida, de maneira similar ao apresentado no capítulo 4. A Curva Tensão-Vida que deveria ser utilizada seria a Curva S-N Unnotched (equação 4.40 e figura 4.24) do lado direito da equação (5.107). Assim, a vida do componente poderia ser estimada utilizando a seguinte equação:

$$
\max _{\theta, \phi}\left\{\sigma_{G D, a}\right\}=S_{f, u n}^{\prime} \cdot(2 N)^{b_{u n}}
$$

Onde

$S_{f, u n}^{\prime} \quad$ : Coeficiente de resistência à fadiga da Curva $S-N$ Unnotched

$b_{u n} \quad$ : Expoente de resistência à fadiga da Curva S-N Unnotched

A resistência à fadiga para $N_{B}$ ciclos do componente é estimada conforme a equação abaixo (similar à equação 4.37):

$$
S_{B, \text { un }}=S_{B, s p} \cdot C_{C} \cdot C_{R} \cdot C_{T} \cdot C_{m, \sigma^{e}}
$$

Uma vez conhecido 2 pontos da curva, $\left(N_{E}, A_{E, \text { un }}\right)$ e $\left(N_{B}, S_{B, \text { un }}\right)$, deve-se utilizar a equação (5.110) para obter o expoente de resistência à fadiga $\left(b_{u n}\right)$ e em seguida a equação (5.111) para obter o coeficiente de resistência à fadiga $\left(S_{f, u n}^{\prime}\right)$. É importante ter em mente que $A_{E, \text { un }}$ é limite de fadiga da Curva Tensão-Vida referente à seção transversal analisada do componente (lado direito da equação 5.108).

$$
\begin{gathered}
b_{u n}=\frac{\log \left(A_{E, \text { un }} / S_{B, \text { un }}\right)}{\log \left(N_{E} / N_{B}\right)} \\
S_{f, \text { un }}^{\prime}=\frac{A_{E, \text { un }}}{\left(2 N_{E}\right)^{b_{u n}}}
\end{gathered}
$$

\footnotetext{
${ }^{44}$ Geometria do entalhe, rugosidade superficial, tratamento superficial, temperatura de trabalho, etc.
} 
Seja um componente sob carregamento de amplitude variável. A análise de fadiga baseada em Elementos Finitos deste componente, utilizando o Critério de Gaier e Dannbauer, deve ser realizada da seguinte forma:

1) Escolher um nó superficial para analisar, intitulado nó $n_{i}$. Para cada nó $n_{i}$, executar os próximos passos:

I. Contabilizar o efeito de entalhe através do cálculo e utilização das 6 componentes do tensor de tensões $\left(\sigma_{x}, \sigma_{y}, \sigma_{z}, \tau_{x y}, \tau_{x z}, \tau_{y z}\right)$ para cada time step, utilizando a equação (5.21);

II. Escolher um plano de corte para análise, intitulado plano $\Delta_{q}\left(\theta_{q}, \phi_{q}\right)$. Para cada plano $\left(\theta_{q}, \phi_{q}\right)$ executar os próximos passos:

a) Calcular as 6 componentes do tensor de tensões $\left(\sigma_{x}^{\prime}, \sigma_{y}^{\prime}, \sigma_{z}^{\prime}, \tau_{x y}^{\prime}, \tau_{x z}^{\prime}, \tau_{y z}^{\prime}\right)$ para cada time step, utilizando a equação (5.84);

b) Calcular a tensão de Gaier e Dannbauer $\left(\sigma_{G D}\right)$ para cada time step, utilizando a equação (5.102);

c) Aplicar o Método de Rainflow Uniaxia ${ }^{45}$ sob a tensão $\sigma_{G D}$ supracalculada. Isto resultará na Matriz de Rainflow (que contém valores da amplitude da tensão de Gaier e Dannbauer $\left(\sigma_{G D, a}\right)$ e da média da tensão de Gaier e Dannbauer $\left(\sigma_{G D, m}\right)$ ) relativa ao plano de análise $\left(\theta_{q}, \phi_{q}\right)$;

d) A Matriz de Rainflow possui vários blocos que devem ser aplicados em sequência para a contabilização do dano por fadiga. Para cada bloco, numerado pelo subíndice “ $j$ ”, deve-se efetuar as seguintes etapas:

i. Cada bloco “ $j$ ” tem uma pseudo tensão alternada $\left(\sigma_{G D, a, j}^{e}\right)$ e uma pseudo tensão média $\left(\sigma_{G D, m, j}^{e}\right)$ associadas à ele, que são aplicados por $n_{j}$ ciclos;

ii. Todos os fatores modificadores mencionados nesta seção devem ser calculados, assim como os parâmetros $A_{E, u n}, S_{B, u n}, b_{u n}$ e $S_{f, u n}^{\prime}$. O fator $C_{m, \sigma^{e}}$ deve ser calculado nesta etapa, utilizando a pseudo tensão média $\left(\sigma_{G D, m, j}^{e}\right)$. Esta tensão será utilizada em uma das equações da seção 4.6.1 para que $C_{m, \sigma^{e}}$ seja contabilizado. Isto fará com que a Curva $S$-N Unnotched translade verticalmente e fará com que o efeito da tensão média seja contabilizado. Após isto, a curva Curva $S$-N Unnotched (lado direito da equação 5.108) deve ser obtida.

iii. Utilizar a pseudo tensão alternada $\left(\sigma_{G D, a, j}^{e}\right)$ na Curva $S-N$ Unnotched calculada no item anterior, conforme ilustra a figura 5.43 , para obter o número de ciclos $N_{j}$.

\footnotetext{
${ }^{45}$ Explicado na seção 4.5
} 
iv. A seguir, deve-se calcular o parâmetro de dano $d_{j}$ que o bloco $j$ causa utilizando a equação 4.115).

e) Nesta etapa de cálculo, todos os blocos da Matriz de Rainflow foram contabilizados para o plano de análise $\left(\theta_{q}, \phi_{q}\right)$ e o dano total para este plano está contabilizado, intitulado $D_{i, q}$.

III. Nesta etapa de cálculo, o dano total foi calculado para todos os planos analisados. O plano que gera o maior dano total é intitulado plano crítico, cujo símbolo é $\Delta^{*}$ $\left(\theta^{*}, \phi^{*}\right)$ e o dano no plano crítico no nó $n_{i}$ é intitulado $D_{i}$.

2) Nesta etapa de cálculo, o dano $D_{i}$ de cada nó $n_{i}$ do modelo FE foi contabilizado. O nó que possuir o maior valor de dano é nomeado ponto/nó crítico, onde espera-se ser o primeiro ponto em que haverá nucleação da trinca e subsequente crescimento da mesma.

De acordo com Gaier \& Dannbauer (2003, 2008), este critério pode ser aplicado para metais dúcteis e frágeis, tanto para carregamento proporcional quanto não proporcional. Entretanto, o artigo de 2003 mostram que este critério, conforme descrito pelas equações citadas dessa seção, somente consegue prever adequadamente a vida em fadiga sob carregamento proporcional. Gaier \& Dannbauer (2003) afirmam que este critério pode ser utilizado em carregamentos não proporcionais, desde que algumas mudanças sejam feitas. Tais modificações são complexas e não são relatadas nesta dissertação. Mais detalhes sobre este critério e sobre as modificações supracitadas podem ser encontrados nos artigos Gaier \& Dannbauer (2003) e Gaier \& Dannbauer (2008). Os trabalhos Gaier \& Dannbauer (2003) e Gaier \& Dannbauer (2008) não demonstram se este critério pode ser utilizado em carregamento de amplitude variável.

Gaier e Dannbauer são especialistas em fadiga e trabalham na Magna Powertrain, com o desenvolvimento do software FEMFAT, incluindo a criação de métodos para FE-Based Fatigue Analysis. Por este motivo, o critério de Gaier e Dannbauer está incluido no FEMFAT. Não se conhece outro software de fadiga comercial que utiliza este critério. 


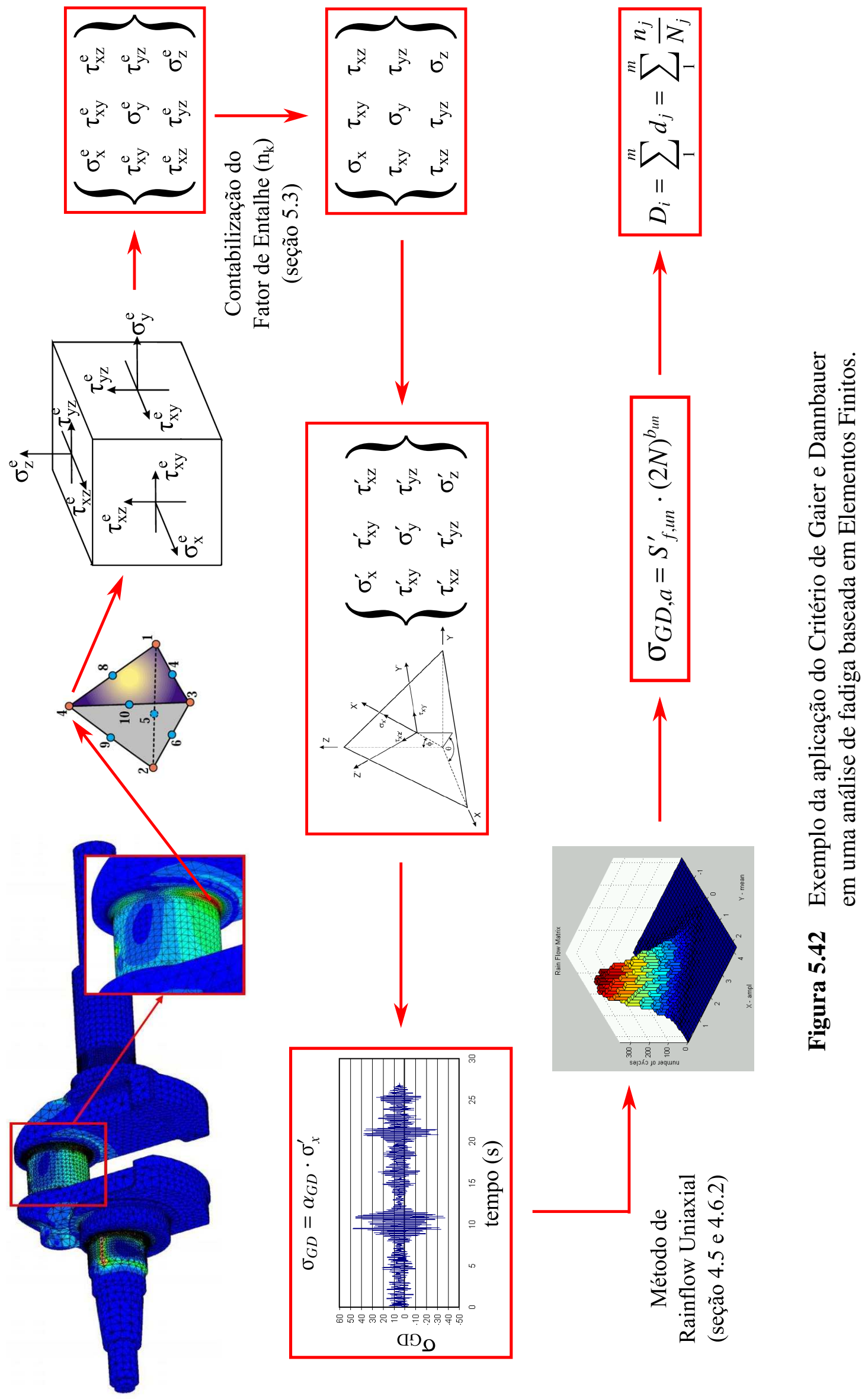




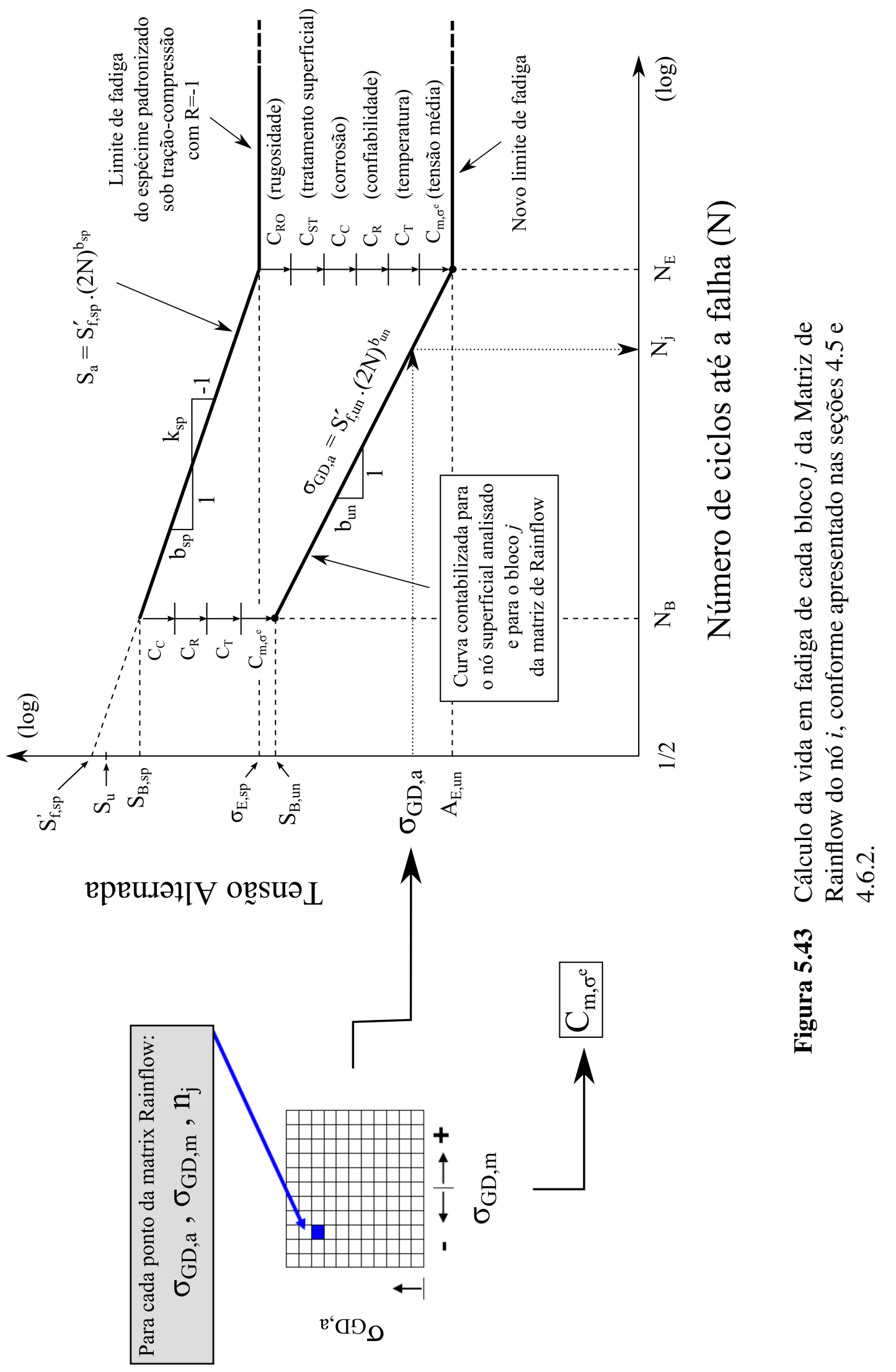




\subsubsection{Modelos Baseados em Tensão Mesoscópica}

\subsubsection{Modelo de Dang Van}

Dang Van (1993); Dang Van et al. (1982) propôs um modelo ${ }^{46}$ onde a abordagem de iniciação de fadiga é multiescalar, baseada no uso das tensões mesoscópicas ao invés de tensões macroscópicas de engenharia. O processo de iniciação da fadiga pode ser descrito por três escalas diferentes, descritas abaixo:

1) Escala macroscópica: a escala macroscópica é caracterizada por um elemento de volume "V, ilustrado na figura 5.44, à volta do ponto onde a análise de fadiga será realizada. Lee et al. (2011, pp.199) relata que é neste volume que ocorre o desenvolvimento de trinca de estagio I (short crack). Este tamanho de escala é da ordem de grandeza de um strain gage ou de um elemento da malha de elementos finitos (Lee et al. (2011, pp.199), Socie \& Marquis (2000, pp.143)). Esta é a escala considerada por engenheiros e é a mesma das tensões e deformações locais, mencionadas na seção 5.3 . Assim, estas tensões ${ }^{47}$ são denotadas por $\sigma_{i j}^{e}\left(\sigma_{x}^{e}, \sigma_{y}^{e}, \sigma_{z}^{e}, \tau_{x y}^{e}, \tau_{y z}^{e}, \tau_{x z}^{e}\right)$ e estas deformações ${ }^{48}$ são denotadas por $\varepsilon_{i j}^{e}\left(\varepsilon_{x}^{e}, \varepsilon_{y}^{e}, \varepsilon_{z}^{e}, \varepsilon_{x y}^{e}, \varepsilon_{y z}^{e}, \varepsilon_{x z}^{e}\right)$. Tanto $\sigma_{i j}^{e}$ quanto $\varepsilon_{i j}^{e}$ dependem da posição dentro do compoennte/estrutura e do tempo.

2) Escala mesoscópica: a escala mesoscópica tem a mesma ordem de grandeza de um grão cristalino no metal ou outra unidade microestrutural adequada, correspondendo à uma subdivisão de dentro do volume "V" (Socie \& Marquis, 2000). Esta unidade microestrutural pode ser o tamanho das bandas de desiocamento plasticas ( de um grão, por exemplo. A ordem de grandeza da escala mesoscópica está ilustrada na figura 5.44. As tensões mesoscópicas $\left(\sigma_{m e s o, i j}\right)$ e as deformações mesoscópicas ( $\varepsilon_{m e s o, i j}$ ) estão relacionadas mas não são iguais à $\sigma_{i j}^{e}$ e $\varepsilon_{i j}^{e}$.

3) Escala microscópica: este nível de escala possui a ordem de grandeza das discordâncias, sendo as tensões diretamente relacionadas às forças de interação entre os átomos. Este tipo de tensão é muito difícil de se medir, pois há uma grande heterogeneidade neste nível de escala, devido a uma série de fatores como tipos de átomos que estão ligados, direções das ligações entre átomos, translação de discordâncias, etc. Por este motivo, é bastante difícil desenvolver um critério de fadiga ou mesmo de falha estática baseado neste nível de escala;

Como mostrado na figura 5.44, Dang Van postula que para uma vida em fadiga infinita (perto do limite de fadiga), a nucleação de trinca nas bandas de deslizamento pode ocorrer na maioria dos grãos desfavoravelmente orientados, que estão sujeitos à deformação plástica mesmo se a tensão macroscópica é elástica. Tensões residuais nestes grãos deformados plasticamente irão ser provocadas devido aos efeitos de restrição dos grãos adjacentes. Desta maneira, este critério parte do princípio que o limite de fadiga está associado com a não propagação de trincas de estágio I (trincas microscópicas de cisalhamento 49 ) além de um único grão Heyes (2011). Este critério depende da tensão de cisalhamento mesoscópica

\footnotetext{
${ }^{46} \mathrm{Na}$ verdade, este modelo surgiu inicialmente durante a pesquisa de doutorado de Dang Van, em 1973

${ }^{47}$ Comumente chamadas de macro tensões.

${ }^{48}$ Comumente chamadas de macro deformações.

${ }^{49}$ vide seção Estágio I: Nucleação de Trinca (2.1)
} 


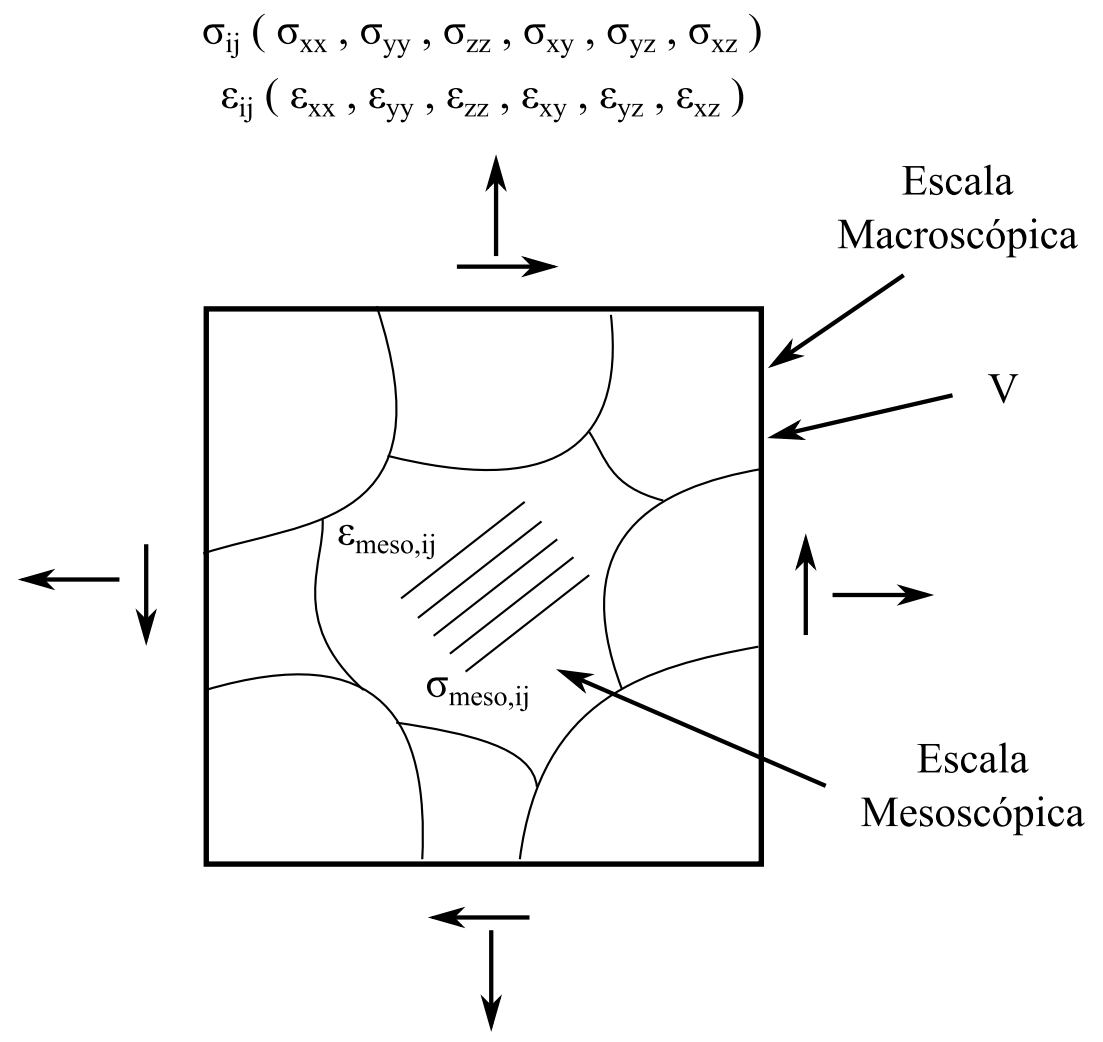

Figura 5.44 Tensões e deformações na escala macroscópica e mesoscópica.

modificada pela tensão hidrostática. A tensão cisalhante mesoscópica é calculada após uma acomodação elástica (assumindo que a plasticidade ocorre dentro de um grão individual).

Dang Van também assumiu que uma acomodaçãd 50 elástica em um estado macroscópico ocorre antes do limite de fadiga e que tanto as deformações plásticas e tensões residuais mesoscópicas e macroscópicas são estabilizadas. Lee et al. (2011) afirma ser importante notar que o material é dito exibir acomodação elástica, correspondendo para a estabilização das respostas elásticas, se escoamento não ocorre durante descarregamento e a subsequente reaplicação do carregamento é totalmente elástica.

O cômputo do estado de acomodação elástica sob carregamento multiaxial é ilustrado com a ajuda da figura 5.45. O domínio elástico inicial de um volume crítico de material é ilustrado pela circunferência $C_{I}$ da 5.45(a), cujo centro é o ponto $I$. Conforme o carregamento evolui, o material sofre uma combinação de encruamento cinemático e isotrópico conforme o centro da superfície de escoamento translada e o raio desta superfície aumenta. Este fenômeno é mostrado nas figuras 5.45(b) e 5.45(c). Depois de várias repetições de carregamento, um domínio cilíndrico estabilizado denominado $C_{F}$ com centro $\alpha^{*}$ e irá envolver todo o histórico de carregamento no espaço das tensões principais. O caminho estabilizado é carecterizado pela menor circunferência $C_{F}$ que circunscreve completamente

\footnotetext{
${ }^{50}$ Tradução livre do autor para shakedown.
} 


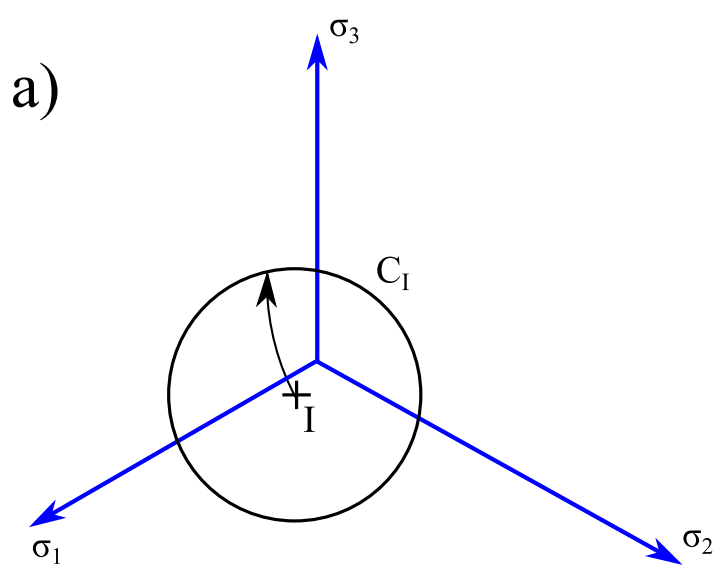

Caminho do carregamento durante todo o histórico de

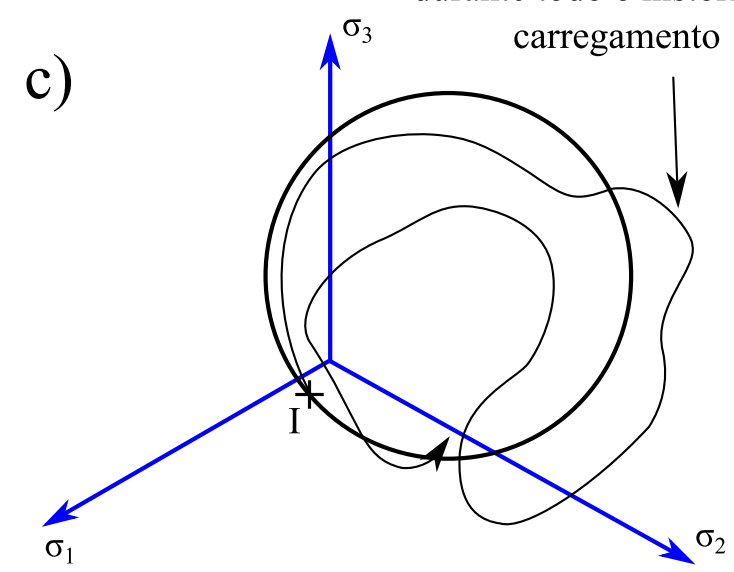

b)
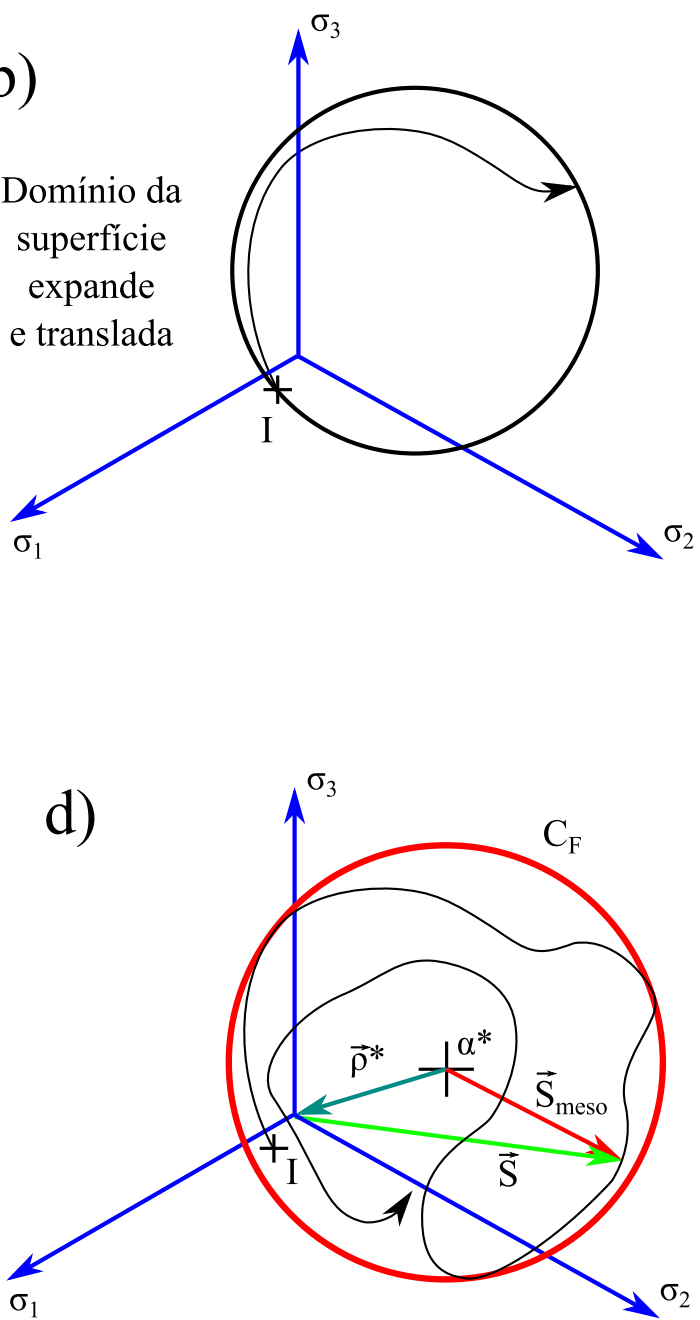

Figura 5.45 Acomodação elástica sob carregamento multiaxial vista no plano octaédrico (adaptado de Socie (2004a)).

todo o caminho do carregamento, conforme ilustrado na figura 5.45 (d). O tensor de tensão residual estabilizado contido no plano octaédrico $\left(\underline{\rho}^{*}\right)$ corresponde a distância entre $O_{L}-0$. No caso de carregamento de tração-compressão\&torção, o domínio $C_{F}$ corresponde à uma circunferência no espaço de tensões $\sqrt{3 \tau-\sigma}$; entretanto, em um caso de carregamento geral onde todas as 6 componentes de tensão variam, o domínio $C_{F}$ é uma hiperesfera com seis dimensões (Socie \& Marquis, 2000).

A teoria assume que, para uma vida em fadiga infinita, o tensor de deformação elástico macroscópica $\left(\underline{\varepsilon}^{e}(t)\right)$ é a soma dos tensores de deformação elástica e plástica mesoscópicas dentro do grão ( $\left.\underline{\varepsilon}_{m e s o}^{e}(t), \underline{\varepsilon}_{m e s o}^{p}(t)\right)$ (Lee et al., 2011). Isto é expressado conforme a equação abaixo:

$$
\underline{\varepsilon}^{e}(t)=\underline{\varepsilon}_{m e s o}^{e}(t)+\underline{\varepsilon}_{m e s o}^{p}(t)
$$

Sendo por definição

$$
\underline{\varepsilon}^{e}(t)=\frac{\underline{\sigma}(t)}{E}
$$




$$
\underline{\varepsilon}_{m e s o}^{e}(t)=\frac{\underline{\sigma}_{m e s o}(t)}{E_{\text {meso }}}
$$

Onde

$$
\begin{array}{lll}
E & : & \text { Módulo de Elasticidade no nívelmacroscópica } \\
E_{\text {meso }} & : & \text { Módulo de Elasticidade no nível mesoscópica } \\
\underline{\sigma}(t) & : & \text { Tensor de tensão macroscópica } \\
\underline{\sigma}_{\text {meso }}(t) & : & \text { Tensor de tensão mesoscópica }
\end{array}
$$

Então, substituindo as equações (5.113) e (5.114) na equação (5.112), esta pode ser reescrita em termos das tensões como

$$
\underline{\sigma}_{\text {meso }}(t)=\frac{E_{\text {meso }}}{E} \underline{\sigma}(t)-E_{\text {meso }} \underline{\varepsilon}_{m e s o}^{p}(t)
$$

Assumindo $\frac{E_{\text {meso }}}{E}=1$, então a equação 5.115 torna-se

$$
\begin{aligned}
\underline{\sigma}_{\text {meso }}(t) & =\underline{\sigma}(t)-E_{\text {meso }} \underline{\varepsilon}_{\text {meso }}^{p}(t) \\
& =\underline{\sigma}(t)+\underline{\rho}^{*}
\end{aligned}
$$

onde o tensor de tensão residual local na escala mesoscópica ( $\underline{\rho}^{*}$ ) é introduzido através da seguinte equação:

$$
\underline{\rho}^{*}=E_{\text {meso }} \underline{\varepsilon}_{\text {meso }}^{p}(t)
$$

É importante lembrar que $\rho^{*}$ é o tensor de tensão residual estabilizado contido no plano octaédrico porque ele é proporcional às deformações plásticas mesoscópicas.

Adicionalmente, o tensor de tensão hidrostático mesoscópico $\left(\underline{\sigma}_{m e s o, h}(t)\right)$ é igual ao tensor hidrostático ${ }^{51}\left(\underline{\sigma}_{h}(t)\right)$ :

$$
\underline{\sigma}_{m e s o, h}(t)=\underline{\sigma}_{h}(t)=\frac{1}{3}(\underline{\sigma}: \underline{I}) \underline{I}
$$

O tensor deviatório ${ }^{52}$ macroscópico ${ }^{53}(\underline{S}(t))$ é igual à diferença entre o tensor de tensões macroscópicas $(\underline{\sigma}(t))$ e o tensor hidrostático $\left(\underline{\sigma}_{h}(t)\right)$ :

$$
\underline{S}(t)=\underline{\sigma}(t)-\underline{\sigma}_{h}(t)
$$

\footnotetext{
${ }^{51}$ Também chamado de tensor de tensão hidrostático.

${ }^{52}$ Também chamado de tensor de tensões deviatóricas.

${ }^{53}$ Calculado para cada instante de tempo.
} 
E a mesma relação utilizada na equação (5.116) pode ser aplicada entre o tensor deviatório macroscópico $(\underline{S}(t))$ e o tensor deviatório mesoscópico $\left(\underline{S}_{\text {meso }}\right)$ :

$$
\underline{S}_{\text {meso }}(t)=\underline{S}(t)+\underline{\rho}^{*}
$$

Dang Van assumiu $\rho^{*}=-\underline{\alpha}^{*}$ onde $\underline{\alpha}^{*}$ representa as coordenadas do centro da menor circunferência que circunscreve completamente o caminho descrito pelo Tensor de Tensões Deviatóricas Macroscópicas $\underline{S}(t)$, conforme ilustrado na figura 5.45 . O parâmetro $\rho^{*}$ é calculado através da modificação do centro da esfera $\left(\underline{\alpha}^{*}\right)$ em cada instante de tempd ${ }^{54}$, para minizimar o valor máximo das tensões de von Mises calculadas a partir do Tensor Deviatório Macroscópico com relação ao centro da superfície de escoamento atualizada para o presente instante de tempo. Isto pode ser visto na figura 5.45 .

É muito importante relembrar que tanto $\rho^{*}$ quanto $\underline{\varepsilon}_{m e s o}^{p}$ são estabilizados e independentes do tempo, medidos depois de um número grande de ciclos de carregamento ${ }^{55}$, conforme exemplificado na figura 5.45. Computacionalmente, o raio inicial 56 do domínio de escoamento deveria ser próximo mas não igual à zero. Socie \& Marquis (2000) afirmam que a adoção de $\left\|\rho^{*}\right\|=0,05$ para a primeira iteração de cálculo é adequado por representar um bom compromisso entre o tempo de processamento e convergência. Lee et al. (2011) menciona que é importante notar que, para carregamentos proporcionais, $\underline{\alpha}^{*}$ é a média dos pontos de tensão deviatórica macroscópica.

O processo de solução min-max pode ser expressado conforme a equação abaixo:

$$
\underline{\alpha}^{*}=\min _{\underline{\alpha}}\left\{\max _{t} \sigma_{V M}(t)\right\}
$$

Sendo a tensão de von Mises em cada instante de tempo calculada conforme segue

$$
\sigma_{V M}(t)=\sqrt{\frac{3}{2}(\underline{S}(t)-\underline{\alpha}(t)):(\underline{S}(t)-\underline{\alpha}(t))}
$$

$$
\begin{aligned}
\sigma_{V M}(t)=\sqrt{\frac{3}{2}} \sqrt{\left(S_{11}(t)-\alpha_{11}(t)\right)^{2}+\left(S_{22}(t)-\alpha_{22}(t)\right)^{2}+\left(S_{33}(t)-\alpha_{33}(t)\right)^{2}+} \\
\sqrt{+2\left[\left(S_{12}(t)-\alpha_{12}(t)\right)^{2}+\left(S_{23}(t)-\alpha_{23}(t)\right)^{2}+\left(S_{31}(t)-\alpha_{31}(t)\right)^{2}\right]}
\end{aligned}
$$

\footnotetext{
${ }^{54}$ Também chamado de time step em uma análise de fadiga baseada em FEA.

${ }^{55} \mathrm{Na}$ verdade, o ideal é calcular $\underline{\rho}^{*}$ utilizando as tensões de todos os instantes de tempo do carregamento, do primeiro time step até o último.

${ }^{56} \mathrm{Ou}$ seja, o raio utilizado ao se computar o primeiro valor de $\underline{\rho}$
} 
Sendo as quantidades $S_{11}, S_{22}, S_{33}, S_{12}, S_{23}$ e $S_{31}$ os valores de dentro do tensor tensão deviatórica macroscópica ( $\underline{S}$ ) em cada instante de tempo, calculado pela equação 5.119 . Este conceito de min-max é ilustrado na figura 5.45. Mais detalhes sobre a obtenção de $\underline{\alpha}^{*}$ pode ser encontrada em Lee et al. (2011, pp.199-209), Dang Van et al. (1982) e Dang Van (1993).

É importante lembrar que $\underline{\rho}^{*}$ representa o tensor de tensão residual estabilizado contido no plano octaédrico $\left(\underline{\rho}^{*}\right)$, conforme pode ser visto na 5.45

Uma vez que $\underline{\rho}^{*}$ é encontrado e o tensor deviatório mesoscópico ( $\underline{S}_{\text {meso }}$ ) é calculado para todos os instantes de tempo (i.e., todos os time steps), a tensão de cisalhamento mesoscópica ${ }^{57}\left(\tau_{m e s o}(t)\right)$ utilizada no critério de falha de Dang Van é calculada conforme a equação (5.124), utilizando o conceito da máxima tensão de cisalhamento de Tresca:

$$
\tau_{m e s o}(t)=\frac{1}{2}\left(S_{m e s o, 1}(t)-S_{m e s o, 3}(t)\right)
$$

Onde

$$
\begin{aligned}
& S_{m e s o, 1}(t) \text { : Maior tensão principal deviatórica mesoscópica no instante " } t \text { " } \\
& S_{m e s o, 3}(t) \text { : Menor tensão principal deviatórica mesoscópica no instante " } t \text { " }
\end{aligned}
$$

As tensões $S_{m e s o, 1}$ e $S_{m e s o, 3}$ são as raízes da equação (5.125), solucionada para cada instante de tempo, sendo $S_{\text {meso, } 1}$ a maior raiz e $S_{\text {meso }, 3}$ a menor raiz. As constantes $I_{1}, I_{2}$ e $I_{3}$ são calculadas conforme a equação 5.126, utilizando as 9 quantidades de dentro do tensor $\underline{S}_{m e s o}\left(S_{m e s o, 11}, S_{m e s o, 12}, S_{m e s o, 13}, S_{m e s o, 21}, S_{m e s o, 22}, S_{m e s o, 23}, S_{m e s o, 31}, S_{m e s o, 32}\right.$ e $\left.S_{m e s o, 33}\right)$.

$$
x^{3}-I_{1} x^{2}+I_{2} x-I_{3}=0
$$

$$
\begin{aligned}
I_{1}= & S_{\text {meso }, 11}+S_{\text {meso }, 22}+S_{\text {meso }, 33} \\
I_{2}= & S_{\text {meso }, 11} \cdot S_{\text {meso }, 22}+S_{\text {meso }, 22} \cdot S_{\text {meso }, 33}+S_{\text {meso }, 33} \cdot S_{\text {meso }, 11-} \\
& -\left(S_{\text {meso }, 12}\right)^{2}-\left(S_{\text {meso }, 23}\right)^{2}-\left(S_{\text {meso }, 13}\right)^{2} \\
I_{3}= & S_{\text {meso }, 11} \cdot S_{\text {meso }, 22} \cdot S_{\text {meso }, 33}+2 S_{\text {meso }, 12} \cdot S_{\text {meso }, 23} \cdot S_{\text {meso }, 13-} \\
& -S_{\text {meso }, 11}\left(S_{\text {meso }, 23}\right)^{2}-S_{\text {meso }, 22}\left(S_{\text {meso }, 13}\right)^{2}-S_{\text {meso }, 33}\left(S_{\text {meso }, 12}\right)^{2}
\end{aligned}
$$

A imagem 5.46 ilustra quais as tensões utilizadas no critério de Dang Van. A tensão de cisalhamento desta imagem é calculada pela equação (5.124) e a tensão hidrostática ${ }^{58}$ da imagem é calculada pela equação (5.118).

\footnotetext{
${ }^{57}$ Instantânea.

${ }^{58}$ Sendo a tensão hidrostática mesoscópica igual à tensão hidrostática macroscópica
} 


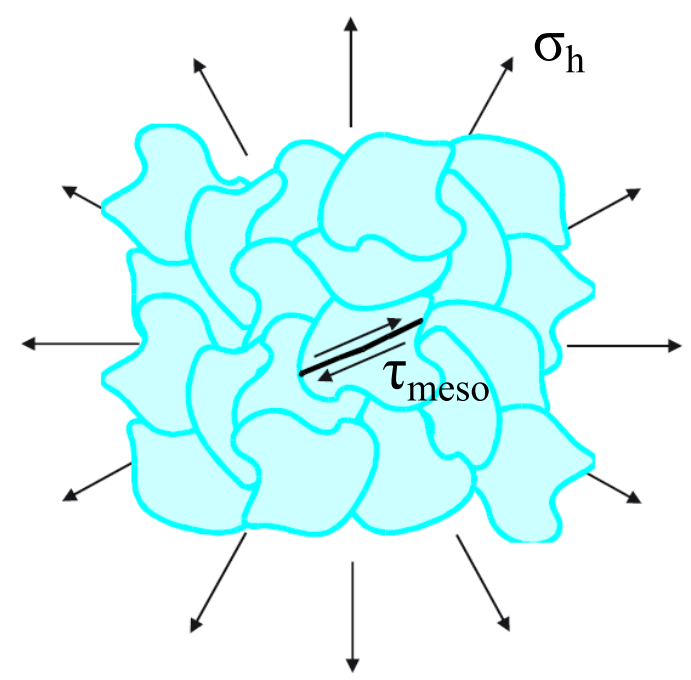

Figura 5.46 Tensão cisalhante e hidrostática utilizadas no critério de Dang Van (adaptado de Heyes (2011)).

O critério de Dang Van é construido sob uma abordagem mesoscópica e assume que a tensão cisalhante mesoscópica $\left(\tau_{\text {meso }}(t)\right)$ em um grão é responsável pela nucleação da trinca em bandas de deslizamento dentro do grão, e a tensão hidrostática mesoscópica $\left(\sigma_{\text {meso }, h}(t)\right)$ irá influenciar a abertura dessas trincas. O modelo de Dang Van utiliza uma combinação de $\tau_{\text {meso }}(t)$ e $\sigma_{h}(t)$ para calcular uma "tensão equivalente" e compara esta com o limite de fadiga ao cisalhamento $\left(\beta_{D V}\right)$. Desta forma, a falha ${ }^{59}$ por fadiga irá ocorrer se a equação abaixo for satisfeita em qualquer instante de tempo:

$$
\begin{aligned}
\tau_{D V}(t) & \geq \beta_{D V} \\
\tau_{m e s o}(t)+\alpha_{D V} \cdot \sigma_{h}(t) & \geq \beta_{D V}
\end{aligned}
$$

Lee et al. (2011) prefere utilizar outra forma de equação, a equação (5.128), que indica que a falha por fadiga irá ocorrer se em algum instante de tempo a equação abaixo for satisfeita:

$$
\max _{t}\left\{\tau_{m e s o}(t)+\alpha_{D V} \cdot \sigma_{h}(t)\right\} \geq \beta_{D V}
$$

Onde

$\alpha_{D V}:$ Fator de sensibilidade à tensão hidrostática de Dang Van

$\beta_{D V}:$ Limite de fadiga utilizado no critério de Dang Van

Um caminho de carregamento que permanece entre as duas linhas de falha, que são as fronteiras de falha, gera uma vida infinita do componente/estrutura. Por outro lado, qualquer carregamento que se estende fora da linha de dano irá causar falha por fadiga 60 porque

\footnotetext{
${ }^{59}$ Ou dano.

${ }^{60}$ Entende-se aqui por "falha" a nucleação e crescimento de uma trinca por fadiga, podendo ocasionar fratura ou não da seção transversal do componente/estrutura.
} 
ocorrem deformações plásticas mesoscópicas (Socie \& Marquis, 2000). Isto está ilustrado na figura 5.47 .

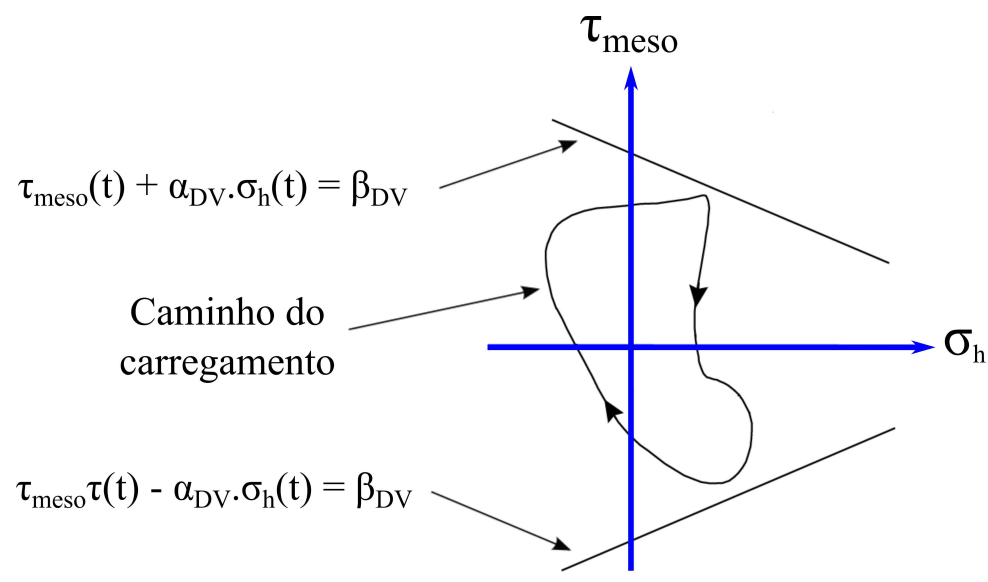

a) Falha não ocorre

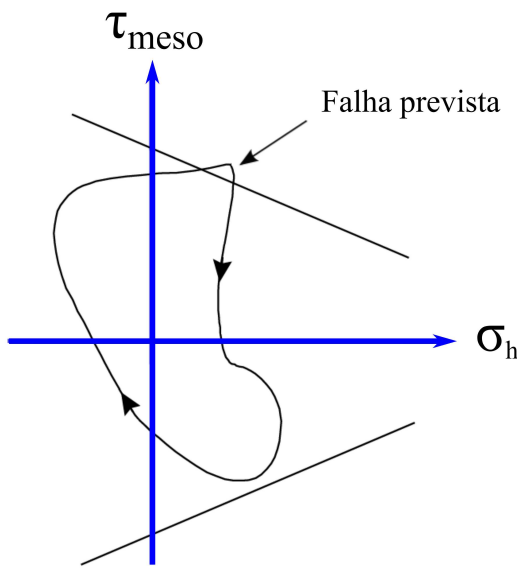

b) Falha ocorre

Figura 5.47 Critério de Dang Van para sucesso ou falha.

Seja um componente não entalhado com características diferentes do espécime padronizado. Seja seu limite de fadiga sob tração-compressão alternado igual à $A_{-1}$ e seja o seu limite de fadiga sob tração-compressão pulsante igual à $A_{0}$. Ambos os limites de fadiga acontecem em $N_{E}$ ciclos. A reta que representa o critério de Dang Van, reta superior apresentada na figura 5.47 passa por dois pontos: $\left(-\frac{A_{-1}}{3}, \frac{A_{-1}}{2}\right)$ e $\left(\frac{2}{3} A_{0}, \frac{A_{0}}{2}\right)$. Assim, as contantes $\alpha_{D V} \mathrm{e}$ $\beta_{D V}$ podem ser obtidas utilizando estes dois pontos na equação (5.129), formando um sistema de duas equações e duas incógnitas, que são encontradas utilizando a equação (5.130). Mais detalhes sobre o processo de obtenção dos parâmetros $\alpha_{D V}$ e $\beta_{D V}$ podem ser encontrados em Lee et al. (2011, pp.203) e Socie \& Marquis (2000, pp.153).

$$
\begin{gathered}
\tau_{\text {meso }}(t)+\alpha_{D V} \cdot \sigma_{h}(t)=\beta_{D V} \\
\alpha_{D V}=\frac{3\left(A_{-1}-A_{0}\right)}{2\left(2 A_{0}+A_{-1}\right)} \quad \beta_{D V}=\frac{A_{-1}}{2}\left(1-\frac{A_{-1}-A_{0}}{2 A_{0}+A_{-1}}\right)
\end{gathered}
$$

De acordo com Papuga (2005), Fojtík (2011) e de Castro \& Meggiolaro (2009a pp.438), se o engenheiro possuir o valor o limite de fadiga sob tração-compressão alternada $\left(A_{-1}\right)$ e o limite de fadiga sob torção alternada $\left(T_{-1}\right)$, então as constantes do critério de Dang Van são encontradas utilizando a equação (5.131). Desta forma, se a equação (5.128) for satisfeita então isto indica que a falha por fadiga ocorrerá em um número de ciclos menor ou igual à $N_{E}$ ciclos. Caso a equação (5.128) não for satisfeita, então isto representa que a falha por fadiga ocorrerá em um número de ciclos maior que $N_{E}$ ciclos ou então não 
ocorrerá (pois a tensão equivalente $\tau_{D V}(t)$ será muito mais baixa do que o limite de fadiga $\left.\beta_{D V}\right)$.

$$
\alpha_{D V}=\left(3 \frac{T_{-1}}{A_{-1}}-\frac{3}{2}\right) \quad \beta_{D V}=T_{-1}
$$

O critério de Dang Van tem como objetivo ser um método para prever o limite de fadiga ${ }^{61}\left(\beta_{D V}\right)$ sob situações de carregamento complexo. Entretanto, algumas vezes ele é utilizado/aplicado também na vida longa mas em regime de vida finita (i.e. em fadiga de alto ciclo) (Socie \& Marquis, 2000, pp.145). Para isto, utiliza-se diferentes valores de $\alpha_{D V}$ e $\beta_{D V}$, sendo estes determinados para diferentes faixas de vida em fadiga. Por exemplo, para saber se um determinado componente vai falhar em $10^{5}$ ciclos, é necessário obter o valor da tensão de tração-compressão alternada que gera fralha no componente em $10^{5} \operatorname{ciclos}\left(A_{-1}\left(@ 10^{5}\right)\right)$ e também a tensão de cisalhamento alternada que gera falha no componente em $10^{5}$ ciclos ( $\left.T_{-1}\left(@ 10^{5}\right)\right)$. Estes valores são então utilizados na equação (5.131) para determinação de $\alpha_{D V}$ e $\beta_{D V}$. Desta forma, se a equação (5.128) for satisfeita então isto indica que a falha por fadiga ocorrerá em um número de ciclos menor ou igual à $10^{5}$ ciclos. Caso a equação (5.128) não for satisfeita, então isto representa que a falha por fadiga ocorrerá em um número de ciclos maior que $10^{5}$ ciclos ou então não ocorrerá (pois a tensão equivalente $\tau_{D V}(t)$ será muito mais baixa do que o limite de fadiga $\beta_{D V}$ ).

É muito comum utilizar o fator de segurança para medir o quão seguro está o componente/estrutura da iniciação de uma trinca por fadiga. Assim, um fator de segurança é calculado para cada instante de tempo "t", conforme segue:

$$
S F(t)=\frac{\beta_{D V}}{\tau_{m e s o}(t)+\alpha_{D V} \cdot \sigma_{h}(t)}
$$

É muito importante entender que a seguinte sequência de cálculo é necessária para se proceder corretamente com o modelo de Dang Van:

1) Ter o tensor de tensão macroscópica ( $\sigma(t)$ ) de cada nó superficial, para cada instante de tempo. Esta informação é obtida através da Análise por Elementos Finitos;

2) Calcular a tensão de von Mises ( $\sigma_{V M}$ ) através da equação (5.123) e o valor do parâmetro $\alpha$ para cada time step;

3) Obter o valor de $\underline{\alpha}^{*}$ através da equação (5.121), e consequentemente o valor de $\underline{\rho}^{*}$;

4) Calcular o valor de $\underline{S}_{\text {meso }}(t)$ através da equação (5.120) para cada time step;

5) Calcular o valor de $S_{m e s o, 1}(t)$ e $S_{m e s o, 2}(t)$ para cada time step;

6) Calcular o valor de $\tau_{\text {meso }}(t)$ através da equação (5.124) para cada time step;

7) Calcular o valor de $\sigma_{h}(t)$ através da equação (5.118) para cada time step;

\footnotetext{
${ }^{61}$ Que acontece em $N_{E}$ ciclos.
} 
8) Calcular o valor da "tensão equivalente" $\left(\tau_{D V}(t)\right)$, também intitulada tensão de Dang Van, representada pelo lado esquerdo da equação (5.127), para cada time step;

$\mathrm{O}$ autor acredita que em um componente entalhado deve-se utilizar as 6 componentes de tensão $\sigma_{x}, \sigma_{y}, \sigma_{z}, \tau_{x y}, \tau_{y z}$ e $\tau_{x z}$ (obtidas através da equação 5.21) nas equações (5.113), (5.115) e (5.116, ao invés das tensões $\sigma_{x}^{e}, \sigma_{y}^{e}, \sigma_{z}^{e}, \tau_{x y}^{e}, \tau_{y z}^{e}$ e $\tau_{x z}^{e}$ ). Desta forma, acredita-se que o efeito de entalhe estaria sendo automaticamente contabilizado, da mesma forma que acontece com outros modelos de fadiga multiaxial descritos na seção 5.5 .

Em suma, o critério de Dang Van funciona em um nível mesoscópico, i.e., em uma escala de um ou dois grãos (MSC.Software, 2008). Ele é baseado na premissa que há plasticidade em um nível mesoscópico, dentro de um ${ }^{62}$ grão, antes de ocorrer uma acomodação. Depois da acomodação, i.e. após vários ciclos de carregamento terem ocorrido, os fatores importantes que controlam a fadiga são a Tensão Cisalhante Mesoscópica $\left(\tau_{\text {meso }}(t)\right)$ e a Tensão Hidrostática $\left(\sigma_{h}(t)\right)$. Este modelo tem a desvantagem de possuir um método complicado de estimar a tensão residual estabilidaza, representada por $\rho^{*}$.

Este é um critério utilizado em fadiga de alto ciclo e na verdade determina se o componente irá ou não falhar por fadiga 63 . Em outras palavras, este é um critério de "passa ou não passa", onde apenas consegue-se saber se haverá uma falha ou não. Entretanto, se os cálculos indicarem que uma falha ocorrerá, não é possível estimar com qual número de ciclos a falha ocorrerá.

Este critério pode ser aplicado em componentes sujeitos à estado triaxial de tensões cíclicas e aplicado a carregamento multiaxial proporcional e não proporcional (Karolczuk \& Macha, 2005; MSC.Software, 2008; MSC.Software, sd). Este critério é perfeitamente aplicável em carregamentos de amplitude variáveis, por isso é comumente utilizado em análise de fadiga de componentes sujeitos à vibração, como componentes automotivos, aeronáuticos, navais e máquinas em geral (Heyes, 2011; MSC.Software, 2008). A figura 5.48 apresenta a análise de fadiga de um eixo sujeito à um carregamento axial variável e também à um carregamento torcional variável, ambos com amplitude variável e não proporcional. Esta imagem representa a análise de fadiga utilizando o software nCode Design Life (HBM). O lado superior direito apresenta o fator de segurança de cada ponto (nó) do eixo. A parte inferior direita ilustra o gráfico $\tau-\sigma_{h}$ contendo os pontos de todos os time steps da análise. Em nenhum momento o caminho do carregamento ultrapassa a linha azul limite, portanto não ocorrerá falha por fadiga neste eixo de acordo com o modelo de Dang Van.

Este critério é amplamente utilizado e ele resulta em uma ótima correlação entre a previsão e os ensaios experimentias. Papuga (2005) apresenta um amplo estudo sobre a precisão

\footnotetext{
${ }^{62} \mathrm{Ou}$ mais de um, porém poucos grãos.

${ }^{63}$ Entende-se aqui por "falha" a nucleação e crescimento de uma trinca por fadiga, podendo ocasionar fratura ou não da seção transversal do componente/estrutura.
} 
de diversos modelos de fadiga multiaxial baseados em tensão e o critério de Dang Van é um dos que apresentam melhor correlação com dados experimentais, onde os resultados possuem baixo desvio padrão. Na tese de doutorado de Papuga (2005), é possível perceber que este critério está entre os melhores, sendo mais preciso que o critério de Sines, de Crossland, de McDiarmid, de Findley, de Matake, de Kenmeugne e que o critério de Spagnoli. O critério de Dang Van empata com o critério de Papadopoulos e é menos preciso que os critérios de Zenner \& Liu, o critério de GAM (Gonçalves et al., 2005) e o critério de Papuga (Papuga, 2005). 


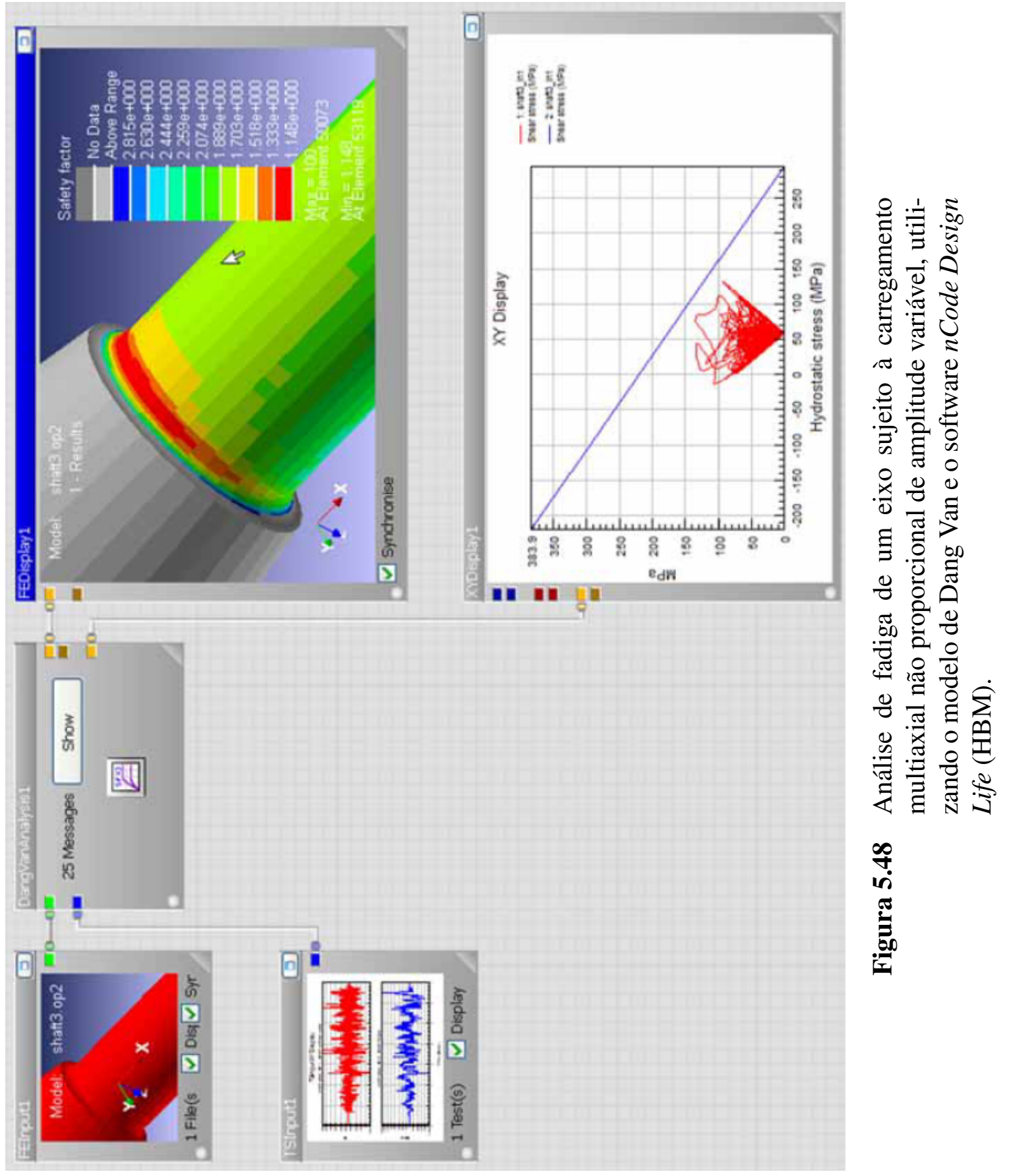


O método de Dang Van está implementado em vários softwares comerciais de fadiga baseada em Elementos Finitos (FE-Based Fatigue Softwares), como os softwares fe-safe (Dassault Systèmes), nCode Design Life (HBM), MSC Nastran Embedded Fatigue (MSC.Software), NX Durability (Siemens) e LMS Virtual.Lab Durability (Siemens).

O modelo de Dang Van tem sido muito estudado e é o modelo de fadiga multiaxial mais utilizado na indústria automotiva, devido a sua excelente correlação com dados experimentais e por estar incluído nos softwares comerciais de fadiga baseada em Elementos Finitos supracitados.

\subsection{Conclusões do Capítulo 5}

Estados de tensão multiaxial são muito comuns em estruturas e componentes na engenharia. Carregamento proporcional é caracterizado quando a orientação dos eixos principais permanecem constante durante todo o histórico de carregamento, enquanto no carregamento não proporcional a direção das tensões principais variam durante cada o histórico de carregamento. Carregamento não proporcional envolve grande dificuldade e geralmente produz encruamento cíclico adicional, quando comparado com carregamento proporcional.

Uma das melhores maneiras, se não a única, de se avaliar se um carregamento é proporcional ou não é através da razão de biaxialidade "a" e da orientação da tensão principal máxima " $\phi_{p}{ }$ ". Estes dois parâmetros são calculados após a transformação do tensor de tensão 3D dos nós superficiais em estado plano de tensões.

Na revisão bibliográfica realizada neste trabalho não foi encontrado um método comprovado cientificamente para contabilizar o efeito de entalhe em componentes entalhados sujeitos à carregamentos multiaxiais. Neste trabalho foi indicado uma alternativa para a contabilização do efeito de entalhe através do fator de entalhe $n_{K}$ (seção 5.3), que pode ser aplicado tanto em carregamento uniaxial quanto em carregamento multiaxial. Para isto, utiliza-se todas as componentes do tensor de tensão dos nós superficiais e subsuperficiais.

O engenheiro não deve ignorar a presença de um estados de tensão multiaxial, uma vez que eles podem, e muito, diminuir significantemente a vida em fadiga, principalmente sob carregamentos não proporcionais. O estado de tensão na raiz de um entalhe, por exemplo, é na mairoria das vezes multiaxial, mesmo sobre quando a estrutura está sujeita à um carregamento externo em uma única direção.

Existem dezenas de critérios de fadiga multiaxial, podendo eles ser classificados em critérios baseados em tensão equivalente, critérios baseados em plano crítico e critérios baseados em tensão mesoscópica. Apenas os modelos mais conhecidos e os que geram resultados 
com maior correlação com os dados experimentais foram relatados aqui. Todos os modelos apresentados nesta dissertação estão inclusos em softwares comerciais de análise de fadiga baseados em Elementos Finitos. Uma descrição detalhada destes softwares pode ser encontrada na seção 6.2 .

Os modelos baseados em tensão equivalente não consegue contabilizar o efeito deletério na vida em fadiga causado por carregamento não-proporcional e portanto nunca devem ser utilizados com este tipo de carregamento. A figura 5.7 e a tabela 5.1 mostram que um carregamento não-proporcional gera vida em fadiga muito menor do que carregamentos proporcionais. Portanto, carregamento não-proporcional deve ser sempre analisado utilizando-se critérios de fadiga que conseguem contabilizar os efeitos deletérios que este tipo de carregamento causa. Adicionalmente, existem carregamentos não-proporcionais que causam maior dano por fadiga do que outros, conforme apresenta a tabela 5.1, e isto também deve ser levado em consideração. Critérios de fadiga baseados em plano crítico refletem a natureza física do dano por fadiga e podem prever muito adequadamente a vida em fadiga sob carregamentos proporcional e não-proporcional, inclusive a orientação do plano de iniciação de trinca. O modelo de Findley gera boas previsões e é um dos mais conhecidos dentre os critérios de fadiba baseados em plano crítico, por isto foi apresentado detalhadamente neste trabalho. Critérios de fadiga baseados em tensão mesoscípica também conseguem prever adequadamente a vida em fadiga sob carregamentos proporcional e não-proporcional. $\mathrm{O}$ modelo de Dang Van também foi apresentado em detalhes por ser o critério baseado em tensão mesoscópica mais conhecido e por gerar excelentes estimativas.

O autor recomenda que o engenheiro faça seguinte procedimento ao realizar uma análise de fadiga de uma estrutura: uma análise uniaxial deve ser inicialmente realizada afim de se encontrar os locais de maior dano. Para cada local crítico, plote o gráfico de razão de biaxialide VS tensão principal máxima (figura 5.14b) e o gráfico de orientação $\phi_{p}$ VS tensão principal máxima (figura 5.14c). Se a razão de biaxialidade e a orientação $\phi_{p}$ não variar consideravelmente, então o carregamento será proporcional e um método baseado em tensão equivalente poderá ser utilizado para solucionar o problema. Caso contrário, haverá estado de tensão multiaxial não proporcional e a utilização de um critério de plano crítico ou de tensão mesoscópica é necessária.

Os modelos de fadiga multiaxial relatados nos livros e artigos utilizados nesta dissertação são apresentados como um critério de "passa ou não passa". Pouquíssimas são as publicações que apresentam um critério de maneira que ele possa ser utilizado para a região de vida finita (por exemplo $10^{3} \leq N \leq 10^{6}$ ). E dentre as poucas publicações encontradas, nenhuma delas informou como se calcular os 3 parâmetros da curva tensão-vida: coeficiente de resistência à fadiga, o expoente de resistência à fadiga e o limite de fadiga. $\mathrm{O}$ autor propôs neste trabalho uma maneira de se utilizar cada critério de fadiga multiaxial também em vida finita, ou seja, utilizá-los para prever o número de ciclos que ocorrerá a falha $(N)$. Adicionalmente, o autor 
também propôs um método para se estimar os valores dos 3 parâmetros da curva tensão-vida de componentes genéricos. 


\section{Capítulo 6}

\section{Aplicação da Metodologia}

\subsection{Introdução}

Um dos objetivos deste trabalho é desenvolver um procedimento para análise de fadiga de componentes que possa ser utilizado juntamente com resultados de Análises por Elementos Finitos e que inclua critérios de fadiga multiaxial. Tal procedimento foi descrito nos capítulos 4 e 5, que apresentaram uma metodologia para análise de durabilidade considerando fadiga uni e multiaxial, incluindo como utilizar os resultados de tensão de análise por Elementos Finitos como dado de entrada de uma análise de fadiga.

Outro objetivo deste trabalho é aplicar a metodologia desenvolvida em exemplos práticos, controlados, a fim de corrobar a validade da mesma. Desta forma, um dos requisitos para isso é possuir total controle dos parâmetros do cômputo da vida em fadiga para verificar a validade da metodologia. Tal requisito não é satisfeito pelos softwares de fadiga comerciais, que são tratados na seção 6.2. Por esta razão, foi desenvolvido nesta dissertação um software em linguagem $M A T L A B^{\circledR}$, denominado $x$ Durability, cujo objetivo é realizar a previsão da vida em fadiga uni e multiaxial de uma estrutura utilizando resultados de análise por Elementos Finitos.

O software $x$ Durability lê os resultados de tensão de uma análise estrutural via Elementos Finitos realizada pelo software $A N S Y S^{\circledR}$ e utiliza estes dados para efetuar o cálculo da vida em fadiga da estrutura objeto de análise. O software utiliza o conceito do Método da Curva S$N$ Sintética onde a Curva S-N Espécime é modificada pelos fatores modificadores, conforme ilustrado nos capítulos 4 e 5. Neste software estão implementados dois critérios de fadiga multiaxial, o critério de von Mises e o critério de Findley. O usuário pode escolher qual critério utilizar.

O software $x$ Durability possui 1129 linhas de comando e está dividido em 24 módulos. Cada módulo de tem a função de executar uma determinada manipulação dentro do soft- 
ware. Uma cópia do software Durability foi gravada dentro de um CD e está sendo entregue anexa a esta dissertação. O software completo compreende 24 módulos, cada módulo sendo compreendido como um arquivo com extensão *.m (arquivo MATLAB ${ }^{\circledR}$ ) sendo o arquivo $x$ Durability_1_main.m o corpo do software. Para se executar o software deve-se realizar o input dos parâmetros na seção INPUT DATA e executar o arquivo xDurability_1_main.m dentro do $M A T L A B^{\circledR}$. Existe um exemplo já com todos os parâmetros especificados dentro da pasta EXEMPLO1. Para executar este exemplo é preciso apenas executar o arquivo xDurability_1_main.m dentro do MATLAB ${ }^{\circledR}$.

Autorizo a reprodução e divulgação total ou parcial deste trabalho, por qualquer meio convencional ou eletrônico, para fins de estudo e pesquisa, desde que citada a fonte. Autorizo também o uso do código-fonte da subrotina contida dentro do $\mathrm{CD}$ anexo à esta dissertação, para fins de estudo e pesquisa, desde que citada a fonte.

\subsection{Softwares Comerciais para Análise de Fadiga}

Foi realizado neste trabalho uma pesquisa de mercado sobre os softwares comerciais de análise de fadiga baseada em Elementos Finitos existentes no mercado. Eu encontrei 7 pós-processadores de fadiga comerciais que são bastante conhecidos no período que eu estava escrevendo esta dissertação. Esta seção apresenta uma descrição desses softwares comerciais. Nessa descrição geral não estão considerados os softwares desenvolvidos para análise de fadiga baseados em Elementos Finitos (FE-Based Fatigue Softwares). A descrição geral das características de cada software estão relatadas a seguir.

\subsection{1 nCode DesignLife}

Desenvolvido pela empresa $H B M$, onCode DesignLife foi o primeiro software comercial de análise de fadiga baseado em Elementos Finitos. A análise de fadiga pode ser realizada utilizando resultados de Análise por Elementos Finitos, provenientes de análises estáticas lineares ou transientes (tanto pelo método da integração direta quanto pelo método da superposição modal).

O software $n$ Code DesignLife permite analisar estruturas utilizando tanto o Método TensãoVida quanto o Método Deformação-Vida Dentro do Método Tensão-Vida, é possível definir a Curva $S$ - $N$ Espécime de 7 maneiras distintas. O efeito da tensão média pode ser contabilizado utilizando o diagrama de Haigh, através do Modelo de Goodman, do Modelo de Gerber ou da interpolação de multiplas curvas. Uma das grandes vantagens deste software é contabilizar o efeito do entalhe através da diretriz do FKM através do Método do Gradiente 
de Tensão Relativo (conforme apresentado nas seções 4.4.2 e 5.3). Dentro da área de fadiga multiaxial o software utiliza critérios baseados apenas na tensão superficial $]^{1}$ ou utilizando as 6 componentes de tensão de cada nó superficial.

Dentro do Método Deformação-Vida, é possível definir a Curva S-N Espécime através do método patrão, definindo um conjunto de curvas que variam com a tensão média, que variam com a razão de tensão $(R)$ ou que variam com a temperatura. es. É possível especificar a contabilização da tensão média através do Modelo de Morrow, Smith-Watson-Topper ou através da interpolacão de curvas múltiplas. Dentro de fadiga multiaxial, é possível utilizar a correção de plastificação de entalhe para transformar as pseudo tensões e pseudo deformações em tensões reais e deformações reais, utilizando a regra de Neuber, Glinka, Hoffman-Seeger ou Seeger-Heuler, juntamente com o modelo de plasticidade multiaxial com a regra de encruamento cinemático de Jiang-Sehitoglu. Aqui também é utilizado o método de Wang-Brown para a contabilização dos ciclos de carregamentos (Heyes, 2011).

O software $n$ Code DesgignLife permite calcular a vida em fadiga de estruturas que que já possuem uma pré-trinca inicial ${ }^{2}$ utilizando a Mecânica da Fratura Linear Elástica (MFLE) Ele utiliza regras de crescimento de trinca de Paris, Walker, Forman e NASGRO. Para isso, o usuário devev selecionar uma geometria, dentre várias presentes em sua biblioteca, ou fornecer os fatores de intensidade de tensão.

O software $n$ Code DesgignLife também possibilita a análise de fadiga em estruturas unidas por soldagem a arco, e para isto utiliza o Método de Fermer (também intitulado de Método Volvo), utilizado com estruturas feitas de chapas unidas por soldagem contínua 3 Para mais informações sobre o Método de Fermer ver Lee et al. (2011, cap.10). O software também permite a previsão da vida em fadiga de solda a ponto, utilizando elementos unidimensionais rígidos (rigid beam). Informações detalhadas sobre a previsão de fadiga de solda a ponto pode ser encontradas em Lee et al. (2005, cap.7) e Lee et al. (2011, cap.11). De acordo com Heyes (2011), o Critério de Morel e o Critério de Yung-Li Lee para avaliação da vida de estruturas soldadas a arco serão implementados na próxima versão do software.

Também tem a capacidade de realizar análise de fadiga no domínio da frequência (Vibration Fatigue), mais rápida que análise no domínio do tempo, sendo especialmente preferidas quando o carregamento não é determinístico como carregamentos de vento ou ondas do mar. Também é possível realizar análise de fadiga termo-mecânica considerando o fenômeno de fluência (métodos de creep de Chaboche e Larson-Miller), fadiga em compósitos com fibras curtas (ex: termoplásticos reforçados com fibra) e também fadiga de ligações que são coladas 4

\footnotetext{
1.e., o software transforma cada nó superficial do modelo em um estado biaxial de tensões, conforme ilustrado pelas figuras $5.11 \mathrm{e} 5.12$

i.e., estruturas com trincas de estágio II

${ }^{3}$ Seam welding

${ }^{4} \mathrm{~A}$ base teórica deste método foi desenvolvida pelo Grupo Volvo.
} 
O software também permite o tratamento de sinais provenientes de campo metidos através de strain gages, possibilitando assim a contagem do número de ciclos e do uso de um critério de fadiga para a previsão da vida em fadiga. O nCode DesgignLife também possui um gerenciador de banco de dados de materiais e de um sistema chamado "Back Calculation to Target Life", que realiza o processo de cálculo inverso e apresenta qual deve ser o nível de tensão alternada equivalente para atingir a vida desejada. O software suporta dados de resultados de Análise por Elementos Finitos de vários softwares FEA, incluindo ANSYS, Nastran, Abaqus e RADIOSS.

\subsubsection{MSC.Fatigue}

Há muitos anos a MSC.Software fez uma parceria com a nCode (Sheffield, Inglaterra) com o objetivo de desenvolver um pós-processador comercial para análise de fadiga. A MSC.Software tinha a função de desenvolver a interface gráfica e integrando este novo software ao MSC.Nastran enquanto a nCode desenvolveu a unidade central responsável pelos cálculos de fadiga e forneceu a integração com o ANSYS, Abaqus e I-deas. Assim nasceu o MSC.Fatigue. Após alguns anos esta parceria terminou e a MSC.Software seguiu sozinha melhorando o MSC.Fatigue enquanto a nCode seguiu vendendo o FE-Fatigue, que atualmente se chama $n$ Code DesgignLife.

O MSC.Fatigue é também bastante modular, possuindo o módulo Basic Stress-Life and Strain-Life, módulo Multiaxial, módulo Vibration, módulo Fracture, módulo Welds, módulo Wheels e módulo Utility. O software é totalmente integrado ao ambiente Nastran. Se o Nastran não está disponível, um módulo Pré e Pós necessita ser comprado junto com o módulo Basic de maneira que seja possível manipular e visualizar os resultados.

A análise de fadiga pode ser realizada utilizando resultados de Análise por Elementos Finitos, provenientes de análises estáticas lineares ou transientes (tanto pelo método da integração direta quanto pelo método da superposição modal). O software possui um gerenciador de banco de dados de material onde armazena as propriedades mecânicas estáticas e cíclicas de diversos materiais

O módulo Multiaxial permite análises através do Método Tensão-Vida utilizando o Critério da Tensão Principal Absoluta, o Critério da Tensão de Cisalhamento Sinalizada, o Critério de von Mises Sinalizado, o Critério de McDiarmid e o Critério de Dang Van. Entretanto, todos os 4 primeiros critérios supracitados são utilizados para análises de fator de segurança, ou seja, não é possível saber com quantos ciclos a estrutura falhará, apenas se ela falhará ou não. Este é uma das principais desvantagens do MSC.Fatigue. Por outro lado, o software possui também critérios de fadiga multiaxial baseados no Método DeformaçãoVida, que estimam o número de ciclos que ocorrerá a vida de iniciação de uma trinca de 
engenharia a partir de um estado multiaxial. Os seguintes critérios, baseados na idéia de plano crítico, estão incluídos no MSC.Fatigue: Critério da Deformação Principal Máxima, Critério da Máxima Deformação de Cisalhamento, Critério de SWT-Bannantine, Critério de Fatemi-Socie e Critério de Wang-Brown (com e sem correção da tensão média). Dentro de fadiga multiaxial, é possível utilizar a correção de plastificação de entalhe utilizando a regra de Klann-Tipton-Cordes, Hoffman-Seeger ou Buczynski-Glinka. Este módulo também utiliza o método Rainflow Multiaxial Wang\&Brown.

O módulo Vibration calcula a vida em fadiga da estrutura quando sujeita a carregamentos em forma de PSD. Neste módulo, a tensão/deformação utilizada para os cálculos é a Tensão Principal Máxima, a Máxima Tensão de Cisalhamento ou a Tensão de von Mises Sinalizada. Os modelos de contabilização da tensão média que podem ser utilizados são o Modelo de Goodman e de Gerber. A Função Densidade de Probabilidade (PDF) são obtidas através dos ciclos de Rainflow e a regra de acúmulo de dano linear de Palmgren-Miner é utilizada, sendo que o usuário escolhe se a falha ocorrerá quando $\mathrm{D}=1$ ou em qualquer outro valor diferente. É possível também fazer as correções de rugosidade superficial. Multiplos métodos de análise podem ser utilizados: Dirlik, Narrow Band, Wirsching, Steinberg, Tunna, Hancock e Kam \& Do

O módulo Weld e possibilita a análise de fadiga em soldas, e para isto utiliza tanto Método Nominal (Normas inglesas BS5400 e BS7608) quanto o Método de Fermer 5 que analisa o modelo FE feito de shell 6 . O módulo Spot Weld permite a previsão da vida em fadiga de solda a ponto, utilizando resultados de FEA estáticos ou dinâmicos juntamente com o Método Tensão-Vida. O módulo utiliza elementos unidimensionais rígidos (rigid beam) para simbolizar o ponto de solda e utiliza as forças $F_{x}, F_{y}$ e $F_{z}$ e os momentos $M_{x x}, M_{y y}$ e $M_{z z}$ neste elemento para prever sua vida em fadiga. Informações detalhadas sobre este modelo pode ser encontradas em Lee et al. (2005, cap.7) e Lee et al. (2011, cap.11).

O mótulo Fracture possibilita a análise da fase do crescimento de trincas através da Mecânica da Fratura Linear Elástica. O MSC.Fatigue foi um dos primeiros software a possibilitar a análise de crescimento de trincas por fadiga e provavelmente é um dos melhores softwares para este tipo de análise. O software consegue contabilizar o efeito da tensão média e permite quantificar os efeitos de fechamento e abertura de trinca. Também permite a contagem Rainflow obedecendo a sequência de carregamento e também reorganiza os ciclos de maneira a analisar computar os ciclos de maior amplitude de tensão primeiro. O software também possui interface para o software NASA/FLAGRO.

O MSC.Fatigue também possui o módulo Strain-Gauge que permite extrair valores de deformações de quaisquer pontos na superfície de um componente para ser então comparado

\footnotetext{
5 também intitulado por Método Volvo. Para mais informações ler Lee et al. (2011, cap.10)

${ }^{6}$ Cuja soldagem foi feita por solda contínua (seam welding).
} 
com as deformações do componente real. Há também o módulo Wheels que possui facilidades para lidar com componentes que sofrem carregamento cíclico. Neste módulo é possível utilizar critérios de fadiga multiaxial baseados em plano crítico, assim como carregamentos de origem determinística (stress-time histories) ou aleatória (PSDs). O módulo Utilities permite realizar uma série de manipulações que facilitam a análise de fadiga como manipulação de carregamentos, display gráfico e análise de fadiga rápida e simplificada. Mais informações sobre este módulo pode ser encontrada em www.mscsoftware.com/product/msc-fatigue.

Embora caro, o software oferece praticamente todas as soluções, exceto para fadiga termo-mecânica com fluência. O único efeito térmico incorporado é a mudança das curvas $\mathrm{S}-\mathrm{N}$ com o uma temperatura alta específica, exatamente conforme apresentado na seção 4.3 .9 .

No ano de 2013 a MSC.Software lançou seu mais novo produto, o MSC.Nastran Embedded Fatigue, que é o MSC.Fatigue totalmente incorporado ao MSC.Nastran. A grande vantagem deste software é que não é necessário a transferência dos resultados das análises FE para os softwares de fadiga baseados em FEA. Isto faz com que a análise de fadiga seja realizada à uma velocidade muito mais rápida. Obviamente, isto só acontece se as análises FE forem realizadas dentro do software MSC.Nastran.

\subsection{3 fe-safe}

O software fe-safe tem sido desenvolvido desde o começo da década de 1990 pela empresa safe technology, situada em Sheffield-UK e fundada por John Draper, atual CEO.

O fe-safe é distribuído individualmente e também junto com o software FEA Abaqus. O software também é dividido em módulos: fe-safe (módulo principal), Verity in fe-safe, fe-safe/TMF, fe-safe/TURBOlife, fe-safe/Composites, fe-safe/Rubber e fe-safe/True-Load. Entretanto, o módulo principal fe-safe possui incluso uma grande quantidade de ferramentas que conseguem atender a necessidade da maioria das análises de fadiga realizadas no dia-adia. Esta é a grande vantagem do fe-safe.

O fe-safe permite lidar com até 4000 históricos de carregamento no tempo através da superposição de todos os históricos. O software permite ler resultados de análise elástica linear ou elasto-plástica, linear ou não linear. É possível realizar a superposição de resultados de tensão/deformação obtidos através de análises transientes via superposição modal.

Com relação à fadiga multiaxial baseada em tensão, o fe-safe consegue prever a vida em fadiga utilizando o Critério da Tensão Principal Absoluta e o Critério de Dang Van. Em fadiga multiaxial baseada em deformação, o software utiliza o Critério da Deformação 
Principal Máxima, Critério da Máxima Deformação de Cisalhamento e o Critério de BrownMiler, utilizando uma regra de Neuber multiaxial para a correção da plastificação nos entalhe e também de um modelo para a contabilização da plasticidade cíclica 7 . Um dos pontos a desejar do fe-safe é pouca quantidade de critérios de fadiga multiaxial baseados em tensão e em deformação e/ou um problema de marketing, pois não há informações detalhadas sobre os critérios implementados para os potenciais compradores do software.

O fe-safe analisa o efeito de entalhe utilizando a Teoria das Distâncias Críticas (mais informações em Santus (2007) e Susmel (2009)) e é o único software a utilizar esta metodologia. O método da Distância Crítica utiliza tensões subsuperficiais provenientes de FEA para contabilizar os efeitos do gradiente de tensão. Os dados são lidos de um modelo FE pelo fe-safe e o método pode ser aplicado a apenas alguns nós (Selecionados pelo usuário) ou a todo o modelo. Outra ferramenta interessante do fe-safe é a possibilidade de efetuar um plot de vetores, indicando assim a direção do plano crítico de cada nó de uma determinada região (selecionada pelo usuário) ou de todo o modelo. O comprimento e a cor de cada vetor indica o dano por fadiga.

O fe-safe utiliza a Abordagem pela Tensão Nominal (a norma inglesa BS-7608) como análise padrão de juntas soldadas continuamente (seam weld). Adicionalmente, a Safe Technology realizou uma parceria com o Instituto Battelle em 2005 e trouxe para o mercado o primeiro software comercial baseado na Abordagem de Tensão Estrutural para a análise de juntas soldadas, entitulado Verity. O módulo Verity permite avaliar a vida em estruturas soldadas, tanto com solda contínua (seam weld) quanto solda a ponto. Este é o único software que inclui o método de análise de fadiga de solda contínua desenvolvido pelo Dr. Pingsha Dong, que trabalha no Instituto Battelle. Este método é insensível à malha FE e é baseado na Abordagem da Tensão Estrutura $]^{8}$, sendo comumente chamado de Método de Dong, Método Battelle ou Método da Tensão Estrutural de Battelle. Este método foi então incluso no módulo Verity, possibilitando assim a aplicação deste método em resultados de Análise por Elementos Finitos. O método possui excelente correlação com resultados experimentais, por este motivo tem sido muito utilizado nos últimos anos. Mais informações sobre este método pode ser encontrado em Lee et al. (2011, cap.10). O módulo Verity também possibilita a análise de fadiga em pontos de soldas.

O fe-safe também calcula fadiga em estruturas sujeitas à carregamentos aleatórios, utilizando tanto históricos de tensões baseados em análises transientes no domínio do tempo quanto no domínio da frequência, sendo que neste o carregamento definido em forma de PSDs. O grupo de desenvolvimento do fe-safe desenvolveu um novo método para análise de fadiga baseado na frequência que utiliza a superposição de PSDs multiaxiais juntamente com análise baseada em plano crítico, utilizada até então apenas em análises de fadiga no

\footnotetext{
${ }^{7} \mathrm{O}$ desenvolvedor não relata quais modelos são utilizados.

${ }^{8}$ Structural Stress Approach ou Structural Stress Method (SSM).
} 
domínio do tempo. Este método, publicado oficialmente no final de 2013, está presente apenas no fe-safe e mais informações sobre o mesmo podem ser obtidas em de Morais Teixeira et al. (2013). Outro artigo sobre o assunto também será publicado em breve na SAE International, cujo autor principal também é o brasileiro especialista em fadiga Giovanni de Morais Teixeira.

O software também possibilita calcular a vida em fadiga considerando alta temperatura, fadiga termo-mecânica e fluência através dos módulos fe-safe/TMF e fe-safe/TURBOlife. Efeitos de manufatura como tensões residuais provenientes de estampagem, forjamento ou quaisquer outros processos de fabricação que introduzem tensões residuais, podem ser incluídos nas análises de fadiga, através do Critério de Dang Van. Para mais informações ler Facchinetti, Weber, Doudard \& Calloch (Facchinetti et al.). Virtual strain-gauges podem ser especificados no fe-safe para correlacionar com os dados medidos em campo/laboratório. $\mathrm{O}$ fe-safe também exporta o histórico de deformações calculado via software para ser aplicado no componente real. Assim, fica mais fácil validar os modelos FE através da comparação com dados medidos.

O fe-safe também tem a capacidade de combinar a variação nas propriedades de fadiga do material com a variabilidade no carregamento para calcular a probabilidade de sobrevivência de uma faixa de vida de serviço, gerando uma espécie de "Curva da Banheira". É possível importar dados do Abaqus, ANSYS, Nastran (MSC, NEi, NX), Beasy, Hypermesh, I-deas, FEMSYS e CADFIX.

O produto é fornecido com um manual, que é o melhor comparado com todos os outros pós-processadores de fadiga. Entretanto, a grande desvantagem do fe-safe é que este não possui um visualizador interno de dados de Elementos Finitos.

\subsubsection{FEMFAT}

O FEMFAT é um software desenvolvido nos últimos 20 anos pelo Engineering Center Steyer (ECS), que é um subsidiário da empresa Magna Steyr, localizada em St. Valentin, Austria. O programa é altamente modular, com preços moderados quando comparado ao MSC.Fatigue. De uma maneira geral, a maioria dos algorítmos utilizados dentro FEMFAT para realização dos cálculos está baseado em métodos desenvolvidos dentro do próprio Engineering Center Steyer. Isto pode ser verificado compando-se a teoria dos livros e artigos científicos da área de fadiga (ex: Lee et al. (2011), Socie \& Marquis (2000)) com a metodologia utilizada dentro do FEMFAT (apresentada no documento Magna Powertrain (2011)).

O módulo FEMFAT basic permite relizar análises utilizando o Método Tensão-Vida, baseando-se em análise de fadiga uniaxial baseada em tensão, (capítulo 4), podendo pre- 
ver a vida em fadiga, o dano ou o fator de segurança com relação ao limite de fadiga $9^{9}$. $O$ software FEMFAT utiliza uma metodologia praticamente idêntica àquela apresentada pelas figuras 4.24 e 4.25 para a obtenção da Curva $\sigma-N$ Local. Entretanto, além da Curva $S$-N Espécime da figura 4.25 ser transladada para cima e sua inclinação ser modificada, o ciclo do limite de fadiga $\left(N_{E}\right)$ também é modificado (i.e. a curva também é transladada para a direita ou esquerda). A metodologia utilizada no FEMFAT para o cálculo da Curva $\sigma-N$ Local é baseado nas pesquisas de Hück et al. (1981), Eichlseder (2000b) e Eichlseder (2000a). Mais informações sobre a metodologia utilizada no software FEMFAT pode ser encontrado nas 3 referências supracitadas e também em Magna Powertrain (2011). O software também calcula o diagrama de Haigh de uma maneira um pouco diferente do informado pela seção 4.3.10 (Diretriz FKM-Guideline (2003)), principalmente quando o metal analisado é semi-frágil ou frágil.

O módulo FEMFAT plast permite calcular a vida em fadiga quando ocorre deformação plástica uniaxial cíclica local.

O módulo FEMFAT max possibilita o cálculo do Dano, da vida em fadiga e do fator de segurança quando carregamentos não proporcionais estão presentes. Para isto, o software permite ao usuário solucionar o problema utilizando dois critérios de fadiga multiaxial: um critério baseado em tensão equivalente medida no Plano Crítico e o Critério de Gaier e Dannbauer. Infelizmente, apenas uma referência (Gaier et al., 2004) cobrindo a solução do critério baseado em tensão equivalente supracitado foi encontrado na área científica. Parece não haver provas suficientes nesta referência para assegurar a validade deste critérid ${ }^{10}$. Adicionalmente, ESC não oferece um esclarecimento completo da sua abordagem e justifica a utilização dos dois critérios no FEMFAT como seu know-how. É importante ressaltar que o FEMFAT consegue apenas resolver problemas de fadiga multiaxial baseada em tensão, pois não possui critérios de fadiga multiaxial que conseguem contabilizar deformação plástica multiaxial cíclica. O FEMFAT (Magna Powertrain) utiliza uma metodologia ligeiramente diferente do Método RSG Multiaxial supracitado; mais informações podem ser encontrados em Magna Powertrain (2011) e Christian Gaier (2010). Este software também calcula o gradiente de tensão relativo conforme a equação (5.17), entretanto utiliza outra fórmula para o cálculo do fator de entalhe $n_{K}$, que pode ser encontrada em Magna Powertrain (2011, pg.73) e Christian Gaier (2010, pg.11).

O FEMFAT apresenta um dos melhores módulos de solda existentes, tanto para solda contínua (FEMFAT weld) quanto para solda a ponto (FEMFAT spot). O módulo FEMFAT weld permite o cálculo da vida em fadiga de estruturas de aço e alumínio utilizando o Método da Tensão Nominal (presente na norma inglesa BS-7608, IIW, EUROCODE 3 e 9, e

\footnotetext{
${ }^{9} \mathrm{Ou}$ limite de endurance.

${ }^{10}$ Papuga (2005) também chegou à esta mesma conclusão.
} 
DIN 15018), o Método de Fermer ${ }^{11}$ que utiliza as forças e momentos nodais e por isto é menos sensível à malha FE, e também o Método da Tensão de Entalhe ${ }^{12}$ Um problema com o módulo FEMFAT weld é que, embora a solução é bem desenvolvida, a interface para a definição da solda não é automatizada. Embora não seja necessário mudanças de forma no modelo FE na localidade da solda, igual ao MSC.Fatigue, o usuário tem que operar bastante sobre os dados do modelo FE de maneira a definir o formato da solda através de vários sistemas de coordenadas e materiais. O módulo FEMFAT spot utiliza um método desenvolvido pela própria ECS e baseado em forças e momentos no spot weld para o cálculo da vida em fadiga do mesmo. Este módulo possui uma característica robusta que identifica automaticamente os pontos de solda e realiza um reposicionamento de malha shell ao redor de qualquer ponto de solda definido. Uma vez que esta remalhagem é automática, todas as definições necessárias de propriedades de malha estão inclusas, ao contrário da solução FEMFAT weld.

O módulo FEMFAT heat permite realizar uma análise de fadiga considerando os efeitos mecânicos, térmicos e químicos, utilizando para isto o método de Sehitoglu. O dano total por fadiga é contabilizado como sendo a soma do dano mecânico, do dano relativo à oxidação e do dano relativo à fluência. Obviamente, é necessário que o usuário introduza os parâmetros de material relativos ao comportamento mecânico, à oxidação e relativo ao dano por fluência (Magna Powertrain, 2011).

O módulo FEMFAT spectral utiliza as Densidades Espectrais de Potências (PSDs) para a análise de fadiga no domínio da frequência. O desenvolvedor do software afirma que o software consegue realizar análises de fadiga no domínio da frequência considerando tanto carregamentos uniaxiais quanto multiaxiais.

O módulo FEMFAT strain permite avaliar o dano por fadiga utilizando resultados de deformação medidos em campo, através de strain gages. Com este módulo também é possível comparar as tensões obtidas experimentalmente com as tensões via FEA.

O módulo FEMFAT break permite calcular os fatores de segurança estáticos quando se utiliza análise estática linear, através da regra de Neuber. Adicionalmente, o software também possui um módulo que permite a inspeção gráfica dos resultados na malha 3D de elementos finitos, incluindo geração de animações. O software também permite a utilização de processamento paralelo para diminuir o tempo de solução das análises. Para finalizar, o FEMFAT permite a comunicação com os seguintes softwares: Ansys, LS-DYNA, Abaqus, Nastran, Marc, I-deas, COSMOS, MECHANICA, TOSCA, HyperMesh, Patran, MEDINA, Adams, SIMPACK, RECURDYN, RPC, DAC e DIADEM.

\footnotetext{
${ }^{11}$ também intitulado de Método Volvo. Para mais informações sobre o método de Fermer ver Lee et al. (2011. cap.10).

${ }^{12}$ Em inglês, Notch Stress Method. Este método aparenta ter sido desenvolvido pela ECS e utilizado apenas no FEMFAT. Mais informações sobre este método pode ser encontrado em Magna Powertrain (2011)
} 


\subsubsection{LMS Virtual.Lab Durability}

O LMS Virtual.Lab Durability é um software da Siemens e é um software mais completo intitulado LMS Virtual.Lab, que tem a capacidade de realizar as mais diferentes análises como análise Dinâmica de Multicorpos, análise estrutural, análise de ruído e vibração, análise de otimização, além de atividades de pré e pós-processamento. O LMS Virtual.Lab Durability é uma evolução do software Falancs que foi modificado após sua aquisição pela LMS International. A LSM realizou uma parceria com a Dassault Systemes e fez com que o software LMS Virtual.Lab Durability utilizasse a interface do CATIA. Assim, o fabricante conseguiu espaço e tempo suficientes para facilitar mais o pós-processamento dos resultados de fadiga.

O módulo incorpora soluções uni e multiaxial. Entretanto, o software LMS Virtual.Lab Durability é muito básico porque apenas estão implementados o Critério de Dang Van para fadiga multiaxial de alto ciclo e o Critério da Deformação Principal Máxima e o Critério da Máxima Deformação de Cisalhamento para fadiga multiaxial de baixo ciclo

Os módulos de fadiga uniaxial, fadiga multiaxial e fadiga no domínio da frequência já estão inclusos no software principal LMS Virtual.Lab Durability. Os módulos relativos à fadiga em solda contínua (seam weld), em solda à ponto (spot weld), fadiga térmica e otimização devem ser comprados a parte. O módulo seam weld permite a análise de fadiga em solda utilizando apenas a Abordagem pela Tensão Nominal. Entretanto, uma característica interessante do software é sua capacidade de detecção automática das localidades esperadas da solda e também da oferta de formatos de soldas ao usuário. O módulo spot weld realiza análise de fadiga de spot welds tanto utilizando uma abordagem baseada em forças e momentos nos spot welds quanto uma abordagem baseada em tensões locais.

O módulo thermal fatigue possibilita o cálculo da vida em fadiga de componentes sujeitos à fluência. O desenvolvedor também indica que o software consegue unir uma análise de fadiga com análise de otimização, entretanto não esclarece como este tipo de acoplamento funciona. O LMS Virtual.Lab Durability supera outros competidores com uma interface muito mais fácil e agradável, ampla possibilidade de pós-processamento dos resultados de fadiga e um módulo seam weld excelente $\mathrm{O}$

\subsubsection{NX Advanced Durability}

O NX Durability é desenvolvido pela Siemens e está incluso como um módulo para o I-deas. Comparado com os softwares supracitados, este é o software que possui a menor quantidade de opções de análise, embora tenha sido desenvolvido por uma empresa amplamente conhecida (Siemens). 
A análise de fadiga com este software pode ser feita a partir de simulações FE estáticas, transientes ou através de análise de fadiga espectral (utilizando uma PSD).

O software permite realizar análise de fadiga uniaxial baseada em tensão e em deformação. A correção de tensão média pode ser feita utilizando o modelo de Goodman, Soderberg, Gerber e Morrow. O critério de Smith-Watson-Topper (SWT) é utilizado em análise de fadiga uniaxial de baixo ciclos. De acordo com o site do fabricante, o software não entende a utilização dos fatores modificadores apresentados no capítulo 4 e tudo indica que o fator de entalhe $\left(n_{K}\right)$ também é calculado automaticamente e deve ser calculado manualmente pelo usuário. Portanto o usuário precisa calcular a Curva $\sigma-N$ Local e a Curva $\varepsilon-N$ Local manualmente.

Dentro da área de Fadiga Multiaxial, as informações do fabricante também indicam que o software consegue realizar análise de fadiga multiaxial baseada em tensão utilizando o Critério da Tensão Principal Absoluta, o Critério de Dang Van e também um critério baseado no plano crítico. Entretanto, o desenvolvedor não relata qual critério de plano crítico está implementado. O desenvolvedor também relata que o software realiza análise de fadiga multiaxial baseado em deformação utilizando o Critério de Brown-Miller, utilizando o método de Neuber para a correção da plasticidade quando análise linear é utilizada.

O software permite realizar análises de fadiga no domínio da frequência (PSD) utilizando Narrow band (Miles) e Wide band (Dirlik). Também possível utilizar tensões ou deformações de campo, medidas através de rosetas, como entrada no software para a análise de fadiga. O software também possui um visualizador que permite visualizar a vida em fadiga, o dano e os fatores de segurança em cada ponto da estrutura, através de um perfil colorido sobre a malha FE.

\subsection{7 winLIFE}

Este software é desenvolvido pela empresa Steinbeis-Transferzentrum em Ulm, Alemanha e é vendido separadamente através do endereço www.stz-verkehr.de. O software possui um módulo básico e 6 módulos adicionais: winLIFE QUICK CHECK, winLIFE Multiaxial, winLIFE GEARWHEELS AND BEARINGS, winLIFE CRACK PROPAGATION, winLIFE RANDOM e winLIFE VIEWER.

O módulo básico (winLIFE BASIC) permite calcular a vida em fadiga de componentes/estruturas sob carregamento dinâmico onde o carregamento é definido no tempo (análise de time steps). A vida em fadiga pode ser calculada do jeito clássico (sem FEA) baseado nas tensões nominais ou utilizando as tensões locais (que são aquelas já aumentadas devido aos fatores de entalhe) de um modelo FE, afim de contabilizar os efeitos locais no entalhe. 
No caso desta última abordagem, as tensões de cada nó são importadas de um software FEA como uma base para o cálculo da vida em fadiga.

O winLIFE permite calcular a vida em fadiga utilizando tanto o Método Tensão-Vida quanto o Método Deformação-Vida. Ele se baseia no método FKM-Guideline (apresentado nesta dissertação) como metodologia base para a análise de fadiga de alto ciclo (Método Tensão-Vida) e a IIW-Guidelines (International Institute of Welding) como base para análise de estruturas soldadas, cuja avaliação é feita através do método hot spot. Este software permite entrada manual dos parâmetros da Curva $S$-N Espécime $\left(S_{f, s p}^{\prime}\right.$ e $\left.b_{s p}\right)$ ou através de relações aproximadas com o limite de resistência à tração $\left(S_{u}\right)$. A Curva $\mathcal{\varepsilon}-N \operatorname{Local}\left(\varepsilon_{f}^{\prime}, c\right.$, $\sigma_{f}^{\prime}$ e $b$ ) também pode ser estipulada manualmente ou através da especificação de laços de histerese medidos em laboratório. É possível utilizar grande parte dos fatores modificadores apresentados no capítulo 4. Entretanto, a grande desvantagem deste software é que o fator de entalhe não é calculado automaticamente conforme apresenta as seções 4.4 .2 e 5.3 . Assim, há a necessidade de estipular manualmente a Curva S-N de cada entalhe, que aumenta consideravelmente o tempo necessário para se encontrar uma solução. Dados de FEA podem ser importandos dos softwares ANSYS, Abaqus, ANDINA, FEMAP, NX-Nastran e NeiNastran.

O módulo winLIFE QUICK CHECK é um módulo para uma primeira análise e checagem rápida de cenários worst case, utilizando para isto análises FE estáticas.

O módulo winLIFE MULTIAXIAL permite analizar estruturas sujeitas à fadiga multiaxial, sendo este módulo fundamental para os casos onde há carregamento não-proporcional presente. $\mathrm{O}$ software permite a plotagem de gráficos de razão de biaxialidade " $a$ " e de orientação da tensão principal máxima " $\phi_{p}$ " para cada nó da estrutra. Este módulo também permite a contabilização do parâmetro de dano utilizando critérios baseados em tensão como o Critério da Tensão Principal Máxima, o Critério da Tensão de Cisalhamento Sinalizada. o Critério de von Mises Sinalizado, o Critério de Findley, assim como a análise de fadiga utilizando critérios baseados em deformação como o Critério de Smith-Watson-Topper e o Critério de Fatemi-Socie ${ }^{13}$. Além da utilização de uma solução elasto-plástica de Neuber Multiaxial ${ }^{14}$, o modelo cinemático de Mróz também está implementado para cobrir a área multiaixial.

O módulo winLIFE GEARWHEELS AND BEARINGS utiliza a teoria presente nos livros de elementos de máquinas para prever a vida em fadiga de engrenagens e mancais. Este módulo permite verificar como o dano por fadiga depende de acordo com o torque aplicado

\footnotetext{
${ }^{13} \mathrm{O}$ critério de Smith-Watson-Topper e o critério de Fatemi-Socie são critérios baseados em deformação e por isto podem ser utilizados em previsão da vida fadiga de baixo ciclo. Sua utilização é mais complexa porque exige a utilização da Curva $\varepsilon-N$ Local. Não faz parte do escopo deste trabalho estudar critérios de fadiga multiaxial baseados em deformação, portanto mais informações sobre estes critérios podem ser obtidas em Lee et al. (2011), Socie \& Marquis (2000), de Castro \& Meggiolaro (2009a), Karolczuk \& Macha (2005) e Fatemi (sdc).

${ }^{14} \mathrm{O}$ desenvolvedor não relata qual é a regra utilizada.
} 
na engrenagem analisada, a rotação da mesma e o tempo de exposição da engrenagem em cada conjunto torque-rotação. O módulo CRACK PROPAGATION permite calcular a vida em fadiga de estruturas que que já possuem uma pré-trinca inicial 15 utilizando a Mecânica da Fratura Linear Elástica (MFLE).

O módulo winLIFE RANDOM permite calcular a vida em fadiga utilizando uma abordagem baseada em PSD (Power Spectrum Density) onde a análise de fadiga é realizada mais rapidamente do que a abordagem baseada no tempo, principalmente se o carregamento for definido por muitos time steps e/ou for aleatório.

O módulo winLIFE VIEWER permite visualizar os resultados através de gradientes coloridos sobre a estrutura, permitindo ser visualizado um plot de dano, amplitude equivalente, fator de segurança com relação ao limite de fadiga ${ }^{16}$ e o número de ciclos até a falha.

\subsection{Detalhamento da Análise de Fadiga Compu- tacional}

O processo global de análise de fadiga utilizando resultados de análises por Elementos Finitos utilizando o software $x$ Durability pode ser dividido em 3 etapas, conforme ilustra a figura 6.1. Na verdade, esta figura simboliza o processo de análise em qualquer software de fadiga comercial.

O fadiga multiaxial baseada em Elementos Finitos pode ser dividida em 3 etapas, cujos detalhes podem ser vistos nas figuras 6.2, 6.3 e 6.4. Esta seção relata detalhadamente cada etapa.

\subsubsection{Etapa 1: Entrada de Dados}

Nesta etapa o software de fadiga realiza a leitura da malha de Elementos Finitos. A posição e numeração de todos os nós do modelo de Elementos Finitos assim como a matriz de conectividade são identificados.

O método de previsão de vida em fadiga baseado em tensão está baseado na idéia de se estimar a vida em fadiga de um componente utilizando os valores de tensão da superfície do mesmo. Por isto nesta etapa também é realizada a identificação de todos os nós localizados na superfície da malha.

\footnotetext{
${ }^{15}$ i.e., estruturas com trincas de estágio II

${ }^{16} \mathrm{Ou}$ limite de endurance.
} 


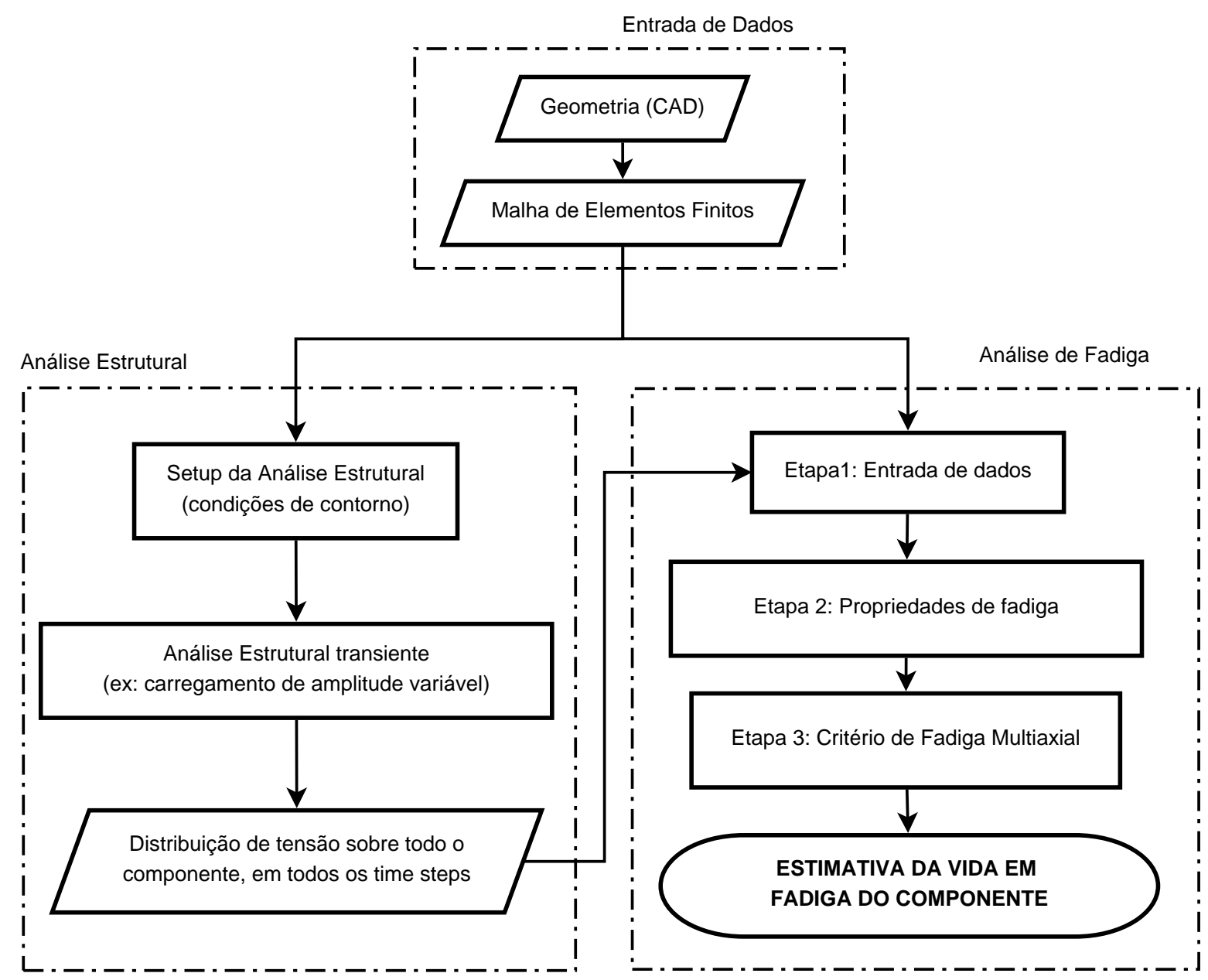

Figura 6.1 Fluxograma do processo global de análise de fadiga de um componente. 
Etapa 1:

Entrada de dados

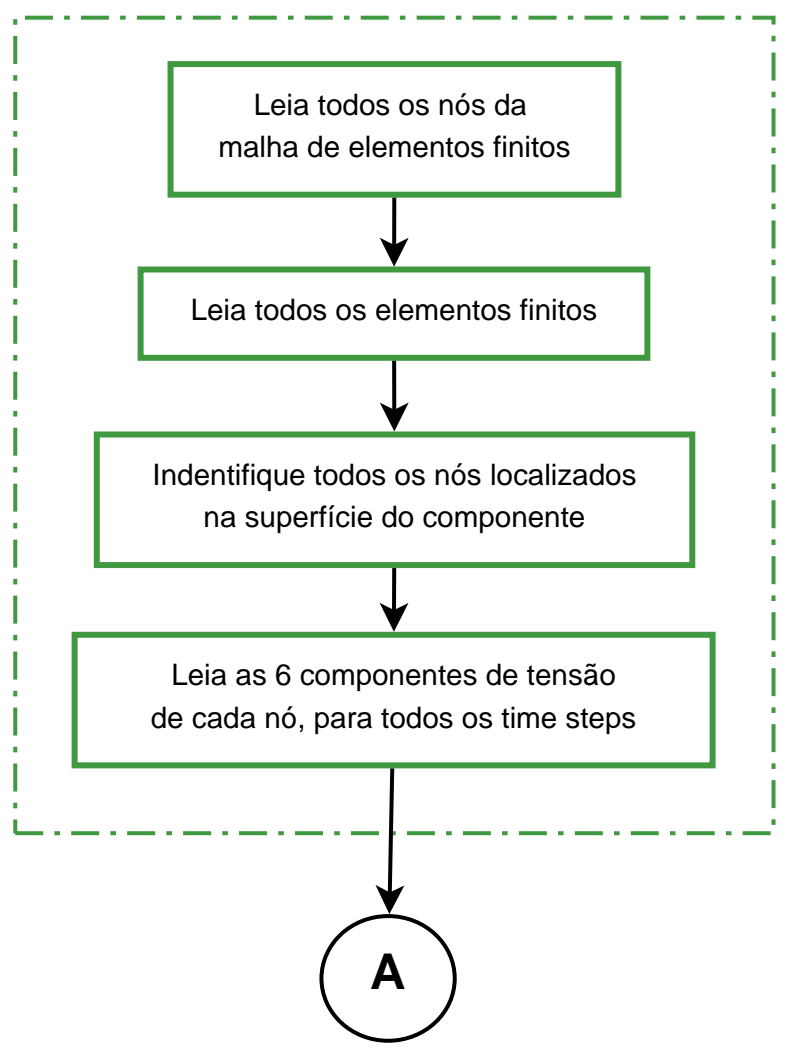

Figura 6.2 Etapa 1: Entrada de dados. 


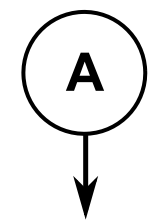

Etapa 2:

Propriedades de fadiga

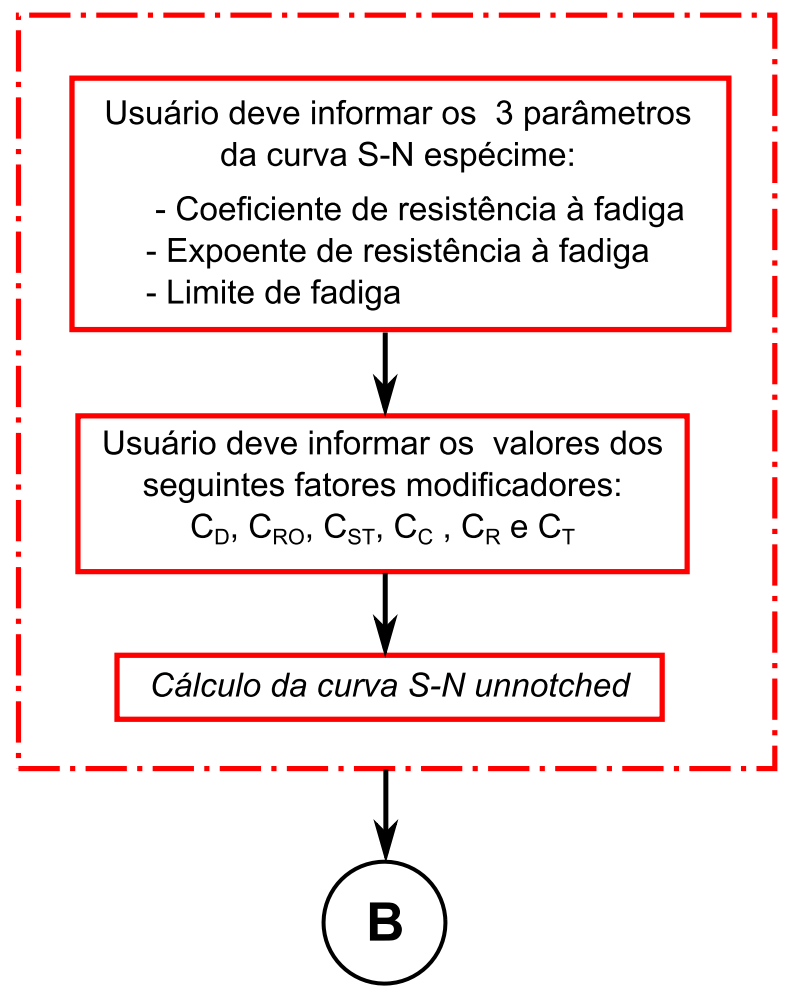

Figura 6.3 Etapa 2: Propriedades de fadiga. 


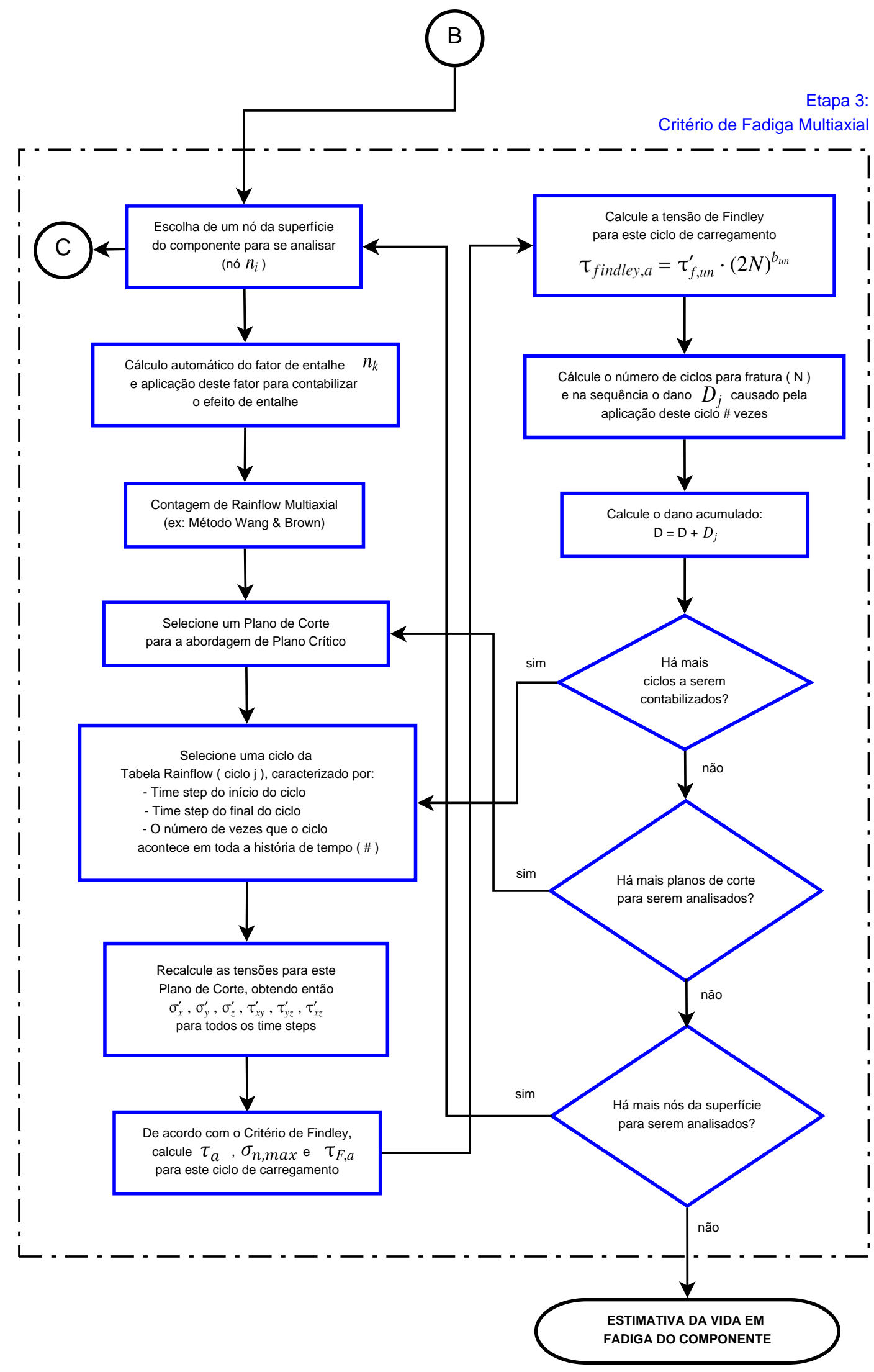

Figura 6.4 Etapa 3: Critério de Fadiga Multiaxial. 
Nesta etapa também é realizada a leitura do resultados da análise estrutural. É armazenado as 6 componentes de tensão de cada nó $\left(\sigma_{x}^{e}, \sigma_{y}^{e}, \sigma_{z}^{e}, \tau_{x y}^{e}, \tau_{x z}^{e}\right.$ e $\left.\tau_{y z}^{e}\right)$ para cada instante de tempo

\subsubsection{Etapa 2: Propriedades de fadiga}

No início da análise de fadiga computacional, o usuário deve informar os parâmetros que identificam a curva tensão-vida do componente. Nesta etapa o usuário deve informar a Curva $S$ - $N$ Espécime assim como o limite de fadiga desta curva $\left(S_{E, s p}\right)$. O usuário também deve fornecer os valores dos fatores modificadores $C_{D}, C_{R O}, C_{S T}, C_{C}, C_{R}$ e $C_{T}$.

O software de fadiga irá calcular automaticamente a Curva E-N Unnotched a ser utilizada na avaliação da vida. O software também computará automaticamente o limite de fadiga a ser utilizado nos cálculos, que poderá ser calculado via o Critério de von Mises, o Critério da Tensão Principal Absoluta, ou o Critério de Findley.

\subsubsection{Etapa 3: Critério de Fadiga Multiaxial}

A análise de fadiga baseada em Elementos Finitos utilizando fadiga multiaxial é descrita a seguir. O Critério de Findley é um dos critérios de fadiga mais complexos e por isto foi utilizado como exemplo de aplicação:

1) Escolha um nó da superfície da malha;

2) O fator de entalhe $n_{K}$ é contabilizado conforme o Método RSG Multiaxial (seção 5.3). Este fator é aplicado para corrigir todo o histórico de cada uma das 6 componentes de tensão no nó analisado, conforme figura 5.19 ,

3) O processo de Rainflow Multiaxial (ex: Wang \& Brown) é aplicado neste nó. Isto resultará em uma tabela de três colunas e várias linhas, onde cada linha representa um bloco de carregamento de amplitude e média constantes. A primeira coluna desta tabela representa o instante de tempo (time step) onde começa o ciclo (chamado aqui de ponto A), a segunda representa o instante de tempo (time step) onde termina o ciclo (chamado aqui de ponto $B$ ) e a última coluna representa o número de vezes que este ciclo ocorre em toda a história de carga;

4) Escolher um plano de corte para análise, intitulado plano $\Delta_{q}\left(\theta_{q}, \phi_{q}\right)$, e calcular as 6 componentes do tensor de tensões $\left(\sigma_{x}^{\prime}, \sigma_{y}^{\prime}, \sigma_{z}^{\prime}, \tau_{x y}^{\prime}, \tau_{x z}^{\prime}, \tau_{y z}^{\prime}\right)$ para cada time step;

5) Selecione um ciclo da Tabela Rainflow; 
6) Calcular a $\tau_{a}, \sigma_{n, \max } \tau_{\text {findley, } a}$;

7) Calcular os parâmetros $\beta_{F}, S_{B, u n}, b_{u n}$ e $\tau_{f, u n}^{\prime}$ e calcular o número de ciclos $N_{j}$ para este ciclo de carregamento;

8) Calcular o parâmetro de dano $d_{j}$ para este ciclo de carregamento;

9) Calcular o dano acumulado $\left(D=D+D_{j}\right)$;

10) Verificar se há mais ciclos para serem contabilizados. Em caso positivo, voltar à etapa (5);

11) Verfificar se há mais planos de corte para serem analisados. Em caso positivo, voltar à etapa (4);

12) Verfificar se há mais nós superficiais para serem analisados. Em caso positivo, voltar à etapa (1);

O procedimento descrito acima resulta em um valor de dano para cada nó da superfície do componente, para um carregamento variável qualquer. É possível gerar um gráfico de contorno do componente utilizando como parâmetro de análise a variável Dano $(D)$. A figura 6.5 apresenta o dano por fadiga de cada nó para uma dada história de carregamento multiaxial variável. A figura 6.6 apresenta o vida prevista para cada nó do componente, sob o mesmo carregamento.

O ponto "C" da figura 6.4 representa uma subrotina que calcula a razão de biaxialidade $a$ e a orientação $\phi_{p}$ em cada intervalo de tempo de cada nó superficial, conforme apresentado na seção 5.2. Desta maneira, o engenheiro pode verificar se cada ponto/nó do componente está sob carregamento proporcional ou não proporcional. Esta subrotina está apresentada na figura 6.7 .

\subsection{Estudos de Caso para Validação do Procedi- mento}

Foram testados 3 casos para a validação do procedimento de análise de fadiga baseada em Elementos Finitos proposto nesta dissertação. O software $x$ Durability foi utilizado para realizar a estimativa de vida em fadiga. Os casos testados estão descritos nas próximas seções. 


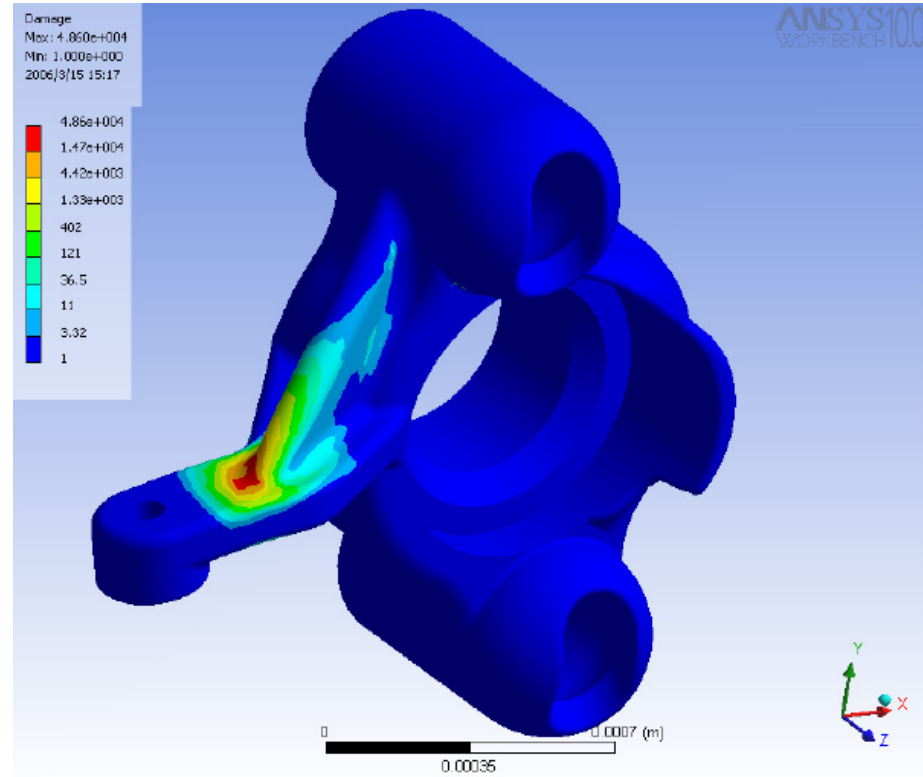

Figura 6.5 Plot de dano por fadiga em todo o modelo (Browell \& Hancq, 2006).

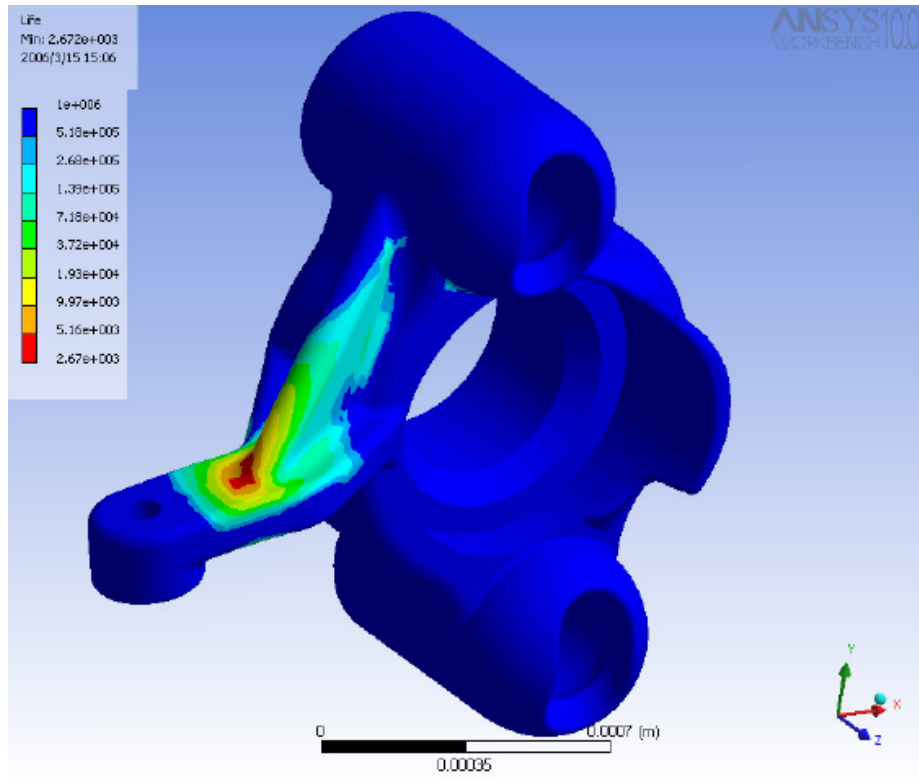

Figura 6.6 Plot da vida em fadiga em todo o modelo Browell \& Hancq, 2006). 


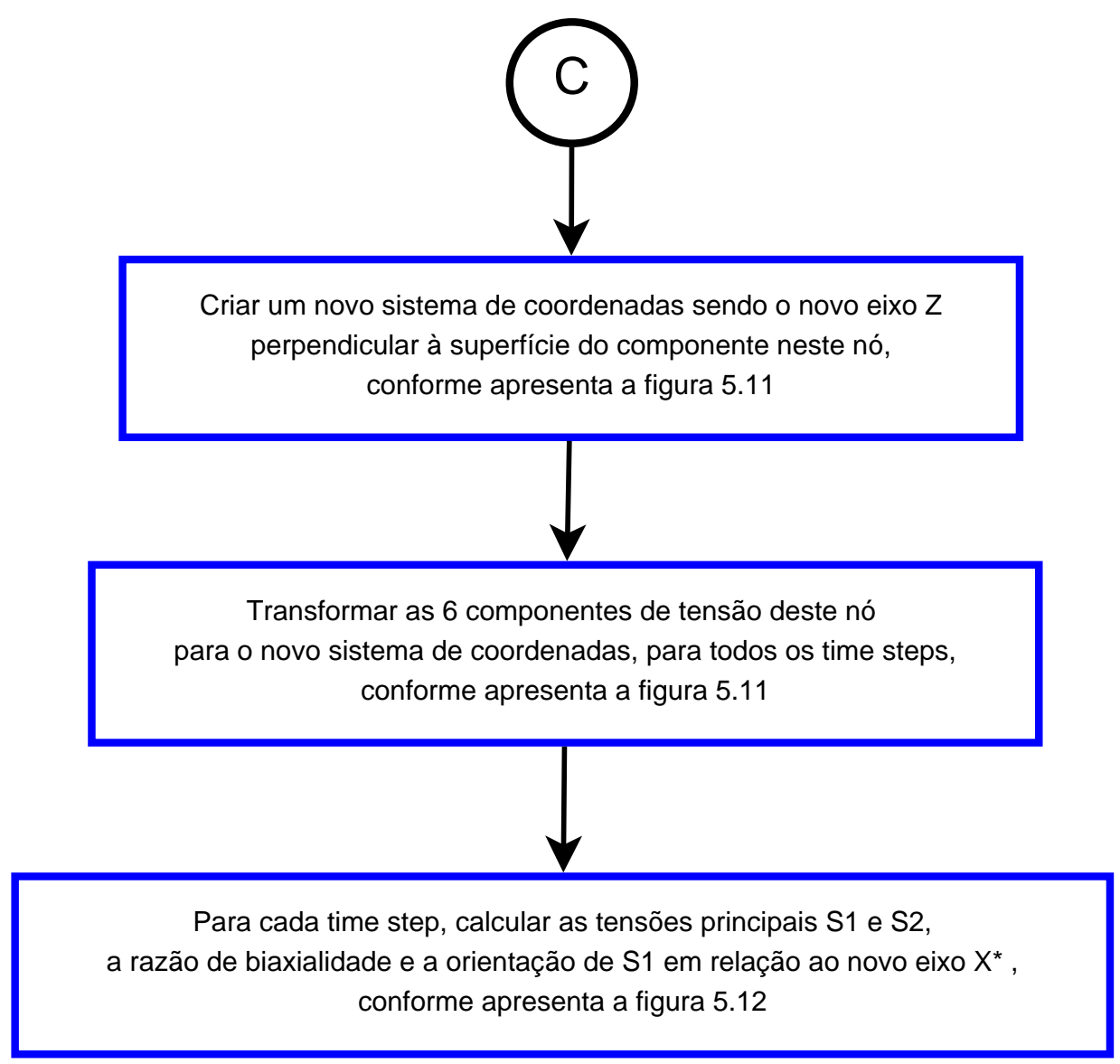

Figura 6.7 Algorítmo para o cálculo da razão de biaxialidade e da orientação $\phi_{p}$.

\subsubsection{Estudo de Caso 1}

Este estudo de caso foi criado para avaliar as funcionalidades básicas do software $x$ Durability, como leitura do modelo de Elementos Finitos, leitura dos valores de tensão, construção da curva tensão-vida sintética e geração de um resultado coerente.

Neste estudo de caso a curva S-N do aço S690 é obtida utilizando espécimes com $\phi=$ $6,5 \mathrm{~mm}$ não entalhados sob flexão alternada $(\mathrm{R}=-1)$. A curva está apresentada na figura $6.8 \mathrm{e}$ os dados da Curva $S$ - $N$ Espécime estão apresentados na tabela 6.1 .

Tabela 6.1 Resultados de fadiga gerados em teste de espécimes cilíndricos sem entalhe de aço $\mathrm{S} 690$ sob flexão rotativa.

\begin{tabular}{lrl}
\hline$b_{s p}$ & $-0,17765$ & \\
$S_{f, s p}^{\prime}$ & 4603,8 & $\mathrm{MPa}$ \\
$S_{E, s p}$ & 309,2 & $\mathrm{MPa}$ \\
$N_{E}$ & $2 \cdot 10^{6}$ & ciclos \\
\hline
\end{tabular}

A teoria prevê que a vida em fadiga deste corpo de prova sob uma tensão alternada de 


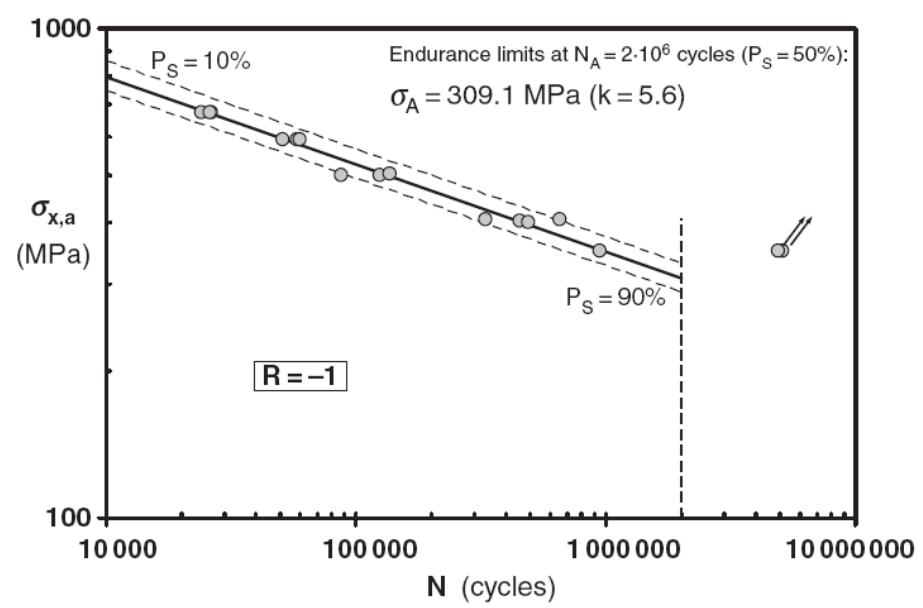

Figura 6.8 Resultados de fadiga gerados em teste de espécimes cilíndricos sem entalhe de aço S690 sob flexão rotativa (Susmel, 2009).

$S_{a}=350,5 \mathrm{MPa}$ é de 987.384 ciclos. A tabela 6.2 apresenta a estimativa da vida em fadiga feita pelo software $x$ Durability. O erro relativo na estimativa do software $x$ Durability foi de apenas $-0,186 \%$. A figura 6.9 apresenta o valor da tensão alternada e da vida estimada para cada nó da superfície da malha de Elementos Finitos.

Tabela 6.2 Resultados do software $x$ Durability.

\begin{tabular}{clrll}
\hline \multirow{2}{*}{ Teoria } & $S_{a}$ & 350,5 & $\mathrm{MPa}$ & Erro Relativo \\
& $\mathrm{N}$ & 987.384 & ciclos & \\
\hline \multirow{4}{*}{ xDurability } & $\mathrm{N}^{\circ}$ nó & 591 & & \\
& $S_{a}$ & 350,52 & $\mathrm{MPa}$ & \\
& $\mathrm{N}$ & 985.550 & ciclos & $\mathbf{- 0 , 1 8 6} \%$ \\
\hline
\end{tabular}

\subsubsection{Estudo de Caso 2}

Este estudo de caso foi construído para avaliar a capacidade do software xDurability em calcular adequadamente o efeito da tensão média em estruturas sujeitas a carregamento cíclico uniaxial com tensão média diferente de zero, através do parâmetro $C_{m}$, conforme apresentado nas seções 4.3.10 e 4.6.1. Foi utilizado a mesma curva $\mathrm{S}-\mathrm{N}$ do estudo de caso 1 , sendo o espécime também igual. Foram simulados 5 loadcases e cada um possui um valor de tensão média diferente. A tabela 6.3 apresenta a estimativa de vida utilizando a teoria para cada loadcase, utilizando o modelo de SWT para contabilização da tensão média diferente de zero. A contabilização da tensão média foi realizada conforme apresenta seção 4.6.1 e o fator de tensão média calculado conforme a equação (4.126). 


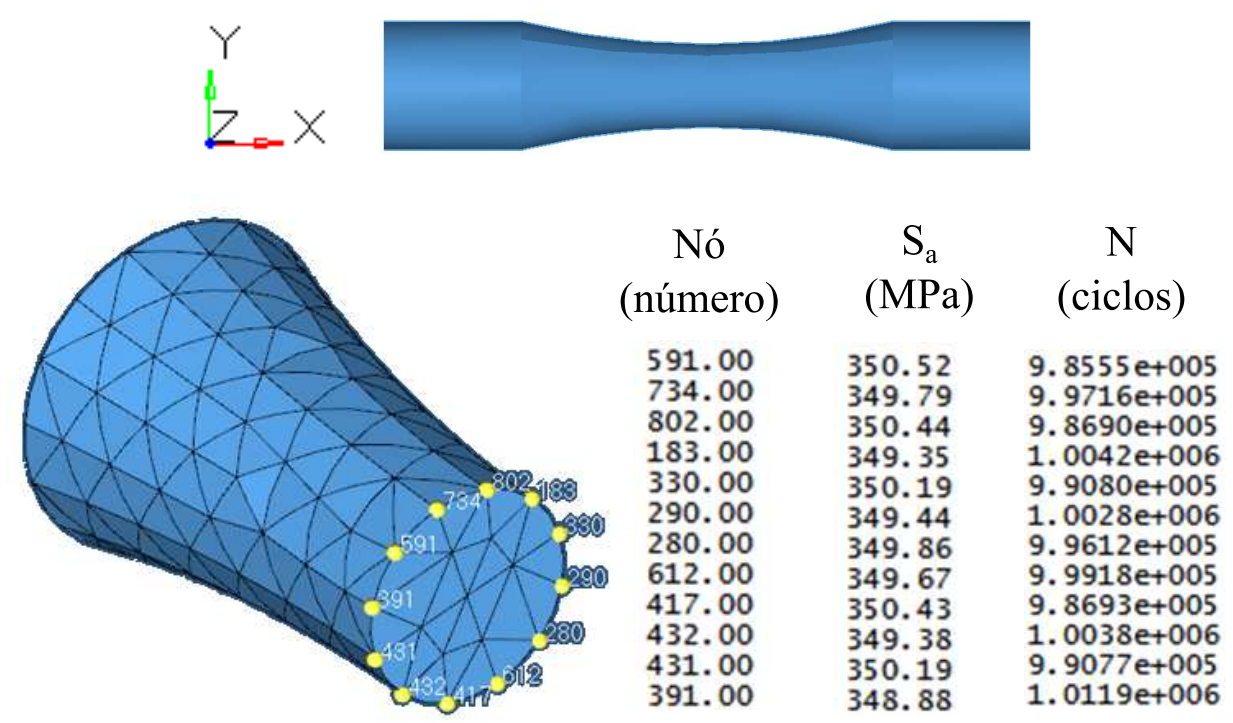

Figura 6.9 Tensão e vida em fadiga nos nós de canto da superfície da malha FE, calculada utilizando o software $x$ Durability.

Tabela 6.3 Estimativa de vida utilizando a teoria.

\begin{tabular}{l|c|c|c|c|c}
\hline \multicolumn{7}{c}{ Teoria } \\
& $\begin{array}{c}\sigma_{a}^{e} \\
(\mathrm{MPa})\end{array}$ & $\begin{array}{c}\sigma_{m}^{e} \\
(\mathrm{MPa})\end{array}$ & $\begin{array}{c}\sigma_{a, R=-1}^{e} \\
(\mathrm{MPa})\end{array}$ & $C_{m}$ & $\begin{array}{c}\mathrm{N} \\
(\text { ciclos })\end{array}$ \\
\hline Loadcase 1 & 356,33 & 0 & 356,33 & 1,0000 & 899.886 \\
Loadcase 2 & 356,33 & 25,45 & 368,83 & 0,9661 & 741.067 \\
Loadcase 3 & 356,33 & 50,90 & 380,93 & 0,9354 & 617.977 \\
Loadcase 4 & 356,33 & 76,36 & 392,65 & 0,9075 & 521.040 \\
Loadcase 5 & 356,33 & 101,81 & 404,04 & 0,8819 & 443.615 \\
\hline
\end{tabular}

Cinco análises de fadiga utilizando o $x$ Durability foram feitas, aplicando-se o carregametno descrito na tabela 6.3 . A tabela 6.4 apresenta os resultados obtidos.

vspace $5 \mathrm{~mm}$

O erro relativo é nulo entre os resultados de tensão normal alternada com média diferente de zero $\left(\sigma_{a}\right)$, para a tensão normal média $\left(\sigma_{m}\right)$ e para o fator de tensão média $\left(C_{m, \sigma^{e}}\right)$.

$\mathrm{O}$ erro relativo com relação à vida em fadiga $(N)$ foi igual para todos os 5 loadcases testados e igual à 7,4\%. Acredita-se que este valor de erro seja causado devido ao cálculo intrísseco do fator de entalhe " $n_{K}$ "no modelo numérico, conforme já relatado no item 4.4.2. Em outras palavras, o espécime utilizado neste estudo de caso (figura 6.9) possui um fator de concentração de tensão $K_{t}$ (e consequentemente um fator de entalhe $n_{K}$ ) ligeiramente maior que a unidade. Assim, na figura 4.49, a Curva $\sigma-\mathbf{N}$ Local (utilizada na análise numérica) será ligeiramente superior à Curva $\mathbf{S}-\mathbf{N}$ Unnotched (utilizada na análise teórica), o que justifica o erro de 7,4\% entre o resultado teórico o numérico para este estudo de caso. $\mathrm{O}$ 
Tabela 6.4 Estimativa de vida utilizando análise numérica.

\begin{tabular}{cc|cc|cc|cc|cc}
\hline \multicolumn{10}{c}{ Análise Numérica } \\
\hline Loadcase & $\begin{array}{c}\text { Nó } \\
\text { crítico }\end{array}$ & $\begin{array}{c}\sigma_{a}^{e} \\
(\mathrm{MPa})\end{array}$ & $\begin{array}{c}\text { Erro } \\
(\%)\end{array}$ & $\begin{array}{c}\sigma_{m}^{e} \\
(\mathrm{MPa})\end{array}$ & $\begin{array}{c}\text { Erro } \\
(\%)\end{array}$ & $\begin{array}{c}C_{m, \sigma^{e}} \\
(\mathrm{MPa})\end{array}$ & $\begin{array}{c}\text { Erro } \\
(\%)\end{array}$ & $\begin{array}{c}\mathrm{N} \\
(\text { ciclos })\end{array}$ & $\begin{array}{c}\text { Erro } \\
(\%)\end{array}$ \\
\hline 1 & 591 & 356,33 & $0 \%$ & 0 & $0 \%$ & 1,0000 & $0 \%$ & 833.028 & $7,4 \%$ \\
2 & 591 & 356,33 & $0 \%$ & 25,45 & $0 \%$ & 0,9661 & $0 \%$ & 686.064 & $7,4 \%$ \\
3 & 591 & 356,33 & $0 \%$ & 50,90 & $0 \%$ & 0,9354 & $0 \%$ & 572.119 & $7,4 \%$ \\
4 & 591 & 356,33 & $0 \%$ & 76,36 & $0 \%$ & 0,9075 & $0 \%$ & 482.399 & $7,4 \%$ \\
5 & 591 & 356,33 & $0 \%$ & 101,81 & $0 \%$ & 0,8819 & $0 \%$ & 410.727 & $7,4 \%$ \\
\hline
\end{tabular}

erro de 7,4\% é considerado insignificante e perfeitamente aceitável dentro da área de durabilidade, pois o valor do erro relativo da vida da maioria dos problemas de fadiga encontrados na indústria é na ordem de $\pm 100 \%$.

\subsubsection{Estudo de Caso 3}

Este estudo de caso tem como objetivo mostrar a aplicação do fator de entalhe $n_{K}$, calculado através do Método RSG descrito nas seções 4.4.2 e 5.3. na previsão de vida em fadiga baseado em Elementos Finitos. Outro objetivo é comparar o resultado da Curva Tensão-Vida de um componente entalhado estimada através do Método RSG com a Curva Tensão-Vida de um componente entalhado obtida experimentalmente.

Seja o espécime de fadiga não entalhado ilustrado na figura 6.10a, feito em aço A517, com seção circular, diâmetro de $6,5 \mathrm{~mm}$, com superfície polida e sem macro tensões residuais. Ensaios de fadiga realizados sob atmosfera e temperatura ambiente e sob tração-compressão completamente alternada $(R=-1)$ resultaram na Curva $S-N$ azul (curva azul da figura 6.11). Esta curva foi construída com os dados das colunas 1 e 4 da tabela 6.5. O eixo das ordenadas desta curva representa a tensão alternada nominal $\left(S_{a}\right)$ aplicada neste espécime, que é igual à força axial alternada aplicada no corpo de prova dividida pela área transversal da seção crítica ${ }^{17}$ (vide figura 4.40). A tabela 6.6 contém as propriedades desta curva. Este

${ }^{17}$ A seção crítica é a seção de menor diâmetro.

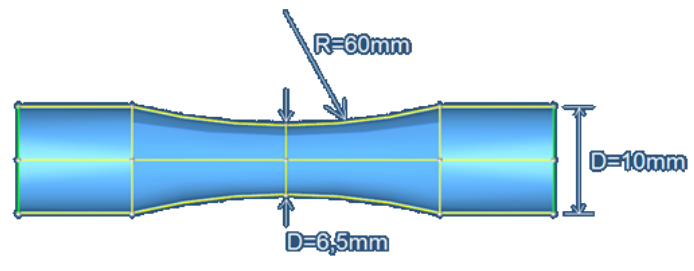

(a) Espécime não entalhado.
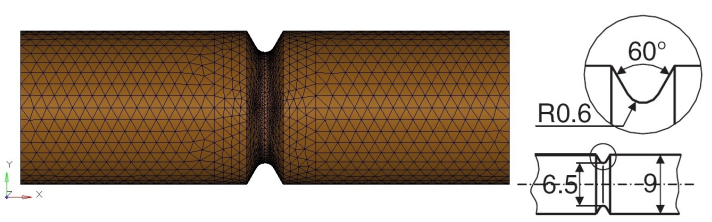

(b) Espécime entalhado.

Figura 6.10 Espécimes. 


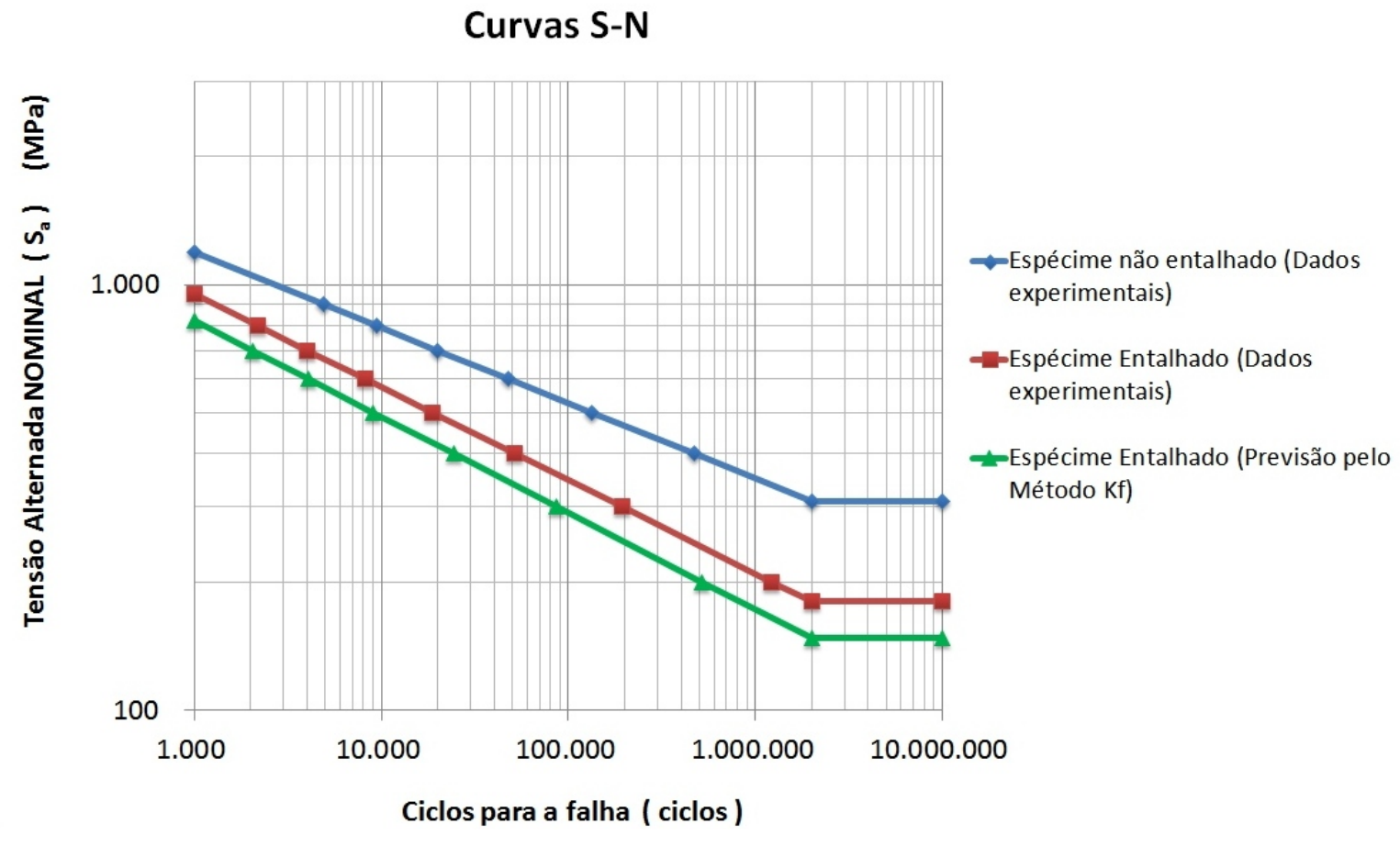

Figura 6.11 Curvas S-N

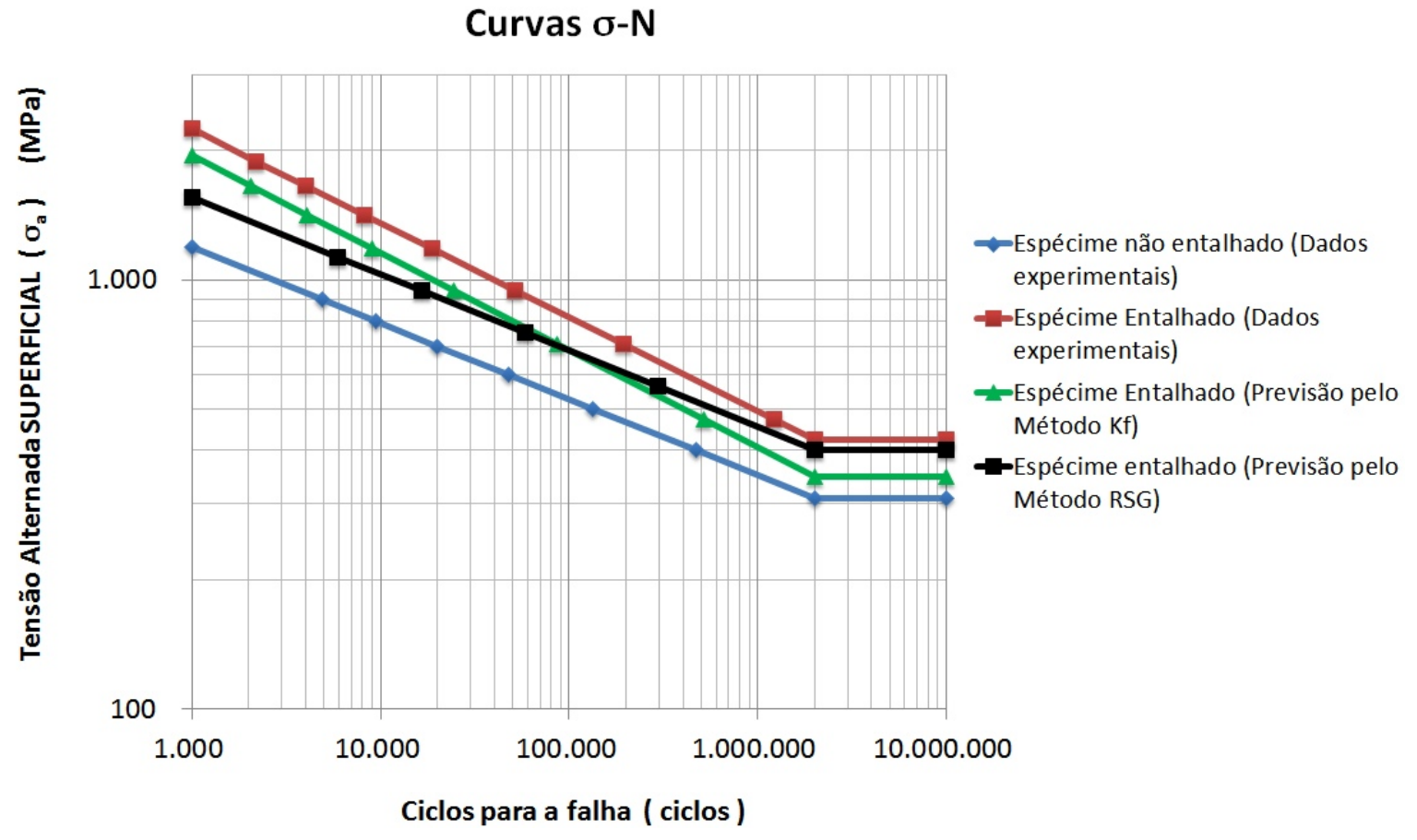

Figura 6.12 Curvas $\sigma-\mathrm{N}$ 
espécime não possui entalhe $\left[K_{t}=1\right)$ portanto, conforme a equação 4.91 , a tensão alternada nominal $\left(S_{a}\right)$ é igual à tensão alternada local $\left(\sigma_{a}\right)$, sendo $\sigma_{a}$ a tensão na superfície do espécime obtida com um strain gauge posicionado na seção crítica. A Curva $\sigma-\mathbf{N}$ azul (curva azul da figura 6.12) é a curva tensão-vida obtida experimentalmente do espécime não entalhado, sendo o eixo das ordenadas igual à tensão alternada local $\left(\sigma_{a}\right)$. A tabela 6.7 contém as propriedades desta curva. É importante lembrar que:

$$
\sigma_{f}^{\prime}=K_{t} \cdot S_{f}^{\prime}
$$

Seja o espécime de fadiga entalhado ilustrado na figura $6.10 \mathrm{~b}$, que possui todas as características iguais ao espécime da figura 6.10a, exceto pelo entalhe. Ensaios de fadiga com este corpo de prova entalhado realizados sob atmosfera e temperatura ambiente e sob traçãocompressão completamente alternada $(R=-1)$ resultaram na Curva S-N vermelha (curva vermelha da figura 6.11). Esta curva foi construída com os dados das colunas 1 e 4 da tabela 6.8. O eixo das ordenadas desta curva representa a tensão alternada nominal $\left(S_{a}\right)$ aplicada neste espécime, que é igual à força axial alternada aplicada no corpo de prova dividida pela área transversal da seção crítica ${ }^{18}$ (vide figura 4.40). A tabela 6.9 contém as propriedades da Curva S-N vermelha. Este espécime possui entalhe com $K_{t}=2,36$, portanto, conforme a equação 4.91), a tensão alternada local $\left(\sigma_{a}\right)$ é maior que a tensão alternada nominal $\left(S_{a}\right)$. A Curva $\sigma$-N vermelha (curva vermelha da figura 6.12) é a curva tensão-vida obtida experimentalmente do espécime entalhado, sendo o eixo das ordenadas igual à tensão alternada local $\left(\sigma_{a}\right)$. Esta curva é construída com os dados das colunas 3 e 4 da tabela 6.8, sendo o eixo das ordenadas igual a tensão alternada local $\left(\sigma_{a}\right)$; a tabela 6.10 contém as propriedades da Curva $\sigma$-N vermelha. A equação 6.1) continua sendo válida para a obtenção da equação da tabela 6.10 .

O Método $K_{f}$, descrito na seção 4.4.1. foi desenvolvido para estimar qual seria a Curva $S-N$ de um componente entalhado, tendo apenas a Curva $S-N$ de um componente não entalhado. O Método $K_{f}$ foi utilizado aqui e a Curva S-N verde (curva verde da figura 6.11) foi estimada a partir da Curva S-N azul. Os parâmetros da Curva S-N verde estão apresentados na tabela 6.12, assim como os parâmetros utilizados para estimá-la. As colunas 1 e 4 da tabela 6.11 são os pontos que satisfazem a equação da tabela 6.12. $\mathrm{O}$ eixo das ordenadas da Curva $S-N$ verde representa a tensão alternada nominal $\left(S_{a}\right)$ aplicada no espécime entalhado, que é igual à força axial alternada aplicada no corpo de prova dividida pela área transversal da seção crítica ${ }^{19}$ (vide figura 4.40). É possível descrever a curva tensão-vida em termos da tensão alternada local $\left(\sigma_{a}\right)$, i.e., a tensão na superfície do espécime obtida com um strain gauge posicionado na seção crítica. Para isto, basta multiplicar a Curva $\mathbf{S}-\mathbf{N}$ verde pelo fator de entalhe $K_{t}=2,36$ para obter a Curva $\sigma$-N verde (curva verde da figura

\footnotetext{
${ }^{18}$ A seção crítica é a seção de menor diâmetro.

${ }^{19}$ A seção crítica é a seção de menor diâmetro.
} 
Tabela 6.5 Dados da Curva S-N azul e Curva $\sigma-\mathrm{N}$ azul.

\begin{tabular}{c|c|c|c}
\hline \multicolumn{5}{c}{ ESPÉCIME NÃO ENTALHADO } \\
\hline \multicolumn{5}{c}{ Dados Experimentais } \\
\hline $\begin{array}{c}\text { Tensão alternada } \\
\text { nominal }\end{array}$ & $\begin{array}{c}\text { Fator de concentração } \\
\text { de tensão }\end{array}$ & $\begin{array}{c}\text { Tensão alternada } \\
\text { local }\end{array}$ & Ciclos para falha \\
$S_{a}(\mathrm{MPa})$ & $K_{t}$ & $\sigma_{a}(\mathrm{MPa})$ & $N$ (ciclos) \\
\hline 1.193 & 1,0 & 1.193 & 1.000 \\
900 & 1,0 & 900 & 4.888 \\
800 & 1,0 & 800 & 9.486 \\
700 & 1,0 & 700 & 20.115 \\
600 & 1,0 & 600 & 47.901 \\
500 & 1,0 & 500 & 133.675 \\
400 & 1,0 & 400 & 469.402 \\
309,2 & 1,0 & 309,2 & 2.000 .000 \\
309,2 & 1,0 & 309,2 & 10.000 .000 \\
\hline
\end{tabular}

Tabela 6.6 Propriedades da Curva S-N azul.

\begin{tabular}{c}
\hline Curva S-N azul: ESPÉCIME NÃO ENTALHADO \\
\hline Dados Experimentais \\
\hline$S_{a}=S_{f}^{\prime} \cdot(2 N)^{b}$ \\
\hline$N_{B}=10^{4}$ ciclos \\
$S_{B}=792,5 \mathrm{MPa}$ \\
$N_{B}=2 \cdot 10^{6}$ ciclos \\
$S_{E}=309,2$ ciclos \\
$S_{f}^{\prime}=4.603,8 \mathrm{MPa}$ \\
$b=-0,1777$ \\
Observações: \\
$R=-1$ \\
$K_{t}=1,0$
\end{tabular}

Tabela 6.7 Propriedades da Curva $\sigma-\mathbf{N}$ azul.

Curva $\sigma$-N azul: ESPÉCIME NÃO ENTALHADO

Dados Experimentais

$$
\begin{aligned}
& \sigma_{a}=\sigma_{f}^{\prime} \cdot(2 N)^{b_{\sigma}} \\
& \sigma_{f}^{\prime}=4.603,8 \mathrm{MPa} \\
& b_{\sigma}=-0,1777
\end{aligned}
$$


Tabela 6.8 Dados da Curva S-N vermelha e Curva $\sigma-\mathbf{N}$ vermelha.

\begin{tabular}{|c|c|c|c|}
\hline \multicolumn{4}{|c|}{ ESPÉCIME ENTALHADO } \\
\hline \multicolumn{4}{|c|}{ Dados Experimentais } \\
\hline $\begin{array}{c}\text { Tensão alternada } \\
\text { nominal } \\
S_{a}(\mathrm{MPa})\end{array}$ & $\begin{array}{c}\text { Fator de concentração } \\
\text { de tensão } \\
K_{t}\end{array}$ & $\begin{array}{c}\text { Tensão alternada } \\
\text { local } \\
\sigma_{a}(\mathrm{MPa})\end{array}$ & $\begin{array}{c}\text { Ciclos para falha } \\
N(\text { ciclos })\end{array}$ \\
\hline $\begin{array}{c}951 \\
800 \\
700 \\
600 \\
500 \\
400 \\
300 \\
200 \\
179,6 \\
179,6\end{array}$ & $\begin{array}{l}2,36 \\
2,36 \\
2,36 \\
2,36 \\
2,36 \\
2,36 \\
2,36 \\
2,36 \\
2,36 \\
2,36\end{array}$ & $\begin{array}{c}2.243 \\
1.888 \\
1.652 \\
1.416 \\
1.180 \\
944 \\
708 \\
472 \\
424 \\
424\end{array}$ & $\begin{array}{c}1.000 \\
2.195 \\
4.037 \\
8.154 \\
18.729 \\
51.826 \\
192.493 \\
1.223 .485 \\
2.000 .000 \\
10.000 .000\end{array}$ \\
\hline
\end{tabular}

Tabela 6.9 Propriedades da Curva S-N vermelha.

Curva S-N vermelha: ESPÉCIME ENTALHADO

Dados Experimentais

\begin{tabular}{c}
\hline$S_{a}=S_{f}^{\prime} \cdot(2 N)^{b}$ \\
\hline$N_{B}=10^{4}$ ciclos \\
$S_{B}=573,7 \mathrm{MPa}$ \\
$N_{B}=2 \cdot 10^{6}$ ciclos \\
$S_{E}=179,6$ ciclos \\
$S_{f}^{\prime}=5.031,3 \mathrm{MPa}$ \\
$b=-0,2192$ \\
\hline Observações: \\
$R=-1$ \\
$K_{t}=2,36$
\end{tabular}

Tabela 6.10 Propriedades da Curva $\sigma-\mathrm{N}$ vermelha.

Curva $\sigma$-N vermelha: ESPÉCIME ENTALHADO

Dados Experimentais

$$
\begin{aligned}
& \sigma_{a}=\sigma_{f}^{\prime} \cdot(2 N)^{b_{\sigma}} \\
& \sigma_{f}^{\prime}=11.874 \mathrm{MPa} \\
& b_{\sigma}=-0,2192
\end{aligned}
$$


6.12, curva na qual o eixo das ordenadas é igual à $\sigma_{a}$. A tabela 6.13 contém a equação e as propriedades da Curva $\sigma-\mathbf{N}$ verde. As colunas 3 e 4 da tabela 6.11 apresentam pontos que satisfazem a equação da Curva $\sigma-\mathbf{N}$ verde. A equação (6.1) continua sendo válida para a obtenção da equação da tabela 6.13 .

O Método RSG, descrito nas seções 4.4.2 e 5.3, foi desenvolvido para estimar qual seria a Curva $\sigma-N$ de um componente entalhado, tendo apenas a Curva $S-N$ de um componente não entalhado. Neste Estudo de Caso, o espécime mostrado na figura 6.10b foi modelado em Elementos Finitos e solicitado a vários níveis de forças axiais, cujos valores estão mostrados nas colunas 1 e 2 da tabela 6.14, estas forças geraram tensões apenas na direção $x$. A coluna 3 apresenta o valor da tensão de von Mises alternada local $\left(\sigma_{v m, a}\right)$ calculada através da equação (5.57). A coluna 4 apresenta o valor do fator de entalhe $\left(n_{K}\right)$ que foi calculado para cada nível de força axial, utilizando a metodologia apresentada na seção 4.4.2. A vida em fadiga estimada para a seção crítica do espécime da figura $6.10 \mathrm{~b}$ foi calculada utilizando a Curva $\sigma-\mathbf{N}$ preta (curva preta da figura 6.12), cuja equação se encontra na tabela 6.15. Conforme apresentado na seção 4.4.2, os parâmetros dessa curva valem:

$$
\begin{array}{ll}
\sigma_{f}^{\prime}=n_{K} \cdot S_{f}^{\prime}=1,326 \cdot 4.603=6.105 \mathrm{MPa} & 4.111 \text { revisitada) } \\
b_{\sigma}=b=-0,1777 & 4.112 \text { revisitada) }
\end{array}
$$

As colunas 3 e 5 da tabela 6.14 contém os pontos que satisfazem a equação da tabela 6.15 . O eixo das ordenadas da Curva $\sigma-\mathbf{N}$ preta representa a tensão alternada local $\left(\sigma_{a}\right)$, i.e., a tensão na superfície do espécime obtida com um strain gauge posicionado na seção crítica. Para isto, basta multiplicar a Curva S-N azul pelo fator de entalhe $n_{K}$ para obter a Curva $\sigma-\mathbf{N}$ preta (curva preta da figura 6.12). A tabela 6.15 contém a equação e as propriedades da Curva $\sigma-\mathbf{N}$ preta.

A figura 6.12 mostra que a Curva $\sigma-\mathbf{N}$ preta estimada através do Método do Gradiente de Tensão Relativo (curva preta da figura 6.12) é muito próxima à Curva $\sigma-\mathbf{N}$ vermelha obtida experimentalmente (curva vermelha da figura 6.12). Também é possível perceber que a Curva $\sigma-\mathbf{N}$ preta se sobrepõe à Curva $\sigma$-N verde, o que demonstra que o Método $R S G$ produz resultados equivalentes ao Método $K_{f}$. Conclui-se, portanto, que o Método do Gradiente de Tensão Relativo pode ser utilizado perfeitamente para a contabilização do efeito de entalhe, gerando resultados com boa precisão.

$\mathrm{O}$ autor recomenda que o leitor compare as figuras 6.11 e 6.12 com as figuras $4.25,4.43$ e 4.49. A Curva $\mathbf{S}-\mathbf{N}$ azul é igual à Curva $\sigma-\mathbf{N}$ azul e ambas equivalem à Curva $\mathbf{S}-\mathbf{N}$ Unnotched das figuras 4.43 e 4.49. A Curva S-N verde equivale à Curva S-N Local das figuras 4.43 e 4.49, A Curva $\sigma-\mathbf{N}$ preta equivale à Curva $\sigma-\mathbf{N}$ Local das figuras $4.25 \mathrm{e} 4.49$. 
Tabela 6.11 Dados da Curva $S-N$ verde e Curva $\sigma$-N verde.

\begin{tabular}{c|c|c|c}
\hline \multicolumn{5}{c}{ ESPÉCIME ENTALHADO } \\
\hline \multicolumn{2}{c}{ Previsão pelo Método $K_{f}$} \\
\hline $\begin{array}{c}\text { Tensão alternada } \\
\text { nominal }\end{array}$ & $\begin{array}{c}\text { Fator de concentração } \\
\text { de tensão }\end{array}$ & $\begin{array}{c}\text { Tensão alternada } \\
\text { local }\end{array}$ & Ciclos para falha \\
$S_{a}(\mathrm{MPa})$ & $K_{t}$ & $\sigma_{a}(\mathrm{MPa})$ & $N$ (ciclos) \\
\hline 824 & 2,36 & 1.944 & 1.000 \\
700 & 2,36 & 1.652 & 2.050 \\
600 & 2,36 & 1.416 & 4.049 \\
400 & 2,36 & 944 & 24.271 \\
200 & 2,36 & 472 & 518.284 \\
147 & 2,36 & 348 & 2.000 .000 \\
147 & 2,36 & 348 & 10.000 .000 \\
\hline
\end{tabular}

Tabela 6.12 Propriedades da Curva S-N verde.

\begin{tabular}{c}
\hline Curva S-N verde: ESPÉCIME ENTALHADO \\
\hline Previsão pelo Método $K_{f}$ \\
\hline$S_{a}=S_{f}^{\prime} \cdot(2 N)^{b}$ \\
\hline$N_{B}=0,5$ ciclos \\
$S_{B}=4.603,8 \mathrm{MPa}$ \\
$N_{B}=2 \cdot 10^{6}$ ciclos \\
$S_{E}=147,3$ ciclos \\
\hline$S_{f}^{\prime}=4.603,8 \mathrm{MPa}$ \\
$b=-0,2264$ \\
\hline Observações: \\
$R=-1$ \\
$K_{t}=2,36$ \\
\hline$S_{u}=800 \mathrm{MPa}$ \\
$a_{p}=0,1426 \mathrm{~mm}$ \\
$r=0,6 \mathrm{~mm}$ \\
$q=0,8080$ \\
$\bar{q}=2,099$ \\
\hline $\bar{K}_{f}=2,0$ ados previstos pelo Método $K_{f}:$ \\
\hline
\end{tabular}

Tabela 6.13 Propriedades da Curva $\sigma-\mathbf{N}$ verde.

\begin{tabular}{c}
\hline Curva $\sigma$-N verde: ESPÉCIME ENTALHADO \\
\hline Previsão pelo Método $K_{f}$ \\
\hline$\sigma_{a}=\sigma_{f}^{\prime} \cdot(2 N)^{b_{\sigma}}$ \\
\hline$\sigma_{f}^{\prime}=10.865 \mathrm{MPa}$ \\
$b_{\sigma}=-0,2264$ \\
\hline
\end{tabular}


Tabela 6.14 Dados da Curva $\sigma-\mathbf{N}$ preta.

\begin{tabular}{c|c|c|c|c|c}
\hline \multicolumn{6}{c}{ ESPÉCIME ENTALHADO } \\
\hline \multicolumn{7}{c}{ Previsão pelo Método RSG - nó crítico: 52.917 } \\
\hline \multicolumn{2}{c}{ Força axial } & $\begin{array}{c}\text { Tensão de von Mises } \\
\text { alternada local } \\
\sigma_{v m, a}(\mathrm{MPa})\end{array}$ & $\begin{array}{c}\text { Fator de } \\
\text { entalhe } \\
n_{K}\end{array}$ & $\begin{array}{c}\text { Ciclos para falha } \\
N(\text { ciclos })\end{array}$ & Dano \\
$F_{x, i}(\mathrm{~N})$ & $F_{x, j}(\mathrm{~N})$ & 1551 & 1,326 & 1.118 & $4,47 \cdot 10^{-4}$ \\
\hline 27.326 & -27.326 & 1130 & 1,326 & 6.644 & $7,53 \cdot 10^{-5}$ \\
19.910 & -19.910 & 942 & 1,326 & 18.541 & $2,70 \cdot 10^{-5}$ \\
16.592 & -16.592 & 753 & 1,326 & 65.109 & $7,68 \cdot 10^{-6}$ \\
13.273 & -13.273 & 565 & 1,326 & 328.776 & $1,52 \cdot 10^{-6}$ \\
9.955 & -9.955 & 402 & 1,326 & 2.235 .833 & $2,24 \cdot 10^{-7}$ \\
7.081 & -7.081 & 402 & 1,326 & 10.000 .000 & $5,00 \cdot 10^{-8}$ \\
7.081 & -7.081 & & & &
\end{tabular}

Tabela 6.15 Propriedades da Curva $\sigma-\mathbf{N}$ preta.

\begin{tabular}{c}
\hline Curva $\sigma$-N preta: ESPÉCIME ENTALHADO \\
\hline Previsão pelo Método RSG - nó crítico: $\mathbf{5 2 . 9 1 7}$ \\
\hline$\sigma_{a}=\sigma_{f}^{\prime} \cdot(2 N)^{b_{\sigma}}$ \\
$\sigma_{f}^{\prime}=6.105 \mathrm{MPa}$ \\
$b_{\sigma}=-0,1777$ \\
\hline
\end{tabular}

\subsubsection{Estudo de Caso 4}

O critério de fadiga multiaxial utilizado para resolver problemas de carregamento multiaxial não-proporcional implementado no software $x$ Durability é o critério de Findley. Para se verificar a capacidade do $x$ Durability em prever a vida sob carregamento multiaxial não proporcional seria necessário que tivéssemos uma curva tensão-vida obtida sob este tipo de carregamento. Entretanto, não foi encontrado na literatura pesquisada tal curva. Entretanto, sendo a tensão de Findley igual à $\tau_{\text {findley, } a}=\tau_{a}+k_{F} \cdot \sigma_{n, \max }$, acredita-se que o software conseguirá prever a vida adequadamente se ele conseguir prever com precisão os parâmetros $\tau_{a}$ e $\sigma_{n, \max }$, calculados conforme as equações e 5.90 e 5.86 . O objetivo deste estudo de caso é:

- Verificar qual os parâmetros do Critério de Findley $\left(\sigma_{n, \text { max }}, \tau_{a}\right.$ e $\left.\tau_{\text {findley,a }}\right)$ calculados a partir do histórico de tensão do ponto crítico, mostrado na figura 6.13 p $^{0}$

$$
\tau_{a}=\max _{\varphi}\left(\tau_{a, \varphi}\right)=\max _{\varphi}\left(\sqrt{a_{1}^{2}(\varphi)+a_{2}^{2}(\varphi)}\right)
$$

\footnotetext{
${ }^{20}$ Este é o objetivo deste estudo de caso, que foi retirado de Lee et al. (2011, pg. 180).
} 


$$
\sigma_{n, \max }=\max _{t \in P} \sigma_{x}^{\prime}(t)
$$

Seja uma viga em balanço, com seção tubular quadrada, engastada à uma placa fixa em uma extremidade e sujeita à flexão $\left(\sigma_{x}\right)$ e torção $\left(\tau_{x y}\right)$ combinadas fora de fase aplicadas em outra extremidade, ilustrada na figura 6.13. A estrutura tubular possui parede fina e seção retangular.

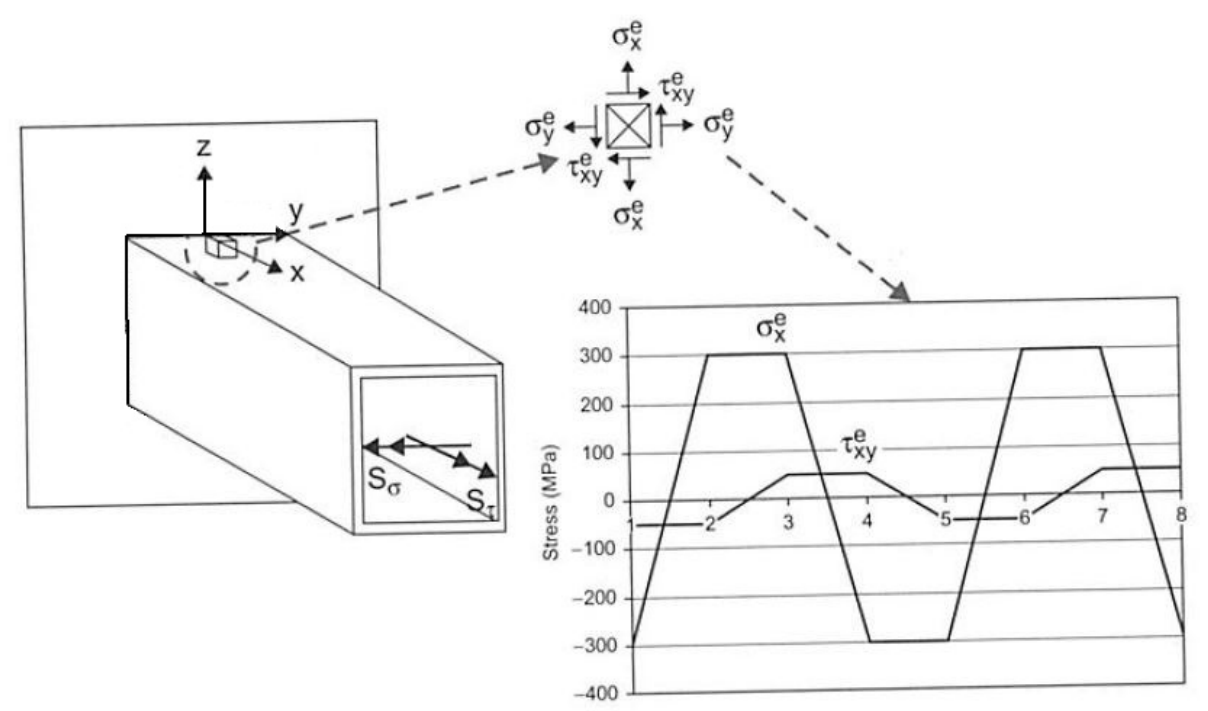

Figura 6.13 Local de iniciação de trinca com um sistema de coordenadas em um componente estrutural sujeito a cargas externas (Lee et al., 2011).

Testes indicaram que a maioria das trincas de fadiga se inicia na raiz do engaste, perto do canto do tubo. Portanto estado de tensão no elemento da superfície (na coordenada Xy) no local de nucleação de trinca pode ser assumido como sendo uma condição de estado plano de tensões e será escolhido para esta previsão de vida em fadiga. As tensões elásticas locais de flexão e torção $\left(\sigma_{x}\right.$ e $\left.\tau_{x y}\right)$ de interesse estão relacionadas às tensões de nominais de flexão e torção $\left(S_{\sigma}\right.$ e $\left.S_{\tau}\right)$ através dos fatores de concentração de tensão elásticos $\left(K_{t, \sigma} \mathrm{e}\right.$ $\left.K_{t, \tau}\right)$ conforme abaixo:

$$
\begin{aligned}
& \sigma_{x}=K_{t, \sigma} \cdot S_{\sigma} \\
& \tau_{x y}=K_{t, \tau} \cdot S_{\tau}
\end{aligned}
$$

A hipótese da restrição $\varepsilon_{y}=0$ leva à seguinte relação

$$
\sigma_{y}=v \cdot \sigma_{x}
$$

Sendo $v$ o Coeficiente de Poisson (assumido como $v=3$ neste exercício). O histórico das tensões no ponto de estudo está mostrado na figura 6.13. O Método da Escadarid ${ }^{21}$ foi

\footnotetext{
${ }^{21}$ Tradução livre do autor para "Staircase Method”. Mais informações vide livro Lee et al. (2011)
} 
conduzido com espécimes semelhantes ao da figura 6.13 para carregamento axial senoidal $\operatorname{com} R=-1$ e $R=0$. Dois limites de fadiga foram encontrados e são $\sigma_{E, s p}=700 \mathrm{MPa}$ e $\sigma_{E, s p}(@ R=0)=560 \mathrm{MPa}$. Utilizando estes dois limites de fadiga nas equações (5.96) e (5.94) resulta:

$$
k_{F}=0,23 \quad \beta_{F}=440 M P a
$$

A figura 6.14 apresenta uma maneira de identificar os ângulos de potenciais planos críti$\cos , \theta^{*}$ e $\phi^{*}$, que são planos que podem surgir trincas por fadiga. A comparação entre a figura 6.14 e a figura 5.37 permite escrever que $\theta=90^{\circ}-\theta^{*}$ e $\phi=\phi^{*}+90^{\circ}$. Para esta geometria, sabe-se que a trinca irá iniciar ao longo da linha formada pela raiz do engaste. Portanto, neste exercício, as trincas irão surgir no ângulo $\theta^{*}=0$ (i.e. $\theta=90^{\circ}$ ). Resta, portanto, determinar qual o ângulo $\phi$ mais provável para uma trinca nuclear. Na figura 5.37, as duas tensões de cisalhamento no plano de análise $\tau_{x y}^{\prime}$ e $\tau_{x z}^{\prime}$ (obtida através da equação 5.84) são combinadas para produzir a tensão de cisalhamento resultante $\left(\tau_{a}\right)$, conforme equação (5.90), que é utilizada no critério de Findley. Para cada plano de análise, a tensão de cisalhamento alternada $\left(\tau_{a}\right)$ e a tensão normal à este plano de análise $\left(\sigma_{x}^{\prime}\right)$ (obtida pela equação 5.84) são calculadas ao longo de todo histórico de carregamento. Neste estudo de caso, há apenas 4 instantes de tempo respectivos aos pontos 1, 2, 3 e 4 da figura 6.13 .
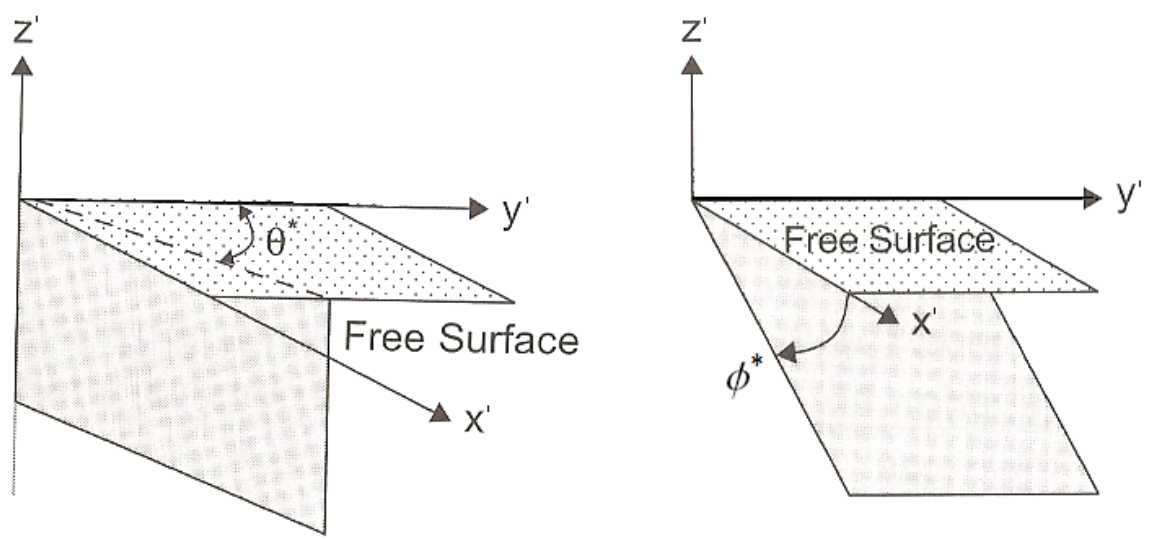

Figura 6.14 Planos críticos em potencial em um local de iniciação de trinca (Lee et al., 2011).

O processo é repetido para vários ângulos variando-se $\phi$ e $\varphi$ com um incremento de $20^{\circ}$. Os valores da tensão de cisalhamento alternada $\tau_{a}$ e a máxima tensão normal $\sigma_{n, \max }$ em cada plano de análise, ambas obtidas analiticamente, estão resumidos na tabela 6.16. A tensão normal $\left(\sigma_{x}\right)$ e a máxima tensão normal $\left(\sigma_{n, \max }\right)$ em cada plano de análise $\phi$ é exibida na tabela 6.16 .

A tabela 6.16 apresenta os resultados obtidos através de cálculos analíticos. A tabela 6.17 apresenta os resultados de vida obtidos numericamente, através do cálculo numérico 
Tabela 6.16 Tensões $\sigma_{n, \max }$ e $\tau_{a}$ em alguns planos de análise.

\begin{tabular}{|c|c|c|c|c|c|c|c|c|c|}
\hline \multicolumn{10}{|c|}{ CÁLCULO ANALÍTICO } \\
\hline \multicolumn{10}{|c|}{$\sigma_{x}$} \\
\hline \begin{tabular}{l|l} 
Ponto & $\phi$ \\
\end{tabular} & $90^{\circ}$ & $110^{\circ}$ & $130^{\circ}$ & $150^{\circ}$ & $170^{\circ}$ & $190^{\circ}$ & $210^{\circ}$ & $230^{\circ}$ & 250 \\
\hline 1 & -300 & -265 & -176 & -75 & -9 & -9 & -75 & -176 & -265 \\
\hline 2 & 300 & 265 & 176 & 75 & 9 & 9 & 75 & 176 & 265 \\
\hline 3 & 300 & 265 & 176 & 75 & 9 & 9 & 75 & 176 & 265 \\
\hline 4 & -300 & -265 & -176 & -75 & -9 & -9 & -75 & -176 & -265 \\
\hline$\sigma_{n, \max }$ & 300 & 265 & 176 & 75 & 9 & 9 & 75 & 176 & 265 \\
\hline \multicolumn{10}{|c|}{$\tau_{a}$} \\
\hline 1 & $90^{\circ}$ & $110^{\circ}$ & $130^{\circ}$ & $150^{\circ}$ & $170^{\circ}$ & $190^{\circ}$ & $210^{\circ}$ & $230^{\circ}$ & 250 \\
\hline $\mathbf{0}^{\circ}$ & 50 & 47 & 38 & 25 & 9 & 9 & 25 & 38 & 47 \\
\hline $20^{\circ}$ & 47 & 77 & 87 & 68 & 26 & 26 & 68 & 87 & 77 \\
\hline $40^{\circ}$ & 38 & 98 & 124 & 103 & 40 & 40 & 103 & 124 & 98 \\
\hline $60^{\circ}$ & 25 & 107 & 147 & 125 & 49 & 49 & 125 & 147 & 107 \\
\hline $80^{\circ}$ & 9 & 103 & 152 & 132 & 52 & 52 & 132 & 152 & 103 \\
\hline $100^{\circ}$ & 9 & 103 & 152 & 132 & 52 & 52 & 132 & 152 & 103 \\
\hline $120^{\circ}$ & 25 & 107 & 147 & 125 & 49 & 49 & 125 & 147 & 107 \\
\hline $140^{\circ}$ & 38 & 98 & 124 & 103 & 40 & 40 & 103 & 124 & 98 \\
\hline $160^{\circ}$ & 47 & 77 & 87 & 68 & 26 & 26 & 68 & 87 & 77 \\
\hline$\tau_{a}$ & 50 & 107 & 152 & 132 & 52 & 52 & 132 & 152 & 107 \\
\hline$\tau_{\text {findley, } a}$ & 119 & 168 & 192,5 & 149,3 & 54,1 & 54,1 & 149,3 & 192,5 & 168 \\
\hline
\end{tabular}

utilizando o xDurabilty. As mesmas condições de carregamento foram aplicadas no modelo numérico utilizado o software $x$ Durability para o cálculo da vida em fadiga.

Ao comparar os resultados das quatro tabelas anteriores é possível perceber que o software $x$ Durability resulta em resultados semelhantes aos obtidos no cálculo analítico. O plano crítico indicado pelo software é o mesmo indicado nos cálculos analíticos (i.e. $\phi=130^{\circ}$ ). O erro relativo entre os valores numéricos e os analíticos das tensões foi menor do que $1 \%$. Este estudo de caso mostrou que os resultados obtidos utilizando a análise de fadiga numérica, baseada em Elementos Finitos, são muito precisos, com erros baixos e altamente confiáveis. Desta forma, acredita-se que é possível utilizar ferramentas computacionais para a previsão confiável de vida em fadiga, principalmente utilizando integração com softwares de Elementos Finitos.

\subsubsection{Estudo de Caso 5}

Este estudo de caso tem como objetivo mostrar a aplicação da metodologia apresentada nos capítulos 4 e 5 na previsão da vida em fadiga de componentes, utilizando Fadiga Multiaxial, o Método dos Elementos Finitos e principalmente a aplicação do Critério de Findley 
Tabela 6.17 Tensões $\sigma_{n, \text { max }}$ e $\tau_{a}$ em alguns planos de análise.

\begin{tabular}{|c|c|c|c|c|c|c|c|c|c|}
\hline \multicolumn{10}{|c|}{ CÁLCULO NUMÉRICO : Software $x$ Durability } \\
\hline \multicolumn{10}{|c|}{$\sigma_{x}$} \\
\hline \begin{tabular}{l|l} 
Ponto & $\backslash \phi$
\end{tabular} & $\mathbf{9 0}^{\circ}$ & $110^{\circ}$ & $130^{\circ}$ & $150^{\circ}$ & $170^{\circ}$ & $190^{\circ}$ & $210^{\circ}$ & $\mathbf{2 3 0}^{\circ}$ & 250 \\
\hline 1 & $-300,4$ & $-265,1$ & $-176,0$ & $-74,8$ & $-8,9$ & $-9,1$ & $-75,3$ & $-176,6$ & $-265,5$ \\
\hline 2 & 300,4 & 265,1 & 176,0 & 74,8 & 8,9 & 9,1 & 75,3 & 176,6 & 265,5 \\
\hline 3 & 300,4 & 265,1 & 176,0 & 74,8 & 8,9 & 9,1 & 75,3 & 176,6 & 265,5 \\
\hline 4 & $-300,4$ & $-265,1$ & $-176,0$ & $-74,8$ & $-8,9$ & $-9,1$ & $-75,3$ & $-176,6$ & $-265,5$ \\
\hline$\sigma_{n, \max }$ & 300 & 265 & 176 & 75 & 9 & 9 & 75 & 176 & 265 \\
\hline \multicolumn{10}{|c|}{$\tau_{a}$} \\
\hline$\varphi \backslash \phi$ & $90^{\circ}$ & $110^{\circ}$ & $130^{\circ}$ & $150^{\circ}$ & $170^{\circ}$ & $190^{\circ}$ & $210^{\circ}$ & $\mathbf{2 3 0}^{\circ}$ & 250 \\
\hline $\mathbf{0}^{\circ}$ & 51,3 & 48,1 & 39,1 & 25,4 & 8,7 & 9 & 25,9 & 39,5 & 48,3 \\
\hline $20^{\circ}$ & 48,3 & 78,3 & 87,3 & 68,3 & 25,6 & 26,3 & 68,9 & 87,7 & 78,3 \\
\hline $40^{\circ}$ & 39,5 & 99,0 & 125,1 & 103,0 & 39,5 & 40,3 & 103,6 & 125,3 & 98,9 \\
\hline $60^{\circ}$ & 25,9 & 107,9 & 147,7 & 125,3 & 48,6 & 49,3 & 125,8 & 147,8 & 107,6 \\
\hline $80^{\circ}$ & 9,2 & 103,7 & 152,6 & 132,4 & 51,8 & 52,5 & 132,8 & 152,5 & 103,3 \\
\hline $100^{\circ}$ & 9,1 & 103,6 & 153,5 & 132,5 & 51,9 & 52,4 & 132,7 & 152,5 & 103,3 \\
\hline $120^{\circ}$ & 25,8 & 107,8 & 147,7 & 125,3 & 48,7 & 49,2 & 125,7 & 147,8 & 107,6 \\
\hline $140^{\circ}$ & 39,4 & 99,0 & 125,1 & 103,1 & 59,6 & 40,1 & 103,5 & 125,3 & 98,9 \\
\hline $160^{\circ}$ & 48,2 & 78,3 & 87,4 & 68,4 & 25,7 & 26,2 & 68,8 & 87,6 & 78,3 \\
\hline$\tau_{a}$ & 51,3 & 107,9 & 153,5 & 132,5 & 59,6 & 52,5 & 132,8 & 152,5 & 107,6 \\
\hline$\tau_{\text {findley, } a}$ & 120,3 & 168,9 & 194 & 149,8 & 61,7 & 54,6 & 150,1 & 193,1 & 168,7 \\
\hline
\end{tabular}

em um componente metálico sujeito a carregamento cíclico multiaxial não-proporcional.

Seja uma viga engastada de seção circular utilizada como objeto de análise para exemplificação da metodologia proposta nesta dissertação. A figura 6.15 apresenta as dimensões da viga analisada. Foram simulados 7 condições de carregamento sobre a viga, doravante denominadas $\boldsymbol{C A S E S}$, e a vida em fadiga da viga foi determinada para cada uma das 7 condições. Em todas as situações foi aplicado duas forças verticais cíclicas na extremidade livre da viga, afim de causar um momento fletor cíclico e um momento torçor cíclico também na extremidade livre. Em todos os CASES o momento torçor está defasado do momento fletor em $90^{\circ}$. A diferença entre os CASES é apenas a intensidade do momento fletor e do momento torçor aplicados. Seja o modelo de elementos finitos da viga ilustrada pela figura 6.16. A superfície cinza representa a parede rígida na qual a viga está engastada e o ponto amarelo representa o nó $\mathrm{n}^{\circ} 110.877$ do modelo de elementos finitos. É interessante adiantar que o procedimento descrito neste estudo de caso foi realizado para cada um dos nós do modelo de elementos finitos. Com esta análise descobriu-se que o nó 110.877 é o nó crítico ${ }^{22}$, pois possui a menor vida em fadiga e portanto é nele que ocorrerá a nucleação da trinca por fadiga. Consequentemente, a seção transversal que

\footnotetext{
${ }^{22}$ Nó critico é aquele localizado no ponto onde espera-se que se inicie uma trinca por fadiga, que se propagará pelo componente analisado.
} 
contém o nó 110.877 é a seção crítica da viga onde ocorrerá a fratura por fadiga. Isto será mais detalhado ao longo deste estudo de caso. Por este motivo, apenas o nó 110.877 será citado neste estudo.

Os carregamentos estão aplicados na extremidade livre da viga em um único nó de um spider composto de elementos rígidos, que transfere os esforços para a viga. As figuras 6.17 e 6.18 apresentam, respectivamente, um instante de tempo onde a força $F_{y}$ e o momento torçor $M_{x}$ são aplicados na viga.

A figura 6.19 apresenta o valor da força $F_{y}$ aplicado na viga no CASE 1, para cada instante de tempo, sendo o valor máximo de $F_{y}$ igual a $2.356 \mathrm{~N}$ e mínimo igual a $-2.356 \mathrm{~N}$. A figura 6.20 apresenta o valor do momento $M_{x}$ aplicado na viga no CASE 1, para cada instante de tempo, sendo o valor máximo de $M_{x}$ igual a $565.407 N m m$ e mínimo igual a $-565407 \mathrm{Nmm}$. A linha tracejada nestas figuras indicam que o carregamento é aplicado continuamente até ocorrer a falha/fratura por fadiga. A figura 6.21a apresenta as tensões $\sigma_{x} \tau_{x y}$ que ocorrem no nó número 110.877 , sendo o valor máximo e mínimo de $\sigma_{x}$ igual a $150 \mathrm{MPa}$ e $-150 \mathrm{MPa}$, respectivamente. O valor máximo e mínimo de $\tau_{x y}$ é igual a $45 \mathrm{MPa}$ e -45MPa, respectivamente. As figuras 6.21b até 6.21g ilustram o histórico das tensões do nó 110.877 conforme os CASES descritos na tabela 6.18, Esta tabela contém os valores da força $F_{y}$ e o momento $M_{x}$ aplicados na extremidade da viga, conforme apresentam as figura 6.17 e 6.18, assim como os valores das tensões normais alternada e média $\left(\sigma_{x, a}\right.$ e $\left.\sigma_{x, m}\right)$ e das tensões de cisalhamento alternada e média $\left(\tau_{x y, a}\right.$ e $\left.\tau_{x y, m}\right)$ do nó 110.877 .

A análise de fadiga considerou que a viga engastada é fabricada de aço inoxidável A304. As propriedades da Curva $\boldsymbol{S}$ - $\boldsymbol{N}$ Espécime, i.e. do espécime padronizado, são apresentadas a seguir:

$$
\begin{aligned}
& S_{E, s p}=160,8 \mathrm{MPa} \\
& N_{E}=10^{6} \text { ciclos } \\
& S_{B, s p}=437,2 \mathrm{MPa} \\
& N_{B}=10^{3} \text { ciclos } \\
& S_{f, s p}^{\prime}=1314,0 \mathrm{MPa} \\
& b_{s p}=-0,1448
\end{aligned}
$$

É importante ressaltar que os parâmetros da equação (6.6) são aqueles da Curva $S$ - $N$ Espécime apresentada na figura (4.24). A curva tensão-vida da figura (5.40) representa a curva tensão-vida que utilizaremos neste estudo de caso para avaliar a vida em fadiga da viga da figura 6.15. Desta maneira, é necessário calcular todos os fatores modificadores, obter sequencialmente os parâmetros $k_{F}, \beta_{F}, b_{u} n$ e $\tau_{f, u n}^{\prime}$. Somente a partir de então é possível 


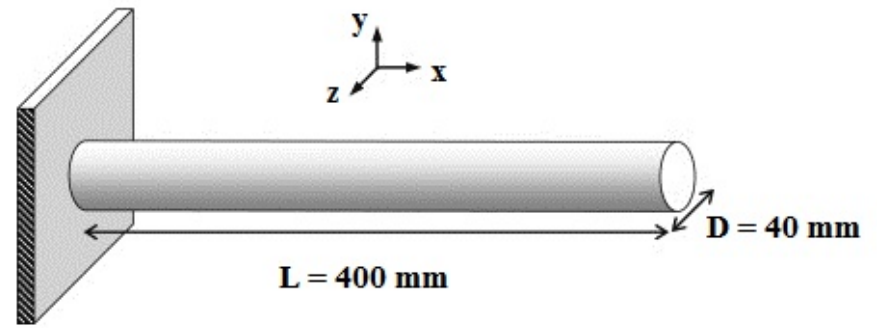

Figura 6.15 Dimensões da viga.

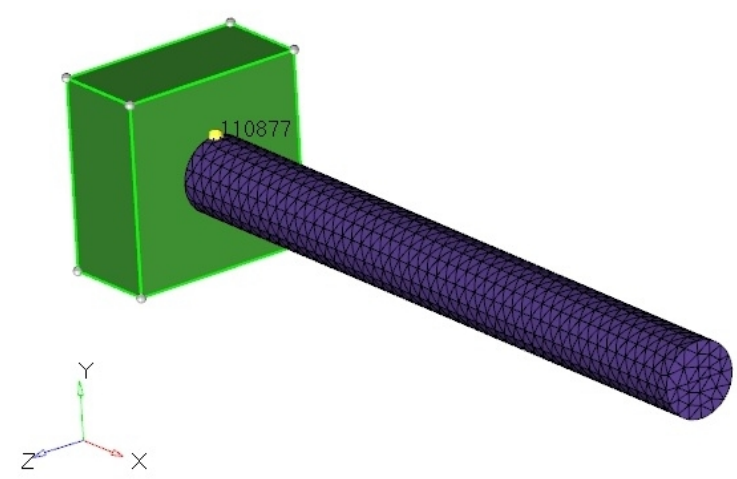

Figura 6.16 Viga engastada e nó número 110.877 .

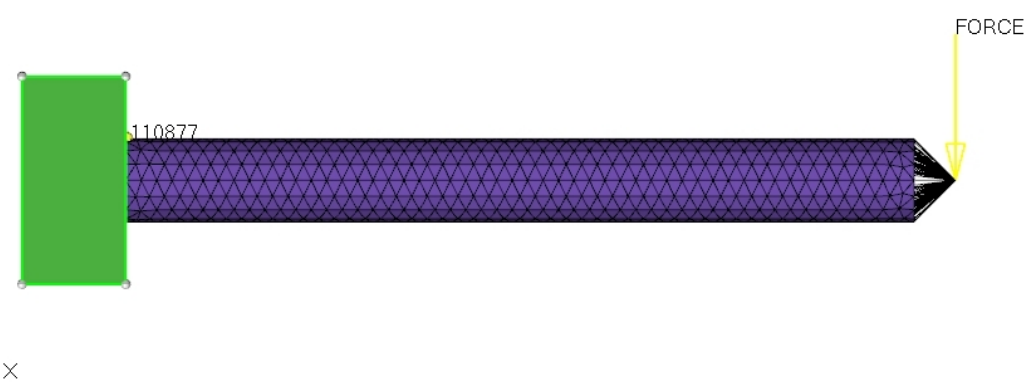

Figura 6.17 Instante de aplicação da força $F_{y}$.

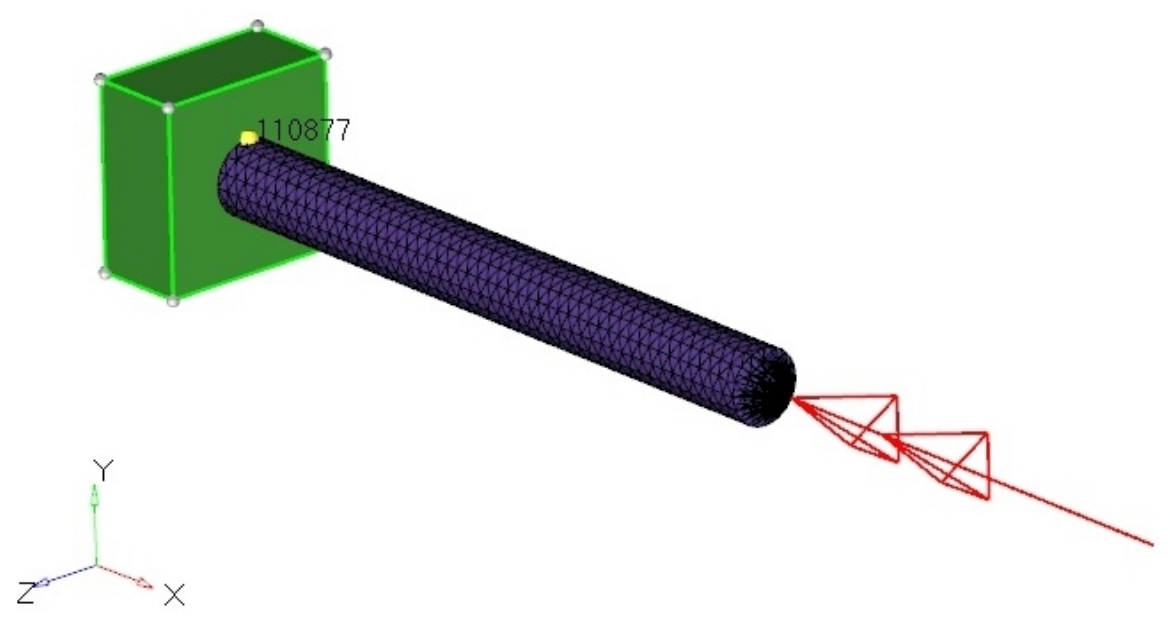

Figura 6.18 Instante de aplicação do momento torçor $M_{x}$. 


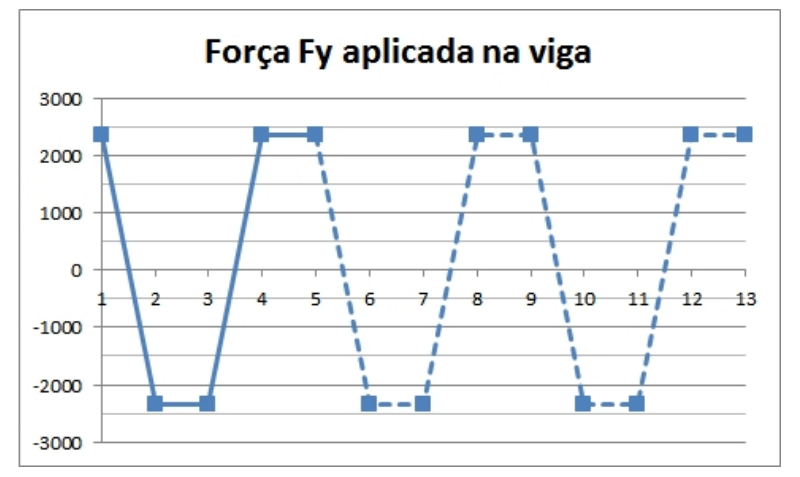

Figura 6.19 Força $F_{y}$ aplicada no CASE 1.

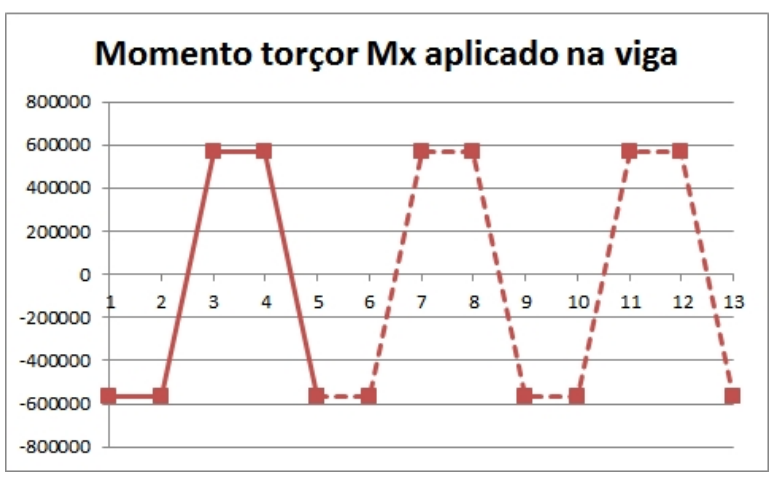

Figura 6.20 Momento $M_{x}$ aplicado no CASE 1 . 


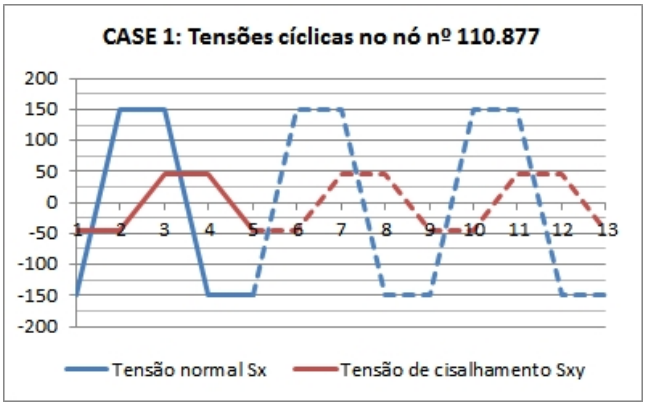

(a) Tensões cíclicas aplicadas no nó 110.877 no CASE 1.

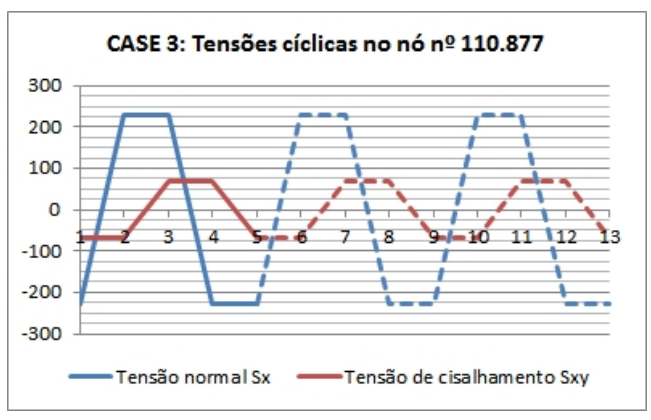

(c) Tensões cíclicas aplicadas no nó 110.877 no CASE 3.

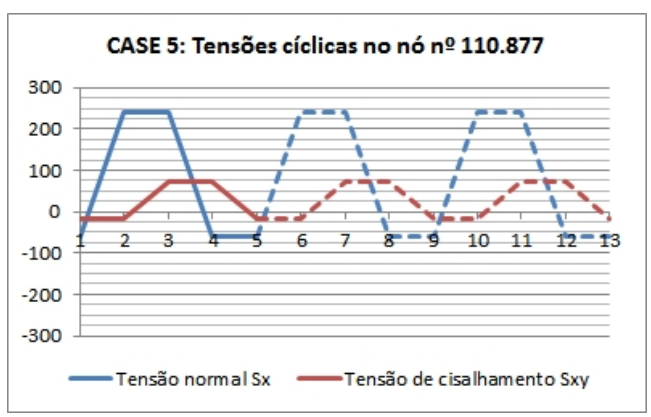

(e) Tensões cíclicas aplicadas no nó 110.877 no CASE 5.

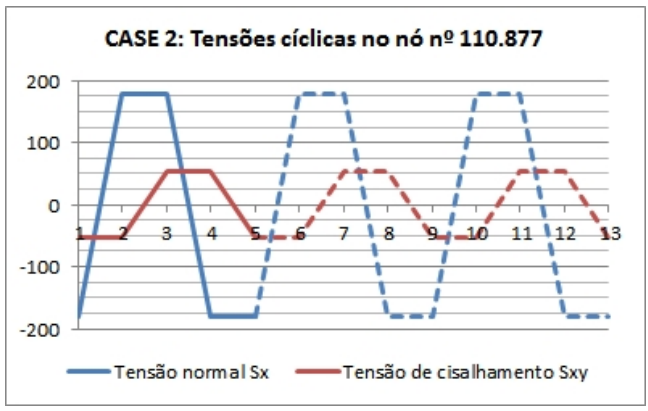

(b) Tensões cíclicas aplicadas no nó 110.877 no CASE 2.

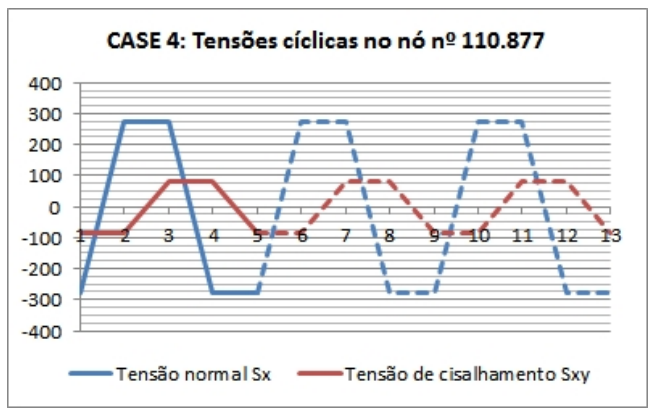

(d) Tensões cíclicas aplicadas no nó 110.877 no CASE 4.

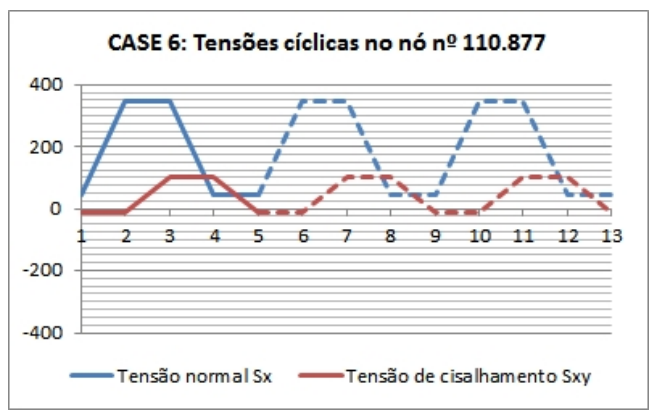

(f) Tensões cíclicas aplicadas no nó 110.877 no CASE 6.

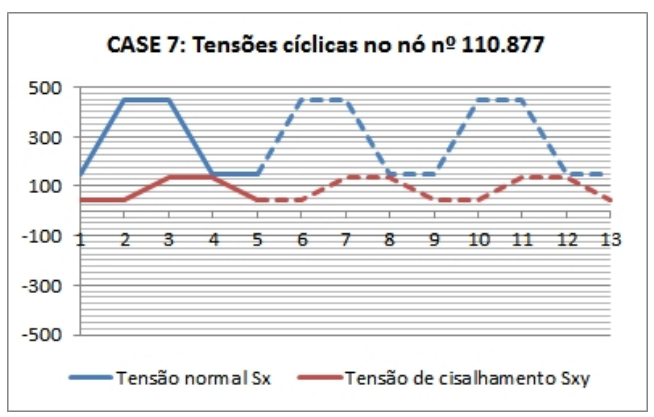

(g) Tensões cíclicas aplicadas no nó 110.877 no CASE 7.

Figura 6.21 Tensões cíclicas aplicadas no nó 110.877 durante os 6 CASES. 
estimar a vida em fadiga da viga da figura 6.15. Os fatores modificadores utilizados neste estudo de caso são:

$$
\begin{aligned}
& C_{R O}=1,0 \\
& C_{S T}=1,0 \\
& C_{C}=1,0 \\
& C_{R}=0,843 \text { (para } 97,5 \% \text { de confiabilidade) } \\
& C_{T}=1,0
\end{aligned}
$$

Considerando $\sigma_{E, s p}=S_{E, s p} \cdot 0,9$ e $\tau_{E, s p}=S_{E, s p} \cdot \frac{1}{\sqrt{3}}$ obtém-se:

$$
\begin{array}{lll}
A_{-1} & =121,99 \mathrm{MPa} & \text { (equação 5.24) } \\
T_{-1} & =78,26 \mathrm{MPa} & \text { (equação 5.28) } \\
k_{F} & =0,2951 & \text { (equação 5.95) } \\
\beta_{F} & =81,59 \mathrm{MPa} & \text { (equação 5.94) } \\
S_{B, \text { un }} & =368,52 \mathrm{MPa} & \text { (equação 5.99) } \\
b_{\text {un }} & =-0,2183 & \text { (equação 5.100) } \\
\tau_{f, \text { un }}^{\prime} & =1936,27 \mathrm{MPa} & \text { (equação 5.101) }
\end{array}
$$

Na tabela 6.18, as tensões das colunas 5 e 6 são obtidas através da Análise Linear por Elementos Finitos ao longo de todos os LoadSteps. No início de uma análise de fadiga de um modelo de Elementos Finitos complexo não é possível saber a princípio qual o ponto/nó onde ocorrerá a nucleação da trinca por fadiga. Por este motivo, deve-se estimar a vida em fadiga (ou o dano em fadiga) de cada um dos nós superficiais. Portanto, também deve-se calcular o fator de entalhe " $n_{K}$ " para todos os nós de canto ${ }^{23}$ da superfície do componente. $\mathrm{O}$ fator de entalhe é um fator que consegue ser obtido automaticamente e por isso o software $x$ Durability calcula o seu valor automaticamente para cada um dos nós de canto superficiais. $\mathrm{O}$ cálculo do fator de entalhe é realizado da maneira apresenta a seção 5.3 . O software $x$ Durability foi utilizado para a resolução deste estudo de caso e portanto ele calculou o fator de entalhe relativo a cada um dos nós de canto superficiais do modelo de elementos finitos. $O$ fator de entalhe " $n_{K}$ " calculado para o nó crítico n ${ }^{\circ} 110.877$ é $n_{K}=1,0375$. As tensões das colunas 8 e 9 foram calculadas utilizando a equação (5.21).

A tabela 6.19 apresenta, para cada um dos 7 CASES, o nó crítico da viga, o fator de entalhe " $n_{K}$ " calculado no nó crítico, a máxima Tensão de Findley $\left(\max _{\theta, \phi}\left\{\tau_{\text {findley,a }}\right\}\right)$ medida

\footnotetext{
${ }^{23}$ Tradução livre do autor para corner nodes.
} 
Tabela 6.18 Cargas aplicadas na viga e tensões no nó crítico 110.877 para cada LoadStep.

\begin{tabular}{|c|c|c|c|c|c|c|c|c|}
\hline & \multirow{2}{*}{\multicolumn{2}{|c|}{ CARREGAMENTO }} & \multirow{2}{*}{\multicolumn{5}{|c|}{ TENSÃO }} \\
\hline & & & & & & & & \\
\hline CASE & LoadStep & Força $\left(F_{y}\right)$ & $\begin{array}{c}\text { Momento } \\
\left(M_{x}\right)\end{array}$ & $\sigma_{x}^{e}$ & $\sigma_{x z}^{e}$ & $n_{K}^{*}$ & $\sigma_{x}$ & $\sigma_{x z}$ \\
\hline \multirow{4}{*}{1} & 1 & 2.356 & -565.407 & $-150,0$ & $-45,0$ & 1,0375 & $-144,6$ & $-43,4$ \\
\hline & 2 & -2.356 & -565.407 & 150,0 & $-45,0$ & 1,0375 & 144,6 & $-43,4$ \\
\hline & 3 & -2.356 & 565.407 & 150,0 & 45,0 & 1,0375 & 144,6 & 43,4 \\
\hline & 4 & 2.356 & 565.407 & $-150,0$ & 45,0 & 1,0375 & $-144,6$ & 43,4 \\
\hline \multirow{4}{*}{2} & 1 & 2.816 & -675.812 & $-179,3$ & $-53,8$ & 1,0375 & $-172,8$ & $-51,8$ \\
\hline & 2 & -2.816 & -675.812 & 179,3 & $-53,8$ & 1,0375 & 172,8 & $-51,8$ \\
\hline & 3 & -2.816 & 675.812 & 179,3 & 53,8 & 1,0375 & 172,8 & 51,8 \\
\hline & 4 & 2.816 & 675.812 & $-179,3$ & 53,8 & 1,0375 & $-172,8$ & 51,8 \\
\hline \multirow{4}{*}{3} & 1 & 3.571 & -857.040 & $-227,3$ & $-68,2$ & 1,0375 & $-219,1$ & $-65,7$ \\
\hline & 2 & -3.571 & -857.040 & 227,3 & $-68,2$ & 1,0375 & 219,1 & $-65,7$ \\
\hline & 3 & -3.571 & 857.040 & 227,3 & 68,2 & 1,0375 & 219,1 & 65,7 \\
\hline & 4 & 3.571 & 857.040 & $-227,3$ & 68,2 & 1,0375 & $-219,1$ & 65,7 \\
\hline \multirow{4}{*}{4} & 1 & 4.327 & -1.038 .298 & $-275,4$ & $-82,6$ & 1,0375 & $-265,5$ & $-79,6$ \\
\hline & 2 & -4.327 & -1.038 .298 & 275,4 & $-82,6$ & 1,0375 & 265,5 & $-79,6$ \\
\hline & 3 & -4.327 & 1.038 .298 & 275,4 & 82,6 & 1,0375 & 265,5 & 79,6 \\
\hline & 4 & 4.327 & 1.038 .298 & $-275,4$ & 82,6 & 1,0375 & $-265,5$ & 79,6 \\
\hline \multirow{4}{*}{5} & 1 & 942 & -226.163 & $-60,0$ & $-18,0$ & 1,0375 & $-57,8$ & $-17,3$ \\
\hline & 2 & -3.770 & -226.163 & 240,0 & $-18,0$ & 1,0375 & 231,3 & $-17,3$ \\
\hline & 3 & -3.770 & 904.651 & 240,0 & 72,0 & 1,0375 & 231,3 & 69,4 \\
\hline & 4 & 942 & 904.651 & $-60,0$ & 72,0 & 1,0375 & $-57,8$ & 69,4 \\
\hline \multirow{4}{*}{6} & 1 & -707 & 169.622 & 45,0 & 13,5 & 1,0375 & 43,4 & $-13,0$ \\
\hline & 2 & -5.419 & 169.622 & 345,0 & 13,5 & 1,0375 & 332,5 & 13,0 \\
\hline & 3 & -5.419 & 1.300 .436 & 345,0 & 103,5 & 1,0375 & 332,5 & 99,7 \\
\hline & 4 & -707 & 1.300 .436 & 45,0 & 103,5 & 1,0375 & 43,4 & 99,7 \\
\hline \multirow{4}{*}{7} & 1 & -2.356 & 565.407 & 105,0 & 45,0 & 1,0375 & 144,6 & 43,4 \\
\hline & 2 & -7.068 & 565.407 & 450,0 & 45,0 & 1,0375 & 433,7 & 43,4 \\
\hline & 3 & -7.068 & 1.696 .221 & 450,0 & 135,0 & 1,0375 & 433,7 & 130,1 \\
\hline & 4 & -2.356 & 1.696 .221 & 150,0 & 135,0 & 1,0375 & 144,6 & 130,1 \\
\hline
\end{tabular}

* Fator de entalhe calculado pelo Método RSG Multiaxial, seção 5.3 
Tabela 6.19 Máxima Tensão de Findley $\left(\max _{\theta, \phi}\left\{\tau_{\text {findley,a } a}\right\}\right)$ para o nó crítico e estimativa da vida em fadiga utilizando o Critério de Findley para cada CASE.

\begin{tabular}{|c|c|c|c|c|c|c|c|}
\hline \multirow{3}{*}{ CASE } & \multirow{3}{*}{ LoadStep } & \multicolumn{6}{|c|}{ SOFTWARE - Critério de Findley } \\
\hline & & \multirow{2}{*}{$\begin{array}{c}\text { Nó } \\
\text { Crítico }\end{array}$} & \multirow{2}{*}{$\max _{\theta, \phi}\left\{\tau_{\text {findley }, a}\right\}$} & \multicolumn{3}{|c|}{ Parâmetros da Curva Tensão-Vida } & \multirow{2}{*}{$\mathrm{N}$} \\
\hline & & & & $\tau_{f, \text { un }}^{\prime}$ & $b_{u n}$ & $\beta_{F}$ & \\
\hline 1 & $\begin{array}{l}1 \\
2 \\
3 \\
4\end{array}$ & 110.877 & 126,7 & $1.936,27$ & $-0,2183$ & 81,59 & 132.986 \\
\hline 2 & $\begin{array}{l}1 \\
2 \\
3 \\
4\end{array}$ & 110.877 & 151,5 & $1.936,27$ & $-0,2183$ & 81,59 & 58.730 \\
\hline 3 & $\begin{array}{l}1 \\
2 \\
3 \\
4\end{array}$ & 110.877 & 192,1 & $1.936,27$ & $-0,2183$ & 81,59 & 19.784 \\
\hline 4 & $\begin{array}{l}1 \\
2 \\
3 \\
4\end{array}$ & 110.877 & 232,7 & $1.936,27$ & $-0,2183$ & 81,59 & 8.211 \\
\hline 5 & $\begin{array}{l}1 \\
2 \\
3 \\
4\end{array}$ & 110.877 & 155,1 & $1.936,27$ & $-0,2183$ & 81,59 & 52.731 \\
\hline 6 & $\begin{array}{l}1 \\
2 \\
3 \\
4\end{array}$ & 110.877 & 188,2 & $1.936,27$ & $-0,2183$ & 81,59 & 21.725 \\
\hline 7 & $\begin{array}{l}1 \\
2 \\
3 \\
4\end{array}$ & 110.877 & 221,3 & $1.936,27$ & $-0,2183$ & 81,59 & 10.338 \\
\hline
\end{tabular}

no nó crítico, os parâmetros da Curva Tensão-Vida utilizada no Critério de Findley e a vida em fadiga da viga (que é a vida relativa à seção transversal que contém o nó crítico). É importante lembrar que a vida estipulada na última coluna desta tabela representa o número de ciclos que se estima ocorrer a fratura/ruptura por fadiga da viga apresentada na figura 6.15. sendo a trinca iniciada no nó crítico e propagando-se pela seção transversal da viga.

\subsection{Conclusões do Capítulo 6}

Este capítulo apresentou o software desenvolvido nesta dissertação para análise de vida em fadiga de modelos baseados Elementos Finitos, que permite contabilizar corretamente o 
dano causado tanto por carregamentos uniaxiais quanto por multiaxiais, através de critérios de fadiga multiaxial. Uma análise detalhada dos principais softwares para análise de fadiga baseados em FEA foi realizado. Também foi detalhado com fluxogramas o processo global de análise de fadiga de uma estrutura, assim como detalhado cada etapa de uma análise de fadiga faseada em FEA, sempre utilizando-se a teoria apresentada nos capítulos anteriores de maneira aplicada. Por último, foram realizados 5 estudos de casos a fim de demonstrar a aplicação de alguns métodos relatados nesta dissertação em problemas reais, assim como demonstrar a validade e aplicação do software $x$ Durability no processo de análise de fadiga. Não faz parte do objetivo desta dissertação realizar estudos de caso a fim de validar todos os métodos e etapas apresentados ao longo de toda a dissertação. Estes inúmeros métodos e etapas já foram validados em artigos científicos e livros publicados no passado e, portanto, são considerados válidos e com adequada correlação experimental.

A tarefa de realizar uma análise de fadiga é complexa e exige profundo conhecimento do analista. Cálculos utilizando a moderna técnica de fadiga multiaxial, por exemplo, tem um papel importante em situações de projetos especializadas. Entretanto, se alguém cometer um erro na aplicação desta técnica em situações de projetos mais simples, a perda na precisão da resposta poderá ser maior do que os ganhos de se utilizar uma ferramenta mais moderna. Além do mais, cálculos manuais ou outros tipos de cálculos simplificados deveriam ser utilizados como uma garantia de qualidade, com o objetivo de verificar se as aproximações adotadas e os resultados utilizando modelos de Elementos Finitos estão corretos. Se isto não é possível, então deve-se ter muita cautela. Em grandes organizações, onde há mais recursos financeiros para investir em testes, curvas de fadiga são obtidas utilizando-se espécimes cortados dos próprios componentes a fim de se contabilizar o efeito da manufatura. Fornecedores de fundidos também costumam fundir seus próprios corpos de prova para que seja contabilizado o efeito do acabamento superficial e os efeitos de formato e tamanho de grão nas curvas de fadiga.

Os termos fadiga, durabilidade e confiabilidade são frequentemente utilizados de maneira inadequada. O termo fadiga deve ser utilizado para descrever o processo pelo qual trincas se iniciam e crescem dentro de materiais quando sujeitos a tensões e deformações flutuantes. O termo durabilidade deve ser utilizado como um termo que descreve o requisito de vida total, tal como durar por 540.000 ciclos ou $300.000 \mathrm{~km}$, por exemplo. O termo confiabilidade deve ser utilizado como um conceito mais amplo que o termo durabilidade. Ele se refere à probabilidade de falha que há para alcançar o requesito de vida total; por exemplo, uma confiabilidade de $95 \%$ significa que há $95 \%$ de probabilidade de que o componente analisado dure $300.000 \mathrm{~km}$ ou mais.

É importante ressaltar alguns aspectos relacionados aos fatores de segurança. O Capítulo 4 Análise de Fadiga Uniaxial Baseada em Tensão apresentou curvas de material que geralmente são plotadas como curvas médias (50\% de falha). Isto significa que, se essas curvas 
forem utilizadas em um projeto de um componente onde nenhum outro fator de segurança estará presente, então será esperado uma taxa de falha dos componentes de 50\%. Provavelmente isto não irá acontecer porque fatores de segurança são geralmente introduzidos em algum momento da análise de fadiga. Por exemplo, curvas de carregamento geralmente possuem margens de segurança (i.e., o histórico de carregamento é amplificado através da multiplicação do mesmo por um número maior do que 1,0) ou algumas vezes a estimativa da vida em fadiga é 6 vezes maior do que a vida requerida. Um projeto de fadiga baseado em Elementos Finitos (FE Based Fatigue Design) possui um importante benefício: a habilidade de gerenciar adequadamente esses fatores de segurança de uma maneira sistemática. Há possibilidade de incluir os fatores de segurança onde se achar necessário, como nas cargas, no material e na geometria do componente.

Deve-se também enfatizar que a dispersão é um aspecto intrísseco em qualquer cálculo de fadiga. Há um desvio padrão nas propriedades de fadiga do material, no histórico de carregamento, nos fatores modificadores e no critério de fadiga multiaxial utilizado. Portanto, certamente a vida em fadiga estimada através dos cálculos não será idêntica à vida da estrutura real. Consequentemente, estimativas que estão entre 0,5 e 3 vezes a vida da estrutura é absolutamente aceitável. Por esta razão, testes em fadiga sempre devem ser exigidos no projeto de um produto, principalmente testes relacionados à validação estrutural de um produto no final de um projeto, chamados testes de validação. 


\section{Capítulo 7}

\section{Conclusões}

O presente trabalho propôs uma metodologia moderna para prever a vida em fadiga de componentes mecânicos, peças e estruturas, feitos de metal, utilizando técnicas e métodos modernos da análise de fadiga, contabilizando adequadamente o efeito da variação aleatória do estado triaxial de tensões e uso de Análise por Elementos Finitos (FEA). Adicionalmente, foi implementado um software contendo a teoria de fadiga uni e multiaxial que lê resultados do software comercial $A N S Y S^{\circledR}$ e calcula a vida em fadiga do componente.

No capítulo 2 foi realizada uma revisão sobre os mecanismos de nucleação e crescimento de trinca por fadiga sob a ótica da mecânica dos materiais. No capítulo 3 foi visto como a análise de fadiga computacional se insere dentro de um projeto de desenvolvimento de produto, assim como os 3 métodos que podem ser utilizados em uma análise de fadiga: Método S-N, Método $\varepsilon-\mathrm{N}$ e Método da Mecânica da Fratura. Também foi revisto como estes métodos estão correlacionados com as filosofias de projeto.

No capítulo 4 foi apresentada uma metodologia para a obtenção da curva S-N de espécimes de aços e outras ligas metálicas, para o caso do engenheiro não conseguir obtê-la através de experimentos. Esta metodologia é uma junção das melhores partes de experimentos, conclusões e recomendações de diversos autores, desde 1962 até 2011. Neste capítulo também foi apresentado o conceito do Método da Curva $S$ - $N$ Sintética, que pode ser aplicável plenamente em conjunto com resultados de Análises por Elementos Finitos, onde a curva tensão-vida do componente é estimada através de fatores modificadores. Uma grande revisão bibliográfica permitiu que fossem apresentados apenas os métodos mais avançados para a contabilização desses fatores modificadores, baseando-se principalmente na FKMGuideline (2003), que é uma das diretrizes técnicas mais conceituadas na área da engenharia mecânica. Destacam-se nesta metodologia o cálculo do fator de tratamento superficial por ser apresentado apenas pela FKM-Guideline (2003), o cálculo do fator de corrosão por ser apresentado apenas pela Bureau Veritas (1998), o efeito da frequência de carregamento e o fator de tamanho, apresentado de maneira diferente pela FKM-Guideline (2003). Enfase 
também é dada ao cálculo do fator de tensão média que pode ser calculado através de diversas formas, inclusive através do padronizado diagrama de Haigh, apresentado apenas pela FKM-Guideline (2003). Também foi realizado um extenso estudo para verificar como se comporta o fator de tensão média quando calculado utilizando a tensão superficial local $\left.\right|^{1}$ obtidas em Análise por Elementos Finitos, ao invés da tensão nominal. No capítulo 4 também foi apresentado os métodos para contabilizar o efeito de entalhe em fadiga, dando-se ênfase ao Método do Gradiente de Tensão Relativo que é o único que pode ser incorporado à um software de análise de fadiga afim de contabilizar automaticamente o efeito de entalhe na análise de fadiga. Por fim, este capítulo também apresentou como lidar com a densidade da malha de Elementos Finitos e com carregamentos de amplitude variável em uma análise de fadiga baseada em Elementos Finitos.

No capítulo 4 foi mostrado que não é possível utilizar o Método $K_{f}$ para a contabilização do efeito de entalhe em análise de fadiga baseada em Elementos Finitos. Apenas o Método RSG (seções 4.4.2 e 5.3) consegue ser utilizado nestes casos, sendo este método apresentado apenas pela FKM-Guideline (2003).

No capítulo 5 foi apresentado o conceito de fadiga multiaxial e como carregamentos multiaxiais não proporcionais geram vida em fadiga menores, quando comparados com carregamentos multiaxiais proporcionais de mesma tensão equivalente. Nesta etapa foi realizada uma extensa pesquisa bibliográfica para o entendimento dos métodos existentes em fadiga multiaxial. Foram encontrados muitos procedimentos, a maior parte deles não possíveis de serem utilizados em conjunto com Elementos Finitos. Assim, procurou-se apresentar apenas os procedimentos que pudessem ser utilizados plenamente com Elementos Finitos na prática da engenharia. Este é o caso da seção 5.2, que apresenta uma maneira de verificar se um carregamento é não proporcional utilizando resultados de análises por Elementos Finitos. Neste capítulo também foi relatado como contabilizar o efeito de entalhe em carregamentos multiaxiais de amplitude variável (seção 5.3) assim como realizar a contabilização de ciclos em carregamentos multiaxiais variáveis (seção 5.4). Foi feita revisão bibliográfica de vários modelos de fadiga multiaxial, mas foram apresentados apenas os modelos mais conhecidos e os que também geram melhores resultados entre precisão e custo computacional. Sete critérios de Fadiga Multiaxial foram apresentados em grande detalhe, dando-se sempre ênfase ao uso do critério em uma análise de fadiga baseada em Elementos Finitos.

A maioria dos critérios de fadiga multiaxial, se não todos, foram formulados para serem critérios de "passa ou não passa". Este tipo de apresentação não permite saber em qual ciclo ocorreria a falha por fadiga, caso a tensão equivalente $\rfloor^{2}$ (lado esquerdo das equações dos critérios de falha) seja maior do que o limite de fadiga (lado direito). Existem poucas referências que relatam como utilizar os critérios de fadiga multiaxial de maneira a obter o

\footnotetext{
${ }^{1}$ Da superfície do compoennte.

${ }^{2}$ Parâmetro de dano.
} 
número de ciclos em que ocorrerá a falha por fadiga ${ }^{3}$. Entretanto, estas poucas referências apresentam equações para se calcular o número de ciclos em que ocorrerá a fratura apenas em um espécime padronizado. Não foi encontrado na revisão bibliográfica desta dissertação referências que relatam como os critérios multiaxiais podem ser expandidos para prever o número de ciclo que ocorrerá a falha de componentes de geometria/características ${ }^{4}$ complexas, diferentes do espécime. Em outras palavras, não foi encontrado na literatura um modo de se obter a Curva Tensão-Vida de um componente genérico que deve ser utilizada no critério de fadiga multiaxial escolhido. Por este motivo, nesta dissertação foi proposta uma metodologia que permite contabilizar esta curva de maneira que cada critério de fadiga multiaxial pudesse ser utilizado para a faixa de vida finita $\pm 10^{3} \leq N \leq 10^{6}$ ciclos. Esta metodologia está descrita em cada critério de fadiga multiaxial apresentado na seção 5.5 .

No capítulo 6 foi realizada a apresentação e análise detalhada dos principais softwares para análise de fadiga baseados em FEA. A seção 6.3 apresentou de maneira detalhada o processo global de análise de fadiga de uma estrutura, detalhando com fluxogramas cada etapa de uma análise de fadiga faseada em FEA, sempre utilizando a teoria apresentada nos capítulos anteriores de maneira aplicada. Por último, foram realizados 5 estudos de casos a fim de demonstrar a aplicação de alguns métodos relatados nesta dissertação em problemas reais, assim como demonstrar a validade e aplicação do software xDurability no processo de análise de fadiga. O software $x$ Durability foi desenvolvido ao longo desta dissertação, cujo objetivo foi de utilizar os resultados de tensão uma análise estrutural por Elementos Finitos de um compontente para estimar a sua vida em fadiga. Este software utiliza toda a metodologia descrita nos capítulos 4 e 5 e contabiliza automaticamente muitas etapas, como o cálculo do fator de entalhe $n_{K}$. Foram analizados 5 estudos de caso com o objetivo de demonstrar a validade de alguns procedimentos apresentados nesta dissertação e a validade do software $x$ Durability. O software supracitado foi utilizado na resolução destes cases devido a facilidade do mesmo em lidar com problemas que possuem grande quantidade de cálculos. Os resultados obtidos pelo software foram muito próximos aos obtidos via cálculos analíticos exatos, cujos erros relativos não ultrapassaram $8 \%$. Por isso considera-se que a metodologia proposta nesta dissertação é adequada para prever a vida de componentes sob fadiga uni e multiaxial, inclusive quando integradas com análises por Elementos Finitos.

Em virtude do que foi mencionado, conclui-se que o trabalho foi positivo no que tange ao estudo completo da análise de fadiga uni e multiaxial baseada em Elementos Finitos. Adicionalmente, o trabalho divulgou à comunidade científica métodos pouco conhecidos e utilizados até então como:

\footnotetext{
${ }^{3}$ Foram encontradas apenas três referências que relatam isto na revisão bibliográfica desta dissertação: Socie \& Marquis (2000, seção 5.2.4), Karolczuk \& Macha (2005) e MSC.Software (2008)

${ }^{4}$ Geometria do entalhe, rugosidade superficial, tratamento superficial, tamanho, etc.
} 
- A realização de análise de previsão de vida em fadiga utilizando resultados de Análise por Elementos Finitos (FEA);

- O cálculo do fator de tamanho $\left(C_{D}\right)$;

- O cálculo do fator de tratamento superficial $\left(C_{S T}\right)$;

- O cálculo do fator de corrosão $\left(C_{C}\right)$;

- O cálculo do fator de tensão média $\left(C_{m}\right)$ utilizando o padronizado diagrama de Haigh;

- O cálculo do fator de tensão média $\left(C_{m, \sigma^{\circ}}\right)$ utilizando pseudo tensões provenientes de FEA,

- A contabilização do efeito de entalhe $\left(n_{K}\right)$ utilizando o Método do Gradiente de Tensão Relativo tanto para carregamento uniaxial quanto para carregamento multiaxial;

- A definição e construção da Curva S-N Espécime, Curva S-N Unnotched, Curva S-N Local e da Curva $\sigma-N$ Local;

- A contabilização do dano por fadiga em carregamento multiaxial de amplitude variável;

- A densidade da malha de elementos finitos adequada para utilizar em fadiga computacional;

- Verificação do tipo de carregamento através da análise da razão de biaxialidade " $a$ " e da orientação da tensão principal máxima " $\phi_{p}$ ";

- O detalhamento da utilização de Critérios de Fadiga Multiaxial, principalmente em FE-Based Fatigue Analyses.

\subsection{Trabalhos Futuros}

Acredita-se que os trabalhos futuros possam explorar os seguintes aspectos não abrangidos nesta dissertação:

- Estudo mais profundo do funcionamento do fator de entalhe $n_{K}$ quando utilizado em estado de tensão triaxial cíclico (seção 5.3);

- Historicamente, os critérios de fadiga multiaxial foram validados apenas para espécimes padronizados. Um trabalho interessante seria verificar se estes critérios podem ser utilizados também em componentes genéricos, com características consideravelmente diferentes dos espécimes padronizados, conforme proposto neste trabalho;

- Historicamente, os critérios de fadiga multiaxial foram formulados como critérios "passa ou não passa". Um trabalho interessante seria verificar se os critérios de fadiga multiaxial podem ser aplicados dentro do regime de vida finita $\left( \pm 10^{3} \leq N \leq 10^{6}\right.$ ciclos), conforme apresentado na seção 5.5 ,

- Historicamente, os critérios de fadiga multiaxial foram formulados para serem aplicados em metal base, i.e., válidos apenas para locais longe de soldas. Por outro lado, o estudo da fadiga em soldas desenvolveu-se considerando apenas tensão uniaxial na solda. $\mathrm{O}$ autor encontrou apenas 1 trabalho científico que considera a contabilização de fadiga multiaxial em soldas (Bäckström, 2003) e, de uma maneira geral, a comunidade científica ainda não entende como a variaçao de todas as componentes de tensão e deformação influenciam na vida em fadiga de regiões soldadas; 
- Historicamente, a análise de fadiga no domínio da frequência, também conhecida de vibration fatigue, foi desenvolvida considerando apenas o critério de fadiga uniaxial. Um trabalho interessante seria considerar o efeito da variação das 6 componentes de tensão quando se realiza análise de fadiga no domínio frequência. Existem pouquíssimos trabalhos publicados que abrangem estes temas. Conhece-se apenas o livro de Nieslony \& Macha (2007), o artigo de Pitoiset et al. (1998) e o artigo de de Morais TeiXeira et al. (2013). Outro artigo sobre o assunto também será publicado em breve na SAE International, cujo autor principal também é o brasileiro especialista em fadiga Giovanni de Morais Teixeira. 


\section{Referências Bibliográficas}

American Societ of Materials (1996). Asm metals handbook vol. 19.

Anderson, T. L. (2005). Fracture Mechanics: Fundamentals and Applications, Third Edition. Taylor \& Francis.

Araújo, J. A., Dantas, A. P., Castro, F. C., Mamiya, E. N., \& Ferreira, J. L. A. (2011). On the characterization of the critical plane with a simple and fast alternative measure of the shear stress amplitude in multiaxial fatigue. Imnternational Journal of Fatigue, 33, 1092-1100.

ASTM E466-07 (2007). Standard Practice for Conducting Force Controlled Constant Amplitude Axial Fatigue Tests of Metallic Materials. Norma técnica da American Society for Testing and Materials. Philadelphia.

ASTM E739-10 (2010). Standard Practice for Statistical Analysis of Linear or Linearized Stress-Life $(\mathrm{S}-\mathrm{N})$ and Strain-Life $(\varepsilon-\mathrm{N})$ Fatigue Data. Norma técnica da American Society for Testing and Materials. Philadelphia.

Bäckström, M. (2003). Multiaxial fatigue life assessment of welds based on nominal and hot spot stresses. PhD thesis, VTT Publications 502, Lappeenranta, Finland. Lappeenranta University of Technology.

Bannantine, J. A. (1989). A Variable Amplitude Multiaxial Fatigue Life Prediction Method. $\mathrm{PhD}$ thesis, College of Engineering, University of Illinois at Urbana-Champaign, Urbana e Champaign, EUA.

Bannantine, J. A., Comer, J. J., \& Handrock, J. L. (1990). Fundamentals of Metal Fatigue Analysis. Prentice Hall.

Bannantine, J. A. \& Socie, D. F. (1991). A variable amplitude multiaxial fatigue life prediction method. In Fatigue under Biaxial and Multiaxial Loading, number 10, (pp. 35-51). ESIS.

Barbosa, H. (2013). MBD for Durability. Technical report, Altair Brazil. Trabalho apresentado no Altair Technology Conference 2013 Brazil.

Barkey, M. E., Socie, D. F., \& Hsia, K. J. A. (1994). A yield surface approach to the estimation of notch strains for proportional and nonproportional cyclic loading. Journal of Engineering Materials and Technology, 116, 173-180. 
Bishop, N. W. M. \& Sherratt, F. (2000). Finite Element Based Fatigue Calculations. NAFEMS.

Boyer, H. E. (Ed.). (1986). Atlas of Fatigue Curves. ASM International (Americam Society of Metals).

Browell, R. \& Hancq, A. (2006). Calculating and displaying fatigue results. Www. ansys.com/Resource+Library/White+Papers/Calculating+and+ Displaying+Fatigue+Results.

Buczynski, A. \& Glinka, G. (2000). Multiaxial stress-strain notch analyisis. In Kalluri, S. \& Bonacause, P. J. (Eds.), Multiaxial fatigue and deformation: Testing and prediction, ASTM 1387, (pp. 82-98)., West Conshohocken, PA. ASTM.

Bureau Veritas (1998). Fatigue Strength of Welded Ship Structures.

Campbell, G. S. (1981). A note on fatal aircraft accidents involving metal fatigue. International Journal of Fatigue, 4(4), 181-185.

Carpinteri, A. \& Spagnoli, A. (2001). Multiaxial high-cycle fatigue criterion for hard metals. International Journal of Fa, 23, 135-145.

Christian Gaier (2010). Multi-axial fatigue analysis with the fe post-processor femfat. Technical report, Magna Powertrain Engineering Center Steyr GmbH. http: //wWW.utmis.org/en/interest/documents/7_christian_gaier_multi_axial_ fatigue_analysis_with_the_fe_post_processor_femfat_utmis_2010.pdf.

Coffin, L. F. (1954a). The problem of thermal stress fatigue in austenitic steels at elevated temperatures. Technical Report No 165, pp. 31, ASTM STP (Special Technical Publications).

Coffin, L. F. (1954b). A study of the effects of cyclic thermal stresses on a ductile metal. Technical Report Vol. 76, pp. 931-950, ASTM Translation.

Collins, J. A. (1993). Failure of Materials in Mechanical Design - Analysis, Prediction, and Prevention. Number 2nd ed. New York: Wiley.

Compass Automotive Group (2013). Fea of a inferior control arm. WWW. compassautogroup.com/images/STR_Animation_1.gif.

Crossland, B. (1956). Effect of large hydrostatic pressure on the torsional fatigue strength of an alloy steel. In Int. Conf. on Fatigue of Metals, (pp. 138-149)., London. Institution of Mechanical Engineers.

da Silva, B. L., de Almeida Ferreira, J. L., Oliveira, F., \& Araújo, J. A. (2010). Influence of mean stress on the fatighe strength of astm a743 ca6nm alloy steel. Frattura ed Integrittà Strutturale, 14, 17-26.

Dang Van, K. (1973). Sur la résistance a la fatigue des métaux. These de Doctorat es Sciences, Sci. Techniq. l'Armement, 47. PhD thesis. 
Dang Van, K. (1993). Macro-micro approach in high-cycle multiaxial fatigue. In Dowell, D. L. \& Ellis, R. (Eds.), Advances in Multiaxial Fatigue, ASTM STP 1991, (pp. 120-130)., Philadelphia, USA. ASTM.

Dang Van, K., Griveau, B., \& Message, O. (1982). On a new multiaxial fatigue limit criterion. In Miller, K. J. \& Brown, M. W. (Eds.), Biaxial and Multiaxial Fatigue, (pp. 479-496)., London: Mechanical Engineering. EGF Publication 3.

Day, L. \& McNeil, I. (2013). Biographical Dictionary of the History of Technology. Taylor $\&$ Francis.

de Castro, J. T. P. \& Meggiolaro, M. A. (2009a). Fadiga: Técnicas e Práticas de Dimensionamento Estrutural sob Cargas Reais de Serviço, volume 1: Iniciação de Trincas. CreateSpace.

de Castro, J. T. P. \& Meggiolaro, M. A. (2009b). Fadiga: Técnicas e Práticas de Dimensionamento Estrutural sob Cargas Reais de Serviço, volume 2: Propagação de Trincas, Efeitos Térmicos e Estocásticos. CreateSpace.

de Moraes Filho, L. F. L. (2007). Análise estrutural e verificação da vida à fadiga de uma roda automotiva utilizando o método dos elementos finitos. Master's thesis, Escola Politécnica, Universidade de São Paulo.

de Morais Teixeira, G., Draper, J., Hazime, R., \& Jones, D. (2013). Random Vibration Fatigue - Frequency Domain Critical Plane Approaches. In Proceedings of the 2013 ASME International Mechanical Engineering Congress $\mathcal{E}$ Exposition, San Diego, CA, USA.

Desmorat, R. (2006). Damage and Fatigue: Continuum Damage Mechanics modeling for fatigue of materials and structures. Technical report, LMT Cachan. http://alertgeomaterials.eu/data/school/2006/8\%20Desmorat\%20R\% 20Damage\%20and\%20fatigue.pdf.

Dieter, G. E. (1981). Metalurgia Mecânica (2 ed.). Rio de Janeiro - RJ: Guanabara Koogan.

Dietmann, H. (1973a). Werkstoffverhalten unter mehrachsiger schwingender Beanspruchung, Teil 1: Berechnungsmöglichkeiten. Materialwissenschaft und Werkstofftechnik (Journal of Materials Science and Engineering Technology), 5, 255-263.

Dietmann, H. (1973b). Werkstoffverhalten unter mehrachsiger schwingender Beanspruchung, Teil 2: Experimentelle Untersuchungen. Materialwissenschaft und Werkstofftechnik (Journal of Materials Science and Engineering Technology), 6, 322-333.

Dowling, N. E. (1998). Mechanical Behavior of Materials: Engineering Methods for Deformation, Fracture, and Fatigue (2nd ed. ed.). New York: Prentice Hall.

Dowling, N. E. (2004). Mean stress effects in stress-life and strain-life fatigue. SAE Techinical Paper, (2004-01-2227).

Draper, J. (s.d.a). Fatigue analysis of an fea model of a suspension component, and comparison with experimental data. Technical report, Safe Technology, Halifax, England. 
Draper, J. (s.d.b). How to achieve valid results in durability analysis from fea software. Technical report, Safe Technology.

Duggan, T. V. \& Byrne, J. (1977). Fatigue as a Design Criterion. Macmillan.

Eichlseder, W. (2000a). Fatigue analysis by local stress concept based on finite element results. Computers $\mathcal{E}$ Structures, 80(27-30), 2109-2113.

Eichlseder, W. (2000b). Synthetic S/N Curves. In Topping, B. H. V. (Ed.), Computational Techniques for Materials, Composites and Composite Structures, (pp. 161-164)., Edinburgh, UK. Civil-Comp Press. doi:10.4203/ccp.67.3.1.

Exova Defiance (2013). Full-Car Road Simulator. www.defiancetest.com/ testing-services/full-vehicle.php.

Facchinetti, M. L., Weber, B., Doudard, C., \& Calloch, S. Taking into account the forming process in fatigue design computations. Technical report.

Fatemi, A. (s.d.a). Fatigue Design Methods. https://www.efatigue.com/training/ Chapter_2.pdf. Universidade de Toledo. Notas de aula.

Fatemi, A. (s.d.b). Fatigue: Notch and Their Effects. https://www.efatigue.com/ training/Chapter_7.pdf. Universidade de Toledo. Notas de aula.

Fatemi, A. (s.d.c). Multiaxial Stresses. https://www.efatigue.com/training/ Chapter_10.pdf. Universidade de Toledo. Notas de aula.

Fatemi, A. \& Montazersadgh, F. H. (2007). Stress Analysis and Optimization of Crankshafts Subject to Dynamic Loading. Technical-executive report, The University of Toledo. https://wWw.forging.org/system/files/field_document/ CrankshaftProjectreportIIAug2007.pdf

Findley, W. N. (1959). A theory for the effect of mean stress on fatigue of metal under combined torsion and axial load or bending. Journal of Engineering for Industry, 301306.

Fischer, J. W. \& Yen, B. T. (1972). Desing, structural details, and discontinuities in steel, safety and reliability of metal struct. Technical report, American Society of Civil Engineers.

FKM-Guideline (2003). Analytical Strength Assessment of Components in Mechanical Engineering. Conselho Alemão de Pesquisa em Engenharia (do alemão, Forschungskuratorium Maschinenbau (FKM) ). Traduzida para o inglês por E. Haibach. 5 ed. Frankfurt, Alemanha.

Fojtík, F. (2011). Aplication of selected fatigue criteria on the results of muti-axial highcycle fatigue experiments. In Modelling of Mechanical and Mechatronic Systems, Faculty of Mechanical Engineering, Technical university of Košice.

Forrest, P. G. (1962). Fatigue of Metals. Londres, Inglaterra.: Pergamon Press.

Frost, N. E. \& Marsh, K. J. (1999). Metal Fatigue. Dover. 
Fuchs, H. O. \& Stephens, R. I. (1980). Metal Fatigue in Engineering. Wiley-Interscience. Wiley.

Gaier, C. \& Dannbauer, H. (2003). Fatigue analysis of multiaxially loaded components with the fe-postprocessor femfatigue. In Carpinteri, A., de Freitas, M., \& Spagnoli, A. (Eds.), Biaxial/Multiaxial Fatigue and Fracture, ECS - Engineering Center Steyr, Magna Steyr. St. Valentin, Austria.

Gaier, C. \& Dannbauer, H. (2008). A multiaxial fatigue analysis method for ductile, semiductile, and brittle materials. Arabian Journal for Science and Engineering, 33(1B)(1B), 224-235.

Gaier, C., Lukacs, A., \& Hofwimmer, K. (2004). Investigation on a statistical measure of the nonproportionality of stresses. International Journal of Fatigue, 26, 331-337.

Gerber, W. Z. (1874). Calculation of the allowable stresses in iron structures. Z. Bayer ArchitIngVer, 6(6), 101-110.

Gonçalves, C. A., Araújo, J. A., \& Mamiya, E. N. (2005). Multiaxial fatigue: a stress based criterion for hard metals. International Journal of Fatigue, 27, 177-187.

Goodman, J. (1899). Mechanics Applied to Engineering (1a edição ed.). Londres: Longmans, Green and Company.

Gough, H. J. (1950). Engineering steels under combined cyclic and static stresses. Journal of Applied Mechanics, 50, 113-125.

Gough, H. J. \& Pollard, H. V. (1935). The strength of metals under combined alternating stresses. In Proceedings of the Institution of Mechanical Engineers, volume 131, (pp. 3-103).

Gough., H. J., Pollard, V., \& Clenshaw, W. J. (1951). Some experiments on the resistance of metals to fatigue under combined stresses. London. His Majesty's Stationery Office.

Grover, H. J., Gordon, S. A., \& Jackson, L. R. (1960). Fatigue of Metals and Structures. Technical report, Bureau of Naval Weapons Document NAVWEPS 00-25-534.

Gu, R. \& Lee, Y.-L. (1997). A new method for estimating nonproportional notch-root stresses and strains. ASME Journal of Engineering Materials and Technology, 119, 40-45.

Haibach, E. E. (1970). Modifizierte Lineare Schadensakkumulations-hypothese zur Berücksichtigung des Dauerfestigkeitsabfalls mit Fortshreitender Schädigung. LBF Technical Memorandum (TM) No 50/70, Fraunhofer Institute for Structural Durability and System Reliability (LBF), Darmstadt, FRG.

Haugein, E. B. \& Wirsching, P. H. (1975). Probabilistic design. Machine Design, 47(12), pp. 10-14.

Hertzberg, R. W. (1996). Deformation and Fracture Mechanics of Engineering Materials (4th ed.). Wiley. 
Heyes, P. (2011). Multiaxial fatigue. Technical report, HBM nCode UK Ltd. Apresentado na Altair Technology Conference 2013 Brazil.

Heywood, R. (1962). Design Against Fatigue of Metals. Reinhold.

Hoffmann, M. \& Seeger, T. (1989). Stress-strain analysis and life predictions of a notched shaft under multiaxial loading. In Multiaxial Fatigue: Analysis and Experiments, Cap. 6, SAE AE-14, (pp. 81-96)., Warrendale, PA. SAE International.

Horger, O. J. (Ed.). (1965). ASME Handbook: Metals Engineering - Design (2nd ed.). New York: McGraw-Hill.

Hück, M., Thrainer, L., \& Schütz, W. (1981). Berechnung von wöhlerlinien für bauteile aus stahl, stahlguss und grauguss-synthetische wöhlerlinien. Technical report, Verein Deutscher Eisenhüttenleute, Berich Nr. ABF 11 (2. überarbeitete Fassung), Düsseldorf.

Ingrassia, T., Buglio, G. L., Lombardo, E., Nigrelli, V., \& Sergio, G. (2011). Numerical fatigue life evaluation of an innovative internal combustion engine shaft. In International Conference on Innovative Methods in Product Design, Venice, Italy.

Instron (s.d.). Rotating beam and axial-torsional fatigue testing systens. http://wWw. instron.com

Irwin, G. (1957). Analysis of stresses and strains near the end of a crack traversing a plate. Journal of Applied Mechanics, 24, 361-364.

Itoh, T., Sakane, M., Ohnami, M., \& Socie, D. F. (1995). Nonproportional low cycle fatigue criterion for type 304 stainless steel. Journal of Engineering Materials and Technology, 117, 285-292.

Jornal El País (2008). El fallo estructural que hundió al "Prestige" era conocido desde 1996. WWw.elpais.com/articulo/espana/fallo/estructural/hundio/ Prestige/era/conocido/1996/elppgl/20080609elpepinac_12/Tes.

Juvinall, R. C. (1967). Engineering Considerations of Stress, Strain, and Strength. McGrawHill series in mechanical engineering. Nova York, EUA: McGraw-Hill.

Juvinall, R. C. \& Marshek, K. M. (2005). Fundamentals of Machine Component Design (4 ${ }^{\text {th }}$ ed.). Wiley.

Karolczuk, A. \& Macha, E. (2005). A review of critical plane orientations in multiaxial fatigue failure criteria of metallica materials. International Journal of Fracture, 134, 267304.

Kenmeugne, J. L., Vidal-Salle, E., Robert, J. L., \& Bahuaud, R. J. (1996). On a new multiaxial fatigue criterion based on a selective integration approach. In Lütjering, G. (Ed.), Proceedings of the Sixth International Fatigue Congress, volume 2, (pp. 1013-1018)., Berlin, Pergamon.

Kuguel, R. (1961). A relation between theoretical stress concentration factor and fatigue notch factor deduced from the concept of highly stressed volume. In American Society of Testing and Materials Proceedings, volume 61, (pp. 732-748). 
Langlais, T. E., Vogel, J. H., Socie, D. F., \& Cordes, T. S. (1995). A multiaxial fatigue life prediction program. In Proceedings of Fatigue Design 1995 Symposium (VTT Symposium 155), volume 1, (pp. 245-259)., Helsinki, Finland.

Lee, S. B. (1985). A criterion for fully reversed out-of-phase torsion and bending. In Miller, K. J. \& Brown, M. W. (Eds.), Multiaxial Fatigue, (pp. 553-568)., Philadelphia. ASM STP 853.

Lee, Y.-L., Barkey, M. E., \& Kang, H.-T. (2011). Metal Fatigue Analysis Handbook: Practical Problem-Solving Techniques for Computer-Aided Engineering (1 ed.). Massachusetts, USA: Butterworth-Heinemann.

Lee, Y.-L. \& Chiang, Y. J. (1991). Fatigue predictions for components under biaxial reversed loading. Journal of Testing and Evaluation, JTEVA, 19(5), 359-367.

Lee, Y.-L., Chiang, Y. J., \& Wong, H. H. (1995). A constitutive model for estimating multiaxial notch strains. ASME Journal of Engineering Materials and Technology, 117, 33-40.

Lee, Y.-L. \& Gu, R. (1999). Multiaxial notch stress-strain analysis and its application to component life predictions. In Cordes, T. \& Lease, K. (Eds.), Multiaxial fatigue of an inducted hardened shaft, volume SAE AE-28, (pp. 71-78)., Warrendale, PA. SAE International.

Lee, Y.-L., Pan, J., Hathaway, R., \& Barkey, M. E. (2005). Fatigue Testing and Analysis: Theory and Practice (1 ed.). Massachusetts, USA.: Butterworth-Heinemann.

Lipson, C. \& Sheth, N. J. (1973). Statistical Design and Analysis of Engineering Experiments. Mc.

Liu, J. \& Zenner, H. (1993). Berechnung der dauerschwingfestigkeit bei mehrachsiger beanspruchung. Mat. Wiss und Werkstofftech, 24(S), 240-249.

Lopes, L. C. R. (2012). Fundamentos da análise de fadiga de metais. Curso presencial SAE Brasil.

Ma, B.-T. \& Laird, C. (1989). Overview of fatigue behavior in copper sinle crystals: Population, size, distribution and growth kinetics of stage i cracks for tests at constant strain amplitude. Acta Metallurgica, 37, 337-348.

Magna Powertrain (2011). Femfat seminar notes. Technical report, Magna Powertrain Engineering Center Steyr GmbH.

Manson, S. S. (1953). Behaviour of materials under conditions of thermal stress. In Heat Transfer Symposium, (pp. 9-75)., University of Michigan. Engineering Research Institute.

Marin, J. (1962). Mechanical Behavior of Engineering Materials. New Jersey: PrenticeHall.

MathWorks (2010). Rainflow Counting Algorithm. http://www.mathworks.com/ matlabcentral/fileexchange/3026-rainflow-counting-algorithm.

Matsuishi, M. \& Endo, T. (1968). Fatigue of metals subjected to varying stress. Japan Society of Mechanical Engineers. 
McClintock, F. A. \& Argon, A. S. (1966). Mechanical Behavior of Materials. AddisMcWesley.

McDiarmid, D. L. (1987). Fatigue under out-of-phase bending and torsion. Fatigue and Fracture o Engineering Materials and Structures, 9(6), 457-475.

McDiarmid, D. L. (1994). A shear stress based critical-plane criterion of multiaxial fatigue failure for design and life prediction. Fatigue and Fracture o Engineering Materials and Structures, 17(12), 1475-1485.

Meggiolaro, M. A. \& de Castro, J. T. P. (2002a). Avaliação estatística das estimativas de propriedades mecânicas no projeto à fadiga. In 57o Congresso Anual da ABM, São Paulo, SP, Brasil.

Meggiolaro, M. A. \& de Castro, J. T. P. (2002b). Avaliação estatística das estimativas dos parâmetros sn e en no projeto à fadiga. In Congresso Nacional de Engenharia Mecãnica (CONEM), São Paulo, SP, Brasil. CONEM.

Meggiolaro, M. A. \& de Castro, J. T. P. (2005). Comparação entre métodos de previsão de vida à fadiga sob cargas multiaxiais: Modelos tensão-vida e deformação-vida. In $60 \mathrm{o}$ Congresso Anual da ABM, Belo Horizonte, MG, Brasil.

Mendes, A. S. \& Cardoso, A. A. (2007). Structural analysis of the aluminum cylinder head for a high-speed diesel engine. SAE Techinical Paper, (2007-01-2562).

Mentley, J. (2013). Fatigue \& durability. Technical report, HBM nCode, São Paulo, SP, Brasil. Apresentado na Altair Technology Conference 2013 Brazil.

Mentley, J. \& Pompetzki, M. (2006). Notch sensivity corrections in msc fatigue and fe-fatigue. Technical report, nCode International, California, EUA. MSC.Fatigue VPD Conference. http://web.mscsoftware.com/events/vpd2006/ na/presentations/54.pdf

Meyers, M. A. \& Chawla, K. K. (2009). Mechanical Behavior of Materials (2 ed.). Nova York, EUA: Cambridge University Press.

Milan, Maluf, Spinelli, \& Bose Filho (2008). Metais: Uma visão objetiva. Apostila de aula.

Miner, M. A. (1945). Cumulative damage in fatigue. ASME Journal of Applied Mechanics, 12, AI59-A164.

Moftakhar, A. A., Buczynski, A., \& Glinka, G. (1995). Calculation of elasto-plastic strains and stress in notches under multiaxial loading. International Journal of Fracture, 70, 357-373.

Molsky, K. \& Glinka, G. (1981). A method of elastic-plastic stress and strain calculation at a notch root. Material Science and Engineering, 50, 93-100.

Morel, F. (1998). A fatigue life prediction method based on a mesoscopic approach in constant amplitude multiaxial loading. Fatigue and Fracture of Engineering Materials and Structures, 21, 241-256. 
Morel, F. (2000). A critical plane approach for life prediction of high cycle fatigue under multiaxial variable amplitude loading. International Journal of Fatigue, 22, 101-119.

Morel, F. \& Paulin-Luc, T. (2002). A non-local theory applied to high cycle multiaxial fatigue. Fatigue and Fracture of Engineering Materials and Structures, 25, 649-665.

Morel, F., Ranganathan, N., Petit, J., \& Bignonnet, A. (1997). A mesoscopic approach for fatigue life prediction under multiaxial loading. In Marcha, E. \& Mróz, Z. (Eds.), Proceedings of the 5th International Conference on Biaxial/Multiaxial Fatigue and Fracture, volume 1, (pp. 155-172)., Technical University of Opole, Opole, Poland.

Morrow, J. (1968). Fatigue properties of metals. In Graham, J. A., Millan, J. F., \& Appl, F. J. (Eds.), Seção 3.2 da Fatigue Design Handbook, volume Pub. No AE-4, (pp. 21-29)., Warrendale, PA. Society of Automotive Engineers. A seção 3.2 é um resumo de um artigo apresentado no encontro da Divisão 4 do SAE Iron and Steel Technical Commitee.

Moura Branco, C., Fernandes, A. A., \& Castro, P. M. S. (1987). Fadiga de Estruturas Soldadas. Gulbenkian.

MSC.Software (2008). Multiaxial fatigue. Technical report, MSC.Software.

MSC.Software (s.d.). MSC.Fatigue User's Guide. MSC.Software. www.mscsoftware. com/training_videos/patran/Reverb_help/index.html\#page/Fatigue\% 20Users\%20Guide/fat_theory.15.1.html.

Neuber, H. (1961). Theory of stress concentration for shear-strained prismatic bodies with arbitrary nonlinear stress-strain law. Journal of Applied Mechanics, 28, 544-550. Transactions of ASSM, Section E.

Newman Jr., J. C. (1998). The merging of fatigue and fracture mechanics cconcept: a historical perspective. Progress in Aerospaces Science, 347-390.

Nieslony, A. \& Macha, E. (2007). Spectral Method in Multiaxial Random Fatigue. Lecture Notes in Applied and Computational Mechanics. Springer.

Norton, R. L. (2006). Machine Design: An Integrated Approach ( $3^{\text {rd }}$ ed.). Worcester, Massachusetts, EUA.: Pearson Prentice Hall.

Novotny, P. \& Pistek, V. (2007). Cranktrain fatigue life prediction of tractor engine. In FEMFAT User Meeting 2007, Steyer, Austria. Institute of Automotive Engineering.

NTSB (National Transportation Safety Board) (1990). Aircraft Accident Report: United Airlines Flight 232. Technical report, NTS.

Palmgren, A. (1924). Die lebensdauer von kugellagern. Zeitschrift des Vereinesdeutscher Ingenierure, 68(14), 339-341.

Papadopoulos, I. V. (1987). Fatigue polycyclique des métaux: Une nouvelle approche. PhD thesis, École Nationale des Ponts et Chaussées, Paris, France.

Papadopoulos, I. V. (1993). Fatigue limit of metals under multiaxial stress conditions: the microscopic approach. Technical note no. I.93.101, Commission of the European Communities, Joint Research Centre, ISEI/IE 2495/93. 
Papadopoulos, I. V. (1994). A new criterion of fatigue strength for out-of-phase bending and torsion of hard metals. International Journal of Fatigue, 16, 377-384.

Papadopoulos, I. V., Davoli, P., Gorla, C., Filipini, M., \& Bernasconi, A. (1997). A comparative study of multiaxial high-cycle fatigue criteria for metals. International Journal of Fatigue, 19(3), 219-235.

Papuga, J. (2005). Mapping of Fatigue Damages: Program Shell of FE-Calculation. PhD thesis, Departament of Mechanics, Faculty of Mechanical Engineering, Czech Technical University in Prague, Prague, Czech Republic.

Papuga, J. (2011). A survey on evaluating the fatigue limit under multiaxial loading. International Journal of Fatigue, 33(2), 153-165.

Paris, P. C., Gomez, M. P., \& Anderson, W. E. (1961). A rational analytic theory of fatigue. The Trend in Engineering, 13, 9-14.

Peterson, R. E. (1959). Analytical approach to stress concentration effects in aircraft materials. Technical Report Technical Report 59-507, U.S. Air Force: WADC Symposium on Fatigue Metals, Dayton, Ohio, EUA. Technical Report 59-507.

Pitoiset, X., Preumont, A., \& Kernilis, A. (1998). Tools for a multiaxial fatigue analysis of structures submitted to random vibration. European Conference on Spacecraft Structures, Materials and Mechanical Testing.

Reed, R. P., Smith, J. H., \& Christ, B. W. (1983). The economic effects of fracture in the united states: Part i (special pub. 647-1). Technical report, National Bureau of Standard, U.S. Dep. of Commerce, Washington, D.C. Special Pub. 647-1.

Revista Veja (1998). O desastre de trem de Eschede. Reportagem impressa.

SAE International (1968). Fatigue Design Handbook. SAE.

SAE International (1988). Fatigue Design Handbook. SAE.

Santos, J. L. T., Freitas, M., Li, B., \& Trigo, T. P. (2003). Fatigue assessment of mechanical components under complex multiaxial loading. In 6th International Conference on Biaxial/Multiaxial Fatigue and Fracture, volume 31, (pp. 463-482).

Santus, C. (2007). The Theory of Critical Distances in Metal Fatigue. http: //www . dimnp.unipi.it/santus/Presentazioni/Santus\%20-\%20Seminar_ TheoryCriticalDistance_TCD.pdf. Facoltà di Ingegneria, Università di Pisa.

Schijve, J. (2008). Fatigue of Structures and Materials (2nd ed.). Springer.

Schütz, W. (1996). A history of fatigue. Engineering Fracture Mechanics, 54(2), 263-300.

Shamsaei, N. \& Fatemi, A. (2010a). Effect of Microstructure and Hardening on Nonproportional Cyclic Hardening Coefficient and Predictions. Journal of Materials Science and Engineering, 3015-3024. 
Shamsaei, N. \& Fatemi, A. (2010b). Fatigue Life Prediction Under General Multiaxial Loading Employing Simple Material Properties. Sae fatigue design and evaluation committee meeting, Chrysler Headquarter and Technology Center.

Shigley, J. E., Mischke, C. R., \& Budynas, R. G. (2003). Mechanical Engineering Design. McGraw-Hill series in mechanical engineering. McGraw-Hill.

Siebel, E. \& Stieler, M. (1955). Significance of dissimilar stress distributions for cycling loading. VDI-Z (Verein Deutscher Ingenieure Zeitschrift), 97(5), 121-131.

Sines, G. (1955). Failure of materials under combined repeated stresses with superimposed static stresses. NACA Report (NACA-TN-3495), NACA, Washington. WwW.recycle-steel.org/ /media/Files/Autosteel/Programs/LongProducts/ cranksfaft_full_report_1.pdf.

Sines, G. (1959). Behavior of metals under complex static and alternating stresses. In Sines, G. \& Waisman, J. L. (Eds.), Metal Fatigue (1 ed.)., (pp. 145-169)., New York, NY. McGraw-Hill.

Smith, K. N., Watson, P., \& Topper, T. H. (1970). A stress-strain function for the fatigue of metals. Jornal of Materials (ASTM), 5(4), 767-778.

Socie, D. F. (2002). Fatigue Made Easy: Historical Introduction. https://www . efatigue. com/training/fatigue_made_easy.pdf. Class Notes.

Socie, D. F. (2004a). Seminar on Fatigue: Multiaxial Fatigue. https://www .efatigue. com/training/MultiaxialFatigue.pdf. Class Notes.

Socie, D. F. (2004b). Seminar on Fatigue: Physics of Fatigue. https://www . efatigue. com/training/FatigueHowandWhy.pdf. Class Notes.

Socie, D. F. (2008). Webinar on Fatigue: The Strain-Life Method. https://www. efatigue.com/constantamplitude/background/strainlife.html.

Socie, D. F. \& Marquis, G. B. (2000). Multiaxial Fatigue. Warrendale, PA: SAE International.

Soderberg, C. R. (1930). Fatigue of safety and working stress. Transactions of the American Society of Mechanical Engineers, 52 (Part APM-52-2), 13-28.

Sonsino, C. M. (1995). Multiaxial fatigue of welded joints under in-phase and out-of-phase local strains and stresses. International Journal of Fatigue, 17(1), 55-70.

Sonsino, C. M. (2007). Course of SN-curves especially in the high-cycle fatigue regime with regard to component design and safety. International Journal of Fatigue, 29(12), 2246-2258.

Spaggiari, A., Castagnettia, D., Dragonia, E., \& Bulleri, S. (2011). Fatigue life prediction of notched components: a comparison between the theory of critical distance and the classical stress gradient approach. Procedia Engineering, 10, 2755-2797. 
Spagnoli, A. (2001). A new high-cycle fatigue criterion applied to out-of-phase biaxial stress state. International Journal of Mechanical Sciences, 43, 2581-2595.

Spiteli, P., Hoand, S., \& Lee, Y.-L. (2007). Assessment of bending fatigue limit for crankshaft sections with inclusion of residual stresses. International Journal of Fatigue, 29(2), 318-329.

Stanzl, S. E., Tschegg, E. K., \& Mayer, H. (1986). Lifetime measurements for random loading in the very high cycle fatigue range. International Journal of Fatigue, 8(4), 195200.

Steinbeis GmbH \& Co (2013). WinLIFE Manual. Prittwitzstrasse 10, 89075 Ulm, Alemanha: KG for Technology Transfer. Www.stz-verkehr.de.

Steiner, W., Steinwender, G., \& Unger, B. (2000). Fatigue simulation of power train components during the design process. In Seoul 2000 FISITA World Automotive Congress, Seoul, Korea.

Stephens, R. I., Fatemi, A., Stephens, R. R., \& Fuchs, H. O. (2000). Metal Fatigue in Engineering. A Wiley-Interscience publication. Wiley.

Suresh, S. (1998). Fatigue of Materials. Cambridge solid state science series. Cambridge University Press.

Susmel, L. (2009). Multiaxial notch fatigue: From nominal to local stress/strain quantities. Woodhead Publishing.

Technology, F.-O. (2005). EngineersToolbox Calculation Software. http://www. fea-optimization.com/ETBX/miner_help.html.

Unger, B. (2011). Fe-based fatigue analysis. In Palestra Técnica SAE Brasil, São Paulo, Brasil. Engineering Center Steyr (ECS).

Van Vlack, L. H. (2000). Princípios de Ciência dos Materiais. São Paulo, SP, Brasil: Edgard Blücher.

Walker, K. (1970). The effect of stress ratio during crack propagation and fatigue for 2024-t3 and 7075-t6 aluminum. In Rosefeld, M. S. (Ed.), Effects of environment and complex load history on fatigue life, number ASTM STP 462, (pp. 1-14)., Philadelphia, PA. ASTM.

Wang, C. H. \& Brown, M. W. (1996). Life prediction techniques for variable amplitude multiaxial fatigue - part 1: Theories. Journal of Engineering Materials and Technology, $118,367-370$.

Wikipedia (2013). Eschede train disaster. http://en.wikipedia.org/wiki/Eschede_ train_disaster.

Wilson, S. J. \& Haigh, B. P. (1923). Stresses in bridges. Engineering, 116(441-413), 446448.

Zenner, H., Simbürger, A., \& Liu, J. (2000). On the fatigue limit of ductile metals under complex multiaxial loading. International Journal of Fatigue, 22, 137-145. 